Rábai Krisztina

\title{
ANJOU-KORI OKLEVÉLTÁR
}

\author{
XL. kötet \\ 1356.
}

Doktori értekezés

Szeged 2012.

Témavezető:

Dr. Almási Tibor

Szegedi Tudományegyetem

Bölcsészettudományi Kar

Történettudományi Doktori Iskola Medievisztika Program 


\section{Bevezetés}

\subsection{A kitûzött kutatási feladat jelentôsége, a munka célja}

Napjainkban a történészek körében egyre nagyobb megbecsülésnek örvendenek a források feltárására, feldolgozására, közzétételére irányuló kutatások. Egyáltalán nem meglepő ez, ha figyelembe vesszük, hogy ezen forráskiadások nemcsak megkönnyítik a kutatók, felhasználók munkáját, hanem egyszersmind alapját, nyersanyagát is adják annak. Dolgozatom bevezetőjében nem szándékozom kitérni mindazon előzményekre, melyek a történeti kútfők kiadásának ebbéli megbecsültségéig vezettek — hiszen azt megtették már előttem sokan mások 1_, sokkal inkább azon erőfeszítésekre, sajátosságokra szeretnék részletesebben kitérni, melyek ezen konkrét munka megszületéséhez vezettek.

Elsődleges célom az volt, hogy bekapcsolódván az Anjou-kori oklevelek feldolgozásának évtizedek óta tartó munkájába, az 1356-os év teljes — bármilyen formában - fennmaradt okleveles anyagának feltárása és magyar nyelvú kivonatok formájában történő közzététele révén elkészítsem a sorozat XL. kötetét, ezzel járulva hozzá az évtizedekkel ezelőtt megjelölt cél eléréséhez, vagyis az 13011387 között kiadott levéltári forrásanyag teljességre törekvő feldolgozásához. ${ }^{2}$

\footnotetext{
${ }^{1}$ Immár hagyománynak számít az Anjou-kori oklevéltár köteteinek készítői körében — s itt elsősorban azokra gondolok, kiknek írása elsóként doktori disszertáció formájában látott napvilágot —, hogy munkájuk bevezetójében ismertetik a hazai középkori forráskiadással kapcsolatos tudnivalókat ekként helyezve el az immár 3 évtizedes múltra visszatekintő, az Anjou-kor teljes okleveles anyagának feldolgozását célul kitűző sorozatot a hazai tudományosság palettáján. Csupán egy példát említenék, Almási Tibor disszertációját, melyben az 1327-es év okleveles anyagát feldolgozva a sorozat XI. kötetét készítette el (Szeged, 1995.), s példaértékú bevezetôjét a késóbbiek során kibővítve, valamint a nemzetközi tudományosság számára is elérhetővé téve idegen nyelven is közreadta The documentary heritage of Angevin Hungary comes to light. Sobotka-Slaski Kwartalnik Historyczny 113/4 (2006) 47-57.

${ }^{2}$ Kristó Gyula: Anjou-kori oklevéltár I. kötet (1301-1305) Budapest-Szeged 1990. 2-10.
} 


\subsection{A feldolgozás fóbb elvei és technikája}

A munka elkészítése során elsősorban azt az évtizedek alatt kialakult gyakorlatot igyekeztem követni, mely a sorozat köteteiben nyomon követhetó. Ahogyan minden eddig megjelent kötetnél, úgy az 1356-os év okleveles anyagának feldolgozásához is a Magyar Országos Levéltárban (a továbbiakban MOL) található középkori okleveles anyag adta az alapot. Ahogyan arra a célkitúzések között már utaltam, a közismert adatok helyett olyan újdonságokra összpontosítok inkább, melyek eltérést jelentenek az eddigiekhez képest.

Hatalmas előrelépést, és az eddig bevett gyakorlat szerinti kezdeti munkafolyamat kiiktatását jelentette a MOL okleveles anyagának digitalizálása és az intézmény honlapján való elérhetővé tétele. Amellett, hogy ezzel kiküszöbölhetôvé vált az oklevelek fénykép formájában való megrendelése, s ezzel komoly időmegtakarításra tehetnek szert a szerkesztők, sokkal jobb minőségben vált olvashatóvá a források sokasága, s ezzel az eddigi olvasati bizonytalanságok nagy része elkerülhetô. A tisztánlátás érdekében még két dologra szeretném ráirányítani a figyelmet. Az egyik, hogy a MOL Diplomatikai Fényképgyújteményében található iratok ezen digitalizálás következtében sem lettek jobb minőségúek, olvashatóbbak, a másik pedig a pápai regisztrumkötetekról készült fényképek elérhetőségének hiánya. Elóbbi probléma orvoslására részben találhatunk gyógyírt a világhálón, hiszen ma már számos olyan nemzetközi projekt elónyeit élvezhetjük, melyek középkori források, s így magyarországi vagy magyar vonatkozású oklevelek digitalizálását túzték zászlajukra. Ezek sorába tartozik a kötet elkészültét nagyban segító, az olvasati bizonytalanságokat feloldó, s az oklevél ill. pecsétleírást komolyan elóremozdító Monasterium ${ }^{3}$ adatbázis anyaga. Jelenleg a sorozat szempontjából legfontosabb és komoly iratmennyiséget tartalmazó Szlovákiai levéltárak anyagát csak igen töredékesen töltötték fel az adatbázisba,

\footnotetext{
${ }^{3} \mathrm{Az}$ oldal, mely magyar nyelven is elérhető (www.monasterium.net), olyan hazai és a történelmi Magyarországon, mai határainkon túli levéltárak anyagát is elérhetôvé teszi igen jó minőségben mutatva a források digitalizált formáját, melyek a MOL gyưjteményében, fekete-fehér, gyakran több darabból álló, s ezáltal körülményesen összeilleszthető részekből állnak.
} 
de a munka folyamatosságát és teljességre törekvését jelzi, hogy egyre több képanyag kerül fel, a levéltári mutatók pedig szinte teljesnek mondhatók.

Szervesen kapcsolódik az oklevelek digitális formában való elérhetővé, vizsgálhatóvá válásához a pecsétleírások technikájában beiktatott változtatás. Az eddigi kötetekhez a pecsétleírásokat a MOL munkatársai készítették, azonban tekintettel az erre fordítható anyagi keret szúkösségére — pontosabban hiányára — és a pecsétek immár bárki számára történő elektronikus hozzáférhetőségére, megkíséreltem magam leírni azokat. Ehhez természetesen szakirodalmi fogódzókba is kapaszkodtam, ${ }^{4}$ azonban a fóbb tisztségviselők és a káptalanok, konventek pecsétjeinek leírásán túl nem merészkedtem, a megyei tisztviselők pecsétjeinek leírását - ebben való járatlanságom miatt — kénytelen voltam mellőzni.

Az alapvető nyersanyagot jelentő okleveleken kívül természetesen ebben a kötetben is feldolgozásra került az oklevelek azon köre, mely napjainkban csak valamiféle kiadásnak köszönheti fennmaradását. Ugyancsak külön egységenként kezeltem azokat az okleveleket, melyek pusztán említésük révén foghatók meg más oklevelekben. Mivel az Anjou-kori oklevéltár sorozatának kötetei nem egységesek e tekintetben, a sorozat első kötetében leírtak szerint eljárva emeltem ki és keltettem életre ezeket az iratokat. Ezen említések jó részében, szinte tökéletesen, apró részleteibe menően rekonstruálni lehet egy-egy elkallódott oklevelet, s éppen ezért nehéz elkülöníteni az említéseket a tartalmi átírásoktól. Kissé aránytalannak túnhet, hogy egy szinte minden pontjában ismert oklevelet az említések kategóriájába sorolok, tekintettel arra, hogy pontos dátuma nem ismert, de megfontolva azt, hogy pusztán a felszínre került információk mennyisége alapján meglehetősen szubjektív lenne döntést hozni, így a dolgozatban szereplók oklevelek közül csak azokat "minősítettem" tartalmi átírásnak, amelyek keltének dátuma egyértelmúen kiolvasható az iratból, s azok,

\footnotetext{
${ }^{4}$ Takács Imre: A magyarországi káptalanok és konventek középkori pecsétjei. Budapest, 1992.; Bodor Imre (szerk.): A középkori Magyarország fópapi pecsétjei a Magyar Tudományos Akadémia Múvészettörténeti Kutató Csoportjának pecsétmásolat-gyủjteménye alapján. Budapest, 1984.
} 
melyek terminus-a bizonyos határok között mozog, ill. bizonyos időpont előttre vagy utánra tehető említésként kerültek regisztrálásra.

Abban az esetben, ha egy napon több oklevél került kibocsátásra, a következő szabályt vettem az egymás utániság sorrendjének alapjául: "Az ugyanazon napra vonatkozó oklevelek sorrendjét a következő hierarchiához kell igazítani: pápa, magyar uralkodó, külföldi uralkodó, dinasztia tagjai, legátusok, pápai tisztviselők, magyar egyháznagyok, érsekek, püspökök, hiteles helyek, érseki, püspöki vikáriusok, országos világi tisztségviselők, megyék, városok, alacsonyabb szintű közösségek, facér egyháziak, közönséges papok, alacsonyabb rangú helyi világi tisztségviselôk (pl. várnagyok, földbírák, közjegyzők), magánosok."5

A dolgozathoz tartozó bibliográfia terjedelme mutatja, hogy igen széles forrásbázisra épít a sorozat, azonban az 1980-as években kezdett, a kiadásban elérhető forrásanyag feldolgozására irányuló gyưjtés nem állhat meg. Az újonnan publikált szakmunkák, forráskiadások folyamatos figyelemmel követése nemcsak nagy terhet ró a szerkesztőkre, hanem egyszersmind meg is könnyíti munkájukat, hiszen sokszor olyan szempontra, apró részletre vagy addig ismeretlen momentumra hívják fel a figyelmet, melynek ismerete jobbá, pontosabbá, teljesebbé teheti a készülő kötetet. Természetesen koránt sem olyan idilli a helyzet, ahogyan az első olvasatra tûnhet, hiszen a listában található bibliográfiai tételek helyben való elérhetősége, hozzáférhetősége igencsak korlátozott.

A sorozat elindultakor elsősorban — és érthető módon — a Károly király uralkodása szempontjából releváns anyag gyưjtése folyt a legnagyobb intenzitással, így pl. több kötetes könyvek, külföldről rendelt szakmunkák esetében a Lajoskori anyag beszerzésére nem került sor. Többek között ezért kezdtem hozzá jelen munka, és a sorozat valamennyi kötete készítése közben haszonnal forgatható sajátos bibliográfia elkészítéséhez. Ennek lényege, hogy a felsorolt tételeket

\footnotetext{
${ }^{5}$ Az idézet Almási Tibortól származik (s neki ez úton is köszönöm), aki Kristó Gyula professzor egykori szóbeli közlését vetette papírra és tekinti mérvadónak köteteiben. Talán nem haszontalan végre lejegyezni.
} 
igyekeztem fellelni a világhálón, s ezen elérhetôségeket rögzítettem. ${ }^{6}$ Az évek során rábukkantam néhány fontosabb, külföldi és hazai adatbázisra, melyekben a kérdéses anyag nagy része megtalálható. ${ }^{7}$ Ezen felül a Magyar Ösztöndíj Bizottság pályázatai révén több külföldi levéltárban és könyvtárban folytathattam kutatásaimat, ${ }^{8}$ melynek célja nem elsősorban egy konkrét kötethez, hanem a sorozat egészéhez való anyaggyújtés volt. Azért sem szabad elhanyagolnunk a külföldön elérhető források és szakirodalom jelentőségét, mivel a Lajos-kor éveinek feldolgozása közben a szerkesztớk egyre inkább szembesülni fognak azzal a ténnyel, hogy a király intenzív külpolitikájának — gondoljunk méltán nevezetes hadjárataira, kiterjedt diplomáciai kapcsolataira vagy a lengyel trónhoz fonódó mind szorosabb kötelékre — köszönhetően jelentős magyar vonatkozású forrásanyag "lappang" külföldi levéltárakban, forráskiadásokban. Mind a külföldi levéltárak, mind a könyvtárak anyaga, kutatóik szakértelme szükséges, és a sorozat egésze szempontjából hosszú távon elengedhetetlen a valóban teljes-

\footnotetext{
${ }^{6}$ Tekintettel arra, hogy ezek gyakran igen hosszú linkek, nem tartottam célszerúnek nyomtatott formában való rögzítésüket és közzétételüket a kötet lapjain, de természetesen minden érintetthez eljuttatom, s bárkivel szívesen megosztom.

${ }^{7}$ A teljesség igénye nélkül említenék néhány jelentősebbet: A hazaiak közül a Magyar Országos Levéltár honlapján, A középkori Magyarország digitális könyvtára; a Pécsi Tudományegyetem Könyvtárának digitális könyvtára, a KlimoTheca; a Magyar Elektronikus Könyvtár; a folyóiratokban történő eligazodást, s a konkrét lapszámokhoz való hozzáférést segítő MATARKA (Magyar folyóiratok tartalomjegyzékeinek kereshetố adatbázisa). A külföldiek közül a Bayerische Staats Bibliothek oldalán elérhetố digitális gyứjteményt, mely külső elérhetőségekkel is kapcsolatban van; az ugyancsak hatalmas anyaggal rendelkezó Internet Archive lapját; a cseh történelem szempontjából releváns középkori forrásokat felvonultató Centrum Medievistických Studií honlapját; a lengyel források vonatkozásában jelentős Kujawsko-Pomorska Biblioteka Cyfrowa oldalát; s folytathatnánk a sort.

${ }^{8}$ A Varsói Állami Levéltárban (AGAD), nemzeti- és egyetemi könyvtárban, továbbá Haus-, Hof- und Staatsarchiv; Hofkammerarchiv; Österreichische Nationalbibliothek; Universitäts Bibliothek Wien), a vilniusi nemzeti és egyetemi könyvtárban (Lietuvos Nacionalinė Martyno Mažvydo Biblioteka; Vilniaus Universiteto Biblioteka), a brnoi városi és tartományi levéltárban (Archiv Mesta Brna, Moravský zemský archiv v Brne), a Prágai nemzeti levéltárban és nemzeti múzeum levéltárában (Národní Archiv Praha; Archiv Národního Muzea), az egyetemi, nemzeti és akadémiai könyvtárban (Univerzita Karlova v Praze; Národní knihovna České republiky, Knihovna Akademie Ved České republiky), valamint az Olomouci megyei levéltárban (Zemský archiv v Opavě, pobočka Olomouc).
} 
ségre törekvő munka elkészítéséhez. Számos olyan adatbázist is módomban állt időlegesen használni, melyek csak adott intézményekben ill. térítés ellenében használhatóak. Ezek közül egyet emelnék ki — a Brepolis Publisher honlapján át elérhető "Ut per litteras apostolicas..." adatbázist, melynek révén elérhetővé válik a pápai oklevelek Anjou-kori oklevéltár sorozatának kötetei szempontjából is fontos és használt kiadványa, a Registres et lettres des Papes du XIVe siécle 48 kötete — s ezzel át is térnék a következő fejezetre, a dolgozat fóbb eredményeinek ismertetésére. 


\subsection{A feldolgozás fóbb eredménye}

Mint minden — a sorozatban megjelent — kötetnek, úgy ennek a kiadás előtt álló munkának is megvannak a maga "vívmányai". Azok a nagyszabású munkák, melyek a középkori írott forrásokra támaszkodva, ám azokat —értelemszerúen - a feldolgozottság mértéke szerint kiaknázva készültek, elsősorban oklevél kiadásokra támaszkodva, számos olyan hibát vagy hiányosságot rejtenek, melyek az aprólékos forrásfeltáró munka során kerülnek felszínre. Így az egyes országos méltóságok hivatalviselésével kapcsolatban a szakirodalomban Engel archontológiájára ${ }^{9}$ támaszkodva általánosan elfogadott adatok pontatlansága, eddig nem ismert adatok napvilágra kerülésével korrigálható (ahogyan erre ebben a dolgozatban is van példa). Találhatunk egy ennél sokkal sajátságosabb, érdekesebb problémát is az 1356-os év pápai okleveles anyagának feldolgozása során, s itt kapcsolódnék vissza az előző fejezet végén félbehagyott gondolatmenethez. A tárgyalt idôszak pápai okleveleinek feldolgozásához elsősorban a MOL Diplomatikai Fényképgyújiteményében található pápai regisztrum kötetekrôl készült fényképek biztosítják a nyersanyagot. ${ }^{10}$

Tudvalévő, hogy az az igen intenzív levelezés, mely az időszakunkban Avignonban székelő pápai kúriát kötötte össze a korabeli keresztény világgal, s így a Magyar Királysággal is, csak kis százalékában maradt fenn eredeti oklevelek formájában, nagyrészt regisztrum kötetek bejegyzéseiból ismerjük őket. Annak a hatalmas anyagnak a feldolgozása, amelyet a Vatikán levéltárai rejtenek már

\footnotetext{
${ }^{9}$ Engel Pál:Magyarország világi archontológiája : 1301-1457. Budapest, 1996.

${ }^{10}$ Emellett természetesen a kiadásban fellelhetô iratanyag feldolgozása is elengedhetetlen az Anjoukori oklevéltár sorozatának célkitúzéséhez igazodva. Az 1350-es évek pápai okleveleinek feldolgozásához nélkülözhetetlen francia forráskiadó sorozat megjelent kötetei a követezők:Lettres secrètes et curiales Innocent VI. (1352-1362). Eddig 6 kötetben látott napvilágot 1959 és 2006. között; Suppliques d'Innocent VI. (1352-1362). Institut historique belge de Rome. Bruxelles, 1911.; Acta Innocentii PP. VI. 1352-1362. e regestis Vaticanis aliisque fontibus collegit Aloysius L. Tautu. Romae, 1961. Ezen felül az egyes országok pápai okleveleinek feldolgozását végző vállalkozások vonatkozó kötetei tartalmazhatnak magyar vonatkozású adatokat, pl. Augustinus Theiner: Vetera monumenta historica Hungariam sacram illustrantia. I-II.; Acta Pataviensia Austriaca : vatikanische Akten zur Geschichte des Bistums Passau und der Herzöge von Österreich (1342 - 1378). 2. Innocenz VI. : (1352 - 1362) Hrsg. Lenzenweger, Josef. Wien, 1992.; 1. bibliográfia.
} 
évszázadok óta zajlik, s hivatalosan 1881-ben XIII. Leó pápa jóvoltából vált a történeti kutatások számára nyitottá. ${ }^{11}$ A magyar történeti vonatkozású forrásokban bővelkedő anyag kiaknázása is igen korán megkezdődött és anélkül, hogy ennek részleteire kitérnék, csak néhány jelentősebb nevet említenék, akiknek tevékenysége évkörünk okleveles anyagához is szorosan kacsolódik. Kiállta az idő próbáját, és manapság is példaértékủ Theiner Ágoston több kötetnyi forráskiadása, ahogyan Fraknói Vilmos tudása, felkészültsége, szervező géniusza is komoly nyomokat hagyott — többek között a Monumenta Vaticana Hungariae köteteinek lapjain — történetírásunkban, s napjaink Rómában zajló kutatásait is megalapozta. ${ }^{12}$ Fraknói nagyszabású, a kor jeles tudósait felvonultató, a vatikáni levéltár magyar vonatkozású — s elsősorban középkori — forrásait feltáró vállalkozásához kapcsolódik Áldásy Antal 1892-93 telén Rómában végzett kutatómunkája, mely "az V. Márton pápa idejéből fennmaradt supplicatiók regesztáinak átkutatására, s a magyarországi vonatkozásúak kijegyzésére irányult", 13 s melynek másodlagos hozományaként tekinthetünk a Történelmi Tár hasábjain megjelent, majd különlenyomat formájában is napvilágot látott "Regesták a Vatikáni Levéltárból" gyưjteményt. ${ }^{14}$ Disszertációm szempontjából azért tartottam érdemesnek pont ezt a momentumot kiemelni, mivel ezen Áldásy-féle kiadvány kapcsán merültek fel sorozatos problémák. Áldásy lényegretörő regesztái közül számos beazonosítására, a MOL anyagában lévő fotókópiával való összekapcsolására sikerrel tettem kísérletet, azonban a regeszták egy ugyancsak nem elhanyagolható százalékánál ilyen irányú erőfeszítéseimet nem koronázta siker. Némelyeknél a szövegben szereplő személyek neve, adott politikai események leírása egyértelmúen azt mutatta, hogy a kapcsolódó oklevél ill. azt fenntartó

\footnotetext{
${ }^{11}$ Érszegi Géza: A Curia Romana középkori levéltárai. Levéltári Szemle 28 (1978) 321-329.

${ }^{12}$ A Vatikánban folyó magyar történeti források kiaknázására összpontosuló kutatások alapos, szakirodalmi hivatkozásokkal bőven ellátott írás legfrissebben Tusor Péter tollából Collectanea Vaticana Hungariae. Classis I. Vol. I. "Magyarország mint a nyugati keresztény múvelődés védóbástyája" : a Vatikáni Levértárnak azok az okiratai, melyek őseinknek a Keletről Európát fenyegető veszedelmek ellen kifejtett erőfeszítéseire vonatkoznak: cca 1214-1606. Összegyújtötte és kiadásra rendezte Artner Edgár. Közreadja Szovák Kornél, Török József és Tusor Péter. Bp., Róma 2004. XV-CXVI.

${ }^{13}$ Áldásy Antal: Olaszországi történelmi kutatások. Magyar Könyvszemle 1 (1892-93) 240.

${ }^{14}$ Történelmi Tár 17 (1894) 15-28; 18 (1895) 58-89, 260-288.
} 
regisztrum bejegyzés nem készülhetett 1356-ban, azaz VI. Ince pápaságának 4. évében. A késóbbiek során Karácsonyi János könyvét ${ }^{15}$ kézbe véve szembesültem azzal, hogy a disszonanciát, már mások is észlelték, azonban a Karácsonyinál található jegyzék az Áldásy által tévesen 1356-ra keltezett oklevelek vonatkozásában nem teljes. Áldásy közlésében a 206. számú, 1356. jan. 7-re keltezett pápai oklevéltől a 266. számot viselő, 1356. dec. 27-én kiadott oklevél regesztája szerepel évkörünkből. Közülük tizenegyról ${ }^{16}$ bizonyította be Karácsonyi, hogy tévesen lettek ide sorolva. Ezen felül további, sem a MOL anyagának vonatkozó évéhez, sem az ismert kiadások adott évkörhöz tartozó hivatkozásaihoz nem köthető regeszták kiszúrésére, esetlegesen tényleges datálásukhoz való kapcsolására került sor.

Első körben, amikor a hiba okát próbáltam felfedni, "a pápasága 4. éve" évjelölésben rejlő félreértés lehetőségét mérlegelve a VI. Incét követő pápák (V. Orbán (1362-1370); XI. Gergely (1370-1378)) ill. pontificatus-uk 4. éve merültek fel, de ez a feltételezésem csak kis mértékben igazolódott be. Végül Áldásy maga adta kezembe a megoldás kulcsát a már idézett kutatási beszámolójában: "VI. Incze pápától fennmaradt összesen 24 kötet vatikáni, 29 kötet avignoni regesta, és 13 kötet breve, eredeti fogalmazványban....... A mi a brevéket illeti, VI. Ince brevéi 13 kötetet töltenek meg, a 244 A- 244 N jelzetúeket. Ezek nagy, folio alakú kötetek melyekbe a brevék egymás alá és mellé vannak beragasztva. A brevéket ugyanis hosszabb-rövidebb kutyanyelvalakú papirosra írták s ezeket egymás mellé ragasztották. Egy lapon rendesen két breve van egymás alá ragasztva, néha három, a milyen nagy épen a terjedelmük....... A papír csak egyik felén van beírva, hátlapján rendesen rövid tartalommal....... Lapszámozás nincsen, hanem a brevék maguk vannak számozva, arab számjegyekkel. A kötetek erős táblájú hártya-kötésbe vannak kötve, hátlapon alul az új levéltári jelzettel, fent pedig a tintával írt,meglehetősen elhalványodott régibb jelzettel: Innoc. VI. Ar-

\footnotetext{
${ }^{15}$ Karácsonyi János: A hamis, hibás keltú és keltezetlen oklevelek jegyzéke 1400-ig. Budapest, 1902. 80-81. [A Történelmi Tár 1908. évi számában megjelent pótlásokkal kiegészítve] A kötetet szerkesztette és az előszót írta: Koszta László. Szeged, 1988.

${ }^{16} 206,209,210,211,226,254,256,260,261$, 264, 265 számúak.
} 
chet. epist. kötetszámmal. A papírlapok egymáshoz illesztésében a chronologiai rend nincs betartva, sôt gyakran találhatók más pápától brevék, pl. V. Orbántól brevék VI. Incze brevéi között."17 Sőt — tehetnénk hozzá utólag —XI. Gergelytől is, ahogyan igazolja ezt egy Áldásy által 1356. szept. 22-re keltezett bejegyzés, melyben a pápa Johanna szicíliai királynóhöz intézett levelének tartalma olvasható, miszerint Lajos király Franciaországból visszatérő követei, István zágrábi püspök és Zudar Péter szlavón bán — akik a magyar király egyik leányának a francia király másodszülött fiával kötendő frigyének részleteiról tárgyaltak az udvarral — felkeresték a pápai kúriát is, ahogyan ennek részletei is leírattak. ${ }^{18}$ A tévesen datált regeszták között túlnyomó többségben vannak azok, melyek az idézettben említett "brevék" jelzeteire hivatkoznak. Ezeken túlmenően két, 1356. jan. 12-i dátummal szereplő feljegyzést sikerül 1357-re helyezni a megjelölt hivatkozása alapján, s azonosítani az ASV. Reg. Av. v. 135., f. 52v és 113r-v (Df. 289540 és 289 543.) jelzetú dokumentumokkal.

Ezeken túlmenően számos érdekes és értékes adat található a kötetben, s reményeim szerint - kisebb átdolgozás és kiegészítés révén, a névmutató hozzákapcsolásával — érdemes arra, hogy az Anjou-kori oklevéltár méltán híres sorozatának köteteit gyarapítsa.

\footnotetext{
${ }^{17}$ Áldásy Antal: Olaszországi történelmi kutatások. Magyar Könyvszemle 1 (1892-93) 249-250.

${ }^{18} 256$. számú regeszta.
} 


\section{INDEX ABBREVATIONUM (Rövidítések jegyzéke)}

\subsection{Archiva, libri, periodica (Levéltárak, könyvek, folyóiratok)}

Abaffy-Dancs-Hanvay = Ila Bálint-Borsa Iván: Az Abaffy család levéltára 12471515. A Dancs család levéltára 1232-1525. A Hanvay család levéltára 12161525. Bp., 1993. [MOL]

Abraham, Stanowisko $=$ W. Abraham: Stanowisko Kurii papieskiej wobec koronacj L̨okietka Księga pamiątkow Uniwersytetu Lwowskiego. 1900.

Acta Albaniae = L. Thallóczy-Const. Jireček-Emil Šufflay: Acta et diplomata res Albaniae mediae aetatis illustrantia. I-II. Vindobonae, 1913-1918.

Acta Arch. = Acta Archaeologica Academiae Scientiarum Hungaricae. Bp., 1952-

Acta Bosnae $=$ Eusebius Fermendžin: Acta Bosnae, potissimum ecclesiastica cum insertis editorum documentorum regestis ab anno 925 usque ad annum 1752. Zagrabiae, 1892. [archive.org]

Acta Clementis VI. = Aloysius L. Tăutu: Acta Clementis PP. VI. Vatican, 1960.

Acta Innocentii VI. = Acta Innocentii PP. VI. 1352-1362. e regestis Vaticanis aliisque fontibus collegit Aloysius L. Tautu. Romae, 1961.

Acta Gent. = Acta legationis cardinalis Gentilis. Gentilis bíbornok magyarországi követségének okiratai. 130-311. Budapestini, 1885.

Acta Kegl. = Acta Keglevichiana. Zagrabiae, 1917.

Acta Pataviensis = Acta Pataviensia Austriaca : vatikanische Akten zur Geschichte des Bistums Passau und der Herzöge von Österreich (1342 - 1378). 2. Innocenz VI. : (1352 - 1362) hrsg. Lenzenweger, Josef. Wien, 1992.

Adatok = Kandra Kabos-Leskó József (szerk.): Adatok az egri egyházmegye történelméhez. I-IV. Eger, 1885-1908.

Adler = Jarbuch der Kais. Kön. Heraldischen Gesellschaft Adler. Wien, 18711916.

AECO = Archivum Europae Centro Orientalis. Bp., 1935-1944.

AGAD = Archiwum Główne Akt Dawnych w Warszawie

AH. $=$ Archiv Hrvatske. Zagreb.

AHA. $=$ Acta Historiae Artium. Bp., 1953-.

A. HAZU. = Archiv Hrvatske Akademije Znanosti i Umjetnosti. Zagreb (Zágráb).

AIR = Arhiva Istorică a României. Serie nouă. Vol. I. nr. 1. Bucureşti, 2004.

AJ. = Arhivă judeţeană.

Akad. Ért. = Akadémiai Értesítő. 
AKÖG. = Arch. f. Kunde Öst. Gesch. Archiv für Kunde Österreichischer Geschichtsquellen. I-XXXIII. Wien 1848-1865. (folytatása: Archiv für Österreichische Geschichte. XXXIV-CXV. Wien 1865-1941).

AL. = Akadémiai Levéltár. Cluj-Napoca (Kolozsvár).

Alapi = Alapi Gyula: Regeszták Komárom város levéltárából. Nemzeti Kultúra 1934.

Áldásy = Áldásy Antal: Regesták a vatikáni levéltárból. Bp., 1895. [KlimoTheca]

Áldásy, Czímereslevelek = Áldásy Antal: A Magyar Nemzeti Múzeum könyvtárának czímereslevelei. I-II. Bp., 1904-1923. [MOL; arhive.org]

Almási, Vasvár = Almási Tibor: A vasvári káptalan 1328-ban átírt oklevelei. In:"Magyaroknak eleirool”. Ünnepi tanulmányok a hatvan esztendős Makk Ferenc tiszteletére. Szerk. Piti Ferenc-Szabados György. Szeged, 2000. 1-8.

Alsó-fehér vm. Évk. = Az Alsó-Fehér vármegyei Történelmi, Régészeti és Természettudományi Egylet Évkönyve. Gyulafehérvár, 1888-908.

Alsószlavónia = Thallóczy Lajos-Horváth Sándor: Alsó-Szlavóniai okmánytár (Dubicza, Orbász és Szana vármegyék). Codex diplomaticus partium regno Hungariae adnexarum (Comitatuum Dubicza, Orbász et Szana) 1244-1710. (Magyarország melléktartományainak oklevéltára III.124-718.) Bp., 1912. [KlimoTheca; archive.org]

AM. = Archiv mesta.

AMB. Inventár = Archív mesta Bratislavy. Inventár stredovekých listín, listov a iných pribuzných písomností. Praha, 1956.

Amlacher $=$ A. Amlacher: Urkundenbuch zur Geschichte der Stadt und des Stuhles Broos bis zum Übergang Siebenbürgens unter Erbfürsten aus dem Hause Österreich. Hermannstadt, 1879.

AMP. = Acta Mvsei Porolissensis .

AN. = Arhiv nadbiskupije. Zagreb (Zágráb).

Anjou-oklt. = Anjou-kori oklevéltár. Documenta res Hungaricas tempore regum Andegavensium illustrantia. Bp.-Szeged, 1990-. [MOL; eruditio]

Antal, Szolnok = Antal Árpád: Olvasókönyv Szolnok megye történetéhez. Szolnok,1969.

AO. = Nagy Imre-Tasnádi Nagy Gyula: Anjoukori Okmánytár. Codex diplom. Hungaricus Andegavensis. I-VII. Bp., 1878-1920. [MOL; archive.org]

AÖG. = Archiv für Österreichische Geschichte. Wien, 1865-.

AP. = Acta Paulinorum. Magyar Országos Levéltár. Bp., Kamarai Levéltár. E. 153.

Apponyi = A Pécz nemzetség Apponyi ágának az Apponyi grófok családi levéltárában ốrizett oklevelei. I. 1241-1526. Bp., 1906. [MOL]

Arch. Ért. = Archaeologiai Értesítő. Pest-Bp., 1869-

Arch. Közl. = Archaeologiai Közlemények. Pest-Bp., 1859-1899. 
Archiv $=$ Archiv des Vereins für siebenbürgische Landeskunde. HermannstadtKronstadt 1843-1852; Neue Folge: Kronstadt-Hermannstadt-Bistritz, 18531944.

Archivum = Archivum. A Heves Megyei Levéltár Közleményei. Eger, 1973-.

Archivum CRB = Archivum Coronae Regni Bohemiae

Arkiv = Arkiv za povestnicu Jugoslavensku. Zagreb, 1851-1898. [archive.org]

Árpádia = Kovacsóczy Mihály: Árpádia. Honi történetek zsebkönyve. Kassa,18331838.

ASV. $=$ Archivio Segreto Vaticano. Roma

Auner = Auner Mihály: Az erdélyi szászok oklevelei a XV. század kezdetéig. Beszterce, 1912.

AUSZ. AH. = Acta Universitatis Szegediensis de Attila József nominatae. Acta Historica. Szeged, 1957-.

AV. $=$ Archivio Vaticano. Roma

AVPT. = Adalékok a veszprémi püspökség történetéhez. I-II. Veszprém, 19011903.

AZ = Archivalische Zeitschrift. Stuttgart-München. Alte Folge: 1876-1888.; Neue Folge: 1890-0914.; Dritte Folge: 1915-.

AZVM. = Adalékok Zemplén-vármegye történetéhez. I-XXII. Sátoraljaújhely, 1895-1917.

Ba. = Batthyaneum. Alba Iulia (Gyulafehérvár).

Bács-Bodrog mon. = Bács-Bodrog vármegye egyetemes monográfiája. I. Zombor, 1896.

Bács-Bodrog vm. Évk. = A Bács-Bodrog vármegyei Történelmi Társulat Évkönyve. Zombor, 1888-1890.

Bakács, Pest megye = Bakács István: Iratok Pest megye történetéhez. Oklevélregeszták 100-437. Bp., 1982. [MOL]

Balassa = Fekete Nagy Antal-Borsa Iván: A Balassa család levéltára. 1193-1526. Bp., 1990. [MOL]

Balássy, Heves vm. = Balássy Ferencz-Szederkényi Nándor: Heves vármegye története. I. Eger, 1897.

Balla, Nagykörös = Balla Gergely: Nagykörösi krónika. Jegyzetekkel és oklevéltárral ellátva kiadták Szabó Károly és Szilágyi Sándor. Kecskemét, 1856.

Balogh, Középk. okl. = Középkori oklevelek a Szabolcs-Szatmár-Bereg Megyei Levéltárban. Összegyưjtötte, átírta Balogh István. Szerk.: Érszegi Géza. Nyíregyháza, 2000. [MOL]

Balogh, Varadinum = Balogh Jolán: Varadinum. Várad vára. II. Múvészettörténeti füzetek. 13/2. Bp., 1982.

Balogh-Németh, Szabolcs-Szatmár = Szabolcs-Szatmár megyei történelmi olvasókönyv. Nyíregyháza, 1970. 
Bánffy = Varjú Elemér-Iványi Béla: Oklevéltár a Tomaj nemzetségbeli losonczi Bánffy család történetéhez. I-II. Bp., 1908-1928. [MOL]

Bar. ht. = Baranyai helytörténetírás. Pécs, 1967-.

Bar. tí. = Baranyai történetírás. Pécs.

Bárány, Torontál vm. = Bárány Ágoston: Torontálvármegye' hajdana. II. Oklevelek. Buda, 1845.

Bárdosy, Moldav. = Joannes Bárdosy: Moldavensis vel Szepsiensis decimae indagatio et huic innexarum sacroprofanarum iurisdictionum evolutio. Posonii, 1802. [HathiTrust]

Bárdosy, Suppl. = Joannes Bárdosy: Supplementum analectorum terrae Scepusiensis I. Leutschoviae, 1802.

Bars = Botka Tivadar: Bars vármegye hajdan és most. I. Regesták és okmányok. II. osztály. Latin okmányok. Pest, 1868.

Bartal = Bartal Aurél: A beleházi és ethekarchai Bartal család. Karcag, 1937.

Bartal, Comment. = Georgius Bartal de Beleháza: Commentariorum ad historiam status jurisque publici Hungariae aevi medii libri XV. I-III. Posonii, 1847.

Bartal, Karcsaiak = Bartal Aurél: A csallóközi Karcsák és Karcsaiak a középkorban. 1941.

Bártfai Szabó, Óbuda = Bártfai Szabó László: Óbuda egyházi intézményei a középkorban. Bp., 1935.

Bártfai Szabó, Széchényi = Bártfai Szabó László: A sárvár-felsővidéki gróf Széchényi család története. I. Bp., 1911. [MOL]

Bátorfy, AZMT. = Bátorfy Lajos: Adatok Zala megye történetéhez. I-V. Nagykanizsa, 1876-1878.

Batthyány, Leges eccl. = Ignatius de Batthyan: Leges ecclesiasticae regni Hungariae et provinciarum adiacentium. I-III. Albae Carolinae-Claudiopoli, 17851827. [BSB]

BAZML. = Borsod-Abaúj-Zemplén Megyei Levéltár. Miskolc.

Ber. Wr. Akad. = Akademie der Wissenschaften. Philosophisch-historische Klasse. Sitzungsberichte. Wien, I-, 1848-.

Bedy = Bedy Vincze: A győri székeskáptalan története. 1938.

Beke $=$ Beke Antal: Az erdélyi káptalan levéltára Gyulafehérvárt. Bp., 1896. [KlimoTheca]

Beke, Czímjegyzék = Beke Antal: A gyulafehérvári káptalani levéltárnak czímjegyzéke.Bp., 1884.

Beke, Kolozsmonostor = Beke Antal: A kolozsmonostori konvent levéltára. Bp., 1898. [KlimoTheca]

Békefi, Balaton = Békefi Remig: A Balaton környékének egyházai és várai a középkorban. Bp., 1907. 
Békefi, Czikádor = Békefi Remig: A czikádori apátság története. Pécs, 1894.

Békefi, Kápt. Iskolák = Békefi Remig: A káptalani iskolák története Magyarországon 1540-ig. Bp., 1910.

Békefi, Népoktatás = Békefi Remig: A népoktatás története Magyarországon 1540-ig. Bp., 1906.

Békefi, Pásztó = Békefi Remig: A pásztói apátság története [I-II.]. A pásztói apátság oklevéltára [III.]. Bp., 1898-1902. [archive.org]

Békés I. = Lud. Aug. Haan: Diplomatarium Békessiense. Békés vármegye hajdana II. Pestini, 1870.

Békés II. = Haan Lajos-Zsilinszky Mihály: Békésmegyei oklevéltár számos, hazánk beltörténetére vonatkozó adatokkal. Bp., 1877.

Békés vm. Évk. = A Békésvármegyei Régészeti és Múvelődéstörténeti Társulat Évkönyve. Gyula, 1874-1897.

Békeszerződések = Köblös József-Süttő Szilárd-Szende Katalin: Magyar békeszerződések 1000-1526. Pápa, 2000.

Bél M., Not. = Bél, M.: Notitia Hungariae novae historico-geographica. I-V. Vindobonae, 1735-1742. [google]

Benedek-Zádorné = Benedek Gyula-Zádorné Zsoldos Mária: Jász-NagykunSzolnok megyei oklevelek 1075-1526. Jász-Nagykun-Szolnok Megyei Levéltár Közleményei 3. Szolnok, 1998. [MOL]

Beniczky Album = Dugovich Titus: Beniczky Album. Beniczky Kálmán Turócz vármegye alispánjának huszonöt éves alispáni jubileuma alkalmából. Turócszentmárton, 1913.

Benkó, Farkas cs. = Benkó Imre: Az inárcsi Farkas család története. Nagykőrös, 1903.

Ber. U. Mitt. Wr. Altertums Ver. = Berichte und Mitteilungen des AltertumsVereines zu Wien. Wien, 1856-1918.

Berger $=$ Albert Berger: Urkunden-Regesten aus dem alten Bistritzer Archive von 1203 bis 1490. Bistritz, 1893. [archive.org])

Berger-Wagner $=$ Albert Berger-Ernst Wagner: Urkunden-Regesten aus dem Archiv der Stadt Bistritz in Siebenbürgen 1203-1570. I. Köln-Wien, 1986. [BSB]

Bertényi = Bertényi Iván (szerk.): Magyar történeti szöveggyưjtemény 10001526. Bp., 2000.

Bessenyei = Széll Farkas: A nagybesenyői Bessenyei-család története. Bp., 1890.

BFL. = Bencés Főapátsági Levéltár. Pannonhalma.

Bgl. = Hans Wagner-Irmtraut Lindeck-Pozza et alii: Urkundenbuch des Burgenlandes und der angrenzenden Gebiete der Komitate Wieselburg, Ödenburg und Eisenburg. I-V. Graz-Köln-Wien, 1955-1999. [BSB]

Bibl. Acad. = Biblioteca Academiei. Bucureşti. 
Bl. f. Ldeske. V. Ndöst. = Blätter des Vereins für Landeskunde von Niederösterreich.

Blagay = Thallóczy Lajos-Barabás Samu: A Blagay-család oklevéltára. Codex diplomaticus comitum de Blagay. Bevezetô tanulmánynyal a család történetéhez. Bp., 1897. [MOL]

Blazovich, Csongrád = Blazovich László (szerk.): Csongrád megye évszázadai. Történelmi olvasókönyv I. Szeged, 1985.

BLÉ. = Borsodi Levéltári Évkönyv. 1977-.

Bodócs, Hetényegyháza = Bodócs Gyula: Történelmi okmányok Hetényegyháza nevének és helyének megállapításához (134-512). Kecskemét, 1960.

Bodor = Bodor Imre (szerk.): A középkori Magyarország főpapi pecsétjei a Magyar Tudományos Akadémia Múvészettörténeti Kutató Csoportjának pecsétmásolat - gyứjteménye alapján. Bp., 1984.

Bogdan = I. Bogdan: Documente privitoare la relaţiile Ţării Româneşti cu Braşovul. Bucureşti, 1905.

Bolla-Rottler $=$ Bolla Ilona és Rottler Ferenc: Szemelvények az 1526 előtti magyar történelem forrásaiból. I. Bp., 1974.

Bónis-Balogh = Bónis György: Szentszéki regeszták. Iratok az egyházi bíráskodás történetéhez a középkori Magyarországon. A szerző hátrahagyott kéziratát gondozta és szerkesztette: Balogh Elemér. Szeged, 1997.

Borovszky, Borsod = Borovszky Samu: Borsod vármegye története a legrégibb időktôl a jelenkorig. I. Bp., 1909.

Borovszky, Csanád vm. tört. = Borovszky Samu: Csanád vármegye története 1715-ig. I. Budapest, 1896. [archive.org]

Bors, Kunszentmiklós = Bors Károly: Kunszentmiklós város történelmi adatai. Kunszentmiklós, 1892.

Bory = Gregorich Mária: A bori és borfői Bory család és levéltára. Családtörténeti éslevéltári tanulmány. Szeged, 1935. [MOL]

Botka, Chák Máté = Botka Tivadar: Trentsini Chák Máté és kortársai. Ért. Tört. Tud. III. 4. Bp., 1873.

Böhmer = Johann Friedrich Böhmer: Regesta chronologico-diplomatica regum atque imperatorum Romanorum inde a Conrado I. usque ad Heinricum VII. Frankfurt, 1831. (911-1313) [BSB]

Böhmer, Reg. Imp. = Johann Friedrich Böhmer: Regesta Imperii inde ab anno MCCCXIIII usque ad annum MCCCXLVII. [Reg. Imp. VII.] Francofurti, 1839. [Additamentum I-III. 1841-1865.] [RI]

Böhmer, Wittelsbach. Reg. = Böhmer, Johann Friedrik: Wittelsbachische Regesten von der Erwerbung des Herzogtums Baiern 1180 bis zu dessen erster Wiedereinigung 1340. In Oberbaiern bis auf Fudolfs I. Tod 1319 und Ludwigs des Baiern Königswahl1314, in Niederbaiern bis auf erlöschen der ersten niederbaierischen Linie 1340. Stuttgart, 1854. 
Bp., I. = Budapest történetének okleveles emlékei. Monumenta diplomatica civitatis Budapest. I. Csánky [!] Dezső gyưjtését kiegészítette és sajtó alá rendezte Gárdonyi Albert. Bp., 1936. [MOL]

Bp. Szml. = Budapesti Szemle. Bp. 1873-1944.

Brüsztle = Josephus Brüsztle: Recensio universi cleri dioecesis Quinqueecclesiensis. I-IV. Quinque-Ecclesiis, 1874-1880.

Bucko $=$ V. Bucko: Reformné hnutie v arcibiskupstve ostrihomskom do r. 1564 . Bratislava, 1939.

Bud. rég. = Budapest régiségei. Bp., 1955-.

Buday, 1912. = Buday Károly: A magyar múvelődés a XIV. század első felében. Bp., 1912.

Bull. Pol. = Irena Sulkowska-Kuraś-Stanisław Kuraś: Bullarium Poloniae. I. 10001342. Romae, 1982.

Buny. = Bunyitai Vincze: A váradi püspökség története alapításától a jelenkorig. I-III. Nagy-Várad, 1883-884.

BV. = Bibliotheca Vaticana. Roma.

Capitulum = Capitulum I. Tanulmányok a középkori magyar egyház történetéból. Szerk. Koszta László. Szeged, 1998.

CD. Boh. $=$ Codex diplomaticus et epistolaris regni Bohemiae. I-. Pragae, 1904. [archive.org]

CD. majoris Pol. = Codex diplomaticus majoris Poloniæ documenta, et jam typis descripta, et adhuc inedita annum 1400 attingentia. Kodeks Dyplomatyczny Wielkopolski. II. (1350-1359) Poznaniae, 1879. [archive.org]

CD. Mor. $=$ Codex diplomaticus et epistolaris Moraviae. I-XV. Olomucii-Brunae, (Brünn) 1836-1903. [cms; archive.org]

CD. Sil. = Codex diplomaticus Silesiae. I-XXXVI. Breslau, 1857-1933. [cms; poznan]

CDES. = Richard Marsina: Codex diplomaticus et epistolaris Slovaciae. I-II. Bratislavae, 1970-1987.

Cesca $=$ G. Cesca: La sollevazione di Capodistria nel 1348. Padova, 1882.

Chaloupecký = Václav Chaloupecký: Kniha Žilinská. Bratislava, 1934.

Chmel = Joseph Chmel: Der oesterreichische Geschichtsforscher. II. Wien, 1841.

Chorényi, Illava = Chorényi József: Illava okmánytára 1339-1526. Trencsén, 1896.

Cicogna, Memorie = Emmanuele Antonio Cicogna: Memorie tratte della Cronaca detta Berbo che data de 421 25. Marzo al 1547. Delle inscrizioni Veneziane raccole ed illustrate. VI. Venezia, 1853.

CJ. Boh. = Codex juris Bohemici. Korunní Archiv Česky (1306-1378). Praze, 1896. [archive.org]

Codex Strig. = Knauz Nándor: Az esztergomi főegyháznak okmánytára. I-II. Esztergom, 1863-1866. 
Coll. Vat. Hung. = Collectanea Vaticana Hungariae. Classis I. Vol. I. "Magyarország mint a nyugati keresztény múvelődés védőbástyája" : a Vatikáni Levértárnak azok az okiratai, melyek őseinknek a Keletről Európát fenyegető veszedelmek ellen kifejtett erófeszítéseire vonatkoznak : cca 1214-1606. Összegyưjtötte és kiadásra rendezte Artner Edgár. Közreadja Szovák Kornél, Török József és Tusor Péter. Bp., Róma 2004.

Commentarii $=$ Steyerer Anton: Commentarii pro historia Alberti II. Ducis Austriae cognomento Sapientis. Lipsiae, 1725. [BSB]

Czeglédy, Diósgyőr = Czeglédy Ilona: A diósgyőri vár. Bp., 1988.

Csáky = Oklevéltár a gróf Csáky család történetéhez. I. 1. rész. Bp., 1919. [MOL]

Csánki = Csánki Dezső: Magyarország történelmi földrajza a Hunyadiak korában. I-III., V. Bp., 1890-1913.

CSML. = Csongrád Megyei Levéltár. Szeged.

Csomor = Csomor Lajos: A kolozsmonostori benczés apátság és birtokai (1556ig). Kolozsvár, 1912.

Csöre, Erdôgazdálkodás = Csöre Pál: A magyar erdőgazdálkodás története. Középkor. Bp., 1980.

Deák-Gyimesi, Borsod = Deák Gábor-Gyimesi Sándor: Olvasókönyv BorsodAbaúj-Zemplén megye és Miskolc város történetéhez. Miskolc, 1965.

Decr. Hung. = Franciscus Döry-Georgius Bónis-Vera Bácskai: Decreta regni Hungariae. Gesetze und Verordnungen Ungarns. 1301-1457. Bp., 1976. [MOL]

Degré, Zala = Degré Alajos: Olvasókönyv Zala megye történetéhez. Zalaegerszeg, 1961.

Densuşianu $=$ Nic. Densuşianu-Eudoxiu de Hurmuzaki: Documente privitóre la istoria Românilor. I/-. Bucuresci, 1887-1890. [BSB]

Densuşianu, Făgăraş = Nic. Densuşianu: Monumente pentru istoria tierei Făgăraşiului. Bucureşti, 1885.

Déprez-Mollat, VI. Kelemen A. = E. Déprez-G. Mollat: Clément VI. (1342-1352) Lettres closes, patentes et curiales rapportant a la France. I-III. Paris, 19011959. [gallica]

Déprez-Mollat, VI. Kelemen B. = E. Déprez-G. Mollat: Clément VI. (134-352) Lettres closes, patentes et curiales intéressant les pays autres que la France. Paris, 1960. [gallica]

Despy $=$ Georges Despy: Lettres [Epistolae] d'Innocent VI. $<1352-1362>$. Textes et analyses. Bruxelles, 1953.

Df. = Magyar Országos Levéltár. Diplomatikai Fényképgyújtemény. Bp.

DHA = Györffy György: Diplomata Hungariae antiquissima. I. Bp., 1992.

D1. = Magyar Országos Levéltár. Diplomatikai Levéltár. Bp.

Doc. Art. Paulin. = Documenta Artis Paulinorum. A magyar rendtartomány monostorai. I-III. Bp., 1975-1978. 
Doc. Rom. Hist. $=$ Documenta Romaniae Historica. C. Transilvania. Vol. X-XIV.(13511375.) Bucureşti, 1977-2002.

Doc. Trans. $=$ Documente privind istoria României. Documenta Romaniae historica. Veacul XIV. C. Transilvania. I-XII. Bucureşti, 1953-1985.

Doc. Val. = Antonius Fekete Nagy-Ladislaus Makkai: Documenta historiam Valachorum in Hungaria illustrantia usque ad annum 1400 p. Christum. Bp., 1941.

Dogiel $=$ Mathias Dogiel: Codex diplomaticus regni Poloniae et magni ducatus Lituaniae. I., III-V. Vilnae, 1758-1759. [BSB; poznan]

Domanovszky, Szepesi városok = Domanovszky Sándor: A szepesi városok árumegállító joga. Lőcse és Késmárk küzdelme az árumegállításért. 13581570. Bp., 1922.

Dreska G., Pannonhalmi konvent I. = Dreska Gábor: A pannonhalmi konvent hiteleshelyi múködésének oklevéltára I. (1244-1398) Győr, 2007.

Dudik, Iter Rom. = Dudik B.: Iter Romanum. I-II. Wien, 1855.

Eder, Observationes = Josephus Eder: Observationes criticae et pragmaticae ad historiam Transsilvaniae sub regibus Arpadianae et mixtae propaginis. Cibinii, 1803.

Egyh. ért. = Egyházi értekezések, és tudósítások. II. Veszprém, 1820.

Elenchus $=$ Elenchus summarius archivi almae Provinciae Hungaricae Ordinis Sancti Pauli Primi Eremitae. Kézirat, 1750. Magyar Országos Levéltár. Bp., E 153. 101.

Elenchus Andrassianae $=$ Elenchus literalium documentorum familiae Andrassianae. OSZK. Fol. Lat. 4396.

ELTE. Kvt. = Eötvös Loránd Tudományegyetem Könyvtára. Bp.

ELTE. TSTsz. = Eötvös Loránd Tudományegyetem. Történelem Segédtudományai Tanszék. Oklevélgyújtemény. Bp.

Enchiridion $=$ Marczali Henrik: Enchiridion fontium historiae Hungarorum. A magyar történet kútfőinek kézikönyve. Bp., 1902. [archive.org]

Endlicher $=$ Stephanus Ladislaus Endlicher: Rerum Hungaricarum monumenta Arpadiana. Sangalli 1849. [archive.org]

Engel, Archontológia = Engel Pál: Magyarország világi archontológiája. 13011457. I-II. História könyvtár. Kronológiák, adattárak 5. Bp., 1996.

Engel P., MKA = Engel Pál: Magyar középkori adattár. CD-ROM. Budapest, 2001.

EPL. = Esztergomi Prímási Levéltár.

Erd. Múz. = Erdélyi Múzeum. Kolozsvár, 1874-1946., 1991-.

Erdélyi Okm. = Jakó Zsigmond-W. Kovács András-Hegyi Géza: Erdélyi okmánytár. Oklevelek, levelek és más írásos emlékek Erdély történelméhez. I-III. Bp., 1999-2009. [MOL]

Erdészeti Ok1. = Tagányi Károly: Magyar erdészeti oklevéltár. I-III. Bp., 1896. 
Érdy, Croy = Érdy János: Magyarországi Croy nemzetségnek története, nemzedékrendje és oklevéltára. Pest, 1848.

Érszegi = Érszegi Géza: Eredeti pápai oklevelek Magyarországon. Bp., 1989. (kézirat az MTA Kvt.-ban)

Érszegi, Tolna $=$ K. Balog János (szerk.): Évszázadokon át. Tolna megye történetének olvasókönyve I. Szekszárd, 1978.

Ért. Tört. Tud. = Értekezések a Történettudományi Osztály (késóbb: a történeti történelmi tudományok) köréből. Bp., 1870-.

Eszt. fókápt. okmt. = Az esztergomi főkáptalan fekvő, s egyéb birtokaira vonatkozó okmányok tára. Pest, 1871. [MOL]

Eszterházy = Gr. Eszterházy János: Az Eszterházy család és oldalágainak leírásához tartozó oklevéltár. Bp., 1901.

Eubel, Bull. Francisc. $=$ C. Eubel: Bullarium Franciscanum. V-VII. Quaracchi, 1898.,1902., 1907.

F. = Georgius Fejér: Codex diplomaticus Hungariae ecclesiasticus ac civilis. IXI. Budae, 1829-1844. [MOL]

Fabre = Paul Fabre: e Liber Censuum de l'église Romaine. I. Paris, 1905.

Fabritius $=$ Karl Fabritius: Urkundenbuch zur Geschichte des Kisder Kapitels vor der Reformation und der auf dem Gebiete desselben ehedem befindlichen Orden. Hermannstadt, 1875.

Farkas-Móra, Fejér = Farkas Gábor-Móra Magda: Fejér megye múltja írott emlékekben. Székesfehérvár, 1962.

Farlati = Daniel Farlati: Illyrici sacri tomi VIII. Venetiis, 1751-1819.

FE. = Föld és Ember. Bp. - Szeged, 1921-1930.

Fejér m. Évk. = Fejér megyei történeti évkönyv. A Fejér megyei Levéltár Évkönyve. Székesfehérvár, 1968-. [MOL]

Fejér, Croatia $=$ Georgius Fejér: Croatiae ac Slavoniae cum regno Hungariae nexus et relationes. Budae, 1839. [BSB]

Fejér, Jurium $=$ Georgius Fejér: Jurium ac libertatum religionis et ecclesiae catholicae in regno Hungariae partibusque adnexis codicillus diplomaticus. Buda, 1847. [BSB]

Fejérm. Szfv. Évk. = A Fejérmegyei és Székesfehérvár Városi Történelmi s RégészetiEgylet Évkönyve. Székesfehérvár, 1885-1893.

Fejérpataky Ek. = Emlékkönyv Fejérpataky László életének hatvanadik évfordulója ünnepére. Bp., 1917.

Fekete Nagy = Fekete Nagy Antal: A Szepesség területi és társadalmi kialakulása. Bp., 1934.

Fekete Nagy A., Temesi Bánság = Fekete Nagy Antal: Temesi bánság okmánytára.Kézirat. Magyar Országos Levéltár P. 1732. (Fekete Nagy Antal-hagyaték. 1. csomó.) 
Felsớm. Évk. = A Felsőmagyarországi Múzeum Egylet Évkönyve. Kassa, 18721902.

Feňarová = Magda Feňarová: Spišské prepoštstvo. Stredoveké listiny 1248-1526. Bratislava, 1964.

Fenyvesi, Tolna = Fenyvesi László: Tolna megye középkori történetéhez kapcsolódó klevelek regesztái. Tolna Megyei Levéltári Füzetek. Tanulmányok. Szekszárd, 2000.

FHKA. = Finanz- und Hofhammerarchiv. Wien.

Fierens, XII. Benedek = Alphonse Fierens: Lettres de Benoit XII. (1334-1342) Textes et analyses. Rome-Bruxelles-Paris, 1910. [gallica]

Finke $=$ H. Finke: Acta Aragonensia. I-III. Berlin-Leipzig, 1908-1923.

Finke, Papsttum $=$ Heinrich Finke: Papsttum und Untergang des Templerordens. II. Quellen. Münster i. W. 1907.

FK. = Filológiai Közlöny. Bp., 1955-.

Florek = Pavol Florek: Turčiansky Sv. Martin v stredoveku. Stredoveký vývin slovenského mesta. Turčiansky Sv. Martin 1941.

Fodor = Fodor Zoltán: Oklevéltár Mezôtúr város történetéhez. Mezőtúr, 1968.

Fodor, Marosvásárhely = Fodor István: Marosvásárhely oklevéltára. Marosvásárhely,1938.

Foltin, Zázty = Foltin János: A zázty-i apátság. XI. századi alapító oklevelének taglalata s ismeretlen helyének meghatározása. Eger, 1883.

Forgách = Bártfai Szabó László: A Hunt-Paznan nemzetségbeli Forgách család története. Esztergom, 1910.

Fraknói = Fraknói Vilmos: Magyarország egyházi és politikai összeköttetései a római szent-székkel. I. kötet 1000-1417. Bp. 1901.

Fraknói, Oklevéltár = Fraknói Vilmos: Oklevéltár a magyar királyi kegyúri jog történetéhez. Bp., 1899. [archive.org]

Fraknói, Szekszárd = Fraknói Vilmos: A szekszárdi apátság története. Bp.,1879.

Frangepán = Thallóczy Lajos-Barabás Samu: Codex diplomaticus comitum de Frangepanibus. A Frangepán család oklevéltára. I-II. 1135-1527. Bp., 19101913. [MOL; archive.org]

GA. = Grande Archivio. Napoli (Nápoly).

Gábor, Megye = Gábor Gyula: A megyei intézmény alakulása és múködése NagyLajos alatt. Bp., 1908. [archive.org]

Ganoczi, Ep. Varad = Antonius Ganoczi: Episcopi Varadienses. I-II. Vindobonae, 1776.

Gasnault-Laurent $=$ Innocent VI. $<1352-1362>$. Lettres [epistolae] secretes et curiales. Publ. ou analysees d'apres les registres des archives vaticanes par Pierre Gasnault et M[aria]-H[yacinthus] Laurent, [OP]. T. 1. Paris, 1959. 
Gelchich, Ragusa = Gelchich József: Ragusa és Magyarország összeköttetéseinek oklevéltára. Diplomatarium relationum rei publicae Ragusanae cum regno Hungariae. Bp., 1887. [MOL]

Georgisch, Reg. chron.-dipl. = P. Georgisch: Regesta chronoligico-diplomatica, in quibus recensuntur omnis generis monumenta et documenta publica. IIV. Frankofurti et Lipsiae, 1740-1744. [BSB]

Gerbertus $=$ Martinus Gerbertus: Taphographia Principum Austriae. Typis Sanblasianis 1772.

Gercken $=$ Ph. W. Gercken: Codex diplomaticus Brandenburgensis. I-VIII. Salzwedel, 1769-1785.

Golubovich $=$ Girolamo Golubovich: Biblioteca bio - bibliografica della Terra Santa e dell'Oriente francescano. I-V. Quaracchi-Firenze, 1906-1927.

Görgey = Görgey Albert: A toporci és görgöi Görgey nemzetség történetéból. Igló, 1908.

Grandjean $=$ Ch. Grandjean: Le registre de Benoit XI. Paris, 1883-1905.

Gutheil, Veszprém = Gutheil Jenő: Az Árpád-kori Veszprém. Veszprém, 1977.

Güssinger = Die Güssinger. Hg. H. Dienst-I. Lindek-Pozza. Eisenstadt, 1989.

Gy. = Györffy György: Az Árpád-kori Magyarország történeti földrajza. I-IV. Bp., 1963-1998.

Gyárfás = Gyárfás István: A Jász-kunok története. I-IV. Kecskemét-Szolnok-Bp., 1870-1885. [http:/ /vfek.vfmk.hu/00000097/index.html]

GYMSML. = Győr-Moson-Sopron Megyei Levéltár.

Györffy, Keleti elemei = Györffy György: A magyarság keleti elemei. Bp., 1990.

Gyốri Füz. = Győri történelmi és régészeti füzetek. I-IV. Győr, 1861-1865.

Gyulafv. Füz. = Gyulafejérvári Füzetek. I-II. Kolozsvár, 1861-1862.

Gyurgyik, Körmöcbánya = Gyurgyik Gyula: Körmöcbánya szab. Kir. Fóbáyaváros és a magyar kir. Bányakincstár között a város területi és stubna uradalmi erdők kezelése és használata iránt fennforgó viszály, tekintettel a hazai bányajogra. Eredeti kútfők után. Bp., 1879.

Hadtört. Közl. = Hadtörténelmi Közlemények. Bp., 1888-1943. Új folyam: 1954-

Hajdú-Bihar m. Évk. = A Hajdú-Bihar megyei Levéltár Évkönyve. Debrecen, 1974-.

Hajdú-bihari tört. olv. = Hajdú-bihari történelmi olvasókönyv. Debrecen 1973.

Hajnóci = Hajnóci R. József: Lőcse szabad királyi város levéltárának tartalomjegyzéke. Lő́cse, 1904.

Halaga $=$ Ondrej Halaga, Archiv mesta Košíc. Praha, 1957.

Halász É., Szlavón = Halász Éva: A szlavón hercegek és bánok 14. századi oklevéladó tevékenysége (1323-1381). PhD-értekezés. Bp., 2008. 
Házi = Házi Jenő: Sopron szabad királyi város története. I. rész -, II. rész -, Oklevelek. Sopron, 1921-1943. [MOL]

HBML. = Hajdú-Bihar Megyei Levéltár. Debrecen.

HDA. = Hrvatski Državni Archiv. Zagreb (Zágráb).

Héderváry = Br. Radvánszky Béla-Závodszky Levente: A Héderváry család oklevéltára. I-II. Bp., 1909-1922. [MOL]

Hermann Zs., 1983. = Hermann Zsuzsanna: Az Egyetemi Könyvtár Werbőczikéziratai és az "Analecta saeculi XVI. Hungarica." Bp., 1983.

Herpay = Herpay Gábor: Debrecen szab. kir. város levéltára diplomagyújteményének regesztái. Debrecen, 1916. [MOL]

Hervay, Rep. Cist. Hung. = Hervay L. Ferenc: Repertorium historicum Ordinis Cisterciensis in Hungaria. Roma, 1984.

Hessisches UB. = Artur Wyss-Heinrich Reimer: Hessisches Urkundenbuch. 1. Urkundenbuch der Deutschordens-Ballei Hessen. I-III. Leipzig, 1879-1899. [archive.org]

Heumann, Com. De re dipl. = Heumann von Teutschenbrunn, Johann: Commentarii de re diplomatica imperatricum augustartum ac reginarum Germaniae ex probis literarum monumentis ad temporum seriem adornati... Accedunt appendices II. in quibus de diplomatibus nonnullis cum augustarum et reginarum Italiae tum imperatricum Constantinopol. disseritur. Norimbergae, 1749. [google]

HHStA. = Haus-, Hof- und Staatsarchiv. Wien (Bécs).

Hilibi Gál, Értekezôdés = Hilibi Gál László: Értekeződés az Erdélyi ns. Szász nemzet eredetéről és némely törzsökös polgári jogairól. Nagy-Enyeden 1846.

Hist. Sbor. = Historické Sbornik. Bratislava 1943-.

Hist. Stud. = Historické Štúdie. Bratislava 1955-.

Hist. Zbor. = Historijski Zbornik. Zagreb 1948-.

HML. = Heves Megyei Levéltár. Eger.

HO. = Hazai okmánytár. Codex diplomaticus patrius. I-VIII. Győr-Bp., 186-891. [MOL]

HOk1. = Hazai oklevéltár 1234-1536. Bp., 1879. [MOL]

Hóman, A magyar királyság pénzügyei = Hóman Bálint: A magyar királyság pénzügyei és gazdaságpolitikája Károly Róbert korában. Bp., 1921. [mek]

Hornyik = Hornyik János: Kecskemét város története oklevéltárral. I-IV. Kecskemét, 1860-1866.

Horvát Á., Bevezetés = Horvát Árpád: Bevezetés a magyar oklevéltanba. Bp., 1880.

Horvát Á., Dipl. írástan = Horvát Árpád: A diplomatikai írástan alapvonalai. Bp., 1883. 
Horvát Á., Oklevélhasonmások = Horvát Árpád: Oklevélhasonmások gyưjteménye.Bp., 1883.

Horváth I. = Horváth István: Werbőczy István emlékezete. II.

Horváth J. = Horváth Jenő: Magyarország államszerződéseinek jegyzéke. Catalogue des traités de la Hongrie 973-1526. Bp., 1921.

Horváth, Galgamente = Horváth Lajos: A Galgamente történetének írott forrásai 1526-ig. Aszód, 1980.

Horváth, Gödöllő = Horváth Lajos: Gödöllő történetének írott forrásai. Gödöllő, 1987.

Horváth, Sopron = Horváth Zoltán: Sopron és a megye múltja egykori iratok tükrében.Sopron, 1964.

Horváth, Zirc = Horváth K.: Zirc története. Veszprém, 1930.

Horváth-Kiss, Vas = Horváth Ferenc-Kiss Mária: Vas megye helytörténeti olvasókönyve. Szombathely, 1975.

Houdek = Fedor Houdek: 600 rokov z minulosti býv. výsadného mesta Ružomberka. Ružomberok, 1934.

Housley, King Louis = Housley, Norman: King Louis the Great of Hungary and the Crusades, 1342-1382. In: Slavonic and East Europen Review 62. (1984) 192-208.

Hunyadm. Évk. = A hunyadmegyei történelmi és régészeti társulat évkönyve. Bp. -Déva, 1882-1913.

Hurmuzaki $=$ Eudozin Hurmuzaki-N. Jorga: Documente privitoare la istoria Românilor, XIV-XV. Bucureşti, 1910-1911.

Húščava, Ján literát = Alexander Húščava: Ján literát a liptovské falzá. Bratislava,1936.

IAV = Istorijski Arhiv Varaždin.

Húščava, Trnava = Alexander Húščava: Najstaršie výsady mesta Trnavy. Bratislava, 1939.

Illés, Bevezetés = Illés József: Bevezetés a magyar jog történetébe. A források története.Függelékül válogatott forráshelyek gyưjteménye. Bp., 1910.

Illéssy = Illéssy János: Igló kir. korona- és bányaváros levéltára. Bp., 1899.

Implom, Gyula = Implom József: Gyula város története szemelvényekben. 1. 1313-1659. Gyula, 1961.

Inventarium $=$ Inventarium privilegiorum omnium et singularum domorum Ordinis Heremitarum Sancti Pauli Primi Heremitae. Kézirat 1522. Egyetemi Könyvtár Bp., Kézirattár. Ab 115. (DAP-BAN)

Irinyi = Irinyi István: Az irinyi Irinyi család levéltára. Szatmár, 1902.

Ivánka = Ivánka Zsigmond: Hat okmány a draskóczi és jordánföldi Ivánka család levéltárából. Bp., 1895. 
Iványi, Bártfa = Iványi Béla: Bártfa szabad királyi város levéltára. I. 1319-1526. Bp., 1910. [MOL]

Iványi, Dom. lev. = Iványi Béla: Dominikánus levelek és oklevelek a körmendi levéltárban. 1318-1672. Körmend, 1942.

Iványi, Eperjes = Iványi Béla: Eperjes szabad királyi város levéltára. Archivum liberae regiaeque civitatis perjes. 1245-1526. Szeged, 1931. [MOL]

Iványi, Körmend = Iványi Béla: A körmendi levéltár Memorabiliái. Körmend, 1942.

Iványi, Teleki = Iványi Béla: A római szent birodalmi széki gróf Teleki család gyömrői levéltára. Archivum Gyömrőense gentis comitum Teleki de Szék. Szeged, 1931. [MOL]

Jahrbch. Kunstsammlgen. d. a. h. Kaiserhauses. = Jahrbuch der Kunsthistorischen Sammlungen des Allerhöchsten Kaiserhauses. Wien. I-XXXVI. 18831918.

Jakab, Bicske = Jakab István László: Bicske története. Bicske, 1969.

Jakó, Kolozsmonostor = Jakó Zsigmond: A kolozsmonostori konvent jegyzőkönyvei (1289-1556). I-II. Bp., 1990.

Jakó-Manolescu = Jakó Zs.-R. Manolescu: A latin írás története. Bp., 1987.

JAL. = Jugoszláv Akadémia Levéltára. Arhiv Jugoslavenske Akademije. Zagreb (Zágráb).

JAMÉ = A Jósa András Múzeum Évkönyve. Nyíregyháza.

Janota, Bardyjów = Eugeniusz Janota: Bardyjów. Kraków, 1862.

Jászberény = Jászberény rt. város levéltárában levő kiváltság- és oklevelek gyújteménye. Jászberény, 1910.

Jékey = Baán Kálmán: A bulyi és jékei Jékey család oklevéltára 1271-1660. Regeszták. Bp., 1937.

Jeršová = Mária Jeršová: Rod Ivanka z Jordánu a Dražkoviec (Príspevok k dejinám Turca). Turčiansky Sv. Martin, 1937.

JNSZ = Benedek Gyula-Zádorné Zsoldos Mária: Jász-Nagykun-Szolnok megyei oklevelek 1075-1526. Szolnok, 1998.

Juck = L'ubomir Juck: Výsady miest a mestečiek na Slovensku I. 1238-1350. Bratislava, 1984.

Juhász, Aradi reg. = Juhász Kálmán: Egy dél-alföldi hiteleshely kiadványai. Aradi regeszták 1229-1552. Gyula, 1962.

Juhász, Csanádi székeskápt. = Juhász Kálmán: A csanádi székeskáptalan a középkorban 1030-1552. Makó, 1941.

Juhász, Stifte $=$ Koloman Juhász: Die Stifte der Tschanader Diözese im Mittelalter. Ein Beitrag zur Frühgeschichte und Kulturgeschichte des Banats. Münster in Westfalen, 1927.

Justh = Borsa Iván: Justh család levéltára 1274-1525. Bp., 1991. [MOL] 
Kállay = A nagykállói Kállay-család levéltára. (Az oklevelek és egyéb iratok kivonatai.) I-II. Bp., 1943. [MOL]

Kanyar J., Somogy = 30 nemzedék Somogyról. Szerk. Kanyar József. Kaposvár, 1989.

Kapocs, Szeremle $=$ Kapocs Nándor: Szeremle középkori oklevelei a Zichy okmánytárban. Baja, 1980.

Kapocs-Kóhegyi = Kapocs Nándor-Kőhegyi Mihály: Katymár és környékének középkori oklevelei a Zichy okmánytárban. Bajai dolgozatok 5. Baja, 1983.

Kar., HH. = Karácsonyi János: A hamis, hibáskeltú és keltezetlen oklevelek jegyzéke 1400-ig. Bp., 1902.[A Történelmi Tár 1908. évi számában megjelent pótlásokkal kiegészítve] A kötetet szerkesztette és az előszót írta: Koszta László. Szeged, 1988.

Karácsonyi, Die ersten Lónyay = Karácsonyi János: Die ersten Lónyay. Pozsony, 1912.

Karácsonyi, Nemz. = Karácsonyi János: A magyar nemzetségek a XIV. század közepéig. I-III. Bp., 1900-1901. (Reprint: Bp., 1995.) [archive.org]

Karcsú, Vácz = Karcsú Antal Arzén: Vácz város története. I-VI. Vácz, 1880-1886.

Károly, Fejér vm. = Károly János: Fejér vármegye története. I-V. Székesfehérvár, 1896-1904.

Károly, Nádasdy = Károly János: Oklevelek gr. Nádasdy Ferencz nádasdladányi levéltárából. Bp., 1889.

Károlyi = Géresi Kálmán: A nagy-károlyi gróf Károlyi család oklevéltára. Codex diplomaticus comitum Károlyi de Nagy-Károly. I-V. Bp., 1882-1897. [MOL]

Katalog = Kazimierz Kaczmarczyk: Katalog archiwum aktów dawnych miasta Krakowa - Zbiory Rusieckich I. Diplomy pergaminowe. Kraków, 1911. [poznan]

Kath. Szle = Katholikus Szemle Bp., 1887-1944.

Katona, Hist. crit. = Stephanus Katona: Historia critica regum Hungariae. PestiniBudae, 1779-1817. [BSB]

KCsA. = Kőrösi Csoma-Archivum. I-III., I. kieg. kötet. Bp., 1921-1941.

Kemény, Notitia = Josephus Kemény: Notitia historico-diplomatica archivi et literalium capituli Albensis Transsilvaniae. I-II. Cibinii, 1836.

Kercselich, Hist. eccl. Zagrab. = Balthasar Adamus Kercselich de Corbavia: Historiarum cathedralis ecclesiae Zagrabiensis partis primae tomus I. Zagrabiae, [1760.]. [BSB]

Kercselich, Not. praelim. = Balthasar Adamus Kercselich de Corbavia: De regnis Dalmatiae, Croatiae, Sclavoniae notitiae praeliminares. Zagrabiae, é. n. [google]

Király, Pozsonyi vám = Király János: A pozsonyi Nagy-Dunai vám- és révjog története. Pozsony, 1890. 
Kirsch $=$ Joh. Peter Kirsch: Die päpstlichen Kollektorien in Deutschland während des XIV. Jahrhunderts. Paderborn, 1894.

Kisbán, 1938. = Kisbán Emil: A magyar pálosrend története. I. Bp., 1938.

Klieman $=$ L. Klieman: Monumenta Vaticana res gestas Bohemiae illustrantia. IV. Pragae, 1903-1905. [vonatkozó kötete: Acta Innocentii VI. Tomus II. 135262; Joannis Fridericus Novák. Pragae, 1907. BSB]

KML. = Komárom-Esztergom Megyei Levéltár. Esztergom

Knauz, Garamszentbenedek = Knauz Nándor: A Garam-melletti Szent-Benedeki apátság. Bp., 1890.

Kodeks Krakowa = Franciszek Piekosiński: Kodeks dyplomatyczny miasta Krakowa. I. Kraków, 1879. [poznan]

Kodeks Małop. = Franciszek Piekosiński: Kodeks dyplomatyczny Małopolski. I-IV. Kraków, 1876-1905. [poznan]

Kodeks Mazow. = Kodeks dyplomatyczny księstwa Mazowieckiego. Warszawa, 1863. [poznan]

Kodeks Wack. $=$ Franciszek Piekosiński: Kodeks dyplomatyczny katedry krakowskiej sw. Wacława. I. Kraków, 1874. [poznan]

Kodeks Wielkop. = Kodeks dyplomatyczny Wielkopolski. II. Poznań, 1878. [poznan]

Kollányi = Kollányi Ferencz: Regesták a római és parmai levéltárakból. Bp., 1905.

Koller = Josephus Koller: Historia episcopatus Quinqueecclesiarum. I-VII. Posonii, Pesthini, 1782-1812. [BSB]

Kolozsvár = Jakab Elek: Oklevéltár Kolozsvár története I., II., III. kötetéhez. Buda, 1870-1888. [mek; archive.org

Komárom = Komárom megyei helytörténeti olvasókönyv. Válogatta és szerkesztette: Ortutay András. Tatabánya, 1988.

Komárom vm. = Alapi Gyula: Komárom vármegye levéltárának középkori oklevelei. Komárom, 1917.

[http://www.jamk.hu/ek/public/10021201/Komaromvarmegye_kozepkori_sz.pdf]

Kordé Z., Székelység = A középkori székelység. Krónikák és oklevelek a középkori székelyekről. A szövegeket válogatta, a kísérő tanulmányokat és a jegyzeteket írta Kordé Zoltán. Csíkszereda, 2001.

Kormos, Kenderes = Kormos László: Kenderes története. II. Oklevéltár 1728-ig. Szolnok, 1979.

Korponay, Abaúj vm. = Korponay János: Abaúj vármegye monographiája. I-II. Kassa, 186-878.

Korrespondenzblatt $=$ Korrespondenzblatt des Vereins für siebenbürgische Landeskunde. Hermannstadt 1878-1930. Siebenbürgische Vierteljahrschrift. Korrespondenzblatt des Vereins für siebenbürgische Landeskunde. Hermannstadt, 1931-1941. 
Kóta $=$ Kóta Péter: Regeszták a vasvári káptalan levéltárának okleveleiről (1130) 1212-1526. Középkori oklevelek Vas megyei levéltárakban I. Vas megyei levéltári füzetek 8 . Szombathely, 1997. [MOL]

Kovachich, Formulae = Martinus Georgius Kovachich: Formulae solennes styli in cancellaria, curiaque regum, foris minoribus, ac locis credibilibus, authenticisque regni Hungariae olim usitati. Pesthini, 1799. [BSB; google]

Kovachich, Mon. vet. Legisl. = Josephus Nicolaus Kovachich: Monumenta veteris legislationis Hungaricae, quae nunc primum detecta. Claudiopoli, 1815. [BSB; google]

Kovachich, Supplementum = Martinus Georgius Kovachich: Supplementum ad vestigia comitiorum apud Hungaros ab exordio regni eorum in Pannonia usque ad hodiernum diem celebratorum. I. Budae, 1798.

Kovachich, Sylloge decr. = Josephus Nic. Kovachich: Sylloge decretorum comitialium inclyti regni Hungariae. I-II. Pesthini, 1818.

Kovachich, Vestigia = Martinus Georgius Kovachich: Vestigia comitiorum apud Hungaros. Budae, 1790. [google]

Kovács, Borsmonostor = Kovács Ignácz: A borsmonostori apátság története. Sopron,1910.

Kovács, Türje $=$ Kovács Imre: A türjei Premontrei Prépostság története. Zalai Gyưjtemény. 32. Szerk.: Gyimesi Endre. Zalaegerszeg, 1991.

Köblös, DREL = Köblös József: A Dunántúli Református Egyházkerület Levéltárának magyar vonatkozású oklevelei. 1265-1525. Pápa, 1997. [mek]

Köfalvi T., Pécsvárad = Kőfalvi Tamás: A pécsváradi konvent hiteleshelyi oklevéltára 1254-1526. PhD-értekezés, kézirat. Szeged, 2000.

Kőfalvi T., Pécsváradi konvent = A pécsváradi konvent hiteleshelyi oklevéltára 1254-1526. Szerkesztette és a bevezetô tanulmányt írta Kőfalvi Tamás. Szeged, 2006.

Középk. hist. = Középkori históriák oklevelekben (1002-1410). A szövegeket válogatta, az előszót és a jegyzeteket írta Kristó Gyula. Szegedi Középkortörténeti Könyvtár. 1. Szeged, 1992.

Közl. Miskolc Borsod = Történelmi és régészeti közlemények Miskolc város és Borsod vármegye múltjából. Miskolc thjf. város Hivatalos Értesítőjének melléklete. Miskolc, 1926-1928.

Közl. Szepes vm. = Közlemények Szepes vármegye múltjából. I-XV. Lő́cse, 1909_ 1932.

Krassó = Pesty Frigyes: Krassó vármegye története. III-IV. Oklevéltár. Bp., 18821883.

KRE. = Kristó Gyula-Makk Ferenc: Károly Róbert emlékezete. Bp., 1988.

Kristó, Békés = Kristó Gyula: Békés megye a honfoglalástól a törökvilág végéig. Békéscsaba, 1981. 
Kristó, Olvasókönyv = Kristó Gyula: Olvasókönyv Békés megye történetéhez. I. A honfoglalástól 1705-ig. Forráskiadványok a Békés Megyei Levéltárból. 1. Békéscsaba, 1967.

Kristó, Rozgony = Kristó Gyula: A rozgonyi csata. Sorsdöntő történelmi napok. 3.Bp., 1978.

Kronstadt $=$ Quellen zur Geschichte der Stadt Kronstadt in Siebenbürgen. I-VII. Brassó, 1886.

Kub. = Kubínyi Ferencz: Oklevelek hontvármegyei magánlevéltárakból. Diplomatarium Hontense. I. Bp., 1888. [MOL]

Kubínyi = ifj. Kubínyi Ferencz: Árpádkori oklevelek. 1095-1301.

Kubinyi, Miskolc $=$ Kubinyi András: Miskolc története I. A kezdetektől 1526-ig. Miskolc, 1996. [MOL]

Kukuljević, Jura = Johannes Kukuljević: Jura regni Croatiae, Dalmatiae et Slavoniae. Zagrabiae, 1862. [archive.org]

Kurz, Friedr. d. Sch = Kurz, Franz: Österreich unter Kaiser dem Schönen. Linz, 1818.

Kutrzeba = Stanisław Kutrzeba: Katalog krajowego archiwu aktów grodzskich i zemskich w Krakowie. III. Kraków, 1909.

Lapedatu, Braşov = A. Lapedatu: Documetele istorice din archivele Braşovului. Bucureşti, 1903.

Laszowski $=$ Emilius Laszowski: Monumenta historica nob. Communitatis Turopolje olim “Campus Zagrabiensis” dictae. I. 1225-1466. Zagrabiae, 1904. [archive.org]

Lasztókay, Eperjes = Lasztókay László: Eperjes szab. kir. város levéltárában található nevezetesebb okiratok ismertetése. Eperjes, 1881.

Lederer $=$ Lederer Emma (szerk.): Szöveggyűjtemény Magyarország történetének tanulmányozásához. I. Bp., 1964.

Lengyel, Győr = Lengyel Alfréd: Győr megye történetének írásos emlékei. Győr, 1965.

LEO. = Litterae et epistolae originales. Egyetemi Könyvtár. Bp., Kézirattár.

Letopis = Letopis Matice Slovenskej. Bystrica-Turč. Sv. Martin, 1866-1875., 1921.

Letopis Srp. = Letopis Matice Srpske. Novi Sad, 1851-.

Levéltártört. Kron. = A magyar levéltártörténet kronológiája. 1000-2000. Bp., 2000.

Libenau = Libenau, H. v.: Lebens-Geschichte der Königin Agnes von Ungarn, der Letzer Habsburgerin des erlauchten Stammhauses aus dem Aargone. Regensburg, 1868. [archive.org]

Libenau, Hundert Urkunden = Libenau, H. v.: Hundert Urkunden zu der Geschichte der Königin Agnes, Wittwe von Ungarn. 1288-1364. Regensburg, 1869. [archive.org] 
Lichnowsky = E. M. Lichnowsky: Geschichte des Hauses Habsburg. I-VIII. Wien, 1836-1844.

Lipt. Reg. = Horváth Sándor: Regesták a liptói és turóczi registrumokhoz. Bp., 1904.

Ljubić = S. Ljubić: Listine o odnosajih izmedju južnoga slavenstva i mletačke republike. I-V. 960-1527. Zagreb, 1868-1875. [archive.org]

LK. = Levéltári Közlemények. Bp., 1923-. [MOL]

Lombardini, Žlinia = Alexander Lombardini: Stručný dejepis slobodného mesta Žliny. Turčanský Svätý Martin, 1874.

Lónyay = Karácsonyi János: Az első Lónyayak. Családtörténeti tanulmány. Nagyvárad, 1904.

LSz. = Levéltári Szemle. Bp., 1961-.

Lucio, Trau $=$ Giovanni Lucio: Memorie istoriche di Tragurio ora detto Trau . Venezia, 1673.

Lucius $=$ J. Lucius: De regno Dalmatiae et Croatiae libri sex. Amsterdami, 1676. [google]

Ludewig $=$ Ludewig, J. P. de: Reliquiae manuscriptorum omnis aevi diplomatum ac monumentorum ineditorum adhuc I-XII. Francofurti et Lipsiae, 17201741. [BSB]

Lukcsics, Vásárhelyi apácák = Lukcsics Pál: A vásárhelyi apácák története. Veszprém, 1923.

Lünig, Cod. Germ. dipl. = Lünig. J. Ch.: Codex Germaniae diplomaticus. I-II. Francofurti et Lipsiae, 1732-1734. [BSB]

M. Ak. Ért. = Magyar Akadémiai Értesítő. Pest 1860-1865. A Magyar Tudományos Akadémia Értesítője. Pest-Bp., 1860-1889.

M. Családtört. Szle = Magyar Családtörténeti Szemle. Bp., 1935-1944.

M. Gazdaságtört. Szle = Magyar Gazdaságtörténelmi Szemle. Bp., 1894-1906.

M. Nemz. Tört. = Szilágyi Sándor (szerk.): A magyar nemzet története. I-X. Bp., 1895-1898. [archive.org]

Madzsar = Madzsar Imre: A Kaplony-nemzetség és a Vetési család történetéhez. In: Fejérpataky Ek. 279-292.

Magdics = Magdics István Diplomatarium Ráczkeviense. Ráczkevei okmánytár. Székesfehérvár, 1888.

Magy. 1ltört. kron. = A magyar levéltártörténet kronológiája. Szerk. Dóka Klára, Müller Veronika, Réfi Oszkó Magdolna. Budapest, Magyar Országos Levéltár. 2000.

Magyar-zsidó oklt. = Magyar-zsidó oklevéltár. Bp., 1903-.

Makay, Kisvárda = Makay László: Kisvárda fejlődése 1486-ig. A Kisvárdai Vármúzeum Kiadványai. 6. Kisvárda, 1975. 
Makkai, Kolozsvár = Makkai László: Kiadatlan oklevelek Kolozsvár középkori történetéhez. Kolozsvár, 1947.

Makkai-Mezey = Makkai László-Mezey László: Árpád-kori és Anjou-kori levelek, XI-XIV. század. Bp., 1960.

Makusev $=$ Vinc. Makusev: Monumenta historica Slavorum meridionalium vicinorumque popularum. Varsaviae-Belgradi, 1874-1882.

Mályusz, Turóc = Mályusz Elemér: Turóc megye kialakulása. Bp., 1922.

Magyar középkor = Magyar középkor 997-1526. Összeállította Nagy Gábor. é. n.

Máramaros = Apsai Mihályi János: Máramarosi diplomák a XIV. és XV. századból. Máramaros-Sziget, 1900. [MOL]

Máriássy = Iványi Béla: A márkusfalvi Máriássy-család levéltára 1244-1803. I. Lőcse, 1917. [MOL]

Matunák = Matunák, Michel: Zdejín slobodného a hlavného banského mestza Kremnice. Kremnica, 1928.

Méhes = Nyéki Méhes Mózes: A Nyéki Méhes család és a rokon családok. II. Bp., 1937.

Melczer $=$ Kellemesi Melczer István: Okmányok a kellemesi Melczer család levéltárából. XIII., XIV., XV. század. Bp., 1890. [MOL]

Meskó = Meskó Márton: A felső-kubini Meskó család leszármazása és történeti emlékei. A család okmányai alapján és iglói Szontágh Dániel munkája segítségével. Mezőberény, 1894.

Mészáros, Visegrád = Mészáros Orsolya: Visegrád késő középkori város története és helyrajza. Debreceni Egyetem BTK 2008.

Mezey, Szöveggyújt. = Mezey Barna (szerk.): A magyar állam- és jogtörténet forrásai. Szöveggyújtemény. Bp.,1998.

Migne, PL. = Jacques Paul Migne: Patrologiae cursus completus. Series Latina. I-CCXXI. Parisiis, 1841-1864.

Mihnea = Istoria unui cnezat ardelean. Revistă de istorie românească. Director: I. Mihnea. Anul X-XII (1934-1936) nr 1. p. 3-61. Iasi, 1936.

MIÖG. = Mitteilungen des Instituts für österreichische Geschichtsforschung. Innsbruck 188-922.; Mitteilungen des Österreichischen Instituts für Geschichtsforschung. Wien, 1922-1925. Innsbruck, 1926-.

Miskolci Múz. Közl. = A Herman Ottó Múzeum Közleményei. Miskolc, 1955-.

Mitt. hist. Ver. Stmk. = Mitteilungen des historischen Vereins für Steiermark. I-L. Graz, 1850-1903.

MKA. = Magyar Kamara Archivuma .

MKszl. = Magyar Könyvszemle. Bp., 1876- .

MNM. = Magyar Nemzeti Múzeum. Bp.,

MNy. = Magyar Nyelv. Bp., 1905-. 
MOL. Jegyzék = A Magyar Királyi Országos Levéltárban közszemlére kitett okleveleknek jegyzéke. Bp., 1882.

MOL. Pecsét mut. = A Magyar Királyi Országos Levéltár Diplomatikai osztályában ơrzött pecsétek mutatója. Bp., 1889.

Mollat = G. Mollat-G. de Lesquen: = Jean XXII. (1316-1334). Lettres communes. I-XVI. Paris, 1904-1947.

Mon. Pol. Vat. $=$ Monumenta Poloniae Vaticana. Tom. III. Continet analeca Vaticana 1202-1366. Edidit Joannes Ptaśnik. Cracoviae, 1914.

Mon. Rag. = Monumenta Ragusina. I-V. Zagrabiae, 1879-1897.

Mons Sacer $=$ Mons Sacer 996-1996. Pannonhalma 1000 éve. I. Szerk.: Takács Imre. Pannonhalma, 1996. [monasterium]

Mon. Vat. Slov. III/2. = Monumenta Vaticana Slovaciae. Tomus III. Registrata Vaticana ex actis Clementis papae VI. res gestas Slovacas illustrantia. Vol. 2. (1342-1352). Ad edendum praeparavit Miloš Marek. Trnavae - Romae, 2010.

Mooyer = Mooyer E. F.: Oklevéli adalékok Magyarország régibb történetéhez. Pest, 1859.

Mosheim = Johann Lorenz Mosheim: Historia Tartarorum ecclesiastica. Helmstedt, 1741.

MS. = Magyar Sion. Esztergom, 1863-1869.

MTA. Kvt. = Magyar Tudományos Akadémia Könyvtára. Kézirattár. Bp.

MTT. = Magyar Történelmi Tár. Pest-Bp., 1855-1934.

Mưv. Tört. Ért. = Mưvvészettörténeti Értesítő. Bp., 1952-.

Nagy I., Pécz nemzetség = Nagy Imre: A Pécz nemzetség örökösödési pere. 1425-1433. Budapest, 1892. (Ért. Tört. Tud. XV. 10. szám.)

Nagy Szeder, Kiskunhalas = Nagy Szeder István: Kiskunhalas város története oklevéltárral. I-IV. Kiskunhalas, 1924-1926.

Nagy, Lipthay = Nagy Iván: F.-győri Lubellei és Kisfaludi Lipthay család nemzedékrende és oklevelei. Pest, 1858.

Nedeczky = Nedeczky Gáspár: A Nedeczky-család. Bp., 1891.

Nemzeti Társalkodó = Nemzeti Társalkodó. Kolozsvár, 1830-1844.

Neumann T., Bereg m. = Neumann Tibor: Bereg megye hatóságának oklevelei (1299-1526). Nyíregyháza, 2006. [MOL]

NI. = Nagy Iván. Családtörténeti értesítő.

Niederöst. Urk. = Niederösterreichisches Urkundenbuch. I-II. Wien, 1891-1901.

NK. = Numizmatikai Közlöny. Bp., 1902-.

Nógrádi évsz. $=$ Nógrádi évszázadok. Olvasókönyv a megye történetéhez. Salgótarján, 1976.

Nyíry, Szathmári = Nyíri Dániel: A Szathmáry Királyi Levéltár Árpád-kori oklevelei. In: Történelmi és Régészeti közlemények. II. 1927. 
OA. = Štátny okresný archiv.

Okolicsányi = Alexander Húščava: Archiv zemianskeho rodu z Okoličného. Litterae e tabulario Okolcsányiorum gentis nobilis prolatae. Bratislava, 1943.

Oltvai, Szeged = Oltvai Ferenc: Szeged múltja írott emlékekben. Szeged, 1968.

ÓMO. = Jakubovich Emil-Pais Dezső: Ó-magyar olvasókönyv. Pécs, 1929.

Opočenská = M. Opočenská: Slovenika uherských listín v domácim dvornim a štátnim archivu ve Vidni. Praha, 1927.

Opočenská = M. Opočenská: Slovenika uherských listín v domácim dvornim a štátnim archivu ve Vidni. Praha, 1927.

Opočenská-Jeršová = Mária Opočenská-Jeršová: Inventár archivu Slovenského národného múzea v Turčianskom Sv. Martine. I. Turčiansky Sv. Martin, 1938.

Orbán = Orbán Balázs: A Székelyföld leírása történelmi, régészeti, természetrajzi s népismei szempontból. I-VI. Pest-Bp., 1868-1873.

Ortvay, Földleírás = Ortvay Tivadar: Magyarország egyházi földleírása a XIV. század elején a pápai tizedjegyzék alapján feltüntetve. I-II. Bp., 1982.

Ortvay, Pozsony = Ortvay Tivadar: Pozsony város története. I-III. Pozsony, 18921894. [archive.org]

Osváth, Kassa = Osváth Gyula: Adalékok Kassa város közjogi helyzetéhez és közigazgatási szervezetéhez I. Lipót koráig. Kassa, 1918.

OSZK. = Országos Széchényi Könyvtár. Kézirattár. Bp.

Óváry = Óváry Lipót: A Magyar Tudományos Akadémia történelmi bizottságának oklevélmásolatai. 1. füzet. A Mohácsi vész előtti okiratok kivonatai. Bp., 1890.

Öbost. UB. = Urkundenbuch des Landes ob der Enns. I-XI. 1856-1956.

P. = Erdélyi László-Sörös Pongrác (szerk.): A pannonhalmi Szent-Benedek-rend története. I-XII/B. Bp., 1902-1916.

Palacky = Franz Palacky: Ueber Formelbücher, zunächst in Bezug auf böhmische Geschichte. I-II. Prag, 1842-1847.

Palásthy = Palásthy Pál: A Palásthyak. I-III. Bp., 1890-1891. [MOL]

Pataki, Anjou = Pataki József: Anjou királyaink és a két román vajdaság. Kolozsvár, 1944.

Péchy = Gárdonyi Albert: A péchújfalusi Péchy-család levéltári lajstroma. Bp., 1909.

Pécsi Múz. Évk. = A Janus Pannonius Múzeum Évkönyve. Pécs, 1955-.

Pest m. = Bártfai Szabó László: Pest megye történetének okleveles emlékei 10021599-ig. Függelékül az inárchi Farkas, az irsai Irsay, valamint a szilasi és pilisi Szilassy családok története. Bp., 1938. [MOL]

Pesty, Oláh kerületek = Pesty Frigyes: A Szörény vármegyei hajdani oláh kerületek. Ért. Tört. Tud. V. 3. Bp., 1876. 
Pesty, Szörény = Pesty Frigyes: A szörényi bánság és Szörény vármegye története.III. Oklevéltár. Bp., 1878. [MOL]

Péterffy = Carolus Péterffy: Sacra concilia ecclesiae Romano-Catholicae in regno Hungariae celebrata ab anno Christi 1016 usque ad annum 1715. I-II. Posonii, 1741-1742.

Petrichevich $=$ Petrichevich-Horváth Emil: A Petrichevich család általános története. I. rész -. Bp.-Pécs, 1934-1942.

Petrichevich, Mogorovich = Petrichevich-Horváth Emil: A Mogorovich nemzetségbeli Petrichevich család regesztái 1069-1526. Veszprém, 1941.

Petróczy = Fekete Nagy Antal: A Petróczy levéltár középkori oklevelei. Különlenyomat a Levéltári Közlemények 1930-1931. évfolyamaiból. Budapest, é. n.

Pettenegg $=$ Gaston Graf von Pöttickh-Pettenegg: Die Urkunden des DeutschOrdensarchiv zu Wien. Prag und Leipzig, 1887. [archive.org]

Pez, Codex dipl. hist. epist. = Pez, Bernhard: Thesaurus enecdotorum novissimus: seu Veterum monumentorum, praecipue ecclesiasticorum ex germanicis potissimumbibliothecis adornata collectio recentissima. I-VI., 17211729. [vol.VI.: Codex diplomatico-historico-epistolaris... Proderunt nunc omnia primum tunc iunctim relicquis Thesauri anecdotorum novissimi tomis, quorum his sextus est, tum etiam separatim ex diversarum bibliathecarum mss. Codd. Et archivorum membranis, opera et studio RR. PP. Bernardi Pez... et Philberti Huber. 1729.]

Pfeiffer, Ung. Dom. = Nicolaus Pfeiffer: Die ungarische Dominikanerordensprovinz von ihrer Gründung 1221 bis zur Tatarenverwüstung 1241-1242. Zürich, 1913.

Pilis = Békefi Remig: A pilisi apátság története. I-II. = 1184-1814. Pécs, 18911892.

Piti F., Szabolcs m. = Piti Ferenc: Szabolcs megye hatóságának oklevelei (12841386). [MOL]Szeged-Nyíregyháza, 2004.

Piti, Bodrog = Piti Ferenc: Bodrog megye hatóságának I. Lajos-kori oklevelei. In: Fons, skepsis, lex. Ünnepi tanulmányok a 70 esztendős Makk Ferenc tiszteletére. Szerk.: Almási Tibor, Révész Éva, Szabados György. Szeged, 2010. 331-340.

Piti, Vay berkeszi = Piti Ferenc: A Vay család berkeszi levéltárának 1342-1382 közötti oklevelei. In: A Nyíregyházi Jósa András Múzeum Évkönyve LII. Nyíregyháza, 2010. 387-606.

PML. = Pest Megyei Levéltár. Bp.

Podhradczky, Béla király = Podhradczky József: Béla király névtelen jegyzőjének idejekora és hitelessége. Budán, 1861.

Podmaniczky = Lukinich Imre: A podmanini Podmaniczky-család oklevéltára. I-V. Bp., 1937-1943. [MOL]

Pór, Csák Máté = Pór Antal: Trencsényi Csák Máté, 1260-1321. Bp., 1888. 
Pór, Keszi = Pór Antal: Keszi Miklós. Magyar Történeti Életrajzok 20/5. Bp., 1904 [mek]

Potthast $=$ Augustus Potthast: Regesta pontificum Romanorum inde ab anno post Christum natum MCXCVIII. ad annum MCCCIV. I-II. Berolini, 18741875.

Pray, Annales = Georgius Pray: Annales regum Hungariae ab anno Chr. 997. usque ad a. 1564. deducti. I-II. Vindobonae, 1763-1764.

Pray, Hier. = Georgius Pray: Specimen hierarchiae Hungaricae complectens seriem chronologicam archiepiscoporum et episcoporum Hungariae cum rudi dioecesium delineatione. I-II. Posonii-Cassoviae, 1776-1779.

Puşcariu, Fragmente = Ioan Puşcariu: Fragmente istorice despre boerii din ţara Făgărašului. Sibiiu, 1907.

Püspöki Nagy, Boldogfa = Püspöki Nagy Péter: Boldogfa. Bratislava, 1981.

Quellen z. Wien = Quellen zur Geschichte der Stadt Wien. Wien, 1895-1919.

Reg. Av. = Registra Avenionensia.

Rábik, Reg. Suppl. = Monumenta Vaticana Slovaciae II. Registra supplicationum ex actis pontificum Romanorum res gestas Slovacas illustrantia. Volumen 1. (1342-1415) Ad edendum praeparavit Vladimír Rábik. TrnavaeRomae, 2009.

Rad = Rad Jugoslavenske Akademije Znanosti i Umjetnosti. I-CCLXXX. Zagreb, 1867-1945.

Raynaldus $=$ Raynaldi Annales ecclesiastici ab a. 1198. I-XV. Lucae, 1747-1756. [archive.org]

Reg. Arp. = Szentpétery Imre-Borsa Iván: Az Árpád-házi királyok okleveleinek kritikai jegyzéke. Regesta regum stirpis Arpadianae critico-diplomatica. III. Bp., 1923-1987. [MOL]

Reg. Arp. duc., regin. = Szentpétery Imre - Zsoldos Attils: Az Árpád-házi hercegeh, hercegnók és királynék okleveleinek kritikai jegyzéke. Bp., 2008. [MOL]

Reg. Boh. Mor. = Regesta diplomatica nec non epistolaria Bohemiae et Moraviae. Pragae, 1855-. [cms; archive.org]

Reg. Clem. = Regestum Clementis papae V. ex Vaticanis archetypis. Romae, 1885.

Reg. Habsb. = Regesta Habsburgica. Abt. III. Die Regesten der Herzoge von Österreich sowie Friedrichs des Schönen als deutschen Königs von 13141330. Bearb. von L. Gross. Innsbruck, 1924.

Reg. Slov. = Vincent Sedlák: Regesta diplomatica nec non epistolaria Slovaciae. I-II. Bratislava, 1980-1987.

Reg. Suppl. = Bossányi Árpád: Regesta supplicationum. I-II. 1342-1394. Bp., 1916-1918. [archive.org]

Régi okm. Bártfa = Rhody Alajos: Régi érdekes okmányok sz. kir. Bártfa városa levéltárából. Bártfa, 1899. 
Regnum = Regnum. Egyháztörténeti Évkönyv. I-VI. Bp., 1936-1946.

Reichert $=$ Benedictus Maria Reichert: Acta capitulorum generalium Ordinis Praedicatorum. I-II. Romae, 1898-1899.

Reizner, Szeged = Reizner János: Szeged története. IV. Szeged, 1900.

Reviczky = Reviczky Sándor: A revisnyei Reviczky-család okmánytára. 12721623. Bp., 1878. [MOL]

Reviczky, Vágújhely = Reviczky Bertalan: A boldogságos Szűzről címzett vágújhelyi prépostság története. Trencsén, 1897.

Revista Arhivelor = Revista Arhivelor. I-. Bucureşti, 1924-.

Riceputi-Pavlovich-Lucich, Memorie = Memorie di cose dalmatiche nella storia della vita di San Giorgio Orsini vescovo di Trau. Scritta del Padre Filippo Riceputi e pubblicata del canonico Stefano Pavlovich-Lucich. Zara, 1864.

Riedel $=$ Adolph Friedrich Riedel: Codex diplomaticus Brandenburgensis. Berlin, 1838-1865.

Riezler, Vat. Akt. = Vatikanische Akten in der Zeit Ludwigs des Bayern (13151350). Ed. S. Riezler. Innsbruck, 1891.

Rimely = Carolus Rimely: Capitulum insignis ecclesiae collegiatae Posoniensis. Posonii, 1880.

Roka, Vitae Vespr. praes. = Joannes Roka: Vitae Vesprimiensium praesulum. Posonii, 1779.

Roskovány, Monumenta = Augustinus de Roskovány: Monumenta Catholica pro Independentia Potestatis Ecclesiasticae ab Imperio Civili. I. Quinqueecclesiis, 1847.

Roskovány, Supplementa = Augustinus de Roskovány: Supplementa ad collectiones Monumentorum et literaturae. V. Nitriae, 1889.

Reg. Vat. = Registrata Vaticana.

ŠA. = Štátny oblastný archiv.

ŠA. v Bytči = Štátny archív v Bytči. Sprievodca po archívnych fondoch. I. Bratislava, 1959.

Salzer, Birthälm = Johann Michael Salzer: Der königl. freie Markt Birthälm in Siebenbürgen. Wien, 1881.

Schier, Mem. prov. Aug. = Paulus Xystus Schier: Memoria provinciae Hungaricae Augustinianae antiquae. Grecii, 1778.

Schmauk, Suppl. = Michael Schmauk: Supplementum analectorum terrae Scepusiensis. Pars II. Szepesváraljae, 1889.

Schmitth, Archi-episc. Strig. = Nicolaus Schmitth: Archi-episcopi Strigonienses compendio dati. Tyrnaviae, 1752. [google]

Schmitth, Ep. Agr. = Nicolaus Schmitth: Episcopi Agrienses fide diplomatum concinnati. I. Jaurini, 1763. [google] 
Schuller, Archiv = Schuller: Archiv für die Kenntniss von Siebenbürgens. Vorzeit und Gegenwart. I. Hermannstadt, 1841.

Schuller, Umrisse $=$ J. K. Schuller: Umrisse und kritische Studien zur Geschichte Siebenbürgen. I. Urkundenbuch. Hermannstadt, 1840.

Schuller, Umrisse II. = J. K. Schuller: Umrisse und kritische Studien zur Geschichte Siebenbürgen II. Hermannsadt, 1851.

Schünemann = Konrad Schünemann: Die Entstehung des Städtewesens in Südosteuropa. Südosteuropäische Bibliothek. 1. Breslau-Oppeln, é. n.

Schwandtner = Ioannes Georgivs Schwandtnervs: Scriptores rervm Hvngaricarvm veteres ac genvini. I-III. Bibliopolae Vindobonensis, 1746-1748.

Schwartner, De scultetiis = Martinus Schwartner: De scultetiis per Hungariam quondam obviis. Budae, 1815.

Schwartner, Introductio = Martinus Schwartner: Introductio in artem diplomaticam praecipue Hungaricam. Pestini, 1790.

Semkowich, Orawa = W. Semkowich: Materjaly zrodlówe do dziejowe osadnictwa górnej Orawy. Zakopane, 1932.

Simon, Supplementum = Matheus Simon: Supplementum ad dissertationem historicocriticam clar. Georgii Pray de Dextra S. Stephani primi Hungariae regis cum historia monasterii Sz. Jog, ubi olim sacra haec Dextra asservabatur. Vacii, 1797.

Sindelár, Adatok = Sindelár József: Adatok a marturina történeti fejlődéséhez az oklevelek alapján. Esztergom, 1900. [archive.org]

Smič, Oslobod. = T. Smičiklas: Dvijestogodišnjica oslobodjenja Slavonije. II. Zagreb, 1891. [archive.org]

Smič. = Marko Kostrenčić-T. Smičiklas: Codex diplomaticus regni Croatiae, Dalmatiae ac Slavoniae. Diplomatički zbornik kraljevine Hrvatske, Dalmacije i Slavonije. I-XVII. Zagrabiae, 1904-1981. [scribd]

SMK. = Somogyi Múzeumok Közleményei.

SML. = Somogy Megyei Levéltár. Kaposvár.

SNA. = Slovensky Národny Archív. Bratislava (Pozsony).

Solymosi L., Földesúri járadékok = Solymosi László: A földesúri járadékok új rendszere a 13. századi Magyarországon. Bp., 1998.

Somogy m. 1t. Évk. = Somogy megye múltjából. Levéltári Évkönyv. Kaposvár, 1970-.

Sopr. Szle = Soproni Szemle. Sopron, 1937-1944.; 1955-.

Sopron vm. = Nagy Imre: Sopron vármegye története. Oklevéltár. I-II. Sopron, 1889-1891. [MOL]

Sölch = Az Eötvös Loránd Tudományegyetem Egyetemi Könyvtárában és Egyetemi Levéltárában őrzött 1526 előtti oklevelek és iratok jegyzéke. Összeállította: Sölch Miklós. Budapest, 2005. 
Spiess, Aufklärgen. i. d. Gesch. u. Diplomatik = Spiess, Philipp Ernst: Aufklärungen in der Geschichte und Diplomatik als eine Forsetzung der Archivischen Nebenarbeiten. Bayreuth, 1791.

Sprawozdanie $=$ Sprawozdanie z poszunkiwań na Węgrzech. Kraków, 1919.

Sprievodca $=$ Sprievodca po výstavke listin župného múzea v Bardiove. V Bardiove, 1926.

Sroka, Doc. Pol. = Documenta ad res Poloniae pertinentia, qae in archivis veteris Regni Hungariae asservantur. Edidit, Praefatione notisque instruxit Stanisłaus A. Sroka. Tom. I. (usque ad a. 1450.) Cracoviae, 1998. Tom. II. (documenta ex annis 1451-1480.) Cracoviae, 2000.

StA. = Stadtarchiv

Starine $=$ Starine Jugoslavenske Akademije Znanosti i Umjetnosti. I-XL. Zagreb, 1869-1939.

Str. $=$ Ferdinandus Knauz-Ludovicus Crescens Dedek: Monumenta ecclesiae Strigoniensis. I-III. Strigonii, 1874-1924.

Strehlke, Tabulae $=$ Ernestus Strehlke: Tabulae ordinis Theutonici ex tabularii regii Berolinensis codice potissimum. Berolini, 1869.

ŠÚA. = Štátny ústredný archiv. Bratislava (Pozsony).

Sugár = Sugár István: Borsodi oklevelek a Heves megyei Levéltárban (12451521). Miskolc, 1980.

Sümeghy = Sümeghy Dezső: Sopron vármegye levéltárának oklevélgyứjteménye. I. Középkori oklevelek (1236-1526). Sopron, 1928. [MOL]

Szabó K., Erd. Múz. okl. = Szabó Károly: Az Erdélyi Múzeum eredeti okleveleinek kivonata (1232-1540). Bp., 1889. [mek]

Szabolcsvm. ok1. = Karlovszky Endre-Pettkó Béla: Szabolcsvármegye levéltárának mohácsi vész előtti oklevelei. 1335-1500. Nyíregyháza, 1901. [MOL]

Szádeczky, Iparfejlődés = Szádeczky Lajos: Iparfejlődés és a czéhek története Magyarországon okirattárral (1307-1848). I-II. Bp., 1913. [archive.org]

Szatmár m. = Piti Ferenc-C. Tóth Norbert-Neumann Tibor: Szatmár megye hatóságának oklevelei (1284-1524). Nyíregyháza, 2010.

Száz. = Századok. Pest-Bp., 1867-.

Székely okl. = Szabó Károly-Szádeczky Lajos-Barabás Samu Székely oklevéltár. I-VIII. Kolozsvár-Bp., 1872-1934. [archive.org]

Szendrei, Miskolc = Szendrei János: Oklevéltár Miskolcz város történetéhez. 1225-1843. Miskolc, 1890.

Szent-Ivány = Mályusz Elemér-Borsa Iván: A Szent-Ivány család levéltára. 1230 1525.Bp., 1988. [MOL]

Szentpétery, Középkori okl. = Szentpétery Imre: Középkori oklevélszövegek. Bp., 1927. 
Szepesvm. Évk. = A Szepesvármegyei Történelmi Társulat Évkönyve. Lőcse, 1885-1914.

Szerbia = Thallóczy Lajos-Áldásy Antal: A Magyarország és Szerbia közti összeköttetések oklevéltára. 1198-1526. Bp., 1907. [KlimoTheca;archive.org]

Szeredai $=$ Antonius Szeredai: Series antiquorum et recentiorum episcoporum Transilvaniae. Albae Carolinae, 1790.

Szeredai, Not. capit. Alb. Trans. = Antonius Szeredai: Notitia veteris et novi capituli ecclesiae Albensis Transilvaniae ex antiquis ac recentioribus litterarum monumentis eruta. Albae Carolinae, 1791.

Szerémi, Draskovich = Szerémi: A Draskovichok trokostyányi levéltárából. Bp., 1893.

Szerémi-Ernyey = Szerémi és Ernyey József: A Majthényiak és a Felvidék. Történelmi és genealogiai tanulmány. I. Bp., 1912.

Szirmay, Not. topogr. Zemplén. = Ant. Szirmay de Szirma: Notitia topographica, politica inclyti comitatus Zempléniensis. Budae, 1803.

Szirmay, Szatmár = Szirmai Szirmay Antal: Szathmár vármegye fekvése, történetei, és polgári esmérete. I-II. Budán, 1809-1810.

Szirmay, Ugocsa = Ant. Szirmay de Szirma: Notitia politica, historica, topographica incliti comitatus Ugochiensis. Pestini, 1805. [google]

Szirmay, Zemplén = Szirmay Antal: Notitia historica comitatus Zempléniensis. Buda, 1804. [google]

Szontagh = Szontagh Dániel: Az iglói és zabari Szontagh-nemzetség és oklevelei. Pest, 1864.

Szontagh, Meskó = Szontagh Dániel: Felső-kubini Meskó család. Pest, 1861.

SZSZBML. = Szabolcs-Szatmár-Bereg Megyei Levéltár. Nyíregyháza.

SzSzBSz = Szabolcs-Szatmár-Beregi Szemle. Nyíregyháza. [szszbmo; epa]

SzTA. TTI. = Szlovák Tudományos Akadémia Történettudományi Intézete. Historický Ústav SAV. Bratislava (Pozsony).

Sztáray = Nagy Gyula: A nagymihályi és sztárai gróf Sztáray család oklevéltára. I-II. Bp., 1887-1889. [MOL]

Szứcs, Debreczen tört. = Szû́cs I.: Szabad királyi Debreczen város történelme I. Debrecen, 1870.

T. = Turul. Bp., 188-950. 1992-.

Tabódy, Munkács = Tabódy József: Munkács múltja és jelene Magyarország történetében. Pest, 1861.

Takács = Takács Imre: A magyarországi káptalanok és konventek középkori pecsétjei. Bp., 1992.

Tanodi $=$ Zlatko Tanodi: Monumenta historica liberae regiae civitatis Varasdini.

I. Varasdini, 1942. 
Tanulm. Csongrád m. = Tanulmányok Csongrád megye történetéból. Szeged, 1977-.

Tanulm. Tolna m. = Tanulmányok Tolna megye történetéből. Szekszárd, 1968-.

TBM. = Tanulmányok Budapest múltjából. Bp., 1932-.

TCST. = Tanulmányok Csongrád megye Történetéből. Szeged, 1977.

Telegdi = Blazovich László-Géczi Lajos: A Telegdiek pere 1568-1572. Dél-Alföldi Évszázadok. 6. Szeged, 1995.

Teleki = Barabás Samu: A római szent birodalmi gróf széki Teleki család oklevéltára. Codex diplomaticus sacri Romani imperii comitum familiae Teleki de Szék. I-II. Bp., 1895. [MOL]

Teleki, Huny. = Teleki József gróf: Hunyadiak kora Magyarországon. I-VI/1., X-XII. Pest 1852-1863.

Temes $=$ Pesty Frigyes-Ortvay Tivadar: Oklevelek Temesvármegye és Temesvár város történetéhez. I. 1183-1430. Pozsony, 1896. [MOL]

TF. = G. D. Teutsch-Fr. Firnhaber: Urkundenbuch zur Geschichte Siebenbürgens. I. Fontes rerum Austriacarum. 2. XV. Wien, 1857.

Thallóczy = Thallóczy Lajos: Tanulmányok a bosnyák bánság kezdetéról fôtekintettel a körmendi levéltár okleveleire. Ért. Tört. Tud. XX. 5. Bp., 1905.

Thallóczy, Kamara haszna = Thallóczy Lajos: A kamara haszna (lucrum camerae) története kapcsolatban a magyar adó- és pénzügy fejlődésével. Bp., 1879.

Thallóczy, Mantova = Thallóczy Lajos: Mantovai követjárás Budán, 1395. Ért. Tört. Tud. XX. 4. Bp., 1905.

Theil-Werner $=$ Rudolf Theil-Karl Werner: Urkundenbuch des Mediascher Kapitels bis zur Reformation. Hermannstadt, 1870.

Theiner $=$ Augustinus Theiner: Vetera monumenta historica Hungariam sacram illustrantia. I-II. Romae, 1859-1860. [archive.org]

Theiner, Mon. Pol. = Augustinus Theiner: Vetera monumenta Poloniae et Lithuaniae gentiumque finitimarum historiam illustrantia. I. Romae, 1860. [poznan; google]

Theiner, Mon. Slav. = Augustinus Theiner: Vetera monumenta Slavorum meridionalium historiam illustrantia. I-II. Romae-Zagrabiae, 1863-1875. [google]

Thorotzkay = Jakó Zsigmond-Valentiny Antal: A toroczkószentgyörgyi Thorotzkay család levéltára. Kolozsvár, 1944. [MOL]

Thuránszky = Thuránszky László: A thuriki (recte thurapataki) és komjathnai Thuránszky család története és leszármazása. Sátoraljaújhely, 1938.

Tkalčić, Mon. civ. Zagr. = Joannes Bapt. Tkalčić: Monumenta historica liberae regiae civitatis Zagrabiae, metropolis regni Dalmatiae, Croatiae et Slavoniae. Povjestni spomenici slob. kralj. grada Zagreba. I-XIV. Zagrabiae, 18891932. [archive.org] 
Tkalčić, Mon. ep. Zagr. = Joannes Bapt. Tkalčić: Monumenta historica episcopatus Zagrabiensis. I-II. Zagrabiae, 1873-1874.

TML. = Tolna Megyei Levéltár. Szekszárd.

Tooth-Szilágyi, Kiskunhalas = Tooth János: Kis-Kun-Halas város története. Oklevéltárral ellátva kiadta Szilágyi Sándor. N.-Körös, 1861.

Tóth = Tóth Péter: A Borsod-Abaúj-Zemplén Megyei Levéltár Miskolcon őrzött középkori oklevelei. Borsod-Abaúj-Zemplén Megyei Levéltári Füzetek. 28. Miskolc, 1990. [MOL]

Tóth I., Boszniai kápt. = Tóth Ildikó: A boszniai káptalan hiteleshelyi oklevelei 1353- ig. Kézirat. Szeged, 1997.

Tóth K., Palásthy = Tóth Krisztina: A Palásthy család levéltára 1256-1847. Esztergom, 2001. [MOL]

Tóth-Zágorhidi = Tóth Endre-Zágorhidi Czigány Balázs: Források Savaria Szombathely történetéhez a római kortól 1526-ig. Szombathely, 1994.

Török, Mo. prímása = Török János: Magyarország prímása. Közjogi és történeti vázlat. Második rész. Oklevelek. Pest, 1859.

Tört. Adattár Csanád egyhm. = Történelmi adattár Csanád egyházmegye hajdana s jelenéhez. I-IV. Temesvár- Bp., 1871-1874.

Tört. Ért. = Történelmi és Régészeti Értesítő. Új folyam. Temesvár, 1885-1917.

Tört. Közl. Abaúj Kassa = Történelmi közlemények Abaúj-Torna vármegye és Kassa múltjából. I-VI. Kassa, 1910-1918.

Tört. Lapok = Történeti Lapok. I-III. Kolozsvár, 1874-1876.

Tört. Szle. $=$ Történelmi Szemle. Bp., 1958-.

Transilvani'a = Transilvani'a. Foi'a Associatiunei Transilvane pentru literatur'a romana si cultur'a poporului romanu. Brasiovu.

TRÉ. = Történelmi és Régészeti Értesítő. A Délmagyarországi Történelmi és Régészeti Múzeumtársulat Közlönye. Temesvár, 1875-1901.

Truhelka $=$ Ciro Truhelka: Die Slavonische Banaldenaren. Wien, 1899.

TSz. = Történeti Szemle. Bp., 1912-1930.

TT. $=$ Történelmi Tár. Bp., 1878-1911.

Tud. Gyứjt. = Tudományos Gyưjtemény. I-XXV. Pest, 1817-1841.

Tudománytár = Tudománytár. Új folyam. Értekezések. Pest, 1837-1845.

Tur. Reg. = Horváth Sándor: A liptói és turóczi registrum. Az eredeti szövegek alapján közzéteszi Horváth Sándor. Bp., 1902. [KlimoTheca]

Tutkó, Kassa = Tutkó József: Szabad királyi Kassa városának történelmi évkönyve. Kassa, 1861.

UB. Enns = Urkunden-Buch des Landes ob der Enns. I-. Wien-Linz, 1852-.

ÚBA. = Ústredný Banský Archív. Banská Štiavnica (Selmecbánya). 
Udvardy, Kalocsa = Udvardy József: A kalocsai fôszékeskáptalan története a középkorban. Bp., 1992.

Új M. Múz. = Új Magyar Múzeum. I-X. Pest, 1850-1860.

UJb. = Ungarische Jahrbücher. Berlin, 1923-1944.

Ujházy = Ujházy László: Monumenta historiae hungaricae diplomatica. Magyar Történelmi Emlékek. Oklevelek. Bp., 1914.

ÚMS. = Új Magyar Sion. Esztergom, 1870-1886.

Vagner, Nyitrai k. = Vagner József: Adalékok a nyitrai székeskáptalan történetéhez. Nyitra, 1896.

VAML. = Vas Megyei Levéltár. Szombathely.

Vámossy = Vámossy István: A pozsonyi katholikus polgári ápoló intézet. Pozsony, 1898.

Vár. Kápt. Stat. = Bunyitay Vincze: A váradi káptalan legrégibb statútumai. Nagy-Várad, 1886.

Vasi Szle = Vasi Szemle. Szombathely 1934-1939., 1958-.

Vat. = Monumenta Vaticana historiam regni Hungariae illustrantia. Series I. Tom. I-IV. Bp., 1885-1891.

VEML. = Veszprém Megyei Levéltár. Veszprém.

Veszprém = Garai János püspök (1346-1357) pecsétje 1356. aug. 6. Rainer Pál: A középkori veszprémi püspökök pecsétjei In.: Tudomány és múvészet Veszprémben a 13-15. században. Felolvasóülések Veszprém történetéből 3. Szerk. V. Fodor Zsuzsa Veszprém : Veszprém Megyei Jogú Város Önkormányzata : Laczkó Dezső Múzeum, 1996. 42-48.

Veress, Gyula = Veress Endre: Gyula város oklevéltára (1313-1800). Bp., 1938. [MOL]

Veress, Olasz egyetemek = Veress Endre: Olasz egyetemeken járt magyarországi tanulók anyakönyve és iratai 1221-1864. Bp., 1941.

Vespr. = Monumenta Romana episcopatus Vesprimiensis. A veszprémi püspökség római oklevéltára. I-IV. Bp., 1896-1908.

Veszp. Reg. = Kumorovitz L. Bernát: Veszprémi regeszták (1301-1387). Bp., 1953. [MOL]

Veszprém pótkötet = Érszegi Géza-Solymosi László: Veszprém város okmánytára. Pótkötet. Veszprém, 2010.

Veszprém város = Gutheil Jenő: Veszprém város okmánytára 1002-1523. Veszprém, 2007.

Vidal = Vidal, J.-M.: Benoit XII. (1334-1342) Lettres communes. I-III. Paris 19021911.

Vidal-Mollat = Vidal, J.-M.-Mollat, G.: Lettres des papes d' Avignon. Benoit XII. (1332-1342). Lettres closes et patentes intéressant le pays autres que la France. I-II. Paris, 1935-1950. 
Viktorin $=$ Viktorin József: Visegrád hajdan és most. Pest, 1872. [mek]

Vitae fratrum $=$ Vitae fratrum. Ordinis Fratrum Heremitarum Sancti Pauli Primi Heremitae. Kézirat. 1526. Egyetemi Könyvtár. Bp., Kézirattár. Ab 151 a. 151 c.

Vjesnik = Vjesnik kr. hrvatsko-slavonsko-dalmatinskog zemaljskog arkiva. Zagreb, 1899-1920.

VMMK = A Veszprém Megyei Múzeumok Közleményei.

Voigt $=$ Johannes Voigt: Codex diplomaticus Prussicus. Königsberg, 1836-1861.

W. = Wenzel Gusztáv: Árpádkori új okmánytár. Codex diplomaticus Arpadianus continuatus. I-XII. Pest-Bp., 1860-1874. [MOL]

Wadding, Ann. Min. = I. Wadding: Annales Ordinis Minorum. I-VIII. Lyon 1625-1664.; IX-XXV. Ed. J. R. da Fonseca. Romae, 1731-1986.

Wadding, Ann. Min. = L. Wadding L.: Annales Ordinis Minorum I-VIII. Lyon 162-664. I-XXV. Ed. Fonseca, J. R. da. Romae, 1731-1862.

Wagner = Carolus Wagner: Analecta Scepusii sacri et profani. I-IV. PosoniiCassoviae 177-778.[neten: MOL adatbázis]

Wagner, Quellen = Ernst Wagner: Quellen zur geschichte der Siebenbürger Sachsen. 1191-1975. Schriften zur Landeskunde Siebenbürgens. 1. Köln-Wien, 1976.

Wagner, Sáros = Carolus Wagner: Diplomatarium comitatus Sarosiensis. PosoniiCassoviae, 1780.

Wass cs., cegei 1t. = Jakó Zs.: Erdélyi Nemzeti Múzeum Levéltára 3. W. Kovács András - Valentiny Antal: A Wass család cegei levéltára. Kolozsvár 2006.

Weber, Podolin = Weber Samu: Podolin város története. Bp., 1891.

Weber, Suppl. = Samuel Weber: Supplementum III. analectorum terrae Scepusiensis. Lőcse, 1908.

Weis = Johann Nepomuk Weis: Urkunden des Cistercienser-Stiftes Heiligenkreuz im Wiener Walde. II. Fontes rerum Austriacarum. 2. XVI. Wien, 1859.

Wenzel, Bányászat = Wenzel Gusztáv: Magyarország bányászatának kritikai története. Bp., 1880.

Wenzel, Diósgyớr = Wenzel Gusztáv: Diósgyőr egykori történelmi jelentősége. Ért. Tört. Tud. II. Pest, 1872.

Wenzel, Dipl. Eml. = Wenzel Gusztáv: Magyar diplomacziai emlékek az Anjoukorból. Acta extera Andegavensia. I-III. Bp., 1874-1876. [MOL]

Wertner, Grafen von Mattersdorf = Moriz Wertner: Die Grafen von MattersdorfFoilhtenstein (Nagymarton und Fraknó). Wien, 1889.

Wertner, Nemzetségek = Wertner Mór: A magyar nemzetségek a XIV. század közepéig. I-II. Temesvár, 1891-1892.

Wertner, Délszláv = Wertner Mór: A középkori délszláv uralkodók genealogiai története. Temesvár, 1891. 
Werunsky $=$ E. Werunsky: Excerpta ex registris Clementis VI. et Innocentii VI. Innsbruck, 1885. Wien. Alte Folge I-II. 1865-66.; Neue Folge I-XXXV.18671901.

Z. = A zichi és vásonkeői gróf Zichy-család idősb ágának okmánytára. Codex diplomaticus domus senioris comitum Zichy de Zich et Vásonkeő. I-XII. Pest-Bp., 1871-1931. [neten: MOL adatbázis]

Zahn, UB = J. v. Zahn: Urkundenbuch des Herzogthums Steiermark. I-III. Graz, 1875-1903.

Zala = Nagy Imre-Véghely Dezső-Nagy Gyula: Zala vármegye története. Oklevéltár. I-II. Bp., 1886-1890. [MOL]

Zalai Gyưjit. = Zalai Gyưjtemény. Zalaegerszeg, 1974-.

Zapiski = Zapiski imperatorskoj akademii nauk. Petersburg.

Zbiór = Stanisław Kuraś-Irena Sułkowska-Kuraś: Zbiór dokumentów Małopolskich. IV. 1211-1400. Wrócław-Warszawa-Kraków, 1969.

Zimmermann, Texte $=$ F. Zimmermann: Texte von Urkunden aus siebenbürgischsachsischen Archiven. Hermannstadt, 1888.

Ziridava = Ziridava. Muzeul Regional Arad. I-. Arad, 1967-. [BSB]

ZML. = Zala Megyei Levéltár. Zalaegerszeg.

Zounuk = Zounuk. A Szolnok (Jász-Nagykun-Szolnok) Megyei Levéltár Évkönyve. Szolnok, 1986-.

ZW. = Urkundenbuch zur Geschichte der Deutschen in Siebenbürgen. I-VI. Hermannstadt-Köln-Wien-Bukarest, 1892-1981. [germa]

ZsO. = Zsigmondkori oklevéltár. I. (1387-1399) Összeáll.: Mályusz Elemér. Bp., 1951.; II/1. (1400-1406) Bp., 1956.; II/2. (1407-1410) Bp., 1958.; III. (14111412). Mályusz Elemér kéziratát kiegészítette és szerkesztette: Borsa Iván. Bp., 1993.; IV. (1413-1414) Bp., 1994.; V. (1415-1416) Bp., 1998.; VI. (14171418) Bp., 1999.; VII. (1419-1420.) Bp., 2001; Borsa Iván-C. Tóth Norbert: VIII. (1421.) Bp., 2003.; IX. (1422.) Bp., 2004; C. Tóth Norbert: X. (1423.) Bp., 2007.; Neumann Tibor-C. Tóth Norbert: XI. (1424.) Bp., 2009. [MOL]

\subsection{Nomina communia et propria (Köz- és tulajdonnevek)}

a. $=$ annus

A. $=$ Arenga

Á. = Átírás

abb. = abbas

abl. = ablativus

acc. $=$ accusativus

alesp. $=$ alesperes

an. = ante 
Ann. = Annuntiatio Marie

ap. $=$ apostolus

Apr., ápr. = Aprilis, április

arch. $=$ arcangelus

Asc. $=$ Ascensio

Ass. $=$ Assumptio

Au. $=$ Ausztria

B. $=$ beatus

Bapt. $=$ Baptista

BB. = beati

BH. = Bosznia-Hercegovina

Bo $=$ Bohemia

Bp. = Budapest

Bu = Bulgária

c. $=$ comes

$\mathbf{C}=$ Croatia

Circ. $=$ Circumcisio

Circumd. $=$ Circumdederunt

Co $=$ Comania

Conc. $=$ Conceptio

conf. $=$ confessor

Conv. $=$ Conversio

cs. = család, családi

Cseho. $=$ Csehország

$\mathbf{C u}=$ Cumania

d. = dominus

D. = Datum

$\mathrm{Da}=$ Dalmatia

dat. $=$ dativus

Dé = dél, déli

Dec., dec. $=$ December, december

Decoll. $=$ Decollatio

Depos. $=$ Depositio

dict. $=$ dictus 
domin. $=$ dominicus

e. $=$ előtt

E. = eredeti

É = észak, északi

é. $\mathbf{n}$. = év nélkül

Elev. = Elevatio

Eml. = említés

Epiph., Epif. = Epiphaniae

ev., ewang. = evalgelista

Exalt. $=$ Exaltatio

f. $=$ feria

Facs. $=$ facsimile, hasonmás

fe. $=$ festum

Febr., febr. = Februarius, február

Fk. = fénykép

Ford. = fordítás

föesp. = föesperes

fr. $=$ frater

Fro. $=$ Franciaország

ft. $=$ forint

$\mathbf{G}=$ Galícia

gen. $=$ genitivus

glor. $=$ gloriosus

$\mathbf{H}=$ Hungaria

hh. $=$ hiteleshely, hiteleshelyi

hj. = határjárás

hn. = helynév

Ho. = Horvátország

id. = idősebb

Id., Yd. = Idus, Ydus

ifj. = ifjabb

ill. = illetve

Incarn. = Incarnatio

ind. $=$ indictio 
Inv. = Inventio

Jan., jan. = Januarius, január

Je $=$ Jeruzsálem, Hierosolitanum

jegyz. $=$ jegyzet

Ju. = Jugoszlávia

Jun., jún. = Junius, június

Jul., júl. = Julius, július

K. = Kalendae

kb. = körülbelül

kápt. = káptalan

Ke $=$ kelet, keleti

konv. = konvent

köv. = következő

1. = lásd

$\mathbf{L}=$ Lodoméria

Lo. $=$ Lengyelország

lt. = levéltár, levéltára

m. = megye

M. = marca, márka

m. 1t., mlt. = magánlevéltár, magánlevéltára

Má. = másolat

Mad. = Madius, május

Marc., márc. = Marcius, Martius, március

mart. $=$ martyr

Mai, May, máj. = Maius, május

Megj. = megjegyzés

mem. $=$ memoria

Mo. = Magyarország

mont. S. Angeli dom. d. = montis S. Angeli dominus

mr. = magister, mester

N. F. = Neue Folge

Nat. $=$ Nativitas

nb. $=$ nembeli

No. $=$ Németország 
nom. $=$ nominativus

Non. $=$ Nonae

Nov., nov. = November, november

$\mathbf{N y}=$ nyugat, nyugati

o. = ország

O. = Olaszország

o. 1 t. = országos levéltár

oct. $=$ octava

Oct., oct. = October, october

old. $=$ oldal

OO. SS. = omnes sancti

p. $=$ post

$\mathbf{P}=$ Polonia

Pent., Penth. $=$ Penthecostes

princ. $=$ princeps

prox. $=$ proximus

Purif. $=$ Purificatio

Quadr. = Quadragesima

quind. = quindena

R. = regesta

$\mathbf{R a}=$ Rama

Reg. $=$ registrum

Remin. $=$ Reminiscere

Resurr. $=$ Resurrectio

Ro. $=$ Románia

S. = Sanctus

s. $\mathbf{k}$. = saját kezével

sabb. $=$ sabbatum

Sal. $=$ Salernitanus

sc. $=$ scilicet

Se $=$ Serbia, Szerbia

Sept., szept. $=$ September, szeptember

Septuag. $=$ Septuagesima

Si $=$ Sicilia, Szicília 
Spo. $=$ Spanyolország

sz. = század

Sz. = Szlovákia

szb. = szolgabíró

Sze. $=$ Szerbia

Szl. = Szlovénia

szn. = személynév

Szt. $=$ szent

Tá. = tartalmi átírás

ti. $=$ tudniillik

u. = után, utáni

$\mathbf{U}=$ Ungaria, Magyarország

ua. = ugyanaz

ue. = ugyanez

Ukr. = Ukrajna

Uo., uo. = ugyanott, ugyanoda

v. = vagy

V = Vngaria, Magyarország

v. 1 t. = városi levéltár, város levéltára

vig. $=$ vigilia

virg. $=$ virgo

vö. $=$ vesd össze

Ze $=$ Zervia, Szerbia

\subsection{Signa (Jelek)}

[ ] additamentum

$\sim$ alia forma correctionis, névváltozat

$\ni$ : correctio, helyesbítés

(?) datum incertum, bizonytalan keltezés

...... lacuna, szöveghiány

[ ?] lectio incerta, bizonytalan olvasat

+ falsae litterae, hamis oklevél

< > pars superflua, felesleges rész 
[!] sic, így

[[ ]] textus discrepans exemplarum, példányok közti eltérő szöveg 


\section{Regeszták}

\section{1. (1355. dec. 15-1356. jan. 13. között)}

A budai kápt. jelenti [I.] Lajos királynak, hogy eleget téve a király parancslevelében foglaltaknak, az abban elrendelteknek megfelelően Zenthemryh-i Sebestyén királyi ember mellé István karpapot (chori ecclesie) adták tanúul, akik visszatérve azt jelentették, hogy [1355.] dec. 15-én (f. III. prox. p. fe. B. Lucie virg. nunc preterita) Domokos mr.-t Paztuh birtokon tiltakozó és eltiltó okleveleivel együtt — bármilyen formában állították is ki azokat a mondott birtok és tartozékai ügyében — jan. 13-ra (ad oct. fe. Epiph. d. prox. preteritas) megidézték a királyi jelenlét bírósága elé a pécsi püspökkel szemben jogai bizonyítása érdekében.

Eml.: A 45. számú oklevélben.

K.: -

\section{2. (1356.jan. 5. e.)}

[I.] Lajos király nyílt oklevélben utasítja a jászói konventet, hogy Zentus-i Mako királyi ember társaságában küldje ki hites tanúját Vngh m.-be, a leleszi Szt. Kereszt-egyház panaszának kivizsgálására, mely szerint Kiskapos és Vizaka birtokaikon Drugeth Miklós fia: János mr. hatalmaskodásokat követett el.

Eml.: A 37. számú oklevélben.

K.: -

\section{3. (1356. jan. 5. u.)}

A vasvári egyház kápt.-jának Miklós nádorhoz írt jelentése szerint Lőrinc fia: Niklynus mr.-t birtokper és hatalmaskodás ügyében, valamint a nádornak mint bírónak és a másik peres félnek fizetendő elégtétel miatt Bozth-i Pál fia: István nádori ember a vasvári kápt. karpapjának, Péternek a tanúságával 3 Sopron m.-i vásáron való kikiáltással — nevezetesen először [1355.] dec. 31-én (f. V. p. fe. Nat. d.) Cheperegh faluban, másodszor [1356.] jan. 4-én (f. II. p. fe. Circ. d.) Luchmann faluban, harmadszor [1356.] jan. 5-én (f. III. p. fe. Circ. d.) Keedhel faluban - megidézte Miklós nádor törvényszéke elé Agyagus-i András fia: Péter ellenében [1356.] jan. 19-re (ad 15. diem diei iam dicte ultime proclamationis).

Eml.: A 303. számú oklevélben.

K.: Sopron vm. I. 255. (193. szám).

\section{1356.jan. 6 .}

A váradi egyház kápt.-ja tudatja: színe e. egyik részról Zanyzlo-i György fia: Mihály, a másikról pedig Mihály fivérének, vagyis nevezett György fia Jánosnak a nemes lánya: Colys megjelenvén, elóbbi kijelentette, hogy mivel fivére, a fiú utód nélkül meghalt János valamennyi birtoka és birtokrésze rá háramlott, abból — az ország szokása szerint 
— a szóban forgó lánynak leánynegyed és az anyja — Damanhyda-i Zeuke (dict.) Miklós lánya - u. őt megillető hitbér s jegyajándék fejében, testvéri szeretettől vezérelve a Zaboch m.-ben levő Leta birtok Ke-i felét - a Vörös (Rufus) Benedek telki rendjében fekvőt (in quo ordine fundus Benedicti Rufi existeret situatus) - minden haszonvételével és tartozékával együtt odaadja, figyelmen kívül hagyva János másik lányát és annak örököseit. A meghatározott fél birtoknak minden jogát és teljes tulajdonát Colys-ra ruházza, a birtok másik felét pedig megtartja magának. Colys mindezekrôl a kápt. színe e. nyugtatja Mihályt és lemond minden jogáról, mellyel atyai adomány címén v. más módon rendelkezett. A kápt. jelen oklevél visszahozatala esetén privilégium kiállítását ígéri, minek emlékezetére autentikus pecsétjével megerősített nyílt oklevelet bocsát ki. D. in fe. Epiph. d., a. eiusdem 1356.

E.: 1. Dl. 51 692. (Kállay cs. lt. 1300. 1123.) Hártyán, hátoldalán késóbbi kéz írásával tárgymegjelölés, valamint mandorla alakú pecsét nyoma, bevágásai, továbbá késóbbi kezekkel Zanizlo és Transcriptum est.

2. D1. 70 635. (Perényi cs. 1t. 49.) Hártyán, hátoldalán késóbbi kéz írásával tárgymegjelölés, valamint mandorla alakú zárópecsét töredéke, bevágásai.

Má.: Uo., mint E. 1., azzal megegyező jelzet alatt; egyszerú újkori Má.-ban.

K.: AO. VI. 417-418. (265. szám) (kihagyásokkal) (E. 2. alapján).

R.: Kállay II. 33. (1169. szám); Doc. Rom. Hist. C. XI. 1. (1. szám) (románul) mindkettő E. 1. alapján.

5. 1356.jan. 7.

Az egri egyház kápt.-ja jelenti Erzsébet királynénak (H): az itt átírt, 1355. dec. 6-án Visegrádon kelt parancslevelében foglaltaknak eleget téve Kerchy-i Simon fia: András, királynéi ember társaságában tanúként küldte ki karpapját, Mihály testvért az ügy kivizsgálására. Visszatértük $u$. a királynéi ember jelentette, hogy az értesüléssel rendelkezők körében, kivált is a királyné Torpa birtokának határosai és szomszédai között, nemkülönben pedig Apati birtokon - ahol a megvádolt hospes-ek sérelmet okoztak — vizsgálatot folytattak. Ennek eredménye szerint a hospes-ek [1355.] nov. 25-én (f. IV. prox. an. fe. S. Andree ap.) felkeresték [Nyr-i] István fia: István mr. Apati birtokát és elhajtották onnan annak disznóit és kocáit, amelyeket a jan. 2-án (sabb. prox. p. fe. Circ. d.) Torpa birtokra érkező kiküldöttek által közvetített királynéi felszólítására sem akarták Istvánnak visszaadni. Bírájukat, Petheu-t és 2 esküdtjüket emiatt jan. 13-ra (ad oct. fe. Epiph.d.) a királyné elé idézték. D. f. V. prox. an. ipsas oct. Epiph. d., a. eiusdem 1356.

E.: Dl. 51 693. (Kállay cs. lt. 1300. 1097.) Papíron, hátoldalán azonos kéz írásával tárgymegjelölés és zárópecsét töredéke, bevágásai.

K.: -

R.: Kállay II. 33. (1170. szám).

6. (1356.jan. 8.e.)

Miklós nádor $(\mathrm{H})$, a kunok bírája jan. 8-ra idézi színe elé Chorna-i Imre fia Lớrinc fia: Jánost, vele szemben pedig Kuchk-i Márton fia: Dénest. 
Eml.: A 30. számú oklevélben.

K.: -

7. (1356.jan. 8. e.)

Zeech-i Miklós országbíró jan. 8-ra idézi törvényszéke elé István budai prépostot Zabori János fia: János ellenében.

Eml.: A 31. számú oklevélben.

K.: -

8. (1356.jan. 8.e.)

Zeech-i Miklós országbíró jan. 8-ra idézi törvényszéke elé Kapulya-i Dezső fiait: Miklóst és Lászlót Jda-i Pál fia: János mr. ellenében.

Eml.: A 32. számú oklevélben.

K.: -

9. (1356.jan. 8. e.)

Zeech-i Miklós országbíró oklevél-bemutatás végett jan. 8-ra színe elé rendeli Simon fia: Miklóst, ill. vele szemben Nogmortun-i Lőrinc fia: Nykul mr.-t.

Eml.: A 33. számú oklevélben.

K.: -

10. (1356.jan. 8. e.)

Zeech-i Miklós országbíró jan. 8-ra rendeli törvényszéke elé Nogsemyen-i István fia: Istvánt Lengel (dict.) János fiai: László, Leukus és Ábrahám (Abraam) ellenében.

Eml.: A 34. számú oklevélben.

K.: -

11. (1356.jan. 8. e.)

A leleszi konvent Zeech-i Miklós országbíró törvényszéke elé idézi Humuk-i Demeter fia: Pétert Humuk-i Iwahun fia: Pál ellenében jan. 8-ra.

Eml.: A 49. számú oklevélben.

K.: Z. III. 19. (7. szám) (Eml.-ben). 
A váradi kápt. - 1356. jan. 8-án (a. verbi incarnati 1356. in oct. diei Strenarum) kelt oklevelének tanúsága szerint - kinyilvánítja, hogy színe e. megjelent egyik részről Bator-i (Tá. 2.: Bathor-i) Bereck fia János fia: László mr. nemes feleségével, a néhai Megyes-i (Tá. 2.: Medgyes-i, Tá. 3.: Megges-i) Miklós vajda fia Móric mr. leányával: Annával együtt, a másik részról pedig az említett Móric mr. fia: Simon mr. képviseletében eljáró, [I.] Lajos király ügyvédvalló levelében több más ügyre általánosan, és különösen erre vonatkozóan meghatalmazott György fia: Demeter, akik bemutatták [I.] Lajos király —itt átírt - 1351. dec. 6-án, Budán kelt (Budae, fe. B. Nicolai conf., a. d. 1351.) nyílt oklevelét, melyet 1355. jan. 1. megerősített (a. 1355. Kal. Jan.) egyszersmind az abban foglalt rendelkezést és megegyezést a felek ismételten megerősítették.

Tá.: 1. Garai Miklós nádor, 1409. márc. 13. > erdélyi kápt., 1746. okt. 31. Dl. 74 677. (Dessewffy grófi cs. 1t. M. 2).

2. erdélyi kápt. 1746. okt. 31. AL. Kolozsvár. Wesselényi cs. görcsöni lt. 50. (Df. 254 823.) (Tá. 1-ról készült 19. sz.-i egyszerú Má.-ban).

3. erdélyi kápt. 1746. okt. 31. AL. Kolozsvár. Teleki cs. kendilónai 1t. 8. (Df. 257 939.) (Tá. 1-ról készült egyszerű Má.-ban) Mindhárom 1356. jan. 8-i datálással.

K.: $\quad$ F. IX. 4. 659-663. (3. szám) (Garai Miklós 1409-es ítéletlevelére hivatkozással) és uo. X. 4. 846-850. (423. szám) (A Kállay cs. többek ellen folytatott perében, 1646-ban kelt gyulafehérvári kápt.-i átírásra való hivatkozással) utóbbiban a tévedés tetézéseként felcserélve az utolsó számjegyeket 1365ös dátummal; Doc. Rom. Hist. C. XI. 1-5. (2. szám) (román fordításban is) 1356-os dátummal.

R.: $\quad$ Erd. Okm. III. 241. (636. szám) 1352. jan. 8-i kelttel.

Megj.: Lajos király 1351. dec. 6. oklevelét l. Doc. Rom. Hist. C. X. (83. szám), 1355. jan. 1. megerősítését 1. Doc. Rom. Hist. C. X. (363. szám). Az oklevél valójában 1352-ben kelt. 2 eredeti példányban maradt fenn Dl. 4233. jelzet alatt, de ide tartozik a Dl. 31 095. Ezt az oklevelet a hosszan elhúzódó családi birtokperek során többször átírták tartalmilag (többek között Bebek Imre nádor, 1390. ápr. 9. Dl. 29992.; Garai Miklós nádor többször: 1406. febr. 27. Dl. 30 099.; 1409. márc. 13. Dl. 31 053.; Váradi kápt. 1409. Dl. 31 053.; Má.: váradi kápt. 16. sz.-i Dl. 70 631.; váradi kápt.18. sz.-i Dl. 71 866. és Dl. 73 665; Df. 257934 és 257 936.). Ezekben helyesen az 1352-es dátum szerepel, míg az apparatusban megadott Tá.-ok és K.-ok a téves 1356-os dátumot vitték tovább.

\section{1356. jan. 9. Bécs}

Albert, Au., Stájero. (Styrie), Karintia hercege, Carniola, Marchia ura és Naonis kikötőjének ura (portus Naonis S. Gen.), Habspurch-i c. és Kyburch, Alsacia ôrgrófja (lantgrafius Alsacie), Phirretae ura (dominusque Phirretarum) kinyilvánítja: pecsétjével megerősített oklevelet bocsát ki, amelyben rögzíti, hogy közte és [I.] Lajos király (H), valamint utódaik között kölcsönös védelmi szövetség köttetett 10 évre, olyan kötelezettséggel, hogy a másikat ért támadás esetén segítséget nyújtanak egymásnak, kikötik továbbá, hogy Lajos nagybátyja, Kázmér király (Lo.) ellen egyikük sem nyújt senkinek sem segítséget. Ha pedig Lajosnak szüksége volna Albert hívei közül valaki(k)re, hozzájárul, hogy az(oka)t szolgálatába fogadja. D. Wienne, 9. die Jan., a. d. 1356.

E.: HHStA. Wien Urkundenabteilung. Allgemeine Urkundenreihe. REP 1. 19. (Df. 257 983.) Hátoldalán korabeli és késóbbi kezek írásával 3 tárgymegjelölés, továbbá aljára illesztett hártyaszalag látszik.

K.: F. IX. 2. 484-485. (232. szám) (a bécsi lt.-ban talált E.-ről).

R.: M. Nemz. Tört. III. 284.; Pór A., Száz. 1907. 781; Opočenská 27. (latin nyelvû). 
A pécsi egyház kápt.-ja tudatja: egyik részról Kemud-i Jakab fiai: Miklós és Konrád (Corrardus) mr., a másik részról Zeredahel-i Ders fia: Miklós mr., s mellette az említett Ders fia Péter fia: Mihály — mindkét félen egyenlő számban lévő fogott bírák közremúködésével - a királyi kápolnaispánnak, s egyben a csázmai egyház prépostjának, Lászlónak az egyezséglevelében foglaltak alapján [1355.] dec. 14-én (in quind. fe. B. Andree ap.), a zselici Szt. Jakab-monostorhoz (monasterium S. Jacobi de Selyzio) mentek, hogy a monostor birtokainak dolgát - mely rájuk, mint kegyurakra tartozik elrendezzék. Az ügyben - ti., hogy melyik fél mely birtokon köteles officialis-t állítani — a kápt. 2 embere is köteles volt megjelenni, ezért a kápt. kiküldte kanonokjait, László mr.-t Jakab fiai oldalán, valamint István mr.-t, egykori dékánt Ders fia: Miklós mr. és Péter fia: Mihály oldalán, akik a felekkel együtt visszatérve, azok jelenlétében jelentést tettek. Eszerint a mondott idóben kimentek az ítélet helyszínére, ahová a felek több fogott bírát vezettek, akik meghallgatva a felek előterjesztéseit a fenti ügyben, a monostor apátjának a jelenlétében és akaratából a következő döntésre jutottak: a rendezés napjától számított 1 évre a monostor valamennyi Ormankuz-i birtokán Jakab fiai, a monostor valamennyi, Zselicben lévő birtokán pedig Ders fia: Miklós mr. és Péter fia: Mihály állítanak officialis-t, a birtokokat pedig kegyurakként birtokolják; az 1 év elteltével Jakab fiai a Zselicben lévő birtokok élére, Miklós mr. és Mihály pedig az Ormankuz-ben lévők élére állítanak officialis-okat és birtokolják azokat a fenti módon. Azt követôen pedig minden egyes évben váltogatják a birtokok élén officiális-aikat egyik évben az egyik, másik évben a másik helyezi officialis-át a tisztségbe, ahogyan azt részletesebben leírja a néhai Károly király egyezséglevele (l. Anjou-oklt. XIII. 66. szám). Elrendelték továbbá, hogy a felek [1356.] ápr. 26-án (3. die fe. B. Georgii mart. nunc venturo) személyesen járuljanak a nevezett monostorhoz, ahol annak apátjával együtt - a kápt. 2 emberének jelenlétében - a monostor birtokain élő valamennyi predialis-t és nemes jobbágyot ugyanabban a szabadságban maradni engedik közös egyetértéssel. Azokat pedig, akiket az egyik v. másik fél nem akar abba a szabadságba meghagyni, mozdítsák el, nehogy bármely fél a másikkal szemben megőrizhessen bárkit is abban a szabadságban. A predialis-ok v. nemes jobbágyok pedig szabadon eldönthessék, hogy a felek közül kit akarnak szolgálni. A többi dologban Károly király említett oklevelének rendelkezései a mérvadóak olyan - a felek által elfogadott - kikötéssel, hogy ha valaki a fentiekben rögzített megegyezéstól elállna, akkor a Károly király oklevelében meghatározott büntetést kapja. D. sabb. prox. p. fe. Epiph. d., a. eiusdem 1356.

E.: Dl. 4585. (Acta eccl. 21. 39.) Hártyán, hátoldalán késóbbi kezek írásával tárgymegjelölés és jegyzet, valamint mandorla alakú pecsét töredéke.

K.: F. IX. 2. 545-547. (266. szám) A bécsi udvari kamaránál őrzött E.-re hivatkozó Hevenesi tom. 44 .

Megj.: László kápolnaispán egyezséglevelét közelebbról nem sikerült azonosítani.

\section{1356. jan. 9.}

A pozsonyi egyház kápt.-ja emlékezetül adja: színe e. a néhai pozsonyi polgárnak, Treufenkes (dict.) Istvánnak a lánya, Klára asszony kinyilvánította, hogy Verkyne birtokon lévő birtokrészeit — amelyeket a néhai Zorardus fiai birtokoltak és Klárát leánynegyed, valamint zálog jogcímén illetik meg -, elzálogosítja Jakus pozsonyi bírónak 50 font fontonként 6 pensa-val számolt — széles bécsi dénárért, továbbá kiköti, hogy Jakus és 
utódai évente minden Húshagyókedden (in quolibet Carnis privio) 5 fontot kötelesek neki fizetni, amit ha elmulasztanának, kétszeresét legyenek kötelesek megadni, amikor pedig Klára ki tudja fizetni a zálogösszeget, a kérdéses részbirtokokat szabadon visszakapja. D. 4. die Epiph. d., a. eiusdem 1356.

E.: AM. Bratislavy. Pozsony város tanácsa 122. (Df. 238 747.) Hátoldalán kerek pecsét töredéke, szalagja, valamint késóbbi kéz írásával tárgymegjelölés.

K.: -

R.: Ortvay, Pozyony III. 318, 363; AMB. Inventár 26. (129. szám) (csehül).

15. (1356.jan. 10.e.)

[I.] Lajos király tudatja, hogy Jakus c., Pozsony város bírája a néhai Streuz (dict.) Marhardus örököseitól 460 M. széles bécsi dénárért váltotta vissza Domokos fia: Miklós valamennyi olyan Pozsony m.-i birtokát, melyeket az egykor Streuz (dict.) Marhardusnak zálogosított el.

Eml.: A 18. számú oklevélben.

K.: AO. VI. 419. (266. szám) (Eml.-ben).

\section{1356. jan. 10. Bécs}

Albert [osztrák herceg] tanúsítja, hogy egyik részrôl [I.] Lajos király $(\mathrm{H})$ ígéretet tett arra vonatkozóan, hogy megfizeti a másik részról érintett Margit bajor (von Bayrn) hercegnőnek a neki járó 30000 ft. értékú nászajándékát, és átengedi neki Tyrnna-t. D. Wienne, domin. p. Epiph. d., a. d. 1356.

K.: F. IX. 2. 498-499. (239. szám)(német nyelvû) hivatkozással a bécsi birodalmi lt.-ra.

R.: Pór A., T. 15 (1897) 14.

\section{1356. jan. 10. Zágráb}

Margit egész Szlavónia, Ho. és Da hercegnéje emlékezetül adja: autentikus függőpecsétjével megerősített privilégiumot bocsát ki, amelyben viszonozván udvarának familiarisa, Tamás fia: István mindazon szolgálatait, amelyeket az néhai férje, István herceg oldalán teljesített, különös tekintettel arra, hogy megsegítette a herceget [I.] Lajos király (H) szerbiai hadjáratában Rascia királya ellen, ill. hogy akkor is igyekezett a herceg szolgálatára lenni, amikor az az udvarban maradni kényszerült; majd annak halála u., ragaszkodásból továbbra is a hercegné és fia, János herceg szolgálatát választotta, jutalomképpen azt a hegyvámot, amely az István által fivérével ([fr.] uterinus), Miklóssal és unokatestvérével ([fr.] patruelis), Mihállyal együtt örökletesen birtokolt Pothgorya birtok u. eddig mint hercegnének neki járt, átengedi a nevezetteknek és örököseiknek. D. Zagrabie, Péter, vasvári prépost és hercegnéi kancellár keze által, in domin. prox. an. oct. fe. Epiph. d., a. eiusdem 1356. A.

E.: HDA. Documenta medievalia varia 63. (Df. 218 559.) Hártyán, függőpecsét sodratával, Halász szerint függő́pecsét nyomaival, hátoldalon a plica-n „conmissio propria et relatio Jenslini Teutonici". 
Má.: Dl. 4586. (NRA. 1509. 32.) (1850. aug. 7. Buda).

K.: Spiess, Aufklärgen. i. d. Gesch. u. Diplomatik 262. (2. szám) (E.-ról), s ennek nyomán F. IX. 2. 500-502. (241. szám); Simč. XII. 320-321. (239. szám) (E.-ről).

R.: Alsószlavónia 16. (45. szám); Wertner M., Hadtört. Közl. 19 (1918.) 208. (18. szám); Halász É., Fons 2007.116-117; Halász É., Szlavón 239. (466. szám).

Ford.: Középk. hist. 295. (150. szám).

18. 1356. jan. 10.

A pozsonyi egyház kápt.-ja e. Streuz (dict.) Marhardus Merhardus néhai pozsonyi polgárnak a leánya, Margit asszony, ill. férje Raznata fia: Iwan, nemkülönben Albert fia: Jenslinus, valamint az említett Marhardus fiának, Jekkul-nak az özvegye, Klára asszony - eljárva Jekkul-tól született gyermekei, a nevezett Marhardus unokái, Mihály és Margit képviseletében is — kinyilvánítják, hogy Pozsony város bírája, a révnél [lakó ?] Jakab fia Miklós fia: Jakus c. (Jakus filius Nicolai filii Jacobi circa portum) az [I.] Lajos király parancslevelében foglaltak értelmében (l. 15. szám) visszaváltotta tőlük Domokos fia: Miklós valamennyi olyan Pozsony m.-i birtokát, azaz Januk, Tolvayfolua, Saralia, Kurmusd, Kukynzarw, Chandal és Kezey birtokokat, amelyeket e Miklós a kápt. egy másik oklevele révén egykor elzálogosított 460 M. - M.-ként 10 pensa-val számolt — széles bécsi dénár ellenében Streuz (dict.) Marhardus-nak; most ugyanezt az összeget megkapva Jakus bírótól, mentesítik ốt minden további követelés alól. D. die domin. prox. p. fe. Epiph. d., a. eiusdem 1356.

E.: Dl. 4587. (Acta eccl. ord. et mon. Poson. 6. 6.) Hártyán, alul az ABC betúivel chirographálás, alján vörös selyemsodraton a pozsonyi kápt. - kissé sérült — pecsétje függ (rajta kéttornyú templom látható, körirata: +S(IGILLVM) EC(C)LESIE SALVATORIS POSO(NIENSIS)).

K.: AO. VI. 419. (266. szám) (kihagyásokkal).

R.: Ortvay, Pozsony III. 318, 363.

19. (1356.jan. 12.e.)

András bán és Vasvár m. szb.-i jan. 11-re halasztják a Hydvig-i András fia: János mr., ill. Walt-i Domokos fia: László és Varda fia: György közötti pert.

Eml.: A 20. számú oklevélben.

K.: HO. I. 215. (144. szám) (kihagyásokkal).

\section{1356. jan. 12. Vasvár}

Elleus fia: Miklós mr., a királyné tárnokmesterének András bánnak, valamint Vasvár, továbbá Sopron m.-knek az alispánja (vicecomes) és Vasvár m. szb.-i emlékezetül adják, hogy abban a perben, amelyet András bán és Vasvár m. szb.-áinak korábbi oklevele (l. 19. szám) értelmében jan. 11-re (f. II. prox. p. fe. Epiph. d.) túztek ki, megjelent egyik részrôl Hydvig-i András fia: János mr., a másik részrôl pedig Walt-i Domokos fia: László 
és Varda fia: György. Előbbinek anyja hitbére és jegyajándéka iránt támasztott követelése tárgyában az oklevél kiadói e. a felek akaratából a pert a korábbi állapot fenntartása mellett júl. 4-re (ad f. II. prox. p. oct. fe. Nat. B. Johannis Bapt.) halasztják el, oly módon, hogy ugyanez a László ....... birtokról [való] felvállalta, hogy fivére (fr. uterinus), János nevében is válaszol. D. in Castroferreo, 2. die termini prenotati, a. d. 1356.

E.: BFL. Guary cs. 1t. 29. (Df. 257 289.) Papíron, foltokban sérült, hátoldalán 4 zárópecsét maradványai (K. szerint 3), továbbá azonos kéz írásával tárgymegjelölés (ebben eltérő névalak: Hydvid), késóbbi kézzel jegyzet.

K.: HO. I. 214-215. (144. szám) (kihagyásokkal); Sörös P., TT. 9 (1908) függelék 22/ A.

\section{1. (1356.jan. 13.e.)}

Zeech-i Miklós országbíró parancslevelében utasítja a bácsi egyház kápt.-ját, hogy a királyi udvarból kiküldött királyi emberrel, Scepes-i András fia: László mr.-rel együtt küldjenek ki tanút a néhai Péter fia: Márton Dombow birtokára és bejárva annak határait, osszák azt fel 4 egyenlő részre, majd a törvényesen összehívott szomszédok és határosok jelenlétében - tekintettel arra, hogy itt ellentmondásnak sem Márton özvegye, sem más részéról nincs foganatja - a részek közül 3 birtoklásába iktassák be Lőrinc fia: Lőrinc és Péter fia: István mr.-eket, akiket királyi adomány címén, idegen jog sérelme nélkül illetnek meg azok a részek. A maradék negyed felett pedig Péter fia: Márton 3 leányának egészen addig van tulajdon- és haszonélvezeti joga, amíg férjhez nem mennek, ezt követően pedig az ország szokása szerint Lőrinc és István köteles oóket kielégíteni az ôket megillető leánynegyed kapcsán. Nem mellőzhető, hogy Márton özvegyének jogában áll hozományát és jegyajándékát visszakövetelni a szóban forgó birtokból. Az országbíró kéri a kápt.-t, hogy küldjön a történtekről számot adó jelentést a királynak febr. 9-re (ad. oct. fe. Purif. B. virg.).

Tá.: A 92. számú oklevélben.

Eml.: A 35. számú oklevélben.

K.: AO. VI. 434-435. (277. szám) (kihagyásokkal). Smič. XII. 330-331. (248. szám).

\section{2. (1356.jan. 13.e.)}

Zeech-i Miklós országbíró ítéletlevelében tisztázó eskü tételére kötelezi Pétert, a Lelez-i Szt. Kereszt-egyház prépostját és a rend testvéreit Torna-i János fiai: László és Egyed mr. ellenében, mivel Péter prépost elődje, az egyház néhai prépostja, Balázs és ugyanezen hely konventje Luchka-i Pál fia: Miklós javára - állításuk szerint tudtuk és egyetértésük nélkül - hamis oklevelet állítottak ki abban a perben, amely egyik részrôl Miklós a másik részrôl pedig nevezett László és Egyed mr. apja, János mr. között zajlott. Ezért utasítja az országbíró a jászói konventet, hogy a felperes, János fiai: László és Egyed részéról Nadasd-i Antal v. Ferceus fia: Lukács (Lucasius) v. Kerch-i Benkus v. Olyuanth-i Tamás fia: Miklós jelenlétében, hasonlóképpen az alperes Péter prépost és a leleszi konvent részéról Boly [!] László v. Zentus-i Meko v. Kerezur-i László királyi emberrel együtt küldje ki a maga embereit, jan. 13-án (in oct. fe. Epiph. d.) az eskütétel lebonyolításához.

Eml.: A 36. számú oklevélben.

K.: - 


\section{1356. jan. 13.}

Az egri egyház kápt.-ja tudatja: egyik részről Lonya-i Jakab fia Jakab fia: Miklós mr., a néhai Luchonch-i Dénes unokája, a másikról pedig Kalanda-i Péter fia: László, Luchonchi Dénes fia István néhai szörényi (de Zeurinio) bán fia: Dénes mr. famulus-a és képviselője jelent meg színe e., ahol is Jakab fia: Miklós mr. kijelentette, hogy mindazon perekben, amelyek korábban megboldogult nemes anyja, a nevezett idősebb Dénes lánya: Klára életében, majd halála u. közte és István fia: ifjabb Dénes valamint utódai között zajlottak, fogott bírák közremúködésével megegyezés született, amelynek megfelelően Kalanda-i László, ura képviselőjeként a kápt. színe e. megfizette Miklós mr.nek az anyja leánynegyede $u$. őt megillető összeget és minden más költséget, melyekról jelen oklevél tanúskodik, továbbá kötelezte magát Miklós mr., hogy Dénest és utódait minden, a leánynegyeddel kapcsolatos késóbbi költségtől és zaklatástól megvédelmezi, amelynek bizonyságául a kápt. autentikus függőpecsétjével megerôsített és chirographált oklevelet bocsát ki. Jelen voltak: László prépost, Imre olvasó-, Sándor éneklő-, Miklós őrkanonok, Domokos Bursua-i, András Zemlyn-i, Miklós Zabouch-i, Miklós Pata-i, László Borsad-i fóesp. D. in oct. fe. Epiph. d., a. eiusdem 1356. [I.] Lajos lévén a király (H), Miklós az esztergomi érsek, a kalocsai egyház széke üresedésben, Miklós az egri püspök.

E.: AL. Cluj. Cluj-Napoca (Kolozsvár). Erdélyi Múzeum Egyesület egykori lt. Bánffy cs. nemzetségi lt. 57. (Df. 260 636.) Alul az ABC betúivel chirographálás, K. szerint hártyán, alján vörös és sárga selyemzsinóron töredezett pecsét.

K.: Bánffy I. 206-207. (169. szám).

R.: Doc. Rom. Hist. C. XI. 5. (3. szám) (románul).

\section{1356. jan. 13.}

István prépost és a Saagh-i Boldogságos Szúz Mária-monostor premontrei rendi testvéreinek konventje János testvérnek, a Been-i Boldogságos Szűz-egyháza prépostjának kérésére és oklevél-bemutatása alapján autentikus pecsétjével megerősítve átírja saját, 1273-ban [Amadé fia: István mr. végrendelete tárgyában] kiadott privilégiumát. D. in oct. fe. Epiph. d., a. eiusdem 1356.

E.: Dl. 3638. (Acta eccl. 53. 2.) Hártyán, alján hártyaszalagon a konvent kissé töredezett pecsétje függ (rajta 2 egymással szembenálló alak, egy szárnyas angyal oldalról, kezében írásszalaggal, és Mária felénk forduló alakja látható; körirata részben kivehetố +S(IGILLVM) (CON)VE(N)T(VS) ECC(LESIE) S(ANCTE) M(ARIE) D(E) SAG IVX(TA) IPVL ORD(INIS) P(RE)MO(N)STRATENSIS), hátoldalán késóbbi kéz írásával jegyzet.

K.: F. IX. 2. 539. (261. szám) (kihagyásokkal, E.-re hivatkozó Hevenesi nyomán).

Megj.: A sági konvent átírt oklevelét 1. F. V. 2. 138-139. (feltüntetett hivátkozása szerint: a sági apátság aktáiból, Rajcsányi-Mednyánszky diplomatikai gyưjtemény), valamint F. VII. 2. 29. (316. szám) (Czech János gyújteményére való hivatkozással). 


\section{1356. jan. 13.}

A vasvári egyház kápt.-ja függőpecsétjével megerősített és az ABC betûivel chirographált privilégiumában tudtul adja: színe e. a Zala m.-i Zenthmargythazzunfolua-i Akus fiai: Jakab és Mihály személyesen, valamint fivérük (fr. carnalis), Miklós helyett is eljárva előadták, hogy a Lyndua-i István fia: Miklóssal, Szlavónia és Ho. bánjával, valamint annak fiaival: István, Ferenc és János mr.-ekkel mint alperesekkel szemben fennforgó pereskedésüket fogott bírák közremúködésével elrendezték. Eszerint valamennyi perükben - és az elődeik által viseltekben is - különös tekintettel birtokpereikre, visszavonhatatlan és békés egyezségre jutottak, amelynek értelmében Miklós bánnak, nemkülönben István, Ferenc és János mr.-eknek, továbbá a bán más fiainak és utódaiknak a büntetését, ill. minden kötelezettségét elengedik oly módon, hogy ha ók v. testvérük, Miklós ennek ellenére valaha is perbe akarná vonni az alpereseket v. azok utódait, ezen oklevél mentesítse majd őket attól. D. in oct. fe. Epiph. d., a. eiusdem 1356. Péter lévén a prépost, s egyben Margitnak, Szlavónia, Ho. és Da hercegnéjének titkos kancellárja, Domokos mr. az éneklő-, Mihály mr. az őrkanonok és a dékán. A.

E.: Dl. 4588. (NRA. 582. 34.) Hártyán, felül az ABC betúivel chirographálás, alján vörös sodraton pecsét függ, (melyen Szt. Mihály glóriával övezett, kiterjesztett szárnyú, álló alakja látható szemből, két kezében kereszt formában végződő lándzsát tart, mellyel a lába e. heverő sárkány fejét szúrja át; körirata: +S(IGILLVM) CAPITVLI S(AN)C(T)I MICHAEL(IS) DE CASTRO FERREO).

K.: -

\section{1356. jan. 14. Zágráb}

Margit, egész Szlavónia, Ho. és Da hercegnéje a zágrábi egyház kápt.-jának: miután Pryztawschyna $\sim$ Pryztawchyna birtokot, amely Gradschan birtok mellett fekszik, a Boldogságos Szúzbe vetett hitéből eredően és néhai férje, István herceg lelki üdvéért, nemkülönben fia, János herceg szerencsés boldogulásáért (pro felici statu) a zágrábelőhegyi Boldogságos Szűz remete testvéreinek adományozta, megparancsolja, hogy a kápt. küldje ki emberét hites tanúul Domokos fia: Bendek mr. v. Morowcha-i Tamás v. ugyanezen Benedek mr. famulusa, Hraschyna-i Gatal hercegnéi ember valamelyikének társaságában a nevezett birtokra, ahol a szomszédosok összehívását követően iktassa be a birtokba s annak minden haszonvételébe és tartozékába a mondott remetéket örök birtoklásra; továbbá utasítja a kápt.-t, hogy ellentmondás esetén idézze meg a feleket színe elé, és mindezekről neki jelentést írjon. D. Zagrabie, 2. die oct. fe. Epiph. d., a. eiusdem 1356.

Á.: A 29. számú oklevélben. > a 654. számú oklevélben. Tkalčić és Smič. hivatkozása szerint az irat Zágrábban, „in archivo regni C[roatie] S[clavonie] D[almatie]”, Act. Convent. Remet. fasc. I. nr. 10. jelzet alatt található. Tkalčić közlése szerint kopott hártyára írt privilégium függópecséttel, mely sárga sodraton függ. A MOL nem tartja nyilván az iratot.

K.: Arkiv III. 86-87. (9. szám) (E.-ről); Tkalčić, Mon. civ. Zagr. I. 209-210. (233. szám) (E.-ről); Smič. XII. 321-322. (241. szám) (E.-rôl v. Tkalčić nyomán).

R.: Halász É., Fons 2007/1. 116-117. (11. szám); Halász É., Szlavón 239-240. (467. szám). 
Megj.: A regeszta az E.-t használó Tkalčić kiadása alapján készült. A kiadásokban eltérő névalakok szerepelnek, így az Arkiv-ban: Prysztawchyna, Prystawschyna, Chorus de Moraucha; Tkalčić-nál és Smič.-nál: Pryztawchyna, Pryztawschyna; Thomas de Morowcha.

\section{1356. jan. 14.}

Az erdélyi egyház kápt.-ja jelenti István, erdélyi alvajdának: megkapták itt átírt 1355. dec. 10-i oklevelét, és az abban foglaltaknak megfelelően Nadas-i Lőrinccel — az alvajda emberével - együtt kiküldték kanonokjukat, a Clwswar-i plébános, Pál káplánját, Tamás papot tanúskodás végett, akik visszatérve jelentették, hogy [1355.] dec. 21-én (in fe. B. Thomae ap.) kimentek a szóban forgó Apaty birtokra a Regen-i Dénes fia: Tamás mr. képviseletét törvényesen ellátó Nagy (Magnus) Miklós jelenlétében és megjárták annak határát. Hj.: a határ egy nyírfánál kezdődik a Marwsius folyó révjénél (portus), innen Dé felé egy nagy közútig, azon keresztül Regen faluhoz, földjel, majd rövidesen a Ny-i részhez ér; ahol egy hegy lábánál földjel; innen egy ásott árok tövéhez tart, ahol elhatárolódik az apát Apaty földje Dénes fia: Tamás mr. Benktelke és Regen birtokától. A másik oldalon a határ Apaty és Gurgin-i (dict.) Péter fia: János birtoka, Abafaya között ugyanezen árok tövénél kezdődik, ahonnan Ke felé 2 közút kereszteződéséhez ér, földjel, majd ebben az irányban eléri Abafaya birtokot, ahol Minden Szentek tiszteletére emelt fa kápolna áll, benne oltár; Bereck apát Apathy földje megjelölésére határjelet állíttatott, ahonnan tartva ugyanezen irányt eléri a Marwsius folyót és itt véget ér. Jóllehet Péter fia: János nem emelt ellentmondást a hj.-kor, mégis, amikor a mondott földet iktatni akarták Bereck apát és egyháza számára, Gurgin-i (dict.) Péter fia: János ellentmondott az iktatásnak, azt állítván, hogy a mondott birtokot királyi adományként kapta. Ót ezért az alvajda embere [1356.] jan. 13-ra (oct. fe. Epiph. d.) [!] a vajda bírósága elé idézte. D. 2. die predictarum oct. fe. Epiph. d., a. eiusdem 1356.

E.: Dl. 28 734. (Kolozsmonostori konvent o. lt. Metales A 17.) Papíron, az oklevél jobb fele és alsó része hiányzik, a meglévő részen a kézírás elhalványult, nehezen olvasható. Hátoldalán azonos kéz írásával az olvashatatlanságig elhalványult sorok, valamint késóbbi kéz írásával tárgymegjelölés, továbbá kerek zárópecsét töredéke (rajta kivehető TRANSSILV körirat), bevágásai, valamint 2 kisebb pecsét töredéke, szalagja, bevágásai (Erdélyi Okm. szerint utóbbiakon pecsétfővel történt pecsételés nyomai).

Má.: 1. Uo., mint E., azzal megegyező jelzet alatt; 1783. jún. 14. Má.-ban.

2. János Zsigmond király 1566. márc. 21. u. Dl. 36 877. (Kolozsmonostori konvent o. 1t. Neoregestrata Torda A 27; Kolozsmonostori konvent o. lt. Cista comitatuum W 17.) egyszerü, hibás Má.-ban.

K.: ZW. II. 118-119. (702. szám); Doc. Rom. Hist. C. XI. 5-8. (4. szám) (román fordításban is).

R.: Erdélyi Okm. III. 301-302. (826. szám).

28. 1356. jan. 15.

A pécsi egyház kápt.-ja e. — miként azt 1356. jan. 15-én (f. VI. prox. p. oct. fe. Epiph. d., a. eiusdem 1356.) pergamenre íródott nyílt oklevele tanúsítja — egyik részról Bodogaszony- 
falwa-i Hektor fia János fia: Bakous a saját, valamint fivérei (carnalis fr.), Gál és László nevében, s vele együtt ugyanezen Hektor fia: Pál, ugyanezen Hektor fia Miklós fiai: Kozma (Cozmas Cosmas), Antal és István képviseletében, a másik részról pedig Nempthy-i Jakab fia János mr. fiai: László és János személyesen megjelenve kijelentették, hogy nevezett részbirtokkal kapcsolatos valamennyi viszályukban és perükben egyezségre jutottak, melynek értelmében a felek felosztják egymás között a Baranya m.-i, a Makrad és Fyzesd folyók között fekvő birtokot.

Tá.: Perényi Imre nádor 1508. aug. 26. > Szentgyörgyi és Bazini Péter királyi országbíró, erdélyi vajda, 1509. okt. 30. Dl. 101 881. (Batthyány cs. lt. Sellye 4.)

Má.: Dl. 104 524. (Batthyány cs. Senioratus. Sellye 25. 4.) Tá.-ról készült 1778. szept. 22-i Má. 14 lapos füzet formájában, mellette 4 lapos, határleírást tartalmazó töredék.

K.: -

\section{1356. jan. 15. Zágráb}

A zágrábi egyház kápt.-ja jelenti Margitnak, egész Szlavónia, Ho. és Da hercegnéjének: teljesítvén itt átírt, jan. 14-én kelt parancslevelében (l. 26. szám) foglaltakat, a hercegné emerének, Gatal-nak a társaságában tanúul küldték kanonoktársukat, János varasdi fő́esp.-t, akik visszatértükkor jelentették, hogy jan. 14-én (f. V. prox. p. predict. oct. Epiph. d.) kimenvén Pryztawschyna birtokra, s ott összehívván a szomszédokat és határbirtokosokat bejárták annak határait, majd - mivel senki nem mondott ellent — iktatták a birtokot a remete testvérek részére örök birtoklásra. D. f. VI. prox. p. oct. Epiph. d. prenotatas, a. eiusdem superius annotato [1356].

Á.: A 654. számú oklevélben. Tkalčić és Smič. hivatkozása szerint Zágrábban, „in archivo regni C[roatie] S[clavonie] D[almatie]", Act. Convent. Remet. fasc. I. nr. 10. Tkalčić közlése szerint kopott hártyára írt privilégium függőpecséttel, mely sárga sodraton függ. A MOL nem tartja nyilván az iratot.

K.: Arkiv III. 86-87. (9. szám) (E.-ről); Tkalčić, Mon. civ. Zagr. I. 210. (234. szám) (E.ről); Smič. XII. 322-323. (242. szám) (E.-ről v. Tkalčić nyomán).

Megj.: A regeszta az E.-t használó Tkalčić kiadása alapján készült. A kiadásokban eltérő névalak szerepel, így az Arkiv-ban: Prystawchyna.

\section{1356. jan. 15. Visegrád}

Miklós nádor $(\mathrm{H})$, a kunok bírája azt a birtokpert, amelyben a korábbi oklevele értelmében (l. 6. szám) jan. 8-ra (oct. diei Strennarum) színe elé idézett Chorna-i Imre fia Lőrinc fia: János helyett a budai kápt. ügyvédvalló levelével Kerechen-i Bekev járt el, vele szemben pedig Kuchk-i Márton fia: Dénes képviseletében a somogyi konvent ügyvédvalló levelében meghatalmazott Sebestyén fia: István jelent meg, nevezett képviselők akaratából a korábbi állapot fenntartása mellett máj. 1-jére (ad oct. fe. B. Georgii mart.) elhalasztja. D. inVyssegrad, 8. die termini prenotati, a. d. 1356.

E.: Dl. 4589. (NRA. 19. 75.) Papíron, hátoldalán azonos kéz írásával tárgymegjelölés és közel egykorú kéz írásával jegyzet, valamint zárópecsét nyoma, bevágásai.

K.: - 


\section{1356. jan. 15. Visegrád}

Zeech-i Miklós c., [I.] Lajos király (H) országbírája, Turuch m. c.-e azt a pert, amely egyik részről István, a budai egyház prépostja - akit egyházának ügyvédvalló levelével Bakou képviselt — , a másik részról pedig a zalavári konvent ügyvédvalló levelében meghatalmazott Nagy (Magnus) János által képviselt Zabor-i János fia: János között forgott fenn, és amely korábbi oklevele (l. 7. szám) értelmében jan. 8-án (in oct. diei Strennarum) volt esedékes, a feleknek törvényszéke elé járult említett képviselői akaratából máj. 1jére (ad oct. B. Georgii mart.) elhalasztja, ha addig ki nem egyeznek. D. in Vysegrad, 8. die termini prenotati, a. d. 1356.

E.: Dl. 4590. (NRA. 1538. 26.) Papíron, hátoldalán azonos kéz írásával tárgymegjelölés, valamint kerek zárópecsét nyoma, bevágásai, szalagja.

K.: -

\section{1356. jan. 15. Visegrád}

Zeech-i Miklós c., [I.] Lajos király (H) országbírája, Turuch m. c.-e azt a pert, amelyben korábbi oklevele (l. 8. szám) értelmében jan. 8-án (in oct. diei Strenarum) hatalmaskodás tárgyában kellett az egri kápt. és a Lelez-i konvent ügyvédvalló levelében meghatalmazott János fia: Kelemen által képviselt Kapulya-i Dezső fiainak: Miklósnak és Lászlónak megjelennie törvényszéke e. Ida-i Pál fia: János mr. ellenében, akit a Jzau-i Jazou-i konvent ügyvédvalló levelében meghatalmazott János fia: Lőrinc képviselt, a felek képviselőinek akaratából máj. 1-jére (ad oct. fe. B. Georgii mart.) elhalasztja, ha a felek nem tudnának megegyezésre jutni ápr. 4-én (in oct. diei medii Quadr.) a Jazou-i konvent e. 4 fogott bíró közremúködésével. D. in Vyssegrad, 8. die termini prenotati, a. d. 1356.

E.: Dl. 4610. (NRA. 1698. 86.) Papíron, hátoldalán azonos kéz írásával tárgymegjelölés, késóbbi kéz írásával jegyzet, továbbá kerek zárópecsét nyoma, bevágásai.

K.: -

\section{1356. jan. 15. Visegrád}

Zeech-i Miklós c., [I.] Lajos király (H) országbírája, Turuch m. c.-e azt a Nogkorong és Urbachannue birtokok kapcsán támadt pert, amelyben oklevelek bemutatására a felperes Simon fia: Miklóst, ill. vele szemben Nogmortun-i Lőrinc fia: Nykul mr.- $\mathrm{t}$ - utóbbit a budai kápt. ügyvédvalló levelével Péter fia: János képviselt — a korábbi oklevelében (l. 9. szám) foglaltak szerint jan. 8-ra (oct. diei Strennarum) törvényszéke elé megidézte, a felek kérésére márc. 16-ra (ad oct. diei Cynerum) elhalasztja 2 M. bírság kirovása mellett. D. in Wyssegrad 8. die termini prenotati, a. d. 1356.

E.: Dl. 39 221. (Archivum regni, RR Y 31.) Papíron, hátoldalon azonos kéz írásával tárgymegjelölés, késóbbi kézzel írott jegyzetek, valamint kerek zárópecsét töredéke, bevágásai.

Eml.: A 133. számú oklevélben.

K.: - 


\section{1356. jan. 15. Visegrád}

Zeech-i Miklós c., [I.] Lajos király (H) országbírája, Turuch m. c.-e azt a pert, amelyben korábbi oklevele (l. 10. szám) értelmében jan. 8-án (oct. diei Strennarum) kellett az egri kápt. ügyvédvalló levelében meghatalmazott Salamon fia: Mihály által képviselt Nogsemyen-i István fia: Istvánnak megjelennie törvényszéke e. Lengel (dict.) János fiai: László, Leukus és Ábrahám (Abraam) ellenében — akiket az egri kápt. ügyvédvalló levelében maghatalmazott Leukus képviselt —, a felek kérésére máj. 1-jére (ad oct. fe. B. Georgii mart.) elhalasztja a korábbi állapot fenntartásával. D. in Vissegrad, 8. die termini prenotati, a. d. 1356.

E.: D1. 51 694. (Kállay cs. lt. 1300. 1127.) Papíron, hátoldalán azonos kéz írásával tárgymegjelölés, valamint kerek zárópecsét töredéke, bevágásai.

Má.: Uo., mint E., azzal egyező jelzet alatt; egyszerű jelenkori Má.-ban.

K.: -

R.: Kállay II. 33. (1171. szám).

\section{1356. jan. 16.}

A bácsi egyház kápt.-ja jelenti [I.] Lajos királynak (H): miután megkapták Zeech-i Miklós országbíró parancslevelét (l. 21. szám), az abban foglaltak szerint Scepes-i András fia: László mr. királyi emberrel együtt tanúként kiküldték a kápt. emberét, Balázs karpapot, akik visszatérve egybehangzóan jelentették, hogy jan. 13-án (in oct. fe. Epiph. d.) Walkow-i Fyle fia Péter fia: István mr., valamint ugyanezen Fyle fia Lőrinc fia: Lőrinc mr. társaságában kimenvén a Valkó m.-i Dombow $\sim$ Dombou birtokra — melyet nevezettek királyi adomány címén birtokoltak - a törvényesen összehívott határosok és szomszédok jelenlétében beiktatatták őket az első hj. alkalmával telkei (sessiones) és más haszonvételei tekintetében 4 részre osztott Dombow birtok háromnegyed részébe, amelynek 3 része idegen jog sérelme nélkül Lőrinc és István mr.-nek királyi adomány címén jutott, figyelmen kívül hagyva (excepta) Péter fia Márton özvegyét. Ezt követóen a 4. részt, ti. az É-on fekvôt járták be, majd beiktatták abba Péter fia: Márton 3 leányát. Hj.: É-ról Dombow falu közepén körtefa, Dombow-ról a Szt. Kereszt-templomhoz vezető út (mely templom egy másik, Dombou nevú faluban áll), völgyszerú hely (vlg.:) zurduk, mező, amelynek fele Lőrinc és István Dombow-i egyházához tartozik, míg a másik fele Dombow-i Péter fia Márton 3 leányáé, Ke-re mező szöglete, Dé-re (vlg.:) mege nevú hely, kúp alakú jel, erdő, cseresznyefa, út, szántóföld melletti körtefa, nagy út, Ny-ra tovább, hosszan az erdő mellett, erdő szeglete, nagy cseresznyefa, ágain kettôs kereszt, É felé tovább, körtefa, 2 szilfa egymásba nóve, út, szilfa több kereszttel jelölve, szántóföld, kúp alakú jel, vissza a határfőül szolgáló körtefához. Emellett Péter fia Márton leányait illeti Dombow halastavának negyede valamennyi haszonvételével együtt. D. sabb. prox. p. oct. Epiph. d. supradictas, a. d. 1356.

Á.: A 92. számú oklevélben.

K.: AO. VI. 435-437. (277. szám) (kihagyásokkal); Smič. XII. 323-325. (243. szám). 


\section{1356.jan. 16.}

Miklós prépost és a Jazo-i Keresztelő Szt. János-egyház konventje emlékezetül adják: Zech-i Miklós országbíró ítéletlevelében (l. 22. szám) foglalt rendelkezés szerint Péter, a Lelez-i Szt. Kereszt-egyház prépostja rendjének valamennyi — abban az egyházban lévő - testvérével együtt tisztázó eskü tételére köteleztetett Torna-i János fiai: László és Egyed mr. ellenében, mivel Péter prépost elődje, az egyház néhai prépostja, Balázs és ugyanezen hely konventje Luchka-i Pál fia: Miklós javára - állításuk szerint tudtuk és egyetértésük nélkül — hamis oklevelet állítottak ki abban a perben, amely egyik részről Miklós a másik részről pedig nevezett László és Egyed mr. apja, János mr. között zajlott. Ezért utasította az országbíró a címzettet, hogy a felperes, János fiai: László és Egyed részéról Nadasd-i Antal v. Ferceus fia: Lukács (Lucasius) v. Kerch-i Benkus v. Olyuanth-i Tamás fia: Miklós jelenlétében, hasonlóképpen az alperes Péter prépost és a Lelez-i konvent részéról Boly [!] László v. Zentus-i Meko v. Kerezur-i László királyi emberrel együtt küldje ki a maga embereit, jan. 13-án (in oct. fe. Epiph. d.) az eskütétel lebonyolításához. Ennek megfelelően ki is küldték egyházuk perjelét, Frigyes testvért a Péter prépost és a konvent oldalán közremúködő Zentus-i Mako királyi ember társaságában, míg László és Egyed mr. részéről — szemben az utasításban rögzítettekkel — nem mutatkozott igény az eskütételnél való jelenlétre, ugyanis a konventhez visszatérő kiküldöttek beszámolója szerint ők jan. 13-án kimentek Lelecz faluba, ahol Péter prépost és valamennyi erre kötelezett rendtársa letették a rájuk rótt esküt, László és Egyed mr. viszont nem jelentek meg és nem is küldtek oda senkit maguk helyett. D. 4. die oct. fe. Epiph. d. prescriptarum, a. eiusdem 1356.

E.: SNA. Leleszi prépostság mlt. Acta saeculi 1300. 82. (Df. 233 689.) Papíron, hátoldalán azonos kéz írásával tárgymegjelölés, valamint kerek pecsét töredéke, szalagja.

K.: -

\section{1356. jan. 16.}

Miklós prépost és a Jazo-i Keresztelő Szt. János-egyház konventje jelenti [I.] Lajos királynak $(\mathrm{H})$, hogy teljesítvén a hozzájuk intézett nyílt oklevelében (patentes generaliter emanatas) (l. 2. szám) foglaltakat, Zentus-i Mako királyi emberrel együtt tanúként küldték ki egyházuk perjelét, Frigyes testvért, akik visszatértükkor jelentést tettek. Eszerint jan. 5-én (fe. III. prox. an. oct. fe. Epiph. d. ) kimenvén Vngh m.-be kikérdezték az értesülésekkel rendelkezőket, amiből az derült ki, hogy a néhai országbírónak, Drugeth Miklósnak a fia: János mr. a Lelez-i Szt. Kereszt egyház Kiskapos és Vizaka nevú birtokainak hasznát és hozadékait magához vonta, Nagy-Kapus-i (de Kapus maiori [!]), Mertholth-i és Leykarthaza-i jobbágyai által erdeit kivágatja, mezőit kaszáltatja, határait szántatja, termését prédáltatja. D. 4. die predictarum oct. fe. Epiph. d., a. eiusdem 1356.

E.: SNA. Leleszi prépostság mlt. Acta saeculi 1300. 83. (Df. 233 690.) Papíron, hátoldalán tárgymegjelölés, valamint kerek pecsét töredéke, szalagja.

K.: -

\section{1356. jan. 16. [Ó-]Fehértó}

Voya-i János fia: László mr. Zabouch-i alispán (vicecomes) és a m. 4 szb.-ja emlékezetül 
adják, hogy Nogsemyen-i László fia: Mihály mr. jobbágya, Phouth — ura kezeskedése mellett - a kitüzött határidőig, azaz jan. 16-ig (sabb. prox. p. oct. Epiph. d.) megfizette az ura és a fogott bírák kérésére 6 ft.-ra enyhített vérdíjat, amire Péter fia Miklós özvegyével szemben ítélték. D. in Feyrtho, termino supradicto, a. d. 1356.

E.: Dl. 51 695. (Kállay cs. lt. 1300. 15.) Papíron, hátoldalán 3 pecsét töredéke és szalagja.

K.: AO. VI. 420. (267. szám).

R.: Kállay II. 33. (1172. szám); Piti F., Szabolcs m. 131. (510. szám).

\section{1356. jan. 17. Pozsony}

[I.] Lajos király $(\mathrm{H})$ emlékezetül adja, hogy Bars m. nemeseinek közössége és más emberek tudósítása alapján, melyet a király számára Lőrinc fia: László mr., barsi c. adott hírül, a király tulajdonában lévő Bars m.-i Kalathna földet, mely mindig Vgrach birtokhoz tartozott és teljes körú adományozási joggal rendelkezik felette, érdemes szolgálataiért, Vgrach birtokkal együtt, új adomány címén, s idegen jog sérelme nélkül Jakab fia: Miklós mr.-nek és örököseinek adományozza. D. Posonii, die domin. prox. p. oct. fe. Epiph. d., a. eiusdem 1356.

E.: D1. 4592. (NRA. 108. 3.) Hártyán, hátoldalán azonos kézzel: Comisso regis per Synka Zudar, valamint késóbbi kéz írásával tárgymegjelölés, továbbá kerek rányomott pecsét nyoma, bevágásai.

Má.: Uo., mint E., azzal megegyező jelzet alatt; egyszerú újkori Má.-ban.

K.: AO. VI. 421-422. (269. szám) (kihagyásokkal).

R.: Ortvay, Pozsony III. 10.

40. 1356. jan. 17.

A pozsonyi egyház kápt.-ja tudatja, hogy az egyik részról a maga nevében eljáró Klára özvegyasszony — Trefunkes (dict.) István néhai pozsonyi polgár leánya —, valamint az általa képviselt, Marhardus fia Jekul pozsonyi polgártól született gyermekei, Mihály és Margit, nemkülönben az említett Marhardus fia Albert fia: Jensul között, a másik részrôl Januk-i Domokos fia Miklós özvegye: Margit és Raznata fia: Iwan - Margit jelenlegi férje - között fennforgó perben fogott bírák közremúködésével megegyezés született. A felek viszálya a Januk-i Domokos fia: Miklós által - a kápt. korábbi oklevelében foglaltak szerint - Marhardus-nak elzálogosított birtokok és birtokrészek körül támadt, amely földeket egyezségük értelmében elóbbiek saját részükből visszaadják utóbbiaknak. ill. az ezzel kapcsolatos korábbi okleveleket semmisnek nyilvánítják. D. die domin. prox. p. oct. Epiph. d., a. in eodem 1356.

E.: D1. 41 277. (Múz. Ta. Nagy István) Hártyán, hátoldalán azonos kéz írásával tárgymegjelölés, valamint a pozsonyi kápt. kerek pecsétjének töredéke (melynek csak körirata olvasható: +S(IGILLVM) EC(C)LESIE SALVATORIS POSO(NIENSIS)), bevágásai.

Má.: Uo., mint E., azzal megegyező jelzet alatt; Mayer Béla aláírással.

K.: AO. VI. 420-421. (268. szám) (kihagyásokkal). 
R.: Ortvay, Pozsony III. 319.

\section{1356. jan. 17. Visegrád}

Miklós nádor 1356. jan. 17-én, Visegrádon (in Wissegrad, 10. die oct. diei Strennarum sub a. d. 1356.) kelt privilégiumának tanúsága szerint Zeech-i Miklós c. tudomására jutott, hogy Domokos fia: Donch és Albert fia: Petheu Leztemer-i nemesek Jenke birtok tulajdonába való beiktatásakor támadt ellentmondás miatt Aprod (dict.) István fiait: András és Péter mr.-eket, ennek az Andrásnak a fiát: Lászlót, és Panky-i Jakab fia: Bator (dict.) János mr.-t 1349. aug. 15-re (ad quind. oct. fe. B. Jacobi ap. in a. d. 1349.) Miklós nádor jelenléte elé idézték alperesként. A több szakaszban zajló perben a bíró végül 1356. okt. 6-ra (ad oct. fe. B. Mychaelis arch. in dicto a. d. 1356.) okleveles bizonyítást rendelt el.

Tá.: Szepesi Jakab országbíró, 1377. márc. 29. Dl. 66 830. (Dessewffy cs. margonyai lt. 50.).

K.: -

\section{2. (1356.jan. 18.e.)}

[I.] Lajos király — gyứrúspecsétjével ellátott parancslevelélben — felszólítja a székesfehérvári kápt.-t, hogy Miklós fia: Márk királyi ember mellé állítson hites tanút, s küldje óket a Tata városban Hem fia: Benedek mr., komáromi c., a m. szb.-i, valamint más m.-i nemesek generalis congregatio-jára.

Eml.: Az 52. számú oklevélben.

K.: -

\section{1356. jan. 19. Pozsony}

[I.] Lajos király $(\mathrm{H})$ emlékezetül adja: Jakus pozsonyi bíró a maga és a város valamennyi polgára és hospes-e nevében a királyi jelenlét e. elmondta, hogy a Challokuz-i kerületból (districtus) származó nemesek, Petus és Lőrinc által szóvá tett panasz szerint rokonaik megkísérelték az ő Pozsony város közvetlen határában lévő Bereknye birtokukat a Challokuz-i folyón lévő révjükkel együtt idegeneknek eladni, és kárukra elidegeníteni. A király kinyilvánítja, hogy ha Petus és Lőrinc bármelyik rokona az említett birtokot és révet eladni, elzálogosítani v. más módon elidegeníteni törekedne, akkor legközelebbi szomszédaikat, a pozsonyi polgárokat és hospes-eket elővételi jog kell hogy illesse a vásárlás, zálogbavétel és bármiféle bérlés lehetőségével. D. Posonii, III. f. prox. p. oct. fe. Epiph. d., a. eiusdem 1356.

E.: AMB. Pozsony város lt. Középkori oklevelek és levelek. 123. (Df. 238 748.) Hártyán, hátoldalán azonos és késóbbi kéz írásával tárgymegjelölés, valamint kerek pecsét lenyomata, szalagja, bevágásai.

K.: -

R.: Ortvay, Pozsony III. 10.; AMB. Inventár 26. (130. szám) (csehül). 


\section{1356. jan. 19. Visegrád}

Miklós országbíró 1356. jan. 19-én, Visegrádon kelt (in Wissegrad 12. die oct. diei Strennarum, a. d. 1356.) oklevele bizonyítja, hogy - a király oklevelében foglaltak értelmében - [1355.] szept. 20-án (die domin. prox. an. fe. B. Mathey ap.) a Pest m.-i Kereztur faluban tartott generalis congregatio alkalmával az ott összegyúlt P[ech]ul birtok szomszédai és határosai tanúsága szerint Bohtoryan (dict.) János és Pál fia: Péter közös őstól származnak Pechul-i Mihály fia: Miklóssal.

Tá.: Kont Miklós nádor, 1360. jún. 13. Dl. 75 368. (Patay cs. lt. 14. 12.) (sérült).

K.: -

R.: Bakács, Pest megye 206. (710. szám).

45. 1356. jan. 20.

Zeech-i Miklós c., [I.] Lajos király (H) országbírája, [Turuch] m. c.-e színe e. a budai egyház kápt.-jának idéző levelében foglaltak szerint jan. 13-án (in oct. fe. Epiph. d.) megjelent Paztuh-i Domokos néhai nádor fia: Domokos mr.-rel szemben Miklós pécsi püspök nevében az annak ügyvédvalló oklevelében adott meghatalmazással eljáró Péter mr. deák, a pécsi várbeli (de castro Quinqueecclesiensi) Szt. János-egyház kanonokja, és bemutatta a budai egyház kápt.-jának idéző levelét (littere evocatorie), amely a püspök előterjesztését tartalmazta. Eszerint Miklós püspök elpanaszolta a királynak, hogy jóllehet a király hûséges szolgálatai fejében örök jogon neki adományozta a Hevesújvár m.-ben lévő Porozlow birtokot minden jogával, jövedelmével és haszonvételeivel, valamint valamennyi tartozékával együtt, azonban a néhai nádornak, Paztuh-i Domokosnak a fia: Domokos mr. azt állította, hogy okleveles bizonyítékokkal rendelkezik Porozlow birtok tulajdonjogára vonatkozólag, és vele szemben a csalárdság különféle fortélyait (diversaque machinamenta fraudis et nequitie) alkalmazva jogának sérelmére és megkérdőjelezésére különböző helyeken és időpontokban folymatosan tiltakozva kápt.-ok, konventek és rendes bíróságok színe e. alattomban gondja volt arra, hogy okleveleket állítasson ki azzal a céllal, hogy kijelentése mind többeknek a fülébe eljusson. A püspök azt is kijelentette a király e., hogy az igazság elhallgatása a csalárdság eszköze, amitől ő őrizkedni akar, de annak érdekében is, nehogy a jövóben előkerülő hamis bizonyítékok alapján megkérdőjelezhető legyen utódai joga a mondott birtokon, ezért őt az ügyben az a törekvés vezeti, hogy ha Domokos bármiféle jogigényt kíván támasztani a mondott birtok tulajdonlására, akkor vele szemben idéztessék bíróság elé, hogy ott oklevél-bemutatással szerezhessen érvényt tulajdonjogának, ha rendelkezik ilyennel. Ezeket hallva a király megparancsolta a budai kápt.-nak, hogy Zenthemryhi Sebestyén királyi ember mellé hites tanút adva idézzék a királyi jelenlét bírósága elé alkalmas időre a szóban forgó Domokos mr.-t a pécsi püspök ellenében valamennyi Porozlow birtok és tartozékai ügyében kiállított tiltakozó és eltiltó levéllel együtt remélt tulajdonjoga bizonyítása érdekében (sua jura si que in eiusdem se habere speraret sine omni dissimulatione et aliquali ad inventa cautione prosecuturum), majd az idézés napját és idejét, az idézett nevét a megjelölt időponttal együtt jelentsék írásban számára. A budai kápt. a királyi parancslevélre írt jelentésében (l. 1. szám) arról számolt be, hogy eleget téve az elrendelteknek Zenthemryh-i Sebestyén királyi ember mellé István karpapot (chori ecclesie) adták tanúul, akik visszatérve azt jelentették, hogy [1355.] dec. 15-én (f. III. prox. p. fe. B. Lucie virg. nunc preterita) Domokos mr.-t Paztuh birtokon tiltakozó és eltiltó okleveleivel együtt — bármilyen formában állították is ki azokat a 
mondott birtok és tartozékai ügyében - jan. 13-ra (ad oct. fe. Epiph. d. prox. preteritas) megidézték a királyi jelenlét bírósága elé a pécsi püspökkel szemben jogai bizonyítása érdekében. A budai kápt.-i jelentés bemutatását követően Domokos mr.-nek az egri egyház kápt.-jától származó ügyvédvalló levélben meghatalmazott képviselője, János fia: Péter azt válaszolta, hogy az említett bizonyítékokat történetesen elidegenítették (casualiter alienata et dispersa) Domokos mr.-tôl, ezért most nem tudja bemutatni azokat. Az országbíró erre az ország báróival és nemeseivel együtt ítélkezve elrendelte, hogy Domokos mr. máj. 1-jéig (useque oct. fe. B. Georgii mart. nunc prox. vent.) találja meg Porozlow birtok ügyében kiállított okleveleit, és a kijelölt időpontban mutassa be színe e. D. in Vysegrad, 8. die termini prenotati, a. d. 1356.

E.: AL. Cluj. Cluj-Napoca (Kolozsvár). Erdélyi Múzeum Egyesület egykori lt. Bánffy cs. nemzetségi lt. 58. (Df. 260 637.) Papíron, hátoldalaláról nem készült Fk.

Á.: 1. A 337. számú oklevélben.

2. A 366. számú oklevélben.

K.: -

\section{1356. jan. 20. Visegrád}

Zeech-i Miklós c., [I.] Lajos király (H) országbírája, Turuch m. c.-e azt a pert, amely korábbi perhalasztó oklevele értelmében jan. 13-án (in oct. fe. Epiph. d.) volt esedékes, a színe e. megjelent peres felek, Novak-i Lukács fia: Dénes, ill. vele szemben Kalnoi Egyed fia: Miklós akaratából máj. 1-jére (ad oct. fe. B. Georgii mart.) halasztja el a korábbi állapot fenntartásával. D. in Vysegrad, 8. die termini prenotati, a. d. 1356.

E.: AM. Košíc. Supplementum Schramianum. 19150. (Df. 271 244.) Papíron, hátoldalán azonos kéz írásával tárgymegjelölés, valamint zárópecsét nyoma, szalagja, bevágásai.

K.: -

\section{1356. jan. 21.}

A váradi egyház kápt.-ja Gyrolth-i László fia: János kérésére és oklevél-bemutatása alapján függőpecsétje alatt privilegiális formában átírja saját, 1311. máj. 8-án kelt [Dedachbeli telek- és malomhelyek felosztása tárgyában kibocsátott] oklevelét (l. Anjou-oklt. III. 57. szám). D. in fe. B. Agnetis virg. et mart., a. d. 1356. Fülöp lévén a prépost, Benedek az olvasó-, László az éneklő-, Gergely az őrkanonok.

E.: Dl. 105 448. (Wesselényi cs. lt.). Megvonalazott hártyán, hátoldalán késóbbi kézzel tárgymegjelölés, alján leszakadt függőpecsét bevágásai.

K.: -

R.: Erdélyi Okm. III. 302. (827. szám).

Megj.: Az átírt oklevelél [] között megadott tárgyát az átíró oklevél közvetlenül nem említi. 


\section{1356. jan. 23.}

A Scepus-i Szt. Márton-egyház kápt.-ja jelenti [I.] Lajos királynak (H): megkapták a király itt átírt, 1355. dec. 24-i oklevelét; az abban foglaltak szerint kiküldött hites emberük, testvérük és kanonoktársuk, Miklós mr., valamint Dubow királyi ember visszatértükkor azt jelentették, hogy jan. 20-án (f. IV. prox.) jelenlétükben egyik részről János fia: László és László fia: Péter, nemkülönben ugyanezen Péter fiai: Miklós és Lőrinc, valamint János fia fentebb említett László fiai: János és Miklós, a másik részről pedig Mychk egykori bán fia: Loránd a maga és fia: Miklós nevében egyezségre jutottak a László, Péter és ennek fiai Lonya birtokát a vele szomszédos — Loránd és nevezett fia tulajdonát képező — birtoktól elválasztó határt illetően. Azt a következőképpen jelölték ki: a kezdő határjel a Bodrug Bodrog folyónál van, a folyó mentén felmegy az Ilsuapotaka patak Bodrug-ba való betorkollásáig, innen a folyó mentén felfelé egy nagy helyre, ahol Ny felól 2 földból emelt jel van a Bodrog folyó közelében, innen Ny-nak tartva eléri a Vermespotak patakot, annak közelében 2 újonnan emelt földjel áll, e pataktól eltávolodva elér 2 földból emelt jelet, ahonnan egy - a mondott Bodrog folyó és a Tapul között emelkedő - hegy tetejére megy fel, s az ott állított 2 földjelben zárul a szóban forgó birtokok elhatárolása. Az oklevél visszahozatala esetére privilégium kiállítását ígéri. D. 3. die fe. B. Agnetis virg. et mart., a. d. 1356.

Á.: Szepesi kápt., 1369. jan. 25. Dl. 4575. (NRA. 576. 39.).

K.: AO. VI. 422-423. (270. szám) (kihagyásokkal).

\section{1356. jan. 23. Visegrád}

Zeech-i Miklós c., [I.] Lajos király (H) országbírája, Turuch m. c.-e emlékezetül adja: a Lelez-i egyház konventjének idézólevelében (l. 11. szám) foglaltak szerint jan. 8-án (in oct. diei Strennarum) színe e. megjelent egyik részról Humuk-i Demeter fia: Péter képviseletében Lászlónak, a csázmai egyház prépostjának s egyben királyi kápolnaispánnak ügyvédvalló levelével meghatalmazott Salamon fia: Miklós, a másik részrôl pedig vele szemben Humuk-i Iwahun Iwahon fia: Pál. Elóbbi előadta, hogy megbízója, Péter a Luprechzaza $\sim$ Luprechtzaza város területén és elóhegyén (promotorium) lévő szőlóból — amely Pétert és Pált közösen illeti — a saját részét megosztás révén, jog szerint vissza akarja kapni az azt jelenleg birtokló nagybátyjától (patruus), Páltól. Ennek hallatán Pál azonnal bemutatott 2, a Péter által követelt szőlővel kapcsolatos oklevelet. Mindkettôt 1330. okt. 29-én (f. II. prox. an. fe. OO. SS., a. d. 1330.) bocsátották ki István c. Luprechzaza-i bíró, valamint a település 12 esküdtje és hospes-ei (l. Anjou-oklt. XIV. 572-573. szám). Közülük az elsố igazolja, hogy Pál fivéreinek, Demeternek és Benedeknek a beleegyezésével 2 M.-ért vásárolta meg mostohaanyjuktól, Elena-tól az ôt jegyajándék jogcímén megillető Luprechtzaza előhegyén birtokolt szőlőjét; míg a másik oklevél bizonysága szerint Pál fivérei, Benedek 2 M.-ért és 30 garasért, Demeter pedig feleségének, Erzsébetnek, valamint fiaiknak: Bálintnak, Jánosnak és Gergelynek a hozzájárulásával - 2 M.-ért eladták Luprechzaza előhegyén fekvő szólőjüket Pálnak. Az országbíró és a bárók, valamint a nemesek soraiból kikerülő bírótársai úgy határoznak, hogy az említett szőlő, a bemutatott oklevelek tanúsága alapján Pált illeti, és tôle nem idegenítheti el - a szőlővel kapcsolatos 2 jogügylet létrejöttekor még meg sem született - Péter, akinek örök hallgatást parancsolnak az ügyben. Minderról a bíróság, az országbíró autentikus pecsétjével megerôsített nyílt oklevelet bocsát ki Pál számára. D in Vysegrad, 16. die oct. diei Strennarum predictarum, a. d.1356. 
E.: Dl. 77 154. (Zichy cs. zsélyi lt. 214. B 41.) Vonalazott hártyán, hátoldalán késóbbi kéz írásával tárgymegjelölés, valamint kerek pecsét nyoma, bevágásai.

K.: Z. III. 18-21. (7. szám).

\section{1356. jan. 23. Kapos}

Vinche Kapus-i pap és Vng-i alesp., valamint Miklós, Munkach-i pap jelenti Lászlónak, az egri egyház prépostjának és kanonokjának, Miklós egri püspök lelkiekben általános vikáriusának: eleget téve az itt átírt 1355. nov. 23-i parancslevelében foglaltaknak, jan. 13-án (in oct. Epiph. d.) felkeresték Brod birtokot, ahol azt az összehívott szomszédok és határosok, valamint más fogott bírák jelenlétében és segédletével 4 egyenlő részre osztották, majd az egyik, királyi mértékkel kimért részt határjelekkel is elválasztották, hogy annak tulajdonába Balázs c.-t és utódait beiktassák. Mivel a tiltakozó Byter fia László fia: Mihály, valamint Domokos fiai: Gergely és Miklós - a szóban forgó Brodról - ellentmondtak az iktatásnak, őket emiatt febr. 9-re (oct. fe. Purif. virg. glor.) László egri prépost színe elé idézték. Jelentik továbbá, hogy Brod-i Fodor (dict.) Tamás a saját, Brod-on lévő birtokrészével kapcsolatban tiltotta Balázst a peres keresettôl (ab accione causali), amely résszel kapcsolatban Balázs békésen elismerte Tamás birtoklását. $\mathrm{D}$ in Kopus, sabb. prox. an. fe. Conv. B. Pauli ap., a. d.1356.

E.: Dl. 77 155. (Zichy cs. zsélyi lt. 218. B 60.) Papíron, hátoldalán azonos kéz írásával tárgymegjelölés, valamint kivehető egy pecsét halvány lenyomata.

K.: Z. III. 16-18. (6. szám).

R.: Bónis-Balogh 132. (1207. szám).

\section{1356. jan. 24. Visegrád}

Miklós nádor $(\mathrm{H})$, a kunok bírája tudatja: a Sarus és Abawyvar m.-i nemesek közösségének generalis congregatio-ján 1347. jún. 18-án (f. II. prox. an. fe. Nat. Johannis Bapt.) Cassa város mellett László fia: Péter mr. és János fia: László mr. Ruzgun $\sim$ Rozgun-i nemesek bemutatták a Zemplén m.-i c. és szb.-ák 3 oklevél példányát (tria paria), melyben nevezettekkel szemben megidézték a néhai Mykch bán fia: Loránd mr.-t, legutóbb [1347.] ápr. 17-re (ad f. III. prox. p. quind. fe. Pasche d.), azelótt ápr.10-re (ad f. III. prox. p. domin. Quasimodo), először márc. 13-ra (ad f. III. prox. p. fe. B. Gregorii pape), ő azonban nem jelent meg és nem is küldött maga helyett senkit, hiába vártak rá 5 napon át. [1347.] júl. 2-án (f. II. prox. p. oct. predict. fe. Nat. B. Johannis Bapt.) Patak város mellet, a Zemplén és Vngh m.-i nemesek közösségének generalis congregatio-ján nevezett Péter és János mr. bemutatták a Zemplén m.-i c. és szb.-ák oklevelét, amelyben többek között benne foglaltatott, hogy márc. 10-én (sabb. prox. an. fe. B. Gregorii pp.) nevezett Loránd mr. hatalmaskodva tört a sértettek Lona nevú - a Tapul és a Budrugh folyók között fekvő - birtokára, és tûzzel felperzselvén elpusztította azt, mely panaszt a m.-ék szb.-ái és ülnökei - a feszületet megérintve - Istenre, a királyra és a Szt. Koronára tett esküvel erősítettek meg. A nádor e. ura, Loránd mr. képviseletével — a nádor ügyvédvalló levelében - megbízott Máté fia: Tamás vonakodott feleletet adni a fenti panaszra, így kérésére a pert [1347.] okt. 6-ra (oct. fe. B. Michaelis arch.) halasztotta oly módon, hogy a per kezdete e. Loránd mr. $3 \mathrm{M}$. bírságot köteles fizetni. A kitúzött időpont elérkeztekor azonban László mr. — mivel királyi parancsnak engedelmeskedve Itáliába utazott — nem tudott megjelenni, Péter mr. - akivel osztatlan birtokot bírt — pedig 
szintén nem tudott megjelenni, így a nádor további egy évvel halasztotta a pert [1348. okt. 6-ra], mely időpont elérkeztekor a bíróság színe e. a Jazou-i konvent ügyvédvalló levelében meghatalmazott János fia: László mr. maga és Péter mr. nevében is követelte, hogy szolgáltassanak nekik igazságot. Ekkor 2 nyílt, királyi oklevelet mutattak be Loránd mr. érdekében, közülük az egyikben, amelyik [1348.] okt. 4-én (in fe. B. Francisci conf.) kelt és a király nagyobb pecsétjével volt ellátva, a király elrendelte, hogy a bíróság Mykch bán fiainak valamennyi perében engedélyezzen bírság nélküli halasztást, mivel — ahogyan azt Loránd mr. maga és fivérei (fr.) nevében a király e. kijelentette — Loránd testvére (fr.), István mr., akinél a szükséges bizonyságlevél van -, a király rendeletéból kifolyólag a tengerentúlra utazott; a másikban, amelyik [1348.] szept. 28-án Budán (in domin. prox. an. fe. B. Michaelis arch.) kelt és a király gyúrúspecsétjével volt ellátva, a király megparancsolta, hogy a tengerentúlon szolgálatban fáradozó Mykch bán fia: István mr. valamennyi perét bírság terhe nélkül okt. 6-ról halasszák el a következő évre [1349.]. László mr. a királyi levelek tartalmának megismerése u. hangot adott azon véleményének, miszerint a fennforgó hatalmaskodási ügyben nincs szükség okleveles bizonyításra, így az ügy elhalasztása sem indokolt. Erre Loránd mr. azt kezdte firtatni, hogy melyik m.-ben és az ország melyik részében fekszik Lonya birtok, amelyen a hatalmaskodást elkövették. László mr. oklevelekkel igazolta, hogy a szóban forgó birtok Zemplén m.-ben, a Tapul és Budrugh folyó között fekszik, és az ő Chichua várukhoz tartozik. Ezzel szemben Loránd mr. azt állította, hogy Lonya birtok Sarus m.-ben fekszik az ô Kekmezeu birtoka mellett, melynek bizonyítására oklevelet csak fivére, István hazatérte u. tud bemutatni, mely okból kifolyólag a pert elhalasztották. Egy év múlva [1350.] azonban, egyéb halasztásra kényszerítő körülmények miatt újfent elhalasztották a pert, mígnem [1355.] okt. 6-án (oct. fe. B. Michaelis arch.) a nádor elé okleveles bizonyítás végett idézett Loránd mr. a László és Péter mr.-eket törvényesen képviselő Miklós fia: István ellenében - aki 21 napon keresztül várta — nem jelent meg, és helyettest sem küldött, ezért Lorandot bírságban marasztalták el. Ezt követően a nádor idézólevelében foglaltak alapján az érintett felek a királyi ember és a Jazou-i konvent tanúja révén [1355.] dec. 7-re (ad oct. fe. B. Andree ap.) idéztették a nádor elé Loránd mr.-t, mely időpont elérkeztekor a felek képviselőinek kérésére a pert a nádor [1356.] jan. 13-ra (ad oct. Epiph. d.) halasztotta. A kitúzött időpontban fogott bírák közremúködésével megegyezés született egyik részról a magukat a szepesi kápt. ügyvédvalló levelében meghatalmazott Miklós fia: István révén képviseltető Rozgun-i nemesek, Péter és László mr., a másik részrôl pedig a Jazou-i konvent ügyvédvalló levelében meghatalmazott Elus (dict.) János képviselte Loránd mr. között, amely szerint Péter és István mr. a hatalmaskodást, birtokfelperzselést és pusztítást megbocsátják, és elengedik Loránd mr. büntetését, aki ezért cserébe elismeri, hogy Lonya birtok Péter és László mr. tulajdonát képezi minden haszonvételével. Az egyezség bizonyságára a nádor autentikus függőpecsétjével megerősített privilégiumot bocsát ki. D. in Wyssegrad, 12. die oct. fe. Epiph. domin. predictarum, a. eiusdem 1356.

E.: Dl. 4593. (NRA. 569. 36.) Hártyán, rajta kékes sodraton függőpecsét, (melyen farkas látható, amely fejét szembefordítja a rátámadó oroszlánra, felettük egyszer vágott, egyszer hasított, negyedelt háromszögú pajzs látható; körirata: +S(IGILLUM) NICOLAI GILETI PALATINI HUNGARIE ET IUDICI COMANOR(UM)), továbbá késóbbi kezek írásával 2 tárgymegjelölés.

Tá.: Ilosvai Lesták nádor, 1394. ápr. 28. Dl. 2361. (NRA. 1544. 23.).

K.: AO. VI. 423-428. (271. szám) (kihagyásokkal).

R.: Wertner M., Hadtört. Közl. 19 (1918) 79. 


\section{1356. jan. 25.}

A [székes-]fehérvári [kápt.] jelenti [I.] Lajos királynak $(\mathrm{H})$ : gyứrúspecsétjével ellátott parancslevelélben (l. 42. szám) foglaltak alapján ....... a király emberével, Miklós fia: Márk Kowachy-i nemessel tanúul küldte a kápt. emberét, György plébánost a Tata városban Hem fia: Benedek mr., komáromi c., a m. szb.-i valamint más m.-i nemesek generalis congregatio-jára, akik visszatérve egybehangzóan jelentették, hogy Benedek mr. jan. 18-án (f. II. prox. an. fe. SS. Fabiani et Sebastiani mart. videlicet in die prenotato congregatione) az egybegyúltek színe e. kijelentette, hogy azok a kikiáltók, akiket (vlg.) warkayatok-nak neveznek, olyan kéréssel fordultak hozzá, miszerint adja tudomására a királynak a szb.-áktól és a vár nemes jobbágyaitól szerzett értesülését, amely szerint az említett kikiáltók emberemlékezetet meghaladó idótól fogva élnek a Komárom m.-i Wyfalu és Kulchud falvakban. Ennek hallatára a néhai Donch mr. fia: Miklós azt állította, hogy a mondott két falu hozzá és Komaren nevú várához tartozik, ahogyan arról Károly király oklevele is tanúskodik, és ezeket más birtokaikért cserébe kapták apja és ő, azonban most a kikiáltók élnek rajtuk. Mindezzel kapcsolatban Benedek mr. a király színe elé küldte Miklóst febr. 1-jére ([ad] quind. diei prenotati, videlicet f. II. prox. an. fe. BB. Fabiani et Sebastiani mart.), hogy a nevezett birtokra vonatkozó oklevele(i)t bemutassa. D. in fe. Conv. B. Pauli ap., a. d. 1356.

E.: Dl. 41 278. (Múz. Ta. Véghely). Papíron, felső része sérült, hátoldalán azonos kéz írásával címzés, tárgymegjelölés, valamint a székesfehérvári kápt. mandorla alakú pecsétjének töredéke.

K.: - -

Megj.: I. Károly király említett oklevelével kapcsolatban l. Anjou-oklt. XVII. 326. szám

\section{1356.jan. 25.}

Péter prépost és a Lelez-i Szt. Kereszt-monostor konventje tudtul adja, hogy színe e. Anarch-i János fia Péter fia: László 36 ft. ellenében 16 évre zálogba adta Warada-i László fia: János mr.-nek Zabolch m.-i Ewsud birtokát, amely Ny-ról Warada-i László Tissca folyó melletti Ewsud birtokával, míg Dé és Ke felől annak Litke birtokával határos. Az ügylethez Borrbasy-i Juan lánya: Anna, valamint annak leánya: Anna is hozzájárulását adta, akiknek a birtok hozományát, ill. leánynegyedét képezte. D in fe. Conv. B. Pauli ap., a. d.1356.

E.: 1. D1. 77 156. (Zichy cs. zsélyi lt. 1. B 286.) Papíron.

2. D1. 77 157. (Uo. 1. B 288.) Hártyán, mind a 2 oklevél hátoldalán a leleszi konvent kerek pecsétje látható (rajta kettôs kereszt egyik oldalon csillag, másikon a Hold, körirata kivehető: +S(IGILLUM) CONVENTVS DE LELES).

K.: Z. III. 21-22. (8. szám).

Megj.: Eltérés a két szöveg között: E. 1. "a parte vero orientali Litke”; E. 2. „a plaga vero orientali Lytke". 
A vasvári egyház kápt.-ja függőpecsétjével ellátott és az $\mathrm{ABC}$ betûivel chirographált privilegiuma révén tudtul adja, hogy a színe e. megjelent egyik részről Herman-i Máté fia: Marcell, míg a másik részrôl Herman-i Károly fia: Bertalan maga és a vasvári kápt. ügyvédvalló levelében meghatalmazva Balay (gen.) fia: Gyure mr., Herman fiai: Miklós és János, továbbá Mihály fia: Mihály Herman-i nemesek nevében is eljárva, valamint Bolkufalua Vanyan-i Máté fia: György a csanádi kápt. ügyvédvalló levelével az említett Mihálynak a másik fia: János képviseltében megjelenvén kinyilvánították, hogy fogott bírák közvetítésével megegyezésre jutottak egymással minden eddig birtokolt és megszerezni remélt birtokuk és birtokrészük tekintetében. D. in fe. Conv. B. Pauli ap., a. d. 1356. Péter mr. lévén a prépost s egyben Margitnak, Szlavónia, Ho. és Da hercegnéjének titkos kancellárja, Domokos az éneklő-, Mihály az őrkanonok, a dékáni tisztség üresedésben. A.

E.: GYMSML. Sopron 3806. (Df. 205 054). Fk. alapján és K. szerint hártyán, felül az ABC betúivel chirographálás, aljára függôpecsét zsinege van erôsítve, pecsétje elveszett.

Á.: Vasvári kápt., 1448. jún. 6. Dl. 3350. (NRA. 29. 50.).

K.: HO. III. 167-169. (135. szám).

R.: Juhász, Csanádi székeskápt. 106. (143. szám).

\section{1356. jan. 26. Visegrád}

[I.] Lajos király (H) megparancsolja a Zemlyen m.-i c.-nek v. alispánnak és a szb.-áknak, hogy 1 v. 2 kiküldött révén vizsgálják ki a magát ártatlannak valló Jako fia: Lászlónak és András fia: Istvánnak, Vetes-i Péter fiaival: Pállal és Miklóssal szemben fennálló ügyét, melyben utóbbiak azzal vádolják elóbbieket, hogy birtokaikról több ökröt elloptak és más, büntetendő hatalmaskodást követtek el. D. in Vysegrad, f. III. prox. p. fe. Conv. S. Pauli ap., a. d. 1356.

Á.: A 147. számú oklevélben.

K.: Sztáray I. 248. (142. szám); Doc. Rom. Hist. C. XI. 8-9. (5. szám) (román fordításban is).

\section{1356. jan. 26. Pozsony}

[I.] Lajos király (H) tudtára adja valamennyi elókelőnek, bárónak, c.-nek, várnagynak, officialis-nak, nemesnek és birtokosnak, akik a földeken v. a vizeken vámokkal (tributa) rendelkeznek — és ezek vámszedőinek is tudomására hozza -, hogy Jakab, pozsonyi bíró a maga, valamint valamennyi pozsonyi polgár és hospes nevében is bemutatta színe e. [I.] Károly király (H) privilegiumát (l. Anjou-oklt. XII. 351. szám), amely többek között azt tartalmazza, hogy ue. polgárok és hospes-ek a hajón v. szekéren Visegrádra szállított bor, gyümölcsök, zab, és más élelemféleségek (victualibus) u., vámot v. más vám jellegú pénzkivetést (tributum vel aliquam tributariam exactionem) nem kötelesek fizetni a királyságban, hanem ezeknek a megfizetése alól teljes mentességet élveznek, amely — apjától kapott — jogában a király meg kívánja őrizni a pozsonyi polgárokat, ezért elrendeli, hogy amikor a pozsonyiak a felsorolt kereskedelmi cikkekkel vámszedő 
helyekre (ad loca tributorum) érnek, tólük semmiféle vámot ne szedjenek, hanem hagyják ooket békében továbbhaladni, személyükben és dolgaikban nem sértvén ooket. $D$. in Posonio, f. III. prox. p. quind. fe. Epiph. d., a.eiusdem 1356.

E.: 1. AMB. Pozsony város lt. Középkori oklevelek és levelek. 124. (Df. 238749 .) Hártyán, hátoldalán azonos kézzel tárgymegjelölés, valamint pecsét töredéke és szalagja.

2. AMB. Pozsony város lt. Középkori oklevelek és levelek. 125. (Df. 238 750.) Hártyán, hátoldalán nagyméretú, kerek pecsét töredéke és szalagja, valamint azonos kéz írásával tárgymegjelölés.

K.: F. IX. 7. 146-147. (92. szám) (E.-ról).

R.: AMB. Inventár 26. (131. szám) (csehül).

57. 1356. jan. 26.

A Scepus-i Szt. Márton-egyház kápt.-ja emlékezetül adja: színe e. a Sarus m.-i Swynie-i Merse mr. fia: Lőrinc mr. kinyilvánította, hogy a közte és Rozgon-i László mr. között, Remenynpataka birtok miatt fennálló perben - mely birtokot a váradi kápt. e. zálogosították el 100 arany ft.-ért a számára — egyezség született, amelynek értelmében László mr. megfizetett 70 ft.-ot neki, a per folyamán felhalmozódott bírságainak megfizetésétól viszont Lő́rinc mr. eltekint. D. in crastino fe. Conv. S. Pauli ap., a. d. 1356.

E.: Dl. 4594. (NRA. 16. 29.) Papíron, hátlapján késóbbi kéz írásával Rozgon + Merse, valamint a szepesi kápt. kerek, rányomott pecsétjének töredéke (rajta kivehető Szt. Márton lovának 2 hátsó lába, valamint a körirat részletei: [+S(IGILLVM) CAPITVLI EC(C)LE]SIE BE[A]T[I M]A[R]TI[NI] DE S[CEP]VS).

Á.: Szepesi kápt., 1359. ápr. 30. Dl. 4818. (NRA. 602. 5.).

K.: AO. VI. 429. (272. szám) (kihagyásokkal) E.-re való hivatkozással.

58. 1356. jan. 26.

A Scepus-i Szt. Márton-egyház kápt.-ja emlékezetül adja: színe e. Vörös (Rufus) János és felesége, Magith asszony, Wichkfalua Wychkfalua-i Detricus nôvérének a lánya kijelentették, hogy teljes tulajdonjogukat, mellyel valamennyi birtokrészükön rendelkeztek és rendelkeznek Feyr (dict.) Miklósra és Wychkfalua-i András fia: Jordanus-ra ruházzák át - a kápt. kötelezvénylevelében foglaltak szerint - Wychkfalua birtok határai között, maguknak semmiféle jogot nem tartva meg. D. in crastino fe. Conv. S. Pauli ap., a. d. 1356.

Á.: Szepesi kápt., 1360. ápr. 15. ŠA. Levoča. Szepesi kápt. 1t. 7. 1. 8. (Df. 272420.$).$

K.: -

59. 1356. jan. 27.

Miklós prépost és a Jazow-i Keresztelő Szt. János-monostor konventje e. egyik részrôl Chythnuk-i László fia: Miklós mr., a másik részról pedig a fiai, Detricus, Miklós, 
Cristlinus és Gerlahus képviseletében is eljáró Polyan fia: Miklós, Elswa-i polgár megjelenvén, utóbbi kinyilvánítja, hogy az ôt és fiait Chythnuk-i Miklós mr., ill. annak apja, László részéról terhelő valamennyi kötelezettségüket megfizették 31 kassai M. kivételével, amely fennmaradt hátralék teljesítéseképpen Guchelfolua birtokban levő birtokrészét tartozékaival és haszonvételevel együtt mint zálogot febr. 3-án (f. IV. prox.) az egyik Gömör m.-i szb. jelenlétében iktatja Chythnuk-i Miklós mr. részére, hogy az nekik [1357.] ápr. 24-ig (ad 2. revolutionem fe. B. Georgii mart.) eme birtokrészt fenntartsa, s ó és fiai ezen határidőn belül ft.-onként 18 garassal számolt $31 \mathrm{M}$. ellenében azt visszaválthassák, amit ha elmulasztanának, a részbirtok Chythnuk-i Miklós mr. kezén marad, ugyanakkor pedig, amennyiben a nevezett Miklós mr. a visszaváltás idejéig nem volna képes tulajdonukat megőrizni, ő és fiai perkezdet e. a bíró része nélkül értendő kétszeres összeggel tartoznak fennálló hátralékukat számára megadni. D. f. IV. prox. P. fe. Conv. S. Pauli ap., a. d. 1356.

\section{E.: Dl. 4595. (NRA. 1538. 17.). Papíron, hátoldalán azonos kéz írásával impignoratio és késóbbi kéz írásával tárgymegjelölés, valamint pecsét nyoma.}

K.: AO. VI. 429-430. (273. szám) (kihagyásokkal).

\section{1356. jan. 27. Visegrád}

Zeech-i Miklós c., [I.] Lajos király (H) országbírája és Turuch m.-i c. tudatja a [székes]fehérvári egyház kápt.-jával: jan. 27-én (3. die fe. Conv. B. Pauli ap.) bárók és nemesek soraiból kikerült bírótársak alkotta törvényszéke e. személyesen megjelent Donatus testvér, a [székes-]fehérvári és a Gyanth-i ispotályosok házának preceptor-a, képviselvén Mo. és Szlavónia Je-i Szt. Keresztes Testvérei Rendjének perjelét, Baldonus Cornutus-t is — tóle kapott ügyvédvalló levéllel — a néhai bán, István fiai: Dénes királyi lovászmr., Miklós, Imre, István és László ellenében és bemutatott 8 oklevelet. Az elsóból kiderült, hogy amikor1348. okt. 16-án (f. V. in fe. B. Galli conf., a. d. 1348.) Naceer (dict.) Máté királyi ember és a [székesfehérvári] egyház kórusának presbitere, Jakab tanúbizonysága mellett a szomszédok és határosok összehívásával be akarták járni Gyanth birtok határait, majd abba be akarták iktatni István bánt, ez utóbbitól a király és a kápt. emberét eltiltotta az urait képviselő Jakab deák (litteratus), Baldonus testvér perjelnek és Donatus testvér preceptor-nak a famulus-a és jobbágya, amely okból kifolyólag a 2 kiküldött a királyi jelenlét elé idézte nov. 18-ra (ad oct. fe. B. Martini conf.) a feleket. Királyi parancs okán azonban Pál c. a megjelölt időpontról [1349.] okt. 6-ra (ad oct. B. Michaelis arch.), innen Tamás c. [1350.] máj. 1-jére (ad oct. fe. B. Georgii mart.), majd 1352. nov. 18-ára (ad oct. fe. B. Martini conf. a. d. 1352.) halasztotta a pert, míg a per István bán halálakor - az ország szokásai szerint — fiaira, Dénes, Miklós, István és László mr.-ekre háramlott az 1353 Húsvétjának tizenötödét követó vasárnap 3. eljövetelére (ad 3. revolutionem diei Domin. prox. p. quind. fe. Passce d., a. eiusedem 1353.); királyi parancslevélre tekintettel azonban Tamás c. oklevelében 1355. máj. 31-re (ad oct. fe. Pent. a. d. 1355.) halasztotta az ügyet, ahonnan Tamás c. halála miatt a Drugeth Miklós c. oklevelében foglaltak szerint [1355.] okt. 6-ra (ad oct. fe. B. Michaelis arch.) napolták el azt, végezetül Drugeth Miklós halálakor királyi oklevél értelmében lezárultak a halasztások. Ám elérkezvén [1355.] okt. 6., István bán fiai nem jelentek meg az országbíró színe e. és nem is küldtek senkit maguk helyett, amiért bírságban marasztalták el őket. Mindezek nyomán az országbíró utasítja a [székes-]fehérvári egyház kápt.-ját, hogy küldje ki tanúságtételre emberét Dws-i János v. Laph-i Barnabás v. Chala-i Mihály v. Novazenthpeter-i Jakab fia: Lőrinc királyi emberek valamelykével és idézzék meg Ist- 
ván bán fiait: Dénes, Miklós, Imre, István és László mr.-eket a királyi jelenlét elé márc. 16-ra (ad oct. diei Cynerum) Baldonus perjel és Donatus preceptor ellenében, majd a kápt. adjon a királynak a történtekról szóló írásos jelentést. D. in Wyssegrad, in die prenotato, a. d. 1356.

Á.: A 70. számú oklevélben.

Eml.: A 136. számú oklevélben.

K.: F. IX. 7. 152-156. (95. szám) E.-ról, a keresztesek kamarai lt.-ra való hivatkozással.

\section{1356. jan. 29. Visegrád}

[I.] Lajos király (H) utasítja a Lelez-i konventet, hogy a Semyen-i István fia: István, ill. Miklós fiai: Loránd és Bereck között fennforgó perben a feleknek királyi jelenlét elé történő megidézéséhez állítson hites tanút Chazar-i Domokos v. Pelys-i Petus v. Rohod-i Beke fia: János királyi emberek valamelyike mellé, egyszersmind az ügyben történtekról számot adva küldjön írásos jelentést. D. in Vyssegrad, f. VI. prox. an. fe. purif. B. virg., a. d. 1356.
Á.: A 82. számú oklevélben.
K.: -
R.: Kállay II. 34. (1176. szám).

\section{1356. jan. 29. Visegrád}

Erzsébet királyné (H) emlékezetül adja: Nyri-i István fia: Istvánnak, a királyi udvar vitézének (miles) a Wary-i hospes-ek ellen 400 sertés ellopása miatti zajló perét márc. 16-ra (ad oct. diei Cinerum prox. venturas) halasztja úgy, hogy addig a szóban forgó felekhez kiküldött királynéi ember Marochok (abl.: Marochokone) királynéi lovászmr.-rel és Beregh m.-i c.-szel együtt — miután megtekintette a vonatkozó okleveleket — derítse ki az igazságot és szolgáltasson elégtételt, végezetül pedig figyelmeztessék Istvánt, hogy ne háborgassa többé a királynét a szóban forgó üggyel kapcsolatban. D. in Wyssegrad, VI. f. prox. an. fe. Purif. virg. glor., a. d. 1356.

E.: D1. 51 696. (Kállay cs. 1300. 1098.) Papíron, hátoldalán azonos kéz írásával tárgymegjelölés, valamint vörös színú, gyứrús zárópecsét töredéke.

K.: -

R.: Kállay II. 33. (1173. szám).

63. 1356. jan. 30.

Az egri kápt. színe e. - miként 1356. jan. 30-án (in a. d. 1356. sabb. prox. an. fe. purif. B. virg.) kelt oklevele tanúsítja — Leztemer-i Domokos fia Miklós fia: Bálint a maga, fivérei Péter, Benedek és Juan, valamint Leztemer-i rokonaik, László fia: Benedek és Máté fia: András nevében is eljárva tiltakozását fejezte ki, mivel - ahogyan tudomásukra jutott — Leztemer-i rokonaik (consanguinei), Domokos fia: Donch és Albert fia: Peteu tudtuk és beleegyezésük nélkül egyezségre jutottak Jenke birtok ügyében István fia: Andrással, 
nevezett István fia Péter fiaival: Péterrel és Jakabbal, valamint Panky-i Bator (dict.) János fia: Istvánnal. Az egyezség értelmében a nevezettek megosztották egymás között Jenke birtokot, a panaszosokat pedig kizárták a birtoklásból és az egyezségból. Bálint arra való hivatkozással, hogy Jenke birtok a panaszosokat leszármazás okán (ratione linee generationalis) illeti meg, eltiltja a szóban forgó Donch-ot és Peteu-t Jenke birtok felének elfoglalásától és az efféle titkos megegyezésektől.

Tá.: Szepesi Jakab országbíró, 1377. márc. 29. Dl. 66 830. (Dessewffy cs. margonyai lt. 50.).

K.: -

\section{1356. jan. 30. Visegrád}

Zeech-i Miklós c., [I.] Lajos király (H) országbírája, Thuruch m. c.-e kéri a Lelez-i egyház konventjét: küldjék ki emberüket hites tanúul Orod-i Tamás fia: Lőrinc v. Orod-i Tamás fia: János v. ezek távollétében Benedek fia: Lukács királyi emberek valamelyikének társaságában, hogy alkalmas időre a királyi jelenlét bírósága elé idézzék Lapuspathak-i Deseu fiait: Lorándot és Jánost, valamint Segney-i Miklós fia: Jánost Komorod-i Tamás fia: János ellenében, majd a történtekről számot adó jelentést küldjenek neki. D. in Wyssegrad sabb. prox. an. fe. Purif. B. virg., a. d. 1356.

Á.: A 126. számú oklevélben.

K.: Z. III. 23-24. (10. szám).

65. 1356. jan. 31. [?]

[I.] Lajos király (H, Da, C, Ra, Se, G, L, Cu, Bu, Sal., mont. S. Angeli dom.) tudatja, hogy bizonyos királyi jogai helyreállítása érdekében kiküldte Simon mr. pozsonyi c. társaságában István testvér nyitrai püspököt, a szt. teológia mr.ét a király rendelete szerint a pozsonyi és Csaloköz-i m. nemeseinek közössége számára [1355.] nov. 8. körül (circa oct. fe. OO. SS.) körül tartott congregatio-ra, ahonnan visszatérve egybehangzó jelentést tettek. Eszerint a Kis Vdvarnok-ról való Marcell fia: Jakab, Baldun fia: Jakab és János fia: Mihály a Csaloköz-i kerületből (districtus) — akiknek földjét v. birtokát a király nevében elfoglalták - a többi nemes közül szólásra emelkedve azt állították, hogy oók maguk ôseiktôl és azok is ôseiktől fogva mindig is igaz és természetes nemesek voltak, és a föld ezen a címen illeti óket. Amikor pedig a püspök és Simon mr. a szokásjog szerint a bíróság esküdt tagjait — nemeseket és más státusú embereket — kérdezték meg ezen Kisuduarnok-i emberek conditio-járól, azok megerôsítették, hogy emberemlékezet óta nemesnek tudják őket. A király ezekről értesülve — nem akarván jogtalanul semmibe venni az ország lakosainak szabadságát - megparancsolja, hogy a felsorolt Kisuduornok-i nemesek és azok utódai nemesi helyzetükból származó előjogaik megőrzése mellett — amelyek a kezdetektől örök időkre összekapcsolódnak az ő ősi és igaz határjelek mentén elkülönített földjeivel és birtokaival —, rokonaikkal és leszármazottaikkal együtt a királyi zászló alatt harcolva tegyenek hú szolgálatokat a királynak és a Szt. Koronának, ahogyan az ország többi nemesei is. Ezen dolog emlékezetére és megerősítésére a király autentikus függőpecsétjével ellátott privilégiumot bocsát ki. Kelt Miklós zágrábi püspök és udvari alkancellár keze által, a. d. 1356. VI. Non. Febr., uralkodásának 15. évében. Méltóságnésor: Miklós lévén az esztergomi érsek, egyben ua. m. örökös c.-e - a kalocsai szék üresedésben -, Domokos a spalatói érsek, Miklós az egri, 
Demeter a váradi, András az erdélyi, Miklós a pécsi, Kálmán a győri, János a veszprémi, Mihály a váci, Tamás a csanádi — a boszniai szék üresedésben —, Tamás testvér a szerémi, István testvér a nyitrai, és Balázs testvér a knini püspök; Miklós az erdélyi vajda és Zolnuk-i c., Csikou a tárnokmr., Zeech-i Miklós az országbíró, Miklós a Machou-i bán, Miklós egész Szlavónia és Ho. bánja, Leukus az asztalnok-, Dénes a lovász- és Péter fia: Tamás az ajtónállómr., valamint Móric fia: Simon a pozsonyi c. A.

\section{E.: -}

K.: F. IX. 2. 476-479. (229. szám) hivatkozással a kisudvarnoki Marczell nemzetség Bako Péter özvegye és mások ellen folyó ügyére 1725-ból.

Megj.: Meglehetősen szokatlan a datálás; könnyen elképzelhető, hogy a dátumsorban kétszer szereplő sexto valójában egyszer szerepelt, s ez esetben febr. 5-én kelt az irat, mivel azonban a F. által hivatkozott oklevelet nem sikerült azonosítani, így e kérdésben semmi biztos nem állítható.

\section{1356. febr. 1.}

[I.] Lajos király (H, Da, C, Ra, Se, G, L, Cu, Bu, Sal., mont. S. Angeli dom.) tudatja, hogy a színe elé járuló Bwchwr fia: Kun Péter a maga, valamint fiai: Miklós és János, nemkülönben unokatestvérei (fr. patruelis), Kabak fia: Baramak és Wezthech fia: Gál nevében is bemutatta a király Zenthkyral és Mendzenth birtokok adományozása ügyében 1354 . márc. 30-án Budán kelt nyílt oklevelét, valamint a budai egyház kápt.-jának 1354. ápr. 10-én kiállított jelentését a szóban forgó birtokok hj.-ának, határjelek állításának és az iktatásnak menetéról, s kérte azoknak elfogadását és privilégiummal történő megerősítését, amely kérésnek a király eleget tesz, függő és autentikus kettős pecsétjével megerősített kiváltságlevelében szó szerint átírva azokat. Kelt Miklós udvari alkancellár, zágrábi püspök keze által, a. d. 1356. Kal. Febr., uralkodásának 15. évében. Méltóságnévsor: Miklós lévén az esztergomi érsek, egyben ua. m. örökös c.-e — a kalocsai szék üresedésben -, Domokos a spalatói érsek, Miklós az egri, András az erdélyi, Domokos [!] a váradi, Miklós a pécsi, Kálmán a győri, János a veszprémi, Mihály a váci, Tamás a csanádi - a boszniai szék üresedésben —, Tamás testvér a szerémi, István testvér a nyitrai és Balázs testvér a knini püspök; Miklós lévén a nádor és a kunok bírája, Miklós az erdélyi vajda és Zonuk-i c., Cykow a tárnokmr., Zech-i Miklós az országbíró és Thwrowcz-i c., Miklós a Machow-i bán, Miklós egész Szlavónia és Ho. bánja, Lewkws az asztalnokmr., Dénes a lovász- és Péter fia: Tamás az ajtónállómr., valamint Móric fia: Simon a pozsonyi c.

Á.: II. Ulászló király, 1493. ápr. 25. Dl. 57 794. (Soós cs. 1t. 634.).

K.: Gyárfás III. 494-495. (41. szám) (tévesen jan. 27-re keltezve).

Megj.: Az átírt okleveleket 1. Gyárfás III. 37. és 39. szám.

\section{1356. febr. 1.}

[I.] Lajos király — miként azt 1356. febr. 1-jén (a. d. 1356. V. Non. Febr., regni autem a. 15.) kelt, kettôs pecsétjével ellátott kiváltságlevele tanúsítja —, miután Pozsony m.-ben és a Chalokwz-i kerületben (districtus) királyi jogait némelyek illetéktelenül elfoglalták, igyekezett visszaszerezni azokat, ezért kiküldte István testvér nyitrai püspököt és egy nemes embert, Megyes-i Móric fia: Simon mr. pozsonyi c.-t, hogy a m. generalis 
congregatio-ján alaposabban vizsgálják ki az ügyet jogai visszaállítása érdekében. Ezek feladatuknak eleget téve a pozsonyi vár várnépeinek nevében (nomine castrensium castri sui Posoniensis) felszólították a Pethen faluból való Miklós fia: Jakabot, Márton fia: Pétert, Chroka fia: Mihályt, Moyus fia: Imrét és Máté fia: Mátét, hogy jan. 13-án (in oct. Epiph. d.) a király e. mutassák be azon iratukat, mely felemelésükről és szabadságukról tanúskodik. Az időpont elérkeztekor a nevezett Imre és Máté képviseletét is ellátó Jakab, Péter és Mihály személyesen jelentek meg a király e., s bemutatták [III.] András király privilégiumát, amely rögzítette ezeknek kivételét a pozsonyi vár szolgáinak sorából, és jóllehet [I.] Károly király — akárcsak utóbb ő is — ésszerú okokból nem fogadták el az András király adományáról és kegyéról szóló privilégiumot, mégis, királyi hatalmánál fogva, ezek húségére és szolgálataira tekintettel Miklós fia: Jakabot, Márton fia: Pétert, Chroka fia: Mihályt, Moyus fia: Imrét és Máté fia: Mátét, valamint ezek örököseit és utódaikat Pethen földdel együtt örökre szólóan mentesíti a pozsonyi vár szolgálatától és mindenféle teherviseléstől, továbbá saját szolgáinak sorába és az ország nemeseinek közösségébe sorolja őket az oklevélben leírt feltételekkel.

Tá.: 1. Győri kápt., 1400. okt. 23. > Mátyás király, 1486. nov. 22. D1. 12 803. (MKA. Acta eccl. ord. et mon. Poson. 67. 18.). E.-je I. Lajos király kettős pecsétjével ellátott privilégium volt.

2. Tá 1. > Mátyás király, 1487. dec. 6. Dl. 12 804. (MKA. Acta eccl. ord. et mon. Poson. 67. 20.) (2.old.)

3. Tá. 2. > Mátyás király, 1490. márc. 31. Dl. 12 839. (MKA. Acta eccl. ord. et mon. Poson. 67. 22.) (2.-3. old.)

4. Tá. 1. > Révay Ferenc turóci ispán, nádori helytartó, 1549. szept. 5. Dl. 1529. (MKA. Acta eccl. 45. 1.)

Eml.: A 87. számú oklevélben.

K.: F. IX. 7. 142-145. (89. szám) Révai Ferenc királyi helytartó 1549. évi, a kamarai lt.ban őrzött levelére történő hivatkozás mellett a kiadás alapja a győri kápt. Tá. 1.ben feltüntetett átíró oklevele.

Megj.: III. András király említett — vélhetően hamis — privilégiumát 1. Reg. Arp. 4240. szám; az I. Károlyra való hivatkozáshoz l. Anjou-oklt. XVII. 38. szám.

68. 1356. febr. 1.

Péter prépost és a Lelez-i Szt. Kereszt-monostor konventje e. Nagy-Anarch-i (de Anarch Maiori) István fia: László mr. a maga, valamint fiai: Miklós, Tamás és István nevében is tiltakozott az ellen, hogy - miként igazmondó híradásból megtudta - Kis-Anarch-i (de Anarch Minori) Péter fia: László és annak nemes anyja a Tyza folyó mellett fekvő Zabolch m.-i Ewzud birtokot — amely rokonság révén (per viam generationem) a panaszosokat is meg kell hogy illesse, minthogy elődeiktől háramlott az említett Péternek az apjára, Jánosra, a szóban forgó Lászlónak a nagyapjára (mint nôvérnek a fiára) jogtalanul elzálogosították Warada-i László fia: János mr.-nek, amivel súlyos kárt okoztak nekik. Ez okból kifolyólag László mr. a maga és felsorolt fiai nevében is tiltja Péter fia: Lászlót és anyját, valamint mindenki mást a szóban forgó birtok elzálogosításától, eladásától v. bármiféle elidegenítésétôl, János mr.-t pedig — $\mathrm{s}$ annak fiait, ill. mindenki mást is - Ewzud zálogba vételétől, megvásárlásától v. más módon történő megszerzésétôl. D. in vig. fe. Purif. virg. glor., a. d. 1356. 
E.: Dl. 77 158. (Zichy cs. zsélyi lt. 1. B 287.) A téglalap alakú hártya jobb alsó sarkán félkörív formában kiszakadt hiányzó rész; hátoldalán azonos kéz írásával tárgymegjelölés, valamint kerek zárópecsét nyoma, bevágásai.

K.: Z. III. 22-23. (9. szám).

\section{1356. febr. 2. Visegrád}

László, a csázmai egyház prépostja, [I.] Lajos király (H) kápolnaispánja és titkos kancellárja emlékezetül adja: színe e. egyik részról Sepec-i Péter fia: Pál a maga, valamint a Saag-i konvent ügyvédvalló levelének meghatalmazásával fiai: Bekes, Tamás, György, Miklós és János, továbbá nemes anyósa, Lylium - Sepec-i Baka özvegye - nevében is eljárva, a másik részről pedig Vossan-i Iuanka fia: Miklós a maga és fivérei (fr. carnales), István és János képviseletével az említett konvent ügyvédvalló levelében felruházva megjelentek abban az ügyben, amely Zeech-i Miklós országbíró e. zajlott a szóban forgó asszony és Iuanka fiai között. A felek a kápolnaispán és titkos kancellár színe e. jan. 8-án (in oct. fe. Epiph. d. prox. preteritis) megegyezésre jutottak egymással, amely szerint Iuanka fiai visszaadják nevezett Pálnak, gyermekeinek és azok utódainak Hont m.-i Sepec birtokuk felét — annak megfelelően, ahogyan a szóban forgó Pál vásárlását az ô oklevele rögzíti - haszonvételeivel egyetemben és a falu telki helyeivel (loci sessionales) együtt, amelyek Ke felól az ottani pap udvarától egészen az ugyaninnen való Iuanka fia: Peteu telkéig (sessio) terjednek ki, de ide nem értve a malmot és az elótte fekvő rétet, valamint Peteu 2 telkét, továbbá Peteu 1 ekealjnyi földjét, miként ilyen tartalmú megállapodásukat Miklós a maga és fivérei nevében ugyancsak megerősíti. Megállapodtak továbbá, hogy Sepec másik része, ti. a fent említett Baka fia: Lukács (Lukachius) része a malommal, a réttel és haszonvételeivel együtt maradjon Miklós, István és János, valamint utódaik tulajdonában, mivel hozzájuk tartozik; az egymás ellen kiállíttatott tiltakozó, eltiltó és peres okleveleiket pedig — kivéve a megegyezést rögzítôt (litteris eorum stabilitis) — mind hatálytalanoknak nyilvánítják. Ugyanakkor Pál a maga és fiai nevében is nyugtatja Iuanka felsorolt fiait az anyósának, a nevezett nemes asszonynak Lukács birtokrészéből járó hozomány és jegyajándék 6 M.-ban megállapított értékének kifizetésével kapcsolatban, míg a hozomány és jegyajándék fennmaradó részére, valamint az asszony lányait megillető leánynegyedre nézve a Lukács birtokrészéból átadott, s leánynegyed gyanánt fiaihoz került részeken túlmenő követelések alól mentesíti Iuanka fiait. Mindkét fél képviseltjeik nevében is kölcsönös kötelezettséget vállal fentiek betartására. Minderról a prépost oklevelet ad ki, amelyet ama királyi pecséttel erősít meg, amely királyi kápolnaispáni tisztsége okán van használatában. D. in Vissegrad, in fe. Purif. virg. glor., a. d. 1356.

E.: Esztergomi székesfőkápt. hh. lt. 2. 9. 4., KML. 77. (Df. 208 515.) Str. alapján hártyán, rajta zöld és lila sodratú selyemzsinóron I. Lajos király első középpecsétje függ, hátoldalán újkori kéz írásával tárgymegjelölés.

K.: Str. IV. 136-137. (109. szám).

\section{1356. febr. 4 .}

A [székes-]fehérvári egyház kápt.-ja jelenti [I]. Lajos királynak $(\mathrm{H})$, hogy eleget téve a Zeech-i Miklós országbíró itt átírt parancslevelében (l. 60. szám) foglaltaknak, Chala-i Mihály királyi emberrel együtt tanúul küldte ki egyházának karpapját, a szerpapi rend- 
del felruházott Fábián klerikust (clericus ordinis diaconatus chori ecclesie nostre) a néhai szlavón bán, István fiainak: Dénes, Miklós, Imre, István és László mr.-eknek Bathyan nevú birtokára, ahol febr. 3-án (f. IV. prox. p. fe. Purif. B. virg.) Baldonus testvér perjel és Donatus testvér preceptor ellenében a király színe elé idézték óket márc. 16-ra (ad oct. diei Cynerum) perük lezárására. D. f. V. prox. p. fe. Purif. B. virg., a. d. supradicto [1356].

E.: Dl. 106 127. (Székesfehérvári keresztesek konventje 3. 1. 14.) Papíron, amelyen harangot formázó - vízjel látható, hátoldalán azonos kéz írásával tárgymegjelölés, késóbbi kézzel 1356. Gyánth, továbbá mandorla alakú zárópecsét nyoma, szalagjai és egy kisebb zárópecsét töredéke (rajta szétterjesztett szárnyú ragadozó madár alakja vehető ki), bevágásai és szalagja.

K.: F. IX. 7. 151-156. (95. szám) (E.-ről).

R.: Érszegi G., Fejér m. Évk. 5 (1971) 188. (15. szám).

71. (1356. febr. 6. e.)

Ábrahám fia János fia: László mr. Zabolch-i alispán és a m. 4 szb.-ja az egyik részról Semien-i Lengel (dict.) István fia János fia: László mr., a másik részról pedig Semien-i László fia: Mihály mr. között zajló perben a döntést febr. 6-ra halasztják.

Eml.: A 75. számú oklevélben.

K.: -

Megj:: Az említő oklevélben foglaltak alapján az oklevelet valamikor a per kirobbanását előidéző tett elkövetése u. (1355. szept. 9.) és a döntés megszületése e. (1356. febr. 6.) állították ki.

\section{1356. febr. 6. Visegrád}

[I.] Lajos király (H) utasítja az egri kápt.-t, hogy sekrestyéjéből keresse elő, írja át és pecsétjével erősítse meg annak az osztályos levélnek a párját, amely Nyek birtok ügyében kelt az egyik részrôl Nyek-i Lodomér fiai: Domokos és István, a másik részrôl pedig Miklós fiai: Dávid és Sándor között fennforgó perben, mivel elóbbiektől a levél eredetijét — saját elmondásuk szerint - ellopták. D. in Vyssegrad, sabb. prox. p. fe. Purif. B. virg., a. d. 1356.

Á.: 1. A 109. számú oklevélben.

2. Á. 1. > Pálóczi Máté nádor, 1435. dec. 4. Dl. 107 790. (Bristow gyứjt. 1982. 1421.).

Má.: 1. Dl. 8802. (AP. Lád 13. 1.).

2. D1. 107 785. (Bristow gyújt. 1982. 1421.) Mindkettő 18. sz.-i egyszerú Má.-ban.

K.: -

R.: Bándi Zs, BLÉ. 5 (1985) 616. (Á. 1. alapján). 


\section{1356 febr. 6. Visegrád}

[I.] Lajos király (H) e. Gergen fia: Márton, Koranicha-i nemes annak a különleges királyi utasításának eleget téve, mely szerint jan. 13-án (in oct. fe. Epiph. d.) köteles bemutatni a maga és rokonai valamennyi, Koranicha földdel és szabadságaikkal kapcsolatos oklevelét Sctenychnak-i [?] Mlachk fia György fiaival szemben, a kitüzött időpontban megjelent, s bemutatta Istvánnak, egész Szlavónia és Ho. bánjának itt átírt, 1351. nov. 3-án Zágrábban kelt nyílt oklevelét, majd kérte a királyt, hogy őket korábbi szabadságaiban erősítse és őrizze meg. A király, mivel a szóban forgó oklevélból megbizonyosodott Márton és Koranicha-i rokonai nemesi címének jogosságáról, István bán oklevelét és azoknak benne leírt szabadságát elfogadja, és jelen oklevelének tanúságával megerősíti. D. in Wysegrad, in. fe. B. Dorothee virg., [a. d. 13]56.

Á.: Zágrábi kápt., 1359. márc. 29. Dl. 4596. (NRA. 726. 20.) E.-je nyílt oklevél volt I. Lajos király nagyobb pecsétjével megerôsítve.

K.: AO. VI. 430-432. (274. szám) (kihagyásokkal); Smič. XII. 327-328. (246. szám) Mindkettő Á. alapján.

Megj.: István bán átírt oklevelét, 1. Halász É., Szlavón 121. (179. szám). Mindkét kiadásban Stenychnak szerepel, az oklevélben ez Sctenylhnak-ként v. Sctenychnak olvasható.

\section{1356. febr. 6. [Ó-]Fehértó}

Ábrahám (gen.: Abre) fia János fia: László mr. Zabolch-i alispán és a m. szb.-ái emlékezetül adják: [Semien-i] Lengel (dict) János fia: László mr. színük e. tiltakozott amiatt, hogy jóllehet embere febr. 4-én (f. V. prox. p. fe. Purif. virg. glor.) Vrus faluban, Simon fia: Imre mr. birtokrészén törvényesen akarta elfogni a gyilkosság miatt menekülő Benedeket, azonban ezt Imre nem engedte, hanem hagyta a gyilkost elmenni, s ezáltal 13 M. és 1 ferto kárt okozott a panaszosnak. D. in Feyrtho, sabb. prox. p. fe. an. dicti, a. d. 1356.

E.: Dl. 51 697. (Kállay cs. lt. 1300. 1119.) Papíron, hátoldalán azonos kéz írásával tárgymegjelölés, valamint 2 kerek zárópecsét töredéke, bevágásai.

Má.: Uo., mint E., azzal megegyező jelzet alatt; újkori Má.-ban rajta másik kéz írásával 1785. ápr.-i javítások.

K.: -

R.: Kállay II. 34. (1174. szám); Piti F., Szabolcs m. 132. (511. szám).

Megj:: a [ ]-ben szereplő információ a hátoldalról származik.

\section{1356. febr. 6. [Ó-]Fehértó}

Ábrahám (gen.: Abre) fia János fia: László mr. Zabolch-i alispán és a m. 4 szb.-ja emlékezetül adják: korábbi halasztó levelükben (l. 71. szám) kötelezték magukat, hogy febr. 6án (sab. prox. p. Purif. B. Marie virg.) a m. nemeseivel együtt döntenek az egyik részról [[Semien-i]] Lengel (dict.) István fia János fia: László mr., a másik részről pedig Semien-i László fia: Mihály mr. között zajló perben. Az időpont elérkeztekor László mr. megerősítette Mihály mr. állítását, nevezetesen hogy a gyilkos Benedeket [1355.] szept. 9-én 
(f. IV. prox. p. fe. Nat. virg. Marie) Byr faluban a falunagy fogságából kiragadta. Ezért úgy ítélkeznek, hogy László mr. fizessen — M.-ként 50 garassal számolt - 13 M.-át és 1 ferto-t Mihály mr.-nek költségei és fáradozásai fejében, mégpedig 3 részletben: az első 4 M.-át ápr. 2-án (sab. prox. p. diei medii Quadr.), a következő 4 M.-át jún. 18-án (sab. prox. p. fe. Pent.), az utolsó részletet, azaz 5 M.-át és 1 ferto-t júl. 30-án (sab. prox. p. fe. B. Jacobi ap.) olyan — László mr. által is elfogadott — megkötéssel, hogy ha az első részletet nem teljesíti, bírságot kell fizetnie, ha a másodikat mulasztja el, akkor annak kétszeresét fizeti, ha a harmadik kifizetésnek nem tesz eleget, akkor a teljes büntetés kétszeresét köteles megfizetni részben forgalomban lévő dénárokban, részben becsértékben. D. in Feyrtho, termino antedicto, a. d. 1356.

E.: 1. Dl. 51 698. (Kállay cs. 1t. 1300. 1128.) Papíron, hátoldalán 3 rányomott pecsét töredékei és szalagjai.

2. Uo., (Kállay cs. 1t. 1300. 1129.) Papíron, hátoldalán 2 rányomott pecsét töredéke és egynek átfúzött hártyaszalagja. (Szövegtöbblete [[ ]] között szerepel.)

Eml.: A 155. számú oklevélben.

K.: -

R.: Kállay II. 34. (1175. a. és b.); Piti F., Szabolcs m. 132. (512. szám).

\section{1356. febr. 7 .}

A [székes-]fehérvári Szt. István király-egyház kereszteseinek konventje e. János Dws-i nemes Dws birtokának harmadrészét telkeivel (sessio) és minden más haszonvételével együtt felesége, Klára asszony beleegyezésével az oklevél keltétől számítva 6 évre zálogba adja 30 - jó súlyú és már megfizetett - aranyft.-ért két Berren-i nemesnek, Péternek, a Szt. Imre herceg-egyház rektorának és fivérének, Pál óbudai alvárnagynak. János és hitvese vállalta, hogy ez idő alatt megvédi Pétert és Pált annak a harmadnak a tulajdonában, és tőlük a 6 év letelte e. nem váltják vissza a zálogot; a 6 év elteltével viszont János v. örökösei mindenféle teher nélkül - ugyanazért az összegért - szabadon élhetnek a visszavásárlás lehetôségével. Rögzítették továbbá, miként a zálogba adó is elfogadta, hogy a mondott Dws-ön lévő bármely részt, telket v. telkeket, földet v. földeket, amelyek eme birtoknak képezik a részét, de már az oklevél kelte e. elzálogosították azokat, a maradék kétharmadba tartozónak számítsák a szóban forgó egyház jogának sérelme nélkül. D. domin. die prox. p. fe. B. Agathe virg. et mart., a. d. 1356.

E.: Dl. 106 128. (Székesfehérvári keresztesek konventje 3. 1. 15.) Hártyán, hátoldalán késóbbi kéz írásával tárgymegjelölés, valamint mandorla alakú pecsét lenyomata, bevágásai.

K.: F. IX. 2. 523-524. (255. szám) Hevenesi gyújtemény, tom. I., p. 259-re utaló hivatkozással; uo.,526-527. (257. szám); Károly, Fejér vm. IV. 431-432. (3. szám) Utóbbiak hivatkozással a Keresztesek Protocolluma II. 297-298-ra.

R.: Pest m. 65. (343. szám); Érszegi G., Fejér m. Évk. 5 (1971) 188. (16. szám).

77. 1356. febr. 9.

A Turuch-i konvent 1356. febr. 9-én (in oct fe. Purif. B. virg., a. d. 1356.) az Árva m.-i Felseukolbyn birtoklása ügyében kelt privilégiális oklevelében átírta [I.] Lajos király — 
Felseukolbyn birtok eladományozása kapcsán - 1355. okt. 23-án (f. VI. prox. p. fe. Luce ewang., a. d. 1355.) kelt nyílt oklevelét.

Reg.: 1. Bebek Imre országbíró, 1391. szept. 27. ŠA. Bytča. (Biccse). Turóci registrum 9. (Df. 283 070.).

2. Dl. 193. (Acta Jes. Thuroc 2. 2.) (18. sz.-i Má.; Reg. 1-ről) 60. szám, 43. old.

3. Dl. 163. (NRA. 1838. 104.) (1778. jan. 15.i Má.; Reg. 1-ről) 38. old.

K.: Tur. Reg. 90. (59. szám); Horváth S., TT. 2 (1902) 224. (59. szám).

R.: F. IX. 2. 568. (273. szám) a turóci registrum-ra való hivatkozással;Horváth S., TT. 5 (1904) 357. (295. szám) (Reg. 1-ról).

78. 1356. febr. 11.

Anno 1356. die 11. mensis Febr. [a velencei kormánytanács] a szlavóniai Paysinaticum kapitányának: a napokban kapták meg a címzett 3 hozzájuk intézett levelét jan. 13-án, jan. 17-én és jan. 25-én (die. 13., 17., 25. Jan.) kelteket s tüstént gondoskodnak arról, hogy az ott felsorolt dolgokat, melyek Scardona várához szükségesek elküldjék neki, ti. fát, két harangot és a szükséges pénzt, hogy a — mostanáig a várban időző — zsoldosok számára tábort alakíthassanak ki (pro faciendis pagis stipendiariis, qui hucusque in dicto castro steterunt) és más szükséges kiadásokra. Az ezeken felül a levelekben foglaltakat megfontolás tárgyává teszik és késóbb értesítik döntésükrôl.

K.: Ljubić II 310. (456. szám); Wenzel, dipl. eml. II. 466. (373. szám) Mindkettő a „Misti” velencei államkönyv alapján XXVII. 58. ep. 139.).

\section{1356. febr. 12. Visegrád}

Zeech-i Miklós c., [I.] Lajos király (H) országbírája, Turuch m. c.-e tanú állítására szólítja föl az egri egyház kápt.-ját András fia: László v. Malah-i Péter fia: Simon v. Mellete-i Kylianus fia: Demeter v. Baba-i Nygwan fia: Miklós királyi emberek valamelyike mellé azzal a céllal, hogy a királyi jelenlét elé idézzék az egykori nádor Pazthuh-i Domokos fia: Domokost, Kaza-i János fia: Lászlót, Lachk fia István fia: Lászlót, Dorugh-i Olivér fia: Istvánt Lekenye-i Forgach (dict.) Miklós fiaival: Miklós és András mr.-ekkel szemben. Kéri továbbá, hogy a kápt. az idézés napjáról és helyéről az idézettek nevével együtt, valamint a kitüzött határnapról írjon jelentést a királynak. D. in Wysegrad, f. VI. prox. an. fe. B. Valentini mart., a. d. 1356.

Á.: A 154. számú oklevélben.

K.: AO. VI. 446-447. (284. szám) (kihagyásokkal).

80. 1356. febr. 13. Brno

[IV.] Károly császár és király levélben értesíti Aldovrandinus estei ôrgrófot, valamint a Gonzaga-i Guido, Philippinus és Feltrinus fivéreket (fr.), Mantova vikáriusait, hogy az ügyet, amely közöttük és Mediolanum vikáriusa között zajlik elhalasztja mivel Mo.-ra utazik birodalmi ügyekról tanácskozni a magyar királlyal. 
R.: RI. VIII. 2434. szám (németül), a mantovai lt.-ban ôrzött E.-re való hivatkozással, s ez alapján Reg. Boh. Mor. pars VI. 145. (285. szám)

81. 1356. febr. 14.

A kalocsai egyház kápt.-ja e. László fia: Éliás (Elyas) és János fia: Gyarmanus Gyarman Alchy-ról kijelentették, hogy az a leánynegyed, amely birtokaikból unokaöccsüknek (nepos), Kozmo-i János fia: Lőrincnek jár anyja, Erzsébet u. — minthogy Erzsébet leánygyereke nagyapjuknak, Gyarmanus-nak, tehát egyaránt nôvére Éliás és Gyarman apjának, Lászlónak és Jánosnak — közös jussuk a nagyapjuk másik lányától, Kevche asszonytól származó fiúval, Péter fia: Lőrinccel. Ezt a lánynegyedet a kápt. oklevelében foglaltaknak megfelelően Alchy birtokból átadták János fia: Lőrincnek minden haszonvételével és tartozékával együtt. D. in fe. B. Valentini mart., a. d. 1356.

Á.: János kalocsai olvasókanonok és érseki vikárius, 1427. jan. 22. Dl. 43 686. (Múz. Ta. Nagy Imre) E-je nyílt oklevél volt.

K.: -

82. 1356. febr. 14.

Péter prépost és Lelez-i Szt. Kereszt-monostor konventje jelentik [I.] Lajos királynak (H): miután megkapták a király nagyobbik pecsétjével ellátott, itt átírt jan. 29-én kelt parancslevelet (l. 61. szám), az abban foglaltaknak megfelelően Rohod-i Beke fia: János királyi ember mellé tanúul adták az egyház familiaris-át, Jánost idézés végett, akik visszatérve jelentették, hogy febr. 13-án (sabb. prox. an. fe. B. Valentini mart.) Semyen-i István fia: Istvánt Napkur birtokán a királyi jelenlét bírósága elé idézték Miklós fiai: Loránd és Bereck ellenében ápr. 6-ra (oct. diei medie Quadr.). D. in predicto fe. B. Valentini mart., a. supradict. [1356].

E.: Dl. 51 699. (Kállay cs. lt. 1300. 1112.) Papíron, hátoldalán azonos kéz írásával tárgymegjelölés, valamint a leleszi konvent kerek zárópecsétjének töredéke (csupán a körirata vehető ki: [+S(IGILLVM) CONVEN]T[U]S DE LELE), szalagja és bevágásai.

K.: -

R.: Kállay II. 34. (1176. szám).

83. 1356. febr. 15.

A Zala-i Szt. Adorján vértanú-monostor konventje e. Tengwrd-i László fia Tiodorus leánya: Klára nemes asszony, jelenleg Gylianus fia András mr. hitvese kijelenti, hogy a Segesd város mellett fekvő, leánynegyedként reá háramlott Zob birtokot szántóföldekkel, erdőkkel, rétekkel, legelőkkel és más haszonvételekkel együtt elzálogosította Posega-i (dict.) Mihály fiainak: István és János mr.-eknek, valamint utódaiknak a tólük megkapott 100 kifogástalan súlyú jó aranyft. (pro 100 florenis boni auri iusti et veri ponderis) ellenében azzal a feltétellel, hogy a birtokot bármikor visszavásárolhatja saját — és nem 
valaki más - ugyanolyan minőségú pénzéért. Az ügylet bizonyságára a konvent pecsétjével ellátott oklevelet ad ki. D. f. II. prox. p. oct. fe. Purif. B. virg., a. d. 1356.

E.: D1. 30 661. (Gulafehérvári kápt. o. 1t. Miscellanea 1. 1. 31.) Hártyán, mely több helyen sérült, hátoldalán késóbbi kezek írásával tárgymegjelölések, alján pecsét felfüggesztésére utaló bevágások.

Má.: Uo., mint E., azzal megegyező jelzet alatt, 1786. júl. 8-i hiteles Má-ban.

K.: AO. VI. 433. (275. szám) (kihagyásokkal).

\section{1356. febr. 16.}

[I.] Lajos király (H, Da, C, Ra, Se, G, L, Cu, Bu, Sal., mont. S. Angeli d.) a színe e. megjelenő Zugy-i $\sim$ Zwgy-i János fia: Mihály udvari ifjú kérésére és oklevél-bemutatása alapján az anyakirályné beleegyezésével elfogadja, átírja és autentikus kettős pecsétjének ráfüggesztésével megerősíti [IV.] László király Kezew $\sim$ Kezw birtokkal kapcsolatos 1274. febr. 16-án (in a. d. 1274, XIV. Kal. Marc., ind. 2.) kiállított privilégiumát. Kelt Miklós zágrábi püspök, udvari alkancellár keze által, a. d. 1356. XV. Kal. mensis Marc., uralkodásának 15. évében. Méltóságnévsor: Miklós lévén az esztergomi érsek, egyben ua. m. örökös c.-e, - a kalocsai szék üresedésben -, Domokos a spalatói érsek, Miklós az egri, András az erdélyi, Demeter a váradi, Miklós a pécsi, Kálmán a győri, János a veszprémi, Mihály a váci, Tamás a csanádi, - a boszniai szék üresedésben —, Tamás testvér a szerémi, István testvér a nyitrai, Balázs testvér a knini püspök; Konth Miklós az erdélyi vajda és Zonuk-i c., - a nádori tiszt üresedésben -, Chykow a tárnokmr., Zeech-i Miklós az országbíró és Thuruch m. c.-e, Miklós a Machow-i bán, Miklós egész Szlavónia és Ho. bánja, Leukus az asztalnok-, Dénes a lovász-, Péter fia: Tamás az ajtónálló mr., Móric fia: Simon a pozsonyi c. A.

E.: Dl. 71 358. (Forgách cs. gimesi lt. 1824.) Hártyán, alján bal oldalon I. Lajos király 1364. okt. 27-i keletú megerősítő záradéka, valamint zöld-vörös sodraton függőpecsét töredéke, (melynek egyik oldalán a jobbjában jogart, baljában országalmát tartó koronás király alakja, másik oldalán kereszt töredéke látható). Hátoldalán közel azonos és késôbbi kezek írásával több tárgymegjelölés.

K.: -

Megj:: IV. László 1274. febr. 16-án kelt oklevelét 1. Reg. Arp. 2455. szám alatt.

\section{1356. febr. 18.}

1355. die 18. Febr. [a velencei kormánytanács] a zsoldosok táborhelyére (pro pagis stipendiariis) és más szükséges kiadásokra a szlavóniai Paysinaticum kapitányának 3000 dukátot, a Jadra-i c.-nek és kapitánynak 3000 dukátot, a Nona-i c.-nek 1000 dukátot küld.

K.: Ljubić II. 310. (457. szám) (A „Misti” velencei államkönyv alapján XXVII. 58.). 


\section{1356. febr. 20. Györ}

Albert, Ausztria, Stájer és Karintia hercege követeinek (Ulrich von Walsee hauptmann in Steier, Hermann von Landenberg von Greifensee, Albern von Puchheim landvogt im Aargau und Thurgau und Otto von Meissau ) teljhatalmat ad a közte és Károly császár között lévő béke [I.] Lajos király $(\mathrm{H})$ általi megújítása ügyében történő tárgyalásokra. Geben ze Rabe am sambstag vor s. Peters tag, alz er auf den stul gesätz warde, a. d. 1356.

Reg.: Comentarii 188.; RI. VIII. 260. szám. (németül); s ezek alapján Reg. Boh. Mor. pars VI. 146. (287. szám).

R.: $\quad$ M. Nemz. Tört. III. 284.

\section{1356. febr. 20.}

A pozsonyi egyház kápt.-ja tudatja: színe e. Pethen-i Miklós fia: Jakab a maga, valamint Péter, András és övéik, nevezetesen Máté, Chuka fia: Mihály, Pál fia: János, András fia: Miklós, Jakab fia: Miklós, Bachan fia: Jakab, Márton fia: Péter, Maius fia: Imre, Pál fia: Péter, és Márton fia: István Pethen-i nemesek nevében a kápt. ügyvédvalló levelével eljárva kijelentette, hogy becsû́ során a királyi mértékkel mérve 4 ekealjnyinak meghatározott erdőrészüket, amely Kysmod Kismod birtok mellett fekszik, 10 pensa-val számolt 12 M. megfizetett széles bécsi dénárért eladták Felmod-i András fiainak: Mihálynak, Jánosnak és Péternek azzal a Miklós zágrábi püspök és királyi alkancellár által kiállított, [I.] Lajos királytól (H) elnyert febr. 1-jén kelt privilégiummal (l. 67. szám) együtt, amely ezeknek a Pethen-i nemeseknek a szabadságairól rendelkezett. Hj.: az első határjel Kysmod falunál azon út felett, amelyen a fát szokták Kismod-ba szállítani, ez jelöli a Felmod-i nemeseknek eladott fentebbi erdőrész elválasztását a Pethen-i nemesek lentebbi részétől, innen É felé halastóhoz (piscina) ér, továbbmenve visszatér Kysmod birtokhoz, majd az említett útnál zárul az erdő határa. A Pethen-i nemesek szavatosságot vállalnak a vevôk háborítatlan birtoklásáért. A kápt. az ügy bizonyságára autentikus pecsétjének felfüggesztésével megerósített privilégiumot ad ki. D. sab. prox. an. fe. B. Mathiae ap., a. d. 1356.

Á.: Kapler Péter pozsonyi c. és a szb.-ák, 1418. máj. 11. (vö. ZsO.VI. 1900. szám) > gyớri kápt., 1422. aug. 28.> győri kápt., 1463. jún. 10. Győri kápt. hh. 1t. 28. (394.) (Df. 273 887.) E.-je I. Lajos király kettôs pecsétjével ellátott privilégium volt.

Má.: Győri kápt. hh. lt. 56.(106.) (Df. 273 914.) (Á.-ról).

Tá.: 1. Á. > Mátyás király, 1486. nov. 22. Dl. 12 803. (MKA. Acta eccl. ord. et mon. Mon Poson. 67. 18.).

2. Tá. 1. > Mátyás király, 1487. dec. 6. Dl. 12 804. (Uo., 67. 20.) 3. old.

3. Tá 2. > Mátyás király, 1490. márc. 31. Dl. 12 839. (Uo., 67. 22.) 3. old. Mindegyikben dátum nélkül.

K.: - 
88. (1356. febr. 22. e.)

György Deresk-i pap — Gömör m.-i segédvikárius — febr. 22-re rendeli színe elé Imre fia Péter Zegzou-i nemes hitvesét, Margit nemes asszonyt Miklós fia: Akus mr. Ordo-i nemessel szemben.

Eml.: A 90. számú oklevélben.

K.: -

89. 1356. febr. 22.

[I.] Lajos király (H, Da, C, Ra, Se, G, L, Cu, Bu, Sal., mont. S. Angeli dom.) a színe elé járult Potun-i Wroch fia László fia: Péternek a maga, valamint atyafia (fr.), István fia: László nevében is előterjesztett kérésére és oklevél-bemutatása alapján a szükséges vizsgálatot követően kettős pecsétjével ellátott privilégiumában átírja és megerősíti Torch birtok tárgyában egyrészt a pozsonyi kápt. 1230. aug. 1-jén kelt privilégiumát, másrészt apjának, [I.] Károly királynak $(\mathrm{H})$ azt az 1326. jún. 3-án kibocsátott privilegiális oklevelét, amely privilegiális átírásban magában foglalta saját 1311. máj. 31-én kiadott, átírásban a pozsonyi kápt. 1309. máj. 11-én kelt privilégiumát tartalmazó és megerôsítő privilegiális oklevelét, amely utóbbi kápt.-i irat pedig átírta Romungus pozsonyi curialis c.-nek az ugyancsak a szóban forgó birtok tárgyában 1309. máj. 3-án kelt nyílt oklevelét. Kelt [Miklós] zágrábi püspök, királyi alkancellár keze által, a. d. [1356.] IX. Kal. Marc., uralkodásának 15. évében. Méltóságnévsor: Miklós lévén az esztergomi érsek, egyben ua. m. örökös c.-e — a kalocsai szék üresedésben -, [Wglinus a spalatói] érsek, Miklós az egri, Demeter a váradi, András az erdélyi, [Miklós a pécsi], Kálmán a győri, János a veszprémi, Mihály a váci, Tamás a csanádi, Tamás testvér a szerémi a boszniai szék üresedésben —, István a [nyitrai, és Balázs a knini] püspök; Miklós az [erdélyi] vajda és Zonuk-i c., Cyko a királyi tárnokmr., Zeech-i Miklós az országbíró, [Miklós] a Macho-i [bán], Miklós egész Szlavónia és Ho. bánja, Leukus [az asztalnok-. és a pohárnokmr., Dénes a lovászmr., Tamás az ajtónállómr.], valamint Móric fia: Simon a pozsonyi c.

E.: Dl. 58 021. (Békássy cs. 1t. 18.). Hártyája a hajtásvonalak mentén több helyen szakadozott, alján vörös-bordó sodraton I. Lajos király kissé töredezett szélú kettős pecsétje függ, (melynek elólapján trónon ülő alak, baljában országalma, jobbjában jogar, hátlapján hármas halmon kettős kereszt látható).

K.: -

Megj.: I. Károly király 1326. jún. 3-án kelt privilégiumát l. Anjou-oklt. X. 231. szám, az 1311. máj. 31-it uo., III. 72. szám, a pozsonyi kápt. 1309. máj. 11-i privilégiumát uo., II. 641. szám, Romungus curialis c.-ét uo. II. 628. szám alatt. A pozsonyi kápt. átírt 1230. aug. 1-jei oklevelét közelebbről nem sikerült azonosítani.

\section{1356. febr. 22. Gömör falu}

György Deresk-i pap — Gumur m.-ben segédvikáriusa Domokos mr.-nek, az esztergomelóhegyi Szt. Tamás vértanú-egyház prépostjának, Miklós esztergomi érsek vikáriusának - emlékezetül adja, hogy az Imre fia Péter Zegzou-i nemes hitvesének, Margit nemes asszonynak Miklós fia: Akus mr. Ordo-i nemessel szemben viselt perét, amely- 
ben a feleket korábbi oklevele révén (l. 88. szám) febr. 22-re (f. II. prox. an. fe. Mathie ap.) rendelte színe elé, a vikárius közbeavatkozására 22 nappal [márc. 14-re] elhalasztja. D. in villa Gumuriensi, termino antedicto, a. d. 1356.

E.: Dl. 4597. (NRA. 1538. 18.) Papíron, több helyen sérült, hátoldalán azonos kéz írásával tárgymegjelölés, valamint pecsétek nyomai.

K.: AO. VI. 433-434. (276. szám) (kihagyásokkal).

91. 1356. febr. 23.

Pál, a Turuch-i Boldogságos Szúz-egyház prépostja és a konventje e. egyik részról a fiait, Jakabot, Miklóst, Jánost és Gergelyt is képviselő Smoran-i Ruman fia: Pál, a másik részről Craz fia: János és Nogchepchin-i Máté fia: Mihály megjelenvén, elóbbi kinyilvánítja, hogy Chepchin és Muchna birtokon lévő teljes részbirtokukat elzálogosítják Jánosnak és Mihálynak, valamint ezek örököseiknek 12 ft.-ért úgy, hogy azt bármikor visszaválthassák. D. III. f. prox. p. fe. Kathedre S. Petri, a. d. 1356.

E.: ŠA. v Banskej Bystrici Pobočka Kremnica Körmöcbánya város lt. Körmöcbánya város tanácsa: Oklevelek és levelek 1. 16. 1. 8. (Df. 249 660.) Hártyán, hátoldalán késóbbi kéz írásával tárgymegjelölés, valamint pecsét nyoma, bevágásai, szalagja.

K.: -

\section{1356 febr. 24. Buda}

Zeech-i Miklós c., [I.] Lajos király (H) országbírája, Turuch m. c.-e emlékezetül adja: mivel Wadakol-i Lő́rinc fia: Lőrinc mr.-t és Mykola-i Péter fia: Istvánt törvényes úton akarta bevezettetni a fiú örökös nélkül meghalt Péter fia: Márton királyi adomány címén óket megillető Dombow birtokon lévő részbirtok harmadának tulajdonába, amelyet egy másik privilégiumban alaposabban ismertetett körülmények között tőlük Dombow-i Péter fia: Márton nemesnek az özvegye visszakövetelt, ezért az országbíró levelet (l. 21. szám) intézett a bácsi egyház kápt.-jához, amelyben kérte, hogy adjanak hites tanút Scepesi András fia: László a királyi udvarból külön erre a feladatra kiküldött királyi ember mellé, hogy a néhai Márton szóban forgó Dombow birtokán az összehívott szomszédok és határosok jelenlétében iktassák a korábban tartott törvényes hj. során 4 egyenlő részre osztott részbirtok háromnegyedét — nem lévén jogereje Márton özvegye v. bárki más ellentmondásának — a nevezett Lőrinc és István részére; míg a fennmaradó negyed felett legyen Péter fia: Márton 3 leányának egészen addig tulajdon- és haszonélvezeti joga, amíg férjhez nem mennek, ezt követően pedig az ország szokása szerint Lőrinc és István köteles számukra elégtételt adni az őket megillető leánynegyeddel kapcsolatban. Azt is rögzítette az országbírói parancslevél, hogy Márton özvegyének a továbbiakban is jogában áll hozományát és jegyajándékát visszakövetelni a szóban forgó birtokból. Az országbíró kérte végül a kápt.-t, hogy febr. 9-re (ad. oct. fe. Purif. B. virg.) küldjön a történtekról számot adó jelentést a királynak. A kitűzött időpontban az István nevébe is eljáró Lőrinc mr. bemutatta az országbíró e. a bácsi kápt. 1356. jan. 16-án (l. 35. szám) kelt jelentését, amelyből megtudta, hogy a birtokrészekbe beiktatták az érintetteket, ezért az országbíró a vele ítélkező bárókkal és nemesekkel együtt megerősíti Lớrinc és István, valamint utódai örökre szóló birtokjogát a szóban forgó birtok harmada fölött, továbbá helyben hagyja Márton 3 leányának haszonélvezeti jogát férjhezmenetelükig a 
fennmaradó részben, egyszersmind kiköti, hogy ezt követően adják ki a nekik járó leánynegyedet. Az ügyben mindezek tanúságára kiállított oklevelet a protonotarius-i és a nagyobb országbírói pecsét hiányában az országbíró gyứrúspecsétjével látják el. D. Bude, 16. die termini reportationis seriei prenonate, a. d. 1356.

E.: Dl. 4591. (NRA. 647. 3.) Hártyán, hátoldalán újkori kéz írásával tárgymegjelölés, valamint rányomott pecsét töredéke, szalagja.

K.: AO. VI. 434-437. (277. szám) (kihagyásokkal); Smič. XII. 330-331. (248. szám).

\section{1356. febr. 26. Buda}

[I.] Lajos király $(\mathrm{H})$ szavát adja Gradonicus János velencei dózsénak, valamint a városi tanácsnak, hogy bárkit és bármikor is küldenek hozzá követségbe, teljes szabadságot élvez a területén való átkeléskor mind az oda-, mind a visszaút alkalmával. D. Bude, mensis Febr. die 26.

K.: Ljubić II 311. (459. szám); Wenzel, dipl. eml. II. 466-467. (374. szám) Mindkettő a "Commemoralium" velencei államkönyv alapján V. 55. ep. 190.).

\section{1356. febr. 27.}

[I.] Lajos király (H, Da, C, Ra, Se, G, L, Cu, Bu, princ. Sal., mont. S. Angeli dom.) a színe elé járult Demeter váradi püspök, Gergely mr. kánonjogi doktor, őrkanonok, különleges királyi káplán (doctor decretorum, custos, specialis noster capellanus), valamint Péter Kewleser-i főesp., a váradi egyház kanonokja kérésére és oklevél-bemutatása alapján az elvégzett vizsgálat megnyugtató eredménye nyomán Erzsébet anyakirályné (principissa) egyetértésével, valamint az ország főpapjainak és báróinak a tanácsára átírja s autentikus kettóspecsétjének felfüggesztésével megerősíti azt, az autentikus királyi pecsétjével ellátott 1342. dec. 10-én kelt nyílt oklevelét (l. Anjou-oklt. XXVI. 642. szám), amely a teljes Bihar m. összes adójának összegyújtése ügyében állíttatott ki ue. egyház javára. Kelt Miklós zágrábi püspök, királyi alkancellár keze által, a. d. 1356., VI. Kal. mensis Marc., uralkodásának 15. évében. Méltóságnévsor: Miklós lévén az esztergomi érsek, egyben ua. m. örökös c.-e, Domokos a spalatói érsek — a kalocsai szék üresedésben -, Miklós az egri, Demeter a váradi, András az erdélyi, Miklós a pécsi, János a veszprémi, Kálmán a győri, Tamás a csanádi, Mihály a váci, István testvér a nyitrai, Tamás testvér a szerémi - a boszniai szék üresedésben —, Balázs testvér a knini püspök; Miklós az erdélyi vajda és Zonuk-i c. — a nádori tisztség üresedésben —, Zech-i Miklós az országbíró, Cykou a tárnokmr., Miklós a Macho-i bán, Lewkews az asztalnokés pohárnokmr., Dénes a lovászmr., Tamás az ajtónállómr., valamint Móric fia: Simon a pozsonyi c.

Á.: 1. I. Mátyás király, 1477. máj. 20. Dl. 24 438. (Gubernium Transylvanicum. Cista diplomatica A. 2.).

2. Mátyás király, 1478. febr. 17. > Guti Ország Mihály nádor, 1478. ápr. 24. > erdélyi kápt., 1516. AJ. Brasov. Brassó város lt. Privilegia 214. (Df. 247 041.).

3. Mátyás király, 1478. febr. 17. > Guti Ország Mihály nádor, 1478. ápr. 24. > kolozsmonostori konv., 1516. Uo. (Df. 247 041.) Utóbbi kettő egy jelzett alatt található két külön oklevél. 
Tá.: 1. Mátyás király, 1478. febr. 17. > Guti Ország Mihály nádor, 1478. ápr. 24. AM. Košic. Kassa város titkos lt. F. 78. (Df. 269 372.).

2. Tá. 1. > kolozsmonostori konvent, 1478. máj. 18. Arhivele Statului Cluj. Kolozsvár város lt. Kolozsvár város tanácsa. Privilégiumok T 55. (Df. 281 179.).

3. Tá. 1. > jászói konvent, 1478. aug. 17. AM. Košic. Kassa város titkos lt. F. 79. (Df. 269 373.).

4. Tá. 2. > erdélyi kápt. 1478. okt. 28. Brassói Evangélikus Egyházközség lt. Barcasági kápt. oklevelek 1. E. 178. (Df. 286 664.).

5. Tá. 1. > erdélyi kápt., 1485. okt. 13. Arhivele Statului Sibiu Szász Nemzeti lt. Urkunden 2. 426. (Df. 245 070.).

6. Tá. 1. > II. Ulászló király, 1492. nov. 24. AM. Košic. Kassa város lt. Suppl. Schramianum 19195. (Df. 271 282.).

7. Mátyás király, 1478. febr. 17. > Guti Ország Mihály nádor, 1478. ápr. 5. > I. Mátyás király, 1480. febr. 25. Arhivele Statului Sibiu Szász Nemzeti lt. Urkunden. 2. 399. (Df. 245 043.) 18. sz.-i egyszerú Má.-ban.

8. Tá. 7. > erdélyi kápt., 1485. okt. 13. Arhivele Statului Sibiu Szász Nemzeti lt. Urkunden 2. 427. (Df. 245 071.).

9. Tá. 7. > aradi kápt., 1492. jan. 21. > II. Ulászló király, 1492. nov. 24. Arhivele Statului Cluj Beszterce város lt. Beszterce város tanácsa. Tanácsi iratok, oklevelek 182. (Df. 247 417.).

10. Tá. 9. > II. Ulászló, 1497. máj. 6. > erdélyi kápt., 1497. aug. 6. Arhivele Statului Cluj Kolozsvár város lt. Kolozsvár város tanácsa. Privilégiumok T 70. (Df. 281 188.).

Má.: 1. Arhivele Statului Sibiu Szász Nemzeti lt. Urkunden 2. 380. (Df. 245 025.). Á. 1. alapján, újkori.

2. D1. 36 974. (Erd. Fisc. 5. 381. E.) (Tá. 1. alapján) a szövegben tévesen IV. Kal. szerepel VI. Kal. helyett.

K.: Kolozsvár I. 6-16. (2. szám) (Tá. 2. alapján); ZW. II. 119-121. (703. szám); AO. IV. 293. (töredékes); Doc. Rom. Hist. XI. C. 9-11. (6. szám) (román fordításban is) Utóbbi három Á. 1 alapján.

R.: Berger, Urkunden 12. (27. szám) Jakab Elek munkájára (1. K. Kolozsvár) való hivatkozással.

95. 1356. febr. 28.

A vasvári egyház kápt.-ja e. egyik részről megjelenő Zala m.-i Zagurheda-i István fia: Benedek, a másik részról pedig Zagurheda-i András fia: Bálint a maga, valamint fivére, János nevében is eljárván - saját terhére vállalván mindent, ha az alábbi egyezséget fivére teljesen v. részben elutasítaná — kijelentették, hogy mivel rokonuk, Zagurheda-i Miklós fia: Zagur (dict.) Pál fiú utód nélkül halt meg, Zagurheda birtokon lévő részbirtoka rokonság révén rájuk szállt, s azt egymás között örökre szóló birtokosztályt eszközölve felosztják olyan módon, hogy É-i felét - 10 hold szántót is beleértve - 
annak valamennyi haszonvételével együtt (ti. jobbágyokkal, telki helyekkel, szántókkal, erdőkkel, vizekkel, rétekkel, ligetekkel, kaszálókkal) a mondott István fia: Benedek és utódai kapják, míg a másik, Dé-i részét, nem lévén benne a 10 hold szántóföld, szintén valamennyi haszonvételével együtt András fiainak: Bálintnak és Jánosnak, valamint ezek örököseinek juttatják annak kijelentésével, hogy mindkét fél végleg megelégszik a szóban forgó felosztás során birtokába került résszel. D. in domin. Exsurge, a. d. 1356.

E.: Dl. 41 279. (Múz. Ta. 1895. 7.) Hártyán, helyenként vízfoltos, hátoldalán kerek pecsét nyoma, bevágásai és felirat: Sanctus spiritus adsit nobis.

Má.: Uo., mint E., azzal megegyező jelzet alatt, László József aláírással.

K.: -

\section{6. (1356.) febr. 29. Avignon}

[VI.] Ince pápa Péter választott boszniai [püspöknek]: mivel Peregrinus püspök halálával megüresedett a boszniai egyházat irányító tisztség, annak betöltésérôl gondoskodván, a címzettet, ugyanezen egyház olvasókanonokját nevezi ki püspökké, akinek tudásáról és erényes életéről meggyőződött, így rábízza ezen egyház lelki és anyagi irányítását és a hívek gondozását. D. Avinione, II. Kal. Marc., pápasága 4. évében [1356].

Reg.: ASV. Reg. Av. v. 132., f. 53r-v (Df. 289 508.)

Eml.: A 386. számú oklevélben.

K.: Theiner, Mon. Slav. I. 233. (313. szám) (Reg. alapján); Smič. XII. 332-333. (249. szám) (Theiner alapján).

R.: Acta Bosnae 32. (177. szám) (Theiner alapján); Áldásy, 38. (212. szám) (Reg. alapján).

\section{7. (1356.) febr. 29. Avignon}

[VI.] Ince pápa a 96. számú oklevélben foglaltakkal egyező tartalmú levélben értesíti a boszniai kápt.-t a Péter boszniai olvasókanonok ue. egyház élére történő püspöki kinevezéséról. D. ut supra [Avinione, II. Kal. Marc., pápasága 4. évében [1356]].

Megj.: Apparátusa megegyezik a 96. számú oklevélével.

\section{8. (1356.) febr. 29. Avignon}

[VI.] Ince pápa a 96. számú oklevélben foglaltakkal egyező tartalmú levélben értesíti a boszniai egyházmegye és egyház klérusát a Péter boszniai olvasókanonok ue. egyház élére történő püspöki kinevezésérôl. D. ut supra [Avinione, II. Kal. Marc., pápasága 4. évében [1356]].

Megj.: Apparátusa megegyezik a 96. számú oklevélével. 
[VI.] Ince pápa a 96. számú oklevélben foglaltakkal egyező tartalmú levélben értesíti [I.] Lajos királyt $(\mathrm{H})$ a Péter boszniai olvasókanonok ue. egyház élére történő püspöki kinevezéséről. D. ut supra [Avinione, II. Kal. Marc., pápasága 4. évében [1356]].

Megj.: Apparátusa megegyezik a 96. számú oklevélével.

100. 1356. febr. 29.

Az egri egyház kápt.-ja teljesítvén a színe e. megjelent, a Gömör m.-i Senthkyral-ból való Bolugh fia: Miklós és Lőrinc fia: Tamás arra hivatkozó kérését, hogy a közöttük létrejött békés megegyezés rendelkezéseiról mindkettejüknek szüksége van az azt írásban rögzítő oklevél külön-külön példányára, oklevél-bemutatásuk alapján átírja és autentikus pecsétjének felfüggesztésével megerôsíti saját, 1347. márc. 12-én kelt privilégiális oklevelét (l. Anjou-oklt. XXXI. 202. szám) László prépost, Imre olvasó-, Konya őrkanonok, Domonkos Borswa-i, András Zemlyn-i, Miklós Zaloch-i, Sándor Patha-i, Benedek Pankatha-i, László Borsud-i, Mihály Heves-i főesp.-ek jelenlétében. D. f. II. prox. p. domin. Exsurge, a. d. 1356. [I.] Lajos lévén a király (H), Miklós az esztergomi érsek - a kalocsai szék üresedésben —, Miklós az egri püspök.

E.: Dl. 3891. (NRA. 694. 24.). Hártyán, alján függőpecsét felfüggesztésére szolgáló bevágások, pecsétje lila-sárga sodraton függött (rajta — az egri székesegyház védőszentjének, Szt. János apostolnak jelképes ábrázolásaként — kiterjesztett szárnyú sas, fejét glória övezi, karmaiban írott szalagot tart; a pecsét körirata: +S(IGILLVM) CAPIT(V)LI AGRIEN(SIS) ECCL(ES)IE POST PLAGAM).

K.: AO. V. 29. (kivonatos).

101. 1356. febr. 29. u.

A Lelez-i konvent - miként azt 1356-ban (a. d. 1356.) kelt hj.-sal, ellentmondással és idézéssel kapcsolatos oklevele tanúsítja - Petheu és Donch birtokügyében tanút adott Welkouch-i Simon királyi ember mellé, akik febr. 29-én (f. II. prox. p. fe. B. Mathie ap.) az összehívott szomszédok és határosok jelenlétében kimentek Jenke birtokra, s Ke-ról a Zuenche folyón lévő rekesztéktől (clausura aque) - (vlg.) gaath-tól - kezdődően bejárták a birtokot, és fel akarták állítani a határjeleket, azonban Ruzka-i Dobou fia: Jakab tiltotta óket, hogy az említett gáttól kezdődően Ny felé haladva a folyó mentén egy nagy kiterjedésú területig, majd egy tölgyfától É felé egy völgyig, onnan pedig egy bizonyos Rakathyaser-ig határjeleket állítsanak és a birtokba iktatást elvégezzék.

Tá.: Szécsi Miklós országbíró, 1358. okt. 13. Dl. 66 810. (Dessewffy cs. margonyai lt. 30.).

K.: AO. VII. 410. (229. szám).

102. 1356. febr.-márc.

[IV.] Károly császár és király a brabanti hercegnóhöz, Johannához és fivéréhez, Vencel herceghez intézett levelében beszámol arról a Mo.-on a napokban [febr. 20.] zajló tárgyalásról, melynek alkalmával a császár megállapodott a magyar királlyal, hogy János 
Morva ôrgróf elsőszülött fia és a király fivére, a megboldogult István herceg lánya között házasság köttetik, melyet ünnepélyes kötelezvénylevéllel erősítettek meg. D. etc. a litomyšl-i püspök, kancellár (cancellarius Luthomislensis) etc.

K.: Reg. Boh. Mor. pars VI. 147. (289. szám) a Świdnica-i formulárium 16. sz.-i Má.-ra való hivatkozással „in formulario bibl. Svidnicensis I 243. fol. 102. n. 60.”, ennek kiadása 1. Schieche, Ein Schweidnitzer Formularbuch Johanns v. Neumarkt, ZFT. d. Ver. f. Gesch. u. Alt. Schles. LXI (1927) 351. (7. szám)

R.: CD. Mor. X. 37. (50. szám); RI. VIII. 347. szám Mindkettő az 1361. febr. 2-án Vyšehradon kelt oklevélre való hivatkozással (németül); Pór A., Száz. 35 (1901) 101-102 (CD. Mor.-re hivatkozással); Fraknói V., Bp. Szml. 153 (1913) 30. (téves hivatkozással).

103. 1356. febr.-márc.

Luna-i Péter a boroszlói préposthoz intézett levelében beszámol arról a pompáról, amivel [I.] Lajos király $(\mathrm{H})$ a császárát fogad ta a kettejük között zajló tárgyalások idején és az ez alkalommal kiosztott adományokról is említést tesz.

K.: Reg. Boh. Mor. pars VI. 147. (288. szám) a Świdnica-i formulárium 16. sz.-i Má.-ra való hivatkozással „in formulario bibl. Svidnicensis I 243. fol. 113. n. 87.”, ennek kiadása 1. Schieche, Ein Schweidnitzer Formularbuch Johanns v. Neumarkt, ZFT. d. Ver. f. Gesch. u. Alt. Schles. LXI (1927) 350. (6. szám)

104. 1356. márc. 1.

A csázmai egyház kápt.-ja e. egyik részről megjelenő Lőrinc fia István leánya, Pál fia Lukácsnak (Lucachius) a felesége, a nemes Bongech asszony kijelenti, hogy mindazokat a birtokrészeket, amelyekre apja Thopolcha v. Crustholouch birtokain és azok haszonvételein atyai v. örökösödési jog alapján, leánynegyed jogcímén jogot formálhat, v. amelyeket fivére adománya gyanánt tartott birtokában, jelen lévő férje beleegyezésével örökre szólóan eladja a másik részról megjelent fivérének (fr. carnalis), István fia: Miklósnak a tóle megkapott $31 \mathrm{M}$. dénár ellenében. Ezenfelül megígérte, hogy a fivére említett adományáról szóló okleveleket visszaadja Miklósnak, ám ha ez elmaradna, akkor azokat késóbbi bemutatásuk esetére hatálytalanoknak nyilvánítja. A kápt. eleget téve a felek kérésének az ügy megerősítésére pecsétjével ellátott oklevelet bocsát ki. D. f. III. prox. p. domin. Exurge, a. eiusdem 1356.

E.: Dl. 100 065. (Batthyány cs. lt. Acta antiqua. Kristallóc 4. 6. 98.) Hártyán, alján piros és zöld színú sodrat függ. Az oklevélhez tartozó cédula mellékleten magyar nyelvú tárgymegjelölés.

K.: -

105. 1356. márc. 1.

Péter prépost és a Lelez-i Szt. Kereszt-monostor konventje e. megjelenő Lezthemer-i Albert fia: Máté a maga, valamint fiai: András és János, hasonlóképpen Domokos fia Miklós fiai: Bálint, Bereck, Péter és Ivan, továbbá László fia: Benedek, nemkülönben ugyanezen Lezthemer-i Peteu fia: János nevében is tiltakozott az ellen, hogy fivére (fr. 
uterinus), nevezett Albert fia: Peteu, továbbá Domokos fia: Donch — hasonlóképpen ugyanezen Lezthemer-ről —Jenke birtokuk határai között lévő és privilégiumukba foglalt földjüket tudtuk és beleegyezésük nélkül, súlyos kárukra odaadták Mihály fia: Andrásnak. Ezért Máté a maga és az általa képviseltek nevében is tiltja Peteu-t és Donchot a szóban forgó földnek bármiféle elidegenítésétől, Mihály fia: Andrást pedig annak birtokbavételétől, továbbá hasznának és haszonvételeinek megtartásától. Annak érdekében pedig, nehogy a hallgatásból káruk származzék, kérik, hogy a konvent adjon ki oklevelet tiltakozásukról. D. f. III. prox. p. fe. B. Mathie ap., a. d. 1356.

E.: ŠA. v Poprade Pobočka Prešov, Úsz cs. úszfalvi lt. 123. 3. (Df. 268 392.). Hátoldalán azonos kéz írásával tárgymegjelölés és zárópecsét nyoma, szalagja, bevágásai.

K.: -

106. 1356. márc. 3 .

Az egri egyház kápt.-ja a színe e. rokonait, Pétert és Terpe (dict.) János fia: Lászlót is képviselő Tarkan-i Máté fia: Miklós kérésére és oklevél-bemutatása alapján az ABC betúivel chirographált privilégiumában átírja, s autentikus pecsétjének ráfüggesztésével megerősíti saját, 1330. máj. 3-án kelt zárt oklevelét (l. Anjou-oklt. XIV. 251. szám) [bizonyos Tarkan birtokbeli földrészekkel kapcsolatos intézkedésekről]. László prépost, Imre éneklő-, Miklós őrkanonok, valamint Domokos Borsuva-i, András Zemlyn-i, Benedek Pankata-i, Miklós Zaboch-i, László Borsud-i, Sándor Patha-i, Sándor Tarcha-i főesp.-ek jelenlétében. D. f. V. prox. an. domin. Esto michi, a. d. 1356. [I.] Lajos lévén a király (H), Miklós az esztergomi érsek, a kalocsai szék üresedésben, Miklós az egri püspök.

E.: HML. 644. Egri székesfőkápt. mlt. 17. 4. 1. 11. (Df. 210 566.) Felül az ABC betưivel chirographálás, hátoldalán közel korú kéz írásával tárgymegjelölés, alján függőpecsét rögzítésére utaló zsineg.

K.: -

Megj.: Az átírt oklevél [ ] között megadott tárgyát az átíró oklevél nem jelzi közvetlenül.

107. 1356. márc. 6. Buda

[I.] Lajos király (H) híveinek, Miklós fia: Miklósnak, valamint más Hedruhuar-i nemesnek és az okleveléról tudomást szerző valamennyi vámszedőjüknek: mivel a pozsonyi polgárok és hospes-ek olyan kiváltságot nyertek el atyjától, [I.] Károly királytól és őtőle is, miszerint örökre mentesek a Pozsonyból Vysegrad-ra szállított bor és gabona valamennyi vámjának megfizetése alól, ezért kénytelen csodálkozásának hangot adni amiatt, hogy rendeletével ellentétesen a minap a pozsonyiak 3 hajóját, amelyen bort szállítottak, vámszedés ürügyén feltartóztatták. Így hát elrendeli, hogy eme parancsa vételét követően azonnal egy, a királyi udvarból külön ezért kiküldött udvari ifjú, János fia: Miklós királyi ember jelenlétében hagyják a szóban forgó 3 hajót a szállított borral együtt mindenféle vámfizetés nélkül békében továbbmenni. Ha ezt mégis vonakodnának megtenni, akkor a nevezett királyi ember által kitűzött időpontban kötelesek lesznek a királyi parancs megszegéséról személyesen számot adni. D. Bude, in domin. Esto michi, a. d. 1356. 
E.: AMB. Pozsony város lt. Középkori oklevelek és levelek. 128. (Df. 238 753.) Hátoldalán kerek pecsét nyoma, valamint késóbbi kéz írásával tárgymegjelölés.

K.: -

R.: AMB. Inventár 27. (134. szám) (cseh nyelvû).

\section{1356. márc. 6. Buda}

[I.] Lajos király $(\mathrm{H})$ valamennyi főpapnak, bárónak, ispánnak, várnagynak, nemesnek és más jogállású embernek, akik vámszedési joggal rendelkeznek a Duna folyó Pozsonytól Vyssegrad-ig terjedő szakaszán, valamint ezek múködő és jövóben kinevezendő vámszedőinek: mivel az ország határait védő pozsonyi polgárok és hospes-ek [I.] Károly király és [I.] Lajos király által kibocsátott oklevelek hatálya folytán olyan szabadságot élveznek, amelynek értelmében örök időre mentesülnek valamennyi, a Pozsony városból Vyssegrad felé szállított bor és gabona u. járó vám megfizetésétől, ezért megparancsolja a címzetteknek, hogy a parancs kézhezvételét követóen akármikor és valahányszor a szóban forgó polgárok és hospes-ek közül bárki érkezik borral és gabonával a vámszedő helyre, hagyják őt vám fizetése nélkül átkelni. Ha valaki az adószedők közül vétségében áthágná ezen rendelkezést, s a pozsonyiak valamely borral és gabonával megrakott hajóját fel merné tartóztatni, nyakasságáról és a királyi parancs megszegéséról köteles lesz személyesen az udvarban a király tekintete e. számot adni. D. Bude, in domin. Esto michi, a. d. 1356.

E.: AMB. Pozsony város lt. Középkori oklevelek és levelek. 126. (Df. 238 751.) R. szerint hártyán, hátoldalán azonos kéz írásával tárgymegjelölés, valamint kerek pecsét nyoma, szalagja, bevágásai.

K.: -

R.: AMB. Inventár 26. (132. szám) (cseh nyelvû).

109. 1356. márc. 6.

Az egri egyház kápt.-ja eleget téve az [I.] Lajos király itt átírt, febr. 6-án Visegrádon kiállított parancslevelében (l. 72. szám) foglaltaknak, amely iratot Nyek-i Lodomér fia: Domokos mutatott be színe e., sekrestyéjéból előkeresi, majd privilégiális formában átírja és autentikus függőpecsétjével megerősíti saját, 1339. ápr. 20-án Nyek birtok osztálya kapcsán kibocsátott oklevelét (l. Anjou-oklt. XXIII. 193. szám). László prépost, Imre olvasókanonok, Miklós órkanonok, Domonkos Bursua-i, András Zemlyn-i, Miklós Zabouch-i, Sándor Pata-i, Sándor Tharchafeu-i, Benedek Pankata-i főesp.-ek jelenlétében. D. in domin. Esto michi, a. supradicto [1356.], [I.] Lajos lévén a király (H), Miklós az esztergomi érsek, a kalocsai egyház széke üresedésben, és Miklós az egri püspök.

E.: Dl. 3222. (NRA. 1711.6.) Hártyán, hátoldalán késóbbi kéz írásával tárgymegjelölés, alján pecsét felfüggesztésére utaló bevágások.

Á.: Pálóczi Máté nádor, 1435. dec. 4. Dl. 107 790. (Bristow gyújt. 1982. 1421.).

Má.: 1. Dl. 8802. (AP. Lád 13. 1.).

2. Dl. 107 785. (Bristow-gyứjt. 1982. 1421.) Mindkettő E. alapján készült 18. sz.-i egyszerű Má.-ban. 
K.: -

R.: Bándi Zs., BLÉ. 5 (1985) 616.

\section{1356. márc. 6. Pozsony}

Vogl (dict.) Hainricus, pozsonyi polgár és felesége, Erzsébet, valamint örököseik tudatják: testi és lelki épségük birtokában, valamennyi barátjuk egyetértésével és bátorítására elhatározták, hogy végrendelkeznek azokról a javakról, melyeket Isten segítségével munkájuk eredményeként birtokolnak. Pozsony város Szt. Márton-egyházának plébánosára, Mártonra, ill. azokra, akik ôt törvényesen követik majd a lelkipásztorságban (in pastoratu ecclesie), ráhagynak örök időkig évi - 3 részletben folyósítandó - 15 fontot: amelyből az első 5 fontot ápr. 24-én (in prox. B. Georgii fe.), a másodikat szept. 29-én (in fe. B. Michaelis), a harmadikat pedig dec. 25-én (in fe. Nat. d.) esedékes megadni. Az első időpont alkalmával Hainricus (dict.) Ayleuer és felesége, Margit v. az utódaik 3 fontot fizessenek a Wedricz-i hajókikötóből (de portu navigii) és a Scharlachsperg-hegyen lévő szőlóből származó jövedelmükból, továbbá ehhez még 2 fontot tegyen hozzá a végrendelkezők Pozsony városban lévő lakóházából eredő bevételból annak jelenlegi v. késóbbi birtokosa. A második alkalommal megfizetendő 5 font bécsi dénárt a Retzstorf-i $\sim$ Retz falvi (de villa Retz) Benedek-hegyen levő két Goltfuez nevezetű szólőjük hasznából teljesítsék annak mindenkori tulajdonosai, ti. 3 font dénárt a lentebb fekvő szőlóből, 2 fontot pedig a föntebbi szólóből. A harmadik alkalommal fizetendő 5 font dénárból 3-at a Retz falvi Benedek-hegyen levő Bleslenis gevang szólóból, 2 font bécsi dénárt pedig az ugyanezen Retz falvi Schinperch-hegyen lévő Leisganth szólőjükből kötelesek adni mindenkori birtokosaik. Ennek fejében a mondott plébános és hivatali utódai örök idôkig kötelesek naponta alkalmas pap által misét mondatni a végrendelkezők és azok szüleinek lelki üdvéért, kivéve a jelesebb ünnepeken, úgy mint Húsvét napján, Pünkösd ünnepén és az Úr születésének ünnepén. Amennyiben Márton plébános vagy örökösei ezen kötelezettségüknek bármilyen okból nem tesznek eleget, úgy javaik örökösei akik az évi 15 fontot kötelesek fizetni - ezt az összeget Pozsony város ispotályainak felújítására fordítsák mindaddig, míg a napi misemondás rendje helyre nem áll. Ha az összeg kifizetése késedelmet szenvedne v. teljesen elakadna, akkor nevezett plébános és utódai kötelesek panaszt tenni a kánoni, ill. a római jog alapján (iure canonico vel civili); ezenfelül pedig, amennyiben ôk és minden egyes utódjuk már elhalnának, akkor atyafijaikra, a polgárok céhébe tömörült megbízható és nagytiszteletú férfiakra bízzák (fidelibus et honestis viris fratribus in cecha civium committimus), hogy ôszinte lelkiismeretük szerint beteljesítsék ezen végintézkedésük rendelkezéseit A pozsonyi Szt. Márton egyház plébánosa, Márton maga és utódai nevében is ígéri, hogy a fentieket betartja, ennek megerôsítésére a város és a pozsonyi kápt. pecsétjeivel megerôsített privilégiális oklevelet állítanak ki, amelyre a plébános saját pecsétjét is ráfüggeszti. D. Posonii, domin. qua canitur Esto michi in deum protectorem, a. d. 1356.

E.: 1. AMB. Pozsony város lt. Középkori oklevelek és levelek. 127. (Df. 238752.$)$ Hátoldalán késôbbi kéz írásával tárgymegjelölés, alján 3 pecsét függ.

2. Uo., 129. (Df. 238 754.) Hátoldalán közel egykorú és késóbbi kezek írásával tárgymegjelölések, alján 3 függőpecsét.

R.: Ortvay, Pozsony 242; AMB Inventár 27. (133. szám és 135. szám).

Megj.: A két oklevél szövege az utolsó sorokban eltér. E. 1. esetében az oklevél végén Márton plébános egyes szám első személyben ígéri meg, hogy az oklevélben fog- 
laltakat betartja. Mindkét oklevél ugyanazon kéz írása és a megerősítésre használt pecsétek is azonosak.

\section{1356. márc. 9. Buda}

László, a csázmai egyház prépostja, [I.] Lajos király (H) kápolnaispánja és titkos kancellárja e. Noghmortun-i Simon fia Lőrinc fia: Niklynus mr. önnön kötelezettségvállalásaként kinyilvánítja, hogy az Esztergom m-i Wyfalu, Bayolth és Peel birtokok fele részét, valamint a Duna folyó másik partján elhelyezkedő Chenke birtokot, továbbá a Duna és Waag folyók között Komárom m.-ben fekvő Kezu birtokot, amelyeket egykor Kanysa-i Imre fia Lőrinc fiai: János és Benedek mr.-ek zálog címén szereztek kezükre tőle, mindaddig egyáltalán nem válthatja ki tôlük, amíg Kanysa-i Lőrinc nevezett fiainak az anyjuk, Katalin nemes úrasszony révén járó leánynegyedet teljesen meg nem fizeti. D. Bude, in die Cynerum, a. d. 1356.

E.: Dl. 4598. (NRA. 21. 16.). Hártyán, hátoldalán kerek pecsét nyoma, bevágásai, valamint későbbi kéz írásával tárgymegjelölés.

K.: AO. VI. 438. (278. szám) (kihagyásokkal).

112. 1356. márc. 12.

[I.] Lajos király (H, Da, C, Ra, Se, G, L, Co, Bu, princ. Sal., mont. S. Angeli dom.) a hozzá folyamodó Hertul fia: Miklós festô elmondásából arról értesülvén, hogy a Sopron m.-ben fekvő Medwes birtok földjeit és haszonvételeit, amelyeket még apja, Hertul kapott szolgálatai viszonzásaként az uralkodó apjától, [I.] Károly királytól (H) örök adományba, késóbb azonban nagy ínségében kénytelen volt különféle embereknek elzálogosítani, eladni, sőt, még bizonyos más jogcímen is elidegeníteni, ő viszont azóta a saját költségén és fáradságán visszavásárolta azokat, és úgy akarja minden tartozékukkal együtt birtokolni ôket, ahogyan az az apjának adott privilégiumban áll, támogatva ezen törekvést, s tekintettel Miklós húségére és érdemes szolgálataira, kivált is mert kedvelt és tetszetős festményei gyönyörködtetésére szolgálnak, új adomány címén a korábbi privilégiumban foglaltakkal megegyező értelmú kiváltságlevelet bocsát ki, függő és autentikus kettős pecsétjével megerősítve azt, s általa Miklósnak és utódainak adományozza Medwes birtokot, kivéve a Fertew tóról e falunál szedett vámot, amelyet magának tart meg. Különleges kegyként úgy is jótáll adományáért, hogy ha valaki esetleg valamilyen jogigénnyel jelentkezne e birtokkal kapcsolatban, iratait a királlyal szemben kell bemutatnia, és követelését is a király ellenében kell érvényesítenie, miként az esetleges elégtétel megadása is az ő királyi kötelessége lesz. Kelt Miklós zágrábi püspök, királyi alkancellár keze által, a. d. 1356. IV. Id. Mart., uralkodásának 15. évében. Méltóságnévsor: Miklós lévén az esztergomi érsek, egyben ua. m. örökös c.-e - a kalocsai szék üresedésben -, Domokos a spalatói érsek, Miklós az egri, Demeter a váradi, András az erdélyi, Kálmán a gyớri, Miklós a pécsi, János a veszprémi, Tamás a csanádi, Mihály a váci, Tamás testvér a szerémi, István testvér a nyitrai — a boszniai szék üresedésben —, Balázs testvér a knini püspök; Miklós lévén az erdélyi vajda és a Zonuk-i c. a nádori tiszt üresedésben - Zech-i Miklós az országbíró, Cyko a tárnokmr., Miklós a Machow-i bán, egyben egész Szlavónia és Ho. bánja, Leukus az asztalnok- és pohárnok-, Dénes a lovász-, Péter fia: Tamás az ajtónállómr., valamint M[óric] fia: Simon a pozsonyi c. A. 
E.: GYMSML. Sopron város 156. (Df. 201 790.) Hátoldalán német nyelvú tárgymegjelölés 16. sz.-i kéz írásával.

K.: Házi I. 1. 107-109. (173. szám).

R.: Jakubovich E., MKszl. 3-4. (1930.) 392. (az oklevélból vett latin idézettel); Házi J., Soproni Szemle 2 (1967) 116, 119.

113. 1356. márc. 12.

A csázmai egyház kápt.-ja a színe e. 1356. márc. 12-én (a. d. 1356. in fe. S. Gregorii pape et conf.) megjelent, s az ingatag közállapotok miatt az eredeti oklevelek szállításának veszélyességére hivatkozó, a kőrösi kerületból (de districtu Crisiensis) való Myke fia: Miklós nemes kérésére és oklevél-bemutatása alapján átírja és pecsétjével megerősíti [I.] Lajos királynak $(\mathrm{H})$ azt a kettős pecsétjével ellátott, 1355. febr. 2-án kiadott privilégiumát, amely István szlavón herceg 1353. nov. 27-i átírásában magában foglalta Miklós horvát bán 1346. júl. 6-án kiadott [— hadi érdemei alapján a szóban forgó Myke fia: Miklósnak a várjobbágyi állapotból történő kivételéról és a nemes királyi serviensek sorába emeléséről intézkedő - ] oklevelét.

E.: Dl. 35 861. (MKA. Collectio Kukuljevicsiana) Hártyán, alján függőpecsét vörös zsinege.

K.: -

Megj:: Miklós horvát bán oklevelének [ ] között megadott tárgyát a csázmai kápt. által fogalmazott átíró oklevél keretszövege nem tartalmazza közvetlenül. István szlavón herceg 1353. nov. 27-én kelt oklevelét 1. Halász É., Szlavón 232. (447. szám), Miklós horvát bán benne átírt 1346. júl. 6-án kelt oklevelét uo., 106. (134. szám) alatt.

114. 1356. márc. 12.

A [székes-]fehérvári Szt. István király-egyház ispotályos háza kereszteseinek konventje e. egyik részrôl Pouka fia István fia: László Lylye-i nemes, a másik részről pedig az ugyanonnan való Rafael (Raphael) fia: János mr. megjelenvén — akiknek a személyét a konvent e. az ugyancsak Lylye-i illetőségú Or[rus (dict.)] Péter, Lukács (Lucasius) fia: Péter, András fia: Mihály és Andich fia: Márton igazolták —, elóbbi kinyilvánítja, hogy azt a 3 kaszaaljnyi kiterjedésú kaszálóját (fenetum), amelyet É felől Vgal-i Pál mr., egykori országbírói ítélőmester (prothonotarius) fiának: Miklósnak, Ny felól pedig Andich fiainak: Mártonnak és Jánosnak, továbbá Nagy (Magnus) Pál fia: Györgynek a kaszálórétjei (fenilia) határolják, szomszédai beleegyezésével, szavatosság vállalása mellett, összes haszonvételével együtt örökre szólóan eladta Rafael fia: Jánosnak a tôle megkapott 13 pensa bécsi dénár ellenében. D. in fe. B. Gregorii pape, a. d. 1356.

E.: Dl. 49 265. (Mérey cs. 1t. 46.) Hártyán, hajtásvonal mentén foltokban hiányos, hátlapján mandorla alakú pecsét nyoma.

K.: -

R.: Borsa I., Somogy m. lt. Évk. 23 (1992) 26. (57. szám). 
115. 1356. márc. 13.

A szekszárdi monostor konventje a színe e. megjelenő Péter testvérnek, az Abram-i Szúz Mária-egyház apátjának kérésére és oklevél-bemutatása alapján privilegiális formában átírja és autentikus pecsétjével megerôsíti a néhai Pál mr., Tolna $\mathrm{m}$-i alispán és a m. szb.ái által 1355. febr. 3-án [— a nevezett apát és a Maguch-i apát Tekere föld hovatartozása körül támadt perében -] kiadott nyílt oklevelét. D. in domin. Invocavit, a. d. 1356., János perjel és őrkanonok, valamint Miklós éneklőkanonok jelenlétében.

E.: EPL. Esztergomi székesfőkápt. mlt. Acta radicalia 73. A 6. (Df. 238 330.) Str. szerint hártyán, a plikán függőpecsét hasítéka, hátoldalán 15. sz.-i kéz írásával Thekere, abbatis de Abraham.

Má.: Dl. 87 304. (Esterházy cs. hercegi ága, Repositorium 35. L 225.) 1734. jan. 10-i egyszerü Má.-ban.

K.: F. IX. 2. 539-540. (262. szám) (Kaprinai alapján); Str. IV. 137. (110. szám).

Megj.: Az átírt oklevél [ ] között megadott tárgyát a szekszárdi konvent átíró oklevelének keretszövege nem tartalmazza közvetlenül.

116. 1356. márc. 15.

A velencei signoria eleget téve [I.] Lajos király $(\mathrm{H})$ követe, a nyitrai püspök kérésének, engedélyezi egy Velencéból számúzött barát visszatérését.

R.: Óváry 47. (56. szám) (Velencei lt.-ra való hivatkozással); uô., TT. 11 (1888) 455.

117. 1356. márc. 15.

A nyitrai kápt. e. - miként azt 1356. márc. 15-én (f. III. prox. p. domin. Invo[cavit] a. d. 1356.] kelt oklevele tanúsítja - Bagamer c. bemutatván [I.] Lajos király nyílt oklevelét, kinyilvánította, hogy az oklevélben foglaltak alapján valamennyi birtokát és részbirtokát, különösképpen azokat, melyek Dauar és Bodok birtokokon vannak, leányainak, Erzsébetnek és Ilonának, rajtuk keresztül pedig férjeiknek Sebeuk-nek és Györgynek, valamint utódaiknak adományozta.

Tá.: Bebek István országbíró, 1360. ápr. 19. Dl. 72 539. (Simonyi cs. 1t. 36.)

Má.: Uo., Tá.-val megegyező jelzet alatt; 5. old.

Megj.: I. Lajos király bemutatott oklevele 1351. szept. 29. körül kelt.

118. (1356. márc. 16.e.)

[I.] Lajos király $(\mathrm{H})$ elrendeli, hogy a Simon fia: Miklós felperes és Nogmorton-i Lőrinc fia: Nykul mr. alperes között Nogkorong és Vrbachanriue birtokok ügyében zajló pert, amelyben márc. 16-án (in oct. diei Cinerum) oklevél-bemutatás lett volna esedékes, máj. 1-jére (ad oct. fe. B. Georgii mart. nunc prox. venturas) halasszák el.

Eml.: A 133. számú oklevélben.

K.: - 
119. (1356. márc. 16.e.)

[I.] Lajos király a Warada-i László fia: János mr. és László fia: István között Pete birtok miatt zajló pert, amelyben márc. 16-án (in oct. diei Cynerum) oklevél-bemutatás lett volna esedékes, Miklós nádor halála miatt máj. 1-jére ([ad] oct. fe. B. Georgii mart.) elhalasztja.

Eml.: A 262. számú oklevélben.

K.: Z. III. 27-28. (15. szám).

120. (1356. márc. 16.e.)

[I.] Lajos király $(\mathrm{H})$ elrendeli, hogy Baldonus Cornutus testvérnek — aki Mo. és Szlavónia Je-i Szt. János Keresztes Testvérei Rendjének perjele - és Donát testvérnek, a fehérvári és Gyanth-i ispotályosok házai preceptor-ának mint felpereseknek, István néhai szlavón bán fiaival: Dénes királyi lovászmr.-rel, Miklóssal, Imrével, Istvánnal és Lászlóval mint alperesekkel szemben Gyanth birtok és más ügyek dolgában viselt perét máj. 1-jére (ad oct. fe. B. Georgii mart. prox. venturis) halasszák el.

Eml.: A 136. számú oklevélben.

K.: -

121. (1356. márc. 16.e.)

A szekszárdi konvent márc. 16-ra ([ad] oct. diei Cynerum) idézi Zeech-i Miklós országbíró elé Darow-i István fia: Miklóst Vztupan-i Peteu fiai: György, Péter és Miklós ellenében.

Eml.: A 137. számú oklevélben.

K.: Str. IV. 138. (111. szám) (Eml.-ben).

122. (1356. márc. 16.e.)

Zeech-i Miklós országbíró márc. 16-ra ([ad] oct. diei Cynerum) rendeli színe elé Waradai László fia: János mr.-t Dorowch-i István fia: János és annak fia: László ellenében.

Eml.: A 134. számú oklevélben.

K.: Zichy. III. 25. (11. szám) (Eml.-ben).

123. (1356. márc. 16.e.)

Zeech-i Miklós országbíró márc. 16-ra ([ad] oct. diei Cynerum) rendeli színe elé Damyani András fia: Herbordus-t Gyurk-i Luueu (dict.) Miklós ellenében.

Eml.: A 135. számú oklevélben.

K.: - 
A győri egyház kápt.-ja jelenti [I.] Lajos királynak (H): megkapták a király által a pannonhalmi Szt. Márton-egyház apátjának Siffridus-nak kiadott, az egyház kezén lévő birtokokkal kapcsolatos idézésre, vizsgálatra, eltiltásra, hj.-ra és határjelek emelésére vonatkozó éves általános megbízólevelét, amelynek kézhezvételét követően Mendzenth-i Pál fia: Mihály — az oklevélben többedmagával megnevezett — királyi ember mellé a szóban forgó apát és egyház Dyenus birtokának hj.-ához és határkitüzéséhez Miklós presbitert (chori nostri presbiterium) adták tanúul, akik visszatérve egybehangzó jelentést tettek. Eszerint márc. 16-án (f. IV. prox. p. domin. Invoc. prox. preterita) a Pozsony m.-i Dyenus birtokra menve valamennyi szomszéd és határos, valamint az apát jelenlétében megjárták annak határait az ôsi határjelek mentén. Hj.: a Duna vizéból kilépve kezdődik, Ke felé völgy, amely Mysser falu balról, ill. Dyenus falu jobbról eső földjét választja el, a völgyben É, majd Ke, végül Dé felé halad, a völgyet elhagyva Ke-nek tart, szántóföldeknél földjel, kőhajításnyira Ke felé újabb földjel a 2 falu között, ahonnan Mysser É-ra, Dyenes Dé-re esik, további földjelek nyíllövésnyi távolságokra, 1 holdnyi hossz u. szántónál vissza a völgyhöz, ároknál régi földjel, amelyet megújítottak, Ke felé Dunaaga folyó a mondott falvak mögött, partján megújított földjel, Ke felé a Mysser faluban épült Szt. Márton-egyházhoz, közelében megújított határjel Ny felől, amely Dé-ról Dyenus birtokot, É felől Mysser falut választja el, Mysser falu közepén futó Posonwth úton tovább, Dé-nek fordulva nagy és régi - most ugyancsak megújított határjel, kőhajításnyira sarkot jelző 3 határjel, egyikük balról, Ke felől Mysser birtokot jelzi, a 2 másik - részben megújított - a jobbról Ny-ról eső Dyenus földet választja el Mysser birtoktól; közúton Dé felé tovább, régi jel Tarch falu balról, Ke felöl eső földjének elválasztására Dyenus falu jobbra levő földjétől; Dé-nek Tarch falu útjának betorkollásáig a Bechke birtokra vivő másik útba, ott régi jel, majd az út mentén további határjelek egészen az újabb szögletet jelző 3 határjelig; ezek egyike jobb oldalról a Ny-ra fekvő Dyenus birtokot, míg a másik 2 balról, Dé felól választja el Bechke és Tarch birtokokat; az úton tovább Dé-nek tartva Bechke falu mellett földjel, a falu mögött másik határjel, 2 út összefutásánál 2 földjel határolja Dyenus falu földjét előbb a Bechke-i nemesek földjétól, majd a szentgyörgyi (de S. Georgio) Péter mr. — Sebus fivére — földjétól; tovább az úton addig, amíg az egy nagy utat el nem ér, ott szemközt 2 útmenti földjel, egyikük balról, Ke felól Sebus fivérének, Péter mr.-nek a birtokát, a másik jobbról Dyenus falu Ny-ról esó birtokát jelzi; az út a Zemmaryawth közútba torkollik, ott határjel; füves úton keresztül Cosmafeulde föld felé, határjel, szöglet (angulus), folyamatos határjel (meta cursualis); Ke felé 2 hold föld hosszan folyamatos határjelzés, Dé-nek fordulva fél holdnyi hosszban, füves útnál Kozmafeulde föld felé határjel, szögletet jelző 3 jel, amelyek egyike Dyenus falunak, másika a nevezett Péter mr.-nek, a harmadik pedig a Zop-i nemeseknek a területét jelzi, völgy közelében Ny-nak fordulva határjel, amely Dyenus birtok és Péter mr. földjeit választja el a Zop-i nemesekétől, Zemmaryawth úton Ny-nak tovább, Syalaza völgy egyik szélénél 5 szögletjelző földjel Dyenus, Kybotur, Zenthmaria és Péter mr. birtokokai találkozásánál, innen le a völgybe, amely fele hosszában akár a réteket, akár más haszonvételeket tekintve Dyenus föld részét, míg Dé-i irányban másik felében Gutur föld részét képezi, a völgy peremén Dé-ról több földjel Kysgutur és Noggutur birtokok elválasztására, Ny felé dombon 4 földjel, amelyek Noggutur, Uduarnok Zemech és Dyenus birtokokat határolják, Chelchut úton É felé tovább, 2 földjel, amelyek egyike Dyenus földet, másika Uduarnok Zemech falu határát jelzik, az úton hosszan továbbhaladva határjel, amely jobbról Dyenus falu földjét, balról Ny felé pedig Zemech falu földjét határolja, Chelkut úton újabb folyamatos határjelzéshez , azt elhagyva É felé szántóföldek, Dyenus földet Zemech földtől elválasztó határjelek, völgy 
közelében határjel, a völgyön át É felé, határjel, Ny-nak tartva a Dunaaga folyó közelében földjel Dyenus és Mysser falvak mögött, át a folyón, ahol egy körtefánál véget ér a határ. Ellentmondás nem történt. D. 4. die diei reambulationis antedicte, a. d. 1356.

Á.: 1. I. Lajos király, 1359. okt. 30. BFL. Pannonhalma, Konventi lt. Acta antiquiora 11. 2. (Df. 208 295.) 18. sz.-i egyszerú Má-ban.

2. Mária királynő, 1384. márc. 12. Uo., Capsarium 41 Q (641). (Df. 207 446.).

Tá.: 1. I. Lajos király, 1359. okt. 30. > Mária királynő, 1384. márc. 12. > Garai Miklós nádor, 1420. jún. 19. Dl. 483. (NRA. 693. 23.).

2. Tá. 1. Dl. 484. (NRA. 693. 23.) 1771. okt. 14. hiteles Má.-ban.

3. I. Lajos király, 1359. okt. 30. > Mária királynő, 1384. márc. 12. > Győri kápt. 1392. okt. 20. > Ilsvai Lesták nádor, 1394. jún. 5. Uo., mint Á. 2., 42 C 3 (671) (Df. 207 484.) Csak évre keltezve.

Má.: Tá. 1-gyel megegyező jelzet alatt, arról készült egyszerü Má-ban.

K.: F. X. 6. 320-324. (118. szám) (Tá. 1. és Tá. 2. alapján); P. II. 420-423. (149. szám) (Á. 2. alapján).

Megj.: Garai Miklós nádor tartalmi átírást adó 1420. évi oklevelét 1. ZsO. 1857. szám alatt.

125. 1356. márc. 20.

Az egri egyház kápt.-ja e. a rokonai, János fiai: István és Mihály, valamint tulajdon fia, Fülöp nevében is megjelenő Bold-i Tamás fia: Gál tiltakozott amiatt, hogy Beregh, Borsod és Veszprém m.-i birtokrészeiket Bold, Fenefew, Bannya és Sasuar birtokokon Bold-i Almus fia: János elidegenítette tôlük, egy részüket már eladta, másokat elzálogosított, a többit pedig most készül eladni, amivel komoly kárt okozott a panaszosoknak. Mivel eddig nem vonták kezükhöz a felsorolt részbirtokokat, János hozzájuk juthatott, ezért megtiltják neki, hogy azokat bármi módon elidegenítse, másokat pedig tiltanak attól, hogy bármi módon megszerezzék e javakat. D. in domin. Remin., a. d. supradicto. [1356.]

E.: Dl. 89 326.(Radvánszky cs. sajókazai lt. 43. 8.) Hártyán, hátoldalon azonos és késóbbi kéz írásával tárgymegjelölések (utóbbi magyar nyelven), valamint kerek zárópecsét töredéke, bevágásai.

Tá.: Szécsi Miklós országbíró, 1383. okt. 21. Dl. 50 278. (Ernst gyújtemény, Radvánszky cs. sajókazai lt.).

K.: -

126. 1356. márc. 20.

Péter prépost és a Lelez-i Szt. Kereszt-monostor konventje jelentik [I.] Lajos királynak (H): Zeech-i Miklós országbíró hozzájuk intézett jan. 30-i levelének ( $l$. 64. szám) értelmében Benedek fia: Lukács (Lucasius) királyi ember mellé tanúul adták egyházuk familiaris-át, János c.-t idézés végett, akik visszatérve jelentették, hogy febr. 24-én (f. IV videlicet in vig. fe. B. Mathie ap. prox.) Deseu fiait: Lorándot és Jánost, valamint Miklós 
fia: Jánost Lapuspathak faluban lévő részbirtokukon a királyi jelenlét bírósága elé idézték Tamás fia: János ellenében márc. 16-ra (oct. diei Cinerum). D. in domin. Remin., a. d. supradicto. [1356.]

E.: Dl. 77 159. (Zichy cs. zsélyi 36. 6.) Papíron, hátoldalán azonos kéz írásával tárgymegjelölés, valamint a leleszi konvent kerek zárópecsétjének töredéke, bevágásai; a pecséttel lezárt hátoldali részen keresztirányban korabeli jegyzet.

K.: Z. III. 23-24. (10. szám).

127. 1356. márc. 21.

[I.] Lajos király (H, Da, C, Ra, Se, G, L, Co, Bu, princ. Sal., mont. S. Angeli dom.) anyjának, Erzsébet királynénak $(\mathrm{H})$ adományozza az Esztergom m.-i Monyoros birtokot minden haszonvételével, tartozékával és jogával együtt ôsi határai mentén, megengedi továbbá, hogy a királyné bárkinek — egyházaknak v. bármely jogállású embernek — szabadon eladományozhassa azt. Ennek bizonyságára autentikus kettős pecsétjével megerősített kiváltságlevelet ad ki. Kelt Miklós zágrábi püspök, udvari alkancellár keze által, a. d. 1356., XII. Kal. Apr., uralkodásának 15. évében. Méltóságnévsor: Miklós lévén az esztergomi érsek - a kalocsai érseki szék üresedésben —, Miklós az egri, Kálmán a győri, Miklós a pécsi, Demeter a váradi — a boszniai szék üresedésben —, Tamás a csanádi, Mihály a váci, János a veszprémi, Tamás testvér a szerémi, István testvér a nyitrai püspök; Miklós lévén az erdélyi vajda - a nádori tiszt üresedésben —, Miklós az országbíró, Cyko a tárnokmr., Miklós a Machow-i bán, Dénes a lovász-, Leukus az asztalnok- és pohárnokmr., valamint Simon a pozsonyi c.

E.: Dl. 4599. (MKA. Acta eccl. ord. et mon. Vet. Buda 1. 5.) Hátoldalán azonos és késóbbi kéz írásával is tárgymegjelölés. Bordó és bordó-kék színú zsinegeken két felfüggesztett pecsét (mindkettő textil tokban), az oklevél alján I. Lajos király 1364. dec. 28-án kelt megerősítő záradéka olvasható.

K.: AO. VI. 438-439. (279. szám) (kihagyásokkal).

128. 1356. márc. 22.

[I.] Lajos király (H, Da, C, Ra, Se, G, L, Cu, Bu, Sal., mont. S. Angeli dom.) a színe e. a zágrábi egyház kápt.-ját is képviselő András mr. dubnici (dubicensis) főesp. kérésére és oklevél-bemutatása alapján, ill. Erzsébet anyakirályné egyetértésével, továbbá a főpapok és bárók tanácsára privilégiumában átírja, s autentikus kettős pecsétjének ráfüggesztésével megerősíti [I.] Károly király $(\mathrm{H})$ - utolsó és harmadik pecsétjével megpecsételt - 1340. jún. 13-án kelt nyílt oklevelét (l. Anjou-oklt. XXIV. 381. szám), amelyben az átírta Tamás erdélyi vajda, királyi tárnokmr.-helyettes 1339. máj. 11-én kiállított oklevelét (l. Anjou-oklt. XXIII. 271. szám), benne Gréc város (civitas Grechensis) esküdtjeinek és bírájának (l. Anjou-oklt. XXIII. 213. szám), nemkülönben a zágrábi kápt.-nak (l. Anjou-oklt. XXIII. 212. szám) 1339. ápr. 28-án kelt okleveleit arról az egyezségról, amely a zágrábi egyház kápt.-ja és a gréci polgárok között jött létre. Kelt Miklós zágrábi püspök és udvari alkancellár keze által, a. d. 1356. XI. Kal. mensis Apr., uralkodásának 15. évében. Méltóságnévsor: Miklós lévén az esztergomi érsek, egyben ua. m. örökös c.-e — a kalocsai érseki szék üresedésben —, Domokos a spalatói érsek, Miklós az egri, Demeter a váradi, András az erdélyi, Miklós a pécsi, Kálmán a győri, János a veszprémi, Mihály a váci, Tamás a csanádi, Tamás testvér a szerémi, István testvér a nyitrai - a 
boszniai szék üresedésben -, Balázs testvér a knini püspök; Miklós az erdélyi vajda és a Zonuk-i c. - a nádori tiszt üresedésben - Zech-i Miklós az országbíró, Cyko a tárnokmr., Miklós a Machou-i bán, egyben egész Szlavónia és Ho. bánja is, Leukus az asztalnok- és a pohárnok-, Dénes a lovász-, Péter fia: Tamás az ajtónállómr., Móric fia: Simon a pozsonyi c. A.

E.: HDA. Archivum capituli Zagrabiensis: Acta antiqua 10.67. (Df. 256347.) I. Lajos király 1364. okt. 25-i keltezésú megerősítő záradékával. Hártyán, hátoldalán azonos, valamint késóbbi kezek írásaival tárgymegjelölések, továbbá függőpecsét zsinege.

K.: -

129. (1356. márc. 23. e.)

Zech-i Miklós országbíró privilégiumba foglalja az Ozlyan-i Miklós fiai: Péter, István, János és Tamás között létrejött egyezséget.

Eml.: A 132. számú oklevélben.

K.: -

\section{1356. márc. 23. Visegrád}

László, a csázmai egyház prépostja, [I.] Lajos király (H) kápolnaispánja és titkos kancellárja e. egyik részről Kekkw-i Byther fia Péter fia: György és a Byther fia Péter fia: Miklós képviseletét a váci kápt. ügyvédvalló levelével ellátó Dorborchan-i Miklós fia: Péter, míg a másik részról a Dobzegh fia Mihály fia: János nevében is eljáró Dobzegh fia: Lőrinc megjelenvén, kinyilvánítják, hogy György és Miklós Thwruch m.-i Kasschaan nevú birtokát, amelyet felmenőik Bodon fia: Dobzegh-nek adományoztak szolgálataiért, utóbb viszont a király Lórinctól és Mihálytól elvett, György és Miklós szolgálataikra tekintettel visszakérték és vissza is kapták Lőrinc és János, valamint leszármazottaik számára. Utóbbiak sorába azonban sem atyafiságuk más tagjai, sem vérrokonok, sem családjuk másik ága, sem további közeli rokonaik nem számítanak bele. Ha Lőrincnek és Jánosnak nem maradnának törvényes leszármazottjaik, akkor a mondott birtok minden vita nélkül Györgyre és Miklósra, továbbá utódaikra szálljon vissza. Ennek bizonyságára a prépost oklevelet ad ki, amelyet a királyi kápolnaispáni tisztje miatt használt pecsétjével erôsít meg. D. in Wyssegrad, f. IV. an. domin. Oculi, a. d. 1356.

Á.: Ország Mihály nádor, 1464. jún. 27. Buda. Dl. 45 108. (Múz. Ta. Vachot) E.-je királyi pecséttel megerősített nyílt oklevél volt.

K.: -

\section{1356. márc. 23. Visegrád}

Zeech-i Miklós c., [I.] Lajos király (H) országbírája, Turuch m. c.-e emlékezetül adja: 1354. jan. 8-án (in oct. diei Strennarum, in a. d. 1354) a Tamás c. egykori országbíró oklevelében foglaltaknak megfelelően Huzyubach-i Huzywbach-i János fiai: Miklós és János, továbbá Zenthmyhal-i Mihály fia: János birtokosztály és oklevél-bemutatás végett személyesen megjelentek Budán a néhai Pál bán fiai: János veszprémi püspök és 
Pál mr., valamint ugyanezen Pál mr. fia István fia: Pál, Bothus (dict.) János fia: András, Bothus (dict.) János fia Demeter fia: János, továbbá Gara-i András fiai: Miklós és Pál ellen zajló perükben, azonban az alperesek közül János veszprémi püspök nem jelent meg és nem is küldött senkit maga helyett, míg fivérét Pált, valamint István mr. fia: Pált is a királyi kápolnaispán ügyvédvalló levelét felmutató Mihály mr. deák képviselte, Demeter fia: János helyett a Kw-i egyház kápt.-jának ügyvédvalló levelében meghatalmazott, s a maga nevében is eljáró Bothus (dict.) János fia: András jelent meg, Gara-i András fiainak: Miklósnak és Pálnak a képviseletét pedig az esztergomi egyház kápt.jának ügyvédvalló levelével fellépő Besenew (dict.) Imre látta el, ám mert ezek arra hivatkoztak, hogy a távolmaradó János püspök nélkül nem tudnak választ adni a birtokosztály ügyében, egy másik időpontban azonban vele együtt készek a válaszadásra, Tamás c. elrendelte, hogy [1354.] márc. 19-én (in die medii Quadr. tunc venturo, scilicet f. IV.) a felek személyesen v. képviselőik révén jelenjenek meg bírói színe e. válaszadás végett, kikötve, hogy a per tárgyalásának további elhalasztását a színe e. akkor megjelenők a távolmaradók személyes jelenlétének elmaradására hivatkozva se kezdeményezhessék, hanem immár az ország jogszokása szerint megfelelő véghatározattal záruljon le a per. Késóbb Tamás c. királyi parancslevél alapján a kitüzött időpontról a Rascia ellen induló királyi had feloszlásának tizenötödére, azaz 1355. jan. 20-ra (ad quind. fe. Epiph. d.) halasztotta a pert, amely időpont elérkeztekor Tamás c. halála miatt a király által az országbírói tisztségre emelt Druget Miklós c. megbékélés céljából az akkori állapot fenntartásával [1355.] máj. 31-re (ad oct. fe. Penth.) napolta el azt, amely napról királyi oklevélben foglaltak alapján [1355.] okt. 6-ra (ad oct. fe. B. Michaelis arch. tunc prox. affuturas) halasztották az ügyet, azonban Miklós c. halála miatt a király által újonnan kinevezett országbíró oklevelében [1356.] márc. 16-ra (ad oct. diei Cinerum prox. tunc venturas) tűzte ki a per tárgyalásának idejét. A kitűzött napon Huzyubach-i János fiai: Miklós és János, továbbá Zenthmyhal-i Mihály fia: János személyesen jelent meg az országbíró e. a mondott birtokosztály és oklevél-bemutatás ügyében a fent felsorolt felekkel szemben, akik közül János püspök képviseletét az ügyvédvalló levelében meghatalmazott István mr. deák látta el, Pál fia: Pál mr. és István fia: Pál helyett a királyi kápolnaispán és a boszniai egyház kápt.-jának ügyvédvalló levelét felmutató Mihály mr. deák és Kendrus-i Pál jelentek meg, András fiait: Miklóst és Pált a boszniai kápt. ügyvédvalló levelének meghatalmazásával Besenew (dict.) Péter fia: Imre képviselte, míg János fia: András és Demeter fia: János nevében István fia: Pál járult a bíróság elé, akik mindenféle nyilvánvaló ok megjelölése nélkül arra hivatkozva, hogy uraik távollétében nem tudnak az ügyben választ adni, kérték a per későbbi időpontra halasztását. Ezért az országbíró úgy határoz, hogy a felsorolt alperesek v. azok törvényes képviselói [1356.] máj. 8-án (in quind. fe. B. Georgii mart. prox. venturis) kötelesek színe e. megjelenve választ adni a szóban forgó ügyben, azonban a per kezdete e. $3 \mathrm{M}$. bírságot kell fizetniük a bírónak és a peres félnek. D. in Vysegrad, 8. die termini prenotati, a. d. 1356.

E.: Dl. 4600. (NRA. 1509. 33.). Papíron, hátoldalán azonos kéz írásával tárgymegjelölés, valamint zárópecsét nyoma, bevágásai.

K.: AO. VI. 439-442. (280. szám) (kihagyásokkal).

R.: Wertner M., Hadtört. Közl. 19 (1918) 207. (7. szám).

\section{1356. márc. 23. Visegrád}

Zech-i Miklós c., [I.] Lajos király (H) országbírája, Turuch m. c.-e felszólítja a garamszentbenedeki (S. Benedictus de iuxta Gron) egyház konventjét, hogy az Ozlyan-i Mik- 
lós fiai: Péter, István, János és Tamás által megerősített egyezség értelmében — amelyet részletesebben magába foglal az országbíró erról kiállított privilégiuma (l. 129. szám) állítson tanút Peel-i János fia: Miklós v. Setethkuth-i János v. Gevrud-i Móric fia: Miklós királyi emberek valamelyike mellé Kalachna birtok iktatásához Jakab fia: Miklós mr. Malkauicha-i várnagy részére. A kiküldötteknek az összehívott szomszédokkal és határosokkal együtt ki kell menniük a birtokra, s bejárni annak határait az ôsi határjelek mentén, ahol pedig szükséges, ott új jeleket emelni a régiek mellé, majd miután elválasztották azt a többi birtoktól, be kell iktatniuk tulajdonába Miklós mr.-t, végül pedig a hj. és az iktatás lefolyásáról jelentéstétellel tartoznak a királynak. D. in Vissegrad, f. IV. prox. an. domin. Oculi, a. d. 1356.

Á.: A 190. számú oklevélben.

K.: Bars, 43-44. (41. szám).

\section{1356. márc. 23. Visegrád}

Zeech-i Miklós c., [I.] Lajos király $(\mathrm{H})$ országbírája, Turuch m. c.-e a korábbi oklevele ( $l$. 33. szám) alapján színe e. márc. 16-án (in oct. diei Cinerum) esedékes oklevél-bemutatást, amelyre egyik részrôl Simon fia: Miklós felperest, a másik részrôl pedig Nogmorton-i Lőrinc fia: Nykul mr. alperest kötelezte Nogkorong és Vrbachanriue birtokok ügyében, a bemutatott királyi parancslevél ( $l$. 118. szám) értelmében annak az $1 \mathrm{M}$. bírságnak a megfizetési kötelezettségével együtt, amely perkezdet e. jár a felperesnek, a fennálló állapot fenntartása mellett máj. 1-jére (ad oct. fe. B. Georgii mart. nunc prox. venturas) elhalasztja. D. in Vyssegrad, 8. die termini prenotati, a. d. 1356.

E.: Dl. 39 222. (Regnicolaris lt. Archivum regni, különböző állagok RR Y 31) Papíron, hátoldalán azonos kéz írásával tárgymegjelölés, valamint zárópecsét nyoma, szalagja, bevágásai; a pecséttel lezárt hátoldali részen keresztirányban korabeli és késóbbi kézzel jegyzet.

K.: -

Eml.: A 271. számú oklevélben.

\section{1356. márc. 23. Visegrád}

Zeech-i Miklós c., [I.] Lajos király (H) országbírája, Turuch m. c.-e a Warada-i László fia: János mr.-nek Dorowch-i István fia: Jánossal és annak fia: Lászlóval szemben indított ama perét, amely az országbíró korábbi oklevele (l. 122. szám) értelmében márc. 16-án (in oct. diei. Cynerum) lett volna esedékes, és amelyben elóbbinek a képviseletét a Lelez-i konvent ügyvédvalló levelében maghatalmazott Dénes fia: Miklós látta el, István fia: János helyett pedig a Lelez-i konvent ügyvédvalló levelét felmutató, s a maga nevében is eljáró László jelentek meg, mivel a János mr. képviselője által hatalmaskodás miatt emelt panaszra László a maga és apja nevében - a vád súlyosságára tekintettel - atyjafiai és rokonai tanácsa nélkül nem tudott választ adni, ezért jún. 19-re (ad oct. fe. Pent.) elhalasztja. D. in Vysegrad, 8. die termini prenotati, a. d. 1356.

E.: Dl. 77 160. (Zichy cs. zsélyi lt. 1. B 280.) Papíron, hátoldalán azonos kéz írásával tárgymegjelölés, valamint kerek zárópecsét nyoma, bevágásai.

Eml.: A 361. számú oklevélben. 
K.: Z. III. 24-25. (11. szám).

\section{1356. márc. 23. Visegrád}

Zeech-i Miklós c., [I.] Lajos király (H) országbírája, Turuch m. c.-e színe e. Damyani András fia: Herbordus az ô korábbi országbírói oklevelében (l. 123. szám) kitúzött márc. 16-án (in oct. diei Cynerum) megjelenvén olyan panaszt adott elő Gyurk-i Luueu $\sim$ Lweu (dict.) Miklós ellenében, miszerint annak veje (gener), Peteu — aki Miklósnál töltötte napjait - [1355.] nov. 8-án (die domin. prox. p. fe. OO. SS) fényes nappal elkötötte az ő $50 \mathrm{ft}$.-ot érő 2 lovát, majd Miklósnak a házához vezette és udvarában tartotta, ahogy azt több nemes és nem nemes szemtanú is látta. Ezt hallva a megvádolt Miklós azt felelte, hogy ebből annyi igaz, miszerint veje, Peteu tényleg nála lakott és lakik, de a többiben ártatlannak vallotta magát. Ezért az országbíró Miklóst - ártatlanságát igazolandó - a nyitrai egyház kápt.-ja e. máj. 1-jén (in oct. fe. B. Georgii mart. nunc venturis) hetedmagával, nemesekkel együtt leteendő esküre kötelezi, míg az erról számot adó írásos kápt.-i jelentéssel a felek máj. 8-án (oct. diei) kötelesek ismét színe elé járulni. D. in Vysegrad, 8. die termini prenotati, a. d. 1356.

E.: - Fk. Dl. 95 568. (Binnyey vétel 30). Papíron, hátlapjáról nem készült Fk., előlapján 2 zárópecsét lenyomata, szalagjai, bevágásai láthatóak.

K.: -

Eml.: A 243. és a 295. számú oklevélben.

\section{1356. márc. 23. Visegrád}

Zeech-i Miklós c., [I.] Lajos király (H) országbírája, Turuch m. c.-e a Baldonus Cornutus testvérnek - aki Mo. és Szlavónia Je-i Szt. János Keresztes Testvérei Rendjének perjele — és Donát testvérnek, a fehérvári és Gyanth-i ispotályosok házai preceptor-ának mint felpereseknek, István néhai szlavón bán fiaival: Dénes királyi lovászmr.-rel, Miklóssal, Imrével, Istvánnal és Lászlóval mint alperesekkel szemben viselt ama perét, amely korábbi ítéletlevele és a fehérvár-i egyház kápt.-jának idézőlevele (l. 60. szám) értelmében márc. 16-án (in oct. diei Cynerum) lett volna esedékes Gyanth birtok és más ügyek dolgában, királyi parancs (l. 120. szám) miatt máj. 1-jére (ad oct. fe. B. Georgii mart. prox. venturis) elhalasztja a fennálló állapot fenntartásával. D. in Vyssegrad, 8. die termini prenotati, a. d. 1356.

E.: Dl. 106 129. (Székesfehérvári keresztesek konventje 31 13). Papíron, hátoldalán azonos kéz írásával tárgymegjelölés, valamint kerek záró pecsét nyoma, bevágásai; a pecséttel lezárt hátoldali részen keresztirányban korabeli jegyzet.

K.: -

R.: F. IX. 2. 566. (271. szám) (latinul).

\section{1356. márc. 23. Visegrád}

Zeech-i Miklós c., [I.] Lajos király $(\mathrm{H})$ országbírája, Turuch m. c.-e a Darow-i István fia: Miklósnak Vztupan-i Peteu fiaival: Györggyel, Péterrel és Miklóssal szemben indított ama perét, amelyben elóbbit famulus-a, Cheutev képviselt előtte a szekszárdi 
konvent ügyvédvalló levelének meghatalmazásával, utóbbiak helyett pedig peridőpont elfogadására meghatalmazott képviselőik (assumptores termini) jelentek meg színe e., és amely per a szekszárdi konvent idéző levele (l. 121. szám) értelmében márc. 16-án (in oct. diei cynerum) lett volna esedékes, más peridőpont elsóbbsége miatt máj. 8-ra (ad quind. fe. B. Georgii mart.) elhalasztja. D. in Wyssegrad, 8. die termini prenotati, a. d. 1356.

E.: KML. Esztergomi székesfőkápt. hh.-i lt.-a 8. 5. 11. (Df. 208 596.). Papír, hátoldalán azonos kéz írásával tárgymegjelölés, valamint kerek zárópecsét nyoma, bevágásai; a pecséttel lezárt hátoldali részen keresztirányban korabeli jegyzet.

K.: Str. IV. 138. (111. szám).

\section{1356. márc. 24. Buda}

[I.] Lajos király (H) a szepesi egyház kápt.-jának: mivel az egyházaknak a perei a hosszas idézések következtében sokakat bizonytalanságban tartanak, ezért megparancsolja a címzett kápt.-nak, hogy amennyiben e levele keltétól számított 1 éven belül a Jazov-i egyház prépostja, Miklós testvér, nemkülönben konventje v. nevükben meghatalmazottjaik és tiszttartóik (procuratores vel officialis eorundem) hozzájuk fordulnak idézések, vizsgálatok, tiltakozások, birtokaikkal kapcsolatos efféle eljárások, valamint hj.-ok, határkitúzések és határmegújítások, nemkülönben pedig egyéb, az ország szokásai szerinti jogeljárások lefolytatása érdekében, minden esetben és valahányszor adjanak hites tanút Zedloch-i Vörös (Rufus) László v. Peder-i György v. Nesd-i Tamás fia: János királyi emberek valamelyike mellé, majd az így sorra kerülő eljárások mindegyikéról kötelesek írásos jelentésben számot adni neki. D. Bude, f. V. prox. p. domin. Remin., a. d. 1356.

Á.: A 452. számú oklevélben.

K.: -

139. 1356. márc. 24.

Zarka (dict.) Miklós szatmári alispán és a m. szb.-ái e. István fia: István mr. elpanaszolta, hogy Kántor (Cantores dict.) Bereck és Loránd márc. 8-án (III. f. prox. an. diem Cynerum) rátörtek az ő Radalh birtokára, s ott jobbágyát, Domonkos fia: Jánost megverték és ruháitól megfosztották. A panasztevő kérte ügye kivizsgálását, amely kérésnek eleget téve Vaya-i János fia: Antalt küldték ki a vizsgálat lefolytatására, aki onnan visszatérve elmondta, hogy kikérdezvén az értesüléssel rendelkezőket igaznak találta István mr. panaszát. D. V. f. prox. p. domin. Remin., a. d. 1356.

E.: Dl. 51 700. (Kállay cs. lt. 1300. 1114.) Papíron, hátoldalán azonos kéz írásával tárgymegjelölés, valamint 2 kerek zárópecsét töredéke, bevágásai.

K.: AO. VI. 443-444. (281. szám) (kihagyásokkal).

R.: Kállay II. 34. (1177. szám); Doc. Rom. Hist. C. XI. 11-12. (7. szám) (románul); Piti-C. Tóth-Neumann, Szatmár 78. (138. szám). 
[I.] Lajos király nagyobb pecsétjével megerősített oklevelében utasítja a vasvári kápt.-t, hogy állítson hites tanút Deuecher-i Miklós fia: Márton v. János fia: Péter, a királyi udvar ajtónállói, mint külön erre a feladatra kiküldött királyi emberek valamelyike mellé,a Sopron m.-i Heuhlyngh és Arlamus birtokok Agyagus-i András fia: Péter számára történő iktatatása végett, akik kimenvén a nevezett birtokokra, s ott az összehívott határosok és szomszédok jelenlétében járják be a birtokhatárokat, és ahol szükséges, emeljenek új határjeleket, majd miután ez ellentmondás nélkül megtörtént, Pétert iktassák be Heuhlyngh birtok háromnegyed részének, valamint Arlamus birtok egészének a tulajdonába, beleértve utóbbinak valamennyi haszonvételét és tartozékát is. Heuhlyngh birtoknak a háromnegyede ezáltal ahhoz a fennmaradó negyedhez fog kapcsolódni, amelyet most András fia: Péter tart kezében.

Eml.: A 158. és a 303. számú oklevélben.

K.: F. IX. 2. 528-529. (258. szám); Sopron vm. I. 251-259. (193.szám) (Eml.-ben).

141. 1356. márc. 25.

A bácsi kápt. a színe e. megjelenő Wolkou m.-i Phile fia Lőrinc fia: Lőrinc mr. és ue. Phile fia Péter fia: István mr. kérésére és oklevél-bemutatása alapján átírja és függőpecsétjével megerôsíti [IV.] Béla király (H) 1244. okt. 31-én kelt, aranypecséttel ellátott privilégiumát, amely átírásban magába foglalja Kálmán halicsi király és szlavón herceg 1237-ben kiadott és a pécsi kápt. 1240. október havában kelt [- Heyreh és Luder földekkel kapcsolatos - ] okleveleit. D. in fe. Ann. B. virg. a. d. 1356. László lévén a prépost, Albert az olvasó-, László az éneklő-, Péter az ôrkanonok, Miklós a bácsi, János a somogyi, Tamás a szegedi főesp., Móric a dékán.

E.: Dl. 222. (NRA. 575. 21.) Hártyán, hátoldalán azonos kéz írásával tárgymegjelölés, alján piros-zöld sodraton függőpecsét.

K.: Smič. XII. 363. (273. szám) E.-ról, tévesen 1356. aug. 15-re keltezve(D. in fe. Assumptionis B. virg., a. d. 1356.).

Megj.: Az átírt oklevelek [ ] között megadott tárgyát a bácsi kápt. által fogalmazott átíró oklevél keretszövege nem tartalmazza közvetlenül. IV. Béla átírt oklevelét 1. Reg. Arp. 787. szám, Kálmán halicsi királyét 1. Reg. Arp. duc. regin. 14. szám.

142. 1356. márc. 25.

A somogyi (de Symigio) Szt. Egyed-monostor konventje e. Tenguld-i László fia Theodorus lánya, Kelyanus fia: András mr. felesége, Klára nemes asszony kijelenti, hogy a Zob birtokon levő birtokrészének a víz felé eső Dé-i felét minden haszonvételével és tartozékával együtt 50 budai márkáért elzálogosította rokonának, Arad-i Tamás fia: Tamás mr.-nek oly módon, hogy azt ugyanazért az összegért bármikor szabadon visszavásárolhassa. Az ügy bizonyságára a konvent függőpecsétjével megerősített privilégiumot bocsát ki. D. in fe. Ann. B. virg., a. d. 1356.

E.: HML. 644. Egri székesfőkápt. mlt. 17. 4. 1. 11. (Df. 236 487.) K. alapján hártyán, alján zöld és lila sodratú selyemzsinóron a somogyi konvent pecsétje, hátoldalán kö- 
zépkori kivonat: Super <colla>tione in Zob pro pignore, valamint újkori latin nyelvű kivonat és levéltári jelzetek.

K.: Str. IV. 138-139. (112. szám).

R.: Borsa, Somogy m. lt. Évk. 9 (1978.) 71. (33. szám); uô., uo. 29 (1998.) 252. szám.

143. 1356. márc. 27.

A Scepus-i Szt. Márton-egyház kápt.-ja e. egyik részről Baior-i Péter fia: Beke mr. és hitvese, Bodomer-i Egyed lánya, nemes Anych asszony, hasonlóképpen Beke mr. fiai: János, Synka, György és Mihály a maguk, továbbá Beke mr. másik két fia: Imre és Pál nevében is, a másik részről pedig az említett Bodomer-i Egyed fia: Miklós mr. megjelenvén, elóbbiek kinyilvánítják, hogy a Sarus m.-ben fekvő Kysbodomer öröklött birtokukat, amelyet a szepesi kápt. oklevelében, ill. az egri egyház kápt.-jának privilégiumában foglaltak alapján Egyed fia: Miklós és fivére János adományozott Beke mr.-nek, hitvesének, Anych asszonynak és örököseinek minden haszonvételével, jogával, tulajdonával és tartozékával együtt, most örök jogon eladják a szóban forgó Egyed fia: Miklós mr.nek és örököseinek az általa megfizetett 135 szepesi garas M. (M. grossorum denariorum numeri Scepusiensis) ellenében. A birtokkal kapcsolatban eddig kibocsátott okleveleket — különösen a birtok adományozásáról szóló, már említett 2 kápt.-i okiratot —, ill. amelyek véletlenül náluk maradnának hatálytalanoknak nyilvánítják. Amennyiben az eladók v. utódaik közül bárki megtámadná Miklóst v. örököseit a birtoklásban, fej és jószágvesztéssel bűnhődjék. Az ügylet megerősítésére a kápt. függőpecsétjével ellátott privilégiumot bocsát ki. D. in domin. Oculi, a. d. 1356. A.

E.: 1. Dl. 41 280. (Múz. Ta. 1894. 19.) Hártyán, alul az ABC betûivel chirographálás, hátoldalán azonos és későbbi kéz írásával tárgymegjelölés, valamint zárópecsét nyoma.

2. D1. 60 980. (Rhédey cs. 1t. 27.) Hártyán, felül az ABC betûivel chirographálás, alján zöld zsineg, hátoldalán ad huc quatuor grossorum tenentur, valamint késóbbi kéz írásával, magyar nyelven tárgymegjelölés.

Má.: Uo., mint E. 1., azzal megegyező jelzet alatt, 20. sz.-i egyszerú Má.-ban Bohdaneczky Imre aláírással.

K.: AO. VI. 444 - 445. (282. szám) (kihagyásokkal) E. 2. alapján.

\section{1356. márc. 28. Lipcse}

[I.] Lajos király $(\mathrm{H})$ utasítja a pozsonyi kápt.-t: állítsanak hites tanút Budafalua-i Pál fia: János v. Budafalua-i Miklós fia: Demeter királyi emberek valamelyike mellé, hogy az színe elé idézze alkalmas időre Mártont, a dömösi egyház prépostját Budafalua-i Vermes fiai: Mátyás deák és Miklós ellenében, majd pedig eljárásukról az idézés helyének, idejének és az idézettek neveinek, nemkülönben a kitűzött időpontnak a feltüntetésével küldjön részére írásban jelentést. D. in Lupche, II. f. prox. p. domin. Oculi, a. d. 1356.

E.: EPL. Pozsonyi kápt. országos 1t. 28. 1. 28. (Df. 261 304.) Hártyán, hátoldalán tárgymegjelölés, valamint zárópecsét szalagja, bevágásai; a pecséttel lezárt hátoldali részen keresztirányban korabeli jegyzet.

K.: Str. IV. 145. (114.szám). 
145. 1356. márc. 28.

A budai egyház kápt.-ja e. a Nyulak szigeti (de Insula Leporum) Boldogságos Szúzkolostor apácáit - azoknak ügyvédvaló levelében meghatalmazottként — képviselő Balázs testvér kinyilvánítja, hogy az apácák Esztergom m.-i Sumudur, más néven Symeg birtokát, amely Sambuk és Epel birtokok mellett fekszik, minden tartozékával és haszonvételével - ti. berkeivel, vizeivel, kaszálóival, rétjeivel és egyebekkel - együtt odaadja a másik részről jelen lévő Nyek-i (dict.) Mihálynak megőrzésre, használatra és benépesítésre az oklevél kiállításától számított 20 évre szavatosság vállalása mellett azzal a feltétellel, hogy nevezett Mihály v. örökösei az apácáknak évenként 1 budai M.-t kötelesek fizetni szept. 29-én (in fe. S. Michaelis arch.), majd a megszabott idő leteltével azt benépesítve és sértetlenül kell visszaadniuk, ezenfelül a bornak v. a gabonának és bármely más haszonnak a tizedét, valamint a birtok benépesítése $\mathrm{u}$. a kamara hasznát is megadni tartoznak az apácák procurator-ának. Kötelezettségvállalásában Mihály elfogadta, hogy amennyiben a fenti feltételeknek nem tenne eleget, azzal a birtokból való kizárás büntetését vonja magára. D. f. II. prox. p.domin. Oculi, a. d. 1356.

E.: Dl. 4601. (Acta eccl. ord. et mon. Vet. Buda 32. 11.) Hártyán, hátlapján mandorla alakú pecsét nyoma, szalagja, bevágásai.

K.: AO. VI. 445-446. (283. szám) (kihagyásokkal).

\section{1356. márc. 28. Gömör}

Balog-i Péter fia: Miklós mr. - Konya mr.-nek a Gömör m.-i alispánja - a Puthnuk-i Miklós fia: László mr. által jobbágyáért, Simonért megfizetni vállalt békebírságot Radnoldus mr. és jobbágya, Tamás ellenében elóbbiek kérésére - a bírság bírói részét illetően - elengedi. D. in villa Gumur, f. II. prox. p. domin. Occuli, a. d. 1356.

E.: Dl. 89 327. (Radvánszky cs. sajókazai lt. 4. 8.) Papíron, hátoldalán azonos kéz írásával tárgymegjelölés, valamint az alispán, töredezett szélú kerek zárópecsét (rajta pajzson kétfejú sas kiterjesztett szárnyakkal), bevágásai.

K.: -

147. 1356. márc. 29.

Tamás mr. Zemlyn-i alispán és a m. 4 szb.-ája jelenti [I.] Lajos királynak (H), hogy 1356. jan. 20-án kelt, itt átírt parancslevele értelmében (l. 55. szám) a Jako [ Jakow] fia: Lászlónak és András fia: Istvánnak [Vetes-i] Péter fiaival: Pállal és Miklóssal szemben támadt peres ügyét — egyet kiküldve maguk közül — kivizsgálták. Leztemer-i Albert fia: Peta márc. 15-én és 16-án (f. III. prox. p. dom. Invoc. prox. nunc preterita; et f. IV. nunc prox. subsequente) kimenvén Szatmár m.-be, vizsgálata során az értesüléssel rendelkezók körében azt derítette ki, hogy a megvádolt felek ártatlanok az ökrök ellopásának és más károk okozásának ellenük felhozott vádjában. D. f. III. prox. p. fe. domin. Oculi, a. supradicto [1356].

E.: D1. 85 310. (Sztáray cs. lt. 96.) Papíron, hátoldalán azonos kéz írásával tárgymegjelölés, valamint négy zárópecsét töredéke, szalagjai, bevágásai.

K.: Sztáray I. 248-249. (142. szám); Doc. Rom. Hist. C. XI. 12-13. (8. szám) (román fordításban is) Mindkettő E. alapján. 
Megj.: A [ ]-ben közölt információk a hátoldalról származnak.

148. (1356. márc. 30.e.)

Zech-i Miklós országbíró ítéletlevelében márc. 30-án (in die medi Quadr.) esedékes oklevél-bemutatásra kötelezi egymás ellenében egyik részről Mykola-i Péter fia: András felperest Mykola birtok ügyében, a másik részról Zondou-i Bereck alperest Zondou birtok ügyében.

Eml.: A 171. számú oklevélben.

K.: -

149. (1356. márc. 30.e.)

Zech-i Miklós országbíró márc. 30-ra ([ad] die medii Quadrag.) idézi színe e. Lőrinc fia: Lászlót, vele szemben pedig Nogmihal-i András fia: Mihályt a köztök fennforgó perben.

Eml.: A 172. számú oklevélben.

K.: Sztáray I. 249. (143. szám) (Eml.-ben).

150. (1356.) márc. 30. Avignon

[VI.] Ince pápa teljesítvén a Mo.-i domonkosok rendje testvéreinek provincialis perjele kérését, átírja az elődje, XXII. János pápa 1327. febr. 1-jén Avignon-ban kiadott oklevelében (l. Anjou-oklt. XI. 62. szám) foglaltakat, [amely irat a Mo. peremvidékeit fenyegetô eretnekekkel szemben keresztes hadjárat meghirdetését engedélyezte a domonkos rendi testvérek számára.] D. Avinione, III. Kal. Apr., pápasága 4. évében [1356.].

Reg.: ASV. Reg. Av. v. 132., f. 472v (Df. 289 515.).

K.: Theiner, Mon. Slav. I. 233-234. (314. szám) (Reg. alapján); Smič. XII. 334-335. (251. szám) (Theiner alapján).

R.: Áldásy, 38. (213. szám); Áldásy A., TT. 18 (1895) 80. (213. szám); Doc. Rom. Hist. C. XI. 13. (9. szám) (románul); Erd. Okm. III. 302. (828. szám)(Reg. alapján).

Megj.: Az átírt oklevél [ ] között megadott tárgyát az átíró oklevél közvetlen megszövegezésében nem jelöli meg. Az Anjou-oklt. XI. kötetének apparátusa ezen átíró példányt nem regisztrálja.

151. 1356. márc. 30.

A pannonhalmi (de Sacro Monte Panonie) Szt. Márton-monostor konventje emlékezetül adja: a Nema-i Szt. Erzsébet-egyház plébánosa, András, hasonlóképpen Gymolth-i Vilmos, György fia: Márton, András fia: Lőrinc, János fiai: Vyda és Lőrinc Nema-i nemesek színük elé járulván tanúsították, hogy okt. 25-én (f. III. prox. p. fe. B. Luce ewang.) a testileg beteg ám elméjében egészséges Nema-i Benchench fia: János végrendelkezését hallották, amikor is más - mindkét nembeli — megbízható emberek jelenlétében János 
úgy végrendelkezett, miszerint valamennyi Nema-i birtokának felét, amelyeket szántóföldekben, mezőkben, telki helyekben, szőlőkben és gyümölcsösökben bárhol birtokolt, feleségének, Katalinnak és lányaiknak, Ilonának és Klárának adta örök és visszavonhatatlan birtoklásra. D. in die medii Quadr., a. d. 1356.

Á.: Pannonhalmi konvent, 1371. aug. 16. SNA. Szepesi kápt. hh. oklt. 12. B 3. 3. (Df. 263 441).

K.: Mons Sacer I. 445. (17. szám); Dreska G., Pannonhalmi konvent I. 78-79. (71. szám).

Megj.: A konvent 1371. évi átíró oklevelét 1. Dreska G., i. m. 202-203. (181. szám).

\section{1356. márc. 30. Visegrád}

Zeech-i Miklós c., [I.] Lajos király (H) országbírája, Turuch m. c.-e emlékezetül adja, hogy eleget téve Wezzus mr. Warosd-i c. baráti kérésének, elengedi Gunya fiai: István és Domokos $6 \mathrm{M}$. összegú bírságának a bírót illető kétharmad részét, amelyet Lotow (dict.) András fiaival szemben róttak ki rájuk, és amelyet a márc. 16-án (in oct. diei Cin.) esedékes oklevél-bemutatás e. kellett volna megfizetniük. D. in Vysegrad, f. IV. prox. an. domin. Letare, a. d. 1356.

E.: Dl. 77 161. (Zichy cs. zsélyi lt. 211. 57.) Papíron, hátoldalán azonos kéz írásával tárgymegjelölés, valamint kerek zárópecsét nyoma, bevágásai.

K.: Z. III. 25. (12. szám).

\section{1356. márc. 31. Visegrád}

[I.] Lajos király (H) tudatja, hogy azt az oklevél-bemutatást, amelyre a néhai Miklós nádor oklevelében foglaltak értelmében a Lelezi konvent ügyvédvalló levelével eljáró Dénes fia: Miklós által képviselt Varada-i László fia: János mr. felperest kötelezték Pyliskei Adas (dict.) László fia: István alperes ellenében — utóbbit a király színe e. a szóban forgó konvent ügyvédvalló levelében meghatalmazott Surdel fia: Antal képviselte -, és amely iratbemutatás márc. 16-án (in oct. diei Cynerum) lett volna esedékes Petee birtok ügyében annak a bírói bírságrésznek a perkezdet előtti megfizetésével együtt, mely királyi bírságból járó kétharmad ugyancsak János mr.-t terhelte, notarius hiányában, ill. mert az új nádornak, Kont Miklósnak a pecsétje sem áll még rendelkezésre, elhalasztja máj. 1-jére (ad oct. fe. B. Georgii. mart.) Kont Miklós nádor bírósága elé a fennálló állapot fenntartása mellett. D. in Vyssegrad, 16. die termini prenotati, a. d. 1356.

E.: Dl. 77 162. (Zichy cs. zsélyi lt. 1. B 291.) Hátoldalán azonos kéz írásával tárgymegjelölés, valamint vörös zárópecsét maradványa.

K.: Z. III. 26. (13. szám).

154. 1356. ápr. 2.

Az egri egyház kápt.-ja jelenti [I.] Lajos királynak (H), hogy eleget téve a Zeech-i Miklós országbíró itt átírt oklevelében (l. 79. szám) foglaltaknak, Nygwan fia: Miklós királyi ember a tanúként kiküldött János karpappal márc. 30-án (in die medii Quadr. sc. f. IV.) 
a királyi jelenlét elé idézte Forgach (dict.) Miklós és András ellenében Nogh (dict.) Domokos mr.-t Haznus birtokon, István fia: Lászlót Toor birtokon, János fia: Lászlót és Olivér fia: Istvánt pedig Dorugh-on, [1356.] ápr. 13-át (quind. eiusdem diei Medii Quadr.) tűzvén ki megjelenésükre határnapul. D. sabb. prox. an. domin. Letare, a. supradict. [1356.].

E.: Dl. 58 543. (Forgács cs. 1t. 181.) Papíron, hátoldalán kerek zárópecsét töredéke, bevágásai valamint azonos kéz írásával tárgymegjelölés, a pecséttel lezárt hátoldali részen keresztirányban korabeli jegyzet.

K.: AO. VI. 446-447. (284. szám) (kihagyásokkal).

\section{1356. ápr. 2. [Ó-]Fehértó}

Ábrahám (Abram) fia János fia: László mr. Zabolch-i alispán és a m. szb.-i emlékezetül adják, hogy az előttük megjelenő Semien-i Lengel (dict.) János fia: László mr. — a korábbi oklevelükben (l. 75. szám) foglaltak szerint — ápr. 2-án (sabb. prox. p. diei medii Quadr.) mindenben eleget tett a gyilkos Benedek rejtegetése miatt rá kirótt büntetésnek, megfizetve $4 \mathrm{M}$.-t - részben dénárban, részben becsérték alapján - Semien-i László fia: Mihály mr. ügyvédvalló oklevéllel megjelenô serviens-ének, Kis (Parvus) Poch-nak. D. in Feyrtho, termino antedict., a. d. 1356.

E.: Dl. 51 701. (Kállay cs. lt. 1300. 1124.) Papíron, hátoldalán azonos kéz írásával tárgymegjelölés, továbbá 3 kerek zárópecsét töredéke, szalagjai, bevágásai.

K.: AO. VI. 447-448. (285. szám).

R.: Kállay II. 35. (1178. szám); Piti F., Szabolcs m. 132. (514. szám)

156. 1356. ápr. 2.

Bizonyságlevél birtokosztályról.

Á.: Nyitrai kápt. 1453. jún. 7., Dl. 95 583. (Binnyei vétel 46.) Olvashatatlan Fk.

K.: -

\section{1356. ápr. 3. Visegrád}

Miklós esztergomi érsek és ue. m. örökös c.-e tudatja Miklós egri püspökkel: amikor az ország nemesei és lakosai mozgolódni kezdtek az ország főpapjaival szemben a tized fizetésének ügyében, egyik püspök iránt sem mutatkozott akkora ellenállás, mint a címzettel szemben. Most pedig Rykolphus fia: László mr. az érsekhez menve elpanaszolta, hogy jobbágyai tizedfizetésének ügye miatt a püspök ôt és jobbágyait jogtalanul sújtotta egyházi tilalommal (interdictum). Az érsek ezért kéri Miklós püspököt, hogy ezeket a nemeseket és valamennyi jobbágyukat oldja fel az egyházi tilalom alól, még ha a tizedet nem fizetnék is, mint más években szokták ......., a következő években lesz alkalma megtenni, nehogy az ország bárói által az ...... valamely véleményükbe. $\mathrm{D}$. in Wissegrad, in domin. Letare, a. d. 1356.

E.: Dl. 105 332. (Berzeviczy cs. berzevicei lt.). Papíron, hátoldalán címzés, valamint az érsek mandorla alakú zárópecsétjének töredéke, mely alatt az oklevél foltokban 
kiszakadt (a pecsét képmezője sérült, körirata nagyrészt olvasható: $+S($ IGILLVM) NICOLAI DEI GRA(TIA) ARCHIEPI(SCOPI) STRIGONIEN(SIS) ET CO(M)ITIS P(ER)PETUI).

K.: -

R.: Balogh-Bónis 132. (1208. szám).

\section{1356. ápr. 3.}

A vasvári egyház kápt.-ja tudatja: megkapta [I.] Lajos király $(\mathrm{H})$ — nagyobb pecsétjével megerősített - a Sopron m.-i Heuhlyngh és Arlamus birtokok Agyagus-i András fia: Péter számára történő iktatatása ügyében írt oklevelét (l. 140. szám), amelyben a király utasította a kápt.-t, hogy állítson hites tanút Deuecher-i Miklós fia: Márton v. János fia: Péter, a királyi udvar ajtónállói (aule regis janitores) mint külön erre a feladatra kiküldött királyi emberek valamelyike mellé, hogy kimenjenek a nevezett birtokokra, s ott az összehívott határosok és szomszédok jelenlétében járják be a birtokhatárokat, és ahol szükséges, emeljenek új határjeleket, majd miután ez megtörtént — és sem Nogmortun-i Lőrinc fia: Nyklinus mr., sem más nem mondott ellent —, Pétert iktassák be Heuhlyngh birtok háromnegyed részének, valamint Arlamus birtok egészének a tulajdonába, beleértve utóbbinak valamennyi haszonvételét és tartozékát is. Heuhlyngh birtoknak a háromnegyede ezáltal ahhoz a fennmaradó negyedhez fog kapcsolódni, amelyet most András fia: Péter tart kezében. A király parancslevelében foglaltaknak eleget téve Domokos mr.-t, az egyház éneklókanonokját adták tanúul Deuecher-i Miklós fia: Márton királyi ember mellé, akik visszatérve jelentették, hogy márc. 25-én (f. VI. sc. in fe. Ann. B. Marie virg. prox. preterito) Heuhlyngh és Arlamus birtokokra menvén, az összehívott szomszédok és határosok társaságában bejárták azok határait minden tartozékukkal és haszonvételükkel együtt a király oklevelében foglaltaknak megfelelően, és örök birtoklásra beiktatták azokba Agyag[u]s-i András fia: Pétert. Hj.: Heuhlyngh birtok határa vadrózsák vöröslő bozótosánál kezdődik egy bodzabokor alatt a Bechwta nevú nagy úttól É-ra, innen É felé 2 folyamatos határjelzés (mete cursuales), földjel, új földjel, innen Ny-nak domb felé, a domb oldalában határjel, Ny felé völgybe le, annak közepén vízfolyás, tovább É felé, folyamatos határjelzés, csaknem 1 mérföld hosszában É-nak, a völgyben emelkedve Ke-nek tart egy szögletet jelző határjelhez, itt új földjelet is emeltek, e ponttól Ke felé Heuhlyngh birtok, Ny-ra Nyklinus mr. Kwesd birtoka, É-ra pedig Zorkw vár birtoka helyezkedik el, tovább Ke felé folyamatos régi határjeleken keresztül, mellettük új határjelek, fel Saarhege domb tetejére, ott kis rét, innen hosszan Ke felé egy szögletpontig, úttól Dé-re lévő határjelhez, domb lábánál É-ról új határjel, tovább az úton hosszan Ny felé, földjel; kissé Dé-nek fordul, nagy völgybe le egy úthoz, ott régi határjel, emellé kő- és földjelet emeltek, az úton tovább Ny felé szőlők közötti földjelhez, majd füves ösvényen (per semitam erbosam) a szólók között Ke felé, az ösvénynél folyamatos régi határjelek, mellettük újonnan emeltek, innen kissé Dé felé, majd újra Ny-nak a szőlő sarkánál emelt határjelhez, innen az ösvényen tovább a dombtetôn Ny felé, a szólók közt Dé-nek fordul nagy út felé, az út szélén újonnan emelt földjel, az úton hosszan Ny felé, régi földjel, amely mellett újat emeltek, az utat elhagyva Dé-nek fordul egy másik útra, azon tovább szántóföldekhez, folyóhatár mentén másik úthoz, szántóföldek között Dé-nek, az úton keveset Ke felé, majd Dé-nek fordul, fúzfák (vlg.) fyz, mellettük É-ról elhaladva Ke-i irányban úthoz, amelyen elmegy egy malom e. Dé felé, víz közelében újonnan emelt földjel; ettól Ke-re Simon mr. Kisheuhlyngh birtoka, Ny-ra pedig András fia: Péter Nogheuhlyngh birtoka, szántóföldeken 
keresztül Dé felé tovább, földjel, mellette új földjel, innen Ny felé szántóföldek között Dé-nek fordul, hosszan tovább határjelhez, mellette új jel, innen Ny-nak fordulva szántók és mezők között régi jelhez ér, mellette tó v. vizenyős terület közelében új jel, innen hosszan Ny-i irányba tovább, határjel, mellette új földjel, e ponttól Dé-re Pordan birtok, É-ra András fia: Péter Nogheuhlyngh birtoka, Ke-re Simon mr. Kysheuhlyngh birtoka; É-nak tovább nagy dombhoz, azon Ny-ról felfelé menve régi határjel, amely mellé új földjelet emeltek, kissé Dé felé fordulva le egy kőjelhez, onnan Dé felé tovább, elér egy vízfolyást, majd Ny-nak fordul, szögletet jelző földjel, mellette újonnan emelt földjel, tovább Ny felé cserjésben vadkörtefa, alatta újonnan emelt földjel, innen lefelé szántók között egyenesen É-nak tartva eléri a határfőként emelt első határjelet, amelytôl Ke-re András fia: Péter Nogheuhlyngh birtoka, Ny-ra Kwesd birtok helyezkedik el, és itt végződik a határ. Az ügy bizonyságára a kápt. függőpecsétjével megerősített és az $\mathrm{ABC}$ betúivel chirographált oklevelet bocsát ki. D. 10. die diei statutionis prenotate, a. d. 1356. Péter lévén a prépost, Hermanus az őr-, Domokos az éneklókanonok, a dékáni tiszt üresedésben. A.

E.: Dl. 4602. (NRA. 1591. 2.) Hártyán, felül az ABC betúivel chirographálás, alján zöld sodraton a vasvári kápt. pecsétje függ (rajta Szt. Mihály szárnyas alakja, feje körül glória, kezében kereszt formában végződő lándzsa, mellyel a lába e. heverő sárkány fejét szúrja át, körirata: +S(IGILLVM) CAPITVLI ECCLESIE CASTRIFERREI); hátoldalán késóbbi kéz írásával Hofleyn und Alramus.

Tá.: A 303. számú oklevélben.

K.: F. IX. 2. 528-533. (258. szám) (E.-ról); Sopron vm. I. 259-260. (193.szám) (Tá.-ról).

\section{1356. ápr. 3. Vasvár}

Illés (Elleus) fia: Miklós mr., András bán királynéi tárnokmr.-nek, s egyben Vasvár és Sopron m.-ék c.-nek az alispánja, valamint Vasvár m. szb.-ái emlékezetül adják: márc. 28-án (f. II. prox. p. domin. qua cantatur officium Oculi) tartott törvényszékük alkalmával a színük e. Kald-i Sefredius fia: Miklós odahozva és megmutatva az általa meggyilkolt, szintén Kald-i Mihály fia: Imrét, azzal vádolta ôt, hogy Imre több alkalommal és egyre gyakrabban követett el hatalmaskodást vele szemben, így márc. 27-én (die domin. qua cantatur officium Oculi) is, amikor gonosz szándéktól vezérelve fegyveresen rátört az ő Kald-i házára, amely lakhelyéül (residentia) is szolgál, s meg akarta ôt ölni, s bár e tervét nem tudta megvalósítani, végül Miklós vejét (gener), Vossan-i Isaak fia: Jakabot mégis életveszélyesen megsebesítette. Mivel Miklósnak a törvényszéki ülésen többször kikiáltott vádjaira senki sem adott feleletet Imre helyett, és nem is állt ki senki mellette, így Vasvár m. valamennyi, a törvényszéken ülésező nemesét, különösen pedig Gyula (Jula) fivérét, Miklós zalai alispánt, valamint István fia: Istvánt és Péter fia: Mihályt — Zala m.-i szb.-ákat —, nemkülönben pedig a Veszprém m.-i Hektor fia: György mr.-t kérdezték a szóban forgó Imrére és annak természetére vonatkozó ismereteikről, akik azt válaszolták — Istenbe vetett hitükre és a Szt. Korona iránti húségükre -, hogy tudomásuk szerint Imre levelesített személy (proscriptus publicus) volt. A törvényszék ennek alapján úgy határozott, hogy Miklós hetedmagával még aznap tegyen esküt Vasváron a fenti panasz megerősítésére, amelynek letételét Boda c. — miután az eskü meghallgatását követően visszatért a törvényszékhez —igazolta előttük. A bíróság ezután elrendelte, hogy Imrét mint levelesített személyt vessék akasztófa alá. D. in Castriferreo, 7. die termini prenotati, a. d. 1356. 
E.: Dl. 100 066. (Batthyány cs. lt. Acta antiqua Káld 5. 5. 69. 12.) Hártyán, hátoldalán rányomott pecsét nyoma, bevágásai, valamint késóbbi kézzel Káldy.

K.: -

160. 1356. ápr. 4. Bécs

Margit, Bajorország hercegnéje, stb. kinyilvánítja, hogy minden olyan jogbiztosító iratot, valamennyi oklevelet, amelyek menyegzője alkalmával hitbérével és jegyajándékával összefüggésben [I.] Lajos királytól ( $\mathrm{H}, \mathrm{Je}, \mathrm{Si})$, nemkülönben boldog emlékezetú férjétôl, István úrtól, Szlavónia hercegétôl, ill. anyjuktól, Erzsébet asszonytól v. bárki mástól a birtokába kerültek, ill. nála ezután is fellelhetôk lennének, érvénytelennek, hatálytalannak és foganat nélkülinek nyilvánít - minthogy legkevésbé sem ...... [kíván] Lajos királynak v. anyjának kárt és jogsérelmet okozni —; nem számítva a jogerôt vesztố iratok sorába azt az egyetlen egyet, amely révén 60 ezer forint értékében Nagyszombat (Tyrnaw) várost hozományként megkapta. D. Viennae, f. II. p. Laetare, a. d. 1356.

K.: F. IX. 2. 499-500. (240. szám) (A bécsi levéltárra való hivatkozással).

R.: Pór A., Turul 15 (1897) 14; Pór A., Száz. 35. (1901.) 100.

161. (1356. ápr. 5.e.)

[I.] Lajos király tanú állítására szólítja fel a győri kápt.-t Harka-i Dénes királyi ember mellé Sopron város határának bejárása végett.

Eml.: A 162. számú oklevélben.

K.: Házi I. 1. 110. (174. szám) (Eml.-ben).

162. 1356. ápr. 5 .

A gyơri egyház kápt.-ja tudatja: a király parancslevelében (l. 161. szám) Sopron város határának bejárására kijelölt királyi ember, Harka-i Dénes mellé Miklós karpapot adták hites tanúul, akik visszatérve jelentették, hogy amikor a határt be akarták járni és a határjeleket fel akarták állítani Basnar Daag-i Daagh-i falunagy (villicus), Daagh-i Lőrinc fiainak és e Lőrinc fivére fiának, Péternek a nevében ellentmondott, de nem a hj.-nak, hanem a határjelek felállításának. Ezzel szemben a város bírája és az esküdtek tiltották Lőrinc fiait és Lőrinc fivérének fiát a megjárt határú földnek a használatától és haszonvételeitôl. D. f. III. prox. p. domin. Letare, a. d. 1356.

E.: GYMSML. Sopron város 157. (Df. 201 791.) Papíron, hátoldalán azonos kéz írásával tárgymegjelölés, valamint kerek zárópecsét töredéke, szalagja.

K.: Házi I. 1. 110. (174. szám).

R.: Mollay K., Sopr. Szle 15/2 (1961) 129. és 15/3 (1961) 195-196. 
163. (1356. ápr. 6. e.)

[I.] Lajos király 1 évre kiállított és nagyobb pecsétjével megpecsételt általános idéző, tudományvételi és tiltó levelet bocsát ki a néhai Vgal-i Pál mr. fia: Miklós számára.

Eml.: A 180. és az 578. számú oklevélben.

K.: -

R.: Borsa I., SMM 29 (1998) 253. szám.

164. (1356.) ápr. 6. Villanova közelében, avignoni egyházm.

[VI.] Ince pápa tudatja Zegra-i Miklós [fia:] Miklós esztergomi kanonokkal, hogy — érdemei elismeréséül — számára rezerválja a Znoyma-i Konrád [fia:] Jánosnak, a veszprémi egyházm.-ben lévő Hántai egyház prépostjának a boszniai egyház kanonoki javadalomba (canonicatus et prebenda) és olvasókanonoki tisztségbe történő kinevezése révén megüresedő préposti tisztet, s ezzel együtt felhívja a veszprémi püspök, a hántai egyház kápt.-ja és mindenki más figyelmét, aki részben v. teljességében ezen javadalom rezerválására jogosult, hogy döntését tartsák tiszteletben. D. apud Villamnovam, Avinionensis diocesis, VIII. Id. Apr., pápaságának 4. évében [1356.].

Reg.: ASV. Reg. Av. v. 134., f. 163r-v (Df. 289 536.).

K.: Vespr. II. 165. (191. szám) (kihagyásokkal; Reg. alapján).

R.: Áldásy, 38-39. (214. szám); Áldásy A., TT. 18 (1895) 80. (214. szám) (Reg. alapján) .

165. (1356.) ápr. 6. Villanova közelében, avignoni egyházm.

[VI.] Ince pápa a 164. számú oklevélben foglaltakkal egyező tartalmú levélben értesíti az esztergomi érseket, a pannonhalmi apátot és az avignoni egyház sekrestyéjét a szóbanforgó javadalom rezerválásáról. D. ut supra [D. apud Villamnovam, Avinionensis diocesis, VIII. Id. Apr., pápaságának 4. évében [1356.]].

Reg.: ASV. RA. v. 134. f. 163v-164r (Df. 289 536.).

K.: -

R.: Áldásy, 38-39. (214. szám); Áldásy A., TT. 18 (1895) 80. (214. szám) (Reg. alapján) .

166. (1356.) ápr. 6. Villanova közelében, avignoni egyházm.

[VI.] Ince pápa tudatja Znoyma-i Konrád [fia:] Jánossal, a veszprémi egyházm.-i hántai egyház prépostjával, hogy eleget téve [I.] Lajos király $(H)$ kérésének — s mintegy érdemei elismeréséül - rezerválja számára a Péter választott boszniai püspöknek a boszniai egyház élére való kinevezése révén megüresedő boszniai kanonoki javadalmat (canonicatus et prebenda) és olvasókanonoki tisztségét, s egyben inti a boszniai kápt.-t és mindenki mást, aki részben v. teljességében ezen javadalom rezerválására jogosult, döntését tartsa tiszteletben. D. apud Villamnovam, Avinionensis diocesis, VIII. Id. Apr., pápaságának 4. évében [1356.].

Reg.: ASV. Reg. Av. v. 134., f. 164r-v (Df. 289 536.). 
K.: Vespr. II. 164-165. (190. szám) (kihagyásokkal; Reg. alapján).

R.: Áldásy, 39. (215. szám); Áldásy A., TT. 18 (1895) 80. (215. szám) (Reg. alapján) .

167. (1356.) ápr. 6. Villanova közelében, avignoni egyházm.

[VI.] Ince pápa a 166. számú oklevélben foglaltakkal egyező tartalmú levélben értesíti a zágrábi püspököt, a gyốri püspököt és a bácsi prépostot a szóbanforgó javadalom rezerválásáról. D. ut supra [D. apud Villamnovam, Avinionensis diocesis, VIII. Id. Apr., pápaságának 4. évében [1356.]].

Megj:: Apparátusa megegyezik a 167. számú oklevélével.

168. 1356. ápr. 6.

[I.] Lajos király (H, Da, C, Ra, Se, G, L, Cu, Bu, Sal., mont. S. Angeli dom.) a színe e. rokonaikat is képviselő Lyuben fia: Péter, Andornuk fia: János, Márton fia: Bálint, Month fia: István és Máté fia: István Ryuche (Á. 3.: Ryche) m.-i nemesek kérésére és oklevélbemutatása alapján privilégiumában átírja s autentikus kettős pecsétjének ráfüggesztésével megerősíti [IV.] László királynak $(\mathrm{H})$ a szóban forgó nemesek szabadsága ügyében 1279-ben kiállított privilégiumát. Kelt Miklós zágrábi püspök, királyi alkancellár keze által, a. d. 1356., VIII. Id. mensis Apr., uralkodásának 15. évében. Méltóságnévsor: Miklós lévén az esztergomi érsek s ua. m. örökös c.-e - a kalocsai érseki szék üresedésben —, Domokos a spalatói érsek, Miklós az egri, Demeter a váradi, Miklós a pécsi, Tamás a csanádi, János a veszprémi, Kálmán a gyớri, Mihály a váci, Tamás testvér a szerémi, István testvér a nyitrai, Balázs testvér a knini, András az erdélyi püspök — a boszniai szék üresedésben -; Kont (Á. 2-3.: Konth), Miklós lévén a nádor és a kunok bírája, Cyko (Á. 2.: Chyko, 3.: Cykow) a tárnokmr., András az erdélyi vajda és a Zonuk-i c., Miklós az országbíró, Miklós a Macho-i bán, Leustachius (Á. 3.: Leustatio) az egész Szlavónia bánja, Somogy, Fejér és Tolna m.-k c.-e, Leukus (Á. 3.: Leukes) az asztalnok- és a pohárnok-, Dénes a lovász-, Tamás az ajtónállómr., Simon a pozsonyi c.

Á.: 1. Csázmai kápt., 1369. aug. 10. Dl. 74 468. (Magyar Történelmi Társulat gyújteménye)

2. Szántói Lack Dávid szlavón bán, 1417. márc. 29. Dl. 33 364. (NRA. 561. 37.)

3. Somogyi konvent, 1419. júl. 3. Dl. 1046. (NRA. 520. 24.) (vö. ZsO. 735. szám) Mindhárom átírás E.-je a király korábbi és akkori kettős pecsétjével megerősített privilégium volt, 1364-es megerôsítő záradékkal.

Tá.: 1. Csázmai kápt., 1417. okt. 23. Dl. 37 361. (562. 14.) és Dl. 33 464. (NRA. 562. 14.) (3 példányban; vö. ZsO. 1031. szám)

2. Tá. 1. > Zsigmond király, 1417. dec. 22. Dl. 10 513. (NRA. 478. 5.)

3. Garai Miklós nádor, 1419. máj. 3. Dl. 33 365. (NRA. 561. 36.) (2 példányban)

4. Tá. 3. > csázmai kápt. 1419. aug. 9. Dl. 10 747. (NRA. 522. 43.)

5. Csázmai kápt. 1374. okt. 15. > Szécsényi Simon országbíró, 1395. máj. 17. Dl. 33 511. (NRA. 520. 58.) (1364. máj. 24-i keltezéssel, amely tévedés az oklevél megerősítő záradéka dátumának az okirat eredeti keltezésével való összekeveréséból ered). 
6. Tá. 5. > Pál kőrösi ispán, 1411. okt. 18. Dl. 33 512. (NRA. 520. 59.) (Dátuma ugyanúgy összekeverve, mint ahogy Tá. 5-nél már jelezve volt.)

K.: -

Megj.: IV. László király átírt privilégiumát 1. Reg. Arp. 2970. és 2971. szám. Vö. a 195. számú oklevéllel.

\section{1356. ápr. 6. Visegrád}

László, a csázmai egyház prépostja, [I.] Lajos király $(\mathrm{H})$ kápolnaispánja és titkos kancellárja Bodok-i (Bodak-i) Lőrinc fia: Bodow Bodou (Wadow) kérésére és oklevélbemutatása alapján átírja [I.] Károly királynak $(\mathrm{H})$ azt az 1330. febr. 18-án kelt, középső nagypecsétjével ellátott privilégiumát (l. Anjou-oklt. XIV. 96. szám) [amely a per tárgyává lett Bodok birtokkal kapcsolatban született egyezség rendelkezéseit foglalta írásba], majd az elkészült átírást ama pecsétjével erősíti meg, amelyet királyi kápolnaispáni tisztje miatt használt. D. in Vissegrad, in oct. diei medii Quadr., a. d. 1356.

E.: D1. 90 917. (Khuen-Héderváry cs. 1t., Viczay és Khuen-Héderváry cs. 1t. 22. 2. 1.) Hártyán, középen, a hajtás mentén hosszúkás lyuk, alján pecsét befüggesztésére utaló hasítékok, hátoldalán késóbbi kezek írásával tárgymegjelölések.

Á.: 1. Pálffy Miklós királyi kamarásmr., pozsonyi c., 1589. jún. 16. Dl. 2583. (NRA. 654. 25.).

2. Uo., mint Á. 1., azzal megegyező jelzet alatt, 1591. máj. 31-i Má.-ban.

Má.: 1. Uo., mint E., azzal megegyező jelzet alatt, 1579. aug. 13-i Má.-ban, Zenthywany Sebestyén aláírással).

K.: Héderváry I. 45. (55. szám) (E.-ről).

Megj.: Á. 1. és Á. 2. eltérő névalakjai zárójelben. Az átírt oklevél [ ] között megadott tárgya az átíró oklevél keretszövegének megfogalmazásában közvetlenül nem szerepel.

170. 1356. ápr. 6.

A [székes-]fehérvár-i egyház kápt.-ja 1356. ápr. 6-án (a. d. 1356., videlicet f. IV. prox. an. domin. Iudica) a színe elé járuló Pál fia: Péter, Domokos fia: Benedek, Jakab fia: János, István fia: Gergely, Péter fia: Benedek, István fia: Domokos, Lybe Buden és Nyers (dict.) János Wereuche-i polgárok kérésére és oklevél-bemutatása alapján átírja és a kápt. autentikus függőpecsétjével megerősíti Kálmán királynak (H [!]), s egyben egész Szlavónia hercegének 1234-ben kelt privilégiumát[, amelyben az megállapította Wereuche nagy falvában élő vendégtelepesei szabadságait és kötelezettségeit]. D. a. d. Incarn. supradicto VIII. Id. mensis Apr. Tatamér (Thatamerius) mr. prépost, a fehérvári egyház elöljárója (prelatus), János éneklő-, Demeter ôrkanonok és István dékán jelenlétében.

E.: Dl. 33 405. (NRA. 590. 19.) Smič. szerint hártyán, rajta piros-zöld selyem sodraton törött pecsét függ.

K.: Smič. XII. 339. (254. szám). 
Megj.: Az átírt oklevél [ ] között megadott tartalmát az átírás keretszövege nem tartalmazza közvetlenül. Kálmán herceg ezen privilégiumát l. Reg. Arp. duc. regin. 13. szám. Smič. az átírt oklevelet tévesen 1279-re datálta.

\section{1356. ápr. 6. Visegrád}

Zech-i Miklós c., [I.] Lajos király (H) országbírája és Turuch m. c.-e tudatja, hogy korábbi ítéletlevelében (l. 148. szám) márc. 30-án (in die medi Quadr.) esedékes oklevélbemutatásra kötelezte egymás ellenében egyik részról Mykola-i Péter fia: András felperest Mykola birtok ügyében, a másik részról Zondou-i Bereck alperest Zondou Zoudou $\sim$ Zodou birtok ügyében. A kijelölt időpontban mindkét fél személyesen megjelent elôtte, és elsóként András mutatta be [IV.] Béla király $(\mathrm{H})$ aranypecséttel ellátott, többek között Mykola birtok ügyében 1247-ben kiállított privilégiumát. Ezt követően Bereck a nyitrai egyház kápt.-jának 1337-ben kelt kiváltságlevelét terjesztette elé, amelyból az derült ki, hogy egyik részról Csanád (Chanadinus) esztergomi érsek és örökös c., a másik részról pedig Musla-i $\sim$ Mysla-i Bacha fia Jakab fia: Bereck és nemes anyja — nevezett Jakab özvegye - , valamint [utóbbinak a] veje (gener), Tuhul-i Domokos fia: János a maguk, továbbá nevezett Jakab lányai, Petronella, Agata, Erzsébet és Klára [nevében] a nyitrai kápt.-hoz menve nyilatkozatot tettek, amely szerint egymás között örök időkre elcserélték birtokaikat kölcsönös szavatosság vállalásával. Szabad akaratukból úgy rendelkeztek, hogy Csanád érsek a Gron folyó melletti, Bars m.-i Zoudou érseki birtokot, amely Mykola és Bogdan falvak között fekszik, valamennyi tartozékával ősi határai mentén Berecknek, Jakab özvegyének, vejének, Jánosnak és Jakab 4 nevezett lányának adta csere címén örök birtoklásra. Bereck és János a maguk, továbbá a szóban forgó 4 lány, valamint az özvegy nevében az Esztergom m.-i Musla nevú érseki falu, és az esztergomi kápt. Ebed nevú falvai között fekvő Mysla birtokot adták örök jogon minden haszonvételével ősi határai mentén az érseknek és rajta keresztül az esztergomi érsekségnek. Mivel Csanád érsek szavatosságot vállalt Bereckkel szemben Zoudou birtok ügyében, így az országbíró az ország nemeseivel együtt elrendeli, hogy máj. 8-án (in quind. fe. B. Georgii mart.) Bereck törvényes idézéssel v. bármely más módon, ahogy az ország szokása megengedi, vezesse a színe e. az érseki méltóságot éppen betöltố Miklós esztergomi érseket a szóban forgó birtokkal kapcsolatos, Csanád érsek által a leírt csere alkalmával vállalt szavatosság miatt, amikor is az országbíró a felek között ítéletet hozhat. D. in Vissegrad, 8 die termini prenotati, a. d. 1356.

E.: Dl. 316. (NRA. 1050. 1.) Papíron, hátoldalán azonos kéz írásával tárgymegjelölés, valamint kerek zárópecsét nyoma, bevágásai, a pecséttel lezárt hátoldali részen keresztirányban korabeli jegyzet.

K.: W. VII. 231. (156. szám) (kivonatos).

Megj.: IV. Béla privilégiumát 1. Reg. Arp. 871. szám; a nyitrai kápt. 1337. aug. 3-i keletû́ oklevelét Anjou-oklt. XXI. 456. szám alatt.

\section{1356. ápr. 6. Visegrád}

Zech-i Miklós c., [I.] Lajos király (H) országbírája, Turuch m. c.-e azt a pert, amely egyik részrôl a színe e. megjelent Lőrinc fia: László, vele szemben pedig Nogmihal-i András fia: Mihály között forgott fenn, és amely korábbi oklevele (l. 149. szám) értelmében márc. 30-án (in die medii Quadrag.) volt esedékes, a felek képviselóinek [!] akaratából 
máj. 8-ra (ad quind. fe. B. Georgii mart.) elhalasztja - békés megegyezés reményében oly módon, hogy a felek sem királyi, sem királynéi levélre hivatkozással, sem hadjárat miatt, sem egyéb közbejött esemény ürügyén ne halaszthassák azt tovább jún. 26-nál (quind. fe. Pent.). D. in Vysegrad, 8. die termini prenotati, a. d. 1356.

E.: Dl. 85 311. (Sztáray cs. 1t. 97.) Vízfoltos papíron, halvány írásképpel, alján közel korú kéz írásával jegyzet (Andreas filius Mychaelis de Kamarnuch cum Lelez, ad quind. residentie exercitus regy in causam attractus [fölötte: due] personaliter). Hátoldalán azonos és késóbbi kezek írásával tárgymegjelölések (közülük az egyik tévesen került az oklevélre, ezt le is húzták és error felirattal látták el), valamint az országbíró kerek zárópecsétje (rajta háromszögú pajzson kiterjesztett szárnyú, kétfejú sas, körirata: +S(IGILLVM) C[O]MITIS NICOLAI).

K.: Sztáray I. 249. (143. szám).

Megj.: K. szerint az oklevélben 2 hiba is van, az egyik a képviselók említése (hiszen a felek személyesen jelentek meg), a másik a máj. 8-ra halasztás, mivel az oklevél végén jún. 26. szerepel, továbbá a hátoldali tárgymegjelölés is jún. 26-ra való halasztást tartalmaz.

173. 1356. ápr. 6 .

Zeech-i Miklós országbíró — miként azt [1356.] ápr. 6.-án (8. die diei medii Quadr., a. in presenti [1356.]) kiállított oklevele tanúsítja - Durugd-i István fia: Pált hatalmaskodás és más jogtalanságok ügyében a királyi jelenlét bírósága elé idézte Lőrinc nemes felesége ellenében, majd a megjelenés elmulasztása miatt $6 \mathrm{M}$. bírságot róttak ki Pálra.

Tá.: Az 584. számú oklevélben.

K.: -

\section{1356. ápr. 6. Szentimre}

István erdélyi alvajda Dezmer-i János fia: István 3 M., az alvajdának fizetendő bírságjussát - amelyben ápr. 6-án (in oct. diei medii Quadr.) Márk fia: János ellenében marasztaltatott el - az erdélyi rész több nemesének kérésére elengedi. D. in S. Emerico, in termino prenotato, a. d. 1356.

E.: Dl. 50 336. (K. Papp Miklós gyújteménye) Papíron, hátoldalán kerek rányomott pecsét töredéke, bevágásai.

Má.: Dl. 36 944. (Erdélyi kincstári lt. 4. 27. Y.) 17v. undecimo; 1750. évi hiteles Má-ban.

K.: -

R.: Erdélyi Okm. III. 302. (829. szám).

175. (1356. ápr. 6.-máj. 1. között)

Miklós kassai (de Cassa) plébános levele szerint neki Barcha-i Miklós fia: Myko c. és Kazmer-i Mykocha fia: Pál fogott bírákkal együtt a László egri prépost, korábbi vikárius írásba foglalt megbízásának megfelelően és ahogyan azt a felperes Sebe asszonynak 
— korábban Komlous-i Balázs fia: Koporth (dict.) Péter özvegyének, utóbb Lőrinc deák feleségének, Sándor fia: Demeter leányának — akkori famulus-a és törvényes meghatalmazottja, Sebestyén is önként vállalta, a felek elóterjesztését és oklevél-bemutatását követően ítéletet kellett volna hozniuk Sebe asszony, ill. a alperes Miklós fia: László perében, amely a szóban forgó nemes asszonynak, továbbá 2 nővérének - ti. Hosguth-i [?] Péter fia: Petew özvegyének és Janula-i Márton fia: Miklós néhai feleségének - a nagyanyjuk és anyjuk u. járó hitbér és jegyajándék, továbbá az óket illető leánynegyed követelése körül forgott, azonban ezt nem lehetett megtenni, mivel a kitúzött időpontban, ápr. 6-án (in oct. diei medii Quadr. iam preteritis) csak az alperes jelent meg készen arra, hogy bármilyen fogott bírói döntést elfogadjon, a felperes asszony viszont távol maradt, és törvényes képviselőjét sem küldte el a 2 fogott bíróval, Barcha-i Mykoval, valamint Mykocha-i Pállal együtt, holott erre ő kötelezettséget vállalt, így Miklós plébános egyedül nem tudott eljárni az ügyben.

Eml.: A 251. számú oklevélben.

K.: -

Megj.: Az oklevél kibocsátásának terminus ante quem-je a szóban forgó ügyet tárgyaló egyházi törvényszéknek az említő oklevélben említett 1356. máj. 1-jei ülése napjából adódik.

\section{6. (1356. ápr. 6.-jún. 5. között)}

István erdélyi alvajda tanúbizonyság kiküldését kérve tudatja az erdélyi kápt.-nal, hogy színe e. egyik részrôl Gyeletus fia: László mr., Beche fia: István és Mihály fia: János, Vilagusberek-i Vilagusberk-i nemesek, a másik részról pedig Mihály fia: Miklós, valamint Fata-i Miklós fia: Mihály megjelenvén, kinyilvánították, hogy a pereikben való megegyezés érdekében tóle kapott bírói engedély alapján ápr. 6-án (in oct. diei medii Quadr.) az urának, az erdélyi vajdának a halasztó levelében foglaltak szerint fogott bírák rendelkezése révén békés egyezségre jutottak egymással. Eszerint Chepan és Fata birtokok között fekvő, per tárgyát képező földdarabjukat - amellyel kapcsolatban az egyezség létrejöttében közremúködő, alább felsorolt fogott bírák korábbi rendelkezése alapján Mihály fia: Miklós és Miklós fia: Mihály, továbbá utóbbi Mihály fia: István az ország szokása szerint [1355.] nov. 2-án (2. die fe. OO. SS. tunc venturi) leteendố eskü tételére voltak kötelezve - a 8 fogott bíró, nevezetesen a Fata-i nemesek részéról Both fia: Gál, Jara-i Tamás fia: Miklós, Tatheur- i Miklós fia: Myke és Ench-i János fia: Márton, míg a Vilagusberek-i nemesek oldalán Chati-i Jakab fia: György, Zaua-i Mark, Bothus (dict.) János és Wlkeyn fia: János jún. 5-én (die domin. prox. an. fe. Penth. tunc affuturum) 3 egyenlő értékú részre tartozik osztani Galaz-i János v. Chazar-i Miklós v. Septeri Pál fia: András alvajdai emberek valamelyikének jelenlétében és a kápt. kiküldendő emberének tanúskodása mellett, majd a birtokosztályt követően a peres föld Fata falu részéból határjelekkel elválasztott kétharmadába az innen való nemeseket, a fennmaradó egyharmadába pedig — amelyet új határjelekkel választottak le Chepan birtokból - a Vilagusberek-i nemeseket kell beiktatni örök birtoklásra, s ezt követően a kápt. a visszatért kiküldöttek jelentése alapján írásban számoljon be a történtekról neki.

Eml.: 1. A 333. számú oklevélben. > Losonci László erdélyi vajda, 1380. jan. 28. > erdélyi kápt., 1380. máj. 6. Dl. 73 765. (Teleki cs. marosvásárhelyi lt. 235.).

2. A 333. számú oklevélben. > Dengelegi Pongrác és Vízaknai Miklós erdélyi alvajdák, 1442. okt. 15. Dl. 44 336. (Múz. Ta. Torma). 
K.: Teleki I. 193-194. (148. szám); ZW. II. 514-516. (1119. szám) mindkettő Eml. 1.-ről.

R.: Erd. Okmt. III. 305. (830. szám).

177. 1356. ápr. 6 - 1359. okt. 22.

András erdélyi vajda és Zonuk-i c. az erdélyi egyház káp.-jának: Pál kanonok, a szebeni (Cybiniensis) egyház prépostja előadta, hogy Noghekemezeu és Kyzekemezeu Kysekemezeu birtokainak határait a királyi oklevélben foglaltaknak megfelelően a kápt. tanújával a néhai erdélyi vajda, István életében bejárták az ősi jelek mentén, és amikor a Ny-i rész felé, Mikezeze falu részétől határjeleket akart állítani Mihály fia: János, Domokos fia: László Chekelaka-i nemesek, valamint az oda sereglő szomszédok és határosok azt állították, hogy Kysekemezeu és Mykezaza falvak között lévő Kyralreue telek (sessio), amely rájuk nagyatyjuktól és dédatyjuktól örökség jogán jutott, nem Mykezaza birtok földjéhez tartozik, hanem a felszólamlóknak Kyralreue birtokával függ össze. Miután ezeket bejárták, elfogadva a királyi és a kápt.-i kiküldött által a szóban forgó Kysekemezeu és Kyralreue birtokok között a többi ôsi földjelet .............. egy bizonyos Noghkerehtal völgyhöz, majd azon keresztül .................... a Kykulleu folyónál ....... földhöz ér Medyes várostól

E.: Dl. 31 101. (Gyulafehérvári kápt. o. lt. Metales N 2.) Papíron, alsó része leszakadt, hátoldalán azonos kézzel címzés, késóbbi kézzel helynevek, valamint kerek pecsét töredéke, bevágásai.

Má.: Uo., mint E., azzal megegyező jelzet alatt; 1786. évi hiteles Má.-ban.

K.: Doc. Rom. Hist. C. XI. 13-14. (10. szám) (román fordításban is).

R.: Erdélyi Okm. III. 303. (831. szám).

Megj:: Az oklevél keltezésének terminus ante quem-je Engel Archontológiájához igazodik, melyben 1356. ápr. 6. szerepel Lackfi András vajdai tisztségének kezdeteként, a terminus post quem András erdélyi vajda — jelenlegi ismereteim szerint utolsó kiadott oklevelének keltéhez igazodik l. Arhivele Statului Covasna, Nagy Jenő gyưjteménye, B 1. (Df. 278 727.); Erd Okm. III. 382. (1093. szám). Az Erd. Okm. Engel alapján 1356. ápr. 6. és 1359. okt. 10. közé helyezte az oklevél keltét.

178. 1356. ápr. 7.

A váradi egyház kápt.-ja e. Keraly-i Csépán (Chepanus) fia: Zouard a maga, valamint fiai: György és János nevében, hasonlóképpen Miklós fia: István a maga és fivére, Márton nevében, nemkülönben Ordo-i Leukus fia: Bertalan a maga és fivérei, János és a másik János nevében, továbbá Keraly-i (dict.) János fia: János személyesen tiltakoztak az ellen, hogy Albert fiai: Mihály és Miklós, valamint Chybak fiai: Mihály és János az ő részbirtokaikat, továbbá a gyermektelenül meghalt Bolchyda-i Ders u. — akivel elsőfokú osztályos atyafiságban voltak — ugyancsak nekik járó birtokokat, ti. Zenthianus-t, Derspalathaia-t, Fanchuka-t és Tarnya-t Bihar m.-ben, valamint Zeureg-et tartozékaikkal együtt elfoglalva tartják, óket pedig kizárták azokból. Nehogy a tiltakozó levél hiánya miatt jogsérelmet szenvedjenek és nehogy kárukra legyen a hallgatás, ezért kérik a kápt.-t, hogy tiltakozásukat írásban rögzítse, hogy majd alkalmas idóben, amikor a körülmények kedvezőek lesznek, ügyüket folytathassák, és jogaik érvényesítését a mondott birtokokon késóbb előmozdítsák. Ugyanis most kezdődött egy hosszas perük, 
mely a bizonyos dolgok és a költség hiányát okozza számukra, de a királlyal szemben más birtokaik ügyében ítélet van kilátásban. D. f. V. prox. an. domin. Judica, a. d. 1356.

E.: D1. 38 168. (Ujhelyi cs. lt.) Papíron, hátoldalán azonos kéz írásával tárgymegjelölés eltérő névalakokkal (Kerali, Cybak), valamint a váradi kápt. mandorla alakú zárópecsétjének töredéke, bevágásai.

K.: Doc. Rom. Hist. C. XI. 15-16. (12. szám) (román fordításban).

Facs.: Doc. Rom. Hist. C. XI. 647.

R.: Komáromy A., Száz. 27 (1893) 876; Erdélyi Okm. III. 303. (832. szám).

Megj.: Vö. a 179. számú oklevéllel.

179. 1356. ápr. 7.

A váradi egyház kápt.-ja e. Keraly-i Csépán (Chepanus) fia: Zouard a maga, valamint fiai: György és János nevében, hasonlóképpen Miklós fia: István a maga és fivére, Márton nevében, nemkülönben Ordo-i Leukus fia: Bertalan a maga és fivérei, János és a másik János nevében, továbbá Keraly-i (dict.) János fia: János nyíltan és határozottan eltiltották Bolchyda öröklött birtokuk valamennyi szomszédját és határosát, különösen pedig Boht-i Tamást és mindenki mást is annak az egész birtoknak v. egy részének az elfoglalásától és hasznának élvezetétől. Azért, hogy hallgatásukból utódaiknak ne származzon kára, kérik a kápt., hogy tiltakozó és eltiltó oklevelet adjon ki számukra, amit a kápt. a jelen oklevél kiállításával teljesít. D. f. V. prox. an. domin. Judica, a. d. 1356.

E.: Dl. 38 169. (Ujhelyi cs. lt.) Papíron, hátoldalán azonos kéz írásával tárgymegjelölés eltérố névalakkal (Bolchhyda), valamint a váradi kápt. mandorla alakú zárópecsétjének töredéke, bevágásai.

K.: -

R.: Doc. Rom. Hist. C. XI. 14-15. (11. szám) (román fordításban).

Megj.: Vö. a 178. számú oklevéllel.

180. 1356. ápr. 9.

A [somogyvári] Szt. Egyed monostor-konventje jelenti [I.] Lajos királynak (H): megkapták az Vgal-i Pál mr. fia: Miklós részére idézésekre, tudományvételre és eltiltásokra vonatkozó éves levelét (l. 163. szám), amelynek alapján Kureky-i János fia: Miklós királyi ember mellé József iskolamestert (magistrum scolasticum) adták tanúul az alább ismertetet vizsgálat elvégzésére, akik visszatérve jelentették, hogy ápr. 8-án (f. VI. prox. an. domin. Judica) nyíltan és titokban kikérdezve az értesüléssel rendelkezőket - nemeseket és nem nemeseket, egyháziakat és világiakat, valamint más jogállású embereket egyaránt - lefolytatták a vizsgálatot. Ennek eredményeként megtudták, hogy Toruei Vgrin fiai: Miklós és László halálos fenyegetésekkel és jobbágyaik megfélemlítésével Vgal-i Pál mr. fia: Miklós Juth birtokát elnéptelenítették, arra kényszerítve a jobbágyokat, hogy az ő birtokaikra költözzenek át, ezenfelül a régtől fogva minden hétfőn (f. II.) tartani szokott vásárt Wyadan $\sim$ Wyadon birtokukra vitték át, ahol már 3 hétfőn vásárt tartottak, de az nem derült ki, vajon ezt királyi és királynéi engedéllyel tették-e 
v. önhatalmúlag (auctoritate) cselekedtek így. Jelentették továbbá, hogy Miklósnak Torue birtokon levő részbirtokát is teljesen elnéptelenítették, valamint megtudták, hogy [1355.] nov. 19-én (fe. B. Elizabeth in a. prox. preterito elapso) a [székes-]fehérvári egyház nemes jobbágya, Domokos fia: János Meger-ról egy női köpenyt (palium), amely Nyari-i István jobbágyának, Móricnak a feleségénél volt, Miklósnak Babun birtokán egy officialis-a révén törvényesen lefoglalt visszavétel végett, majd a felek akaratából a bírói ítélet napjául (pro termino iuris et iustitie) dec. 5-ét (sabb. prox. p. fe. B. Andree ap. prox. preteritum) jelölték ki, mely időpontban László hatalmaskodva tört Babun birtokra, a szóban forgó köpenyt elvette Miklós officialis-ától, akit meg akarván ölni csúful mocskolt szavaival, és mindezekkel komoly kárt okozott Miklósnak. D. sabb. prox. an. domin. Judica supradictam, a. d. 1356.

E.: Dl. 87 315. (Esterházy cs. hercegi ága Repositorium 47. U 5.) Papíron, hátoldalán azonos kéz írásával címzés és tárgymegjelölés, valamint késóbbi kézzel tárgymegjelölés, továbbá a somogyi konvent kerek zárópecsétjének töredéke (rajta kivehető egy hosszú ruhát viselő alak, valamint a körirat egy része: [+S(IGILLVM) CAPITVLI MONASTERII EGIDII] DE SVMIGIO), bevágásai.

K.: -

R.: Borsa I., Somogy m. lt. Évk. 29 (1998) 253. szám.

181. 1356. ápr. 9.

A veszprémi kápt. — miként azt 1356. ápr. 9-én (sab. prox. an. domin. Iudica a. d. 1356) kelt zárt oklevele tanúsítja - jelenti [I.] Lajos királynak, hogy a tihanyi (Tykoniensis) apát, Bertold (Bertholdus ) testvér részére írt királyi parancslevélben foglaltakat teljesítvén a megnevezett királyi ember és a jelentést tevő kápt. embere felkeresték a somogyi konventet az igazság kivizsgálása érdekében a tihanyi Szt. Ányos-monostor birtokát régtől fogva képező Igal nevú birtokon lévő birtokrésszel kapcsolatban, amelyet a [Nyulak-]szigeti (de Insula) Boldogságos Szúz-kolostor apácáinak ott tartózkodó jobbágyai haszonvételeivel együtt jogtalanul használnak, nem kis kárt okozva ezzel a tihanyi apátnak és konventjének. Mindezekról megbizonyosodván a kiküldöttek eltiltották a szóban forgó jobbágyokat a mondott birtokrész elfoglalástól és hasznai bitorlásától.

Tá.: Bebek Detre nádor, 1402. ápr. 16. Dl. 36 436. (Acta eccl. 68. 6.) Egyszerú 18. sz.-i Má.-ban.

K.: P. X. 615. (104. szám).

R.: P. X. 555. (67. szám).

182. (1356. ápr. 10.e.)

[I.] Lajos király a Nyulak szigeti (de Insula Leporum) Boldogságos Szűz-kolostor apácái számára idézésekre, tudományvételre, eltiltásokra és az apácák kezében lévő birtokok határainak bejárására és határjelek állítására, valamint minden más az ország szokása szerint szükséges dolog lebonyolítására vonatkozó éves levelet bocsát ki.

Eml.: reg:1356apr10:00023

K.: AO. VI. 448. (286. szám) (Eml.-ben). 
[I.] Lajos király (H) a Jazow-i egyház konventjéhez: Wytez-i László fia: Lőrinc eléje terjesztett panasza szerint Perwen-i Miklós márc. 28-án (f. II. prox. an. domin. Letare) hatalmaskodva és felfegyverkezve rátört Korlathuagasa birtokára, ahol az ott halászó Lőrincet meg akarta ölni, 2 famulus-át, Pétert és Istvánt pedig életveszélyesen megsebesítette, jóllehet Lőrinc és Miklós között per van függóben. A király ezért utasítja a konventet, hogy Huthka-i Fábián fia: Miklós királyi ember mellé adjon hites tanút a panasz kivizsgálására, majd a vizsgálat eredményéről küldjön írásos jelentést számára. D. in Vyssegrad, in domin. Judica, a. d. 1356.

Á.: A 259. számú oklevélben.

K.: F. IX. 2. 543-544. (265. szám) E.-ról Jankovics gyújteményre való hivatkozással.

\section{1356. ápr. 10. Visegrád}

[I. Lajos király] utasítja a szepesi kápt.-t, hogy Azar-i Miklós fia: István v. Boh... [?]-i Tamás fia: László ....... királyi emberrel küldje ki a kápt. a maga emberét hites tanúul, és vizsgálják ki [Vytez-i László fia:] Lőrincnek királyi színe e. előadott panaszát, amely szerint [Peren-i Miklós fia: Miklós] ....... márc. 28-án ([in] f. II. prox. an. domin. Letare) [felfegyverkezve] érkezett [a panaszos Korlatwagasa] nevú birtokára, ahol Lőrinc éppen halászott, [s ott meg akarta ôt ölni], továbbá famulusait, Pétert és Istvánt életveszélyesen megsebesítette, jóllehet nevezett Lőrinc és Miklós között peres eljárás van függóben. A király a vizsgálatról jelentést kér. D. in Vyssegrad, in domin. Judica, [a. d. 13]56.

Á.: A 274. számú oklevélben.

K.: -

Megj:: a [ ]-ben közölt információk az átíró oklevélból és az ugyanezen ügyben íródott 259 számú oklevélból származnak.

185. 1356. ápr. 10.

A budai egyház kápt.-ja jelenti [I.] Lajos királynak (H), hogy eleget téve a Nyulak szigeti (de Insula Leporum) Boldogságos Szűz-kolostor apácái számára kiállított, idézésekre, tudományvételre, eltiltásokra és az apácák kezében lévő birtokok határainak bejárására és határjelek állítására, valamint minden más az ország szokása szerint szükséges dolog lebonyolítására vonatkozó éves levelében (l. 182. szám) foglaltaknak, Dary-i Aba fia: Jakab királyi ember mellé tanúul adták egyházuk presbiterét, Benedeket, akik ápr. 4én (f. II. prox. p. domin. Letare nunc preterita) kimenvén az apácák Pozsony m.-i Tune birtokára, az összehívott szomszédok és határosok jelenlétében bejárták annak határait, hogy határjelek emelésével elkülönítsék más birtokoktól, majd amikor a birtokot iktatni akarták az apácák részére, Olastal birtokosa, az odavaló Simon fia: István tiltakozott az ellen, hogy birtokán határjeleket állítsanak, aminek folytán a királyi ember máj. 8-ra (ad quind. fe. B. Georgii mart. nunc affuturas) a királyi jelenlét bírósága elé idézte ôt az apácákkal szemben. D. in domin. Iudica, a. d. 1356.

E.: Dl. 4603. (Acta eccl. ord. et mon. Poson. 16. 2.) Papíron, hátoldalán azonos és késóbbi kéz írásával tárgymegjelölés (utóbbi magyarul), valamint a budai kápt. man- 
dorla alakú zárópecsétje (rajta Szt. Péter ap. trónon ülő alakja, püspöki ornátusban, baljában kulcsokkal; körirata: +SIGILLVM CAPITVLI BVDENSIS), bevágásai.

K.: AO. VI. 448-449. (286. szám) (kihagyásokkal).

186. 1356. ápr. 11.

Mihály mr., Kunth Miklós nádornak és a kunok bírájának Sarus-i alispánja tudatja, hogy Trochan-i Miklós fia: György az ugyaninnen való Tamás fiait: Miklóst és Egyedet, valamint ezeknek sógorát (gener), Kosa-t az egyik szolgabíró, Miklós c., valamint Koal-i József útján ápr. 11-ére (f. II. prox. p. domin. Judica) az alispán színe elé idézte azzal, hogy azok famulus-ukat Pétert ugyancsak állítsák ítélőszéke elé, ám a nevezettek közül senki nem jelent meg, és nem is küldött senkit maga helyett, és Pétert sem állíttották elő, hiába várta György jövetelüket. D. in Sarus, die prenominata, a. d. 1356.

E.: Dl. 87 316. (Esterházy cs. hercegi ága Repositorium 47. T 7.) Papíron, hátoldalán azonos és késóbbi kéz írásával tárgymegjelölés, valamint kerek zárópecsét töredéke, bevágásai.

K.: -

187. (1356.) ápr. 13. Villanova közelében, avignoni egyházm.

[VI.] Ince pápa az esztergomi érseknek és a veszprémi püspöknek: [I.] Lajos király (H) levélben és követei révén tudatta a pápával, hogy a veszprémi egyházm.-ben lévő pilisi Boldogságos Szűz cisztercita kolostor, amelyet ősei (progenitores) alapítottak és láttak el adományokkal, s amely egykor bővelkedett tudásban és múveltségben, mostanság bizonyos apátok gondatlansága miatt az idők folyamán súlyosan leromlott állapotba került, és lelkiekben is erősen lehanyatlott, ezért e helyzet orvoslása érdekében, tekintettel arra, hogy számos ősének teste ott nyugszik, és mert előző apátja, Jakab sincs már az élők sorában, az apáti tisztség megürültével a király a padovai (Pataviensis) egyházm.-ben lévő Szt. Kereszt rend monostorának celarius-át, Henriket szemelt ki utódjául, s levelében egyházfői figyelmébe ajánlotta személyét, ígérvén, hogy a monostor lelki természetú, ill. hétköznapi (spiritualis et temporalis) ügyeinek helyrehozatala terén egyaránt támogatásában fogja ôt részesíteni. Ezért a pápa a király előterjesztésének megerősítése érdekében arra utasítja a címzetteket, hogy a Boldogságos Mária monostor helyzetéről, valamint Henrik igazgatási képességét bizonyító érdemeiról és alkalmasságáról tájékoztassák. D. apud Villamnovam, Avinionensis diocesis, Id. Apr., pápaságának 4. évében [1356.].

Reg.: ASV. Reg. Av. v. 133., f. 225v-226r (Df. 289 525.).

K.: Vespr. II. 165-166. (192. szám) (Reg. alapján).

R.: Áldásy, 36. (216. szám); Áldásy A. TT. 80. (216. szám) (Reg. alapján).

188. 1356. ápr. 13.

A somogyvári (de Symigio) Szt. Egyed monostor konventje e. egyik részról Myhaldi-i János fia: Mihály és felesége Fyle, a másik részről pedig az ura Ders fia: Miklós mr. nevében eljáró famulus és ügyvéd, Chakana-i (dict.) Demeter megjelenvén, előbbiek kinyil- 
vánítják, hogy a Somogy m.-i Myhald birtokukat minden haszonvételével és tartozékával együtt, kivéve a mondott birtokból Fyle számára járó hitbért és jegyajándékot, valamint a leányaiknak, Erzsébet és Ilona asszonyoknak járó leánynegyedet, átadták Ders fia: Miklós mr.-nek, valamint fiainak: Ders-nek, Györgynek és Jánosnak, oly módon, hogy utóbbiak vállalták, miszerint Mihályt és feleségét lányaikkal együtt életük végéig saját birtokukon rangjukhoz illően (iuxta decentiam honoris eorum) ellátják ruhával és élelemmel, ugyanakkor ha időközben fiú örökösük születne, úgy a birtok tulajdonjoga teljes egészében visszaszáll majd arra, ha pedig mégsem születne, akkor haláluk u. a birtok minden tartozékával és haszonvételével Miklós mr. és fiai tulajdonába kerül. $D$. f. IV. prox. p. domin. Judica, a. d. 1356.

E.: Dl. 69 975. (Sibrik cs. 1t. 23.) Hártyán, hátoldalán késóbbi kezek írásával tárgymegjelölés, valamint kerek pecsét nyoma, bevágásai.

K.: -

R.: Borsa I., Somogy m. 1t. Évk. 29 (1998) 253. szám.

\section{1356. ápr. 14. Zágráb}

[I.] Lajos király $(\mathrm{H})$ eleget téve a színe elé járuló Rakonuk-i Bertalan fia László nemes özvegye és fia: Benedek kérésének, visszaadja nekik azt a Rakonuk birtokon lévő részbirtokukat, amely egykor hozzájuk tartozott, azonban Mykch, egész Szlavónia bánja elfoglalta azt, és a bánság területéhez csatolta ama bírságnak a fejében, amelyben a nevezett László a bán e. zajló perben Rakonuk-i Domokos fia: Tamás ellenében elmarasztaltatott. A király saját üdvére ill. jó emlékú öccsének, István hercegnek a lelki üdve érdekében is elengedi a szóban forgó bírságot, és visszaadja a részbirtokot a nevezett özvegynek, valamint fiainak: Tamásnak és Benedeknek minden haszonvételével és jogával együtt örök birtoklásra. Úgy kívánja, hogy mindezekrôl Margit hercegné, István herceg özvegye is privilégiumot állítson ki az özvegy és fia, Benedek számára. Jelen oklevél visszahozatalának esetére privilégium kiállítását ígéri az ügyben. D. Zagrabie, f. V. prox. an. domin. Ramispalmarum, a. d. 1356.

E.: Dl. 35 862. (MKA. Collectio Kukuljevicsiana) Hártyán, hátoldalán azonos kéz írásával tárgymegjelölés kétszer, valamint kerek pecsét nyoma, bevágásai.

K.: Smic. XII. 340-341. (255. szám).

190. 1356. ápr. 14.

A garamszentbenedeki (S. Benedictus de iuxta Gron) monostor konventje jelenti [I.] Lajos királynak $(\mathrm{H})$ : miután megkapták Zeech-i Miklós országbíró itt átírt oklevelét (l. 132. szám), amelyben az Jakab fia: Miklós mr. érdekében elrendelte Kalachna birtok hj.át és iktatását, az abban foglaltak szerint Móric fia: Miklós királyi ember mellé tanúul adták papjukat, András testvért, akik ápr. 7-én (f. V. prox. an. domin. Judica) és az azt követő napon kimenvén Kalachna birtokra, az összehívott határosok és szomszédok, valamint a testvérét, Miklóst az említett konvent ügyvédvalló levelével képviselő Jakab fia: István mr., továbbá a Baradyan Baradian-i nemesek, Geleth fia János fia: Péter, ennek Demeter nevú officialis-a, valamint Ugrouch falubeli lakosok jelenlétében megjárták a birtok határát, és határjeleket állítottak fel. Hj.: mivel Kalachna birtok a Kolos-i Boldogságos Szt. Szűz-monostor birtokával határos, ezért a hj.-t ott kezdték, ahol a birtokhatár 
a monostor határjeleivel először érintkezik, a monostor 2 régi határjele a Hrussov-ból Nogugrouch-ra tartó nagy út mellett, amelyet mindkét fél - így a testvérét, Miklóst is képviselő Jakab fia: István mr., valamint a monostor apátja nevében megjelent perjel is - elfogadott, a továbbiakban régi határjelek a monostor birtoka és Kalachna között, 2 régi jel Baradyan falu és Kalachna birtok, ill. a monostor birtokának határán, amelyek mellé egy harmadik, új földjelet emeltek a Cyrik-hegy oldalában a Kolos-ról Nogugrouch-ra tartó út mellett hogy mindhárom birtokhoz külön-külön jelzés tartozzék, völgyön át tovább É felé, ebben forrás, mellette új földjel, majd É felé 2 völgy találkozása, hármas útelágazás (vie trite) mellett 2 új jelben Baradyan falu, ill. Kalachna birtok határa, a nagyobb völgyben Ozychna-hegy oldalában 2 új földjel Bardadyan falu és Kalachna elhatárolásaként, tovább É felé, az Ozychna-hegy tetején 2 régi kőjel, amelyeket mindkét fél — így Miklós mr. képviselője és a Baradian-i nemesek is - elfogadott határul, előbb röviden Ke felé, utána É-nak fordul, a Kusugrouch-ra vivő úton tovább 2 régi, síkságon lévő Baradyan-t és Kusugrouch-ot elválasztó határjelhez, amelyek mellé harmadikat is emeltek Kalachna határjelölésére, innen a hegygerinc mentén haladó úton egy erdóhöz, amely szakaszon az út a határ Kusugrouch és Kalachna között, s itt lezárulnak a Baradian faluhoz tartozó határjelek, Ke felé tovább Sypig-hegyhez, tetején kisebb - (vlg.) Evrhig-nek nevezett — halom határjelként Kalachna és Nogugrouch birtok elválasztására, amelynél bevégződik a határ. Mivel ellentmondás nem volt, Kalachna birtokot iktatták Jakab fia: Miklós mr. részére örök birtoklásra. D. f. V. prox. p. domin. Judica, a. d. prenotato [1356.].

E.: Dl. 16 113. (Keglevich cs. lt. AM 18.) Hártyán, hátoldalán azonos és késóbbi kéz írásával tárgymegjelölés, valamint kerek pecsét nyoma, bevágásai.

Má.: Uo., mint E., azzal megegyező jelzet alatt, egyszerú Má.-ban.

K.: Bars, 43-44. (41. szám) (hiányos).

\section{1356. ápr. 15. Visegrád}

[I.] Lajos király $(\mathrm{H})$ [az esztergomi] egyház kápt.-jának: Dalmad-i Tamás fia: István panaszából arról értesült, hogy Lőrinc fia: László mr. barsi (B[ursyensis]) ispánnak az officialis-ai, [Che]nk-i Dénes és Gulach-i Péter ápr. 5-én (f. III. prox. p. domin. Letare) hatalmaskodva rátörtek Dalmad-on lévő házára, s miután összetörték az ajtót (confracto domus seu hostio), meg akarták ölni a panaszost, de végül egy nyíllövéssel csak megsebesítették lovával együtt, ezenfelül jobbágyait - a férfiakat és a nőket egyaránt - megverték, majd arra kényszerítették, hogy levetkőzzenek. A király utasítja a kápt.t, hogy adjon hites tanút Dersenye-i Lipót (Lypoldius) fia: Mihály v. Magyarad-i János fia: Miklós v. Borfew-i István fia: Tamás királyi emberek valamelyike mellé a fenti panasz kivizsgálásához, majd a királyi embernek alkalmas időre a királyi jelenlét elé kell idéznie a barsi ispán, Solmus-i László officialis-ait, Dénest és Pétert Istvánnal szemben, a kápt. pedig mind a tudományvételról, mind az idézésról neki írásos jelenéstétellel tartozik. D. in Wysegrad, f. VI. prox. p. domin. Iudica, a. d. 1356.

Á.: A 250. számú oklevélben.

K.: Str. IV. 145-146. (115. szám). 
[I.] Lajos király (H) tudatja az egri egyház kápt.-jával: Borsua-i Tamás fia: László a maga és fivére (fr. uterinus), Tamás fia: Miklós nevében arról számolt be az ô és az anyakirályné színe e., hogy az Abaújvár (Abawyuriensis) m.-i Borsua v. más néven Zunoghaza birtokuk ügyében kelt oklevelüket tólük ellopták, ill. az valami módon idegen kézre jutott, másik példánya viszont az egri kápt. sekrestyéjében v. levéltárában (conservatorium) fellelhető, s ez most szükséges lenne számukra jogaik biztosítása és igazolása végett. Ezért a király megparancsolja a kápt.-nak, hogy keressék elő a kérdéses oklevelet, és ha az irat Borsua v. más néven Zunoghaza birtokot, továbbá Tamás fiait: Lászlót és Mihályt érinti, valamint a kápt. kétségtelenül bizonyos Tamás fiainak felismerésében, akkor adja ki nekik a szóban forgó oklevelet, óvva inti ugyanakkor óket, nehogy valamilyen félrevezetés v. hamisság essék mindezek teljesítése közben. D. in Vyssegrad, sabb. prox. an. domin. Ramispalmarum, a. d. 1356.

Á.: A 198. számú oklevélben.

K.: -

\section{1356. ápr. 16. [Nagy-]Kapos}

László fia: János mr. Vng m.-i c. és a m. 4 szb.-ja tudatják, hogy Nedam fia: Mihály — a Lelez-i konvent ügyvédvalló levelének meghatalmazásával László fiai: Tamás, Mihály és László nevében eljárva — az egyik szb. közremúködésével eltiltotta Tamás fiait: János mr.-t, Simont, Lászlót és Imrét Strite, Rath és Chop birtokok valamennyi haszonvételének használatától és megszerzésétól. Erről a m. hatósága tilalmazó oklevelet ad ki. D. in Kapus, sabb. prox. an. domin. Ramispalmarum, a. d. 1356.

E.: Dl. 57 342. (Soós cs. lt. 142.) Papíron, vízfoltos, hátoldalán azonos kéz írásával tárgymegjelölés, valamint 4 kerek zárópecsét töredéke, szalagjai, bevágásai.

K.: -

194. 1356. ápr. 17. Visegrád

[I.] Lajos király $(\mathrm{H})$ tudatván Pozsony m. ispánjával, alispánjával és szb.-áival a színe e. Varkon-i János fiainak: Amadénak (Omodeus) és Lotárnak (Lothardus) a panaszából szerzett azon értesülését, amely szerint a Nyulak szigeti (de Insula Leporum) apácák Patas falubeli officialis-a törvényes tiltásuk ellenére Patas birtok Varkon felóli részén felállított egy határjelet, amivel kapcsolatban utasítja a címzetteket, hogy 2 kiküldött szb. vizsgálja ki a panaszt, majd ennek eredményét jelentsék írásban számára. D. in Vissegrad, in domin. Ramispalmarum, a. d. 1356.

E.: Dl. 48 572. (Üchtritz-Amadé cs. 1t. 5. 1. 63.) Papíron, hátoldalán azonos kéz írásával tárgymegjelölés, valamint vörös záró gyưrüspecsét, bevágásai.

K.: HO II. 99-100. (70. szám).

Megj.: Vö. a 212. számú oklevéllel. 
[I.] Lajos király (H, Da, C, Ra, Se, G, L, Cu, Bu, Sal., mont. S. Angeli dom.) a színe e. rokonaik nevében is megjelent István fia: Petew, János fia: Péter, Pál fia: Miklós, Rodizlow fia: András, Iwahim fia: Miklós, Fábián fia: Imre, Éliás (Elyeus) fia: Balázs és Gordas nb. Zeker fia: György kérésére és oklevél-bemutatása alapján autentikus kettős pecsétje alatt kibocsátott privilégiumában átírja és megerősíti [IV.] László királynak $(\mathrm{H})$ azt az 1279-ben kiállított kiváltságlevelét, amely a kedvezményezetteknek Ryuche-i várjobbágyi helyzetükból való kiemeléséról és a valódi nemesek sorába iktatásáról rendelkezett. Kelt Miklós zágrábi püspök és királyi alkancellár keze által, a. d. 1356., XIV. Kal. mensis Maii, uralkodásának 15. évében. Méltóságnévsor: Miklós lévén az esztergomi érsek, egyben ua. m. örökös c.-e - a kalocsai érseki szék üresedésben -, Wglinus a spalatói érsek, Miklós az egri, Demeter a váradi, András az erdélyi, Miklós a pécsi, János a veszprémi, Kálmán a győri, Mihály a váci, Tamás a csanádi, Tamás testvér a szerémi, István testvér a nyitrai — a boszniai szék üresedésben —, Balázs testvér a knini püspök; Kunth Miklós lévén a nádor és a kunok bírája, Tyko a tárnokmr., András az erdélyi vajda és a Zonuk-i c., Zeech-i Miklós az országbíró, Miklós a Machow-i bán, Leustachius mr. Somogy, Fejér és Tolna m.-k c.-e, egyben az egész Szlavónia bánja, Leukus az asztalnokés a pohárnok-, Dénes a lovász-, Péter fia: és Tamás az ajtónállómr., valamint Móric fia: Simon a pozsonyi c. A

E.: AH. Akademije Diplomata latina 2. 53. (Df. 230 215.).

K.: F. IX. 7. 140-142. (88. szám) Egy 1357. nov. 4-én kelt, I. Lajos király által kiadott Á.-ra való hivatkozással; Smic. XII. 341-342. (256. szám) E.-re való hivatkozással, Horvát Akadémiai zágrábi lt. Diplomata a. 1279.

Megj.: Vö. a 168. számú oklevéllel. IV. László király 1279- ben kelt privilégiumát 1. Reg. Arp. 2972. szám.

196. 1356. ápr. 18.

Anno 1356. die 18. Apr. utasítják a Mo. királyához tartó követeket, hogy mivel a király v. valamely alattvalója a néhai Pál c.-nek egy unokáját (nepos) és egyik lányát túszként (obses) kezeiben tartja, ezért amikor a [velencei] köztársaság más ügyeiról beszélnek, legyen gondjuk arra, hogy ezeknek az elengedése megtörténjen.

K.: Ljubić II. 319-320. (475. szám); Wenzel, Dipl. Eml. II. 472. (377. szám) Mindkettő a „Misti” velencei államkönyv alapján XXVII. 72.

197. 1356. ápr. 19.

A [pécs-]váradi monostor konventje tudatja: megkapták Zeech-i Miklós országbírónak, Thuruch m. c.-ének itt átírt, 1355. okt. 13-án Visegrádon kelt oklevelét, és az abban leírt kérésnek megfelelően Myslen-i Sebestyén királyi ember mellé a két fél oldalára tanúul adták Pál és János pap testvéreket, akik ápr. 13-án (in quind. medii Quadr.) kimentek Narad és Kulked birtokokra, s ott a pécsi püspök nevében eljáró Demeter mr. pécsi kanonok bemutatta a birtokra vonatkozó oklevelet, ezzel szemben Miklós és László mr.ek semmiféle oklevelet nem tudtak bemutatni, és még határjeleket sem tudtak mutatni, ezért a püspök oklevele alapján akarták a szóban forgó két birtokot a határjelek mentén 
elválasztani, de ettől a Teuteus mr. fiai: Miklós és László mr.-ek személyében megjelenő Herbordus fia: Mark eltiltotta óket. D. f. III. prox. p. domin. Ramispalmarum, a. d. 1356.

E.: D1. 87 317. (Esterházy család hercegi ága, Repositorium 32. C 144.) Papíron, hátoldalán azonos és késóbbi kéz írásával tárgymegjelölés, valamint kerek zárópecsét nyoma, töredékei, bevágásai.

K.: -

R.: Kőfalvi T., Pécsvárad 157. (245. szám).

198. 1356. ápr. 20.

Az egri egyház kápt.-ja tudatja: színe e. Borsua-i Tamás fia: László bemutatta [I.] Lajos király ápr. 16-án kelt, itt átírt oklevelét (l. 192. szám), majd az abban foglalt parancsnak megfelelően sekrestyéjükből előkeresték a Borsua birtokkal kapcsolatban az egri kápt. által 1326-ban kiállított privilégiumot (l. Anjou-oklt. X. 570. szám) - amelyben átírták [IV.] Béla király 1264. ápr. 8-án kelt adománylevelét —, s a fellelt okiratot átírták és átadták a kérelmező Lászlónak jogai biztosítékául, az eredeti példányt pedig megőrzésre visszatették. D. f. IV. prox. p. domin. Palmarum, a. d. 1356.

E.: Dl. 71 868. (Rákóczi-Aspremont cs. 34. 2. 2.) Hártyán, hátoldalán késóbbi kéz írásával tárgymegjelölés, valamint kerek rányomott pecsét nyoma, bevágásai.

K.: -

Megj.: IV. Béla király privilégiumát 1. Reg. Arp. 1401. szám.

199. 1356. ápr. 21.

Az egri egyház kápt.-ja e. Sebus-i Synka fia Péter fia: János a maga, apja, Péter, valamint fivérei: Miklós, László és István nevében is tiltakozik az ellen, hogy Poharus (dict.) Péter mr. és Souar-i Péter fia: Sows (dict.) Miklós a kiküldött királyi és kápt.-i emberekkel utóbbinak Sowar, míg Péter mr.-nek Kapy birtoka határait bizonyos, az ő Sebus és Gergerfolua birtokaik szomszédságában levő helyeken — amelyek vitás hovatartozása körül közöttük per támadt —, bejárták a határokat, jóllehet Péter és Miklós a hj.-t és a birtokok elkülönítését nem tehették volna meg a köztük lévő peres ügyekre tekintettel, ám mégis ezt tették, s eljárásuk során a panaszosok birtokaiból nagy darab földeket igyekeztek a saját birtokaikhoz csatolni azok nem kis kárára. Ezért, ahogyan már a minap Souar és Kapy birtokokon szemtől szemben a királyi és kápt.-i emberek e. eltiltották Péter mr.-t és Miklóst, ill. mindenki mást is ezen cselekményektől, most ugyanígy megtiltja a kápt. színe e. is a maga, továbbá apja és fivérei nevében, hogy birtokaikból a nevezettek valamely földrészt csalárdul elfoglaljanak. D. in die Cene d., a. eiusdem 1356.

E.: Dl. 57 343. (Soós cs. 1t. 143.) Papíron, hátoldalán késóbbi kéz írásával tárgymegjelölés, valamint kerek pecsét nyoma, bevágásai.

K.: AO. VI. 449- 450. (287. szám) (kihagyásokkal). 
Az aradi kápt. - miként azt ápr. 23. u. kelt oklevele tanúsítja - tudatja, hogy [Pisky György fia:] Balázs a királyi és a kápt.-i emberrel ápr. 23-án (in sa[n]cto sabb. a. d. 1356.) Nadasd és Pisky birtokokra ment, ahol törvényesen összehívott szomszédok és határosok jelenlétében be akarták járni a birtokok határait és azoknak tulajdonába beiktatatni Balázst, azonban Cykou mr. famulus-a, Mihály ura nevében ellentmondott az iktatásnak és eltiltotta őket attól.

Tá.: Szécsi Miklós országbíró, 1358. jan. 8. u. > uő., 1358. dec. 8. > Bebek István országbíró, 1361. máj. 20. Dl. 87 369. (Esterházy cs. hercegi ága, Repositorium 47. P 8.).

K.: -

\section{1356. ápr. 24.}

Szigfrid (Syfridus), a pannonhalmi (de Sacro Monte Panonie) Szt. Márton-monostor apátja és ue. hely konventje tudatja, hogy Pozsonyban a Duna nagy vizén és Challoban, ti. Verkenye faluban a monostor és apátja számára fizetett vám harmadrészét az oklevél keltétól számítva 10 évre bérbe adják Pozsony város bírájának, Miklós fia: Jakus c.-nek olyan feltétellel, miszerint Jakus c. évente jó súlyú aranyban $240 \mathrm{ft}$.-ot tartozik késedelem nélkül megfizetni 2 időpontban, ti. 120 ft.-ot ápr. 24-én (in fe. B. Georgii mart.), a fennmaradó $120 \mathrm{ft}$.-ot pedig szept. 29-én (in fe. S. Michaelis arch.), amiról a monostor igazoló levelet fog kiállítani. Kikötik továbbá, hogy ha Jakus c. a 10 év folyamán bármikor elmulasztaná az első fizetési határidőt, akkor kétszeresét fizesse, ha a másodikat hagyná figyelmen kívül, akkor az első kifizetést nem veszik figyelembe, a második kifizetést pedig 100 M. ezüst büntetés terheli; ezen felül megállapodtak, hogy ha a mondott vám részét haszonvételeivel együtt a 10 év leteltével Jakus c. nem akarná visszaadni v. valaki más foglalta volna el eközben, akkor bármely bíró elé kerüljön is a per, Jakus v. örökösei a bírói rész nélkül $50 \mathrm{M}$. ezüst bírságot köteles fizetni az apátnak és a monostornak, ha pedig Jakus időközben meghalna, akkor a vám szóban forgó harmada azonnal visszaszáll az apátra és a monostorra. A vámrész bérbeadásáról a konvent függőpecsétjével megerősített privilégiumot bocsát ki. D. in fe. S. Georgii mart., a. d. 1356.

E.: BFL. Capsarium 31 E2 (436). (Df. 207 226.) Hártyán, hátoldalán későbbi kezek írásával tárgymegjelölés, alján pecsét felfüggesztésére utaló bevágások, pecsétje elveszett.

K.: P. II. 423-424. (150. szám) (E.-rôl).

R.: Király, Pozsonyi vám 9; Ortvay, Pozsony II. 890.

Megj.: Jó minőségú, digitalizált változatát 1.

http://www.mom-ca.uni-koeln.de/mom/HU-PBFL/PannHOSB/1356_IV_24/charter?q=207226

202. 1356. ápr. 25.

Pál, a Thurocz-i Boldogságos Szúz-egyház konventjének prépostja tudatja: színe e. a Liptó m.-i Mese fia László fia: Mihály kijelentette, hogy mivel veje (gener), az ugyanazon m.-beli Szentkeresztról (de S. Cruce) való Leustachius fia: Chyneghe $\sim$ Czyneghe annak idején támogatta ôt kiadásaiban Arva [m.-ben] lévő Ieszenoua birtok megszerzésekor, ezért vejének, Chyneghe-nek, az [I.] Károly királytól megszerzett Ieszenoua birtokon 
ugyanakkora részt ad örök birtoklásra, amekkorát a birtokosztály során egyik v. másik gyermekének adott. Az ügyletről a konvent függőpecsétjével megerősített oklevelet állít ki mindkét fél jelenlétében. D. sequenti die fe. B. Georgii mart., a. d. 1356.

E.: -

K.: F. IX. 2. 538. (260. szám) (Kéler Godofréd kéziratos oklevélgyújteményéból IV., 512.).

203. (1356. ápr. 28.e.)

Zeech-i Miklós országbíró felszólítja a [székes-]fehérvári egyház kápt.-ját, hogy adjon hites tanúkat mindkét fél - ti. a veszprémvölgyi Boldogságos Szúz-egyház apácái és a felsorolt Chayagh-i nemesek - részére a királyi udvarból külön erre a feladatra kiküldött királyi ember, Konrád (Corrardus) fia: Miklós - a királyi udvar ifja (aule regalis iuvenis) - mellé, azzal a céllal, hogy ápr. 28-án (f. V. prox. p. fe. Pashe d.) Chytim birtokra menve az apácák v. törvényes képviselőjük révén helyben bemutatott, Károly királytól származó privilégiumban leírtak alapján bejárják a Chayagh birtok felé eső határokat az elsótól az utolsó határjelig. Ha a határjelekról bebizonyosodott, hogy azok igazak és jogosak, akkor azok mentén válasszák el az érdekeltek birtokait - mivel a felek ellentmondást nem tehetnek —-, amennyiben bárki más nem él ellentmondással, úgy szükség szerint állítsanak a régi határjelek mellé újakat, az ily módón elválasztott birtokok maradjanak örök jogon tulajdonosaik birtokában. Ha a hatájeleket nem találnák rendben és valamely földdarab a felek között vitás és peres maradna, akkor azt lehetőség szerint mérjék meg a királyi mértékkel, s ha ez nem lehetséges, akkor fogott bírák közremúködésével becsüljék meg, majd a hj. lefolyásáról a kápt küldjön részletes jelentést a királynak máj. 1-jére (ad oct. fe. B. Georgii mart.).

Eml.: A 214. és a 296. számú oklevélben.

K.: AO. VI. 462-463. (298. szám) (kihagyásokkal).

204. 1356. ápr. 28.

[I.] Lajos király (H, Da, C, Ra, Se, G, L, Cu, Bu, Sal., mont. S. Angeli dom.) a színe e. atyja és fivére, György nevében is eljáró Berberius-i (de Berberio) Ugrin (Ugrinus) fia Budizlaus c. fia: Gergely mr. kérésére és oklevél-bemutatása alapján privilégiumában átírja és autentikus kettős függôpecsétje alatt megerősíti azt a saját, 1345. ápr. 17-én kiadott nyílt oklevelét, amelyben a kérelmezóket megerősítette Rogh várának és szigetének, nemkülönben pedig a magtalanul elhalálozott atyjafiuk, Berberius-i (de Berberio) Iurgius fia: János u. maradt birtokoknak és örökségnek a tulajdonában. Kelt Miklós zágrábi püspök és udvari alkancellár keze által, a. d. 1356. IV. Kal. mensis Mai., uralkodásának 15. évében. Méltóságnévsor: Miklós lévén az esztergomi érsek, egyben ua. m. örökös c.-e — a kalocsai érseki szék üresedésben —, Vglinus a spalatói érsek, Miklós az egri, Demeter a váradi, Miklós a pécsi, András az erdélyi, Tamás a csanádi, János a veszprémi, Kálmán a győri, Mihály a váci, Péter a boszniai, Tamás testvér a szerémi, István testvér a nyitrai, Balázs testvér a knini püspök. Kunt Miklós lévén a nádor és a kunok bírája, Cyko a tárnokmr., András az erdélyi vajda és a Zonuk-i c., Miklós az országbíró, Miklós a Machov-i bán, Leustachius mr. a Somogy, a Fejér és a Tolna m.-i c., egyben az egész Szlavónia bánja, Leukus az asztalnok- és a pohárnok-, Dénes a lovász-, Tamás az ajtónállómr., valamint Móric fia: Simon a pozsonyi c. A. 
E.: - K. szerint a privilégium új kettős királyi pecséttel történő megújítására és megerősítésére 1366. aug. 25-én kerül sor.

K.: F. IX. 2. 479-481. (230. szám); Simč. XII. 343-345. (258. szám) Mindkettő Cornides gyújteménye (I. 5-7.) alapján.

R.: F. IX. 2. 492. (236. szám) (latinul) Jankovics gyújteményben őrzött oklevélre való hivatkozással, mely oklevelet a király új pecsétjével erősítettek meg 1366-ban; Doc. Rom. Hist. C. XI. 16. (14. szám)(románul).

Megj.: Az átírt 1345. évi nyílt oklevelet 1. F. IX. 1. 283-284. (144. szám) (az 1356. évi Á.-ból), valamint ennek nyomán Smič. XII. 197. (149. szám).

\section{1356. ápr. 28.}

A veszprémi egyház kápt.-ja e. Jutas-i Demeter fia: Tamás kinyilvánítja, hogy nagyanyjának, a néhai Ayka-i Bolcha nemes feleségének hozományát és jegyajándékát, valamint ugyanezen Bolcha lányának, Chuna-nak — vagyis Tamás anyjának — a leánynegyedét, amely az ország szokása szerint a szóban forgó asszonyokat a Bolcha kezén volt összes részbirtokból megillette, Ayka-i István fia: Miklós pénzben teljesen kifizette, s ezzel ôk teljes körú elégtételhez jutottak. Ezért Tamás nevezett Miklóst és örököseit a kápt. színe e. nyugtatja a fenti hozományt, jegyajándékot és leánynegyedet illetően, s szavatosságot vállal a részükről felmerülő további követelések elmaradásáért. D. f. V. prox. p. fe. Passce d., a. eiusdem 1356.

E.: Dl. 66 144. (Thaly cs. 1t. 72.) Hártyán, hátoldalán késóbbi kézzel tárgymegjelölés, valamint kerek rányomott pecsét lenyomata, bevágásai.

K.: -

206. (1356. ápr. 30.e.)

[?] Zabolch-i c. és a szb-ák tudatják, hogy a váradi egyház kápt.-jának korábbi oklevelében foglaltak szerint a Szt. ........ ünnepének nyolcadát követő 15. napon (in quind. oct. B. .......(regis Ladizlai [?] [= 1355. [!] júl. 18. ?]) ....... színük e. [Byri-i Tamás] 3 M.-t volt köteles fizetni Panala-i Péter fiainak ........ azok Semien-ben lévő, ôrá háramlott birtokrészéért, mégpedig úgy, hogy másfél M.-t a szóban forgó ünnep nyolcada utáni 8. napon (in 8. die earumdem oct.), további másfél M.-át az ünnep nyolcadát követő 15. napon (in quind. earumdem oct.), míg az időpontok elmulasztása pénzbüntetést von maga u. A kitűzött határnap elérkeztekor Panala-i Péter fiai személyesen jelentek meg, azonban Byri-i Tamás nem jött el, és nem is küldött senkit maga helyett.

E.: Dl. 56 534. (Kállay cs. 1t. App. 1300. 42.) Erősen vízfoltos papíron, hátoldalán azonos kéz írásával tárgymegjelölés, valamint 2 zárópecsét nyoma, bevágásai.

K.: -

R.: Kállay I. 133. (570. szám); Piti F., Szabolcs m. 132. (513. szám).

Megj.: Az irat keltének terminus ante quem-je az ugyanezen ügyben kelt (l. 207. szám) ápr. 30-i kibocsátási napjából adódik. A korábbi feldolgozások közül Kállay az elmosódott terminust Szt. László király ünnepeként határozta meg, s ebból keltezte 1339. körül [!] júl. 11-i időpontra az oklevelet, kiadójaként pedig Mihály fia: László 
mr. szabolcsi alispánt jelölte meg. Piti F. a Dl. 51 702. (l. 207. szám) jelzetú oklevélre való hivatkozással 1356. febr. 6-ra datálta az iratot, ami az elsô fizetési határnap téves olvasatából ered (8. die oct. M[arcelli] a helyes olvasat: in 8 die earundem oct. helyett). Amennyiben olvasatként Kállay feltételezése az irat 2. sorában helyes, és ott valóban in quind. oct. B. regis Ladizlai szerepel, úgy ez az oklevél ténylegesen 1355. júl. 18-ra keltezendő. A [ ]-ben közölt név a hátoldali tárgymegjelölésen és a kapcsolódó ápr. 30-án kelt oklevélen alapul.

\section{1356. ápr. 30. [Ó-]Fehértó}

Cantor (dict.) Bereck mr., Zabolch-i alispán és a m. szb.-ái e. személyesen megjelent mind Panyala-i Péter fia: János, mind az ellene alkalmas időre megidézett Byri-i Tamás mr., amely alkalommal elóbbi János bemutatta a váradi kápt. kötelezvénylevelét, azt állítván, hogy a m.-i hatóság által kiállított bírságlevele is van, mire Tamás a per súlyosságára és nehézségére tekintettel kérte annak elhalasztását. A m. hatósága ezért a pert mindkét fél akaratából teljes válaszadás végett máj. 21-re (ad 22. diem p. datarum presentium) elhalasztja. D. in Feyrthou, sab. prox. p. fe. d. Pasce, a. d. 1356.

E.: Dl. 51 702. (Kállay cs. 1t. 1300. 1020.) Papíron, hátoldalán azonos és késóbbi kéz írásával tárgymegjelölés (eltérő névalakja: Panala), valamint 3 zárópecsét töredéke, bevágásai, szalagjai.

K.: -

R.: Kállay II. 35. (1179. szám); Piti F., Szabolcs m. 133. (515. szám).

Megj.: Vö. a 206. számú oklevéllel.

208. (1356. máj. 1.e.)

[I.] Lajos király $(\mathrm{H})$ elrendeli, hogy a Warada-i László fia: János mr.-nek Pylyskee-i Adas (dict.) László fia: István ellen Pete birtokkal kapcsolatban viselt perét - tekintettel utóbbi fél tengeri hadjáratában való részvételére — halasszák a királyi hadoszlás 15. napjára.

Eml.: A 262. számú oklevélben.

K.: Z. III. 28. (15. szám) (Eml.-ben).

209. (1356. máj. 1.e.)

[I.] Lajos király (H) elrendeli, hogy Benedek fia: Egyednek és Budur fia: Antalnak az egykori bán Lyndua-i István fia: Miklós ellen indított perét Ozyuagh Zengyurgh birtokba való beiktatáskor történt ellentmondás ügyében halasszák a királyi hadoszlás 15. napjára (ad quind. residentie exercitus).

Eml.: A 263. számú oklevélben.

K.: - 
210. (1356. máj. 1.e.)

[I.] Lajos király (H) elrendeli, hogy István fia: Miklós egykori bánnak Scepethnuk-i Mysich, Gegeu, Peder és Péter alperesek ellen indított perét - a Mura folyón, Scengyurgh birtokon lévő bizonyos malommal kapcsolatban — halasszák a királyi hadoszlás 15. napjára (ad quind. residentie exercitus).

Eml.: A 264. számú oklevélben.

K.: Zala I. 565. (360. szám) (Eml.-ben).

211. (1356. máj. 1. e.)

[I.] Lajos király (H) elrendeli, hogy Heem fia Pál fia: Benedek mr. Kurbeu birtok ügyében Karulus fiai: András és Miklós, Detricus fia: Dávid, András fia: István, János fia: Gyuke, Demeter fia: Demeter, Cha[... ?]-i nemesek ellen viselt perét halasszák a királyi hadoszlás 15. napjára.

Eml.: A 273. számú oklevélben.

K.: -

212. (1356. máj. 1. e.)

A budai egyház kápt.-ja hj.-sal és idézéssel kapcsolatos oklevelében a Nyulak szigeti apácáknak a Warkun-i János fiaival: Amádéval (Omodeus) és Lothardus-szal szemben a Pathos birtok iktatásakor és határkitúzésekor történt ellentmondás miatt támadt perében Zeech-i Miklós országbíró színe elé idézi máj. 1-jére ([ad] oct. fe. B. Georgii mart.) a feleket.

Eml.: A 266. számú oklevélben.

K.: -

Megj.: Vö. a 194. számú oklevéllel.

213. (1356. máj. 1.e.)

Miklós egri püspök az Erdutheluk-i Vörös Máté fia: Polhus (dict.) István felperesnek Dénes fia: Tamás, ennek fiai: István és Tamás, valamint Regen-i és Luchonch-i ue. Dénes fia István fia: Dénes alperesekkel szemben indított perét máj. 1-jére ([ad] oct. fe. S. Georgii mart. prox. praeteritis) elhalasztja.

Eml.: A 253. számú oklevélben.

K.: -

214. (1356. máj. 1. e.)

A fehérvári kápt. jelenti [I.] Lajos királynak, hogy az országbíró levelében (l. 203. szám) foglaltak szerint Konrád fia: Miklós, uralkodói kegyból kiküldött királyi ember mellé Chech (dict.) János presbitert adta tanúul az apácák oldalán, akik visszatérve jelentést 
tettek. Eszerint a birtok szomszédainak és határosainak összehívását követôen a felsorolt Chayagh-i nemesekkel és Benche törvényes képviselővel Chytim birtokra mentek, ahol a Károly király bemutatott privilégiumában foglaltak szerint az elválasztó határjelek mentén el akarták választani más birtokoktól. A határok bejárása és kitúzése ellentmondás nélkül megtörtént.

Eml.: A 296. számú oklevélben.

K.: AO. VI. 463-465. (298. szám).

215. (1356. máj. 1. e.)

Miklós nádor $(\mathrm{H})$, a kunok bírája az egri egyház kápt.-ja e. 3 nemessel együtt máj. 1jén (in oct. fe. Pasche d.) leteendő eskü tételére kötelezi Laad-i Domokos fia: Donchot Torna-i János fia: László ellenében, hogy bizonyítván ártatlanságát ezzel tisztázza magát a szóban forgó János Ynanch birtokának szomszédságában lévő Dobza birtok elzálogosítása során felmerült $25 \mathrm{M}$. értékű kár okozásával kapcsolatban.

Eml.: A 279. számú oklevélben.

K.: AO. VI. 456. (294. szám) (Eml.-ben).

216. (1356. máj. 1.e.)

A váci kápt. jelenti Zeech-i Miklós országbírónak, hogy az országbírói parancslevél vételét követően Zeuleu-i Miklós fia: Balázs királyi ember mellé András mr.-t, a Zygethfeui főesp.-t adták tanúul Kysker-i Tódor fia István fia: Mihály oldalán, ugyanakkor a másik királyi ember, Dorchan-i János fia: Jakab társaságában pedig kanonokjukat, János mr.-t küldték ki Keer-i István fia: János és János fia: Mihály részére hites tanúul, akik visszatérve olyan jelentést tettek, miszerint máj. 1-én (in oct. fe. B. Georgii mart. prox. preteritis) kimentek Simon fia Pál fiainak: a néhai Jánosnak és Lászlónak szóban forgó földrészére, ahol azt az összehívott szomszédok és a felek jelenlétében - kivéve István fia: Jánost, akit az országbíró ügyvédvalló levelével Tordas fia: Egyed képviselt — az István fia: Mihály által bemutatott Saag-i konventi nyílt oklevelében foglaltak alapján bejárták ősi határai mentén, és a szükséges helyeken új határjeleket emeltek a szomszédos birtokoktól való elválasztás végett, ahogy azt jelen oklevél részletesen tartalmazza, majd - miután senki nem mondott ellent - beiktatták annak örök jogú tulajdonába István fia: Mihályt és örököseit, a fennmaradó részbe pedig János fia: Mihályt és István fia: Jánost, valamint örököseiket.

Eml.: A 305. számú oklevélben.

K.: -

217. (1356. máj. 1.e.)

Zeech-i Miklós c. királyi országbíró a Benedek fia: Egyed és Budur fia: Antal által az egykori bánnal, Lyndua-i István fia: Miklóssal szemben az Ozyuagh Zengyurgh birtokba való iktatás során történt ellentmondás miatt indított perben máj. 1-jére ([ad] oct. fe. B. Georgii mart.) rendeli színe elé a feleket. 
Eml.: A 263. számú oklevélben.

K.: -

218. (1356. máj. 1.e.)

Zeech-i Miklós c. királyi országbíró az egykori bánnak, István fia: Miklósnak Scepethnuki Mysich, Gegeu, Peder és Péter alperesekkel szemben viselt perében a Mura folyón, Scengyurgh birtokon lévő malommal kapcsolatos oklevél-bemutatás végett máj. 1-jére ([ad] oct. fe. B. Georgii mart.) rendeli színe elé a feleket.

Em1.: A 264. számú oklevélben.

K.: Zala I. 564. (360. szám)(Eml.-ben).

219. (1356. máj. 1.e.)

Zech-i Miklós c. királyi országbíró az Albert fia: Peteu és Leztemer-i Domokos fia: Donch által a Bezeu birtok iktatása során történt ellentmondás miatt Dobou fia: Jakabbal, János deákkal és Kylianus Zeech-i plébánossal szemben indított perben máj. 1-jére ([ad] oct. fe. B. Georgii mart.) rendeli színe elé a feleket.

Eml.: A 265. számú oklevélben.

K.: AO. VI. 455. (292. szám) (Eml.-ben).

220. (1356. máj. 1.e.)

Zeech-i Miklós c. királyi országbíró a Byry-i Tamás fiainak: Jánosnak és Lászlónak, valamint Tamás feleségének István fia: Istvánnal szemben támadt perében máj. 1-jére ([ad] oct. fe. B. Georgy mart.) rendeli színe elé a feleket.

Eml.: A 267. számú oklevélben.

K.: -

221. (1356. máj. 1.e.)

Zeech-i Miklós c. királyi országbíró a Byry-i Tamás fiainak: Jánosnak és Lászlónak, valamint Tamás feleségének Kallou-i László fiaival: Mihállyal és Ubullal szemben támadt perében máj. 1-jére ([ad] oct. fe. B. Georgy mart.) rendeli színe elé a feleket.

Eml.: A 268. számú oklevélben.

K.: -

222. (1356. máj. 1.e.)

Zeech-i Miklós c. királyi országbíró a Magyar (dict.) Pál mr. hitvesének, Margit nemes asszonynak Varada-i László fia: János mr.-rel szemben viselt perében — amely közöttük egy Varada birtok felől elhelyezkedő és állítólag Patroh birtokhoz tartozó földdarab 
iktatása során történt ellentmondás miatt támadt — máj. 1-jére ([ad] oct. fe. B. Georgy mart.) rendeli színe elé a feleket.

Eml.: A 269. számú oklevélben.

K.: Z. III. 26-27. (14. szám)(Eml.-ben).

223. (1356. máj. 1. e.)

Zech-i Miklós országbíró máj. 1-jére ([ad] oct. fe. B. Georgii mart.) idézi bírói színe elé Lyder-i Tamás fia: Lorándot Jako-i Kozma (Cosma) fiai: Henrik, Miklós és István ellenében.

Eml.: A 270. számú oklevélben.

K.: -

224. (1356. máj. 1.e.)

Zeech-i Miklós c. királyi országbíró a Huzyubach-i János fiainak: Miklós és János mr.eknek a Szerém m.-i Bodon-i Simon fia: Jánossal szemben egy, a Scimotha birtokon lévő részbirtok iktatása során történt ellentmondás miatt indított perében máj. 1-jére ([ad] oct. fe. B. Georgii mart.) rendeli színe elé a feleket.

Eml.: A 272. számú oklevélben.

K.: -

225. (1356. máj. 1.e.)

Zech-i Miklós c. királyi országbíró a Kurbeu birtokkal kapcsolatos oklevél-bemutatás kötelezettsége ügyében, amelynek Heem fia Pál fia: Benedek mr. ellenében az általa perbe vont Cha[. ?]-i nemeseknek, Károly fiainak: Andrásnak és Miklósnak, Detricus fia: Dávidnak, András fia: Istvánnak, János fia: Gyuke-nek, és Demeter fia: Demeternek [Dettricus-nak?] kellett eleget tenniük, máj. 1-jére ([ad] oct. fe. B. Georgii mart.) rendeli színe elé a feleket.

Eml.: A 273. számú oklevélben.

K.: -

226. (1356. máj. 1. e.)

Zeech-i Miklós országbíró Oryauicha birtokrész ügyében esedékes oklevél-bemutatás végett máj. 1-jére ([ad] oct. fe. B. Georgii mart.) rendeli bírói színe elé Orboua-i Péter fia Leukus nemes hitvesét Dobouch-i Cymba (dict.) István fia: Istvánnal, valamint Dobouch-i Cymba (dict.) István fia: Domokos nemes leányaival, Anych-csal és Bogowval szemben.

Em1.: A 298. számú oklevélben.

K.: AO. VI. 466. (299. szám) (Eml.-ben). 
[VI.] Ince pápa Bertalan traui püspökhöz: utasítja a püspököt, hogy mielóbb térjen vissza az apostoli székhez és számoljon be azokról az ügyekrôl, amelyeknek elintézését a pápa rá és Péter patti-i (Pactensis) püspökre bízta Rassia, Da. és Szlavónia országában, s amelyekről övéit elő szóban úgyszintén tájékoztassa. D. Avinione, Kal. Maii, pápasága 4. évében [1356.].

Reg.: ASV. Reg. Av. v. 132., f. 538r (Df. 289 519.).

K.: Theiner, Mon. Slav. I. 234. (315. szám) (Reg.-re alapján); Smič. XII. 345. (259. szám) (Theiner alapján).

\section{1356. máj. 1. Prága}

[IV.] Károly római császár és király (Bo) eleget téve [III.] Kázmér király (P) kérésének birodalmi pecsétjével megerôsített privilégiumában átírja [I.] Lajos király (H) két, 1353. máj. 27-én Budán kelt oklevelét [, amelyben Lajos király a császárnak örökre átadja a Świdnica-i és a Jawor-i fejedelemségeket (ducatus); valamint a Płock-i fejedelemségért cserében, melyeket Kázmér királlyal együtt kaptak meg a császártól, átadják Byczyna (Byczina) és Kluczbork (Kreuzburg) városokat.] D. Prage, a. d. 1356., Kal. Maii, császársága 10. évében.

E.: AGAD Archiwum Korone Krakowskie: Documenty pergaminowe 16. (Df. 288 959.) Hártyán, a plikatúrán átfüzött hártyaszalaggal.

K.: -

R.: RI. VIII. 264. szám.

Megj.: I. Lajos király két átírt oklevelét 1. ŠÚA. Praha (Prága). Archiv české Koruny, Oklevelek és iratok 392. (Df. 287 462.) és uo. 393. (Df. 287 463.), kiadása: CJ. Boh. II. 1. 369-371. (333. szám) és 369. (322. szám).

\section{1356. máj. 1. Prága}

[III.] Kázmér király (P, Russie, Cracovie, Sandomirie, Syradie, Lancicie, Cuyauie és Pomeranie terrarum et ducatum dominus et heres) tudatja, hogy az 1348. nov. 22-én Namysłowban (in opido Namislauia sub a. d. 1348., ind. 1., X. Kal. Dec., Károly római király uralkodásának 3. évében) IV. Károly császárral és királlyal (Bo) kötött megállapodást eskü alatt kölcsönösen megerősítik. Ezenfelül részletesen leírt feltételek szerint kölcsönös anyagi és katonai jelegû segítségnyújtást ígérnek egymásnak ellenségeikkel szemben, amelynek teljesítéséhez Kázmér király [I.] Lajos királyt (H), Károly császár pedig fivérét, János morva őrgrófot jelöli meg kezesül. Pecsétjével látja el az oklevelet. Actum et datum Prage, a. d. 1356. die BB. Philippi et Jacobi ap.

E.: ŠÚA. Praha (Prága). Archiv české Koruny, Oklevelek és iratok 565. (Df. 287467.$)$ Hártyán, alján rozsdaszín sodraton Kázmér király pecsétje függ (rajta trónon ülő, koronás alak, baljában országalma, jobbjában jogar, köriratán a király intitulatioban megjelölt címei olvashatók), hátoldalán tárgymegjelölés.

K.: CD. Mor. IX. 12-14. (13. szám); CD. majoris Pol. III. 50-52. (1340. szám); Reg. Boh. Mor. VI. 173-174. (326. szám). 
R.: RI. VIII. 262. szám; Archivum Coronae Regni Bohemiae IV. 1. 89. (567. szám).

Megj.: Jó minőségú digitalizált változatát 1. http://lehre.hki.uni-koeln.de/monasterium/img/CZ-NAI/ACK/NA-ACK_13560501_00565_r.jpg. A Namysłow-i paktum szövegének kiadását 1. CJ. Boh. II. 1. 314. (282. szám).

\section{1356. máj. 1. Prága}

[III.] Kázmér király (P, Russie, Cracovie, Sandomirie, Syradie, Lancicie, Cuyauie és Pomeranie terrarum et ducatum dominus et heres) átírja [I.] Lajos király (H) 1353. máj. 27-én Budán kelt oklevelét, s ezzel a Świdnica-i és a Jawor-i fejedelemségeket (ducatus) átadja [IV.] Károly császárnak és egyben lemond az őt és a Lengyel Királyságot a fejedelemségekben megillető jogairól. Actum et datum Prage, a. d. 1356., die BB. Philippi et Jacobi ap.

E.: ŠÚA. Praha (Prága). Archiv české Koruny, Oklevelek és iratok 563. A MOL nem tartja nyilván az iratot. Jó minőségú digitalizált változatát 1. http://lehre.hki.uni-koeln.de/monasterium/img/CZ-NA-I/ACK/NA-ACK_13560501_00563_r.jpg.

R.: RI. VIII. 263. szám; Archivum CRB IV. 1. 88. (565. szám); Reg. Boh. Mor. VI. 174. (327. szám).

\section{1356. máj. 1. Prága}

Kázmér király (P) a Płock-i fejedelemségért cserében, amelyeket [IV.] Károly császár és király visszaadott számára, átadja neki mint cseh királynak Byczyna (Byczina) és Kluczbork (Kreuzburg) városokat, Bolko Świdnica-i herceget (dux) pedig felmenti minden kötelezettsége alól. Átírja [I.] Lajos király (H) 1353. máj. 27-én ugyanezen ügyben kelt oklevelét. Actum et datum Prage, a. d. 1356. die BB. Philippi et Jacobi ap.

E.: ŠÚA. Praha (Prága). Archiv české Koruny, Oklevelek és iratok 564. A MOL nem tartja nyilván az iratot. Jó minőségú digitalizált változatát 1. http://lehre.hki.uni-koeln.de/monasterium/img/CZ-NA-I/ACK/NA-ACK_13560501_00564_r.jpg.

R.: Archivum CRB IV. 1. 88-89. (566. szám); Reg. Boh. Mor. VI. 175. (328. szám).

\section{1356. máj. 1. Visegrád}

László, a csázmai egyház prépostja, [I.] Lajos király $(\mathrm{H})$ kápolnaispánja és titkos kancellárja tudatja: a korábbi egyezséglevelében foglaltak szerint Miklós zágrábi püspök, udvari kancellár, rokonának, Saro-i Bede fia: Péternek a nevében kötelezte magát, hogy László, az egri egyház prépostja, továbbá Demeter, barsi főesp., nemkülönben testvéreik (fr. uterinus), Ders fia Tamás fiai: István és Péter számára az 1354. ápr. 6-tól (a domin. Ramispalmarum, a. d. 1354) számított 2 éven belül kieszközöl valamilyen királyi kegyet v. birtokadományt. Ha ez nem sikerülne, akkor a királyi kápolnaispán e. nevezett Bede fia: Péter a 3. évben, nevezetesen [1356.] máj. 1-én (in oct. B. Georgii mart., in 3. scilicet reuolutione annuali) 15 budai M.-t köteles készpénzben, dénárokban (in promptis denaris) fizetni a nevezett prépostnak és fivéreinek. Az időpont elérkeztekor a kápolnaispán színe e. megjelent Magarad-i János fia: Mihály az esztergomi kápt. ügyvédvalló levelével Bede fia: Péter képviseletében, s mivel Miklós püspök nem tudott 
királyi kegyet v. birtokadományt kieszközölni a nevezettek javára, így megbízója nevében Mihály kifizette a mondott összeget a fivéreit is képviselő egri prépostnak a Hont m.-i Lyso birtok folyamatos birtoklása fejében, ti. a birtokot korábbi királyi és kápolnaispáni oklevelek értelmében az egri prépost és fivérei elidegenítették Péternek. A prépost nyugtatja Pétert az összeg átvétele felől. D. in Vissegrad, in oct. B. Georgii mart. prenotatis, a. d. 1356.

E.: Dl. 58 545. (Forgách cs. 1t. 179.) Hártyán, hátoldalán késóbbi kéz írásával tárgymegjelölés, valamint a király kerek rányomott pecsétjének a töredéke (körirata: [+S(IGILLVM)] LODOVICI DEI [GRATIA R]EGIS HVN[G]ARIE), bevágásai.

K.: F. IX. 2. 512-514. (250. szám) A Forgách cs. lt.-ban őrzött E.-re való hivatkozással.

R.: Pór A., Magyar Történeti Életrajzok 20 (1904) 66-67.

Megj.: Az 1354-ben kelt egyezséglevelet közelebbról nem sikerült azonosítani.

\section{1356. máj. 1.}

Az egri egyház kápt. e. Gepu-i Gogan fia: Zeuke mr., Miklós egri püspök rokona és famulus-a (proximus et famulus) a maga, valamint - a veszprémi kápt. ügyvédvalló levelével képviselt — nemes felesége, Dobronth-i Bada fia Miklós c. lánya, Margit nevében is kinyilvánítja, hogy az Obon püspöki faluból való néhai hospes-nek, Kysded (dict.) Mihálynak a fiai: Miklós, Benedek és Pál attól az idótól kezdve, hogy ốk feleségével együtt Eger városába érkeztek, nekik hú szolgálatokat tettek, ügyes-bajos dolgaikban a megfelelő idóben és helyen rendre segítségükre lenni törekedtek, ezért szolgálataik viszonzásaképpen annak a teleknek (fundus seu locus sessionalis) a felét, amely egykor Kysded (dict.) Pálé, az egri egyház néhai püspökének, Mártonnak a famulus-áé volt az Egurvyze folyó mellett, Ny felól Eger új város házsorával átellenben (iuxta fluvium Egurvyze ex opposito contrahate nove civitatis Agriensis a plaga occidentali adiacentem), amelyet hajdan kanonoki helynek (locus canonicalis) mondtak, valamennyi haszonvételével és tartozékával, továbbá a rajta emelt épületekkel együtt neki adják Mihály felsorolt fiainak, a másik felét pedig, amely az egri völgy szokása szerint (juxta huius vallis Agriensis consuetudinem) nemes feleségének a tulajdonát képezi, a kápt. e. az asszony nevében eladja Mihály fiainak örökre és visszavonhatatlanul azért a 16 királyi ft.-ért, amelyet azok már teljesen megfizettek neki. Az ügylethez a kápt. - beleegyezésének megadása mellett - olyan, Mihály fiai által elfogadott, s örököseikre nézve is kötelező érvényú feltételt köt, hogy ha Mihály fiai az idők folyamán közösen v. külön-külön ezt a kanonoki telket (locus sessionalis concanonicalis) el akarnák adni, akkor azt ne adhassák el bárkinek, csakis az egri egyház kanonokjának. D. in oct. fe. Resurrectionis d., a. eiusdem 1356.

E.: HML. 87. Egri székeskápt. mlt. 3. 1. 1. 4. (Df. 209 987.) Hátoldalán késóbbi kezek írásával tárgymegjelölések.

K.: -

234. 1356. máj. 1.

A somogyvári (de Symigio) Szt. Egyed-monostor konventje tudatja: jóllehet a színe elé járult Rupul-i Amádé (Omodeus) fia Miklós egykori bán fia Miklós fia: János mr. átadta 
a Somogy m.-ben, Folkus és Zenthpal birtokai között fekvő Nemthy nevezetú örökletes birtokát annak minden tartozékával együtt visszavonhatatlanul örök birtoklásra a másik részról megjelent Saag-i Máté fia: János deáknak (literatus), azonban a konvent ezt magába foglaló privilégiumában nem írták le a birtok határait, amit most a jövőbeni békesség kedvéért Miklós fia: János mr. beszámolója alapján rögzítenek. A határ Ke-en kezdődik egy forrásnál a Petedgudrufeu nevú helyen, a vízfolyásban Dé felé egy szögletben Márk fia: János malmához, Ny felé tovább, Gycheudmolna malom, Nemthy birtokhoz tartozó újabb malom, majd Moius fia: Péter malma, Kenderatofeu nevú hely, É felé régi árkon keresztül egy cserjéig, É felé tovább elkanyarodva, keresztezi a Mogas faluba vezetố nagy útat, tovább É felé, Kysuelg völgy, bejáratánál körtefák, egyikük kereszttel jelölve, a határjel itt alámegy egy örvénynek (subit unam gurgitem), onnan a vízfolyás forrásánál (in rivi capite) lévő, birtokszögletet jelző nagy tölgyfához, Ke felé domb irányában tovább, a szőloók mellett egy ösvényhez ér, tovább a Korogpataka patakba, abban tovább Myko fia: Pál malma alatt a Kerekberuk völgyi forráshoz, majd a völgytorok felé, ahol a Nemthy-ból Folkus-ba vezető út kettéválik, közöttük az esővíz folyásakor kimosott árok, Ke felé másik dombon keresztül vissza a kezdőponti forráshoz Petedgudrufeu-nél. D. in oct. fe. B Georgii mart., a. d. 1356.

E.: D1. 4604. (NRA. 1018. 17.) Hártyán, hátoldalán késóbbi kéz írásával tárgymegjelölés, valamint kerek rányomott pecsét nyoma, bevágásai.

K.: AO. VI. 450-451. (288. szám) (kihagyásokkal).

R.: Borsa I., Somogy m. lt. Évk. 29 (1998) 255. szám.

Megj.: A somogyvári konvent említett kiváltságlevele 1355. nov. 18-án kelt, 1. Dl. 4559. (NRA. 555. 18.).

\section{1356. máj. 1.}

A Scepus-i Szt. Márton egyház kápt.-ja e. Forkach (dict.) Miklós mr. a maga, valamint fivérei nevében is tiltakozik az ellen, hogy — miként arról értesült — [I.] Lajos király (H) anyjának, Erzsébet királynénak adományozta az ő Gyemes várukat tartozékaival együtt, amelyet annak idején vérük ontásával [szereztek]. A királyt a vár és a hozzá tartozó birtokok eladományozásától, a királynét azok birtokbavételétől tiltja. D. in oct. fe. Pasche, d. a. eiusdem 1356.

E.: DL 58 544. (Forgách cs. lt. 180.) Papíron, hátoldalán azonos és késóbbi kezek írásával is tárgymegjelölés (elóbbiben eltérô névalak: Farkoch), valamint a szepesi kápt. kerek zárópecsétjének töredéke (körirata: + S[IGILLVM] CAPITVLI EC[C]LESIE BE[ATI MA]RTINI DE SCEPUS), szalagjai, bevágásai.

K.: F. IX. 2. 511-512. (249. szám) A Forgách cs. lt.-ban őrzött E.-re való hivatkozással.

236. (1356. máj. 1-8. között

Az egri egyház kápt.-ja tanúsítja, hogy a színe e. megjelent Laad-i Domokos fia: Donch máj. 1-jén (in oct. fe. Pasche d.) harmadmagával esküt tett arra vonatkozólag, hogy Dobza nevú birtoka elzálogosításakor $25 \mathrm{M}$. értékben nem károsította meg a szomszédos Ynanch birtokosát, Torna-i János fia: Lászlót.

Eml.: A 279. számú oklevélben. 
K.: AO. VI. 457. (294. szám) (Eml.-ben.).

237. (1356. máj. 2.e.)

A pécsi egyház kápt.-ja memorialis oklevelében rögzíti azt a Ders fia: Miklós mr. és fia, Ders részéről elfogadott fogott bírói ítéletet, amely az egyik részról a nevezettek, a másik részről pedig a néhai Suklos-i Péter fia Pál mr. fiai: Gyula, Miklós és István között fennforgó viszályban először Miklós mr. fia: Ders-et kötelezte, hogy máj. 2-án (II. die oct. fe. Pasche d.) a kápt. színe e. 100 magához hasonló nemessel együtt leteendő esküvel tisztázza magát azzal kapcsolatban, miszerint ő maga nem mérgezte meg, és nem is ölte meg Suklos-i Péter fia: Pál mr.-t és annak fivérét (fr. carnalis), Istvánt, majd pedig azután Ders fia: Miklós mr.-t is ugyanazon a napon és helyen, ugyancsak 100 nemes eskütárssal együtt letendő esküvel bizonyítsa, hogy a szóban forgó mérgezés és halál nem az ô tudtával vagy akaratából történt.

Em1.: A 244. számú oklevélben.

K.: -

238. (1356. máj. 2.e.)

Zeech-i Miklós országbíró tudatja a bácsi egyház kápt.-jával azon ítéletét, amelyben a kápt. e. máj. 2-án (2. die oct. fe. B. Georgy mart.) ötvenedmagukkal — fejenként 24-24 nemes eskütárssal - együtt leteendő esküre kötelezi Huzybach-i János fiait: Miklóst és Jánost B.......-i Sebestyén fia: János ellenében, hogy igazolhassák, miszerint Kanata és Huzyubach falvakban lakó (residentes) famulus-aik, Beke, Ipolitus és Erdeus [?] fia: Tamás egy éve (revolutio annualis) [1355.] márc. 5-én (f. V. prox. p. domin. Remin.) nem az ó egyetértésükkel és tudtukkal verték agyon a Huzyubach faluból a piacról távozó és a közúton haladó Sebestyén fia: János fivérét (fr. uterinus), Balázst. A felek az eskütételtől számított 8 . napon (8 die), máj. 9-én kötelesek bírói színe e. a kápt. erról írt jelentését bemutatni.

Eml.: A 286. számú oklevélben.

K.: -

239. (1356. máj. 2.e.)

Zeech-i Miklós országbíró ítéletlevelében tudatja az egri egyház kápt.-jával, hogy a kápt. e. máj. 2-án (2. die oct. fe. Passce d.) leteendő esküre kötelezi Chahol-i János fia: Sebestyén mr.-t ötvenedmagával, nemes eskütársakkal együtt Berue-i István fia: András ellenében, ezzel bizonyítandó panaszát, miszerint István fia: András az elmúlt év [1355.] márc. 11-én (f. IV. in die medii Quadr.) Berue birtokáról hatalmaskodva rátört Prazna birtokra, ahonnan a panaszos 16 M.-át érő 2 lovát elkötötte, és Berue-be vitte. A feleknek az eskü letételéról számot adó kápt.-i jelentést — eskütevő társaik nevének feljegyzésével — máj. 9-re (8. die) kell az országbírónak visszavinniük.

Eml.: A 287. számú oklevélben.

K.: - 
[I.] Lajos király $(\mathrm{H})$ a zágrábi kápt.-nak: a színe elé járuló Miklós testvér, az első remete, Szt. Pál rendjének Mo.-i és Szlavónia provinciális perjele, és János, ugyanezen rend zágráb-elóhegyi Boldogságos Szûz házának perjele kérésének eleget téve - mivel a Boldogságos Szűz háza és a benne lakó testvérek szükséget szenvednek szántóföldekben — utasítja a kápt.-t, hogy küldje ki emberét Paris fiai: Fülöp v. Pasa, v. Maryas fia: Márk királyi emberrel Pristauchy[na] birtokra, ahol az összehívott határosok és szomszédok jelenlétében ki kell mérniük 35 ekealja földet valamennyi tartozékával és haszonvételével együtt, és — ha ellentmondó nincs — iktatniuk kell ezen királyi adományt örök birtoklásra a mondott egyház és szerzetestestvérei részére. Ellentmondás esetén alkalmas időre színe elé idézni parancsolja a feleket, a történtekról pedig írásos jelentést vár. D. Zagrabie, 2. die oct. fe. Pasce d., a. eiusdem 1356.

Á.: A 289. számú oklevélben.

K.: Smič. XII. 345-346. (260. szám) (1369-es Á.-ról).

\section{1356. máj. 2. Zágráb}

[I.] Lajos király $(\mathrm{H})$ — miként azt [1356.] máj. 2-án Zágrábban (II. die oct. fe. Passce d. prox. preteriti Zagrabie) kelt és nagyobb pecsétjével megerősített parancslevele tanúsítja — elrendeli, hogy Lengel (dict.) János fiainak valamennyi perét halasszák el a királyi hadoszlás 15. napjára.

Tá.: A 277. számú oklevélben.

K.: -

242. 1356. máj. 2.

IV.Károly császár figyelmezteti I. Lajos királyt (H), hogy ne lépjen egyezségre Velencével, tekintettel arra, hogy a császárnak hatalmában áll a szükséges feltételek elfogadására szorítani a signoriát.

R.: Óváry 47. (57. szám) (Velencei lt.-ra való hivatkozással); uô., TT. 11 (1888) 455.

\section{1356. máj. 2.}

A nyitrai egyház kápt.-ja e. a Zeech-i Miklós c., országbíró, Turuch m.-i c. márc. 23-i oklevelében (l. 135. szám) foglaltaknak megfelelóen Dwb-i Lunev Lweu (dict.) Miklós 7 nemessel együtt esküt tett máj. 1-jén (in oct. fe. B. Georgy mart. prox. preterito) arra vonatkozólag, hogy Miklósnál lakó veje, Petheu [1355.] nov. 8-án (die domin. prox. p. fe. OO. SS. ) nem lopta el fényes nappal Damyan-i András fia: Herbordus 50 ft.-ot érő 2 lovát és nem is vitte azokat Miklós házához; e lovak nincsenek és nem is voltak Miklósnak a telkén soha, és ott azokat senki, sem nemesek, sem nemtelenek nem láthatták. D. f. II. prox. p. oct. fe. S. Georgii mart. supradictas, a. d. 1356.

E.: - Fk. Dl. 95 261. (Ocskay cs. 1t. 31.).

K.: - 


\section{1356. máj. 2.}

A pécsi egyház kápt.-ja emlékezetül adja: a korábbi, fogott bírói ítéletből eredő kötelezettségeket rögzítő memorialis oklevélben (l. 237. szám) foglaltakat teljesítve Miklós fia: Ders a kápt. színe e. máj. 2-án (II. die oct. fe. Pasche d.) századmagával, nemes eskütársakkal együtt letett esküjével tisztázta magát azzal kapcsolatban, hogy vétlen Suklos-i Péter fia: Pál mr. és annak fivére (fr. carnalis), István megmérgezésében, ill. megölésében, azután pedig apja, Ders fia: Miklós mr. hasonlóképp 100 eskütevővel együtt esküdve bizonyította, hogy a szóban forgó mérgezés és halál nem az ő tudtával v. akaratából történt. Az eskütételnél megjelent az elhunyt Pál mr. fia: Gyula Giula is fivéreit, Miklóst és Istvánt ugyancsak képviselve D. in termino supradict., a. d. 1356.

E.: Dl. 4605. (NRA. 1698. 88.). Papíron, hátoldalán azonos kéz írásával tárgymegjelölés, valamint mandorla alakú pecsét nyoma.

K.: AO. VI. 451-452. (289. szám).

\section{5. (1356. máj. 2-9. között)}

A bácsi egyház kápt. jelenti Zeech-i Miklós országbírónak, hogy a hozzá intézett ítéletlevélben (l. 238. szám) foglaltaknak megfelelően máj. 2-án (2. die oct. fe. B. Georgy mart.) színe e. sor került Huzybach-i János fiai: Miklós és János , valamint eskütársaik B.......-i Sebestyén fia: János elleni esküjére.

Eml.: A 286. számú oklevélben.

K.: -

246. (1356. máj. 2-9. között)

Az egri kápt. jelenti Zeech-i Miklós országbírónak: a kápt.-hoz intézett ítéletlevelében (l. 239. szám) foglaltak szerint eljárva (l...szám) Chahol-i János fia: Sebestyén mr. máj. 2án (in f. II. prox. an. oct. fe. Passce d.) panaszát bizonyítandó esküt tett István fia: András ellenében a név szerint felsorolt 49 nemessel együtt (l. 287. szám). Az eskütételt István fia: András az egri kápt. e. személyesen hallgatta meg.

Eml.: A 287. számú oklevélben.

K.: -

247. 1356. máj. 3.

Az egri egyház kápt.-ja e. a maga, valamint fivérei, László és Péter nevében is fellépő Scarus-i Miklós fia: István tiltja atyai rokonuknak (patruelis ipsorum), Bok (dict.) Jánosnak nemes lányait, Ilonát (Elena) - Dobazy (dict.) Mihály özvegyét —, valamint Erzsébetet - Bely-i Gergely feleségét - attól, hogy a tólük leánynegyedként kapott Gömör m.-i Boroznok birtokot eladadják v. bármilyen más módon elidegenítsék — hiszen az óket, a tiltakozókat inkább megilleti, mint bárki mást —, Hunth fia Sándor fiait: Jánost és Andrást, valamint ugyanezen Hunth fia János fia: Farkast (Farkasius) pedig annak a birtoknak a megszerzésétól. D. in die fe. Inv. S. Crucis, a. d. 1356. 
E.: Dl. 56 874. (Hanvay cs. 1t. 66.) Papíron, hátoldalán azonos kéz írásával tárgymegjelölés, valamint 16. sz.-i jegyzet, továbbá kerek zárópecsét töredéke, bevágásai.

Má.: Uo, mint E., azzal megegyező jelzet alatt.

K.: AO. VI. 452-453. (290. szám) (kihagyásokkal).

R.: Abaffy-Dancs-Hanvy 105. (76. szám).

248. 1356. máj. 3.

A Kw-i egyház kápt.-ja e. a korábbi oklevelében 25 ft. megfizetésére kötelezett Husyubachyi János fiai: Miklós és János máj. 1-jén (in oct. fe. B. Georgii mart.) megjelentek és készpénzben, dénárokban (in promptis denariis) teljesen kifizették a meghatározott összeget a másik részről a [székes-]fehérvári egyház prépostjának, Tatamérnak (Thatamerius) és kápt.-jának képviseletét törvényesen ellátó Bálint bácsi rektornak és Zakan-i (dict.) Péternek, a [székes-]fehérvári egyház kanonokjainak, akik erről nyugtatják Miklóst és Jánost. D. in fe. Inv. S. Crucis, a. d. 1356.

E.: SNA. Zay cs. ugróci lt. Krasznecz László elenchusa szerint rendezett iratok B 1. 80. F. (Df. 265 644.).

K.: -

Megj.: Az említett kötelezvénylevél 1355.nov. 7-én kelt, 1. SNA. Zay cs. ugróci lt. Krasznecz László elenchusa szerint rendezett iratok B 1. 80. D. (Df. 265 642.).

249. 1356. máj.3.

A pannonhalmi (de Sacro Monte Pannonie) Szt. Márton-monostor konventje e. Vgh-i Vgh fia: Lőrinc kinyilvánítja, hogy jóllehet atyai rokonát (fr. patruelis), Koppuan-i Tamás fia: Jánost Vgh birtokon lévő öröklött birtokrészének elzálogosításától, Durugh-i István fiait: Pált és Istvánt pedig annak elfoglalásától és használatától eltiltotta, mérlegelvén azonban István fiainak megbízhatóságát és szomszédságuk maga számára hasznos voltát, mégis hozzájárul zálogügylettel kapcsolatos megegyezésükhöz. D. in fe. Inv. S. Crucis., a. d. 1356.

E.: Dl. 91 485. (Festetics cs. lt. Veszprém 3.) Hártyán, hátoldalán kerek pecsét nyoma, bevágásai.

K.: Mons Sacer I. 445. (18. szám); Dreska G., Pannonhalmi konvent I. 79. (72. szám).

250. 1356. máj. 4.

Az esztergomi kápt. jelenti [I.] Lajos királynak (H): megkapta a király ápr. 15-én, Visegrádon kelt, itt átírt parancslevelét (l. 191. szám) és az abban foglaltak szerint Magyarad-i Miklós királyi ember mellé egyházuk javadalmasát (prebendarius), Bereck presbitert adták tanúul az elrendelt vizsgálat lefolytatásához, akik máj. 2-án (f. II. prox. p. oct. fe. Passce d.) Hont m.-ben, elsősorban Dalmad birtok szomszédságában és környékén az ország szokásai szerint kikérdezvén az értesüléssel rendelkezôket, igaznak találták Tamás fia: István panaszát László mr., barsi (Bursyensis) c. officialis-aival, Dénessel és 
Péterrel szemben. Ezért a vizsgálatot követően Dénest Thenk-en Pétert pedig Solmuson még aznap a király jelenléte elé idézték a panaszt tevő István ellenében máj. 16-ra (ad quind. eiusdem diei inquisitionis, scilicet f. II.). D. 2. die fe. Inv. S. Crucis, a. antedicto. [1356].

E.: EPL. Ipolyi-gyưjtemény 25. (Df. 248 887.) Papíron, felső része szakadozott, hátoldalán azonos kéz írásával tárgymegjelölés, valamint az esztergomi kápt. kisebb, kerek zárópecsétjének töredéke, bevágásai; a pecséttel lezárt hátoldali részen keresztirányban korabeli jegyzet.

K.: Str. IV. 147-148. (117. szám).

\section{1356. máj. 5. Eger}

Domokos, az erdélyi egyház prépostja, az egri egyház kanonokja, Miklós egri püspök lelkiekben általános vikáriusa emlékezetül adja: 1356. máj. 1-jén (in oct. fe. S. Georgii mart., a. Nat. d. videlicet 1356.) az ő — helyesebben püspökének — egyházi törvényszékén (nostro, imo verius dicti domini nostri episcopi consistorio) az ülnökökkel együtt peres ügyekben ítélkeztek, amikor Koxo-i Sándor fia Miklós fia: László szólásra emelkedve bemutatta Miklós kassai (de Cassa) plébános jelentését (l. 175. szám). Eszerint a nevezett plébánosnak, továbbá Barcha-i Miklós fia: Myko c. és Kazmer-i Mykocha fia: Pál fogott bíráknak a László egri prépost, korábbi vikárius írásba foglalt megbízásának megfelelően és ahogyan azt a felperes Sebe asszonynak - korábban Komlous-i Balázs fia: Koporth (dict.) Péter özvegyének, utóbb Lőrinc deák feleségének, Sándor fia: Demeter leányának - akkori famulus-a és törvényes meghatalmazottja, Sebestyén is önként vállalta, a felek előterjesztését és oklevél-bemutatását követően ápr. 6-án (in oct. diei medii Quadr. iam preteritis) fogott bírói ítéletet kellett volna hozniuk Sebe asszony, ill. az alperes Miklós fia: László perében, amely a szóban forgó nemes asszonynak, továbbá 2 nővérének — ti. Hosguth-i [?] Péter fia: Petew özvegyének és Janula-i Márton fia: Miklós néhai feleségének - a nagyanyjuk és anyjuk u. járó hitbér és jegyajándék, továbbá az őket illető leánynegyed követelése körül forgott, azonban ezt nem tudták megtenni, mivel a kitúzött időpontban csak az alperes jelent meg, a felperes asszony viszont távol maradt, és törvényes képviselőjét sem küldte el a 2 fogott bíróval, Barcha-i Myko-val, valamint Mykocha-i Pállal együtt, holott erre ő kötelezettséget vállalt, így Miklós plébános egyedül nem tudott eljárni az ügyben. Bár a vikárius elnökölte törvényszék e. a Sovar-i egyház rector-ának és a Sarus-i kerület alesp.-ének (vicearchidiaconus de districtu Sarus), János papnak az ügyvédvalló levelében meghatalmazott Zend-i László fia: Domokos a felperes nevében megjelent, s a kassai plébános levelének tartalma hallatán különféle ürügyekkel (diversis cautelis pretensis) igyekezett a nemes asszonyt védelmezni, azonban mert indokai nem voltak elfogadhatóak, ezért a bíróság olyan végső ítéletet hoz, miszerint mert a felperes törvényes képviselője, Sebestyén megbízója nevében nem nyomásra (compulsus) v. kényszer hatására, hanem szabad akaratából egyezett bele, hogy - miként László prépost mondott levele tanúsítja - kötelezettséget vállal arra vonatkozóan, hogy ha a kijelölt helyen és idóben nem jelenne meg Miklós plébános e., és a bíróság ítéletét nem fogadná el, valamint a 2 bírót nem vezetné oda, akkor keresetét és fellebbezési jogát egyaránt elveszíti - míg az alperes Lászlóra a fogott bírói ítélet visszautasításának esetére $3 \mathrm{M}$. búntetésének terhe hárult —, ezért Sebe asszonyt, Lőrinc deák feleségét Miklós fia: Lászlóval szemben a vikárius bírói hatalmának teljességéból pervesztesnek nyilvánítja. Ezenkívül a László prépost korábbi vikárius, továbbá Péter mr. Heves-i főesp. és Gothardus mr. egri kanonok — ki utóbbiak 
ideiglenesen múködtek a vikáriusság bírói tisztségében — neve alatt kelt oklevelekból az is kiderült, hogy Koxo-i Demeter fiai, a már elhunyt György, Dezső és János a szóban forgó hozománynak, jegyajándéknak és leánynegyednek a fejében már kifizettek 10 rőf (ulna) ipres-i posztót a 3 asszonynak, így erről a bíróság nyugtatja Lászlót és örököseit, míg Lőrinc feleségének és örököseinek örök hallgatást parancsol az ügyben. A vikárius mindezek bizonyságára autentikus pecsétjével megerősített oklevelet bocsát ki. D. Agrie, V. die oct. fe. S. Georgii mart. supradictarum, a. etiam prenotato [1356.].

E.: - Fk. Dl. 83 278. (Bárczay cs. 1t. 9. 10.) Hátoldalán késóbbi kézzel tárgymegjelölés, kerek pecsét nyoma, bevágásai.

K.: -

R.: Bónis-Balogh 132. (1209. szám); Erdélyi Okm. III. 303-304. (833. szám).

\section{1356. máj. 5. [Szuha-]Kálló falu közelében}

Rechk-i László fia: Miklós mr., Chyko mr. Borsod m.-i alispánja és a m. szb.-ái emlékezetül adják: [I.] Lajos király $(\mathrm{H})$ parancsára a m. nemeseinek közössége számára máj. 5-én (f. V. prox. p. oct. B. Georgi mart.), Karlou falu közelében tartott generalis congregatio alkalmával Puthuk-i [!] Miklós fia: László mr. tiltakozott az ellen, hogy fivére (fr. uterinus), ugyanezen Miklós fia: János mr. 1 éve, ápr. 24-én (in fe. B. Georgi mart. tunc revolutione annuales prox. preterisset) Patha nevú birtokukon az ô tiltása ellenére jobbágyaiktól $50 \mathrm{ft}$.-ot követelt, azonban annak harmad részét nem adta oda László mr.nek, akit az jogosan megilletett volna. László a bíróság e. a törvényben előírt ideig hiába várta Jánost, az nem jelent meg, és nem is küldött senkit maga helyett. D. loco et termine, in a. d. 1356.

E.: D1. 89 328. (Radvánszky cs. sajókazai lt. Kakas 41.) Papíron, hátoldalán azonos kéz írásával tárgymegjelölés, valamint 3 kerek kissé töredezett zárópecsét, bevágásai.

K.: -

\section{1356. máj. 6. Eger}

Domokos, az erdélyi egyház prépostja, az egri egyház kanonokja, Miklós egri püspök lelkiekben általános vikáriusa az Erdutheluk-i Vörös Máté fia: Polhus (dict.) István felperesnek Dénes fia: Tamás, ennek fiai: István és Tamás, valamint Regen-i és Luchonch-i ue. Dénes fia István fia: Dénes alperesekkel szemben indított ama perét, amely a vikárius - pontosabban szólva inkább püspökének — halasztó levele (l. 213. szám) értelmében máj. 1-jén (in oct. fe. S. Georgii mart. prox. praeteritis) lett volna esedékes, és amelyben utóbbiak képviseletében [I.] Lajos király, Zeechy (dict.) Miklós országbíró és a Clusmonostora-i konvent ügyvédvalló levelében meghatalmazott Endes-i Magiar (dict.) Dénes c., Kalanda-i Gergely fia: Lachk és Anthalius fia: Beke jelentek meg az egyházi törvényszék e., a vikárius királyi parancsra — nem önszántából, hanem kényszerúségből - köteles a királyi udvarba átküldeni. Azonban, mert a perek efféle átküldése a Szt. János ap.-egyházának és az ország határain belül lévő más székesegyházaknak (katedralis ecclesia) is komoly kárára van - minthogy a leánynegyeddel kapcsolatos kereseteket nem a királyi kúriában a világi bírák, hanem emberemlékezet óta, és még inkább a jogrend előírásai szerint az anyaszentegyház főpapjai és vikáriusai kötelesek megítélni -, ezért a szóban forgó pert a felperes és az alperesek képviselőjének kéré- 
sére júl. 1-jére (ad oct. fe. Nat. S. Johannis Bapt.) elhalasztja mindenféle teher nélkül, olyan módon, hogy ha időközben a felek egyezségre jutnának, akkor az rendben van, ha viszont nem, akkor a fennálló állapot fenntartásával válaszadásra jelenjenek meg színe e. Elrendeli továbbá, hogy a felek a kitűzött időpontról sem királyi, sem királynéi levéllel, sem más felmerült ürügyre való hivatkozással ne halaszthassák tovább a pert. D. Agrie, 6. die termini praenotati, a. d. 1356.

E.: - A MOL nem tartja nyilván az iratot. K. és R. hivatkozása alapján az Erdődy cs. galgóci lt.-ban lad. 28, fasc. 13, nr. 3. Papíron, hátoldalán tárgymegjelölés és zárópecsét töredékével.

K.: Bánffy I. 207-208. (170. szám).

R.: Doc. Rom. Hist. C. XI. 19. (16. szám) (románul); Bónis-Balogh 132. (1210. szám); Erdélyi Okm. III. 304. (834. szám).

\section{1356. máj. 6. [Gyula-]Fehérvár}

Salamon mr. tordai főesp., András erdélyi püspök lelkiekben általános vikáriusa e. máj. 1-jén (in oct. fe. B. Georgii mart.) egyik részről Cheh-i Pancelus (dict.) János, a másikról pedig a Clusmon[o]stra-i konvent ügyvédvalló levelében meghatalmazva, felesége, Borbála és Kamaras-i (dict.) Bálint hitvese, Erzsébet - mindketten Chenthe (dict.) János fia János leányai - nevében eljáró Zenthmartun-i Kalach megjelenvén, kinyilvánítják, hogy bírói engedély alapján fogott bírák közremúködésével egyezségre jutottak egyrészt Cheh birtokkal kapcsolatban, amelyből Borbálát és Erzsébetet atyjuk, János u. jog szerint leánynegyed illeti meg, és amely birtok leszármazás jogán Pancelus (dict.) Jánosra szállt, másrészt pedig az anyjuk u. a 2 leányt megilletố hozomány (dos) és jegyajándék ügyében. A megegyezés értelmében János rokonai kedvében akarván járni, önként kiadja Cheh nevezetú birtokából a szóban forgó leánynegyedet minden haszonvételével és tartozékával együtt a nevezett asszonyoknak, azok férjeinek és örököseiknek, ezenfelül pedig a birtokba iktatás alkalmával a hitbér és a jegyajándék fejében 25 M.-át fizet nekik. János a kiadott leánynegyeddel kapcsolatban szavatosságot vállal, Kalach pedig képviseltjei és azok utódai nevében is nyugtatja Jánost a leánynegyed, a jegyajándék és a hozomány dolgában. D. Albe, 6. die oct. fe. B. Georgii mart. predictarum, a. d. 1356.

E.: Dl. 27 427. (Kolozsmonostori konvent o. lt. Cista comitatuum. Doboka P 37.) Hártyán, hátoldalán késóbbi kezek írásával tárgymegjelölés és jegyzetek.

Á.: László erdélyi vajda, 1377. máj. 28. > erdélyi kápt., 1395. jún. 3. > Stibor erdélyi vajda, 1399. jan. 17. Dl. 42 694. (Múz. Ta. Lukács) (vö. ZsO. I. 5671. szám).

Má.: Uo., mint E, azzal egyező jelzet alatt; 1839. aug. 27-én kelt hiteles Má.-ban.

K.: AO. VI. 453-454. (291. szám) (kihagyásokkal); Doc. Rom. Hist. C. XI. 17-19. (15. szám) (román fordításban is) mindkettő E. alapján; AO. VI. 576-578. (369. szám) (kihagyásokkal) tévesen 1357. máj. 6-ra keltezve; Á alapján.

R.: Bónis-Balogh 134. (1226. szám); Doc. Rom. Hist. C, XI. 123. (125. szám) (románul) Mindkettőben AO. VI. 369. szám nyomán tévesen 1357. máj. 6-ra keltezve; Erdélyi Okm. III. 304. (835. szám).

Facs.: Doc. Rom. Hist. C. XI. 648. 
Megj.: Az átíró oklevélben hamisnak mondják ezt az oklevelet, mivel [Szengyeli] István, a kolozsmonostori konvent hamisítás miatt fej- és jószágvesztésre ítélt, máglyahalált halt jegyzője mutatta be. Vö. Kar., HH. 38. (194. szám) és Jakó, Zs. LK. 55 (1984) 134-138.

\section{1356. máj. 6-13. között}

Bizonyságlevél a Hont m.-i Syrok, más néven Kezu birtokon lévő részbirtok kapcsán kötött egyezségról. D. in Vissegrad, f. VI. prox. ....... quind. [?] fe. Pasce d., a. eiusdem 1356.

E.: - Fk. Dl. 95 804. (Siráky cs. 1t. 6.) Csonka, hiányos, írása az olvashatatlanságig elhalványult.

K.: -

256. 1356. máj. 7.

A [székes-]fehérvári egyház kápt.-ja jelenti [I.] Lajos királynak (H): miután látták a király által János veszprémi püspök és kápt.-ja számára kiadott idézéshez, kivizsgáláshoz és eltiltáshoz, nemkülönben minden máshoz, az ország jogszokása szerint felmerülő dolgokhoz felhasználandó éves általános megbízólevelét, Sceuleus-i Volpoth fia: László — az oklevélben többedmagával megnevezett - királyi ember mellé kanonoktársukat, a német (Teutonicus) István mr.-t adták tanúul a veszprémi kápt. által kért alábbi eltiltás elvégzéséhez. Ezek visszatérve egybehangzóan jelentették, hogy máj. 3-án (f. III. prox. p. oct. fe. Passce d.) kimentek Kouachy birtokra, ahol is Kouachy-i Beke fiait: Lászlót, Benedeket, Györgyöt és Leustasius-t valamint jobbágyaikat eltiltották a falunagy és Beke fiainak valamennyi jobbágya jelenlétében a veszprémi egyház Premorton birtokának hasznától és használatától, különösen pedig ménesük ottani legeltetésétől, amellyel minden évben igen nagy kárt okoztak a kápt. jobbágyainak. D. sabb. prox. infra quind. fe. Passce d., a. eiusdem 1356.

E.: Veszprémi székeskápt. mlt. Oklevelek. Peremarton 8. (Df. 200 935.) Papíron, hátoldalán azonos kéz írásával címzés és tárgymegjelölés, továbbá késóbbi kéz írásával tárgymegjelölés, valamint mandorla alakú zárópecsét nyoma, bevágásai.

K.: -

R.: Veszpr. Reg. 189. (470. szám) (tévesen ápr. 30-ra keltezve).

257. 1356. máj. 8.

[I.] Lajos király (H, Da, C, Ra, Se, G, L, Cu, Bu, Sal., mont. S. Angeli dom.) a színe e. valamennyi hospes-társukat (cohospites) is képviselő Gyungiuk kőrösi (de Crisio) falunagy, nemkülönben pedig az ugyanonnan való Máté fia: Sebestyén és István fia: Balázs kérésére és oklevél-bemutatása alapján a főpapok és bárók tanácsára privilégiumában átírja, s autentikus kettôs pecsétjének ráfüggesztésével megerôsíti [IV.] Béla király 1253. aug. 16-án kelt kiváltságlevelét, amelynek cikkelyei a kérelmezók szabadságait tartalmazták. Kelt Miklós zágrábi püspök és királyi alkancellár keze által, a. d. 1356, VIII. Id. mensis Maii, uralkodásának 15. évében. Méltóságnévsor: Miklós lévén lévén az esz- 
tergomi érsek, egyben ua. m. örökös c.-e — a kalocsai szék üresedésben —, Vglinus a spalatói érsek, Miklós az egri, Demeter a [váradi], András az erdélyi, Miklós a pécsi, János a veszprémi, Kálmán a győri, Tamás a csanádi, Mihály a váci, Péter a választott boszniai (Boznensi), Tamás testvér a szerémi, István testvér a nyitrai és Balázs testvér a knini püspök; Konth Miklós a nádor és a kunok bírája, $\mathrm{Cy}$ [kou] a tárnokmr., András az erdélyi vajda és a Zonuk-i c., Miklós c. az országbíró, Miklós a Machow-i bán, Leustachius a Somogy, Fejér és Tolna m.-i c., egyben az egész Szlavónia bánja, Leukus az asztalnok- és a pohárnokmr., Dénes a lovászmr., Tamás az ajtónálló mr., Simon a pozsonyi c. A.

Á.: [I.] Lajos király, 1380. jan. 12. HDA. Grad Križevci: Diplomata 4. (Df. 267 984.).

K.: Smič. XII. 348-349. (262. szám).

Megj.: IV. Béla király privilégiumát 1. Reg. Arp. 996 szám.

— 1356. máj. 8. [! Э: 1352. máj. 8.]

A budai kápt. e. - miként azt 1356. máj. 8-án (in quind. fe. B. Georgii mart. in. dicto a. d. 1356.) kelt és az $\mathrm{ABC}$ betúi chirographált privilégiuma tanúsítja - megjelent Simon mr., nemkülönben a váradi kápt. ügyvédvalló levelében meghatalmazott Bathor-i János fia: László mr., feleségének, Anna nemes asszonynak a képviseletében, ahol Simon mr. valamennyi oklevelét, amely Somlyo vár és bizonyos birtokok lánytestvére, Anna számára történő adományozásával kapcsolatos, átadta Lászlónak, hogy irassa át azokat a kápt.-nal.

Tá.: 1. Garai Miklós nádor, 1409. márc. 13. > erdélyi kápt., 1746. okt. 31. Dl. 74 677. (Dessewffy grófi cs. 1t. M. 2).

2. erdélyi kápt. 1746. okt. 31. AL. Kolozsvár. Wesselényi cs. görcsöni lt. 50. (Df. 254 823.) Tá. 1-ról készültt 19. sz.-i egyszerú Má.-ban.

3. erdélyi kápt. 1746. okt. 31. AL. Kolozsvár. Teleki cs. kendilónai lt. 8. (Df. 257 939.) Tá. 1-ról készült egyszerú Má.-ban. Mindhárom 1356. máj. 8-i datálással.

K.: $\quad$ F. IX. 4. 663-664. (4. szám) (Garai Miklós 1409-es ítéletlevelére hivatkozással).

Megj.: Az oklevél valójában 1352-ben kelt. Eredeti példányban nem maradt fenn. A késóbbi Tá.-ból viszont egyértelmúen kiderül, hogy az irat valójában 1352-ben és nem 1356-ban kelt. Tartalma szerint idetartozó bizonyítékul szolgál az 1352. jan. 8-i keletú, eredeti állapotában fennmaradt Dl. 31095. jelzetú irat. Ezt az oklevelet a hosszan elhúzódó családi birtokperek során többször átírták tartalmilag (többek között Bebek Imre nádor, 1390. ápr. 9. Dl. 29992.; Garai Miklós nádor többször: 1406. febr. 27. Dl. 30 099.; 1409. márc. 13. Dl. 31 053.; Váradi kápt. 1409. Dl. 31 053.; Má.: váradi kápt. 16. sz.-i Dl. 70 631.; váradi kápt.18. sz.-i Dl. 71 866. és Dl. 73 665; Df. 257934 és 257 936.). Ezekben helyesen az 1352-es dátum szerepel, míg az apparatusban megadott Tá.-ok és K.-ok a téves 1356-os dátumot vitték tovább.

258. 135[6. ?] máj.8.

A budai egyház kápt.-ja e. egyik részről Katalin asszony, Sidow $\sim$ Sydow-i Bekch mr. özvegye és fia, István, a másik részrôl pedig Iklad-i Mach fia Dénes leánya: Katalin asszony — fivérének, Ágostonnak a kíséretében - megjelenvén, utóbbi kinyilvánítja, hogy az Iklad birtokon lévô részbirtokát, mely leánynegyed jogcímén volt eddig birtokában Heuizuelg-ben Olsomach birtok mellett, minden haszonvételével, tartozékával és valamennyi jogával együtt eladja Sidow-i Bekch mr. özvegyének, fiának és leányának, Margitnak Pomaz-i Benedek feleségének és örököseiknek a már megfizetett 40 budai M. ellenében örökre és visszavonhatatlanul, idegen jog sérelme nélkül. Az ügy bizonyságára a kápt. függőpecsétjével megerôsített és az ABC betúivel chirographált 
privilégiumot bocsát ki. Kelt Dénes mr., olvasókanonok keze által, in quind. fe. Passce d., a. eiusdem 135[6 ?]. Péter mr., éneklő-, János őrkanonok, László, Imre és László ...kanonokok jelenlétében.

E.: Dunamelléki Református Egyházkerület Ráday lt. Ráday cs. 1t. 1011. (Df. 275 679.) Foltos hártyán, helyenként nehezen olvasható, különösen keltezésének utolsó számjegye bizonytalan; felül az ABC betúivel chirographált, alján függőpecsét zsinege.

Má.: Dunamelléki Református Egyházkerület Ráday Lt. Ráday cs. lt. gazdasági iratok A 1. 35. 1. (Df. 280 528.) 18. sz.-i egyszerú Má.-ban, amelyben tévesen ápr. 24-i (in quind. fe. Passionis d., a. Incarn. 1356.) napi dátum szerepel.

K.: -

R.: Bakács, Pest megye 192-193. (661. szám) (1352. ápr. 22. dátummal, E. alapján).

259. 1356. máj. 8 .

Miklós prépost és a Jazov-i Keresztelő Szt. János monostor konventje jelentik [I.] Lajos királynak $(\mathrm{H})$ : eleget téve a király itt átírt, ápr. 10-én kelt parancslevelében (l. 183. szám) foglaltaknak, Huthka-i [Fábián fia:] Miklós királyi ember mellé tanúul adták János testvért, akik a kért vizsgálat lefolytatása $u$. visszatérve egybehangzó jelentést tettek. Eszerint máj. 2-án (f. II. prox. p. oct. fe. Passce d.) Sarus [?] m.-be menve, az értesüléssel rendelkezôk körében, kivált Korluthuagasa birtok szomszédjai körében nyíltan és titokban vizsgálatot folytattak, amelynek eredménye szerint márc. 28-án ([in f. II. prox.] an. domin. Letare) [Perwen-i Miklós] felfegyverkezve, ellenségesen rátört [Wytez-i] Lőrinc birtokára, ôt magát meg akarta ölni, 2 famulus-át, Pétert és Istvánt pedig életveszélyesen megsebesítette, jóllehet nevezett Lőrinc és Miklós között peres eljárás van függóben. D. 2. die fe. B. Stanizlai mart., a. supradicto [1356].

E.: Dl. 41 283. (Múz. Ta. Berthóty 48.) Papíron, középen erősen szakadozott és foltos, hátoldalán azonos kéz írásával tárgymegjelölés, valamint kerek zárópecsét töredéke, bevágásai.

K.: F. IX. 2. 543-544. (265. szám) (kihagyásokkal) A Jankovics-gyújteményben ơrzött E.-re való hivatkozással.

Megj.: A [ ]-ben közölt információk az átírt oklevélból származnak.

260. 1356. máj. 8 .

A pozsonyi egyház kápt.-ja e. Body-i Domokos fia: Kelemen kinyilvánítja, hogy a Palazoukuzi Body birtokon lévő öröklött részbirtokát minden haszonvételével és tartozékával együtt eladja a jelenlévő Jakus-nak, Pozsony város bírájának és örököseinek M.-ként 10 pensaval számolt $32 \mathrm{M}$. széles bécsi dénár ellenében, amely adásvételbe és elidegenítésbe Kelemen nővérei, ti. Domokos lányai, az ugyancsak jelenlévő Erzsébet és Katha asszony is beleegyeztek, ezenfelül az őket Body birtokrészből jogosan megillető leánynegyed, valamint anyjuk hozománya és jegyajándéka tekintetében mentesítik Jakus-t és örököseit. Az ügy bizonyságául a kápt. autentikus függőpecsétjével megerősített és középen az ABC betúivel chirographált privilégiumot bocsát ki Jakus és örökösei részére. $D$. in quind. B. Georgii mart., a. d. 1356. 
E.: Dl. 4607. (Acta eccl. ord. et mon. 62. 11.). Hártyán, alul az ABC betúivel chirographálás, továbbá sárga-vörös befüzött sodrat, hátoldalán super possessionem Body venditionalis 1359, valamint késóbbi kéz írásával in Csaloköz.

K.: AO. VI. 455-456. (293. szám) (kihagyásokkal).

R.: Ortvay, Pozsony III. 319 és 363.

\section{1356. máj. 8.}

A váradi egyház kápt.-ja — miként azt 1356. máj. 8-án (in quind. fe. B. Georgi mart. sub a. d. 1356.) kelt privilégiuma tanúsítja — átírja ....... [III.] András király (H) 1209. [! Э: 1299.] okt. 19-én kelt [— az erdélyi kápt. birtokainak bejárása kapcsán kiállított — ] kiváltságlevelét.

Tá.: Péter erdélyi alvajda, 1364. nov. 25. > kolozsmonostori konvent, 1365. jan. 25. Dl. 30 662. (Gyulafehérvári konvent. o. 1t., Centuriae M 40. (42)).

Má.: Uo., mint Tá., azzal megegyező jelzet alatt 1 egyszerú és 2 hiteles Má.-ban (utóbbiak kelte: 1786. nov. 27.).

K.: Doc. Rom. Hist. C. XII. 368-371. (román fordításban is).

R.: Doc. Rom. Hist. C. XI. 19-20 (17. szám) (románul); Edélyi Okm. III. 304. (836. szám).

Megj.: III. András király oklevelét 1. Reg. Arp. 4272. szám.

\section{1356. máj. 8. Visegrád}

Konth Miklós nádor $(\mathrm{H})$, a kunok bírája e. — azok u., hogy hivatali elődje, a korábbi nádor s kun bíró, Miklós perhalasztó oklevele értelmében a Pete birtokkal kapcsolatos márc. 16-án (in 8. diei Cynerum) esedékes oklevél-bemutatást a király a nevezett nádor halála miatt perhalasztó levelélben (l. 119. szám) máj. 1-jére (oct. fe. B. Georgii mart.) elnapolta —, a kitûzött időpontban megjelent a Warada-i László fia: János mr. képviseletét a váradi egyház kápt.-jának ügyvédvalló levelével ellátó Zeuke (dict.) Péter s vele szemben Pylyskee-i Adas (dict.) László fia: István, ám a pert a nádor a király oklevelében (l. 208. szám) foglaltakra tekintettel — minthogy az utóbbi fél részt vesz az uralkodó tengeri hadjáratában - elhalasztja a királyi hadoszlás 15. napjára a fennálló állapot fenntartása mellett. D. in Wyssegrad, 8. die termini prenotati, a. d. 1356.

E.: Dl. 77 163. (Zichy cs. zsélyi lt. 1. B 289.) Papíron, hátoldalán azonos kéz írásával tárgymegjelölés, valamint a nádor kerek zárópecsétjének töredéke, bevágásai; a pecséttel lezárt hátoldali részen keresztirányban korabeli jegyzet.

K.: Z. III. 27-28. (15. szám).

R.: Wertner M., Száz. 39 (1905) 442; uő., Hadtört. Közl. 19 (1918) 211. (1. szám).

\section{1356. máj. 8. Visegrád}

Zeech-i Miklós c., [I.] Lajos király (H) országbírája, Turuch m. c.-e Benedek fia: Egyednek és Budur fia: Antalnak az egykori bán Lyndua-i István fia: Miklós ellen indított ama perét, amely az országbíró korábbi oklevele (l. 217. szám) értelmében máj. 1-jén (in oct. 
fe. B. Georgii mart.) lett volna esedékes az Ozyuagh Zengyurgh birtokba való beiktatáskor történt ellentmondás ügyében, a bemutatott királyi rendelet nyomán ( $l$. 209. szám) a királyi hadoszlás 15. napjára (ad quind. residentie exercitus) elhalasztja. D. Vysegrad, 8. die termini prenotati, a. d. 1356.

E.: Dl. 4608. (NRA. 1538. 21.) Papíron, hátoldalán azonos kéz írásával tárgymegjelölés, valamint kerek zárópecsét nyoma, bevágásai, írott szalagja.

K.: -

\section{1356. máj. 8. Visegrád}

Zeech-i Miklós c., [I.] Lajos király $(\mathrm{H})$ országbírája, Turuch m. c.-e István fia: Miklós egykori bánnak Scepethnuk-i Mysich, Gegeu, Peder és Péter alperesek ellen indított ama perét, amelyben az országbíró korábbi oklevele (l. 218. szám) értelmében máj. 1-jére (in oct. fe. B. Georgii mart.) rendelt el oklevél-bemutatást a Mura folyón, Scengyurgh birtokon lévő bizonyos malommal kapcsolatban, királyi rendelet nyomán (1.210. szám) a királyi hadoszlás 15. napjára elhalasztja. D. in [V]ysegrad, 8. die termini prenotati, a. d. 1356.

E.: Dl. 4609. (NRA. 1538. 20.) Papíron, hátoldalán azonos és késóbbi kéz írásával tárgymegjelölés, valamint zárópecsét nyoma.

K.: Zala I. 564-565.(360. szám).

\section{1356. máj. 8. Visegrád}

Zeech-i Miklós c., [I.] Lajos király (H) országbírája, Turuch m. c.-e Albert fia: Peteu-nek és Leztemer-i Domokos fia: Donch-nak Dobou fia: Jakabbal, János deákkal és Kylianus Zeech-i plébánossal szemben indított ama perét, amely az országbíró korábbi oklevele (l. 219. szám) értelmében máj. 1-jén (in oct. fe. B. Georgii mart.) lett volna esedékes, s amelyben elóbbiek képviseletében a Lelez-i konvent ügyvédvalló levelében meghatalmazott ue. Albert fia: Máté, utóbbiak helyett pedig ugyancsak a Lelez-i konvent ügyvédvalló levelét felmutató Domokos fia: János jelent meg a Bezeu birtokba való beiktatáskor támadt ellentmondás ügyében, a felek képviselóinek akaratából aug. 22-re (ad oct. fe. Ass. virg. glor.) elhalasztja. D. in Vissegrad, 8. die termini prenotati, a. d. 1356.

E.: Dl. 4611. (NRA. 193. 20.) Papíron, hátoldalán azonos kéz írásával tárgymegjelölés, valamint kerek zárópecsét töredéke, bevágásai, szalagja.

K.: AO. VI. 455. (292. szám) (kihagyásokkal).

\section{1356. máj. 8. Visegrád}

Zeech-i Miklós c., [I.] Lajos király (H) országbírája, Turuch m. c.-e a Nyulak szigeti (de Insula Leporum) Boldogságos Szúz-egyház apácáinak Warkun-i János fiaival: Amádéval (Omodeus) és Lothardus-szal szemben indított ama perét, amelyben elóbbieket Balázs testvér képviselte az ő ügyvédvalló levelüknek a meghatalmazásával, utóbbiak helyett pedig peridőpont elfogadására meghatalmazott képviselőik jelentek meg, és amely per a budai egyház kápt.-jának idézố és határbejáró oklevele (l. 212. szám) értelmében a Pathos birtok iktatásakor és határjelek állításakor támadt ellentmondás 
ügyében máj. 1-jén (in oct. fe. B. Georgii mart.) lett volna esedékes, más peridőpont elsóbbsége miatt okt. 6-ra (ad oct. fe. B. Michaelis arch.) elhalasztja. D. in Vysegrad, 8. die termini prenotati, a. d. 1356.

E.: Dl. 48 571. (Üchtritz-Amadé cs. lt. 5. 1. 62.) Papíron, hátoldalán azonos kéz írásával tárgymegjelölés, valamint kerek zárópecsét töredéke, szalagja, bevágásai.

K.: - -

Megj.: Vö. a 194. számú oklevéllel.

\section{1356. máj. 8. Visegrád}

Zeech-i Miklós c., [I.] Lajos király (H) országbírája, Turuch m. c.-e a Byry-i Tamás fiainak: Jánosnak és Lászlónak, valamint Tamás feleségének István fia: Istvánnal szemben indított ama perét, amely az országbíró korábbi oklevele (l. 220. szám) értelmében máj. 1-jén (in oct. fe. B. Georgy mart.) lett volna esedékes, és amelyben elóbbieknek a képviseletét a váradi egyház káp.-jának ügyvédvalló levelében maghatalmazott Tamás látta el, István fia: István helyett pedig az egri egyház kápt.-jának ügyvédvalló levelét felmutató Vörös (Rufus) Miklós jelent meg, a felek képviselőinek akaratából okt. 6-ra (ad oct. fe. B. Mychaelis arch.) elhalasztja, a fennálló állapot fenntartásával, hacsak a felek ez idố alatt ki nem egyeznek. D. in Wyssegrad, 8. die termini prenotati, a. d. 1356.

E.: D1. 51 703. (Kállay cs. lt. 1300. 1108.) Papíron, hátoldalán azonos kéz írásával tárgymegjelölés, valamint az országbíró kerek zárópecsétjének töredéke (rajta kivehető a kiterjesztett szárnyú sas alakja).

K.: -

R.: Kállay II. 35. (1181. szám).

\section{1356. máj. 8. Visegrád}

Zeech-i Miklós c., [I.] Lajos király (H) országbírája, Turuch m. c.-e a Byry-i Tamás fiainak: Jánosnak és Lászlónak, valamint Tamás feleségének Kallou-i László fiaival: Mihállyal és Ubullal szemben indított ama perét, amely az országbíró korábbi oklevele (l. 221. szám) értelmében máj. 1-jén (in oct. fe. B. Georgy mart.) lett volna esedékes, és amelyben előbbieknek a képviseletét a váradi egyház káp.-jának ügyvédvalló levelében maghatalmazott Tamás látta el, László fiai helyett pedig a váradi egyház kápt.-jának ügyvédvalló levelét felmutató Péter fia: János jelent meg, a felek képviselőinek akaratából okt. 6-ra (ad oct. fe. B. Mychaelis arch.) elhalasztja. D. in Vyssegrad, 8. die termini prenotati, a. d. 1356.

E.: Dl. 51 704. (Kállay cs. lt. 1300. 1109.) Papíron, hátoldalán azonos kéz írásával tárgymegjelölés, valamint kerek zárópecsét töredéke, bevágásai, szalagja; a pecséttel lezárt hátoldali részen keresztirányban korabeli jegyzet.

K.: -

R.: Kállay II. 35. (1180. szám). 


\section{1356. máj. 8. Visegrád}

Zeech-i Miklós c., [I.] Lajos király (H) országbírája, Turuch m. c.-e Magyar (dict.) Pál mr. hitvesének, Margit nemes asszonynak Varada-i László fia: János mr.-rel szemben viselt ama perét, amely az országbíró korábbi oklevele (l. 222. szám) értelmében máj. 1-jén (in oct. fe. B. Georgii mart.) lett volna esedékes egy Varada birtok felól elhelyezkedô és állítólag Patroh birtokhoz tartozó földdarab iktatása során történt ellentmondás ügyében, és amelyben Margit képviseletét a királyi kápolnaispán ügyvédvalló levelében maghatalmazott Kwnak-i István látta el, János mr. helyett pedig a Lelez-i konvent ügyvédvalló levelét felmutató Zewke (dict.) Péter jelent meg, a felek képviselőinek akaratából okt. 6-ra (ad oct. fe. B. Michaelis arch.) elhalasztja. D. in Vysegrad, 8. die termini prenotati, a. d. 1356.

E.: Dl. 77 164. (Zichy cs. zsélyi lt. 1. B 292.) Papíron, hátoldalán azonos kéz írásával tárgymegjelölés, valamint kerek zárópecsét töredéke, bevágásai.

K.: Z. III. 26-27. (14. szám).

\section{1356. máj. 8. Visegrád}

Zech-i Miklós c., [I.] Lajos király (H) országbírája, Turuch m. c.-e emlékezetül adja: a korábbi oklevelében (l. 223. szám) foglaltak szerint máj. 1-jén (in oct. fe. B. Georgii mart.) Lyder-i Tamás fia: Loránd bírói jelenléte elé járulván Jako-i Kozma (Cosma) fiai: Henrik, Miklós és István ellenében előadta, hogy a 3 nevezett fivér egy évvel korábban, [1355.] júl. 29-én (f. IV. prox. p. fe. B. Jacobi ap. cuius nunc adveniret revolutio annualis) Lyder birtok területén hatalmaskodva elragadott 20 kepe gabonát (20 capetias frugum). Ennek hallatán Kozma fia: Iwan és Tamás fia: János a meggyanúsított 3 fivér képviseletét a Lelez-i konvent ügyvédvalló levelével ellátva azt állították, hogy képviseltjeik ártatlanok az ellenük felhozott vádban. Mivel pedig Loránd panaszát sem vizsgálati oklevéllel, sem tanúkkal nem tudta igazolni, ezért az országbíró elrendeli, hogy Henrik, Miklós és István személyesen tegyenek esküt a Lelez-i konvent színe e. júl. 1-jén (in oct. fe. Nat. B. Johannis Bapt.) azzal kapcsolatban, hogy a Loránd által felhozott vádban ártatlanok, majd az erről írott konventi jelentést a felek kötelesek aug. 1-jén (in oct. fe. B. Jacobi ap.) visszavinni az országbírónak. D. in Vissegrad, 8. die termini prenotati, a. d. 1356.

E.: - Fk. Dl. 96 347. (Vay cs. berkeszi lt. 345.).

K.: -

R.: Piti F., SzSzBSz $40 / 3$ (2005) 335. (tévesen máj. 1-jére keltezve); Piti F., Vay 444. (163. szám).

\section{1356. máj. 8. Visegrád}

Zeech-i Miklós c., [I.] Lajos király (H) országbírája, Turuch m. c.-e azt az oklevél-bemutatást, amelyre korábbi oklevelében (l. 133. szám) kötelezete egyik részről Simon fia: Miklós felperest, a másikról pedig Nogmarton-i Lőrinc fia: Nykel mr.-t, a királyi kápolnaispán ügyvédvalló levelében meghatalmazott Kozma fia: Bekeu által képviselt alperest, és amely máj. 1-jén (in oct. B. Georgii mart.) lett volna esedékes Nogkorungh és Vrbycharywy birtokok ügyében, jóllehet a felperes késznek mutatkozott az oklevél-bemutatásra, 
mivel Bekeu nem tudott ilyet tenni, hanem nyomós indok nélkül kérte a bemutatás elhalasztását, ezért az országbíró a per kezdete e. megfizetendő $3 \mathrm{M}$. bírságra kötelezve Nykel mr.-t okt. 6-ra (ad oct. fe. B. Mychelis arch.) elhalasztja a fennálló állapot fenntartásával. Mivel pedig a szóban forgó képviselő az $1 \mathrm{M}$. bírság Miklóst illető részét nem fizette meg, ezért a kitúzött napon annak kétszeresét köteles megfizetni. D. in Wissegrad, 8. die termini prenotati, a. d. 1356.

E.: Dl. 98 398. (Sigray cs. 1t. 42. 12.) Papíron, hátoldalán azonos kéz írásával tárgymegjelölés, késóbbi kéz írásával kereszt irányban lapszéli jegyzet, valamint zárópecsét töredéke, bevágásai.

Má.: Uo., mint E., azzal megyegyezố jelzet alatt; 18. sz.-i egyszerú Má.-ban.

K.: -

\section{1356. máj. 8. Visegrád}

Zeech-i Miklós c., [I.] Lajos király (H) országbírája, Turuch m. c.-e a Huzyubach-i János fiainak: Miklós és János mr.-eknek a Szerém m.-i Bodon-i Simon fia: Jánossal szemben indított ama perét, amely az országbíró korábbi oklevele (l. 224. szám) értelmében máj. 1-jén (in oct. fe. B. Georgii mart.) lett volna esedékes, és amelyben elóbbieknek a képviseletét a Szt. Ireneus vértanú-egyház kápt.-jának ügyvédvalló levelében maghatalmazott Kenez (dict.) István látta el, János helyett pedig az említett kápt. ügyvédvalló levelét felmutató Péter fia: Mihály jelent meg, mivel a Scimotha birtokon lévő részbirtok iktatásakor támasztott ellentmondás ügyében János képviselóje nem adott választ, hanem mindenféle nyomós ok nélkül arra törekedett, hogy késóbbi időpontot eszközöljön ki, ezért aug. 1-jére (ad oct. fe. B. Jacobi ap.) elhalasztja, ám 3 M. bírság perkezdet előtti megfizetésére kötelezi Jánost a másik fél, ill. a maga számára. D. in Vissegrad, 8. die termini prenotati, a. d. 1356.

E.: SNA. Zay cs. ugróci lt. Krasznecz László elenchusa szerint rendezett iratok B 1. 10. (Df. 265 553.) Papíron, zárópecsét nyomával.

K.: -

\section{1356. máj. 8. Visegrád}

Zech-i Miklós c., [I.] Lajos király (H) országbírája, Turuch m. c.-e azt az oklevél-bemutatást, amelyre korábbi oklevelében (l. 225. szám) kötelezte [az alpereseket,] Karulus fiait: Andrást és Miklóst, Detricus fia: Dávidot, András fia: Istvánt, János fia: Gyuke-t, Demeter fia: Demetert [Dettricus-t ?], Cha[. ?]-i nemesekeket Heem fia Pál fia: Benedek mr. ellenében, és amely máj. 1-jén (in oct. fe. B. Georgii mart.) lett volna esedékes Kurbeu birtok ügyében, a Benedek mr. által hozott királyi parancsra (l. 211. szám) való tekintettel a királyi hadoszlás 15. napjára elhalasztja a fennálló állapot fenntartása mellett. D. in Vissegrad, 8. die termini prenotati, a. d. 1356.

E.: Győri kápt. hh. lt. 193. (342. B) (Df. 274 050.) Papíron, hátoldalán azonos kéz írásával tárgymegjelölés (benne eltérő névalak: Heym), valamint zárópecsét töredéke, szalagja, bevágásai; a pecséttel lezárt hátoldali részen keresztirányban korabeli jegyzet, feltehetőleg az oklevélben betoldást, javítást eszközlő kézzel és tintával.

K.: - 
Megj.: A [ ] között szereplő adatok utólagos javításból, pótlásból származnak.

274. 1356. máj. 8.u.

A szepesi [kápt.]....... jelenti [I. Lajos királynak]: eleget téve a király itt átírt ápr. 10-én kelt parancslevelében (l.184. szám) foglaltaknak, István királyi ember mellé tanúul adták Pál presbitert az elrendelt vizsgálat lebonyolításához, akik máj. 8-án (in quind. fe. Pasce d.) nyíltan és titokban kikérdezvén mindenkit az értesüléssel rendelkezők köréból, ti. Ludueg birtok szomszédait és határosait, különösképpen pedig Syroka-i P.......ch fiait: Györgyöt, Lászlót, és Mihályt, valamint Frich-i Jakabot, Sygre-i Imre fia: Pétert, Pertold-i Egyed fia: Synka-t, Scu.........a-i Pétert, Badah-i Miklós fia: Demetert, a Zebinioi plébánost és polgárokat megtudták, hogy Peren-i Miklós fia: Miklós márc. 28-án (in f. II. an. dict. domin. Letare) fegyveresen rátört Lőrinc Korlatwagaza [birtokára], ahol az éppen halászó Lőrincet....... lerohanta és meg akarta ölni........ [2 famulus-át] Pétert és [Istvánt] pedig életveszélyesen megsebesítette, jóllehet per volt közöttük függóben........ [D.] ....... prox. p. quind. fe. Pasce, a. eiusdem prenotato [1356].

E.: Dl. 41 282. (Múz. Ta. Berthóty 47.) Papíron, csonka, hátoldalán azonos és késóbbi kéz írásával tárgymegjelölés, valamint a szepesi kápt. kerek zárópecsétjének töredéke (kivehető rajta Szt. Márton alakja és a pecsét köriratának egy része:+S[(IGILLVM) CAPITVLI EC(C)LES(I)E BEATI MARTINI DE] SCEPVS.

K.: -

Megj.: A [ ]-ben közölt információk az átírt oklevélból származnak.

275. (1356. máj. 9.e.)

János mr., Bars m. alispánja és a m. szb.-ái tudatják: 3 M. bírság kilátásba helyezésével arra kötelezik Wezeken-i Miklós fia: Jánost, hogy máj. 9-én ([in] f. II. prox. p. quind. fe. B. Georgii mart.) a m. 2 szb.-jának jelenlétében fizesse meg $6 \mathrm{M}$. összegú tartozását az ugyaninnen való Miklós nemes özvegyének és gyermekeinek, továbbá utasítják a feleket, hogy az azt követő máj 12-én (sequenti f. V.) színük e. jelenjenek meg.

Eml.: A 282. számú oklevélben.

K.: Bars 42. (40. szám), s ennek nyomán Palásthy III. 100. (81. szám) (Eml-ben).

276. 1356. máj. 10.

A vasvári egyház kápt.-ja e. egyik részrôl Rohunch-i Kokas (dict.) Miklós fia: Henrik mr., a másikról pedig az óbudai egyház prépostja, István és Chourna-i Lőrinc fia: János mr. a maga, valamint fivérük (fr. uterinus), Benedek nevében is - akinek terhét magukra vállalták, ha nem fogadná el az alábbi rendelkezést — kinyilvánítják, hogy a Kedhyda birtok visszavétele miatt Henrik mr. által Lőrinc fiaival szemben indított, s régóta fennforgó perben a felek békés megegyezésre jutottak, s vállaltak, hogy a bíró engeszteléséül a békeváltságot fele-fele részben fogják megfizetni. D. in oct. fe. Inv. S. Crucis, a. d. 1356.

E.: Dl. 4612. (NRA. 1698. 87.) Papíron, hátoldalán azonos kéz írásával tárgymegjelölés, valamint kerek zárópecsét töredéke, bevágásai. 
K.: -

\section{1356. máj. 10. Visegrád}

Konth Miklós nádor $(\mathrm{H})$, a kunok bírája a Bery-i Tamásnak István fia: István mr.-rel, László fiaival: Mihály és Vbul mr.-ekkel, valamint Lengel (dict.) János fiaival: Lászlóval, Leukus-sel és Ábrahámmal (Abram), Kallo-i nemesekkel szemben indított ama perét, amely elődjének, Miklós nádornak $(\mathrm{H})$ és a kunok bírájának oklevele értelmében máj. 1-jén (in oct. fe. B. Georgii mart.) lett volna esedékes, és amelyben színe e. utóbbiak képviseletében az egri, valamint a váradi egyház ügyvédvalló levelében meghatalmazott Salamon fia: Miklós és Péter fia: János jelentek meg, egyrészt a nádor e. bemutatott, [1356.] máj. 2-án (II. die oct. fe. Passce d.) Zágrábban kelt és a király nagyobb pecsétjével ellátott oklevélben (l. 241. szám) foglaltak alapján — miszerint a király elrendeli, hogy Lengel (dict.) János szóban forgó fiainak bármely, a nádor e. folyó perét halasszák el —, másrészt, mivel István, Mihály és Vbul képviselői János fiainak a távollétében megtagadták a válaszadást az ügy egységére való hivatkozással (propter cause unionem), ezért a királyi hadoszlás 15. napjára elhalasztja a fennálló állapot fenntartásával. D. in Vissegrad, 10. die termini prenotati, a. d. 1356.

E.: 1. Dl. 51 705. (Kállay cs. 1t. 1300. 1110.) Papíron, hátoldalán azonos kéz írásával tárgymegjelölés, valamint Konth Miklós kerek zárópecsét töredéke (köriratból olvasható: +S NICOLAI .......), bevágásai, szalagja.

2. D1. 51 706. (Kállay cs. 1t. 1300. 1110.) Papíron, kissé sérült, hátoldalán azonos és késóbbi kéz írásával tárgymegjelölés, továbbá a nádor kerek zárópecsétjének töredéke, bevágásai; a pecséttel lezárt hátoldali részen keresztirányban korabeli jegyzet.

K.: -

R.: Kállay II. 35. (1182 a. és b. szám).

\section{1356. máj. 10. Visegrád}

Konth Miklós nádor (H), a kunok bírája a váradi egyház kápt.-jának ügyvédvalló levelében Warda-i László fia: János mr. képviseletére meghatalmazott Zeuke (dict.) Péter kérésére nyugtatja János mr.-t a képviselője által nevében teljesen megfizetett $10 \mathrm{ft}$. bírsággal kapcsolatban, amelynek megfizetésére még elődje, Miklós nádor, a kunok bírája kötelezte oklevelében Warda-i László fia: János mr.-t, s amelynek oklevél-bemutatás előtti kifizetése a bíró és a másik fél számára eredetileg márc. 16-án (in oct. diei Cynerum) lett volna esedékes, azonban ezt a kötelezettséget a nádor idóközbeni halála miatt máj. 1-jére (ad oct. fe. B. Georgii mart.) halasztották, és ennek teljesítése történt meg kétharmad részben a bíró, egyharmad részben pedig a másik fél számára. $D$. in Wysegrad, 10. die termini prenotati, a. d. 1356.

E.: Dl. 77 165. (Zichy cs. zsélyi lt. 1 B 290.) Papíron, hátoldalán azonos kéz írásával tárgymegjelölés, valamint jegyzet, továbbá a nádor kerek zárópecsétjének töredéke (körirata részben olvasható: +S(IGILIVM) [NI]COLAI [KVNT REGNI] HVNGARIE PALATINI [ET] IVDICI(S) COM[AN]OR(UM)), bevágásai, szalagja.

K.: Z. III. 28-29. (16. szám). 


\section{1356. máj. 11. Visegrád}

Miklós nádor $(\mathrm{H})$, a kunok bírája emlékezetül adja, hogy miután a korábbi oklevelében (l. 215. szám) foglaltaknak megfelelően Laad-i Domokos fia: Donch az egri egyház kápt.ja e. máj. 1-jén (in oct. fe. Pasche d.) harmadmagával esküt tett arra vonatkozólag, hogy Dobza nevú birtoka elzálogosításakor $25 \mathrm{M}$. értékben nem károsította meg a szomszédos Ynanch birtokosát, Torna-i János fia: Lászlót, ezt követően pedig a mondott kápt. oklevelével (l. 236. szám) máj. 8-án (ipso termino reportacionis seriei dicti iuramenti) megjelent színe e. - ellentmondó nem lévén - , felmentette Donch-ot a vád alól. D. in Vyssegrad, 4. die reportacionis seriei premissorum, a. d. 1356.

E.: Dl. 4606. (NRA. 1538. 19.) Papíron, hátoldalán kerek pecsét töredéke, bevágásai.

K.: AO. VI. 456-457. (294. szám) (kihagyásokkal).

280. 1356. máj. 12.

[I.] Lajos király (H, Da, C, Ra, Se, G, L, Cu, Bu, Sal., mont. S. Angeli dom.) tudtul adja: mivel eddig nem rendelkezett tudomással a Zawa folyón (in fluvio Zawe), Jeleneuch falu alatt lévố révnek (portus) a pontos helyzetéról (conditio), amelyet a király nevében egész Szlavónia néhai bánja, István fia: Miklós foglalt el, és amelyet a bánok azóta is elfoglalva tartanak, ezért a zágrábi egyház kápt.-ja olyan okleveleket mutatott be királyi színe e., mint a megboldogult Béla szlavón herceg által kiadott privilégium, amelynek értelmében a rév és a hozzá tartozó vám (dictum portum et tributum in navigio exigendum) a zágrábi kápt.-hoz tartozik, és azt illeti meg. Ezért a király nem akarván veszélyeztetni önnön üdvösségét, valamint a legszentebb István király iránti tiszteletből is, Jeleneuch révet valamennyi jogával együtt visszaadja a zágrábi kápt.-nak örök időkre, aminek bizonyságára, ill. annak biztosítására is, hogy ezután sem a király, sem a hercegek, sem a bárók, sem egyéb officialis-ok nem fogják azt visszavenni, függő és autentikus kettős pecsétjével ellátott privilégiumot bocsát ki. Annak érdekében pedig, hogy elkerüljék a gyanút, miszerint a zágrábi püspök, Miklós, aki jelenleg a király alkancellárja és pecsétjének őre, csalárdul használta fel a pecsétet az oklevél megerősítésére, a király saját, kisebb és titkos ügyekben használt kerek pecsétjének ráfüggesztésével is megerősíti az oklevelet. Kelt Miklós zágrábi püspök, udvari alkancellár keze által, a. d. 1356. IV. Id. mensis May, uralkodásának 15. évében. Méltóságnévsor: Miklós lévén az esztergomi érsek s ua. m. örökös c.-e, Vglinus a spalatói érsek — a kalocsai érseki szék üresedésben -, Miklós az egri, Demeter a váradi, Miklós a pécsi — az erdélyi szék üresedésben -, Tamás a csanádi, János a veszprémi, Mihály a váci, Péter a boszniai, [Tamás] testvér a szerémi, István testvér a nyitrai, Balázs testvér a knini püspök; Konth Miklós a nádor s a kunok bírája, Cykow a tárnokmr., András az erdélyi vajda s a Zonuk-i c., Zeech-i Miklós c. az országbíró s a Turuch-i c., Miklós a Machow-i bán, Lewstachyus az egész Szlavónia bánja, Somogy, Fejér és Tolna m.-k c.-e, Leukus az asztalnok- és a pohárnokmr., Dénes a lovászmr., Tamás az ajtónállómr., Móric fia: Simon a pozsonyi c. A.

E.: HDA. Archivum capituli Zagrabiensis: Acta antiqua 23. 61. (Df. 256 524.) Alján 1364. okt. 25-én kelt megerôsítő záradék, valamint pecsétek felfüggesztésére utaló 3 sodrat, hátoldalán azonos és késóbbi kezek írásával is tárgymegjelölés.

Á.: Zsigmond király, 1395. nov. 28. HDA. Archivum capituli Zagrabiensis: Acta antiqua 23. 63. (Df. 256 526.). 
K.: -

R.: Kercselich, Hist. Eccl. Zagrab. 131., s ennek nyomán F. IX. 2. 491-492. (235. szám); Smič. XII. 342- 343. (257. szám).

Megj.: Kercslich zavaros tartalmú közlésében a fenti szöveg után szerepel még egy — látszólag összefüggéstelen — dátumjelölés XI. Kal. Apr., amely Smič.-nál a közlés bizonytalan alapon megválasztott dátumául szolgál és téves meghatározása révén ápr. 22-i keltezést eredményezett.

281. 1356. máj. 12.

A csanádi egyház kápt.-ja tudatja: András erdélyi vajda és fivére, Miklós mr. kérésére kiküldte kanonokját, Buda-i (dict.) Péter mr.-t, aki visszatérve jelentette, hogy az egykori székely ispánnak, László mr.-nek a fiai: András vajda és Miklós mr. kinyilvánították beleegyezésüket abba, hogy mostohaanyjuk, Margit nemes asszony megvásárolja a Csanád m.-i birtokaik szomszédságában fekvő Zeleus és Zentmyklos birtokokat, ezenfelül Margit háborítatlan birtoklásáért a maguk, továbbá fivérük, a néhai István vajda fiainak és más rokonaiknak, ill. örököseiknek a nevében is szavatosságot vállaltak az atyafiságukba tartozókkal szemben. Az ügy bizonyosságára a kápt. pecsétje ráfüggesztésével megerősített privilégiumot bocsát ki. Kelt Miklós olvasókanonok keze által, fe. B. Johannis an. portam Latinam, 1356. Mihály prépost, Mihály éneklő-, Máté ơrkanonok és István temesi, Miklós marosi, valamint Márton krassói főesp. jelenlétében. A.

E.: Dl. 4613. (NRA. 587. 24.) Hártyán, a szövegkezdő iniciálé (C) 2 emberfejjel díszített, alján, zöld sodraton pecsét függ (rajta halványan kivehető Szt. György lovon ülő alakja és az előtte heverô sárkány), hátoldalán késóbbi kéz írásával tárgymegjelölés.

Á.: I. Lajos király, 1357. júl. 21. Dl. 4643. (NRA. 587. 25.) Megerôsítő záradékkal ellátva 1364. jún. 18-án.

K.: AO. VI. 457-458. (295. szám) (kihagyásokkal; E. alapján).

282. 1356. [máj. 12.,(v.u).]

János mr., Bars m. alispánja és a m. szb.-ái emlékezetül adják: korábbi memorialis oklevelükben (l. 275. szám) $3 \mathrm{M}$. bírság kilátásba helyezésével arra kötelezték Wezeken-i Miklós fia: Jánost, hogy máj. 9-én ([in] f. II. prox. p. quind. fe. B. Georgii mart.) a m. 2 szb.-jának jelenlétében fizesse meg $6 \mathrm{M}$. összegú tartozását az ugyaninnen való Miklós nemes özvegyének és gyermekeinek, továbbá utasították a feleket, hogy az azt követő máj 12-én (sequenti f. V.) színük e. jelenjenek meg. A felek mindezeknek eleget téve a kitűzött időpontokban megjelentek, ahogyan a 2 kijelölt szb., nevezetesen Rendve-i Miklós és Fys-i Vörös (Rufus) (dict.) Tamás is, s utóbbiak egybehangzó jelentést tettek, miszerint Miklós fia: János a szóban forgó özvegynek és gyermekeinek a maga birtokaiból 3 helyen kiadott földben fizette meg $6 \mathrm{M}$. összegú hátralékát, ti. Kyral Ziluaija, valamint Beel részbirtokokon, továbbá a nyitrai egyház püspökének Leueled földje közelében lévő területen 12 ekealja földet adott át számukra azzal a kikötéssel, hogy ezen részbirtokokat János a megszabott pénzért bármikor visszavásárolhassa, az özvegy és gyermekei pedig kötelesek legyenek visszaadni azokat neki; a. d. 1356. 
E.: - Az iratot közreadó Botka Tivadar cs.-i lt.-ban őrzött E.-re hivatkozik, melynek hátoldalán 5 pecsét töredéke látható.

K.: Bars 42-43. (40. szám), s ennek nyomán Palásthy III. 100-101. (81. szám).

\section{1356. máj. 13.}

Az aradi kápt. e. - miként azt 1356. máj. 13-án (f. VI. prox. p. oct. fe. BB. Philippi et Jacobi ap., a. d. 1356.) kelt oklevele tanúsítja - a Hevesvyvar m.-i Bw-i Péter fia: Domokos a maga, valamint fivére (fr. uterinus), János és Bw-i Forgach (dict.) Péter fia: Cantor (dict.) Mihály nevében is eltiltotta Bw-i István fia: Konya-t Kenderes birtok eladásától v. bármilyen más módon való elidegenítésétől, ezenfelül Miklóst, valamint Scybes fiait: Balázst és Jánost - ahogyan mindenki mást is — a szóban forgó birtok bármi módon való megszerzésétól.

Tá.: Egri kápt., 1405. ápr. 8. > Garai Miklós nádor, 1405. jún. 9. Dl. 4253. (NRA. 258. 40.).

Má.: 1. Dl. 25 818. (MKA. AP. Buda 1. 92.) 1730. ápr. 3-i hiteles Má.-ban; 29. old.

2. D1. 19 026. Ismeretlen provenienciájú iratok. 1731. jún. 30-i egyszerú Má.-ban; 3. old. Mindkettő Tá. alapján készült.

K.: Gyárfás III. 544. (76. szám) (Tá. alapján).

\section{1356. máj. 13. Visegrád}

László, a csázmai egyház prépostja, [I.] Lajos király (H) kápolnaispánja és titkos kancellárja emlékezetül adja: a színe e. megjelent Márton dömösi (Demesiensis) prépost nyugtatja Zeer-i Pousa fia: Miklóst annak a 4 ft. értékú éves census-nak a megfizetése ügyében, amelyet az a dömösi egyháznak Csongrád m.-i Leng birtoka u. tartozott megfizetni. D. in Vissegrad, f. VI. prox. p. quind. Pasce d, a. eiusdem 1356.

E.: D1. 91 484. (Festetics cs. lt. Csongrád 10.) Papíron, hátoldalán azonos kéz írásával tárgymegjelölés, valamint kerek zárópecsét töredéke (körirata részben kivehetô: [+S(IGILLVUM) DEI GRACIA] REGIS HVNGARIE), bevágásai.

K.: AO. VI. 460. (297. szám) (kihagyásokkal).

285. 1356. máj. 13.

Az esztergomi egyház kápt.-ja e. egyik részról Vech unokája Miklós fia Miklós fia Zoardus fia: Domokos, továbbá ugyanezen Domokos fiai: Lơrinc, Zoardus és János, a másik részrôl pedig az Erzsébet királyné képviseletére annak ügyvédvalló levelében meghatalmazott Demeter mr., a királyi gyưrüspecsét őre megjelenvén, elóbbiek előadják, hogy egykor az Esztergom m.-i Monyoros birtok oklevelekkel igazolhatóan Domokos nagyapjára, Miklósra háramlott, ám Markus fia: István még 50 évvel ezelőtt (50 preterisset revolutio annualis) elvette tóle, majd az idő előrehaladtával elóbb a király, az ô révén pedig azután a királyné kezére került, ki utóbbi azonban könyörületességból, ill. együtt érezve a volt birtokosokkal, önkéntes akaratából 250 tiszta arany ft.-ot fizetett Monyoros birtokért, valamint a vele kapcsolatban kiállított oklevelekért Domokosnak és fiainak, amely összeget a kápt. e. a királyné képviselője meg is fizette nekik, ezek pedig cserében 
átadták a szóban forgó okleveleket, egyúttal az esetleg titkon visszatartott okleveleiket semmiseknek és hatálytalanoknak nyilvánítják, Monyoros birtokot pedig annak minden haszonvételével, ti. telki helyekkel (loci sessionales), múvelt és parlagon hagyott földekkel, szőloókkel és mindenkinek a szőlőjéből származó, a birtokon szokás szerint behajtott hegyvámmal, nemkülönben erdőkkel, ligetekkel, vizekkel és a Szt. János tiszteletére szentelt kőegyházzal, továbbá a birtok minden hasznával, jogával, jövedelmével és tartozékával együtt, azon ősi határok mentén, ahogyan Domokos nagyapja Miklós is birtokolta, a királynénak és rajta keresztül annak v. azoknak, akiknek ő eladományozza, örökre átadják és eladják, maguknak semmiféle jogot nem tartván fenn abban. Kikötötték továbbá, hogy ha Domokos v. utódai az idők folyamán a birtok v. tartozékai ügyében keresettel állnának elő a királynéval v. azzal szemben, akinek ő a birtokot eladományozta, akkor patvarkodásban marasztaltassanak el. Ezenfelül Domokos és fiai szavatosságot vállaltak azokat illetően, akik követeléssel állnának elő az ôket Monyoros birtokból megilletô leánynegyed, hozomány és jegyajándék dolgában; ha pedig ennek nem tennének eleget, akkor párbajvesztesként ítéljék el óket (in succubitu duelii facti potentialis convincerentur). Minderrôl a kápt. nagyobb függốpecsétjével ellátott és az ABC betúivel chirographált privilégiumot bocsát ki, amelyet regisztrumába is átír, az oklevél párját pedig egyháza levéltárában (in custodia seu conservatorio) pecsétje alatt helyezi el örök őrizetre. Kelt Bálint olvasókanonok keze által, f. VI. prox. p. quind. fe. Passce d., a. eiusdem 1356. Vilmos (Gwillermus) bíboros lévén a prépost, Markus az olvasókanonok, János a gömöri, Máté a komáromi, Péter a nógrádi, Konrád a nyitrai, István a zólyomi, Demeter a barsi főesp., Domokos a Szt. Tamás-, János a Szt. György vértanú[-egyház] prépostja. A.

E.: 1. Dl. 4614. (NRA. Vet. Buda 1. 4.) Vonalazott hártyán, felül az ABC betúivel chirographálás, alján függőpecsét rögzítésére utaló bevágásokkal, a hozzá tartozó hiteles helyi nagyobb pecsét épen megmaradt (rajta koronázási jelenet két álló alakkal, a jobb oldali szemből látható, palástot viselő királyi alak jobbjában jogart, baljában országalmát tart; mellette főpapi ornátusba öltözött alak oldalról ábrázolva, kezeiben koronát emel a másik alak fejére, fejük felett háromosztatú baldachin lebeg; körirata: +S(IGILLVM) MAIVS CAPITVLIST(RI)GONIEN(SIS) ECCL(ES)IE; a királyi alak mellett REX VNGARIE, a főpap mellett ARCHIEP(ISCOPV)S ST(RI)GONIEN(SIS) felirat), hátoldalán késóbbi kéz írásával tárgymegjelölés.

2. Uo., mint E. 1., azzal megegyező jelzet alatt. Vonalazott hártyán, felül BC betûivel chirographálás, alján függőpecsét rögzítésére utaló bevágásokkal, ép pecséttel (l. előző pecsétleírás), hátoldalán késóbbi kéz írásával tárgymegjelölés.

K.: AO. VI. 458-460. (296. szám) (kihagyásokkal).

\section{1356. máj. 13. Visegrád}

Zeech-i Miklós c., [I.] Lajos király (H) országbírája, Turuch m. c.-e tudtul adja: korábbi ítéletlevelében (l. 238. szám) a bácsi egyház kápt.-ja e. máj. 2-án (2. die oct. fe. B. Georgy mart.) ötvenedmagukkal - fejenként 24-24 nemes eskütárssal - együtt leteendő esküre kötelezte Huzybach-i János fiait: Miklóst és Jánost B........-i Sebestyén fia: János ellenében, hogy igazolhassák, miszerint Kanata és Huzyubach falvakban lakó (residentes) famulus-aik, Beke, Ipolitus és Erdeus [?] fia: Tamás egy éve (revolutio annualis) [1355.] márc. 5-én (f. V. prox. p. domin. Remin.) nem az ô egyetértésükkel és tudtukkal verték agyon a Huzyubach faluból a piacról távozó és a közúton haladó Sebestyén fia: János fivérét (fr. uterinus), Balázst. Az eskütételtól számított 8. napon (8 die), máj. 9-én kel- 
lett a feleknek bírói színe e. bemutatni a kápt. erről írt jelentését. A kitűzött időpontban Miklós és János nevében Kenez (dict.) István jelent meg színe e., és bemutatta a bácsi egyház kápt.-jának oklevelét (l. 245. szám), amely tanúsította János szóban forgó fiainak és társaiknak eskütételét, ez alapján pedig felmenti óket a vád alól. D. in Wysegrad, 12. die termini prenotati, a. 1356.

E.: SNA. Zay cs. ugróci lt. Krasznecz László elenchusa szerint rendezett iratok B 1. 80. H. (Df. 265 646.) Hátoldali fényképe hiányzik.

K.: -

\section{1356. máj. 16. Visegrád}

Zeech-i Miklós c., [I.] Lajos király (H) országbírája, Turuch m. c.-e tudtul adja: korábbi ítéletlevelében (l. 239. szám) Chahol-i János fia: Sebestyén mr.-t az egri kápt. e. máj. 2-án (2. die oct. fe. Passce d.) ötvenedmagával, nemes eskütársakkal együtt leteendő esküre kötelezte Berue-i István fia: András ellenében, ezzel bizonyítandó panaszát, miszerint István fia: András az elmúlt év [1355.] márc. 11-én (f. IV. in die medii Quadr.) Berue nevú birtokáról hatalmaskodva rátört Prazna birtokra, ahonnan a panaszos 16 M.-át érő 2 lovát elkötötte, és Berue-be vitte. Az eskü letételéről számot adó kápt.-i jelentést — eskütevő társaik nevének feljegyzésével — máj. 9-re (8. die) kellett visszavinniük az országbírónak. A kitüzött időpontban az országbíró színe e. egyik részről a Sebestyén mr. nevében az egri kápt. ügyvédvalló levelében meghatalmazott János fia: László, a másikról pedig István fia: András képviseletében a Lelez-i konvent ügyvédvalló levelét felmutató István fia: Jakab jelent meg, és bemutatták az egri kápt. jelentését (l. 246. szám), amely szerint Sebestyén mr. máj. 2-án (in f. II. prox. an. oct. fe. Passce d.) a fenti ügyben esküt tett István fia: András ellenében az itt felsorolt 49 nemessel együtt: ti. a Szatmár m.-i Dombou-i Péter fia: János, János fia: János ugyaninnen, a Borsod m.-i Heythu-i János fia: József, a Vasvár m.-i Olad-i Bodor fia: Gergely, a Gömör (Gemeriensi) m.-i Cholthey-i Mihály fia: Miklós, a Szatmár m.-i Wray-i Cobak András, a Zolnuk m.-i Zenthkyral-i Péter fia: László, Ody-i László fia: András, Wray-i János fia: Pál, a Borsod m.-i Nyek-i Beke fia: György, a Borsod m.-i Olth.......-i Miklós fia: László, Thokay-i Gergely fia: Thorna, Tylay-i Lőrinc fia: Miklós, Cherh-i Imre, a Borsod m.-i Byky-i Bertalan, a Szatmár m.-i Thatarfalua-i Thatar (dict.) István fia: János, a Zolnuk m.-i Thur-i Miklós fia: István, a Zabouch m.-i Rohod-i László fia: János, a Szatmár m.-i Gywth-i János fia: Mihály, ugyaninnen Vaya-i András fia: László, a Borsod m.-i Jethey-i Miklós fia: Kelemen, ue. Rohod-ból való Beke fia: Pál, ugyeninnen való Sándor fia: János, a Szatmár m.-i Pelys-i Lukács (Lukasy) fia: János, Wgacha-i Vgocha-i Tyuadarfalua-i János fia: Tamás, ugyaninnen való Syrma-i Márton fia: Miklós, a Zolnuk m.-i Doba-i Bekes fia: Miklós, a Szatmár m.-i Padad-i Tamás fia: István, a Zabouch. m.-i Bogdan-i Olivér fia: Lókös (Leukes), a Hewes Heues m.-i Wecthe-i János fia: György, a Borsod m.-i Baba-i Jakab fia: Péter, ugyaninnen Jakab fia: János, a Heues m.-i Lak-i Iwanch fia: Pál, ugyaninnen való Felpyspuky-i István fia: Péter, a Zolnuk m.-i Theteuthelek-i Pál fia: István, Alathk-i Lőrinc fia: Balázs, a Bereg m.-i Swryan-i Sampson (gen: Sampsonis) fia: Jakab, Vgocha m.- Beken-i Gergely fia: János, Dorman-i Jakab fia: Benedek, a Zolnuk m.- Sylag-i János fia: Egyed, a Szatmár m.-i Wylak-i István fia: László, a Zabouch m.-i Kerch-i Simon fia: András, a Szatmár m.-i Moyg-i Miklós fia: András, Lydow-i [?] Tamás fia: Lóránd, az Vgacha-i Gewgenhasa-i Gewden fia: Balázs, a Zolnok m.-i Kawas-i Twrol fia: Demeter, ugyaninnen Doba-i Bertalan fia: Miklós, Vgacha m.-i Sarwar-i György fia: János, a Szatmár m.-i Mand-i Péter fia: István. Az eskütételt István fia: András az egri 
kápt. e. személyesen hallgatta meg. Az országbíró, miután bemutatták neki az oklevelet, már éppen ítéletet akart hozni, azonban István fia: András törvényes képviselője, Jakab azt állította, hogy az egyik eskütevő, név szerint Alathk-i Lőrinc fia: Balázs nem nemes ember, és birtokkal sem rendelkezik (impossessionatus), mi által nem esküdhetett nemes emberként. Ezzel szemben Sebestyén mr. képviselője, János fia: László azt állította, hogy a szóban forgó Balázs birtokos nemes, így alkalmas az eskütételre. Az országbíró a vele együtt ülésező bárókkal és nemesekkel kötelezte Sebestyén mr.-t, hogy a királyi hadoszlás 15. napjára [1357. márc. 29.] (in quind. residentie exercitus regii) bizonyítsa a bíróság e. Lőrinc fia: Balázs nemesi mivoltát, amelynek megtörténtét követően dönt majd a bíróság a fennforgó ügyben. D. in Wissegrad, 8. die termini prenotati, a. d. 1356.

E.: Dl. 38 864. (Ismeretlen provenienciájú iratok) Papíron, hátoldalán azonos kéz írásával tárgymegjelölés, valamint 2 kerek zárópecsét nyoma, bevágásai; a pecséttel lezárt hátoldali részen keresztirányban korabeli jegyzet.

K.: -

\section{1356. máj. 17. Visegrád}

László, a csázmai egyház prépostja, [I.] Lajos király (H) kápolnaispánja és titkos kancellárja e. Miklós testvér, a premontrei rend Jazo-i monostorának konventjéból a maga, valamint konventje nevében tiltakozó nyilatkozatot tett, mivel a Jazo-i monostor prépostja, Miklós testvér nem ebból az országból való, hanem idegen földrôl származik, így nem ismerve az ország törvényeit és szokásait, sem a bíróságokat sem a perek eljárásrendjét, a monostor ügyeiben tétován és gondatlanul járt el, ami a monostor több birtokának és jogának a pusztulásához, elvesztéséhez és elidegenítéséhez vezetett. A konvent mindezekre nem fordítván kellő figyelmet, mostanáig tekintettel volt a prépostra mint főpapra, akinek a gondatlansága a leírt helyzethez vezetett. Azonban a jövóben - megértve a történtek fenyegető voltát, és el akarva kerülni a további romlást — a Jazo-i prépostot eltiltják az eladástól, és bármi más módon történő elidegenítéstől, másokat pedig — így a nyitrai püspököt, Harkach-i Gál deákot és a Sankfolua-i nemeseket, valamint a Scepsy-i polgárokat és hospes-eket is - a Jazo-i monostor jogainak és birtokainak a megszerzésétól, megvásárlásától és elfoglalásától, különösen pedig az Abawyuar m.-i Pereche és Gömör m.-i Saulendrefeulde birtokoknak az elidegenítésétől és bármi módon való megszerzésétől, valamint a monostor határai között lévő erdők elvételétôl és a monostor bármely más, bárhol lévő tulajdonának az elfoglalásától, nemkülönben minden olyan megegyezéstől, amely a monostor jogainak megszerzésére irányul. D. in Wyssegrad, 17. die oct. fe. Passce d., a. eiusdem 1356.

E.: SNA. Jászói prépostság mlt. 34. (Df. 232 835.) Hátoldalán több — késő középkori és újkori — kéz írásával helynév-megjelölések, valamint kerek pecsét nyoma, bevágásai.

K.: -

289. 1356. máj. 17. Zágráb

A zágrábi egyház kápt.-ja jelenti [I.] Lajos királynak $(\mathrm{H})$ : a király itt átírt máj. 2-án kelt parancslevelében (l. 240. szám) foglaltaknak eleget téve Paris fia: Fülöp királyi ember mellé kanonoktársukat, János Warosd-i főesp.-t adták tanúul, akik Prystauchyna földre 
érve az összehívott szomszédok és határosok jelenlétében egy 35 ekealja nagyságú földdarabot valamennyi haszonvételével és tartozékával együtt a Boldogságos Szúz egyházának és odatartozó testvéreinek iktattak örök birtoklásra ellentmondás nélkül. D. f. III. prox. p. fe. B. Nereii et Achyllei mart., a. d. 1356.

Á.: A 302. számú oklevélben.

K.: Smič. XII. 353. (265. szám) (Á-ról).

290. (1356. máj. 18.e.)

[I.] Lajos király tanú állítására szólítja fel az esztergomi kápt.-t Vadach-i Teke fia: Péter királyi ember mellé Moniorous birtok Taath birtokkal érintkező határszakaszának kitűzéséhez.

Eml.: Az 529. számú oklevélben.

K.: -

291. (1356. máj. 18.e.)

Az esztergomi kápt. jelenti, hogy a hozzá intézett királyi parancslevélben foglaltaknak megfelelően Vadach-i Teke fia: Péter királyi ember és társaságában a tanúbizonyságul küldött Miklós presbiter, az esztergomi egyház javadalmasa (prebendarius) máj. 18-án (f. IV. prox. p. 22. die fe. Passce d. prox. preterita) felkeresték a királyné Moniorous birtokát, s ott elsóként azon a részen, ahol a királyné birtoka a szentkirályi keresztesek Taath birtokával határos, valamennyi határtárs és szomszéd jelenlétében 4 határjelet állítottak fel a régi határjelek mellett. Ekkor azonban a keresztesek mr.ének officialis-a tiltakozást jelentett be, ezért a kiküldöttek jún. 2-ra (ad vig. fe. Assc. d. prox. preteritam) a királyi jelenlét elé idézték Vilmos (Gillermus) bíborost, titeli prépostot, a [budafel-]hévizi Szt. Háromság-egyház kereszteseinek (cruciferorum S. Trinitatis de Calidis Aquis), továbbá az esztergomi Szt. István király-egyházának (S. regis Stephani de Stirgonio) mr.-ét Erzsébet királyné $(\mathrm{H})$ ellenében.

Eml.: Az 529. számú oklevélben.

K.: -

\section{1356. máj. 18. Visegrád}

László a csázmai egyház prépostja, [I.] Lajos király (H) kápolnaispánja és titkos kancellárja e. egyik részről Arukkuzisar-i László fia: Gergely a maga, valamint a vasvári kápt. ügyvédvalló levelében meghatalmazva fivére (fr. carnalis), Tamás nevében is, a másik részrôl pedig a Kald-i László fiai: Antal és János nevében a vasvári kápt. ügyvédvalló levelével eljáró János fia: Domokos és Iuanka fia: Péter kinyilvánítják, hogy egymás között fennforgó ügyekben a felek megegyezésre jutottak. Eszerint a békéltetésben közremúködő fogott bírák (boni viri communes) döntése értelmében László fiai: Antal és János 15 nappal azután, hogy a királyi hadjáratból visszatérnek (in quind. reversionis de exercitu regio prox.) a Huzyutouth-i Szt. Mihály arkangyal egyházánál, a nevezett kápt. tanújának jelenlétében századmagukkal, nemes eskütársakkal együtt — ti. mindkettejük esetében 50-50 fő eskütételével - kötelesek bizonyságot tenni arra vonatko- 
zólag, hogy Gergelynek és Tamásnak Tormasfyues birtokon lévő házait nem égettették fel és azok birtokainak különféle haszonvételeit a törvényes tiltás ellenére hatalmaskodva nem ragadták magukhoz, és nem is bitorolják. Ezenfelül a Gergelyt és Tamást privilégiumokkal igazolhatóan jog szerint megillető Zala m.-i Tomasfyues, Markfeulde és Vk birtokokat haladéktalanul visszaadják, továbbá a vasvári kápt.-ban júl. 1-jén (in oct. fe. Nat. B. Johannis Bapt.) Kald-i László szóban forgó fiai 3 M.-t kötelesek fizetni Gergelynek és Tamásnak részben használatban lévő ....... zalai súllyal számolt dénárokban, részben pedig becsértékben, és soha többé nem merészelik Gergely és Tamás akarata ellenére az ő birtokainak és részbirtokaiknak a haszonvételeire rátenni kezüket és használni azokat. A felek a kápolnaispán e. tudományvételi, perrel- és bírsággal kapcsolatos valamennyi oklevelüket, amelyeket ez ideig egymással szemben kiállíttattak, ezenkívül a tiltó-, egyezség- és véglegesítő- (perpetuales) okleveleket is mind hatálytalanoknak nyilvánítják, hozzáfüzve, hogy ha László fiai a kijelölt időpontban késlekednének a bírság megfizetésével, akkor annak kétszeresét lesznek kötelesek a másik félnek megfizetni, amennyiben pedig a Zala m.-i ispán v. alispán állna elő a fent nevezett per okán Gergellyel és Tamással szemben bármekkora pénzösszeg követelésével, akkor a nevezetteknek ezzel kapcsolatban nem kell egyáltalán semmit sem fizetniük, amint mindezekról a felek a prépost és kápolnaispán színe e. is rendelkeztek. D. in Vissegrad, 18. die oct. fe. B. Georgii mart., a. d. 1356.

E.: ELTE 1t. Történeti intézet iratgyújtemény (Df. 250 421.) Papíron, hátoldalán azonos kéz írásával tárgymegjelölés (eltérő névalakja: Huzyutot), valamint kerek zárópecsét töredéke, bevágásai.

K.: -

\section{1356. máj. 18.}

Az egri egyház kápt.-ja e. Orosy-i Egyed fia Simon fia: Imre mr. a maga és fivére Péter nevében is elpanaszolta, hogy Biry-i János fia: Tamás, valamint fiai: László, János és Fülöp a Beregh m.-i Bodolou Bodolow birtokon lévő teljes részbirtokukat az ô tudtuk és beleegyezésük nélkül elzálogosították rokonuknak, Nogsemyen-i István fia: István mr.nek. Mivel ôk - mint ahogyan István mr. is - köztudottan részbirtokkal rendelkeznek azon a birtokon, ezért tiltják Tamást és fiait a szóban forgó birtok elzálogosításától, eladásától v. bármilyen más módon történő elidegenítésétől, a megjelent István mr.-t és másokat pedig annak elfoglalásától, hozzátéve, hogy ők, bárki is idegenítse el Tamástól és fiaitól a mondott részbirtokot ugyanúgy mint István mr. is, készek minden módon megszerezni azt a maguk részére. D. f. IV. prox. an. fe. S. Elene regine, a. d. 1356.

E.: Dl. 51 707. (Kállay cs. 1t. 1300. 1117.) Papíron, hátoldalán azonos és késóbbi kéz írásával is tárgymegjelölés, valamint kerek zárópecsét nyoma, bevágásai, szalagja.

R.: Kállay II. 36. (1183. szám).

Megj.: Mind az oklevél szövegében, mind a hátoldali tárgymegjelölésben Orosy-i Iwan neve szerepel, amit az előlapon áthúztak és a sor fölötti beszúrással Egyed-re javítottak.

294. 1356. máj. 19.

A Lelez-i konvent e. — miként azt 1356. máj. 19-én (a. d. 1356. f. V. prox. an. fe. B. El- 
ene regine) kelt oklevele tanúsítja —Domokos fia Donch fia: János és Leztemer-i Albert fia Peteu fia: János nevében Leztemer-i László fia: Simon panaszt tett, mivel nevezettek apái, Donch és Peteu Jenke birtok ügyében, amely a két János nagyapjától, Domokostól és Alberttól háramlott rájuk, egyezséget kötöttek szentandrási (de S. Andrea) István fia: Andrással, ugyaninnen való Péter fia: Péterrel, valamint Bator (dict.) János fia: Istvánnal, mely megállapodás értelmében Jenke birtokuk felét Andrásnak, Péternek és Istvánnak adják, megkárosítva ezzel a panaszosokat és utódaikat. Ezért a nevükben eljáró Simon Donch-ot és Peteu-t a szóban forgó birtokfél bárminemú elidegenítésétől, Andrást, Pétert és Istvánt pedig annak elfoglalásától tiltja a konvent e.

Tá.: Szepesi Jakab országbíró, 1377. márc. 29. Dl. 66 830. (Dessewffy cs. margonyai lt. 50.).

K.: -

\section{1356. máj. 19. Visegrád}

Zeech-i Miklós c., [I.] Lajos király $(\mathrm{H})$ országbírája, Turuch m. c.-e emlékezetül adja: a korábbi oklevelében foglaltaknak megfelelően (l. 135. szám) Dwb-i Leueu (dict.) Miklós hetedmagával, nemes eskütársakkal együtt, máj. 1-jén (in oct. fe. B. Georgy mart.) esküt tett a nyitrai egyház kápt.-ja e. Damyan-i András fia: Herbordus-szal szemben arra vonatkozólag, miszerint Miklós veje, Peteu — aki Miklósnál töltötte napjait — [1355.] nov. 8-án (die domin. prox. p. fe. OO. SS) fényes nappal nem kötötte el Herbordus 50 ft.-ot érő 2 lovát, és így nem is vezette azokat Miklós házához. A jelentés (l. 243. szám) máj. 8-i (in 8. die diei oct. B. Georgii) bemutatása u. az országbíró felmenti Miklóst minden vád alól. D. in Wyssegrad, 12. die reportationis seriei prenotate, a. d. 1356.

E.: - Fk. Dl. 95 262. (Ocskay cs. 1t. 31 A). A MOL adatbázis szerint hártyán, hátlapján zárópecsét nyomaival.

K.: -

\section{1356. máj. 20. Visegrád}

Zeech-i Miklós c., [I.] Lajos király (H) országbírája, Turuch m. c.-e emlékezetül adja: az egykori országbíró, Drugeth Miklós c. oklevelében foglaltak szerint [1355] nov. 8-án (in oct. fe. OO. SS.) megjelent színe e. a veszprémvölgyi Boldogságos Szúz-egyház apácáinak képviseletében az ő országbírói ügyvédvalló levelében meghatalmazott Pál fia: Benche, vele szemben pedig Luka fia: Péter, Bodur $\sim$ Budur fia: Máté, Zerie $\sim$ Zerye fia: Balázs, Jakab fia: László mr., ennek fivére, János, János fia: Miklós, és Mark fia: Jakab Chayagh-i nemesek, s Benche előterjesztette, hogy amikor a nevezett apácák a királyi és a [székes-]fehérvári egyház káp.-jának emberével amazok Chytim birtokát amely az apácák kezére jutott - határai mentén az összehívott szomszédok jelenlétében be akarták járni, és határjelek állításával el akarták választani, akkor a felsorolt Chayagh-i nemesek eltiltották őket a Chayagh birtok felé eső határjelek felállításától, amelynek okát az apácák meg akarták tudni. Benche bemutatta ugyanakkor [I.] Károly király $(\mathrm{H})$ 1330. évi - a Havasalföldön elveszett (in partibus Transalpinis casu deperdito) —, középsőként használt pecsétjével megerősített privilégiumát ( $l$. Anjouoklt. XIV. 230. szám), Lodomér néhai esztergomi érsek és egyházának kápt.-ja 1296-ban kiadott oklevelét, amely tartalmazta Kálmán király (H) 1109-es kiváltságlevelét, amely 
átírta és megerősítette Szt. Istvánnak, Mo. első királyának és apostolának a veszprémvölgyi Boldogságos Szűz kolostora javára, alapítása kapcsán adományokkal való ellátása tárgyában kiállított oklevelét. Utóbbi bizonyítja, hogy alapításukkor más birtokokkal együtt adományként kapták Chytim udvarnoki birtokot (possessio udvarnicalis) az oklevélben rögzített határok mentén. Erre válaszként az említett nemesek nevében Chayag-i Miklós fia: János és Péter fia: János azt válaszolták, hogy azért tiltakoztak a határok felállítása ellen, mert Chayagh birtokból az apácák egy nagy részt el akartak foglalni, és a sajátjukhoz csatolni. Mivel az országbíró és a vele ítélkező bárók és nemesek úgy rendelkeztek, hogy az oklevélben leírt határok mentén el kel választani az apácák Chytim és a nemesek Chayagh birtokát királyi ember révén és a [székes-]fehérvári egyház kápt.-jának tanúságtétele mellett, ezért az országbíró levelet (l. 203. szám) intézett a nevezett kápt.-hoz, amelyben kérte, hogy adjon hites tanúkat mindkét fél részére a királyi udvarból külön erre a feladatra kiküldött királyi ember, Konrád (Corrardus) fia: Miklós - a királyi udvar ifja (aule regalis iuvenis) - mellé. A kiküldötteknek ápr. 28-án (f. V. prox. p. fe. Pashe d.) Chytim birtokra menve az apácák v. törvényes képviselőjük révén helyben bemutatott, Károly királytól származó privilégiumban leírtak alapján kellett bejárniuk a Chayagh birtok felé eső határokat az elsótôl az utolsó határjelig. Ha a határjelekről bebizonyosodott, hogy azok igazak és jogosak, akkor azok mentén kellett elválasztani az érdekeltek birtokait - mivel a felek ellentmondást nem tehetnek —, amennyiben bárki más nem él ellentmondással, úgy szükség szerint a régi határjelek mellé újakat kellett állítaniuk, az elválasztott birtokokat pedig meg kellett hagyniuk jogos tulajdonosának örök és békés birtoklásra idegen jog sérelme nélkül. Ha a hatájeleket nem találnák rendben és valamely földdarab a felek között vitás és peres maradna, akkor azt lehetőség szerint meg kellett mérniük a királyi mértékkel, s ha ez nem lehetséges, akkor fogott bírák közremúködésével kellett azt becsú alá vetniük, majd a hj. lefolyásáról a kápt. máj. 1-jére (ad oct. fe. B. Georgii mart.) írásos jelentéstétellel tartozott a király számára. A kitűzött időpontban az országbíró e. megjelent az apácák nevében Pál fia: Benche procurator és bemutatta a fehérvári kápt. királynak címzett jelentését (l. 214. szám), amelyben többek között benne foglaltatott, hogy a kápt. nevezett Konrád fia: Miklós, uralkodói kegyből kiküldött királyi ember mellé Chech (dict.) János presbitert adta tanúul az apácák oldalán, akik visszatérve jelentést tettek. Eszerint a birtok szomszédainak és határosainak összehívását követően a fentebb felsorolt Chayagh-i nemesekkel és Benche törvényes képviselővel Chytim birtokra mentek, ahol a Károly király bemutatott privilégiumában foglaltak szerint az elválasztó határjelek mentén el akarták azt választani más birtokoktól. Hj.: az első határjel egy Kayaritya nevû helyen kezdődik Dé-ről, ahonnan tovább haladva régi határjelek tûnnek fel az alább leírt rendben, amelyek közelében újakat emeltek; az első jeltől É felé tartva 2 jelhez ér, közülük az apácák birtokától elválasztó határjel mellett egy új jelet emeltek, innen tovább a Kayar-ból Kense birtokra vezetố úthoz, majd azon keresztül Ny felé az út melletti 2 földjelhez, ahol egy újat is emeltek, majd keveset É felé haladva 2 földjel, mellettük újat emeltek, tovább haladva újabb 2 határjel, mellettük újat emeltek, majd megint 2 jel, mellettük egy újonnan emelt, és továbbhaladva ismét 2 jel, közelükben új határjel, majd innen úton átkelve berch-hez ér, rajta 2 földjel, mellettük egy újonnan emelt, innen É-nak tart 2 földjelhez, mellettük újat emeltek, ahonnan ismét 2 földjelhez ér, mellettük újat emeltek, majd tovább 2 földjelig, mellettük egy újonnan emelt, ahonnan tovább menve úthoz érkezik, mellette 2 földjel, közelükben új határjelet emeltek, majd az úton átkelve Ke-nek tart és elér 2 földjelhez, amelyek mellett újat emeltek, tovább menve újabb úthoz ér, mellette 2 földjel, az egyik egy körtefánál, a másik az út közelében, ezek mellett is újat emeltek, innen továbbhaladva 3 földjelhez ér, közülük az egyik a veszprémi egyház kápt.-jának Kezeu birtokát, a másik Chayagh birtokot, a 
harmadik az apácák Kenche birtokát választja el és itt ér véget Chytim határa. Azt is jelentették a kiküldöttek, hogy az országbíró oklevelében foglaltak ellenére a Chayagh-i nemesek a kitűzött időpontban nem vezették Chytim birtokra a kápt. tanúját, a kiküldöttek a hj. elvégezték és az elválasztott földeket meghagyták az apácáknak örök időkre idegen jog sérelme nélkül. Az országbíró a vele törvénykező nemesekkel együtt a kápt.i jelentés alapján Chytim birtokot a rögzített határok mentén örökre a veszprémvölgyi apácák tulajdonában hagyja. D. in Wysegrad, 20. die oct. fe. B. Georgii mart., a. d. 1356.

E.: Dl. 4615. (MKA. Acta Jes. Jaurin. 3. 10.) Vonalozott hártyán, hátoldalán azonos és későbbi kezek írásával tárgymegjelölés, alján függőpecsét beillesztésére utaló vágások.

Má.: 1. Dl. 25 081. (MKA. Acta Jes. Jaurin. 7. 36.) (a vége hiányzik).

2. Dl. 25 123. (Uo., 31. 13.)

3. Dl. 25 124. (Uo., 31. 4.) 13-19. old. Mindhárom 18. sz.-i egyszerú Má.-ban.

Reg.: Dl. 25 125. (Uo., 6. 24.) (18. sz.-i latin nyelvú kivonat).

K.: AO. VI. 461-465. (298. szám) (kihagyásokkal) E.-ról.

Megj.: Kálmán király átírt oklevelét 1. DHA. I. 368-380. (136/II.); Lodomér esztergomi érsek privilégiumát F. VI. 2. 38-42., ennek hitelességével kapcsolatban 1. DHA. I. 368. (136/II.) B. not. 1. Vö. DHA. I. 374. (136/II. m.).

\section{1356. máj. 21.}

[I.] Lajos király (H, Da, C, Ra, Se, G, L, Cu, Bu, Sal., mont. S. Angeli dom.) az eléje járuló Dénes, Kemluk-i főesp.-nek a zágrábi egyház kanonokjának kérésére - aki az égi dolgokat a földiek elé, az örökké valókat pedig a mulandók fölé helyezni akarván különleges felajánlást tett - hozzájárul ahhoz, hogy Dénes a zágrábi egyházban Szt. Mária Magdaléna tiszteletére emelendő oltár létesítéséhez és az ott szolgáló pap használatára a Zágráb m.-i Luca fia: István birtokának szomszédságában lévő, egykor Cychorya, most Petrouch nevû́ vásárolt birtokrészét, amelyet ifjú korától jogosan és békében birtokol, egyházi javadalom céljával rendelkezésre bocsáthassa, s odaadott birtokával a mondott egyház ugyanolyan feltételekkel és szabadsággal élhesen, mint amilyennel más birtokai esetében rendelkezik. Kelt Miklós zágrábi püspök és királyi alkancellár keze által, a. d. 1356., XII. Kal. mensis Junii, uralkodásának 15. évében. Méltóságnévsor: Miklós lévén az esztergomi érsek, egyben ua. m. örökös c.-e - a kalocsai szék üresedésben -, Wglinus a spalatói érsek, Miklós az egri, Demeter a váradi — az erdélyi szék üresedésben -, Miklós a pécsi, János a veszprémi, Kálmán a győri, Tamás a csanádi, Mihály a váci, Péter a választott boszniai, Tamás testvér a szerémi, István testvér a nyitrai és Balázs testvér a knini püspök; Konth Miklós a nádor és a kunok bírája, András az erdélyi vajda és a Zonuk-i c., Cykow a tárnokmr., Zeech-i Miklós az országbíró és Turuch-i c., Miklós a Machow-i bán, Leustachius a Somogy, Fejér és Tolna m.-i c. és az egész Szlavónia bánja, Dénes a fólovász mr., Leukus az asztalnok- és a pohárnok mr., Péter fia: Tamás az ajtónálló mr., Móric fia: Simon a pozsonyi c. A.

E.: HDA. Archivum capituli Zagrabiensis: Acta antiqua 76. 16. (Df. 256 757.) Hártyán, bal alsó sarkában 1364. febr. 23-i megerősítő záradék, alján pecsét felfüggesztésére utaló zsineg, hátoldalán késóbbi kéz írásával tárgymegjelölés.

K.: Tkalčić, Mon. civ. Zagrab. I. 211-213 (236. szám); Smič. XII. 353-355. (266. szám). 
Zeech-i Miklós c., [I.] Lajos király (H) országbírája, Turuch m. c.-e tudtul adja, hogy miután színe e. az Orboua-i Péter fia Leukus nemes hitvesét a boszniai egyház kápt.jának ügyvédvalló levelével képviselő Barnabás fia: Pál a Dobouch-i Cymba (dict.) István fia: Istvánnal, valamint Dobouch-i Cymba (dict.) István fia: Domokos nemes leányaival, Anych-csal és Bogow-val szemben fennforgó perben máj. 1-jétől (ab oct. fe. B. Georgii mart.) 20 napon át hiába várakozott amazok érkezésére, holott korábbi országbírói oklevele ( $l$. 226. szám) értelmében Oryauicha birtokrész ügyében kötelesek lettek volna bemutatni okleveleiket, minthogy nem jöttek el és nem is küldtek senkit maguk helyett, bírságban marasztalja el ôket, hacsak alapos indokkal ki nem mentik magukat. D. in Wissegrad, 21. die termini prenotati, a. d. 1356.

E.: Dl. 41 284. (Múz. Ta. Békássy) Papíron, hátoldalán azonos kéz írásával tárgymegjelölés, valamint kerek zárópecsét nyoma, bevágásai, szalagja.

Má.: Uo., mint E, azzal megegyező jelzet alatt; modern kori Má.-ban.

K.: AO. VI. 466. (299. szám) (kihagyásokkal).

\section{1356. máj. 21. Visegrád}

Zeech-i Miklós c., [I.] Lajos király (H) országbírája, Turuch m. c.-e a Zalok-i Zalouk-i Domokos fia Miklós fia: Domokosnak Zalok-i Péter fia: Warada ellenében indított ama perében, amelyben Tamás c. néhai országbíró korábbi oklevele értelmében a felek végleges válaszadás végett kötelesek voltak megjelenni, bírságban marasztalja el Warada-t, hacsak alapos indokkal ki nem menti magát, mivel színe e. Domokos máj. 1-jétől (ab oct. fe. B. Georgii mart.) 20 napon át hiába várakozott érkezésére, ő nem jelent meg és képviselőt sem küldött maga helyett. D. in Vissegrad, 21. die termini prenotati, a. d. 1356.

E.: Dl. 84 271. (Lónyay cs. lt. AG 10. 137.) Papíron, hátoldalán azonos kéz írásával tárgymegjelölés, valamint Szécsi Miklós kerek zárópecsétjének töredéke (egy madár karmos lábai és szétterjesztett szárnyai vehetőek ki a pecsétképen), bevágásai, szalagja.

K.: -

\section{1356. máj. 23. Visegrád}

Zech-i Miklós c., [I.] Lajos király országbírája, Turuch m. c.-e a Byry-i Tamásnak Kozma fia: Iwan-nal szemben indított ama perét, amely a királyi kápolnaispán Wyssegrad-on kiállított idéző és tudományvételi levelében foglaltak szerint máj. 20-án (f. VI. prox. an. fe. B. Wrbani pape) lett volna esedékes országbírói törvényszéke e., a felek akaratából aug. 1-jére (ad oct. fe. B. Jacobi ap.) elhalasztja a fenálló állapot fenntartásával. D. in Wyssegrad, 4. die termini prenotati, a. d. 1356.

E.: Dl. 51 708. (Kállay cs. 1t. 1300. 1107.) Papíron, hátoldalán azonos kéz írásával tárgymegjelölés, valamint zárópecsét nyoma, bevágásai; a pecséttel lezárt hátoldali részen keresztirányban korabeli jegyzet.

K.: - 
R.: Kállay II. 36. (1184. szám)

\section{1356. máj. 24. Visegrád}

László, a csázmai egyház prépostja, [I.] Lajos király kápolnaispánja és titkos kancellárja emlékezetül adja: az ország lakóinak a királynéhoz eljuttatott azon panaszát igyekezvén orvosolni, miszerint a fóesp.-ek és helyetteseik folyamatosan jogtalanságot és búnt követve el a meggyilkoltak temetéséért a legnagyobb díjat hajtják be tőlük, ill. a hozzátartozóktól, ezért a kápolnaispán engedelmeskedve a királyné utasításának, átírja az ilyen természetû ügyben rendelkező [XII.] Benedek pápa 1335. aug. 13-án kiállított oklevelét (l. Anjou-oklt. XIX. 500. szám), amelyben az egyházfő utasította az esztergomi érseket, hogy vonja egyházi fenyíték alá azokat az egyháziakat, akik Mo.-on egyházi temetés címén jogtalanul 1 M.-t szednek be a temetésért, majd László prépost az átíást azzal a királyi pecséttel látja el és erôsíti meg, amely kápolnaispáni tisztségéból kifolyólag van használatában. D. in Wyssegrad, f. III. prox. an. fe. B. Vrbani pape, a. d. 1356.

E.: 1. Dl. 4584. (MKA. Acta eccl. 1. 4.) Hártyán, alján zöld sodraton pecsét függ, mely a MOL leírása alapján természetes színú viasz, függőpecsét (52 mm), a pajzs bal oldaldalán 4 folyó, jobb oldalán Anjou-liliomok csillagszerú keretben; körirata: +S(IGILLVM) LODOVICI DEI GRACIA REGIS HVNGARIE." Hátoldalán késóbbi kezek írásával tárgymegjelölés.

2. E 1. Fk. formátumban. AMB. Pozsony város lt. Középkori oklevelek és levelek 130. (Df. 238 755.)

K.: -

R.: AMB. Inventár 26. (136. szám) (cseh nyelvû).

\section{1356. máj. 25. Zágráb}

[I.] Lajos király $(\mathrm{H})$ az első remete, Szt. Pál rendjéből, a zágráb-elóhegyi rend valamennyi szerzetes testvére és perjele képviseletében eljáró Miklós testvér kérésére és oklevél-bemutatása alapján nyílt oklevelében átírja a zágrábi kápt. máj. 17-én kelt jelentését (l. 289. szám) bizonyos Pristauchyna részbirtok iktatása kapcsán. D. Zagrabie, in fe. B. Urbani pp., a. d. 1356.

Á.: - Smičiklas szerint Lajos király 1356. máj. 25-i oklevelét 1364. aug. 22-én megerősítő záradékkal látta el. Az oklevél szövegét a zágrábi kápt. 1369. okt. 22-i átírta tartotta fenn és erról készült Smičiklas kiadása, amelyet akkor a zágrábi levéltárban őríztek „Actor convent. Remetensis fasc. I. no. 11.” jelzet alatt. A MOL nem tartja nyilván az iratot.

K.: Smič. XII. 355-356. (267. szám) (Á-ról).

\section{1356. máj. 25. Visegrád}

Konth Miklós nádor $(\mathrm{H})$, a kunok bírája tudatja, hogy amikor isteni kegyból a nádori és bírói tisztségbe emeltetett, s az ország báróival és nemeseivel máj 1-én (in oct. fe. B. Georgii mart.) elsőként ítélkeztek együtt, többek között Agyagus-i András fia: Péter 
is eléje terjesztette peres ügyét bemutatva egyrészt a király nagyobb pecsétjével megerősített, a vasvári Szt. Mihály arkangyal-monostor kápt.-jához birtokba iktatás tárgyában küldött oklevelét (l. 140. szám), amely az előterjesztőnek a Simon fia Lőrinc mr. fia: Niklynus Niklinus ellenében Miklós nádor $(\mathrm{H})$, a kunok bírája e. birtokok tulajdonjogának tisztázása és hatalmaskodás ügyben zajló perének a folyamatát írta le, másrészt a kápt. jelentését (l. 158. szám). Ezekból kiderült többek között, hogy Agyagus-i András fia: Péter [I.] Lajos király színe elé járulva eléje terjesztette annak a több éve zajló pernek az anyagát, mely az őt örökség jogán megillető Sopron m.-i Hewlyn birtokának háromnegyed része és teljes Arlamus birtok ügyében, valamint az ezeket hatalmaskodva elfoglaló Nogmortun-i Simon fia: Lőrinc mr. fia: Niklynus ellen folyik, s amely már a végső döntéshez ért, de Miklós nádor halála miatt befejezni nem tudta. Erre való tekntettel Péter arra kérte a királyt, hogy segítse elő a per lezárását végleges döntés meghozatala révén. A király az eléje terjesztett oklevelekből, úgymint kápt.-ok, Sopron m. alispánjának és szb.-áinak idéző és tudományvételi leveleiből, valamint az ezekbe foglalt, Miklós nádor által kiállított ítéletlevelekből, idézésekből, vásári kikiáltásokra vonatkozó felszólításokból megtudta, hogy Miklós nádor színe e. - ennek ügyvédvalló levelével meghatalmazva - [1355.] szept. 22-tôl (a quind. fe. Nat. virg. glor.) 16 napon át folyamatosan várakozott az Agyagus-i András fia: Péter nevében eljáró Fülöp fia: György, azonban a győri egyház kápt.-jának idézôlevelében törvényesen megidézett Sopron m.-i Nogmortun-i Simon fia: Lőrinc fia: Niklynus mr. nem jött el és képviselőt sem küldött, így bírságban marasztalták el. Ugyanekkor Péter képviselője bemutatta Miklós nádor e. Drugeth Miklós c., néhai országbíró egyik oklevelét, valamint Miklós nádor 3 ítéletlevelét. A győri kápt. idézólevelébe foglaltak szerint Lőrinc fia: Niklynus mr.-t András fia: Péter ellenében Miklós c., hajdani országbíró jelenléte elé idézték először [1355.] jan. 13-ra (ad oct. fe. Epiph. d.), másodszor [1355.] márc. 18-ra (ad oct. diei medii Quadr.), harmadszor [1355.] máj. 1-jére (ad oct. fe. B. Georgii mart.), negyedszer [1355.] aug. 1-jére (ad oct. fe. B. Jacobi ap.), azonban az sem saját személyében sem képviselője révén nem tett eleget az idézéseknek, ezért az 5 időpont elmulasztása miatt bírságban marasztalták el; mindezeken felül Péter képviselője minden alkalommal követelte, hogy Miklós nádor szolgáltasson igazságot urának Niklynus mr.-rel szemben. Mivel azonban az ország szokása szerint nem szokás egy ügyben pusztán idézés u. végső ítéletet hozni, hanem az idézéseket felszólításoknak kell követnie, nehogy úgy tûnjön, hogy elsietik az igazságszolgáltatást, ezért Miklós nádor az ország nemeseivel együtt ítélkezve úgy döntött, hogy ismét színe elé idézteti a német (theutunicus) Niklynus mr.-t, hogy az számot adhasson arról, milyen jogcímen foglalta el és tartja hatalmában a Sopron m.-i lakott Hewlyn birtok háromnegyed részét, Hewlyn-nek azon a negyedén felül, mely Péter birtokában van, nemkülönben a teljes lakatlan Arlamus birtokot, mely Hewlyn negyedével együtt Péter örökletes birtoka. Ugyanis, ha jogosan (efficaciter) teszi ezt, akkor rendben van, de ha mégsem, akkor jogtalanul szedi — ahogyan Péter képviselóje állította - a Hewlyn birtok negyedén lévő szólóhegy vámját, németül peregreht, s ezzel 70 dénár $\mathrm{M}$. kárt okozott Péternek. Ezen túlmenően Nyklinus mr. és társai [1355.] jan. 8-án (f. IV. prox. p. fe. Epiph. d., in a. prox. transacto peteritum) eltávozva Pomogh birtokról rátörtek Péter Saruld birtokára, ahol jobbágyainak 100 hálóját (sagenae sive gulgustra) és vorsa wrosa-ját (vlg.) elégették, további 100-at pedig tönkretettek és összaszabdaltak, jóllehet per van közöttük függóben. Miklós nádor levelet intézett a vasvári kápt.-hoz, melyben tanú állítására szólította fel a kápt.-t, azzal a céllal, hogy Niklynus-t törvényesen idézzék jelenléte elé, ahol is választ kell adnia a vele szemben felhozott vádakra, valamint hogy miért nem jelent meg ötszöri megidézésre sem, ezenfelül köteles megfizesse a rá kirótt bírságot a nádornak és a másik félnek; továbbá kérte a kápt.-t, hogy a történtekról történtekról számot adó je- 
lentést küldjön nov. 25-re(ad quind. fe. B. Martini conf.) belefoglalva az idézés napját, helyét, s a megidézett nevét. A kitűzött időpontban a nádor ügyvédvalló levelében Péter képviseletében meghatalmazott György jelent meg a vasvári kápt.jelentésével, melyben Hewlyn birtokon Bazt-i Pethev fia: György kiküldött, Gergely klerikus tanúságával nov. 8-án ([in] f. III. prox. p. fe. OO. SS. prox. tunc preteritum) idézte a nádor elé Niklynus mr.-t válaszadás végett és a Péterrel szembeni bírság megfizetése miatt nov. 25-re (ad quind. fe. B. Martini conf.). A megjelölt napon, azonban Niklynus mr. nem jelent meg és nem is küldött senkit, így hatodszor vonta magára bírság terhét, míg Péter képviselője 17 napon át várt hiába a nádor e. Mivel azonban az ország szokása szerint a perbehívást egymást követő piacokon szokás kihirdetni, ezért Miklós nádor levelében kérte a vasvári egyház kápt.-ját, hogy kiküldötte mellé adjon hites tanút, akinek a jelenlétében Niklynus mr.-t a már ismertetett ügyekben idézzék színe elé 3 m.-i vásáron az utolsó nyilvános kikiáltás 15. napjára (ad dict. 15. diem diei ultime proclamationis), ugyanott figyelmeztetve, hogy ha az idézés szerint megjelenik, választ ad és megfizeti a rá kirótt bírságot a nádornak és a másik peres félnek, akkor rendben van, de ha nem tesz eleget mindezeknek, akkor a nádor — mivel ennek távolléte és makacssága nem akadály végső döntést hozhat; a kihirdetés napjáról és helyéról pedig jelentést kér a kápt.-tól az utolsó nyilvános kikiáltás 15. napjára (ad dict. 15. diem diei ultime proclamationis). A megjelült napon bemutatták a vasvári kápt. jelentését (l. 3. szám) Miklós nádornak a vásári kihirdetésről, melyben Lőrinc fia: Niklynus mr.-t birtok és hatalmaskodás ügyében döntô válaszadásra, valamint a bíróval és a másik peres féllel szemben rá kirótt bírság megfizetése miatt Miklós nádor embere, Bozth-i Pál fia: István a kápt. tanújának Péter klérikusnak a jelenlétében 3 m.-i vásáron, ti. először [1355.] dec. 31-én (f. V. p. fe. Nat. d.) Cheperegh faluban, másodszor jan. 4-én (f. II. p. fe. Circumcisionis d.) Luchman faluban, harmadszor jan. 5-én (f. III. p. fe. Circumcisionis d.) Keedhel faluban Sopron m.-ben Agyagus-i András fia: Péter ellenében a nádor elé idézték az utolsó nyilvános kikiáltás 15. napjára (ad dict. 15. diem diei ultime proclamationis). Ezen kívül bemutatott a királynak 3 tudományvételi levelet, az egyik a vasvári kápt.é, a másik a győri kápt.-é, a harmadik Mihály soproni alispáné és a m. szb.-áié, valamennyi az előzó évben (in a. prox. transacto) kiállított jelentés. Ezekben többek között leírták, hogy Agyagus-i András fia: Péter a király elé terjesztette, s fentebb imsertetett panaszát arról a hatalmaskodásról és halászháló (gulgustra, wrosa) rongálásról, melyet Nogmortuni Simon fia Lőrinc fia: német Nykkul s társai követtek el [1355.] jan. 8-án (f. IV. prox. p. fe. Epiph. d. in predicto a. prox. transacto preteritum) Péter Saruld. Ezekról értesülve a király írásban utasította a vasvári és a győri egyház kápt.-át, valamint a soproni alispánt és szb.-kat, hogy küldjenek ki tanúkat az ügy kivizsgálására, s kikérdezvén az értesüléssel rendelkezőket vizsgálják ki a a panaszt, majd a vizsgálat eredményéról küldjenek minden részletre kiterjedő jelentést a királynak. A vasvári kápt. a királyi parancslevélben foglaltaknak megfelelően Bazth-i Pethew fia: György királyi emberrel Gergely klerikust, a győri kápt. pedig Bazth-i György királyi emberrel János kanonokot, Mihály alispán és a szb.-ák pedig maguk közül Saagh-i Mihály fia: Miklóst küldték a vizsgálat elvégzésére. A kiküldöttek visszatérve jelentést tettek, miszerint a vasvári kápt. tanúja a királyi emberrel 1355. márc. 22-én (sabb. prox. an. domin. Judica), a győri kápt. királyi ember mellé adott tanúja és a Sopron m.-i kiküldött is [1355.] márc. 8-án (in domin. Oculi) kimenve kikérdezték az értesüléssel rendelkezóket, különös tekintettel a Sopron m.-i nemesekre, s vizsgálódásuk eredményeként megbizonyosodtak a panasz valós voltáról. Hewlyn birtok tulajdonjoga kapcsán bemutatásra került János alispán és Sopron m. szb.-áinak 1351. szept. 26-án (f. II. prox. an. fe. B. Michaelis arch.) kiállított nyílt oklevele, melyben többek között leírták, hogy az Usl nemből származó Agyagus-i András fia: Péter szept. 26-án (in f. II. prox. an. fe. B. Michaelis arch.) megje- 
lenve az alispán és a szb.-ák e. tudatta, hogy Simon fia: Pál mr.-nek életében és halálát követően Nogmorton-i Simon fia Lőrinc fia: Niklynus mr. Hewlyn birtok negyed részéről adóban, ti. a szőlőhegy peregreth-e tekintetében $70 \mathrm{M}$. kárt okozott neki a saját részén; elmondta, hogy Hewlyn teljes egészében örökletes birtoka, amit több m.-i nemes is megerősített az alispán és a szb.-ák törvényszéke e. A szóban forgó hegyvám jövedelmének a beszedéséről Mihály alispán és a Sopron m.-i szb.-ák [1355.] nov. 9-én (f. II. prox. an. fe. B. Martini conf.) kelt nyílt oklevelét mutatták be, mely többek között magába foglalta, hogy Agyagus-i Andrsá fia: Péter az alispán és a szb.-ák színe e. előadta, miszerint Simon fia Lőrinc fia: Niklynus mr. engedélye nélkül, akarata ellenére, 4 talentum peregreht (dict.) hegyvámot szedett be Hevlyn birtok egy részén, ezért Péter hatósági ember kiüldését kérte, mely kérésnek eleget téve Fülöp fia: Györgyöt küldték, aki visszatérve jelentette, hogy [1355.] nov. 3-án(f. III. prox. p. fe. OO. SS. tunc preteritum) famulus-ával kiment ezeket szmrevételezni. Péter famulus-a be akarta szedni a bor adóját (tributum vini), azonban Niklynus mr. falunagya eltiltotta ettól mondván, hogy urát illeti az az adó; az alispán és a szb.-ák embere révén kikérdezett Niklynus mr. megerősítette, hogy a tiltás az ő engedélyével történt. A birtok elfoglalásának okát, a hatalmaskodást, az idézések és vásári kihiretések alkalmával való távolmaradását pedig nem tudta és akarta megmagyarázni. A király tehát a nádor halála miatt és az ország báróinak távollétében úgy határoz, hogy Hewlyn birtok 3 részét és a teljes Arlamus birtokot András fia: Péternek és örököseinek ítéli minden haszonvételével és tartozékával együtt, mivel az jog szerint ôt illeti, ôsi határai mentén, örök jogon, idegen jog sérelme nélkül. A hatalmaskodással kivizsgálását a nagyobb bizonyosság kedvéért máj. 1-jére (ad presentes oct. fe. B. Georgii mart.) elhalasztja, s megparancsolja a vasvári kápt.-nak, hogy küldöj tanút Deuecher-i Miklós fia: Márton v. a királyi udvar ajtónállója, János fia: Péter a királyi udvarból külön erre a feladatra kiküldött királyi emberek valamelyike mellé, menjenek Hewlyn és Arlamus birtokokra, ahol törvényesen összehívva a szomszédokat és határtársakat, járják be azok határait az ôsi határjelek mentén, ahol pedig szükséges, ott emeljenek újakat; a hj.-t követően Hewlyn háromnegyed részét, Arlamus birtokot pedig teljes egészében valamennyi haszonvételükkel és tartozékukkal iktassák András fia: Péternek, ahogyan Hewlyn birtok negyedét; ha pedig valaki — Niklynus mr. és örökösei kivételével — bármiféle jogigénnyel állna elő, jelentsék az iktatás lefolyásával együtt a királynak máj. 1-jére (ad oct. fe. B. Georgii mart.). A vasvári kápt.-nak a királyhoz intézett jelentése (l.158. szám) beszámol arról, hogy a királyi parancslevélben foglaltaknak megfelelően Dewecher-i Miklós fia: Márton királyi ember mellé kanonoktársukat, az egyház éneklőkanonokját, Domokos mr.-t adták tanúul, akik visszatérve jelentették, hogy [1356.] márc. 25-én (f. VI. scilicet in fe. Ann. B. Marie virg. prox. preterito) Hewlyn és Arlamus birtokokra menve, az összehívott szomszédok és határtársak jelenlétében bejárták a birtokok határait ősi határjeleik mentén és beiktatták azokba Agyagus-i András fia: Pétert örök birtoklásra. Hj. (l. a vasvári kápt. oklevelében)Miklós nádor arra való tekintettel, hogy Niklynus mr. nem tudta ésszerú okát adni annak, hogy az eddigi idézések és vásári kihirdetések dacára miért nem jelent meg a bíróság e. András fia: Péter ellenében, valamint a király oklevelében és a vasvári kápt. hj.-sal és iktatással kapcsolatos jelentésében foglaltak alapján Hewlyn birtok háromnegyed részének a hozzá tartozó negyeddel együtt, valamint teljes Arlamus birtok tulajdonában megerősíti Pétert és utódait, idegen jog sérelme nélkül. Az ügylet bizonyságára függő és autentikus pecsétjével megerősített privilégiumot bocsát ki András fia: Péter számára. D. in Vyssegrad, 25. die oct. fe. S. Georgii mart., a. d. 1356.

E.: Dl. 41 286. (Múz. Ta. Jankovich) Hártyán, hátoldalán késóbbi kéz írásával tárgymegjelölés, alján rózsaszín-zöld sodraton Kont Miklós pecsétje függ (körirata:+ S(IGILLUM) NICOLAI KVNT REGNI HVNGARIE PALATINI ET IVDICI(S) COMANOR(UM)). 
K.: Sopron vm. I. 250-261. (193. szám).

Megj.: A hj.-ra vonatkozó részt 1. még F. IX. 2. 530-532. (258. szám).

\section{1356. máj. 27. Visegrád}

Erzsébet királyné (H) utasítja Marochok királynéi fólovászmr.-t, Beregh-i c.-t — ill. az ő távollétében alispánját -, hogy György mr. Lupprechtzaza-i plébánosnak, királynéi káplánnak és különleges kiküldött emberének a jelenlétében ismertesse az összehívott Wary-i és a Torpa-i hospes-ek számára az elküldött másik királynéi levelében foglaltakat a Gallow-i István fia: István mr. sertéseinek elhajtása miatt zajló perben elrendelt elégtételadás ügyében, egyszersmind megparancsolja, hogy ha a szóban forgó hospesek nem teljesítenék az oklevélben foglalt elégtételnyújtási kötelezettségüket, akkor az elhajtott sertések értékének megfelelő - azaz a Wary-i hospes-ek esetében 400, a Torpai hospes-ek esetében 150 sertés értékével felérő — zálogot kell adniuk; Marochok mr. és György királyi ember pedig minden részletre kiterjedô jelentést írjon a királynénak. D. in Wyssegrad, VI. f. p. 4. domin. fe. Passce, a. d. 1356.

E.: Dl. 51 709. (Kállay cs. 1t. 1300. 1099.) Papíron, hátoldalán azonos kéz írásával címzés, valamint vörös gyưrû́s zárópecsét, bevágásai.

K.: -

R.: Kállay II. 36. (1185. szám).

\section{1356. máj. 27. Visegrád}

Zeech-i Miklós c., [I.] Lajos király (H) országbírája, Turuch m. c.-e tudatja: ahogyan arról korábbi oklevele tájékoztat, színe e. egyik részról Keer-i János fia: Mihály mr. a maga, valamint a váci egyház kápt.-jának meghatalmazó levelével Keer-i István fia: János és Tardas fia: Egyed nevében is, a másik részrôl pedig Tódor (Teodor) fia István fia: Mihály megjelenvén, kinyilvánították, hogy a közöttük az örökös nélkül meghalt néhai Simon fia Pál fia: László birtokrésze miatt zajló perben, amely birtokot [I.] Lajos király eladományozta Mihály mr.-nek és Jánosnak, fogott bírák közremúködésével és az országbíró engedélyével [1355.] okt. 6-án (in oct. fe. B. Michaelis arch.) egyezségre jutottak egymással. Eszerint a feleknek [1356.] máj. 1-jén (in oct. fe. B. Georgii mart. prox. tunc venturis) a felperes Mihály és János mr. oldalán eljáró Dorchan-i Péter fia: Miklós v. ugyaninnen való János fia: Jakab v. Kyurtuus-i Simon fia: Miklós királyi emberek valamelyikének, ill. az alperes, István fia: Mihály oldalán közremúködő Zeuleu-i Miklós fia: Balázs v. Geech-i Péter v. Tas-i János királyi emberek valamelyikének a társaságában a váci kápt. kiküldött tanúival együtt ki kellett menniük a néhai László birtokára és ott az István fia: Mihály által bemutatandó, a Saag-i konvent által kiállított nyílt oklevelében foglaltaknak megfelelően kellett bejárniuk a határokat, meghagyva az oklevéllel igazolt részt István fia: Mihálynak és örököseinek örök birtoklásra, míg a Saag-i konvent oklevele értelmében fennmaradó résznek a tulajdonába a királyi embereknek a váci kápt. tanúbizonysága mellett János fia: Mihály mr.-t és István fia: Jánost, valamint örököseiket kellett iktatniuk örök birtoklásra. Mindezekról a váci kápt. máj. 8-ra (ad oct. dict. oct.) eljuttatott írásos jelentésében számolt be az országbírónak, amely napon István fia: Mihály személyesen járulván színe elé mutatta be a mondott jelentést (l. 216. szám). Ebben leírták, hogy az országbírói parancslevél vételét követően Zeuleu-i Miklós fia: Balázs királyi ember mellé András mr.-t, a Zygethfeu-i főesp.-t ad ták tanúul Kysker-i Tódor fia 
István fia: Mihály oldalán, ugyanakkor a másik királyi ember, Dorchan-i János fia: Jakab társaságában pedig kanonokjukat, János mr.-t küldték ki Keer-i István fia: János és János fia: Mihály részére hites tanúul, akik visszatérve olyan jelentést tettek, miszerint máj. 1-én (in oct. fe. B. Georgii mart. prox. preteritis) kimentek Simon fia Pál fiainak: a néhai Jánosnak és Lászlónak szóban forgó földrészére, ahol azt az összehívott szomszédok és a felek jelenlétében - kivéve István fia: Jánost, akit az országbíró ügyvédvalló levelével Tordas fia: Egyed képviselt — az István fia: Mihály által bemutatott Saag-i konventi nyílt oklevelében foglaltak alapján bejárták ősi határai mentén, és a szükséges helyeken új határjeleket emeltek a szomszédos birtokoktól való elválasztás végett, majd miután senki nem mondott ellent — beiktatták annak örök jogú tulajdonába István fia: Mihályt és örököseit, a fennmaradó részbe pedig János fia: Mihályt és István fia: Jánost, valamint örököseiket. István fia: Mihály birtokrészének határai a következők: a határ tó szélén (in fine cujusdam lacus) földból emelt új határjelnél kezdődik, ahol elválik János és László földje É felől az esztergomi érsek földjétől, innen É felé a tó gázlóján keresztül (per portum eiusdem lacus) egy hegyhez tart, nagy út, azon keresztül Obwar faluba ér, közelében a hegyen új határjelet emeltek, innen Ereztuen (vlg.) ligethez (nemus), amelynek szélén 2 új határjel, leereszkedik Oluarweulg völgybe, majd byrch nevú kis domb, ott tölgyfa alatt új földjel, tovább Lyzkowwlg Lyzkowlg völgybe, 2 új földjel a völgy oldalában Ke felől, a völgyön keresztül másik, Kyslezkow nevú völgybe, ott új földjel, a völgy végében 2 új határjelnél az esztergomi érsek földjéhez kapcsolódik, 2 új határjel, ....... Ny felé elér 2 régi határjelhez, amelyek közül az egyik az érseké, a másik Jánosé és Lászlóé, innen a már említett Lyzkowlg völgyhöz, majd Ny felé berch (dict.) dombhoz ér, ahol régi határjel választja el János és László részét az esztergomi érsekétől, Wluagwlg völgy, 2 régi határjel, Ny felé át a völgyön, berch dombon új földjel, Zalaguswlg völgy, új földjel, át a völgyön, majd szántóföldekhez ér, ahonnan János és László földjének ez a része István fia: Mihály tulajdonába és örökségébe tartozó területtel érnitkezik, régi földjel mellé emelt új határjelnél véget ér az elhatárolt rész, amelynek a tulajdonába a kiküldöttek bevezették Mihályt. A váci kápt. bemutatott jelentése alapján az országbíró és bírótársai a fenti egyezségben foglaltakkal mindenben megegyező döntésükkel jóváhagyják a szóban forgó birtok fenti megosztás szerinti tulajdonlását a felek részéről. Az országbíró minderről autentikus és függő pecsétjével megerősített privilégiumot bocsát ki. D. in Vyssegrad, 20 die termini prenotati, a. d. 1356.

E.: D1. 72 987. (Darvas cs. 1t. 13.) Vonalazott hártyán, helyenként részben vagy teljesen elhalványult írással, hátoldalán közel korú és késóbbi kezek írásával tárgymegjelölés, valamint jegyzetek, alján függépecsét felerősítésére utaló zöld zsineg.

Má.: Uo., mint E., azzal megegyező jelzet alatt; modern kori Má.-ban.

Tá.: 1. Garai Miklós nádor, 1406. febr. 17. KML. Palásthy cs. 1t. 1. 1. 59. (3062.) (Df. 281 851.).

2. Garai Miklós nádor, 1409. nov. 14. Dl. 72 995. (Darvas cs. 1t. 21.).

3. Tá. 2. > Zsigmond király, 1411. máj. 27. Dl. 69 360. (Kubinyi cs. lt. 180.).

K.: -

306. 1356. máj. 28.

Erzsébet királyné (H) a Scepsy-i bírónak, esküdteknek és a polgárok közösségének: a Jazou-i monostor prépostja és konventje panaszából arról értesült, hogy az egyházuk 
erdőjét és más haszonvételeit engedélyük nélkül használják hatalmaskodva és szüntelenül, minek következtében a monostor komoly károkat kénytelen elszenvedni. Ezért a királyné, meg akarván őket védelmezni és őrizni jogaikban, megparancsolja a címzetteknek, hogy az egyház szóban forgó erdőjének és más haszonvételeinek, valamint terményei hasznának megszerzésétôl tartózkodjanak, és ne merészeljék másként használni, csakis a monostor prépostjának és konventjének az engedélyével. D. in Wyssegrad, sabb. prox. an. fe. Asc. d., a. eiusdem 1356.

E.: SNA. Jászói prépostság mlt. Oklevelek és iratok 35. (Df. 232 798.) Papíron, hátoldalán azonos kéz írásával tárgymegjelölés, valamint gyưrüspecsét töredéke.

K.: -

Megj.: Vö. a 288. és a 452. számú oklevéllel.

\section{1356. máj. 28. Beregszász}

Tamás fia: Miklós mr., a Bereg m.-i Moruchock mr. alispánja és a m. szb.-ái emlékezetül adják, hogy a 7 törvényszéki napon (in septem terminis) elmarasztalt Gersse-i Chamaz fia: Demeter eleget tett a Wary-i plébános, Péter meggyilkolása miatt rá bírságul kirótt összeg megfizetésének az oklevélkiadó bírói hatóság, valamint ugyanezen Péter testvérének, Mihálynak a fiai: Bálint és István számára. D. in Loppretzaza, sabb. prox. an. Rogationum, a. d. 1356.

E.: Dl. 4616. (NRA. 68. 14.) Papíron, hátoldalán 3 zárópecsét nyoma, bevágásai.

K.: AO. VI. 482. (301. szám) (kihagyásokkal).

R.: Neumann T., Bereg m. 44. (54. szám).

\section{1356. máj. 30.-jún. 6. között}

A csázmai egyház kápt.-ja e. egyik részrôl Lőrinc fia: Miklós, valamint a fivérét (fr. carnalis), Bendeket is képviselő Mihály fia: János, míg a másik részról rokonaik, Iwachinus Iwachynus fiai, továbbá Lőrinc fivérei megjelenvén, elóbbiek kinyilvánítják, hogy a másik oldalon állókkal szemben felhagynak valamennyi olyan perrel, amelyek kártételekkel ........[hatalmaskodó ?] cselekedetekkel és egyéb birtokokügyekkel — különösen Alexandrovina birtokkal - összefüggésben támadtak közöttük, egyszersmind kötelezik magukat ....... a vonatkozó oklevelek átadására, ha pedig ezt nem tennék meg v. csalárdul ilyeneket visszatartanának, a szóban forgó okleveleket hatálytalanoknak nyilvánítják. János ugyanakkor olyan kötelezettséget is vállal, hogy amennyiben testvére, Benedek a jövóben bármikor is pert kezdeményezne Iwachinus fiaival szemben, akkor őt, Jánost a párbajvesztesek büntetésével marasztalják el. D. f. II. prox. ... fe. Assc. d., a. eiusdem 1356.

E.: Dl. 100 067. (Batthyány cs. lt. Acta antiqua. Misc 5. 7. 203.) Hártyán, az íráskép több helyen elmosódott, olvashatatlan; hátoldalán mandorla alakú pecsét töredéke, bevágásai.

K.: - 
Megj.: Az oklevél keltének bizonytalanságát a dátum sorban az olvashatatlanságig elhalványult szó adja, mely vontakozhat a megjelölt ünnep előtt (ante fe. Assc. d.) ill. utánai (post fe. Assc. d.) hétfőre.

\section{1356. jún. 1. Visegrád}

Sech-i Miklós c., [I.] Lajos király $(\mathrm{H})$ országbírája, Turuch m. c.-e tudatván Gömör m. ispánjával, ill. alispánjával és szb.-áival a színe e. Demeter fia: Péter mr., az aradi egyház éneklókanonokja részérôl emelt panaszból szerzett azon értesülését, amely szerint Ragal-i Mihály fia: Simon és jobbágya, a Ragal-on időző Antal bizonyos Kazmerteleke földdarabot, amelynek egyik fele vásárlás jogcímén, a másik fele pedig szomszédság okán a panaszos Péter mr.-t illeti meg, s amely miatt a nevezett és Bubech (dict.) István mr. között hosszan elhúzódó per forgott fenn, felszántotta, valamint a bepanaszolt Simon használta és jobbágya, Antal révén most is használja az ô kárára és sérelmére, minekutána utasítja a címzetteket, hogy 1 v. 2 kiküldöttjük vizsgálja ki a panaszt, továbbá tiltsá(k) el nevezett Simont és jobbágyát, Antalt a szóban forgó Kazmerteleke földdarab használatától és hasznainak beszedésétôl a király nevében, majd ezt követően a vizsgálat eredményéról és az eltiltásról jelentsenek a királynak. D. in Visegrad, in vig. fe. Asc. d., a. eiusdem 1356.

Á.: A 444. számú oklevélben.

Má.: Uo., mint Á., azzal megegyező jelzet alatt; 2 példányban, az egyik a 20. sz. elején készült egyszerú Má.-ban, a másik szintén egyszerú Má.-ban Zsinka Ferenc aláírással.

K.: -

310. (1356. jún. 3. e.)

Domokos, az erdélyi egyház prépostja, az egri egyház kanonokja, Miklós egri püspök lelkiekben általános vikáriusa felszólítja Kapus-i Vince Wg........-i [Wngh-i] alesp.-t, Chazlouch-i .......t és Palagh-i Jakabot, hogy jún. 3-án (in crastino fe. Asc. d.) a megnevezett felekkel és fogott bírákkal együtt menjenek ki a Beregh m.-i Brod birtokra, s annak negyed részéból harmadot felmérve és felbecsülve valamennyi tartozékával és haszonvételével együtt, és bárminemú ellentmondástól függetlenül iktassák be abba a néhai Lewe Brod-i nemes unokáját (nepos), György fia: Balázs c.-t a mondott Lewe nemes ....... [leánya], Erzsébet u. járó leánynegyed kiegyenlítése címén, majd a történtekrôl küldjenek jelentést jún. 19-re (ad oct. fe. Penth. tunc sequentes) számára.

Eml.: A 358. számú oklevélben.

K.: Zichy III. 30 (18. szám) (Eml.-ben)

311. 1356. jún. 3.

IV.Károly császár tudatja a velencei dózséval, hogy a dózse és I. Lajos király (H) közötti háborúban utóbbi fél pártján áll.

R.: Óváry 47. (58. szám) (Velencei lt.-ra való hivatkozással); uô., TT. 11 (1888) 455. 
A pannonhalmi (de Sacro Monte Pannonie) Szt. Márton-monostor apátja, Szigfrid (Siffridus) és a konvent e. egyik részról Móric fia: Simon mr. pozsonyi c., a másik részról pedig Péter testvér Beel-i apát megjelenvén, kinyilvánították, hogy jóllehet Simon mr. a mondott Beel-i egyház Arpas birtokát Péter apát elődjének Miklós apátnak és a konventnek az engedélyével és adománya folytán évenként $1 \mathrm{M}$. széles bécsi dénárért mostanáig haszonbérletként (feudaliter) tartotta kezén, mégis, mivel a szóban forgó birtok Simon mr. birtokával érintkezik, s ebból adódóan az mind számára, mind pedig birtoka számára igencsak kedvező, úgyszólván nélkülözhetetlen helyzetet teremt, egyszersmind pedig amiatt is , hogy földjének igénybe vétele $u$. az eredményes birtokkezelésból a Beel-i egyháznak is nagyobb jövedelme származzék, ezért Simon mr. ezentúl a Beel-i egyház birtokának használati jogáért a malommal, a szántóföldekkel és minden más haszonvétellel valamint tartozékkal együtt az apátnak és utódainak, nemkülönben az egyháznak minden évben böjtközépkor (in die medii Quadr.) a Beel-i egyházban egy összegben és késedelem nélkül köteles 2 M. — M.-ként 10 pensá-val számolt — széles bécsi dénárt megfizetni olyan kikötéssel, hogy ha valamely évben ő v. utódai a rögzített idóben és helyen nem fizetnék meg a mondott összeget, és ezért az apát bírósághoz fordulna, akkor a bírói részen kívül az összeg kétszeresét fizetik az apátnak a per kezdete e., a birtokot pedig annak elnéptelenítése, ill. minden akadékoskodás és késlekedés nélkül kötelesek visszaadni valamennyi kapcsolódó részelemével és jogával együtt. Az Arpas birtokra telepített és ezután odatelepülő népek pedig a tizedet és a szokásos járandóságokat (consueta) nem másnak, mint az apátnak és az egyháznak törvényesen, mindig idóben kötelesek megfizetni - az erról kiállított privilégiumban foglaltak szerint -, ahogyan arra Simon mr. utódai nevében is önként kötelezettséget vállalt. D. 2. die fe. Asc. d., a. eiusdem 1356.

E.: BFL. Capsarium 50. PP (432) (Df. 207 228.) Papíron, hátoldalán késóbbi kéz írásával tárgymegjelölés, valamint kerek rányomott pecsét töredéke, bevágásai, szalagja.

Eml.: 1. Pál bakonybéli apát, 1375. okt. 20. BFL. Capsarium 50. DD (599) (Df. 207 398.).

2. Garai Miklós nádor, 1410. febr. 17. BFL. Capsarium 50. QQ (748) (Df. 207561.) > Pálóczi Mátyus nádor. 1436. márc. 12. BFL. Capsarium 42. R (973) (Df. 207 793.).

K.: Gy. IV. 395-396; Sopron vm. I. 261-263. (194. szám); Dreska G., Pannonhalmi konvent I. 79-80. (73. szám) mindhárom E.-ről; F. IX. 5. 72-73. (22. szám); Sopron vm. I. 416-417. (291. szám) mindkettő Eml. 1-rôl; HO. IV. 259-261. (194. szám); P. VIII. 488-492. (194. szám) mindkettő Eml. 2-ről.

R.: Ortvay, Pozsony III. 130.

Megj:: Jó minőségú digitalizált változatát 1.

http://www.mom-ca.uni-koeln.de/mom/HU-PBFL/PannHOSB/1356_VI_03/charter\#anchor

313. 1356. jún. 3.

A pozsonyi egyház kápt.-ja e. Welk-i Chezte fia: Tamás kinyilvánítja, hogy valamennyi birtokát és birtokrészét — bárhol is feküdjenek azok — fiainak: Jánosnak, Istvánnak és Péternek, valamint örököseiknek adja és adományozza örök birtoklásra 28 M. - M.ként 10 pensá-val számolt — széles bécsi dénár ellenében, mivel nevezettek ôt a jelzett 
pénzösszeg árán a pozsonyi ispán fogságából, valamint a Kathus asszonnyal szembeni fizetései kötelezettségtől megszabadították. D. 2. die fe. Asc. d., a. eiusdem 1356.

Á.: Pozsonyi kápt., 1420. márc. 19. Dl. 4617. (NRA. 359. 5.).

K.: -

\section{4. (1356. jún. 3-9. között)}

Kapus-i Vince Wg........-i [Wngh-i] alesp., Chazlouch-i ....... és Palagh-i Jakab eleget téve Domokos vikárius hozzájuk intézett levelében (l. 310. szám) foglaltaknak, kimenve Brod birtokra úgy tettek, ahogyan a parancslevélben állt, ám mert István fia: Domokos és Byter fia: László fiaikkal Gergellyel, Miklóssal és Mihállyal együtt ellentmondtak, minthogy nevezettek a teljes birtok negyedének nem a harmadrészébe, hanem kilencedrészébe akarták beiktattatni György fia: Balázst, ezért a kiküldöttek mégsem tudták véghezvinni megbízásukat.

Eml.: A 358. számú oklevélben.

K.: Zichy III. 30 (18. szám) (Eml.-ben)

\section{1356. jún. 4. Zágráb}

[I.] Lajos király $(\mathrm{H})$ tudtul adja: neki mint katolikus, keresztény fejedelemnek már régóta szándékában áll az isteni kegyelem kedvezéséból és az Úr sugallatára Istenért, a szentegyházért és a keresztény hitért Szerbia királyságát (Rascia) — amelyre már elődei is jogot formáltak, és melyet jelenleg az egyedüli anyaszentegyház lázadó, szakadár, hútlen ellenségei tartanak elfoglalva — visszavezesse a keresztény hitre, a szentegyház egységébe és saját joga alá, amely célból a Szt. Kereszt jelét kívánja felvenni alattvalóival együtt. Tekintettel arra, hogy ebbéli szándékát VI. Ince pápa támogatásra érdemesnek tartotta, miként azt hozzá címzett apostoli bullája tanúsítja, amelyet a király káplánja, János révén küldött el hozzá, ezért az ügyben követe(ke)t indít a pápához. Jelen, nagyobb pecsétjével megerősített oklevelét törvényes képviselőjével, István budai préposttal, királyi káplánnal, külön erre a feladatra elküldött megbízottjával juttatja el az egyházfő v. a Szentszék v. a Szentegyház bíborosainak színe elé, remélvén, hogy onnan majd apostoli levelet kap a szükséges tartalommal, valamint, hogy esküjét - képviselője révén - leteheti a pápának v. a pápa hatalmával felruházott személynek, amely a Szt. Evangéliumra tett - esküjében megígéri, hogy a Szt. Kereszt oltalma alatt indítandó háború során Jézus Krisztus és Szt. anyja, a Boldogságos Szúz Mária, valamint a római Szt. egyház tiszteletére igyekszik visszavezetni az eltévelyedetteket, valamint abbéli törekvését, hogy elődei és saját jogát újra gyakorolhassa és megerősíthesse a jelzett területen. Mivel pedig az országokat, városokat, várakat, földeket, falvakat és más helyeket, amelyeket keresztény hívek tartanak hatalmukban a legkevésbé sincs szándékában megtámadni és elfoglalni, azonfelül arra is ügyelve, hogy az átvonuláshoz szükséges területet, ill. azt az országrészt, s azokat a városokat, várakat, falvakat és földeket, amelyeket a mondott királyságból isteni jóváhagyással szándékozik elfoglalni, ne terhelje meg a köteles jog felett, mindezeket meghagyja inkább ősi kiváltságaikban, és az anyaszentegyház egységébe visszavezeti óket, míg az egyházakat, monostorokat és más helyeket az egyházi szabadsághoz, kiváltságokhoz, mentességekhez juttatja, és azokban megőrizni és gyarapítani törekszik őket. A pápa és az apostoli szék legátusát 
— aki a keresztet kitûzi a szakadárokkal szemben — szívesen fogadja. D. Zagrabie, ind. VIII., mensis Jun., die 4., a. d. 1356.

E.: ASV. Archivum arcis, Armaria superiora 1. 18. 596. (Df. 289 177.)Hártyán, alján pecsét függ, mely Coll. Vat. Hung.-ban olvasható leírás alapján sérült, rajta csúcsíves díszítésú trónon ülő koronás alak, jobbjában liliomos pálca, baljában országalma; köriratából olvasható: ........LMACIE CROACIE RAME SVIE ... DOMERIE....

Eml.: A 373. és a 449. számú oklevélben.

K.: Raynaldus XXVI. 12-13. (24-26. caput); Pray, Annales III. 101-103; Katona, Hist. crit. X. 160-165.; F. IX. 2. 471-475. (228. szám); Smič. XII. 356-358. (268. szám); Coll. Vat. Hung. I. 1. 69-72. (74. szám).

R.: Fraknói 241. (Katona alapján); Alsószlavónia 16-17. (46. szám) (Raynaldus és F. alapján).

316. 1356. jún. 4.

A csanádi egyház kápt.-ja ...... kérésére és oklevél-bemutatása alapján függőpecsétjével megerősített és az ABC betúivel chirographált kiváltságlevelében átírja a csanádi kápt. 1337. nov. 24-én (l. Anjou-oklt. XXI. 617. szám) [— Rabe birtok adományozásának megújítása kapcsán kiadott privilégiumát-], valamint Péternek, a Szt. Üdvözítő-egyház prépostjának, Jakab csanádi püspök lelkiekben általános vikáriusának 1337. szept. 15én (l. Anjou-oklt. XXI. 532. szám) [—Zokona birtokon kiadott leánynegyed ügyében - ] kiadott okleveleit. Kelt Miklós mr. olvasókanonok keze által, sabb. prox. p. fe. Asc. d., a. d. 1356. Mihály, a székesegyház prépostjának, Mihály éneklő-, Máté ơrkanonoknak, István temesi, Miklós Maroson túli, Márton erdélyi főesp.-nek a jelenlétében.

Á.: Csanádi kápt., 1400. nov. 10. > csanádi kápt., 1439. febr. 26. Magángyújt. Reszegi cs. berettyóújfalusi 1. (Df. 285 546.).

K.: -

317. 1356. jún. 4.

A pozsonyi kápt. a színe elé járuló Dobragaz-i Mátyás fia: Miklós kérésére és oklevélbemutatása alapján az $\mathrm{ABC}$ betúivel chirographált privilégiumában átírja s autentikus függőpecsétjével megerősíti a kápt. által [— a fiúörökös nélkül elhunyt István Dobragazon lévő birtokrészének adományozásáról szóló - ] 1343. márc. 21-én kiállított nyílt oklevelet (l. Anjou-oklt. XXVII. 121. szám). D. sabb. prox. p. fe. Asc. d., a. eiusdem 1356.

E.: EPL. Pozsonyi kápt. országos lt. 14. 4. 5. (Df. 261 256.) Hártyán, alul az ABC betûivel chirographálás, hátoldalán közel korú kéz írásával Doborgaz, késóbbi kéz írásával tárgymegjelölés, alján — K. szerint — vörös selyemsodraton a pozsonyi kápt. pecsétje függ.

K.: Str. IV. 148-149. (118. szám). 
Az egri kápt. kötelezvénylevele szerint a Tyba-i András fia Lőrinc fia: Miklós és ugyanezen Lőrinc fiai: György és László között az Ung m.-i Rachkzubugya földdarab körül fennforgó pert a felek kötelesek jún. 5-én (die domin. prox. an. fe. Penth.) a leleszi prépost és konvent kiküldött tanúságtevőinek jelenlétében a maguk által választott 3 fogott bíró által meghozandó fogott bírói ítélettel lezárni és elrendezni.

Eml.: A 323. számú oklevélben.

K.: Sztáray I. 250. (144. szám).

\section{1356. jún. 5.}

Kálmán győri püspök tudtul adja, hogy miután Sopron város lakossága, ill. polgárai mindazon kártalanítási, bírság- és váltságfizetési kötelezettségüknek maradéktalanul eleget tettek, amelyeket elődjével, a néhai Miklós püspökkel szemben teljesíteni tartoztak, kápt.-beli testvéreinek egyetértésével mentesíti óket és utódaikat minden további követelés alól, kinyilvánítva, hogy egyháza részéról a teljesített kötelezettségeket illetően pert ezután nem kezdeményeznek, hanem végképp békén hagyják a soproniakat. Erről függőpecsétjével ellátott oklevelet bocsát ki. D. domin. die prox. p. Asc. d., a. eiusdem 1356.

E.: GYMSML. Sopron 158. (Df. 201 792.) K. alapján hártyán, alján zöld-piros selyemsodraton Kálmán győri püspök vörös viaszba nyomott pecsétje függ.

K.: Házi I. rész 1. 110-111. (175. szám).

320. 1356. jún. 5.

A zobori (de Zoburio) Szt. Ipolit-monostor konventje tudatja: színe e. egyik részról a monostorának konventjét is képviselő Ulrik testvér garamszentbenedeki ([de] S. Benedicto de iuxta Gron) apát, a másik részről pedig Barakcha-i Jakab fiai: Miklós és István mr.-ek megjelenvén, elóbbi kinyilvánította, hogy a monostor Bessenew nevú birtokát, amely Bars m.-ben a Sitwa folyó mellett fekszik, a legközelebbi szept. 29-tôl (a prox. venturo fe. B. Michaelis arch.) számított 11. év fordulójáig (usque ad undecimam revolutionem) jövedelmeinek használatával és valamennyi tartozékával együtt használat és benépesítés céljából bérbe adja évenként $4 \mathrm{M}$. széles bécsi dénárért v. más, az országban használt - M.-ként 10 pensá-val számolt - dénárért, amelyet Miklós és István késedelem nélkül minden év szept. 29-én (fe. B. Michaelis arch.) kötelesek megfizetni a nevezett apátnak és konventjének azok monostorában. Ha ezt a kijelölt időpontban elmulasztanák teljesíteni, akkor büntetés gyanánt a bérleti díj kétszeresét kötelesek fizetni okt. 13-ig (quind. iam dict. fe. B. Michaelis arch.), ha addig sem fizetnének, akkor a szóban forgó birtok haszonvételeivel és tartozékaival visszakerül a monostor tulajdonába. Eltelvén pedig a 11 év, amely idő alatt évenként rendben megfizették az esedékes 4 M.-át, a benépesített Bessenew birtokot jövedelmeinek használatával és valamennyi tartozékával együtt nevezett Miklós és István mr.-ek a garamszentbenedeki monostor apátjának, konventjének és a monostornak — mindenféle keresett ürügytôl és kifogástól függetlenül - kötelesek visszaadni, míg ha ennek nem tennének eleget, akkor perkezdet e. 50 M. büntetést tartoznak megfizetni, ahogyan azt ők szabad akaratukból vállalták. D. die domin. infra oct. Asc. d., a. eiusdem 1356. 
E.: EPL. Esztergomi Székesfőkáp. mlt., Acta radicalia 3. 1. 10. (Df. 235 841.) K. szerint papíron, hátoldalán pecsét lenyomata és szalagja, valamint közel azonos kéz írásával Besenew, továbbá újkori kéz írásával tárgymegjelölés.

K.: Str. IV. 149-150. (119. szám).

321. 1356. jún. 6.

A győri egyház kápt.-ja e. főpapjuk, Kálmán győri püspök kinyilvánítja, hogy miután a soproni polgárok maradéktalanul eleget tettek az elődjével, Miklós püspökkel szemben fennálló összes kártalanítási, bírság- és váltságfizetési (iudiciorum garavamina, birsagia, emenda) kötelezettségüknek, mentesíti őket ezek tárgyában minden további követelés alól, továbbá megígéri, hogy ezek miatt ellenük és utódaik ellen nem kezdeményez pert. D. f. II. prox. p. fe. Asc. d., a. eiusdem 1356.

E.: GYMSML. Sopron város 159. (Df. 201 793.) K. szerint hártyán, hátoldalán pecsét nyoma.

K.: Házi I. rész 1. 111-112. (176. szám).

\section{1356. jún. 6. Gömör falu}

Kemen fia: János mr., Konya mr. Gömör m.-i alispánja és a m. szb.-ái tudatják: Puthnuki Miklós fia: László mr. kérésére pecsétjükkel kiküldték emberüket, Heeth-i Vgra fia: Antalt, aki visszatérve jelentést tett, amely szerint máj. 26-án (f. V. prox. an. diem Rogationum) felkereste Renoldus mr. Male-n lévő birtokrészét, ahol nevezett Renoldus mr.-t eltiltotta attól, hogy László mr. Male faluban élő jobbágyának, Danik fia: Tamásnak egy bizonyos földrészét (unam particulam terre pragiorum [!]) felszántassa jobbágyával, Basth fia: Jánossal. D. in villa Gumur, f. II. prox. p. fe. Asc. d., a. eiusdem 1356.

E.: Dl. 89 329. (Radvánszky cs. sajókazai lt. 4. 9.) Papíron, hátoldalán azonos kéz írásával tárgymegjelölés, valamint 2 zárópecsét töredéke és egynek nyoma, bevágásaik, szalagjaik.

K.: -

323. 1356. jún. 9.

Péter prépost és a Lelez-i Szt. Kereszt-monostor konventje emlékezetül adja: az egri kápt. kötelezvénylevelében foglaltak szerint (l. 318. szám) - az abban leírt kötelezettséggel és feltételekkel - az egyik részről Tyba-i András fia Lőrinc fia: Miklós felperes, a másik részről pedig ugyanezen Lőrinc fiai: György és László között az Wngh m.-i Rachkzubugya földdarab ügyében fennálló pert a felek által választott 3 nemesember révén jún. 5-én (die domin. prox. an. fe. Penth.) tartoztak a konv. tanúságtétele mellett elrendezni. A konvent Miklós részére Pál testvért, egykori Hothwan-i prépostot, György és László oldalán pedig Balázs mr.-t, Wngh m.-i notarius-t, a nevezett konvent prépost és konvent familiaris-át és procurator-át küldte ki tanúbizonyságul, akik Györgyel és Miklós társaságában visszatérvén jelentést tettek, amelynek során Balázs mr. elmondta, hogy jún. 5-én (in dict. die domin. an. fe. Pent.) Györggyel, Lászlóval és az általuk választott bírákkal (arbitri electi) kimentek a peres földre, ahol a megjelölt, ill. a rákövet- 
kező napon (in quo die domin. et f. II. tunc. prox. subsequente) hiába várakoztak délig, sem Miklós, sem képviselője nem jelent meg. ........ Pál prépost az esố és sár miatti rossz útviszonyokkal magyarázta a távolmaradást, azonban azt állította, hogy jún. 6-án (f. II. prox. p. predict. diem domin.) Miklóssal és a választott bírákkal ebéd idején (hora prandium) hiába jelentek meg a helyszínen, a másik felet nem találták ott. A felek tehát a konvent színe e. vitáztak, s jóllehet Miklós kérte a konventi ember haladék nélküli kiküldését a szóban forgó földdarabra, hogy ne halasszák késóbbre az ügyet, azonban György - arra hivatkozva, hogy Pünkösd e. egy héttel (in septimana an. predict. fe. Pent.) más súlyos pere van a Nogmihal-i nemesekkel - kérte a maga és fivére, László nevében is a megegyezés, ill. fogott bírói ítélet késóbbre halasztását, hiszen ilyen rövid idố alatt nem lehet ítéletet mondani, sőt, egyetértés sem születhet a felek között; ezért tekintettel arra, hogy György vállalta: amint említett másik súlyos perében felszabadul, kész bárhol és bárhogyan eleget tenni ebben a perben fivérével, Miklóssal szemben a rá kirótt ítéletnek, így a pert a fennálló állapot fenntartásával elhalasztják. D. f. V. prox. an. fe. Pent. prenotatum, a. d. 1356.

E.: Dl. 85 312. (Sztáray cs. lt. 98.) Papíron, foltokban elmosódott, szakadozott, hátoldalán azonos és késóbbi kéz írásával tárgymegjelölés, valamint a leleszi konvent zárópecsétje (rajta kettős kereszt, felső harmadánál egyik oldalon csillag, másikon hold, körirata: +S(IGILLVM) C[ON]VENTVS DE LELES), bevágásai, szalagja.

K.: Sztáray I. 250-251. (144. szám).

\section{1356. jún. 10. Vidin város elött, Bulgáriában}

[I.] Lajos [király] megerősíti Vgocha és Bihar m.-i birtokaik jogaiban János fia: János mr.-t és Ardou-i Zouardus fia: Györgyöt, a királyi udvar ifjait és rajtuk keresztül fivéreiket (fr. carnales) és örököseiket az ország szükségében tanúsított húségükért és szolgálataikért. D. an. civitatem Bodinensem in Bulgaria, f. VI. prox. an. fe. Pent., a. d. 1356.

R.: Szirmay, Ugocsa 72; erre való hivatkozással F. IX. 2. 492-493. (237. szám) mindkettő latinul.

Megj.: Szirmaynál an. civitatem Podimensem szerepel a dátumsorban, F.-nél an. civitatem Bodinensem, azonban a fejregesztában Vidinensem alak olvasható.

\section{1356. jún. 10.}

Az egri egyház kápt.-ja emlékezetül adja: színe e. jún. 9-én (in oct. fe. Asc. d.) a néhai nádonak, Paztuh-i Domokosnak a fia: Nagy (Magnus) Domokos mr. eleget téve a Zeech-i Miklós c., [I.] Lajos király országbírája által kiadott ítéletlevélben (1...szám) foglalt kötelezettségének, esküt tett Miklós pécsi püspökkel szemben arra vonatkozólag, hogy nincs a birtokában semmiféle bizonyító eszköz, jogbiztosító írat a Tisza (Tycie) folyó mellett lévő Hevesújvár (Heuesuyuariensis) m.-i Porozlow birtokkal kapcsolatban, ahogyan semmi más használható bizonyítékot sem talált. Az eskütételre a püspököt képviselő famulus-a és officialis-a, Domokos mr. jelenlétében került sor. D. in crastino eiusdem iuramentalis depositionis, a. d. 1356.

E.: AL. Cluj. Cluj-Napoca (Kolozsvár). Erdélyi Múzeum Egyesület egykori lt. Bánffy cs. nemzetségi lt. 63. (Df. 260 642.) K. szerint hártyán, hátoldalán „a kápt. zárópecsétjének helye felett" az országbíró kisebb pecsétje. 
Eml.: A 366. és a 337. számú oklevélben.

K.: Bánffy I. 209-210. (171. szám).

326. (1356. jún. 11. e)

[I.] Lajos király $(\mathrm{H})$ gyưrúspecsétjével megjelölt levelet bocsát ki Boncha fiai érdekében a Bihar m.-i Gyante birtok Tatamér székesfehérvári prépost általi eladományozása tárgyában.

Eml.: A 327. és a 336. számú oklevélben.

K.: Str. IV. 151. (120. szám) (Eml.-ben).

327. (1356. jún. 11.e)

[I.] Lajos király (H) gyưrúspecsétjével megjelölt parancslevélben arra utasítja a [székes]fehérvári kápt.-t, hogy 2 - testületükből (collegium) való - kiküldött révén jutassa el Tatamér fehérvári préposthoz a király másik, gyưrüspecsétjével ellátott, Boncha fia: István, a királyné udvari apródja (aule reginalis excellencie parvulus) és annak testvére (fr. uterinus) érdekében kiállított, s a préposthoz intézett oklevelét, amely a Bihar m.-i Gyante birtoknak Tatamér prépost általi, Bocha említett fiai javára szóló adományának tárgyában kelt. A király parancsa szerint, ha a prépost megvizsgálva e neki átadott királyi oklevelet (l. 326. szám) az abban foglaltakat a maga által Boncha fiai javára Gyante birtokkal kacsolatban kibocsátott privilegiáis oklevélhez képest kifogástalanul igaznak találja, úgy a címzett kápt. ennek bizonyságára adjon ki privilegiális oklevelet Boncha fiai számára.

Eml.: A 336. számú oklevélben.

K.: Str. IV. 151. (120. szám)(Eml.-ben).

\section{1356. jún. 11. Visegrád}

[I.] Lajos király (H) tudatja a budai egyház kápt.-jával, hogy meghallgatván a Nyulak szigeti (de Insula Leporum) Szt. Szúz-egyház apácáinak procurator-a, Péter testvér által az ô és édesanyjának, a királynénak a színe e. előterjesztett panaszát, amely szerint Vybeech-i Dorozlo fia: János Vybeech-i jobbágyai révén nem fizeti meg az adókat (tributa) az említett apácáknak, s ebból a panaszosoknak jelentős káruk származik, egy külön kiadott másik királyi oklevelélben (l. 331. szám) megparancsolta a kápt.-nak, hogy intézkedjen az adófizetés ügyében, ha azonban a nevezett János olyan oklevéllel rendelkezik, amely alapján a szóban forgó jobbágyok nem kötelesek adót fizetni az apácáknak, akkor azt az oklevelet királyi jelenléte e. jún. 27-én (2. die oct. fe. S. Trinitatis) bemutatni tartozik. Ezenfelül a király utasítja a kápt.-t, hogy miután a kápt. embere a mondott másik királyi oklevelet ezzel együtt bemutatja előttük, bármit tegyen v. válaszoljon is Dobozlo fia: János, adják azt írásos jelentésben hírül számára. D. in Vyssegrad, in vig. fe. Penth., a. d. 1356.

Á.: A 356. számú oklevélben.

K.: AO. VI. 484-485. (303. szám) (kihagyásokkal). 


\section{1356. jún. 11. Visegrád}

[I.] Lajos király (H) utasítja a Lelez-i konventet, hogy az Ezen-i Tamás fia: János a maga és fivérei, Simon, László és Imre nevében is kinyilvánított kérésére tekintettel, miszerint a Zemplén m.-i Bozza birtokuk határainak bejárása volna szükséges, küldje ki hites tanúját Kystarkan-i László v. Apati-i Kapulch v. Kerechun-i Barrabas királyi emberek valamelyikével a szóban forgó birtokra, ahol az összehívott szomszédok és határtársak jelenlétében járják be a birtok határait, és ahol szükséges, ott a régi határjelek mellett emeljenek újakat, ha nincs ellentmondás. Ha ellentmondók lennének, azokat idézzék Tamás fiaival szemben a királyi jelenlét bírósága elé alkalmas időre, majd a határjárás menetéról és - ha akadnak ilyenek - az ellentmondók nevéról, valamint a kijelölt időpontról küldjön számára a konvent írásos jelentést. D. in Wyssegrad, in fe. B. Barnabe ap., a. d. 1356.
Á.: 1. [I.] Lajos király, 1358. jún. 5. Dl. 77 227. (Zichy cs. zsélyi lt. 214. C 49.).
2. A 365. számú oklevélben.
K.: Z. III. 115. (74. szám).
R.: Z. XII. 31. (29. szám).

330. 1356. jún. 11.

A győri egyház kápt.-ja e. a Komárom m.-i Aranyas-i Koncha fia: Miklós özvegye, Mylertteui [!] Jakab lánya, Katalin asszony — akinek személyazonosságát Cychwan-i Péter fia: Dénes igazolta a kápt. e. - kinyilvánítja, hogy Aranyas-i Koncha fiai: János, Imre és Pál — Katalin férjének fivérei - az ország szokása szerint eleget tettek az özvegyet férje Aranyas birtokon lévő részéból megillető hozomány és jegyajándék kifizetésének, amiről Katalin ooket és utódaikat is nyugtatja, valamint lemond minden velük szemben a hozomány és jegyajándék ügyében indítandó perról. D. in vig. fe. Penth., a. d. 1356.

E.: BFL. Pannonhalmi főapátság hh.-i lt. 26. A (277.) (Df. 274 112.) Hártyán, hátoldalán késóbbi kéz írásával jegyzetek, valamint kerek pecsét töredéke, bevágásai, szalagja.

K.: -

\section{1. (1356. jún. 11. körül)}

[I.] Lajos király (H) utasítja a budai egyház kápt.-ját, hogy intézkedjen azon adófizetéssel kapcsolatos panasz ügyében, amelyet a Nyulak szigeti (de Insula Leporum) Szt. Szűz-egyház apácáinak procuratora terjesztett eléje, s amely szerint Vybeech-i Dorozlo fia: János Vybeech-i jobbágyai révén nem fizeti meg az adókat (tributa) az említett apácáknak.

Eml.: A 328. és a 356. számú oklevélben.

K.: AO. VI. 484. (303. szám) (Eml.-ben). 
[I.] Lajos király (H, Da, C, Ra, Se, G, L, Cu, Bu, princ. Sal., mont. S. Angeli dom.) a színe e. nemzetségüket és rokonaikat is képviselő Endre fia: Pál, Sándor fia: Brakunch, Goizlaus (gen.: Goizlay) fia: Petk, Tamás fia: Jorizlow Prechyna-ból Prechyne-ból való Gyurse nb. nemesek kérésére és oklevél-bemutatása alapján, a főpapok és bárók tanácsára privilégiumában átírja, s autentikus kettős pecsétjének ráfüggesztésével megerősíti [IV.] Béla király 1256. márc. 24-én kelt kiváltságlevelét a kérelmezők Gora m.-ben (in comitatu de Gora) fekvő örökölt földjei ügyében. Kelt ... zágrábi püspök, udvari alkancellár keze által a. d. 1356, II. Id. mensis Jun., uralkodásának 15. évében. Méltóságnévsor: Miklós lévén az esztergomi érsek, egyben ua. m. örökös c.-e - a kalocsai szék üresedésben —, Wglinus a spalatói érsek, Miklós az egri, Demeter a váradi — az erdélyi szék üresedésben -, Miklós a pécsi, János a veszprémi, Kálmán a győri, Tamás a csanádi, Mihály a váci, Péter a boszniai, Tamás testvér a szerémi, István testvér a nyitrai és Balázs testvér a knini püspök; Konth Miklós a nádor és a kunok bírája, András az erdélyi vajda és a Zonuk-i c., Cykow a tárnokmr., Seech-i Miklós az országbíró, Miklós a Machow-i bán, Leustachius az egész Szlavónia bánja, Lewkus az asztalnok-, Dénes a lovász-, Péter fia: Tamás az ajtónálló mr., Móric fia: Simon a pozsonyi c. A.

Á.: Zágrábi kápt., 1357. márc. 25. Dl. 431. (NRA. 1531. 18.).

K.: Smič. XII. 358-360. (269. szám).

R.: Doc. Rom. Hist. C. XI. 22. (21. szám) (románul).

Megj.: IV. Béla oklevelet 1. Reg. Arp. 1082. szám.

333. 1356. jún. 13.

Az erdélyi kápt. - miként azt 1356. jún. 13-án (2. die fe. Penth., a. d. 1356.) kiadott privilégiuma bizonyítja - a néhai István alvajda oklevelében (l.176. szám) foglaltak szerint Galaz-i János alvajdai ember mellé jegyzőjét (notarius), László mr.-t adta hites tanúul a Vilagusberk-i (Viragosberk) nemesek oldalán, a Fata-i (Fatha) nemesek részére pedig a Lekenche-i (Lekencze) egyház rektorát, Balázst küldte ki, akik visszatérve jelentették, hogy jún. 5-én (in die domin. an. fe. Penth. tunc praeterito) a felekkel - Beche fia: István kivételével, akinek nevében a hatályos ügyvédvalló levélben meghatalmazott famulusa, Nagy (Magnus) András jelent meg — a Fata és Chepan birtokok között fekvő peres földre mentek, s jóllehet a 8 fogott bírából 4, ti. Zaua-i Mark, Wlken fia: János, Miklós fia: Myke, és Tamás fia: Miklós tudott csak megjelenni - ugyanis a többi négyet törvényes elfoglaltság akadályozta a megjelenésben —, mégis, ezeknek segítségével a szóban forgó földrészt szemrevételezés alapján felosztották, tekintettel arra, hogy az erdôk rendkívüli sûrúsége és a hegyek magassága miatt másként nem tudták volna jól felosztani. A föld Chepan birtokból elválasztott harmad részébe a Vilagusberk-i nemeseket, a Fata birtokból új határjelek állításával elhatárolt kétharmad részbe pedig a Fata-i nemeseket iktatták be örök birtoklásra az ellentmondás nélküli felosztást követően.

Tá.: 1. Losonci László erdélyi vajda, 1380. jan. 28. > erdélyi kápt., 1380. máj. 6. Dl. 73 765. (Teleki cs. marosvásárhelyi lt. 235.).

2. Dengelegi Pongrác és Vízaknai Miklós erdélyi alvajdák, 1442. okt. 15. Dl. 44 336. (Múz. Ta. Torma).

K.: Teleki I. 193- 195. (148.szám); ZW. II. 514-516. (1119.szám) mindkettő Tá. 1.-ről. 
R.: Doc. Rom. Hist. C. XI. 22. (22. szám) románul, Tá. 1. alapján; Erd. Okmt. III. 305. (837. szám).

Megj.: A ( )-ben közölt névalakok Tá. 2-ből származnak.

\section{1356. jún. 13. Gömör falu}

Kemen fia: János mr., Konya mr. Gömör m.-i alispánja és a m.-e szb.-ái tudatják: Starusi Miklós fia: László kérésére pecsétjükkel küldték ki Sanchfalua-i Pál fia: Jánost vizsgálat lefolytatása céljából, aki visszatérve jelentette, hogy jún. 8-án (f. IV. prox. an. fe. Barnabe ap.) Durusgh és Scrasa birtokok szomszédságába lefolytatta a vizsgálatot az értesüléssel rendelkezők körében. Ennek eredményeként megtudta, hogy elszánt katonák (strenui milites), nevezetesen Bebek (dict.) István mr. és György az ő Dereske-i officialis-aik, népeik és jobbágyaik révén használják Miklós fia: László sérelmére annak - a Darnopataka folyón túl, attól É-ra, Strasa birtok határai között elterülő — részbirtoka valamennyi haszonvételét. D. in villa Gumur, in crastino fe. Penth., a. d. 1356.

E.: $\quad$ SNA. Szepesi kápt. hh.-i lt. 11. 1. 11. (Df. 263 318.) Papíron.

K.: -

\section{1356. jún. 15. Esztergom}

Miklós esztergomi érsek és ue. m. örökös c.-e a színe elé járuló Hermann Lypche-i plébánosnak, liptói alesp.-nek a kérésére és oklevél-bemutatása alapján autentikus függőpecsétjével ellátott privilégiumában átírja a néhai Boleszló esztergomi érsek által egyházának szabadságai ügyében 1324. nov. 8-án Visegrádon kiadott privilégiumát (l. Anjouoklt. VIII. 496. szám), amelyben megerősítette Lodomér esztergomi érsek és örökös c. 1283. máj. 28-án Esztergomban kiállított oklevelét, ebben átírva Fülöp esztergomi érsek, királyi kancellár 1243. ápr. 20-án Esztergomban kelt, [a Liptó m.-i Lypche falu plébániájának kiváltságairól szóló] oklevelét. D. Strigonii, f. IV. prox. p. fe. Pent., a. d. 1356.

E.: ŠA. Bytči Pobočka Liptovský Mikuláš. Liptói Múzeum gyújteménye: Németlipcse város lt. Oklevelek 10. (27910) (Df. 271 797.) Hártyán, alján sodraton pecsét függ.

Á.: Tamás esztergomi érsek, 1368. ápr. 28. ŠA. Bytči Pobočka Liptovský Mikuláš. Liptói Múzeum gyújteménye: Németlipcse város lt. Oklevelek 11 (24521) (Df. 271798.$).$

K.: -

336. 1356. jún. 15.

A [székes-]fehérvári egyház kápt.-ja eleget téve az [I.] Lajos király (H) gyứrúspecsétjével ellátott, Boncha fia: István, a királynéi udvar apródja (parvulus) és fivére (fr. uterinus), Péter érdekében kibocsátott, a Bihar m.-i Gyante birtok Tatamér (Thatamerius) [székes]fehérvári prépost általi eladományozásával kapcsolatban küldött parancslevélben ( $l$. 327. szám) foglaltaknak, testületükból (collegium) kiküldött 2 kanonok testvérük — nevezetesen Mihály Wrs-i plébános, valamint Tót (Sclavus) Imre kápt.-i jegyző (notarius) - kézbesítette Tatamér préposthoz a király gyưrúspecsétjével ellátott másik, szintén a szóban forgó birtok adományozása tárgyában Boncha fiai érdekében kiállított oklevelét (l. 326. szám). Ezek visszatérve egybehangzóan jelentették, hogy jún. 11-én (in vig. fe. 
Penth.) a fent nevezett préposthoz mentek, és bemutatták neki a király szóban forgó oklevelét, aki ennek megnézésekor látta a maga privilegiális oklevelét, amely révén Gyante birtokot Bonche fiainak adományozta, majd meggyőződve az irat hibátlan valóságtartalmáról, kijelentette, hogy valódi ez a tóle származó privilégium, és ő adta unakaöccseinek, Boncha fiainak, emellett pedig nevezett kápt.-i kiküldöttek e. arra nézve is szóbeli nyilatkozatot tett, hogy Gyante birtokot annak idején unokaöccsei Bulkuz birtoka fejében jól megfontolt csereként adta oda a szóban forgó privilégiuma révén örökre szóló és visszavonhatatlan birtoklásra, és ahogyan annak idején átörökítette rájuk, most ugyanúgy örökös tulajdonukba adja azt. Mivel a király a kápt.-hoz intézett levelében megparancsolta, hogy ha a prépost igaznak mondja a nevezett birtok adományozásával kapcsolatos privilegiális oklevelet, akkor a kápt. köteles arról a birtokról privilégiumot kiállítani Boncha fiai részére, ezért a kápt. teljesítvén a királyi parancsot, ill. Boncha fiainak kérése nyomán is autentikus függőpecsétjével megerősített privilégiumot bocsát ki az ügy bizonyságára. D. a. d. Incarn. 1356., XVII. Kal. mensis Iul., Tatamér lévén a prépost, János az éneklő-, Demeter az őr- és István a dékánkanonok.

E.: EPL. Acta radicalia T 20. (Df. 248 654.) Hártyán, K. szerint alján vörös-zöld selyemsodraton a székesfehérvári kápt. pecsétje függ.

K.: Str. IV. 150-151. (120. szám).

\section{1356. jún. 16. Visegrád}

Zeech-i Miklós c., [I.] Lajos király $(\mathrm{H})$ országbírája, [Turuch] m. c.-e [dátum nélkül] átírja saját, jan. 20-án kelt oklevelét (l. 45. szám) [azon, Porozlou birtok ügyében zajló perben, amelyben az országbíró Miklós pécsi püspökkel szemben máj. 1-jén esedékes oklevél-bemutatásra kötelezte Paztuh-i Domokos fia: Domokos mr.-t]. A[z oklevélbemutatásra] kijelölt időpontban [máj. 1-jén ([in] oct. fe. B. Georgii mart.)] az országbíró e. megjelent ura, Miklós pécsi püspök képviseletében az annak ügyvédvalló levelével maghatalmazott Péter mr. deák, kérve az okleveles bizonyítékok bemutatását, amelyre válaszul a Domokos mr. helyett az egri egyház kápt.-jának ügyvédvalló levelében kapott meghatalmazással eljáró Péter fia: János kijelentette, hogy ura sem bizonyítékokkal, sem okleveles megerősítéssel nem rendelkezik Porozlou birtok ügyében. Az országbíró az ország báróival és nemeseivel együtt - a püspök panaszára tekintettel elrendeli, hogy Domokos mr. személyesen tegyen esküt jún. 9-én (in. oct. fe. Asc. d. nunc venturis) az egri kápt.-ban arra vonatkozólag, hogy nem rendelkezik semmiféle bizonyító erejû oklevéllel Porozlou birtok ügyében. Az eskütételrôl a felek a kápt. oklevelében kötelesek az országbírónak jelenteni az esküt követő 8. napon (ad 8. diem dict. oct.), azaz jún. 16-án. A kitűzött időpontban (ipso oct. diei oct. prescripti fe. Asc. d.) a Domokos mr. képviseletét az egri kápt. ügyvédvalló levelével ellátó János fia: Péter bemutatta az országbíró színe e. az egri kápt.-nak az eskütételról írt jelentését ( $l$. 325. szám), amely többek között magában foglalta, hogy a kijelölt napon színük e. Domokos mr. Miklós pécsi püspökkel szemben megesküdött arra, hogy semmiféle bizonyítékkal és okleveles megerósítéssel nem rendelkezik a Hevesújvár m.-i, a Tisza (Tycie) folyó mellett fekvő Porozlow birtok ügyében. Az oklevél bemutatását követően a képviselők kérésére mindezek tanúságára jelen oklevelet bocsátja ki a püspök számára. $\mathrm{D}$. in Vysegrad, in die reportationis serie prenominate, a. d. 1356.

E.: AL. Cluj. Cluj-Napoca (Kolozsvár). Erdélyi Múzeum Egyesület egykori lt. Bánffy cs. nemzetségi lt. 60. (Df. 260 639.). 
K.: -

Megj.: Vö. a 366. számú oklevéllel.

338. 1356. jún. 16. Fraknó

Nagymartoni Miklós fia: Miklós bizonyos birtokát elzálogosítja feleségének, Annának. Der brief ist geben ze Vorchtenstain, nach Christes gepurt Dreuczehen hvndert iar darnach in dem sechs vnd fuenfczikisten Jar, dez Phincztag in Phingstwochen.

E.: Dl. 4619. (NRA. 973. 1.) Német nyelvư, hártyán, alján pecsét felfüggesztésére utaló bevágásokkal.

K.: Sopron I. 263-264. (195. szám).

339. (1356. jún. 18.e.)

[I.] Lajos király parancslevelében Semien-i Lengel (dict.) János fia: László valamennyi peres ügyét a királyi hadoszlás 15. napjára rendeli halasztani.

Eml.: A 340. számú oklevélben.

K.: -

340. 1356. jún. 18. Fehértó

Cantor (dict.) Bereck mr. Zabolch-i alispán és a m. szb.-ái tudatják: Kallo-i Iwan fia: Demeter törvényesen és alkalmas időpontra színük elé idézte Semien-i Lengel (dict.) János fia: Lászlót, amely időpont elérkeztével Demeter képviseletében serviens-e, az ügyvédvalló oklevélben meghatalmazott András, míg a nevezett László személyesen jelent meg és bemutatta a király oklevelét (l. 339. szám), melyben László valamennyi perét a királyi hadoszlás 15. napjára halasztja, így a m.-i hatóság a királyi oklevélben foglaltaknak megfelelően ezt a pert is a meghatározott idôpontra halasztja. D. in Feyrtho, sab. prox. p. fe. Penth., a. d. 1356.

E.: D1. 51 710. (Kállay cs. lt. 1300. 1033.) Papíron, hátoldalán azonos kéz írásával tárgymegjelölés, valamint 3 zárópecsét töredéke, bevágásai.

K.: -

R.: Kállay II. 36. (1186. szám); Piti F., Szabolcs m. 133. (516. szám).

341. (1356. jún. 19.e.)

Zeech-i Miklós országbíró perhalasztó oklevelében jún. 19-re rendeli színe elé Waradai László fia: János mr.-t, vele szemben pedig Darouch-i István fia: Jánost és ennek a Jánosnak a fiát, Lászlót hatalmaskodás ügyében.

Eml.: A 361. számú oklevélben.

K.: - 


\section{1356. jún. 19. körül}

A pozsonyi egyház kápt.-ja e. Pathly-i Miklós fia: Tamás mr. Sopron m.-i Tord birtokát hitvesének, Jakab fia Miklós leányának, Margitnak - Jakus, Pozsony város bírája leánytestvérének - elzálogosítja az asszony hozománya és jegyajándéka azaz libránként 6 pensa-val számolt 400 libra súlyú bécsi dénár fejében úgy, hogy azt akár ô, akár rokonai ugyanazért az összegért visszaválthassák tôle. A zálogügylet bizonyságára a kápt. függő és autentikus pecsétjével ellátott és az ABC betúivel chirographált kiváltságlevelet bocsát ki Margit úrasszony és örökösei részére. D. ....... fe. S. Trinitatis, a. d. $1[3] 56$.

E.: SNA. Pozsonyi kápt. hh. 1t. 14. 18. 9. (Df. 226 830.) Hártyán, alul az ABC betúivel chirographálás, valamint függőpecsét zsinege, hátoldalán későbbi kéz írásával tárgymegjelölés.

K.: -

343. 1356. jún. 19.

A váradi egyház kápt.-ja a színe e. fivéreit, Demetert és Andrást is képviselő Ohat-i Márton fia Miklós fia: Mihály kérésére és oklevél-bemutatása alapján autentikus függőpecsétjével megerősített privilégiumában átírja [ - bizonyos Zobolch és Bihar m.-i birtokok cseréjének ügyében -] 1335. nov. 8-án kelt nyílt oklevelét (l. Anjou-oklt. XIX. 678. szám) D. in fe. S. Trinitatis, a. d. 1356. Fülöp lévén a prépost, Benedek az olvasó-, László az éneklő-, Gergely az ôrkanonok.

E.: D1. 99 579. (Károlyi cs. nemzetségi lt. Bosnyák cs. 6. 13.) Vonalazott hártya, hátoldalán késóbbi kezek írásával tárgymegjelölések (magyarul is), továbbá függőpecsét zsinege az alján.

K.: Károlyi I. 234. (147. szám).

R.: Herpay 24. (26. szám); Doc. Rom. Hist. C. XI. 20. (23. szám) (románul).

344. 1356. jún. 20.

Az egri egyház kápt.-ja e. egyik részrôl Forrou-i Aladár fia Jakab fia: János mr., a másik részrôl pedig a hitvesét, Imbreg-i Dénes fia András leányát, Erzsébet nemes asszonyt képviselő Bedechke-i Domokos fia: Choka (dict.) István megjelenvén, előbbi kinyilvánítja, hogy a Harnad folyó mellett fekvő Abauywar m.-i Euzed öröklött földjét minden haszonvételével és tartozékával együtt, különös tekintettel a mondott folyó Ke-i partján fekvő malomra, a benne lévő 3 malomkővel együtt ínségtól szorongatva, de leginkább is azért, mert a királyi hadjáratban való részvétel miatt kénytelen elutazni, szavatosság vállalása mellett eladta feleségének Erzsébetnek a tőle kapott 60 garas budai M.-ért, s másik részről a kápt. e. Bedechke-i Domokos fia: Choka (dict.) István képviselte feleségének és örököseinek, semmi jogot nem tartva fenn abban magának. Elmondása szerint az asszony a mondott összeget kelengyéjével együtt (cum rebus suis scrinalibus) a szóban forgó birtokért és malomért már átadta neki, ezzel biztosítván a birtokláshoz való jogot a maga és örökösei számára. A kápt. az oklevél visszahozatalának esetére privilégium kiállítását ígéri az ügyben. D. in crastino fe. S. Trinitatis, a. d. 1356. 
E.: Dl. 4620. (NRA. 949. 5.) Hártyán, hátoldalán késóbbi kéz írásával jegyzet, valamint kerek rányomott pecsét nyoma, bevágásai.

K.: AO. VI. 483. (302. szám) (kihagyásokkal).

\section{1356. jún. 20. Szentimre}

Domonkos erdélyi alvajda a Clusmunustra-i Boldogságos Szűz Mária-monostor konventjének: a néhai István alvajda halasztó levelében foglaltak szerint Reche-i Lőrinc fia: János végleges válaszadás végett köteles volt megjelenni az alvajda színe e. jún. 19-én (in oct. fe. Penth.) Chente (dict.) János lányai, Kalach és Kamaras-i Bálint feleségei ellenében abban a perben, amelyben a nevezett asszonyok követelték tóle a Bare és Zengel birtokokon lévő, s ôket nagyanyjuk révén osztályos jogon megilletô birtokrészekkel kapcsolatos elégtételadást, továbbá anyjuk leánynegyedének kiadását, amely nekik Nagy- és Kis- (de Maiori et Minori) Reche, valamint Paluara, Kerezur [!], Nok és Tamasteleke birtokokból a természeti jog szerint (iure naturali) jár, nemkülönben azon földekből őket megillető osztályrészüket, amelyet ezen özvegyek [!] apjuktól [örököltek], miként azt a Clus m.-i szb.-ák István alvajdához intézett jelentése tartalmazza. A megjelölt napon, jóllehet a Lőrinc fia: János mr. helyett érvényes ügyvédvalló levélben meghatalmazott ....... fia: Mihály megjelent, mégsem válaszolt a bíró háromszori kérdésére, hanem az ügy halasztását kérte. Mivel István alvajdának a felek által bemutatott oklevelében az szerepelt, hogy János mr. a szóban forgó asszonyok keresetével nem helyezkedett szembe, ezért az alvajda a vele ítélkezố nemes bírótársakkal együtt úgy határozott, hogy Jara-i Jakab fia: György, Both fia: Gál, Zaua-i Mark c. és Corpad-i Bagar (dict.) János külön erre a feladatra kiküldött alvajdai ember júl. 25-én (in die fe. B. Jacobi ap. prox. nunc venturi) a konvent tanújával együtt - kinek kiküldésére az alvajda felszólítja a konventet - menjenek Zengel és Bare birtokokra, s ott az összehívott szomszédok, valamint a peres felek által odavezetett fogott bírák jelenlétében határjelekkel válasszák el a szóban forgó asszonyoknak anyjuk u. járó birtokrészét azoktól, amelyek Bare és Zengel birtokokon Lőrinc fia: János kezén maradnak, majd iktassák be abba örök jogon a 2 asszonyt; ezt követően pedig Nagy- (Maior) és Kis- (Minor) Reche birtokra menve tegyenek eleget a kedvezményezetteket anyjuk leánynegyede fejében megillető rész kiadásának az ország szokása szerint. Ellentmondás esetén alkalmas időre színe elé idézni parancsolja a feleket, a történtekről pedig írásos jelentést vár. D. in S. Emerico, 2. die oct. fe. Penth. predictarum, a. d. 1356.

Á.: A 421. számú oklevélben.

Má.: Uo., mint Á., azzal megegyező jelzet alatt; 1837. évi egyszerü Má.-ban.

K.: AO. VI. 491-493. (309. szám) (kihagyásokkal); Doc. Rom. Hist. C. XI. 23-25. (24. szám) (román fordításban is) mindkettő Á. alapján.

R.: Erdélyi Okm. III. 305. (838. szám).

Megj:: Az oklevél hitelességét kétségessé teszi, hogy a kolozsmonostori konvent hamisítási ügybe keveredett és emiatt halálra ítélt jegyzőjének, István deáknak az ügyeihez kapcsolható, emellett a szöveg szokatlan szerkezete, zavarossága is a hamisítás gyanúját ébreszti. 
A [székes-]fehérvári Szt. István király-egyház ispotálya kereszteseinek konventje (conventus cruciferorum domus hospitalis ecclesie B. regis Stephani de Alba) választott bírói döntésről szóló és eskütételre vonatkozó oklevelében színe e. jún. 21-én (f. III. prox. p. fe. S. Trinitatis)leteendő esküre kötelezi Theberchuk-i Nacher (dict.) Máté alperest 25 - magához hasonló - emberrel együtt a felperes Tatamér (Thatamerius) mr. fehérvári prépost ellenében 1 jó ló és 2 ökör elvételével kapcsolatban.

Eml.: A 349. számú oklevélben.

K.: -

347. 1356. jún. 21.

A Posaga-i kápt. e. - miként azt [1356.] jún. 21-én (f. III. prox. p. fe. S. Trinitatis prox. tunc preteritum) kiállított nyílt oklevele tanúsítja - egyik részrôl Dobouch-i Cymba (dict.) István fia: István, a másik részrôl pedig Velyke-i Tamás fia Beke fia: László kinyilvánították, hogy a Posaga m.-i Felsew- és Alsow-Orboua birtokokkal kapcsolatos perben, amelyet István ősei és atyafiai, László és fivére őseivel szemben folytattak, és azóta is zajlik István és László között, fogott bírák közremúködésével egyezségre jutottak egymással. Ennek értelmében István fia: István Felsew- és Alsow-Orboua birtokokat minden haszonvételükkel és tartozékukkal együtt - elismerve, hogy azokat jogellenesen nem bitorolhatja tovább - visszaadja Beke fiainak: Lászlónak, Miklósnak és Tamásnak, valamint ezen Tamás fia Miklós fia: Lászlónak, továbbá Velyke-i Simon fia: Jánosnak örökre és visszavonhatatlanul, továbbá átadja peres ellenfeleinek valamennyi, a birtokokkal v. tartozékaikkal kapcsolatban zajló perben bármilyen hatóság által a per kezdetétől ez ideig kiállított oklevelét, egyszersmind arra az esetre, ha a későbbiekben bárki ilyesfélét mégis bemutatna a bíróság e., azt mind hatálytalannak nyilvánítja. Ezzel szemben Beke felsorolt fiai, valamint Miklós fia: László és Simon fia: János elismerték, hogy a per tárgyát képezô birtokok illetéktelen birtoklásának megszüntével, ill. e javak visszaszerzésével ôk teljes körú elégtételhez jutottak.

Tá.: 1. Az 502. számú oklevélben.

2. Szécsi Miklós országbíró, 1382. aug. 23. Dl. 33 726.(NRA. 1511. 19.).

K.: Smič. XII. 366-67. (276. szám) (Tá. 1. alapján); Smič. XVI. 311. (251. szám) (Tá. 2. alapján).

348. (1356. jún. 21.u.)

Zeech-i Miklós országbíró tanú állítására szólítja fel a Posaga-i kápt.-t Bagyun-i János fia: Péter v. Deuecher-i Miklós fia: Márton - a király ajtónállói -, v. Abhostyan-i Pál fia: János királyi emberek valamelyike mellé Felsew- és Alsow-Orbaua birtokok hj.-t elvégzendő, majd azt követően Beke fia: László és atyafisága számára történő iktatását végrehajtandó.

Eml.: Az 502. számú oklevélben.

K.: AO. VI. 502. (314. szám); Smič. XII. 369. (276. szám) (Eml.-ben). 
A [székes-]fehérvári Szt. István király-egyház ispotálya kereszteseinek konventje (conventus cruciferorum domus hospitalis ecclesie B. regis Stephani de Alba) tanúsítja, hogy miután korábbi, választott bírói döntésrôl szóló és eskütételre vonatkozó oklevele (l. 346. szám) értelmében színe e. jún. 21-én (f. III. prox. p. fe. S. Trinitatis) Theberchuk-i Nacher (dict.) Máté alperes 25 - magához hasonló - emberrel együtt köteles volt esküt tenni a felperes Tatamér (Thatamerius) mr. fehérvári prépost ellenében 1 jó ló és 2 ökör elvételével kapcsolatban, amely cselekedet Olop faluban Pál fia: János személyes szállásán (in hospitio proprio) bírói ember jelenlétének hiányában, önkényesen és önhatalmúlag történt. Máté a kitüzött napon megjelent a szóban forgó 25 társával együtt, s a konvent erre kijelölt és kiállított emberének, László karbéli klerikusnak a színe e., továbbá Tatamér prépost törvényes képviselőjének, Keruzkuz-i Lászlónak a jelenlétében rendben eleget tett eskütételi kötelezettségének. D. f. IV. prox. p. fe. S. Trinitatis, a. d. 1356.

E.: Státní Archiv v Brne, Seilernové: Rodinny Archiv (Archiv Révayu a Serényiu) 37. (Df. 249 105.) Papíron, alsó széle szakadozott, hátoldalán azonos kéz írásával tárgymegjelölés, valamint mandorla alakú pecsét töredéke.

K.: -

350. 1356. jún. 22.

Miklós mr., Lyptow-i alispán és a m. 4 szb.-ája bizonyítja, hogy Yako fia: Péter megfizette nekik a bírságot és a felperesnek is elégtételt szolgáltatott azzal, hogy felújította és helyreállította a határjeleket. D. prox. IV. f. an. fe. B. Johannis Bapt., a. d. 1356.

E.: Dl. 64 821. (Fejérpataky cs. 1t. 5.) Papíron, hátoldalán azonos kéz írásával tárgymegjelölés (eltérő névalakkal: Yakow), valamint 2 zárópecsét töredéke, szalagjai, bevágásai.

K.: -

351. 1356. jún. 23.

Péter prépost és a Lelez-i Szt. Kereszt-egyház konventje e. egyik részről Warada-i László fia: János mr., a másik részrôl pedig Euzud-i Tenkes (dict.) János fia Péter fia: László megjelenvén, utóbbi kijelenti, hogy a Zabouch m.-i Euzud birtokát, amely az említett János mr.-nek volt elzálogosítva, és amely János mr. birtokaival határos — Ny-ról a Tyssa folyó mellett egy másik Euzud, Dé-ről Duge, Ke-rôl pedig Lythke határolják-, minden haszonvételével és tartozékával, ti. tavakkal, erdőkkel, kaszálókkal, múvelt és múvelés alatt nem álló földekkel együtt eladja a szóban forgó László fia: János mr.-nek és örököseinek 43 budai M. ellenében örök és háborítatlan birtoklásra, idegen jog sérelme nélkül. A kápt. az oklevél visszahozatalának esetére privilégium kiállítását ígéri. $\mathrm{D}$. in vig. fe. Nat. B. Johannis Bapt., a. d. 1356.

E.: Dl. 77 166. (Zichy cs. zsélyi lt. 1 B 293.) Hártyán, az írás elhalványult, hátoldalán kerek rányomott pecsét nyoma, bevágásai.

Á.: A 627. számú oklevélben. 
K.: Z. III. 29-30. (17. szám) (E.-ről); Z. III. 39-40 (26. szám) (Á.-ról).

\section{1356. jún. 24.}

A velencei államtanács követei révén tudatja Treviso városával, hogy I. Lajos magyar király serege élén feléjük közeledik, s inti őket, hogy tegyék meg a szükséges előkészületeket.

R.: Óváry, 47. (59. szám) (Velencei lt.-ra való hivatkozással); uő., TT. 11 (1888) 455.

353. 1356. jún. 24.

A zalai konvent e. - miként azt 1356. jún. 24-én (in die fe. B. Johannis Bapt., a. d. 1356) kiállított privilégiuma tanúsítja - egyik részről Terpen-i Pazman fia: Lőrinc a maga, valamint fiai, János és Benedek nevében, a másik részről Terpen-i Sala fia: András és fiai: Anthol és Gaal a maguk, valamint ugyanezen András távolmaradt további fiai: György és István képviseletében is megjelenvén, kinyilvánították, hogy Onth fia: Sala részbirtokának ügyében fogott bírák közremúködésével békés megegyezésre jutottak egymással. Eszerint Sala részbirtokának az É-i felét az alábbi határok mentén elválasztották Sala nemes özvegyének, Florys-nak a hitbére (dos) gyanánt, és hasonlóképpen András feleségének, Erzsébetnek, ill. Sala leányainak, Kegyes-nek és Margyth-nak a leánynegyede címén. Ezt a részt Lőrinc valamennyi haszonvételével együtt átengedte Andrásnak és fiainak örök jogon és visszavonhatatlanul, a birtok másik fele Dé-ről viszont megmaradt Lőrincnek és fiainak örök birtoklásra. Hj.: a határ Ke-ról Zaladach helyen indul egy forrásnál lévő megjelölt fúzfával, É felé szántóföldeken át út menti földjelhez jut, e nagy utat keresztezve a szántóföldeken tovább Ny felé, földjel, kissé Dé felé diófánál másik, felhantolt gesztenyefától Ny felé tovább, eléri András és a fiai szőlőskertjének Dé felől eső sövényét (indago), dombra fel, út, azon É felé egy völgynyílásban határjelül szolgáló tölgyfához ér, le a völgybe Ny felé, kijáratánál újra tölgyfa a határjel, Dé-nek fordul a szántóföldek szélén újonnan emelt földjel, Ny felé dombra fel, ahol egy tölgyfánál ér véget a határ; ettôl É-ra fekszik Andrásnak és fiainak birtokfele, Dé-re pedig Loorincnek és fiainak a része.

Tá.: Pálóci Máté országbíró, 1426. márc. 23. Dl. 102 969. (Batthyány lt. Illésházy cs. 23. 24. 6.).

K.: -

354. (1356. jún. 25.e.)

[I.] Lajos király tanú állítására szólítja fel az egri kápt.-t Fyzy-i Tamás fia: Jakab királyi ember mellé, hogy bevezessék Akus mr.-t — Mich-nek, az egész Szlavónia néhai bánjának a fiát - egyrészt Sumugy birtokba, másrészt pedig az elmondások szerint Szepes m.-ben birtokolt Podolyn, Luchna és Ofalu falvakban kivetni szokott ama vámoknak (tributum) az uralmába, amelyeket a jelentések szerint a király, ill. a néhai Fülöp nádor nemes özvegyének adománya jutatott Akus mr. kezére.

Eml.: A 382. számú oklevélben.

K.: $\quad$ AO. VI. 485. (304. szám) (Eml.-ben). 
355. 1356. jún. 25.

A velencei signoria Cornaro Márkot küldi a paduai podestához a magyar királlyal való béketárgyalások ügyében.

R.: Óváry 47. (60. szám) (Velencei lt.-ra való hivatkozással); uő., TT. 11 (1888) 455.

356. 1356. jún. 25.

A budai egyház kápt.-ja jelenti [I.] Lajos királynak (H): a király jún. 11-én kelt és itt átírt oklevelében (l. 328. szám) foglaltaknak eleget téve a másik királyi oklevél ( $l$. 331. szám) bemutatása végett egyházuk karbéli klérikusát, Andrást küldték ki Dorozlo fia: Jánoshoz, aki visszatérve jelentést tett. Eszerint jún. 24-én (in fe. Nat. B. Johannis Bapt.) Dorozlo fia: János távollétében érkezett ennek Vybech-i jobbágyaihoz, akik kérdésére azt válaszolták, hogy az apácáknak járó adót mindig és késedelem nélkül megfizették azok adószedőinek, az adó megfizetéséről v. meg nem fizetésére vonatkozó oklevéllel pedig nem rendelkeznek, hacsak uruk birtokában nincs ilyen. D. 2. die fe. Nat. B. Johannis Bapt. prenotati, a. d. supradicto [1356].

E.: Dl. 4618. (MKA. Acta eccl. ord. et mon. Poson. 58. 56.) Papíron, helyenként elmosódott írásképpel, kissé rongált; hátoldalán késóbbi kéz írásával magyar nyelvú tárgymegjelölés, valamint mandorla alakú rányomott pecsét lenyomata, bevágásai.

K.: AO. VI. 484-485. (303. szám) (kihagyásokkal).

R.: Pest m. 65-66. (344. szám).

357. 1356. jún. 26.

A velencei államtanács hadiintézkedései Treviso és Mestre városoknak a magyar hadsereg elleni védelme érdekében.

R.: Óváry 48. (61. szám) (Velencei lt.-ra való hivatkozással); uô., TT. 11 (1888) 455. (jún. 24-i és júl. 5-i dátummal).

358. 1356. jún. 26. Eger

Domokos, az erdélyi egyház prépostja, az egri egyház kanonokja, Miklós egri püspök lelkiekben általános vikáriusa tudatja Miklóssal a Munkach-i, Pállal a Rakus-i, Jánossal a Ruzka-i és Jakabbal a Palagh-i ........ [egyháznak a] papjával, hogy nemrégiben Kapus-i Vince Wg........-i [Wngh-i] alesp.-hez, Chazlouch-i ........-hoz és Palagh-i Jakabhoz intézett levelében (1. 310. szám) felszólította a címzetteket, hogy jún. 3-án (in crastino fe. Asc. d.) az alább feltüntetett felekkel és fogott bírákkal együtt menjenek ki a Beregh m.-i ........ [Brod] birtokra azzal a céllal, hogy a teljes Brod birtok negyed részének harmadát felmérjék és becsú alá vessék valamennyi tartozékával és haszonvételével együtt, és bárminemú ellentmondástól függetlenül iktassák be abba a néhai Lewe $\sim$ Leue Brod-i nemes unokáját (nepos), György fia: Balázs c.-t a mondott Lewe nemes ....... [leánya], Erzsébet u. járó leánynegyed kiegyenlítése címén, majd a történtekről küldjenek jelentést jún. 19-re (ad oct. fe. Penth. tunc sequentes) számára. Hivatkozott levelének címzettjei ele- 
get akarván tenni a felszólításnak, kimentek Brod birtokra, s úgy tettek, ahogyan a parancslevélben állt, ám mert István fia: Domokos és Byter fia: László fiaikkal Gergellyel, Miklóssal és Mihállyal együtt ellentmondtak, minthogy nevezettek a teljes birtok negyedének nem a harmadrészébe, hanem kilencedrészébe akarták beiktattatni György fia: Balázst, ezért a kiküldöttek mégsem tudták véghezvinni megbízásukat, ahogyan Vince alesp. és társainak a jelentéséból az kiderül (l. 314. szám). Amikor pedig ennek láttán a vikárius bíróságának ülnökeivel — mi több magával a püspökkel — együtt, a jogtalan ellentmondás miatt a felek között végső ítéletet akartak hozni, Hupkahelmechi Simon fia: Péter Domokos c.-nek és fiainak, valamint Zaplow-i István fia: Tamás Byter fia: Lászlónak és ezen László fia: Mihálynak a képviselői, akik hatályos ügyvédvalló oklevéllel jelentek meg, s a jogtalan ellentmondás miatt rokonaik elkerülhetetlen elmarasztalásával számolva a felperes, ill. a képviselők egyetértésével létrejött korábbi egyezségétől bírói engedéllyel eltekintve és az alól felmentve új egyezséget kötöttek a kérdéses leánynegyeddel kapcsolatos kereset dolgában, amelynek értelmében elégtétel gyanánt Domokos c., Byter fia: László és ezeknek fiai képviselőik révén nemcsak Balázs c.-nek, hanem valamennyi Leue c.-tôl származó rokonának és mindenki másnak is, aki igényt tart a mondott leánynegyedre, kötelesek azt átadni örök birtoklásra. Mivel pedig a birtokrész ismételt iktatásához a püspök embereinek kiküldésére van szükség, ezért a vikárius utasítja a címzetteket, hogy levele kézhezvételét követően aug. 27-én (in oct. fe. S. regis Stephani......venturis) a nevezett [felekkel] v. törvényes képviselőikkel ........ Brod birtokra menve a szomszédok összehívását követően járják be és becsüljék meg a 4 egyenlő részre osztott birtokot, majd a Ny-ra, Iuany birtok határának közelében fekvő, a másik 3 résztôl elválasztott negyednek, továbbá valamennyi haszonvételének és tartozékának a birtokába - a vikárius ezzel kapcsolatban kiállított és a helyszínen a felek által a címzettek jelenlétében bemutatandó másik oklevelének (l.359. szám) megfelelően — iktassák be Balázs c.-t és örököseit örök jogon, figyelmen kívül hagyva mindenki ellentmondását, minthogy a már régóta fennforgó perben Domokos és László fiain kívül senki más nem támasztott ellentmondást. Ha pedig valaki ezek után mégis jogigénnyel állna elő, akkor Balázs c.-szel és fiaival szemben szállhat perbe, de csak úgy, ha előbb megtéríti Balázs c.-nek a per során eszközölt kiadásait. Utasítja továbbá a címzetteket, hogy az iktatást, becslést és határjelek állítását követően a Lelez-i konvent és prépost levelében szept. 15-ig (ad oct. fe. Nat. B. virg. iam venturas) jelentsenek neki, ugyanakkor ót - mint bírájukat - a felek közösen kötelesek a békeváltság megfizetésével engesztelni. A fentiek teljesítésére interdictum és $3 \mathrm{M}$. bírság kilátásának terhe alatt kötelezi a címzetteket, akik menjenek és térjenek vissza lovon jelen oklevél vivőjének költségén. D. Agrie, in quind. dicti fe. Penth., a. d. 1356.

E.: Dl. 77 167. (Zichy cs. zsélyi lt. 218. B 61.) Papíron, a hajtások mentén erősen rongálódott, hátoldalán kerek pecsét nyoma.

K.: Z. III. 30-32. (18. szám).

R.: Bónis-Balogh (1212. szám); Erdélyi Okm. III. 306. (839. szám).

\section{1356. jún. 26. Eger}

Domokos, az erdélyi egyház prépostja, az egri egyház kanonokja, Miklós egri püspök lelkiekben általános vikáriusa tudatja, hogy egyik részről Brood-i $\sim$ Broud-i $\sim$ Brod-i István fia: Domokos c. és ennek fiai, Miklós és Gergely képviseletében a Lelez-i prépost és konvent ügyvédvalló levelében meghatalmazott Hubkahelmece-i Simon fia: Péter, s nemkülönben a Brood-i Byter fia: László és fia, Mihály nevében Vince papnak, a 
Kapus-i egyház rector-ának és Vngh-i alesp.-nek az ügyvédvalló levelével eljáró Zaploi István fia: Tamás, a másik részrôl pedig — az éppen Munkach királynéi faluban időző - György fia Balázs c.-nek a fia: István ugyancsak Vince pap ügyvédvalló levelében kapott felhatalmazással atyja nevében eljárva színe e. megjelentek és kinyilvánították, hogy jóllehet különféle vitás ügyek miatt, különös tekintettel pedig a néhai Leue c., egykori Broud-i nemes leányának - György hitvesének —, Erzsébetnek a leánynegyedére Balázs c. által Broud birtokból támasztott igény miatt, amely keresettel Balázs c. először a vikárius elődjének jelenlétében, majd utóbb Domokos vikárius színe e. állt elő, pereskedés és viszály támadt a felek között, végül azonban perükben békéltető fogott bírák közremúködésével egyezségre jutottak. Eszerint valamennyi, a szóban forgó leánynegyeddel kapcsolatos kereset ügyében kiállított korábbi oklevelük érvényét veszíti, ugyanakkor nevezett Domokos c., Byter fia: László és ezeknek fiai a leánynegyeddel kapcsolatos kereset teljes körü elrendezése érdekében a Bereg m.-ben a Latorcha — más néven Ztara - folyó mellett fekvő teljes Brod birtok negyedrészét Iuani birtoktól Ny-ra, annak határjelei mellett, valamennyi haszonvételével és tartozékával együtt — ti. szántóföldekkel, legelókkel, erdőkkel, ligetekkel, a Ztara folyón lévő halászó helyekkel, továbbá nyájak legelőivel és makkoltató erdőkkel a folyó mindkét partján nemcsak Balázs c.-nek, hanem vérrokonainak, Leue c. utódainak, akiket a természet jogán és az ország szokása szerint Brod birtokból leánynegyed illet — kivéve Domokosnak és Lászlónak a nôvéreit és lányait — a szóban forgó Simon fia: Péter és István fia: Tamás képviselői hatalommal felruházva a fent nevezett Domokos és László, valamint fiaik nevében a vikárius színe e. egy darabban átadják örök jogon és visszavonhatatlanul idegen jog sérelme nélkül. A maradék háromnegyed rész Domokos c.-nek, Lászlónak és fiaiknak a tulajdonában marad olyan feltétellel, hogy ha az idő múlásával más vérrokonok v. egyéb nemesek Brod birtok negyedén lévố részeiket egyszerúen elajándékozni v. eladni, esetleg elzálogosítani törekednének, ezt nem tehetik meg szabadon v. idegenek számára, hanem csakis Domokos c.-nek, Lászlónak, valamint ezek fiainak, ill. Balázs c.-nek és fiainak a részére, avagy mindezeknek a beleegyezésével; ha pedig maga Balázs c. és fiai akarnák elidegeníteni részeiket, idegennek ók se adhassák el azokat, hanem csak Domokos c.-nek, Byter fia: Lászlónak és ezek fiainak megfelelő értékükön. Balázs fia: István szavatosság vállalása mellett képviselői hatalmánál fogva apja nevében is nyugtatja Domokos c.-t és Lászlót, valamint fiaikat és örököseiket Brod birtok negyedrészéból a fenti feltételekkel kiadott leánynegyedre vonatkozó további követelésekkel kapcsolatban, kivéve Domokosnak, Lászlónak és fiaiknak a lányai részéról az ilyen természetú birtokszerzésre irányuló esetleges törekvéseket. A vikárius mindezek bizonyságára függőpecsétjével megerősített oklevelet bocsát ki, egyszersmind azt is megígéri a feleknek, hogy okiratának az egri kápt. elé történő elhozatala esetén a nagyobb biztosíték érdekében a kápt.-tól is kieszközli oklevél kiadását az ügyben. D. Agrie, in quind. dicti fe. Peth., a. d. 1356.

E.: Dl. 105 778. (Ilosvay cs.) Hártyán, hátoldalán késóbbi kéz írásával tárgymegjelölés, alján zöld-sárga sodraton Domokos vikárius pecsétje függ (rajta kiterjesztett szárnyú madár, feje körül dicsfény, csőrében írott szalag; a pecsét körirata: +S(IGILLVM) DOMINICI P(RE)POSITI TRANSILVA(NI) V(I)CARI AGRIE(N)SIS).

Á.: Opuliai László nádor, 1370. júl. 29. u. Dl. 97 852. (Ujhelyi cs.).

K.: - 
Konth Miklós nádor $(\mathrm{H})$, a kunok bírája e. egyik részról Anglyus Anglyuss nemes asszony, Harka-i Bertalan leánya, Miklós Papnyo-i ([?] abl.) polgár hitvese, hasonlóképpen a másik részrôl Harka-i István fiai: Nykus és Péter megjelenvén, kinyilvánítják, hogy jóllehet a király Anglyus asszonyt atyja, Bertalan részbirtokaiban, valamint Keőryn, Kiss Peti, Harka és Egered birtokaiban — királyi kegyből kifolyólag s hatalmánál fogva - fiúsította, mégis a békesség kedvéért arra a megegyezésre jutottak, hogy egymás között felosztják azokat a következőképpen: Anglyus asszonynak és örököseinek adják örök birtoklásra apjának, Bertalannak birtokrészeit Harka és Egered birtokokon, utóbbin annak a 10 ekealjnyi földnek és 10 kaszányi rétnek a kivételével, amelyeket Bertalan ősei és István fiainak ôsei Keőryn birtokhoz kapcsoltak. Bertalannak valamint fiainak bárhol máshol fekvő birtokait és birtokrészeit a szóban forgó István fiainak: Nykus-nak és Péternek, valamint örököseiknek juttatják valamennyi haszonvételükkel és tartozékukkal együtt olyan — mindkét fél által elfogadott — kikötéssel, hogy ha valamelyik fél az idők folyamán elállna az egyezségtől, akkor a szerződéshez hú másik féllel szemben párbajvesztes hatalmaskodóként ítéljék el (succubitu duelli facti potentialis convincatur). Erról a nádor D. in Csepregh, die domin. prox. p. fe. Corporis Christi, a. d. 1356.

Má.: 1. Dl. 87 318. (Esterházy cs. hercegi ága, Repositorium 17. Q 598.) 1758-i évi hiteles Má.-ban; 3-4. old.

2. Uo., mint Má. 1., azzal megegyező jelzet alatt.

K.: -

\section{1356. jún. 26. Visegrád}

[Zeech-i] Miklós c., [I.] Lajos király (H) országbírája, Turuch m. c.-e a Warada-i László fia: János mr.-nek Darouch-i István fia: Jánossal és annak fia: Lászlóval szemben indított ama perét, amely az országbíró korábbi oklevele (l. 134. szám) értelmében jún. 19-én (in oct. fe. Penth.) lett volna esedékes, és amelyben előbbinek a képviseletét a Lelez-i konvent ügyvédvalló levelében meghatalmazott András fia: Mihály látta el, István fia: János helyett pedig a Lelez-i konvent ügyvédvalló levelét felmutató, s a maga nevében is eljáró László jelentek meg a hatalmaskodással kapcsolatos peres ügyben, a felek akaratából nov. 18-ra (ad oct. fe. B. Martini conf.) elhalasztja a fennálló állapot fenntartásával. D. in Vysegra[d], 8. die termini prenotati, a. [d.] 1356.

E.: D1. 84 272. (Lónyay cs. lt.) Papíron, felső széle szakadozott, baloldalon vízfoltos, nehezen olvasható, hátoldalon azonos kéz írásával tárgymegjelölés, valamint kerek zárópecsét nyoma, bevágásai, írott szalagja; a pecséttel lezárt hátoldali részen keresztirányban korabeli jegyzet.

K.: -

362. 1356. jún. 27. Csepreg

Konth Miklós nádor $(\mathrm{H})$, a kunok bírája tudatván a vasvári egyház kápt.-jával a színe e. Altalkend-i Varda fia György fia: János részéról emelt panaszból szerzett azon értesülést, amely szerint Kueskuth-i Duska (dict.) Miklós jún. 26-án (die domin. prox. p. 
fe. Corporis Christi) rabló módjára érkezett Altalkend birtokára, ahol 3 jobbágyát megfosztotta ruháitól és megverte, minekutána utasítja a címzettet, hogy János fia: Lőrinc v. Walth-i Jakab fia: János v. Beud-i Mihály fia: Egyed v. ...... fia: Kozma v. Bogath-i András fia: István nádori emberek valamelyike mellé adjon tanút az ügy kivizsgálására, melynek eredményéról jelentést kér. D. in Cheperegh, f. II. prox. p. fe. Corporis Christi, a. eiusdem 1356.

Á.: A 369. számú oklevélben.

K.: Sörös P., TT. 31 (1908) 179-180. (23. szám).

\section{1356. jún. 28.}

1356. ind. 9., die 28. Jun.: [a velencei államtanács döntése értelmében,] mivel azok a tettek, melyeket meg kell tenni a magyar királlyal nagyok és terhesek, és ezek során számos meggondolandó dolog merül fel, ezeknek természetéból kifolyólag néhány személy megválasztása vált szükségessé, ezért úgy döntöttek, hogy 25 nagy tapasztalatú férfiút (sapientes) választanak, akik a dózséval (dominus), a tanácsosokkal és a polgárokkal a 40-ból (cum capitibus de XL) tanácsot alkotva a mondott ügyek mérlegelésével, megítélésével és a szükséges dolgok végrehajtásával kapcsolatban teljhatalommal lesznek felruházva; továbbá kötelességeikre, azok elmulasztása esetén rájuk kirótt büntetéseikre vonatkozólag ugyancsak rendelkeznek.

K.: Ljubić II. 326-327. (487. szám) Maius Consilium. Novella 44. alapján; Wenzel, Dipl. Eml. II. 473-474. (377. szám) a „Misti” velencei államkönyv alapján XXVII. 72.

364. 1356. jún. 29.

A győri egyház kápt.-ja e. Péter testvér, a pannonhalmi (de Sacro Monte Pannonie) Szt. Márton-monostor celerarius-a Szigfríd (Siffridus) apát és a teljes konvent nevében hatályos paranccsal és képviselettel felruházva - tiltakozásuknak hangot adva tudatja, hogy a minap Móric fia: Simon, győri és bakonyi c. elfoglalt egy, a monostor Vassyan birtokának határain belül fekvő nagy darab földet, és azt Cheztnek várhoz csatolta, továbbá a monostornak jelentős kárt okozva népeket gyưjtött ott össze egy falut alapítva, amit Chykator-nak nevezett el, és egy másik nevet - Dombotelek — is adott neki; ezáltal a monostor az azon a földön lakó emberektől és a szóban forgó várhoz csatoltaktól is folyamatos jogtalanságot szenved el. Ezért Péter testvér képviseltjei nevében a kápt. tanúságával nyilvánosan eltiltja Móric fia: Simon mr.-t a megjelölt föld elfoglalásától, a mondott várhoz való csatolásától és a falu odatelepítésétól. A tiltás bizonysága végett a kápt. oklevelet bocsát ki, ahogyan az ország törvénye megkívánja. D. in fe. ap. Petri et Pauli BB., a. d. 1356.

E.: BFL. Capsarium 3. T (433). (Df. 207 229.) Hártyán, hátoldalán későbbi kezek írásával tárgymegjelölés és jegyzet, valamint kerek rányomott pecsét nyoma, bevágásai.

K.: P. II. 426-427. (152. szám).

Megj.: Jó minőségű, digitalizált változatát 1.

http://www.mom-ca.uni-koeln.de/mom/HU-PBFL/PannHOSB/1356_VI_29/charter\#anchor?q=207229 
Péter prépost és a Lelez-i Szt. Kereszt-monostor konventje jelenti [I.] Lajos királynak (H): a jún. 11-én (l. 329. szám) kelt, itt átírt királyi parancslevelében foglaltak szerint Apaty-i Kapulch királyi ember társaságában Lukács (Lukasius) testvért küldték hites tanúul Bozza birtokra, akik onnan visszatérve jelentették, hogy jún. 20-án (II. f. prox. an. fe. Nat. S. Johannis Bapt.) az összehívott szomszédokkal bejárták a szóban forgó birtok határait. Hj.: a határ É-on kezdődik a Bodrug folyó mellett 2 (vlg.:) zylfa-nál, Ke felé kereszttel megjelölt tölgyfa, másik tölgyfa, alatta földjel, síkságon átvágva mező közepén álló nyárfa alatt földjel, Lyka nevú erdő, bal szélén 2 tölgyfa alatt 2 földjel, amelyek egyike Hozyeumezew birtok, a másik pedig Bozza birtok határát jelzi, Lyka erdóben tovább, közepén kereszttel jelölt tölgyfa, Lyka folyó partján tölgyfa alatt földjel, amely ugyancsak Bozza és Hozyeumezeu birtokokat választja el, É-on a Lyka folyó Bozza birtok határa, majd azt Ke felól Darnow-i Balázs birtokától határolja el, tovább a Lykapataka folyó medrén keresztül Dé felé, kiterjedt síkságon keresztül eléri Tusa birtok határát, tölgyfa a Lyka folyó partján, alatta földjel, ahonnan Ny felé keresztülvág egy réten, s egy patak-hoz (vlg.:) er-hez jut, a partján tövises szederbokor és vadalmafák, alattuk földjelek, továbbhalad az er-en keresztül Lyka erdóbe, közepén kereszttel jelölt tölgyfa, át az erdőn, balról zyl- és tölgyfák, alattuk földjelek, mező, szántóföldek, nagy út, azon keresztülvágva földjelhez jut, majd a mezőn át egy patak-hoz ér, azon túl földhatárjel, Ny felé .......ogrug erdóben eljut egy er-hez, azon keresztül a Bodrug folyóhoz, annak partján nyárfa alatt földjel, ami Bozza birtokot elválasztja Koch fiainak birtokától, É felé visszafordulva a Bodrug választja el Bozza birtokot Tusa birtoktól, s itt véget ér a határ. D. in fe. BB. Petri et Pauli ap., a. prenotato [1356].

E.: Dl. 77 168. (Zichy cs. zsélyi lt. Misc. 15.) Papíron, az oklevél bal fele hiányzik, hátoldalán azonos kéz írásával tárgymegjelölés, valamint zárópecsét rögzítésére utaló bevágások.

Á.: [I.] Lajos király, 1358. jún. 5. Dl. 77 227. (Zichy cs. zsélyi lt. 214. C 49.).

K.: Z. III. 115-117. (74. szám) (Á.-ról).

R.: Z. XII. 31. (29. szám).

\section{1356. jún. 30. Visegrád}

Zeech-i Miklós c., [I.] Lajos király (H) országbírája, [Turuch] m. c.-e [dátum nélkül] átírja saját, jan. 20-án kelt oklevelét (l. 45. szám) [azon, Porozlou birtok ügyében zajló perben, amelyben az országbíró Miklós pécsi püspökkel szemben máj. 1-jén esedékes oklevél-bemutatásra kötelezte Paztuh-i Domokos fia: Domokos mr.-t]. A[z oklevélbemutatásra] kijelölt időpontban [máj. 1-jén ([in] oct. fe. B. Georgii mart.)] az országbíró e. megjelent ura, Miklós pécsi püspök képviseletében az annak ügyvédvalló levelével maghatalmazott Péter mr. deák, kérve az okleveles bizonyítékok bemutatását, amelyre válaszul a Domokos mr. helyett az egri egyház kápt.-jának ügyvédvalló levelében kapott meghatalmazással eljáró Péter fia: János kijelentette, hogy ura sem bizonyítékokkal, sem okleveles megerősítéssel nem rendelkezik Porozlou birtok ügyében. Az országbíró az ország báróival és nemeseivel együtt — a püspök panaszára tekintettel elrendeli, hogy Domokos mr. személyesen tegyen esküt jún. 9-én (in. oct. fe. Asc. d. nunc venturis) az egri kápt.-ban arra vonatkozólag, hogy nem rendelkezik semmiféle bizonyító erejű oklevéllel Porozlou birtok ügyében. Az eskütételről a felek a kápt. okle- 
velében kötelesek az országbírónak jelenteni az esküt követő 8. napon (ad 8. diem dict. oct.), azaz jún. 16-án. A kitúzött időpontban (ipso oct. diei oct. prescripti fe. Asc. d.) a Domokos mr. képviseletét az egri kápt. ügyvédvalló levelével ellátó János fia: Péter bemutatta az országbíró színe e. az egri kápt.-nak az eskütételról írt jelentését ( $l$. 325. szám), amely többek között magában foglalta, hogy a kijelölt napon színük e. Domokos mr. Miklós pécsi püspökkel szemben megesküdött arra, hogy semmiféle bizonyítékkal és okleveles megerősítéssel nem rendelkezik a Hevesújvár m.-i, a Tisza (Tycie) folyó mellett fekvő Porozlow birtok ügyében. Miklós püspök famulus-a és officialis-a, Domokos c., urát képviselvén az esküt látta és hallotta. Az országbíró az ügy bizonyságára nyílt oklevelet ad ki e Domokos mr. részére. D. in Wissegrad, 15. die reportationis serie premissorum, a. d. 1356. E.: AL. Cluj. Cluj-Napoca (Kolozsvár). Erdélyi Múzeum Egyesület egykori lt. Bánffy
cs. nemzetségi lt. 59. (Df. 260 638.).

K.: -

Megj.: Vö. a 337. számú oklevéllel.

367. 1356. jún. 30.

Erney fia: Vythus bíró, András fia: Jakab, Máté fia: Tamás, János fia: Miklós és Pál fia: János a Pothok-i polgárok és hospes-ek közösségének esküdtjei (scabini sive jurati totaque cohors) e. egyik részról Jakab fia: Frank és Galos fia Demeter fia: János polgárok, a másikról pedig Péter fia: Bekch és veje, Péter fia: László Capos-ról megjelenvén, elóbbiek kinyilvánítják, hogy a Királyhegyen (in Monte Regis) lévő szőlejüket, amely a kóbánya hegyére vivő út alatt fekszik, alatta pedig egy másik út van, és amely É felől (a plaga venti superioris) Korch (dict.) Miklós és Cassa-i Albrehth szólei szomszédságában, ill. a város felól Mokwyanus fia Tamás fia: Miklós szólője mellett helyezkedik el, minthogy ezt a szólőt atyafiságukba tartozó rokonuk, Miklós v. más néven István fia: Kowsa Kousa végóráján azzal hagyta rájuk, hogy adják el, és lelki üdvéért tegyenek belőle az egyháznak felajánlást, ill. adományt, így most Kowsa valamennyi további rokonának és említett szomszédainak hozzájárulásával mindazon haszonvételekkel és tartozékokkal együtt, amelyekkel azt Kowsa és elődei korábban birtokolták, ellentmondás nélkül és szavatosságot vállalva eladják Bekch-nek és Lászlónak az általuk fizetett $60 \mathrm{M}$. garas ellenében. Az eladott szőlő egyik fele Bekch-et és örököseit, a másik fele pedig Lászlót és utódait illeti örök jogú birtoklásra. Mindezek bizonyságára a város hatósága pecsétjével megerősített oklevelet ad ki. D. f. V. prox. p. fe. Nat. S. Johannis Bapt., a. d. 1356.

E.: SNA. Leleszi konvent hh. 1t. Acta anni 1356. 43. (Df. 219 468.) Hátoldalán késóbbi kéz írásával tárgymegjelölés, kerek pecsét nyoma, bevágásai.

K.: -

\section{8. (1356.) júl. 1. Villanova közelében, avignoni egyházm.}

[VI.] Ince pápa [I.] Lajos királynak (H): már ezideig is ismertesek voltak a pápa e. a királynak azon tettei, melyeket az anyaszentegyház érdekében cselekedett elődei nyomdokain haladva. Bonjohannes, fermói püspök a napokban tért vissza a pápához és előadta a király kéréseit, amivel kapcsolatban a pápa támogatásáról biztosítja Lajost. Ezen felül arra kéri a királyt, hogy hitelt adva legátusa, La Caucina-i Arnold, krakkói scolasticus- 
t szavainak — akit már írásban részletesebben is tájékoztatott az ügyrôl — küldjön fegyveres segítséget az itáliai részekre, ahová azzal a céllal küldte az apostoli szék legátusát, Egyed testvért, sabinai püspököt (episcopus Sabinensis), hogy egyházának híveit, akiknek verejtékét és könnyeit az egyház ellen lázadók és a kárhozottak fiai nyaldossák, az elnyomó igából kiragadja. D. apud Villamnovam, Avinionensis diocesis, Kal. Jul., pápasága 4. évében [1356.].

K.: Theiner II. 20. (30. szám) (f. 118.-ra való hivatkozással); Gasnault-Gotteri 2224. szám (v. 238., f. 117-re való hivatkozással).

369. (1356.) júl. 2.

A vasvári kápt. jelenti [Konth Miklós] nádornak $(\mathrm{H})$, a kunok bírájának: megkapta a nádor jún. 27-én kelt s itt átírt parancslevelét (l. 362. szám), és az abban foglaltaknak megfelelően János fia: Lőrinc nádori emberrel kiküldte emberét, Péter mr. kanonokot, akik visszatérve egybehangzóan jelentették, hogy jún. 29-én (f. IV. prox. an. oct. predict. fe. Corporis Christi) Vasvár m.-i nemesek, nemtelenek és más jogállású emberek nyíltan és titokban történő kikérdezése révén megtudták, hogy Kueskuth-i Kemen fia: Duska (dict.) Miklós jún. 26-án (die domin. prox. p. fe. Corporis Christi) György fia: János Altalkend birtokára ment, és ott annak 3 jobbágyát bizonyos dolgaitól s ruháitól megfosztotta, majd meg is verte. D. 4. die inquisitionis.

E.: BFL. Guary cs. lt. 30. (Df. 257 290.) Teteje csonka, az íráshordozó több helyen szakadt, foltos. K. alapján pecséttel.

K.: Sörös P., TT. 31 (1908) 179-180. (23. szám).

370. 1356. júl. 3.

A Scepus-i Szt. Márton-egyház kápt.-ja tudtul adja: eleget téve a Tamás c.-nek, [I.] Lajos király $(\mathrm{H})$ országbírájának az egri kápt.-hoz intézett, tanú kiküldését szorgalmazó oklevelében foglaltaknak, amely okirat egyszersmind a Pál fia: Wychlow és Chana fia: Egyed felperesek által perbe vont Rycolphus mr. és annak fia, Péter prépost között fennforgó perben született bírói rendelkezéseket is tartalmazta, ezek értelmében a [Scepus-i] kápt. azon privilégiumát, amelyet Tamás c. vizsgálatra elküldve a maga országbírói pecsétje alatt lezárt oklevéltartóban (in quodam trapello) helyezett el, és az alperesek képviseletét ellátó Rycolphus fia: László mutatott be a [Scepus-i] kápt. színe e. az egri egyház kápt.-jának kiküldött tanúi, János mr. kanonok és György deák, nemkülönben pedig a Tamás c. levelében erre kijelölt királyi emberek, Sygra-i Péter fia: László és Machola-i Bálint jelenlétében, miután a [Scepus-i] kápt. az oklevéltartót kibontva abból kivette a nevezett privilégiumot, majd a maga levéltárában (conservatorium) elókereste, s megtalálta e privilégium eredeti példányát, azután elolvasta és alapos vizsgálattal összevetette az oklevéltartóból kivett iratot a megtalált eredetivel, s minthogy minden gyanútól mentesen hitelesnek találta azt, a megtalált példányból átírja és pecsétje alatt megerósíti szóban forgó saját, 1290. máj. 28-án kelt [— Tharcha birtok adományozása ügyében kibocsátott, IV. László királynak a szóban forgó kápt.-hoz intézett parancslevelét, ill. a kápt.-nak a birtok hj.-áról és Rycolphus c. fiai: Kokos és János számára történt iktatásáról számot adó jelentését is magában foglaló-] privilegiális oklevelét. Minderról a kápt. pecsétjével megerősített oklevelet ad ki. D. 3. die oct. fe. Nat. B. Joannis Bapt., a. d. 1356. 
Á.: I. Ferdinánd király, 1546. jún. 11. SNA. Szepesi kápt. hh.-i lt. Oklevelek Met. Sáros 3. 2. 1. (Df. 262 707.).

K.: -

Megj:: Az átíró oklevélben foglaltak szerint E.-je hártyára írott és a kápt. függőpecsétjével megerősített privilégium volt. Tamás országbíró említett ítéletlevele 1352. dec. 7-én kelt (Dl. 68 903.); az átírt okleveleket 1. Reg. Arp. 3480. szám és 3519. szám alatt.

371. 1356. (júl. 4. e. [?])

A velencei tanács béketárgyalások megindítása végett a raguzai Marino Goziot küldi követségbe I. Lajos királyhoz $(\mathrm{H})$.

R.: Óváry L., TT. 11 (1888) 456. (csak évre datálva).

372. (1356.) júl. 4. Villanova közelében, avignoni egyházm.

[VI.] Ince pápa kéri [I.] Lajos királyt (H), hogy higgyen a hozzá küldött Bonjohannes fermói püspöknek és hallgasson szavára, mellyel a király és vérrokonai, Durazzoi (de Duracius) Lajos és Róbert között - a Sátán ármánykodása folytán támadt - viszályt akarja elsimítani. D. apud Villamnovam, Avinionensis diocesis, IIII. Non. Jul., pápasága 4. évében [1356.].

K.: Theiner II. 21. (32. szám); Gasnault-Gotteri 2229. szám; Wenzel, Dipl. Eml. II. 474475. (378. szám) (tévesen IV. Non. Junii szerepel a dátumsorban) v. 238., f. 117.-re való hivatkozással.

373. (1356.) júl. 4. Villanova közelében, avignoni egyházm.

[VI.] Ince pápa [I.] Lajos királynak (H): a minap a király követe és levele (l. 315. szám) révén értesült azon törekvéséról, melynek célja az, hogy Rassia országát - elüzve a szakadárok sötétségét és szétárasztva a keresztény hit fényességét - elfoglalja, kérve a pápát, hogy segító jobbját kinyújtva parancsolja meg országában és más részeken is, hirdessen keresztes hadjáratot az ilyenkor szokásos búnbocsánattal, mely kérés hallatán örvendez a pápa és lelke dicséri az Urat, s abbéli reményét fejezi ki, hogy Lajos király sikerrel végezve fogadalmát, visszavezesse a sötétben tévelygőket az anyaszentegyház kebelére. Azonban az a hír járja, hogy ellenségeskedés támadt a király és a velenceiek dózséja között, s Lajos most hatalmának erejét egy keresztény ellen akarja fordítani. A pápa a széthúzás veszedelmének orvoslása céljából Bonjohannes fermói püspököt, ezen oklevél vivőjét küldi a királyhoz és a dózséhoz, s kéri a királyt, hogy fogadja ôt kegyesen és hallgasson a béke szavára. D. apud Villamnovam, Avinionensis diocesis, IIII. Non. Jul., pápasága 4. évében [1356.].

K.: Theiner II. 21-22. (33. szám) (f. 118.-ra való hivatkozással); Wenzel Dipl. Eml. II. 475-476. (379. szám); Gasnault-Gotteri (2230. szám) v. 238., f. 118-ra való hivatkozással.

R.: F. IX. 2. 502. (242. szám) (Raynaldusra való hivatkozással, latinul, csak évre keltezve). 


\section{4. (1356.) júl.4. Villanova közelében, avignoni egyházm.}

[VI.] Ince pápa utasítja Bonjohannes fermói püspököt, hogy a D, C, és Szlavónia részeinek tartományainak pátriárkái, érsekei, püspökei, választott [püspökei], apátjai, főpapjai, klerikusai és egyházi személyei számára mentesség, szabadság, kiváltság, adomány és egyéb ügyekben kiállított privilégiumok átírásait küldje el az apostoli székhez. D. apud Villamnovam, Avinionensis diocesis, III. Non. Jul., pápasága 4. évében [1356.].

K.: Theiner II. 20-21. (31. szám); Gasnault-Gotteri (2234. szám) v. 238., f. 120; v. 244 F, f. 120, ep. 299. alapján.

\section{5. (1356.) júl.4. Villanova közelében, avignoni egyházm.}

[VI.] Ince pápa Erzsébet királynénak (H): kéri, hogy Bonjohannes fermói püspököt, akit a [I.] Lajos király (H) és a velenceiek dózséja (dux) között támadt viszály elsimítására küld a királyhoz és a dózséhoz, a királynál hathatósan támogassa és segítse a béke helyreállításában. D. apud Villamnovam, Avinionensis diocesis, III. Non. Jul., pápasága 4. évében [1356.].

K.: Theiner II. 22. (34. szám); Gasnault-Gotteri (2231. szám) Mindkettő v. 238 f. 119-re való hivatkozással, valamint utóbbi v. 244 G f. 84, ep. 610. alapján.

R.: Áldásy 81. (221. szám) v. 244. G. n. 610. alapján.

376. (1356.) júl. 4. Villanova közelében, avignoni egyházm.

[VI.] Ince pápa a megelőző, a 375. számú oklevélben foglaltakkal egyező tartalmú levelet küld Erzsébet királynénak $(\mathrm{H})$ [I. Lajos király feleségének]. D. ut supra [apud Villamnovam, Avinionensis diocesis, III. Non. Jul., pápasága 4. évében [1356.]].

Megj.: Apparátusa megegyezik a 375. számú oklevélével.

\section{7. (1356.) júl.4. Villanova közelében, avignoni egyházm.}

[VI.] Ince pápa kéri Grandonicus Jánost, a velenceiek dózséját, hogy Bonjohannes fermói püspököt, akit a Lajos király $(\mathrm{H})$ és a velenceiek dózséja (dux) között támadt viszály elsimítására küld jó szívvel fogadja és fontolja meg intéseit. D. apud Villamnovam, Avinionensis diocesis, IIII. Non. Jul., pápasága 4. évében [1356.].

K.: Gasnault-Gotteri (2232. szám) v. 238., f. 119; v. 244 G, f. 66, ep. 562. alapján.

R.: Áldásy 39. (220. szám); Áldásy A., TT. 18 (1895) 81. (219. szám) v. 238. f. 119. alapján.

\section{8. (1356.) júl.4. Villanova közelében, avignoni egyházm.}

[VI.] Ince pápa az esztergomi érseknek: Bonjohannes fermói püspöknek a pápához intézett jelentéséból értesült arról, hogy amikor bizonyos dolgok elintézése végett azokra a részekre küldte a püspököt, az esztergomi érsek ezek elintézésének előremozdításában segítette, amit megköszönve a pápa kéri az érseket, hogy a mostanság ugyanazokra a 
részekre elküldött szóban forgó püspököt tájékoztassa és lehetőségeihez mérten támogassa a rábízott feladatok végrehajtásában. D. apud Villamnovam, Avinionensis diocesis, IIII. Non. Jul., pápasága 4. évében [1356.].

K.: Theiner II. 22. (35. szám); Gasnault-Gotteri (2236. szám) Mindkettő v. 238 f. 120-ra való hivatkozással; s utóbbi ezen felül v. 244 G f. 53, ep. 531. alapján.

\section{9. (1356.) júl.4. Villanova közelében, avignoni egyházm.}

[VI.] Ince pápa a megelőző oklevélben (l. 378. szám) foglaltakkal egyező tartalmú levelet küld ........testvér zágrábi, Miklós testvér pécsi és ....... testvér csanádi (Cenadiensis[!]) püspöknek. D. ut supra [apud Villamnovam, Avinionensis diocesis, IIII. Non. Jul., pápasága 4. évében [1356.]].

Megj:: Apparátusa megegyezik a 378. számú oklevélével.

\section{1356. júl. 4. Conegliano vára alatt}

I. Lajos király $(\mathrm{H})$ menedéklevele Marinode Gozio ragusai polgárnak, melyben engedélyezi, hogy elé engedjék nevezettet 5 társával és a velencei tanács valamely tagjával. D. sub castello Coneglianii 4. die mensis Jul., a. d. 1356.

R.: Óváry 48. (62. szám) (Velencei lt.-ra való hivatkozással); uô., TT. 11 (1888) 455.

381. 1356. júl. 4. Újlak

Miklós Machou-i bán s több más m. mellett Wolkou-i c. tudósítván a bácsi egyház kápt.ját a színe e. megjelent Zenthmihal-i Mihály fia: János panaszából szerzett azon értesüléséról, amely szerint Micola-i Péter fia: István Sumugh-i jobbágyai, nevezetesen Senk fia: Bálint és Hemeth fia: Pál, valamint Berzethe (dict.) Jánosnak a vajdája, Kysfaludi Péter vajda (voyvoda), nemkülönben pedig Pál fia: Benedeknek Terepeneye-ról való jobbágya, Gylkus (dict.) Mátyás a fiával együtt jún. 29-én (in fe. ap. Petri et Pauli BB. a. in presenti nunc preterito) felfegyverkezve és hatalmaskodva rátörtek a panaszos személyes lakóhelyéül is szolgáló Pachyntha birtokára, ill. ottani házára, és a saját otthonában akarták őt megölni, továbbá több sebet is okoztak 2 famulus-ának, nevezetesen Iuanka fia: Balázs Gabanyas-i nemesnek, valamint Mátyás fia: Istvánnak, amely elpanaszolt súlyos sérelmek és kártételek nyomán felszólítja a címzett kápt.-t, hogy állítson hites tanút Kelemen-i László fia: Benedek v. ugyaninnen való György fia: Péter v. Leue-i Dániel fia: Mátyás v Palagar-i Márton fia: János báni emberek valamelyike mellé az igazság kivizsgálásához, majd a vizsgálat eredményéról írásos jelentést kér. D. in Wylak, f. II. prox. p. fe. predictum, a. d. 1356.

Á.: A 393. számú oklevélben.

K.: - 
Az egri egyház kápt.-ja tudatja: miután megkapta [I.] Lajos király oklevelét (1.354. szám), az abban foglaltaknak megfelelően Fyzy-i Tamás fia: Jakab királyi ember társaságában kiküldte kanonokját, Sándor mr. Pata-i főesp.-t, hogy tanúbizonysága mellett a nevezett királyi ember bevezesse Akus mr.-t - Mich-nek, az egész Szlavónia néhai bánjának a fiát - egyrészt Sumugy birtokba, másrészt pedig az elmondások szerint Szepes m.-ben birtokolt Podolyn, Luchna és Ofalu falvakban kivetni szokott ama vámoknak (tributum) az uralmába, amelyeket a jelentések szerint a király, ill. a néhai Fülöp nádor nemes özvegyének adománya jutatott Akus mr. kezére. A kiküldöttek visszatérve jelentették, hogy jún. 25-én és 26-án (sabb. prox. p. fe. Nat. S. Johannis Bapt. et sequenti domin.) kimentek a szóban forgó birtokokra, ahol nem lévén ellentmondás, iktatták Akus mr. és örökösei részére összes haszonvételével, jövedelmével és hozamával együtt Sumugy birtokot és a szóban forgó 3 vámot örök birtoklásra, hozzátéve, hogy Akus mr. személyében a helyette megjelent famulus-át és officialis-át, Belse-i Chyhe fia: Péter c.-t vezették be Sumugy birtokba és a szóban forgó vámok uralmába. Ennek bizonyságául a kápt. autentikus, függốpecsétjével ellátott és az $\mathrm{ABC}$ betúivel chirogaphált oklevelet ad ki. László prépost, Imre olvasó-, György éneklő-, Miklós őrkanonok, András Zemlyn-i, Domonkos Bursua-i, Sándor Pata-i, Miklós Zabouch-i, Sándor Tharcha-i, László Borsod-i, Benedek Pankata-i főesp.-ek jelenlétében. D. f. II. prox. p. oct. fe. Nat. S. Johannis Bapt., a. d. 1356. [I.] Lajos lévén a király (H), Miklós az esztergomi érsek, a kalocsai szék üresedésben, és M[iklós] az egri püspök.

E.: Dl. 4622. (MKA. Acta eccl. ord. et mon. Vet. Buda 33. 21.) Hártyán, alján piros és sötét ibolyaszínú selyemsodraton az egri kápt. pecsétje függ, (rajta szárnyát kiterjesztő sas, mely karmaival IOANNES feliratú szalagot tart, feje - melyet dicsfénykoszorú övez - balra fordul; körirat: +S(IGILLUM) CAPIT(V)LI AGRIEN(SIS) ECCL(ES)IE POST PLAGAM) alul az ABC betúivel chirographálás.

K.: $\quad$ AO. VI. 485-486. (304. szám) (kihagyásokkal).

\section{1356. júl. 5. Visegrád}

László a csázmai egyház prépostja, [I.] Lajos király $(\mathrm{H})$ kápolnaispánja és titkos kancellárja e. egyik részről a feleségét, Raska-i Vyd leányát, Klára nemes asszonyt, valamint fiaikat: Jakabot, Pétert és Miklóst, továbbá leányukat: Annát képviselő Noghmyhal-i Jako fia: László mr., a másik részról pedig nevezett Raska-i Vyd fia: János megjelenvén, kinyilvánítják, hogy János a Zemlen m.-i Kochand birtokon levő teljes birtokrészét, valamennyi haszonvételével együtt szavatosság vállalása mellett elzálogosította Klárának és fent nevezett gyermekeinek az asszony leánynegyede fejében, amely őt a János kezén lévő valamennyi birtokrész és hozzájuk kapcsolódó jogosítvány után jogosan megilleti,, ezenfelül pedig azért a $20 \mathrm{ft}$.-ért, amelyet László mr. nevezett felesége és gyermekei nevében a prépost e. teljes egészében megfizetett. A felek rendelkezése szerint János a szóban forgó birtokot bármikor visszavásárolhatja ugyanezért a összegért, továbbá a még efölött fizetendő akkora pénz mennyiségéért, amennyire a János összes - a magyar, a szlavón és a horvát királyságok területén fekvő — birtokára a felek, ill. a szóban forgó nemes asszony v. a gyermekei által kivivendő királyi és kápt.-i v. konventi emberek a Klárát és gyermekeit jog szerint megillető leánynegyed értékét ítélik és becsülik. Abban az esetben viszont, ha János v. utódai nem tudnának eleget tenni a szavatosság vállalásnak, akkor az említett eljáró hatósági személyek tüstént újra felkeresvén a leány- 
negyed kiadásában megterhelendő valamennyi birtokot, ill. szemügyre véve az ottani, jövedelemforrásul szolgáló jogokat, ismét végezzék el a becsút, és állapítsák meg a leánynegyed értékét, amelyet - a szóban forgó 20 ft. megadása mellett — Jánosnak, ill. azon személyeknek kell megfizetniük, akikhez az érintett birtokrészek akkor erősebb jogosultság alapján éppen tartoznak. Minderról a prépost oklevelet ad ki, amelyet ama királyi pecséttel erősít meg, amely királyi kápolnaispáni tisztsége okán van használatában. D. in Wyssegrad, f. III. prox. p. fe. BB. Petri et Pauli ap., a. d. 1356.

E.: Dl. 85 313. (Sztáray cs. 1t. 99.) Hártyán, hátoldalán késóbbi kezek írásával tárgymegjelölések, rajta kék és vörös sodraton Lajos király kissé töredezett pecsétje (rajta hatos karámmal övezett alapon háromszögú pajzs; körirata: +S(IGILLVM) LODOVICI DE[I GRA]TIA [REG]IS [HVN]GARIE).

K.: Sztáray I. 251-253. (145. szám).

\section{1356. júl. 6. Sacile}

Az aquileai pátriárka tudatja a velencei dózséval, hogy IV. Károly császár akaratából I. Lajos királyt $(\mathrm{H})$ fogja segíteni a velencei köztársaság ellen. D. Sacili, die 6. mensis Jul., indict. 9. [1356.].

R.: Óváry 48. (63. szám) (Velencei lt.-ra való hivatkozással); uő., TT. 11 (1888) 455.

385. 1356. júl. 6.

A velencei tanács utasítja az I. Lajos királyhoz $(\mathrm{H})$ küldött 3 személyes követséget, hogy a rájuk bízott béketárgyalások megindítása során tudassák a királlyal: a signoria kész lemondani Záráról, valamint a meghódolt Da-i és szlavóniai részekról Mo. javára.

R.: Óváry 48. (64. szám) (Velencei lt.-ra való hivatkozással); uô., TT. 11 (1888) 455.

\section{6. (1356.) júl. 7. Villanova közelében, avignoni egyházmegye}

[VI.] Ince pápa Péter választott boszniai püspöknek: mivel korábban a pásztor nélkül maradt boszniai egyház irányítására Pétert jelölte ki apostoli hatalmánál fogva és Péter szerzetes testvéreinek tanácsára, ahogy ezt az arról kiállított oklevele (l. 96. szám) részletesebben tartalmazza, most Péter kérésének eleget téve, engedélyezi, hogy a felszentelés tisztségét 2 v. 3 - az Apostoli Szék kegyét élvező — püspöktól kaphassa meg. A püspök(ök) vegyen(ek) Pétertől húségesküt, olyan formában, ahogyan a pápai bulla alatt küldött levél tartalmazza, majd Péternek legyen rá gondja, hogy az eskü szövegét pecsétjével ellátott nyílt oklevélben követe révén elküldje a pápának, hogy ez által a kalocsai érseknek, akinek a szóban forgó egyház alá van vetve ne származzon semmi kára. D. apud Villanovam Avinionensis diocesis, Non. Iulii, pápasága 4. évében [1356.].

Reg.: ASV. Reg. Av. v. 132., f. 488r (Df. 289 517.).

K.: Theiner, Mon. Slav. I. 235-236. (318. szám) (Reg. alapján).

R.: Acta Bosnae 32. (179. szám); Áldásy 40. (224. szám); Áldásy A., TT. 18 (1895) 81. (224. szám) (Reg. alapján). 


\section{1356. júl. 8. Visegrád}

Zeech-i Miklós c., [I.] Lajos király (H) országbírája, Turuch m. c.-e a Miklós fiainak: Lorándnak és Berecknek Semyen-i István fia: Istvánnal szemben indított ama perét, amelyet az országbíró korábbi oklevele értelmében előzóleg már júl. 1-jére (in oct. fe. Nat. B. Johannis Bapt.) halasztottak, az István számára hozott királyi parancslevélben foglaltak szerint a királyi hadoszlás 15. napjára (ad quind. residentie exercitus regii) újra elhalasztja a fennálló állapot fenntartásával. D. in Vysegrad, 8. die termini prenotati, a. d. 1356.

E.: Dl. 51 711. (Kállay cs. lt. 1300. 1113.) Papíron, hátoldalán azonos kéz írásával tárgymegjelölés, késóbbi kézzel Kantor, valamint kerek zárópecsét töredéke, szalagja, bevágásai.

K.: -

R.: Kállay II. 36. (1187. szám).

\section{1356. júl. 9. [Ó-]Fehértó}

Cantor (dict.) Bereck mr. Zabolch-i alispán és a m. szb.-ái tudtul adják, hogy fogott bírák közremúködésével megegyezés született az egyik részről Kallou-i Iwan fia: Demeter, a másik részról pedig Semien-i Lengel (dict.) János fia: László mr. között fennforgó, a nevezettek peres viszálykodásából eredő ama perben, amely Demeter képviselójének (procurator), András [serviens-nek] az elfogatása miatt támadt közöttük. A felek elállnak a per folytatásától, ugyanakkor a hatóságnak a megegyezéshez való hozzájárulásáért járó váltság megfizetését kétharmad részben László, egyharmad részben pedig Demeter vállalta magára. Mindez azzal a kikötéssel egészül ki, hogy azt a felet, amelyik az ügyet újra bíróság elé viszi, patvarkodásban ítéljék el. D. in Feyrtho, sab. prox. an. Margarete virg., a. d.1356.

E.: Dl. 51712 (Kállay cs. lt. 1300. 1131.) Papíron, hátoldalán azonos kéz írásával tárgymegjelölés, valamint 3 zárópecsét töredéke, bevágásai.

K.: -

R.: Kállay II. 37. (1188. szám); Piti F., Szabolcs m. 133. (517. szám).

Megj.: A [ ]-ben közölt kiegészítés a hátlapról származik.

\section{1356. júl. 10. Visegrád}

Zeech-i Miklós c., [I.] Lajos király (H) országbírája, Turuch m. c.-e ez egri egyház kápt.jának: a bírói rendelkezéseit tartalmazó korábbi levelében foglaltak szerint a királyi emberként Batur-i Bereck fia: Miklós mr. és ue. Bereck fia: Leukus fia: Péter mr. oldalán eljáró Mark-i Egyed fia: Erne-nek, s hasonlóképpen az alperes Benedek fia: Pouch oldalán szintén királyi emberként közremúködő Tordas-i Miklósnak az egri kápt. tanúbizonysága mellett az összehívott szomszédok és határbirtokosok, valamint a felek, ill. képviselőik jelenlétében [1356.] jún. 19-én (in oct. fe. Penthecoste prox. preteritas) fel kellett keresniük Abraam $\sim$ Abram birtokot, s ott a néhai Miklós nádornak a helyszínen Pouch részérôl bemutatandó, bírói határozatát tartalmazó privilegiális oklevele alapján el kellett végezniük egy olyan birtokrésznek a hj.-át, amelyet birtokosztályuk során a 
fentebb nevezett Miklós és Péter mr.-ek, valamint további fr.-eik jutattak Pouch kezére, s a hj. eredményeképpen az eljáró személyek azt is elfogulatlanul kideríteni tartoztak, hogy az a hely, ahonnan Pouch fákat vágatott, ill. gyökerestôl irtatott ki, Abraam birtok közös területét képezi, a fák pedig Miklós és Péter mr.-ek gyümölcstermő fái voltak-e, miként azt ók állították, avagy egy olyan berekról van szó, amely a Miklós nádor említett privilégiuma értelmében beleesik a Pouch-nak jutó földdarab telki helyekül (locus sessionalis) szolgáló részébe, s ő a berket csak a jobbágytelkek megnövelése és bővítése érdekében irtatta ki, ahogyan arról a már hivatkozott országbírói oklevelében részletesebben is szó esik, majd ha mindezen teendőkkel végeztek, az eljárás ereményérôl júl. 1-jére (ad oct. fe. Nat. B. Johannis Bapt.) kellett a királynak írásos jelentésben számot adni. A kitűzött időpontban az egyik részről Bereck fia: Miklós mr. személyesen, mellette Péter mr. nevében pedig a Lelez-i konvent ügyvédvalló levelében meghatalmazott Pelis-i András, míg a másik részról maga Pouch járult az országbíró színe elé, és bemutatták a királynak írt egri kápt.-i jelentést, amely többek között azt tartalmazta, hogy nevezett kápt. a fentiek kivizsgálásához Mark-i Egyed és Tordas-i Miklós királyi emberek mellé részint Tamás presbitert adta tanúul a felperesek, Bereck fia: Miklós és Leukus fia: Péter mr.-ek oldalára, részint pedig Miklós mr. deákot, ........ aljegyzőjét (subnotarius) az alperes, Benedek fia: Pouch oldalán, visszatérésükkor pedig a királyi emberek azt jelentették, hogy jún. 19-én (in oct. fe. Penth.) Abraam birtokra mentek, és jóllehet a felek készek voltak arra, hogy a birtokon a királyi emberekkel együtt az országbíró ítéletlevelében, valamint a néhai Miklós nádornak a helyszínen Pouch által bemutatott privilégiumában foglaltak szerint mindenben eleget tegyenek eljárási kötelezettségeiknek, de a királyi hadjárat megindulása miatt Leukus fia: Péter mr., Bereck fia János fiai: László és György, nemkülönben Abraam birtok amúgy is érdektelen szomszédainak és határbirtokosainak a távolmaradása következtében - akik a királyi hadjáratban vettek részt — nem tudtak kielégítően eljárni a hj., a helyszíni szemle, valamint a liget, ill. gyümölcsfák szemügyre vételének teendőiben, hanem kénytelenek voltak dolguk végezetlenül visszatérni. A jelentés bemutatását követően a felek az országbírót kérték az ügy lezárására, aki viszont arra való tekintettel, hogy a jelentés szerint az ott felsorolt érintettek távolléte miatt nem volt lebonyolítható az eljárás, ezért ismételten kéri az egri kápt.-t, hogy adjon hites tanúkat mindkét fél oldalára, így a felperesek, Miklós és Péter mr.-ek mellett királyi emberként közremúködő Kudey-i Pál v. Mogh-i Miklós fia: Péter v. Bagach-i Miklós fia: Mihály v. Mark-i Erne fia: Egyed valamelyike mellé, s hasonlóképpen az alperes Pouch oldalán eljáró Chaba-i Deseu fia: Jakab v. Tordas-i Miklós v. Tamás fia: Gergely v. Adorján fia: István királyi emberek valamelyike mellé is, akik nov. 7-én (in oct. fe. OO. SS.) Abraam birtokra menve Miklós nádor privilégiumának a Pouch általi bemutatását követően járjának el mindenben úgy, ahogyan a fent említett országbírói oklevél eredetileg leírta azt, majd a történtekról jelentsenek a királynak a királyi hadoszlás 15. napjára. D. in Vissegrad, 10. die termini prenotati, a. d. 1356. Hozzáfúzi: a feleknek engedélyt adott a békés megegyezésre a bírót illető békeváltság megfizetésének terhe mellett. D. ut supra.

E.: Dl. 30 663. (Gyulafehérvári kápt. o. 1t. Miscellanea 3. 4. 6.). Papíron, hajtásvonalak mentén foltokban kissé szakadozott, máshol vízfoltos, hátoldalán azonos és késóbbi kezek írásával tárgymegjelölés, valamint kerek zárópecsét nyoma, bevágásai.

Má.: Uo., mint E., azzal megegyező jelzet alatt; 18. sz.-i. hiteles Má.-ban.

K.: AO. VI. 487-490. (306. szám) (kihagyásokkal).

Megj.: Miklós nádor említett privilégiuma 1355. jún. 19-én kelt, 1. Dl. 4526. (NRA. 841. 
17.); AO. VI. 326-335. (208. szám).

\section{1356. júl. 10. Visegrád}

Zee[ch]-i Miklós c., [I.] Lajos király (H) [országbírája] és Thuruch m. c.-e tudatván a szepesi egyház kápt.-jával Torkw-i Rykolphus fia: Jakabnak fivérei (fr.) János, László, Kelemen, Lőrinc, Miklós, Rykolphus és Henrik mr.-ek nevében is eléje terjesztett panaszából szerzett azon értesülését, amely szerint a Hennenkfolua-i királyi népek v. jobbágyok (populi vel jobagiones) a panaszosok törvényes tiltása ellenére Sarus vár (castrum) javainak cseréje hallatán márc. 31-én (f. V. prox. p. fe. Ann. virg. glor.) Veresalma nevú birtokuknak szántóföldjeit hatalmaskodva felszántották, kiszántották őszi vetésüket, majd saját vetőmagjukat vetették el, ezzel nagy kárt és veszteséget okozva a panasztevőknek, amivel kapcsolatban utasítja a címzettet, hogy küldjön hites tanút Sigre-i [?] Péter fia: László v. Janusfolua-i Lőrinc fia: Pál v. Elsouicha-i Mihály fia: János királyi emberek valamelyike mellé az ügy kivizsgálására, majd ennek eredményéról írjanak mindenre kiterjedő jelentést a királynak. D. in Vyssegrad, f. VI. prox. an. fe. Penth., a. d. 1356.

Á.: A 414. számú oklevélben.

K.: -

391. 1356. júl. 10. Déva

András erdélyi vajda és Zonuk-i c. tudatván az erdélyi egyház kápt.-jával Geubul fia: Jakab c.-nek eléje terjesztett panaszából szerzett azon értesülést, amely szerint jún. 19én (in fe. S. Trinitatis) Kyzd, Erkud és Radus [falvakból], nemkülönben a Keerch-i apát 3, nevezetesen Kereztur, Mesche és Zenthmiclosteleke falujából valamennyi ott lakó szász (universi saxones) előre megfontolt gonosz szándéktól vezérelve fegyveresen támadt a panaszos Haasfalua Haasfalu birtokára, ahol házait felégette, javait elrabolta, továbbá feleségét 3 leányával együtt meg nem engedhető szavakkal illette és meg akarta ölni, ôk azonban a templomba menekültek elólük, amelynek kapuit betörve a támadók minden ingó és ingatlan (mobiles et immobiles) dolgot magukkal vittek, de ezzel nem elégedtek meg, hanem rátámadtak Saard birtokára is, a templom kapuját ott is betörték és házából minden dolgot és értékes tárgyat (universas res et alia clenodia) elraboltak, mintegy 100 M. kárt okoztak; éppúgy jún. 21-én (f. III. prox. p. dict. fe. S. Trinitatis) Boda faluba érkezve a templomot felforgatták, a levéltárának (conservatorium eiusdem ecclesie) ajtaját betörték és valamennyi, a birtokaikkal kapcsolatos okiratot (instrumenta et literarum munimenta) magukkal vittek, amivel kapcsolatban a vajda utasítja a kápt.-t, hogy adjon hites tanút Herpey-i Bálint v. Tunughy-i András fia: Pál v. Saard-i (dict.) Domokos fia: Miklós vajdai ember mellé a panasz kivizsgálására, majd ennek eredményét jelentsék számára írásban. D. in Dewa, die domin. prox. an. fe. B. Margarethe virg. et mart., a. d. 1356.

E.: Dl. 29 429. (Gyulafehérvári kápt. o. lt., Cista com. Doboka 1. 6.) Papíron, hátoldalán azonos kéz írásával címzés, valamint késóbbi kéz írásával tárgymegjelölés, továbbá kerek zárópecsét nyoma, szalagja, bevágásai.

Facs.: Doc. Rom. Hist. C. XI. 649.

K.: AO. VI. 486-487. (305. szám) (kihagyásokkal); ZW. II. 121-122. (704. szám); Doc. Rom. Hist. C. XI. 25-27. (25. szám) (román fordításban is). 
R.: Erdélyi Okm. III. 306. (840. szám).

\section{1356. júl. 10. Visegrád}

László, a csázmai egyház prépostja, [I.] Lajos király (H) kápolnaispánja és titkos kancellárja e. Butka-i Pál fiai: István és János kinyilvánítják, hogy azon unokatestvéri kapcsolatra tekintettel (ratio patruelis fraternitatis), amellyel Butka-i Miklós fia: Miklóshoz kötődnek, bizonyos dolgok ellenében (pro rebus) visszavásárolták nevezett Miklósnak a Zemplén m.-i Butka-n lévő birtokrészét valamennyi haszonvételével és tartozékával együtt Chahul-i Nagy Jánostól, a szóban forgó Miklós ellenfelétől, akivel szemben ôt a néhai Miklós nádor hatalmaskodásban marasztalta el. A visszavásárolt részt Miklós fia: Miklósnak és az ő fiának, Jakabnak és örököseiknek adják vissza, mivel az őket illeti, maguknak és utódaiknak semmiféle jogot nem tartanak fenn. D. in Vissegrad, die domin. prox. an. fe. B. Margarete virg. et mart., a. d. 1356.

E.: D1. 66 809. (Dessewffy cs. margonyai lt. 29.) Hártyán, hátoldalán kerek rányomott pecsét nyoma, bevágásai.

Tá.: Bebek István országbíró, 1366. okt. 17. Dl. 66 822. (Dessewffy cs. margonyai lt. 41.).

K.: -

393. 1356. júl. 10.

A bácsi egyház kápt.-ja jelenti Miklós Machou-i bánnak, hogy a júl. 4-én kelt és itt átírt oklevelében (l. 381. szám) foglaltaknak eleget téve tanúul adták Palagar-i Márton fia: János báni ember mellé János karpapot (clericum chori) a kért vizsgálat lebonyolítására, akik visszatérve egybehangzó jelentést tettek. Eszerint júl. 7-én (f. V. prox. p. oct. BB. Petri et Pauli ap.) Wolkou m.-ben az értesüléssel rendelkezók körében vizsgálatot folytattak, amelynek eredménye szerint Mycola-i Péter fia: Istvánnak a jobbágyai, nevezetesen a Somogy falubeli Senk fia: Bálint és Henych fia: Pál, valamint a Berzethe (dict) Jánoshoz tartozó (pertinens ad Johannem dictum Berzethe) Kysfolud-i Péter vajda (voyvoda), továbbá Terpene-i Pál fia: Benedek mr.-nek a jobbágya, Gyolkus (dict.) Mátyás a fiával együtt fegyveresen rátörtek szentmihályi (de S. Michaele) Mihály fia: János Pachyntha birtokára, valamint ott lévő házára - ahol János lakóhelye (residentia) is van —, s ott Jánost meg akarták ölni, 2 serviens-ét pedig, ti. Iuanka fia: Balázs Gabanyas-i nemest és Mátyás fia: Istvánt életveszélyesen megsebesítették, anélkül, hogy azok bármivel is rászolgáltak volna erre. D. in die domin. prox. an. fe. B. Margarethe virg. et mart., a. d. supradicto [1356.].

E.: D1. 91 486. (Festetics cs. lt. Valkó 28.) Papíron, hátoldalán azonos kéz írásával tárgymegjelölés és a bácsi kápt. mandorla alakú zárópecsétjének töredéke, (rajta kivehetô [Szt. Pál] köpenyt viselő, szakállas alakja, feje glóriával övezve, jobb kezében pallost tart, mely jobb vállának támaszkodik, a pecsét körirata: + S(IGILLVM) MEMORIALE [CA]PTIV[L]I B[A]CHIENSIS), szalagja, bevágásai.

K.: - 
Domokos erdélyi alvajda felszólítja az erdélyi egyház kápt.-ját, hogy keressék elő és privilégiális formában írják át a sekrestyéjükben v. levéltárukban őrzött másodpéldányait azoknak az okleveleknek (instrumentorum suorum alia paria in sacristia seu conservatorio ecclesie vestre), amelyek Scuchak-i Miklós fia: András állítását alátámasztva igazolják, hogy vétel jogcímén az ő tulajdonát képezi Felső- (Superior) Machkas birtok, ahol Szt. Márton vértanú tiszteletére építtett kőegyház áll, mivel az ezt bizonyító oklevelek nemrégiben tûz martalékává váltak. D. in S. Emerico, in fe. B. Benedicti conf., a. d. 1356.

Á.: A 398. számú oklevélben. > András erdélyi vajda, 1358. febr. 2. > kolozsmonostori konvent, 1358. ápr. 8. Dl. 26 752. (Kolozsmonostori konvent o. 1t. Cista com. Kolos B 106.)

Má.: ugyanott, Á.-val megegyező jelzet alatt (1839.).

K.: AO. VII. 144. (78. szám); Doc. Rom. Hist. C. XI. 27-28. (26. szám) (román fordításban is) mindkettô Á. alapján; júl. 11-re keltezve.

R.: Erdélyi Okm. III. 306. (841. szám) 1356. júl. 11. dátummal.

Megj.: K. szerint az oklevél nem Benedek vértanú, hanem Benedek apát translatiojának napján, azaz júl. 11-én kelt, mivel az erdélyi kápt. júl. 15-én állította ki a szóban forgó privilégiumot.

\section{1356. júl. 11. Gömör falu}

Kemen fia: János mr., Konya mr. alispánja és Gömör m. szb-ái Scarus-i Miklós fia: László kérésére pecsétjükkel küldték ki emberüket, Sarncfalua-i Pál fia: Jánost vizsgálat elvégzésére, aki visszatérve jelentette, hogy júl. 11-én (f. III. fe. translationis S. Benedicti abb.) a Strasafolde $\sim$ Strasafelde és Darnomelleke $\sim$ Dornomelleke birtokokkal szomszédos és határos falvakba menve vizsgálatot tartott az értesüléssel rendelkezők körében. Ennek eredményeként megtudta, hogy Deresk-i Bebek (dict.) István és György mr.-ek az ő Deresk-i officialis-uk, népeik és jobbágyaik révén a szóban forgó László Strasafelde és Dornomelleke birtokainak haszonvételeit törvényes tiltása ellenére magukhoz vonták. D. in villa Gumur, f. II. prox. an. fe. Margarete virg. et mart., a. d. 1356.

E.: SNA. Szepesi kápt. hh.-i lt. Oklevelek 11. 1. 10. (Df. 263 317.) Papíron, 3 zárópecsét nyomával, bevágásaival.

K.: -

Megj.: Vö. a 412. számú oklevéllel.

396. 1356. júl. 14.

Tamás fia: István mr., Haram-i várnagy és Karasso m.-i c., valamint a m. szb.-áinak ülésén (in sede nostra) júl. 14-én (f. V. prox. an. fe. Divisionum ap.) a nemesek közül szólásra emelkedve János fia: Péter urai, Pousa mr. fiai nevében — azok törvényes képviselőjeként - eltiltott mindenkit, így a szomszédokat és határosokat is attól, hogy urai birtokainak haszonvételét és jövedelmét elbitorolják, különös tekintettel Kukaeghazaz és Péterfalva (homines ... Petri ville) falvak lakóira. D. die et loco prenotato, a. d. 1356. 
E.: Dl. 91 487. (Festetics cs. lt. Krassó 32.) Papíron, hátoldalán azonos kéz írásával tárgymegjelölés, valamint 3 zárópecsét töredéke, bevágásai, szalagja.

K.: -

\section{1356. júl. 15. Visegrád}

László a csázmai egyház prépostja, [I.] Lajos király (H) kápolnaispánja és titkos kancellárja e. a Zemplén m.-i Noghmyhal-i Jako fia László fia: Jánosnak az özvegye, Mezeulaki László leánya, Ilona (Elena) nemes asszony kinyilvánítja, hogy őt az ország joga és szokása szerint néhai férje valamennyi birtokából és birtokrészéből megilletô hozomány és jegyajándék teljes kielégítéseképpen Jako fia: László budai számítással értett, készpénzben, ft.-okban lerótt 50 M.-át fizetett neki (50 marcas compoti Budensis cum promptis florenis), amivel kapcsolatban Ilona nyugtatja Lászlót és utódait, mentesítést adva számukra minden további követeléssel szemben. Minderról a prépost oklevelet ad ki, amelyet ama királyi pecséttel erősít meg, amely királyi kápolnaispáni tisztsége okán van használatában. D. in Wyssegrad, in fe. Divisionis ap., a. d. 1356.

E.: Dl. 85 314. (Sztáray cs. 1t. 100.) Hártyán, aljára vörös-kék sodraton pecsét van erősítve, hátlapján későbbi kéz írásával tárgymegjelölés.

K.: Sztáray I. 253. (146. szám).

398. 1356. júl. 15.

Az erdélyi egyház kápt.-ja eleget téve a Domokos, erdélyi alvajda júl. 11-én kelt — itt átírt — oklevelében (l.394. szám) foglaltaknak, egyháza levéltárából (in conservatorium) előkeresvén kért saját, 1313. ápr. 27-i keletű, [egy a Clus m.-i Felső- (Superior) Machkas birtokban fekvő birtokrész felének elajándékozása tárgyában kibocsátott] privilégiumát (l. Anjou-oklt. III. 492. szám), privilegiálisan átírja és függőpecsétjével megerősíti azt. D. in fe. Divisionis ap., a. d. 1356. Domokos lévén a prépost és a választott [erdélyi püspök], Lóránd az őrkanonok, Miklós a Clus-i főesp.

Á.: András erdélyi vajda, 1358. febr. 2. > kolozsmonostori konvent, 1358. ápr. 8. Dl. 26 752. (Kolozsmonostori konvent o. 1t. Cista com. Kolos B 106.).

Má.: Á-val azonos jelzet alatt; 1839. aug. 12-i egyszerú Má.-ban.

K.: AO. VII. 144-145. (78. szám); Doc. Rom. Hist. C. XI. 28-29. (27. szám) (román fordításban is) mindkettő Á.-ról.

R.: Erdélyi Okm. III. 306-307. (842. szám).

Megj.: Az átírt 1313. évi oklevél [ ] között megadott tárgyát az átíró oklevél keretszövege nem jeköli meg közvetlenül.

399. 1356. júl. 16. Buda

Konth Miklós nádor $(\mathrm{H})$, a kunok bírája függőpecsétjével megerősített oklevelet bocsát ki annak a közte és utódai, valamint a veszprémi kápt. között létrejött ügyletnek a bizonyságára, amelynek értelmében a szóban forgó kápt. engedve az ő kérésének alapos 
megfontolás után, s uruknak, János veszprémi püspöknek az egyetértését és hozzájárulását is megszerezve évi 6 pensa járandóság, ill. census (pro debito et censu annualis) fejében bérbe adta neki és örököseinek azt a Veszprém m.-i Lowos predium-on fekvő, a [székes-]fehérvári kápt. ugyancsak Lowos nevú, v. másképpen Tykolylese és Ews névvel illetett birtokai közé ékelődő, s É-ra az ô [ti. a nádor] Zynil birtokával érintkezô részbirtokát, tételesen 1 ekealja földet, 6 kamarási telket (6 cubiculariorum sessio), 1 malomhelyet és más egyebeket, amelyeket a falusiakkal közösen használnak (alia cum villanis comuniter in se habentem), és amelyeket a nevezett predium-on a kápt. [I.] Szt. László király kiváltságlevelének erejével birtokol valamennyi tartozékával együtt. A bérlet örök időre szól olyan megkötéssel, hogy ha a nádort v. örököseit a birtoknak és haszonvételeinek tulajdonában bárki perben támadná meg, akkor a kápt. az említett kiváltságlevél felmutatásával köteles őket megvédeni abban; a nádor v. utódai pedig az évenkénti 6 pensa-t az 1357. évtől kezdődően minden évben nov. 18-án (in oct. fe. B. Martini conf.) tartozik a kápt.-nak megfizetni, amiről az igazoló levelet köteles kiállítani. Ha egy évben a 6 pensa bérleti díjat nem fizetik meg, büntetésképpen kétszeresét kell teljesíteni, ha pedig egy rákövetkezố második évben nem egyenlítik ki a bérleti díjat, ugyancsak kétszeres összeg megfizetésével tartoznak, ám ha már az azutáni harmadik évben sem fizetnek, akkor kötelesek békésen visszaadni a kápt.-nak a bérelt földdarabot minden tartozékával és építményeivel együtt. D. Bude 2. die fe. Divisionis ap., a. d. 1356.

E.: Veszprémi székeskápt. mlt. Oklevelek, Lovas in Veszpr. 3. (Df. 200 936.) Hártyán, alján függőpecsét rögzítésére utaló bevágások, hátoldalán késóbbi kézzel tárgymegjelölés.

K.: -

R.: Veszp. Reg. 189. (472. szám).

Megj.: I. László király említett [1082. ápr. 29-i keltezésú] — hamis — oklevelét 1. Reg. Arp. 21. szám és DHA. I. 228-240. (81. szám) alatt, utóbbinál Kont Miklós ezen oklevele: 231.1 .

400. (1356.) júl.17. Villanova közelében, avignoni egyházm.

[VI.] Ince pápa megparancsolja ....... [Miklós] testvér aquileai pátriárkának és a salzburgi érseknek, hogy támogatván [I.] Lajos királyt $(\mathrm{H})$ azon nemes tervében, hogy Szerbia országából fegyverrel ûzi és törli el az eretnekeket, legyen gondjuk rá, hogy senki, aki hatalmuk alá tartozik ne tehessen a király szándékát akadályozót közvetlen v. közvetve támogatva - akár ténylegesen, akár tanácsokkal — az eretnekeket vízen v. szárazföldön.

K.: Theiner II. 22-23. (36. szám); Gasnault-Gotteri (2272. szám) Mindkettő v. 238 f. 152re való hivatkozással.

R.: Áldásy 41. (228. szám); Áldásy A., TT. 18 (1895) 82. (228. szám) v. 238 f. 152-re való hivatkozással.

\section{1. (1356.) júl. 17. Villanova közelében, avignoni egyházmegye}

[VI.] Ince pápa Gradonicus Jánosnak, a velenceiek dózséjának: a pápa tudomásárajutott, hogy a dózse és a velenceiek Istennek és a keresztény hívek ellenségével, a szerb királlyal és más szakadár szerb eretnekekkel léptek esküvel megerôsített szövetségre. 
A pápa óva inti a címzettet attól, hogy ezt a szövetséget fenntartsa, s hogy bármiféle segítséget nyújtson az eretnekeknek [I.] Lajos királlyal (H) szemben, aki a szerbiai eretnekség ellen küzd. D. apud Villanovam Avinionensis diocesis, XVI. Kal. Aug., pápasága 4. évében [1356.].

K.: Wenzel, Dipl. Eml. II. 478-479. (382. szám); (Ljubić II. 327-328 (489. szám) (Commemorialiam V. 79. ep. 169-re való hivatkozással); Theiner, II. 23. (37. szám); GasnaultGotteri (2273. szám) v. 238., f. 153.-ra való hivatkozással.

\section{1356. júl. 18. Visegrád}

[I.] Lajos király (H) tudatván az egri egyház káp.-jával a Capulna-i Nagy (Magnus) Lőrinc nevében panaszt tevő András fia: Miklóstól származó azon értesülését, amely szerint Treztenie-i Baynok (dict.) Miklós fiai: Dénes és János, Matha fia: Miklós famulus, valamint Domolaz-i Tekus fia: Jánosnak az officialis-a, Zeuld (dict.) Simon jún. 26-án (die domin. prox. an. fe. B. Ladislai regis et conf.) hatalmaskodva rátörtek nevezett Lőrinc Capulna birtokára, ahol a panaszt tevő Miklós talált 2 marhát ura, Lőrinc erdejében, ahonnan Lőrinc falunagyának, Miklósnak az udvarába (curia) hajtotta és bezárta azokat, azonban a felsorolt hatalmaskodók betörték Miklós falunagy udvarának (curia) kapuját, és elhajtották a jószágokat onnan, minekutána utasítja a kápt.-t, hogy adjon hites tanút Tornahaza-i Hodos fia: Miklós v. Nylas-i Boxa fia: Bálint v. Balaht-i László fia: János királyi emberek valamelyike mellé a panasz kivizsgálására és az igazság kiderítésére, s ezt követően a történtekról számot adó írásos jelentést kér. D. in Wisegrad, f. II. prox. p. fe. Divisionis ap., a. d. 1356.

Á.: A 491. számú oklevélben.

K.: -

\section{1356. júl. 18. (?) Győr}

Simon mr. győri c. tanúállításra kéri a győri egyház kápt.-ját kiküldöttje, Chakvar-i Balázs mellé annak a panasznak a kivizsgálásához, amelyet a Beel-i Szt. Móric- monostor apátja, Péter terjesztett elé azzal, hogy Zeredahel-i falusiak (villani) és a Sambuk-i prépost jobbágyai júl. 18-án (f. II. sc. in fe. S. Alexii conf.) hatalmaskodva rontottak rá egyházának Kayar birtokára, és Zezcuth kaszálóról 30 kocsira való szénát Zeredahel-re vittek, valamint serviens-ét, Alap-i Benedek fia: Miklóst megsebesítették a lábán egy nyíllövéssel. A vizsgálat eredményéról a c. 1́rásos jelentést kér. D. Jaurini, 2. die fe. prenotati, a. d. 1356.
Á.: A 406. számú oklevélben.
K.: P. VIII. 333-334. (71. szám).
R.: Horváth R., Győr 39. (6. szám).

Megj.: K. problémafelvetése alapján kizárt, hogy a hatalmaskodás és az azt követő apáti panasz ugyanazon a napon történt volna, ezért kétséges a hatalmaskodás dátumaként megadott „f. II.” helyessége. „Elek július 17-re esik, az pedig 1356ban vasárnap, tehát a feria secunda nem helyes. Vö. a szöveget alább, mely szerint feria secunda proxima post festum Sancti Alexi volt, de így meg a júl. 18-iki dátum nem helyes." 
Miklós prépost és a Jazov-i Keresztelő Szt. János-monostor konventje e. Zubud-i Demeter fia: Beke a maga és nemes felesége nevében is megjelenvén, kinyilvánítja, hogy Péter fia: Miklósnak és Chakan-i János fia: Istvánnak azt a Chakan-ban lévő birtokrészét, amelyet az egri egyház kápt.-jának és Gömör m. c.-ének, valamint 4 szb.-ájának az okleveleiben foglaltak szerint 13 kassai M. ellenében nevezettek elzálogosították neki és feleségének, most valamennyi hasznával, haszonvételével, tartozékával és jogai teljességével együtt visszaadják Miklósnak és Istvánnak, a nevezett kápt. és m.-i hatóság okleveleit pedig hatálytalanítják; hozzáfúzve, hogy a szóban forgó föld éves termését ebben az évben még - a tized nélkül — szabadon betakaríthatják maguknak. D. f. IV. prox. an. fe. B. Marie Magdalene, a. d. 1[3]56.

E.: Dl. 4623. (NRA. 1538. 22.) Papíron, hátoldalán késóbbi kéz írásával tárgymegjelölés, valamint kerek, rányomott pecsét töredéke.

K.: -

Megj:: Az oklevélben a birtok elhelyezkedésének meghatározásakor az „in eadem Chakan" kifejezést egy kipontozással érvénytelenített rész követi az odaírt hakan névvel.

405. 1356. júl. 21.

A velencei köztársaság követeket küld I. Lajos királyhoz $(\mathrm{H})$ béketárgyalások megindítása céljából. 21. Jul., 9. indict. [1356.].

R.: Óváry L., TT. 11 (1888) 456.

406. 1356. júl. 22.

A győri egyház kápt.-ja jelenti Móric fia: Simon mr. győri c.-nek, hogy a hozzájuk intézett júl. 18-án kelt és itt átírt oklevelében (l. 403. szám) foglaltak szerint eljárva, Balázs kiküldött mellé hites tanúul adták Mihály karpapott (chori nostri clericus), akik visszatérve egybehangzó jelentést tettek. Eszerint júl. 20-án (f. IV. prox. an. fe. B. Marie Magdalene) a kivizsgálandó panasz kapcsán Győr és Veszprém m.-ben kikérdezték az értesüléssel rendelkezóket és megtudták, hogy júl. 18-án (f. II prox. p. fe. S. Alexii conf.) a Zeredahel-i népek és a Sambuk-i prépost jobbágyai hatalmaskodva rátörtek a Beel-i apát Kayar birtokára, ennek Zezcuth kaszálójáról 30 kocsira való jó szénát Zeredahel birtokra vittek, valamint Alap-i Benedek fia: Miklóst, az apát familiaris-át egy nyílvesszővel a lábán megsebesítették, mindezekkel sérelmét okozva az apátnak. D. 3. die diei inquisitionis antedicti, a. supradicto [1356].

E.: BFL. Capsarium 53. S2 (440). (Df. 207 230.) Papíron, hátoldalán azonos kézzel címzés, azonos és késôbbi kézzel tárgymegjelölés, továbbá kerek zárópecsét töredéke, bevágásai.

K.: P. VIII. 333-334.(71. szám).

R.: Horváth R., Győr 39. (6. szám).

Megj:: Jó minőségű digitalizált változatát 1.

http://www.mom-ca.uni-koeln.de/mom/HU-PBFL/PannHOSB/1356_VII_22/charter\#anchor 
A Clusmunustra-i Szt. Szűz-monostor konventje e. egyik részről Gerolth-i Miklós fia János fiai: András és Miklós, a másik részrôl pedig György fia: Éliás (Elyas) megjelenvén elóbbiek kinyilvánítják, hogy szorongató inségükben a Clus m.-i Tonchaza birtokon örökösödés jogán tulajdonukban lévő részbirtokukat szavatosság vállalásával 10 évre elzálogosították nevezett Éliásnak - M.-ként 80 garassal számolt és már meg is fizetett - $12 \mathrm{M}$. ellenében, mégpedig olyan feltétellel, hogy más pénzén azt ne válthassák vissza csak a sajátjukon, ha pedig az ínség szoratásában másoknak akarnák lekötni a szóban forgó birtokrészt, azt Éliáson kívül senkinek ne tehessék meg. D. VI. f. prox. an. fe. B. Jacobi ap., a. d. 1356.

E.: Ba. Gyulafehérvári kápt. lt. Erdélyi kápt. mlt. Oklt. Beke 1. 139. (1. 161.) (Df. 277 336.) K. és R. alapján papíron, hátoldalán befüggesztett kerek pecsét töredéke.

K.: Doc. Rom. Hist. C. XI. 29-30. (28. szám) (román fordításban is).

R.: Beke 759. (139. szám); Erdélyi Okm. III. 307. (843. szám).

408. 1356. júl. 22.

A pécsi egyház kápt.-ja e. megjelenő Kurthueles-i István fia: Jakab kijelenti, hogy jóllehet Kurthueles falu patakján egy bizonyos malomhelyen, amelynek épületei régtől fogva elhagyatottan álltak, a malmot saját költségén helyreállíttatta, azonban mivel fivére (fr. carnalis), Bakou fia: István azon a malomhelyen — jog szerint — tulajdonrésszel rendelkezik, ezért a malom negyedét haszonvételeivel visszaadja neki örök birtoklásra; ezenfelül pedig vállalja, hogy Istvánnal szembeni tartozása fejében nov. 8-án (in oct. fe. OO.SS.) fél M.-t fog fizetni, ha pedig elszalasztaná az időpontot, akkor büntetésként az összeg kétszeresét fizeti meg. D. in fe. B. Marie Magdalene, a. d. 1356.

E.: Dl. 4624. (NRA. 1711. 13.) Hártyán, hátoldalán késôbbi kéz írásával tárgymegjelölés, valamint rányomott mandorla alakú pecsét nyoma, bevágásai.

K.: AO. VI. 490. (307. szám) (kihagyásokkal).

409. (1356. júl. 23. u.)

A Posaga-i kápt. jelent Zeech-i Miklós országbírónak, hogy a parancslevelében (l. 348. szám) foglaltaknak megfelelően eljárva Bagyun-i János fia: Péter királyi ember mellé a Posaga-i kápt. részéről kiküldött Luka őrkanonok tanúskodása mellett [1356.] júl. 23án (sabb., in fe. B. Appolinaris ep. et mart.) az összehívott szomszédok és határtársak jelenlétében ellentmondás nélkül végrehajtotta, s Felsew- és Alsow-Orboua birtokokat Beke fiai: László, Miklós és Tamás, valamint Miklós fia: László, nemkülönben Velyke-i Simon fia: János részére iktatta.

Eml.: Az 502. számú oklevélben.

K.: AO. VI. 503. (314. szám); Smič. XII. 370. (276. szám) (Eml.-ben). 
Simon mr. [győri] c. és a m.-e 4 szb.-ja teljesítvén a Beel-i monostor apátjának, [Péternek] a képviseletében színük elé járult Kapton-i András kérését, a szb.-ák közül Pech-i Pált, valamint Kachvara Balázst küldték ki azzal a céllal, hogy az apát Kayar birtokára menve a Zerdahel-i népeket és a Sambuk-i prépost jobbágyait a birtok használatától és haszonvételeinek megszerzésétől eltiltsák, amit a kiküldöttek júl. 20-án (f. IV. an. fe. Marie Magdalene) meg is tettek, ahogyan egybehangzó jelentésük igazolja. D. Iaurini, sabb. prox. p. fe. prenotatum, a. d. 1356.

E.: BFL. Capsarium 55. P (435.) (Df. 207 231.) Papíron, vízfoltos, írásképe meglehetősen elhalványult, hátoldalán azonos kéz írásával tárgymegjelölés, valamint kerek zárópecsét töredéke, bevágásai, szalagja.

K.: Horváth R., Győ́r 39-40. (7. szám).

Megj:: A [ ]-ben közölt kiegészítések a Df. 207 230. oklevélből származnak. Jó minőségú digitalizált változatát 1 .

http://www.mom-ca.uni-koeln.de/mom/HU-PBFL/PannHOSB/1356_VII_23/charter\#anchor?q=207231

\section{1356. júl. 25. Veszprém}

János veszprémi püspök, a királynéi udvar kancellárja az esztergomi egyház kápt.jának a nevében eljáró Miklós honti főesp. kérésére és oklevél-bemutatása alapján átírja és autentikus pecsétjével megerôsíti saját, 1349. jún. 7-én kelt, [Nyr birtokon kápolna építéséhez adott püspöki engedélyét tartalmazó,] gyưrüspecsétjével megpecsételt oklevelét, amelyben az oklevél visszahozatala esetére annak átírását és nagyobb, autentikus pecsétjével való megerősítését ígérte. D. Wesprimii, in fe. B. Jacobi ap., a. d. 1356.

E.: Esztergomi székesfókápt. mlt. Acta radicalia 29. 1. 15. (Df. 236 716.) K. szerint hártyán, hátoldalán azonos és újkori kéz írásával tárgymegjelölés, valamint késóbbi kézzel Nostri capituli Stri[goniensis], továbbá hártyaszalagon János veszprémi püspök pecsétje.

K.: F. IX. 2. 509-511. (248. szám) (esztergomi püspöki levéltárra való hivatkozással); Str. IV. 152. (121. szám) (tévesen jún. 25-re datálva).

Megj.: A veszprémi püspök 1349. évi átírt oklevelének [ ] között megadott tárgyát az átíró oklevél keretszövege nem tartalmazza közvetlenül; az átírt oklevelet 1. Str. III. 685. (913. szám) alatt.

\section{1356. júl. 25. Gömör falu}

Kemen fia: János mr., Konya mr. Gömör m.-i alispánja és a m. szb.-ái eleget tévén Scarusi Miklós fia: László kérésének pecsétjükkel kiküldték emberüket, Sarncfalua-i János fia: Miklóst, aki visszatérve jelentette, hogy júl. 19-én (f. III. prox. an. fe. B. Jacobi ap.) László mr. Straza, más néven Dornomelleke birtokán - ahogyan a m. joga megkívánja nyilvánosan eltiltotta Deresk-i Bebek (dict.) István és György mr.-eket, nemkülönben Deresk-i jobbágyaikat a mondott birtok bárminemú hasznának elvételétől. D. in villa Gumur, f. II. sc. in die fe. B. Jacobi ap., a. d. 1356. 
E.: Dl. 56 875. (Hanvay cs. 1t. 77.) Papíron, hátoldalán azonos és késóbbi kéz írásával tárgymegjelölés, utóbbi magyarul, továbbá 2 zárópecsét töredéke, bevágásai, szalagja.

K.: AO. VI. 491. (308. szám).

R.: Abaffy-Dancs-Hanvay 105. (77. szám).

Megj.: Vö. a 395. számú oklevéllel.

\section{1356. júl. 27. Treviso}

[I.] Lajos király (H) e. Makwa-i Mark fia: Petew kinyilvánítja, hogy Mezado és Gern nevú, ôt jog szerint megillető 2 Vasvár m.-i birtokát András fia László leánya: Margit nemes asszony - Magyar (dict.) Pál mr. felesége — elfoglalva tartja az ő kárára, és ahogyan hallomásból a tudomására jutott, a szóban forgó asszony arra törekszik mostnában, hogy ezeket a birtokokat elidegenítse v. érékesítse. Ezért a királyi jelenlét e. ellentmondva eltiltja Margitot a birtokok elidegenítésétől v. eladásától. D. sub Teruisio, 3. die fe. B. Jacobi ap., a. d. 1356.

E.: Dl. 91 488. (Festetics cs. Vas 40. A.) Papíron, hátoldalán azonos és késóbbi kéz írásával tárgymegjelölés (eltérő névalakjai: Peteu, Meezadou), valamint zárópecsét töredéke, bevágásai, szalagja.

K.: HO. V. 130-131. (108. szám).

414. 1356. júl. 27.

A [szepesi] Szt. Márton egyház kápt.-ja jelenti [I.] Lajos királynak (H): miután megkapta Zeech-i Miklós országbírónak, Th[uruch] m. c.-ének júl. 10-én kelt, itt átírt oklevelét (l. 390. szám), az abban foglaltaknak eleget téve Lőrinc fia: Pál királyi ember mellé tanúul adta Pál mr. kanonokot a panasz kivizsgálásához, akik visszatérve jelentették, hogy júl. 25-én (in fe. B. Jacobi ap.) a helyszínen — nyíltan és titokban — vizsgálatot folytattak az értesüléssel rendelkezők körében, amelynek eredményeként olyan ismeretekhez jutottak, miszerint Sarus vár c.-ének és várnagyának a cseréjét követően — abban az időben tehát, amikor Konth Miklós nádornak, a kunok bírájának és több más m. mellett Sarus m. c.-ének az alispánjai, Frank fiai: Mihály és Jakab mr.-ek éppen megszerezték a rendelkezést annak a várának a javadalma (beneficium) fölött - , a király Hennengfoluai népei v. jobbágyai (populi seu jobagiones) Rykolphus fiainak törvényes tiltása ellenére márc. 31-én (f. V. prox. p. fe. Ann. glor. virg.) e tiltakozók Veresalma birtokán lévő szántóföldjeit önhatalmúlag felszántották, az őszi vetést kiszántották, és a földeket saját, nyári vetômagjukkal (seminibus estivalibus) vetették be, ahogyan azt a kiküldöttek saját szemükkel is látták, súlyos kárt okozván ezzel Rykolphus fiainak. D. f. IV. prox. p. fe. B. Jacobi ap., a. d. prenotato [1356.]

E.: Dl. 64 677. (Péchy cs. 1t. 35.) Papíron, egy helyen szakadás, hátoldalán késóbbi kéz írásával tárgymegjelölés, továbbá a szepesi kápt. pecsétje (rajta a glóriával övezett Szt. Márton lovon ülő alakja, lova balra felé lépdelve, oldalról van ábrázolva, feje felett 6 ágú csillag, maga a szt. szemból látható, amint bal karjával palástját emeli, jobbjával pedig levág belőle egy darabot az e. a földön időző koldusnak; körirata: +S(IGILLVM) CAPITVLI EC(C)LES(I)E BEATI MARTINI DE SCEPVS). 
K.: -

\section{1356. júl. 30. Pilis}

Erzsébet királyné $(\mathrm{H})$ a zobori (Zuburiensis) monostor konventjéhez: a garamszentbenedeki (S. Benedicti de iuxta Gron) monostor apátjának és konventjének eléje terjesztett panasza szerint a Ladamar-i királyi jobbágyok és ugyanonnan András vámszedő (tributarius) több jogtalanságot követtek el a monostor Apati faluból való jobbágyai ellen, és szüntelenül károkat okoznak nekik, terményeiket elviszik a mezőről, szénájukat lekaszálják. A királyné utasítja ezért a konventet, hogy Geured-i Miklós v. Balwan-i Benedek fia: Miklós v. Geured-i János királynéi emberek valamelyike mellé állítson hites tanút a panasz kivizsgálásához, majd az igazságot kiderítve királyi és királynéi szóval mondják meg Zobonia fia: László Sasku-i várnagy nemes feleségének — amely várhoz Ladamar falu is tartozik — v. a várnagy helyettesének, hogy a jobbágyok részéről elégtétellel tartoznak a fentiekért, a késóbbiek során pedig ne engedjék azokat a királyi jobbágyokat és András vámszedôt efféle kártételek és jogtalanságok elkövetését véghezvinni. Az eljárásról a konvent részletes jelentést tartozik küldeni a királynénak. D. in Pelysio, sabb. prox. p. fe. B. Jacobi ap. a. d. 1356.

Á.: A 439. számú oklevélben.

K.: Str. IV. 153-154. (123. szám).

\section{1356. júl. 30. Fehértó}

Cantor (dict.) Bereck mr. Zabolch-i alispán és a m. szb.-ái tudatják: a korábbi fizetségi köelezettségről kiállított levelükben foglaltaknak megfelelően (l. 75. szám) Lengel (dict.) János fia: László mr. Semien-i nemes, mivel [embere, ?] Pooch egy Benedek nevú gyilkost bilincséből (de vinculo) önhatalmúlag kiszabadított, nemes fogott bírák ítélete alapján M.-nként 50 garassal számolt 13 M.-át és 1 fertót volt köteles fizetni Semien-i László fia: Mihály mr.-nek, mégpedig 3 időpontban, ti. ápr. 2-án (sab. prox. p. diei medi Quadr.) 4 M.-t, jún. 18-án (sab. prox. p. fe. Pent.) szintén 4 M.-t, utoljára pedig júl. 30-án (sab. prox. p. fe. B. Jacobi ap.) 5 M.-t és 1 fertót olyan fizetési teher kikötése mellett, hogy az első, a második és a harmadik fizetési kötelezettség teljesítésének elmulasztása a bírságösszeg megkétszerezését, valamint az addig teljesített fizetség(ek) elveszését vonja maga után. A kijelölt időpontokban László mr. személyesen járulván a m.-i hatóság színe e., teljesen megfizette a megszabott összeget Mihály mr.-nek, amiról az alispán és a szb.-ák pecsétjeikkel megerősített igazolólevelet állítanak ki László mr. számára. D. in Feyrtho, sab. prox. p. fe. B. Jacobi ap., videlicet in ultimo termino solutionis, a. d. 1356.

E.: Dl. 51 713. (Kállay cs. 1t. 1300. 1130.) Papíron, hátoldalán 3 rányomott pecsét töredéke, bevágásai, szalagjai.

K.: -

R.: Kállay II. 37. (1189. szám); Piti F., Szabolcs m. 133. (518. szám).

Megj.: Vö. a 74. és a 155. számú oklevéllel. 
Leo, Wysschegrad-i bíró, Hermannu[s], .......ner, Ulricus, Bolognai (Bononiensis) János, Váci (de Waczia) Mihály (Michahahel), Mátyás, Miklós, H...... visegrádi esküdt polgárok emlékezetül adják: a színük elé járult szász (Saxo) Guntherus pénzverô kinyilvánította, hogy ........ [egy ingatlant] a magyar városrészben ([unam ar]eam in Hungaricali civitate), Szt. László király kolostora mögött, Pesczo (gen.: Pesczonis) pénzverő özvegyének [háza/telke] mellett, a királyi kamara udvarával szemben, megvásárolt $14 \mathrm{ft}$.ért Vörös (Ruffus) Cuczelmus-tól, aki azt az ingatlant alapos megfontolásból törvényes felesége, Katalin, valamint nővére, Klára, nemkülönben valamennyi gyermekük tanácsából idegenítette el az ő és felesége, Katalin számára és az ő örököseinek szabadon és teljesen, minden megkötés nélkül, örökségi jogon. Ennek megfelelően a városi hatóság kinyilvánítja, hogy nevezett Guntherus és felesége, valamint örököseik ennek az ingatlannak igaz és törvényes örökösei és birtokosai. A ügylet tanúságára az esküdtek, tanúk és más szavahihetô férfiak Wysschegrad város pecsétjét függesztik e privilégiumra. D. in Wysschegrad, sabb. prox. p. fe. B. Jacobi ap. maioris, a. d. 1356.

E.: EPL. Acta radicalia T 21. (Df. 248 655.) Hártyán, hátoldalon újkori kéz írásával tárgymegjelölés, a plicán lila és zöld sodrat, pecsétje eltûnt.

K.: Str. IV. 152-153. (122. szám) (tévesen júl. 2-ára datálva); Mészáros, Visegrád 139140. (17. szám).

R.: Pest m. 66. (345. szám); Bakács, Pest megye 206. (712. szám); Viktorin 12.

\section{8. (1356. aug. 1.e.)}

Domokos erdélyi alvajda azt a régóta húzódó pert, amely a néhai Peturfolua-i Hennyng fia: Miklósnak ue. Fehér m.-i Peturfolua-n lévő birtokrésze, valamennyi szőlőjének fele, nemkülönben Sebus városban fekvő telke (unus fundus curiae), továbbá Peturfolua-i 3 malmának harmadrésze körül forgott Kelnuk-i Salamon fia Miklós fiai: István és András, ill. Enyed-i Mihály c. között, részint a per fogóssága miatt, részint pedig a [bíráskodáshoz megjelent] nemesek alacsony száma miatt a vajdai bírói szék elé utalva aug. 1-jére (ad oct. fe. B. Jacobi ap.) elhalasztja, hogy a felek birtokjogát igazoló, akkor bemutatandó okirataik és egyéb bizonyítékok alapján a vajda bírósága perdöntő ítéletet hozzon.

Eml.: Az 569. számú oklevélben.

K.: Zichy III. 48. (33. szám); ZW. II. 123. (706. szám); Doc. Rom. Hist. C. XI. 41. (45. szám) (mind Eml.-ben).

R.: Erdélyi Okm. III. 311-312. (861. szám) (Eml.-ben).

\section{1356. aug. 1. - nov. 8. között}

András erdélyi vajda az ügy nagyobb bizonyossága érdekében az erdélyi részek nemeseinek nov. 8-i congregatio-jára halasztja a - Domokos alvajda oklevelében (l. 418. szám) foglaltak szerint oklevél-bemutatás céljából — színe e. aug. 1-jén megjelenő István és András, valamint velük szemben az Enyed-i Mihály c. képviseletében vajdai ügyvédvalló levéllel eljáró famulus-a, Simon közötti pert, jóllehet a felek készek lettek volna okleveleiket bemutatni, a vajda azonban nem akart elhamarkodottan dönteni. 
Eml.: Az 569. számú oklevélben.

K.: Zichy III. 48. (33. szám); ZW. II. 123. (706. szám); Doc. Rom. Hist. C. XI. 41. (45. szám) (mind Eml.-ben).

R.: Erdélyi Okm. III. 311-312. (861. szám) (Eml.-ben).

\section{1356. aug. 1. Treviso ostrománál}

[I.] Lajos király (H) engedve híve, Makwa-i Mark fia: Petew mr. kérésének, szolgálataira való tekintettel annak Zala m.-i Pacha birtokán szabad vásár (forum liberum) tartását engedélyezi minden egyes hétfői napra (singulis feriis secundis) a szomszédok vásárainak sérelme (preidicium) nélkül. Biztosít egyben valamennyi, a falut a vásár miatt felkereső kereskedőt és minden más személyt is, hogy az engedélyével ezután hétfőnként tartandó vásárra szabadon jöhetnek, adás-vételeiket biztonságosan lebonyolíthatják, a kereskedés végeztével pedig oda, ahová igyekeznek, javaikban és személyükben sértetlenül (salvis rebus et personis) távozhatnak; akarja továbbá, hogy mindezt tegyék közhírré a vásárokon. D. in obsidione civitatis Trevisane, in fe. S. Petri ad vincula, a. d. 1356.

E.: Dl. 91 489. (Festetics cs. 1t. Zala 29.) Hártyán, hátoldalán kerek, rányomott pecsét nyoma, bevágásai.

K.: Zala I. 565. (361. szám).

R.: Reiszig E., Vasi Szle 5-6 (1944) 161.

421. 1356. aug. 1 .

A Clu[smunustra-i]Boldogságos Szűz-monostor konventje jelenti Domokos erdélyi alvajdának: miután megkapták az alvajda itt átírt, jún. 20-án kelt levelét (l. 345. szám), az abban foglaltak szerint eljárva Corpad-i Bagar (dict.) János alvajdai ember mellé tanúul adták Miklós pap testvért, akik visszatérve jelentették, hogy a vajda által kijelölt napon, azaz júl. 25-én (in die fe. B. Jacobi ap.) a mondott birtokra mentek, azonban mivel sem az oklevelében megnevezett többi alvajdai ember, sem más nemesek nem tudtak ott megjelenni, ezért a jelenlévôk kis számára való tekintettel a birtokfelosztás ügyét az erdélyi vajda és Zonuk-i c. legközelebbi generalis congregatio-jára halasztották a fennálló állapot fenntartása mellett, mindenféle bírság kirovása nélkül (sine omni gravamine birsagii), hogy akkor a vajda és az alvajda hozzanak végső döntést az ügyben. D. in oct. fe. predicti, a. d. ut supra [1356].

E.: Dl. 28 909. (Kolozsmonostori konvent o. lt. Miscellanea A 48.) Papíron, felső részen foltokban szakadt, hátoldalán azonos és késóbbi kéz írásával tárgymegjelölés, valamint kerek zárópecsét nyoma, bevágásai.

Má.: Uo., mint E., azzal megegyező jelzet alatt; egyszerú Má.-ban 1836. dec. 14. kelettel.

K.: AO. VI. 491-493. (309. szám) (kihagyásokkal); Doc. Rom. Hist. C. XI. 30-31. (29. szám) (román fordításban is).

R.: Erdélyi Okm. III. 307. (845. szám).

Megj:: Az oklevél hitelességét kétségessé teszi, hogy a kolozsmonostori konvent hamisítási ügybe keveredett és emiatt halálra ítélt jegyzőjének, István deáknak az 
ügyeihez kapcsolható, emellett a szöveg szokatlan szerkezete, zavarossága is a hamisítás gyanúját ébreszti; 1. Jakó Zs., LK 55 (1984) 134-138.

\section{1356. aug. 3. Treviso alatt}

[I.] Lajos király $(\mathrm{H})$ meghallgatva a színe elé járuló és szolgálati érdemeire hivatkozó Beulch-i Dénes fia Domokos fia: Zudor (dict.) Péter mr.-nek, [a királyi udvar] ifjának kérését - miszerint a néhai Olnad-i Jakab fia Pál fia: István valamennyi birtokát és birtokrészét, különösen azt a Borsod m.-i Olnad birtokot, amely elmondások szerint elóbb [zálog, utóbb pedig] vételi jogcímen tartozott a nevezetthez, tekintettel arra, hogy István örökös nélküli halála folytán összes birtoka királyi kézre háramlott, adja oda neki és fivéreinek (fr.) Istvánnak, Mihálynak, Simonnak, Györgynek, Jánosnak és Imrének —, miután megfontolásba vette Péter mr. húségét, továbbá az ország ügyes-bajos dolgaiban és háborúiban teljesített szolgálatait, az örökös nélkül meghalt István összes birtokát a vételi jogon birtokoltakat is — valamennyi tartozékukkal és haszonvételükkel együtt Zudor (dict.) Péter mr.-nek és rajta keresztül fivéreinek (uterini fr.), Istvánnak, Mihálynak, Simonnak, Györgynek, Jánosnak és Imrének, valamint örököseinek adományozza új adomány címén örökre és visszavonhatatlanul, idegen jog sérelme nélkül. Az erról kiállított nyílt oklevelének visszahozatala esetére privilégium kiállítását ígéri. D. sub Trevisyo, in fe. Inv. Corporis S. Stephani prothomart., a. d. 1356.

E.: Dl. 4625. (NRA. 1538. 23.) Hártyán, egy foltban kiszakadt, hátoldalán késóbbi kezek írásával tárgymegjelölés, valamint kerek rányomott pecsét nyoma, bevágásai.

Á.: Az 556. számú oklevélben.

K.: AO. VI. 493-494. (310. szám) (E.-ről; kihagyásokkal).

\section{1356. aug. 3. Treviso alatt}

[I.] Lajos király (H) az egri kápt.-nak tudtára adván az előző királyi oklevelében (l. 422. szám) foglaltakat utasítja a kápt.-t, hogy Bezegh-i Bors fia: Petheu vagy Checch-i Pousa fia: László vagy Abon-i Kis (Parvus) Jakab királyi emberek valamelyikével küldje ki tanúbizonyságul a maga emberét az érintett birtokokra, elsősorban is a Borsod m.i Olnad birtokra, s ott a határosok és szomszédok jelenlétében járják meg a birtokok határait, ahol szükséges a régi határjelek mellé emeljenek újakat, és iktassák be ezen, új adomány címén elnyert birtokokba nevezett Bulch-i Dénes fia Domokos fia: Zudor (dict.) Péter mr.-t, a királyi udvar ifját és fivéreit (uterini fr.), Istvánt, Mihályt, Simont, Györgyöt, Jánost és Imrét örök birtoklásra. Ha valaki ellentmondana az iktatásnak, azt idézzék meg a királyi jelenlét elé alkalmas időre, a történtekről pedig minden részletre kiterjedő jelentést küldjenek számára. D. sub Trevisyo, in fe. Inv. Corporis S. Stephani prothomart., a. d. 1356.

Á.: Az 556. számú oklevélben.

K.: -

424. (1356.) aug. 4. Villanova közelében, avignoni egyházm.

[VI.] Ince pápa Durazzói (de Duratio) Lajosnak: mivel a pápa az [I.] Lajos király (H) és 
a címzett, valamint fivére (germanus), Durazzoi Róbert között elmérgesedett viszony helyreállítására törekszik, ezért a fermói (Firmanum) püspököt, Bonjohannest küldte a nevezett királyhoz. A pápa írt a címzett lányunokáinak feloldozásáért (pro liberatione) is egy másik levelet, ahogyan a címzett látni fogja a hozzá küldött másolatban. A jóra inti a túlvilági üdvösség elnyerését helyezve kilátásba. D. apud Villamnovam, Avinionensis diocesis, II Non. Aug. [pápasága] 4. évében, [1356.]

K.: Gasnault-Gotteri (2311. szám) Reg. Av. v. 238., f. 139r-ra való hivatkozással.

425. (1356.) aug. 4. Villanova közelében, avignoni egyházm.

[VI.] Ince pápa tudatja Miklós testvérrel (fr.), a hajdani zágrábi püspökkel, hogy eddigi szolgálataira és a zágrábi egyház élén folytatott tevékenységére tekintettel kinevezi és megerôsíti ôt a Dénes kalocsai érsek halálával megüresedett érseki tisztségben. D. apud Villamnovam, Avinionensis diocesis, II. Non. Aug., pápasága 4. évében [1356.].

Reg.: ASV. Reg. Av. v. 134., f. 80r-v (Df. 289 534.).

R.: Áldásy 41-42. (232. szám); Áldásy A., TT. 18 (1895) 83. (232. szám) (Reg. alapján).

426. (1356.) aug. 4. Villanova közelében, avignoni egyházm.

[VI.] Ince pápa a megelőző oklevélben (l. 425. szám) foglalt intézkedését tudatja a kalocsai egyház kápt.-ával. D. ut supra [D. apud Villamnovam, Avinionensis diocesis, II. Non. Aug., pápaságának 4. évében [1356.]].

Megj.: Apparátusa megegyezik a 425. számú oklevélével.

427. (1356.) aug. 4. Villanova közelében, avignoni egyházm.

[VI.] Ince pápa a 425. számú oklevélben foglalt intézkedését tudatja a kalocsai egyházm. és a város lakosságával. D. ut supra [D. apud Villamnovam, Avinionensis diocesis, II. Non. Aug., pápaságának 4. évében [1356.]].

Megj.: Apparátusa megegyezik a 425. számú oklevélével.

428. (1356.) aug. 4. Villanova közelében, avignoni egyházm.

[VI.] Ince pápa a 425. számú oklevélben foglalt intézkedését tudatja a kalocsai egyház vazullusaival. D. ut supra [D. apud Villamnovam, Avinionensis diocesis, II. Non. Aug., pápaságának 4. évében [1356.]].

Megj.: Apparátusa megegyezik a 425. számú oklevélével.

429. (1356.) aug. 4. Villanova közelében, avignoni egyházm.

[VI.] Ince pápa a 425. számú oklevélben foglalt intézkedését tudatja a kalocsai egyház valamennyi suffraganeus testvérével. D. ut supra [D. apud Villamnovam, Avinionensis diocesis, II. Non. Aug., pápaságának 4. évében [1356.]]. 
Megj.: Apparátusa megegyezik a 425. számú oklevélével.

430. (1356.) aug. 4. Villanova közelében, avignoni egyházm.

[VI.] Ince pápa a 425. számú oklevélben foglalt intézkedését tudatja [I.] Lajos királlyal (U). D. ut supra [D. apud Villamnovam, Avinionensis diocesis, II. Non. Aug., pápaságának 4. évében [1356.]].

Megj.: Apparátusa megegyezik a 425. számú oklevélével.

431. (1356.) aug. 4. Villanova közelében, avignoni egyházm.

[VI.] Ince pápa tudatja István választott zágrábi püspökkel, hogy eddigi szolgálataira tekintettel — melyeket, mint a veszprémi egyházm.-i budai egyház prépostja véghezvitt —, mint erre a legalkalmasabb személyt kinevezi ôt a Miklós egykori zágrábi püspök kalocsai érsekké való kinevezése révén megüresedett tisztségbe, s ezzel rábízza ezen egyház lelki és anyagi irányítását, valamint a hívek gondozását. D. apud Villamnovam, Avinionensis diocesis, II. Non. Aug., pápasága 4. évében [1356.].

Reg.: ASV. Reg. Av. v. 134., f. 76r-v (Df. 289 533.).

Eml.: A 481. számú oklevélben.

R.: Áldásy 41. (231. szám); Áldásy A., TT. 18 (1895) 83. (231. szám) (Reg. alapján).

432. (1356.) aug. 4. Villanova közelében, avignoni egyházm.

[VI.] Ince pápa a megelőző oklevélben (l.431. szám) foglalt intézkedését tudatja a zágrábi egyház kápt.-ával. D. ut supra [D. apud Villamnovam, Avinionensis diocesis, II. Non. Aug., pápaságának 4. évében [1356.]].

Megj.: Apparátusa megegyezik a 431. számú oklevélével.

433. (1356.) aug. 4. Villanova közelében, avignoni egyházm.

[VI.] Ince pápa a 431. számú oklevélben foglalt intézkedését tudatja a zágrábi egyházm. és a város lakosságával. D. ut supra [D. apud Villamnovam, Avinionensis diocesis, II. Non. Aug., pápaságának 4. évében [1356.]].

Megj.: Apparátusa megegyezik a 431. számú oklevélével.

434. (1356.) aug. 4. Villanova közelében, avignoni egyházm.

[VI.] Ince pápa a 431. számú oklevélben foglalt intézkedését tudatja a zágrábi egyház vazullusaival. D. ut supra [D. apud Villamnovam, Avinionensis diocesis, II. Non. Aug., pápaságának 4. évében [1356.]].

Megj.: Apparátusa megegyezik a 431. számú oklevélével. 
435. (1356.) aug. 4. Villanova közelében, avignoni egyházm.

[VI.] Ince pápa a 431. számú oklevélben foglalt intézkedését tudatja Miklós egykori zágrábi püspökkel, választott kalocsai érsekkel. D. ut supra [D. apud Villamnovam, Avinionensis diocesis, II. Non. Aug., pápaságának 4. évében [1356.]].

Megj.: Apparátusa megegyezik a 431. számú oklevélével.

\section{6. (1356.) aug. 4. Villanova közelében, avignoni egyházm.}

[VI.] Ince pápa a 431. számú oklevélben foglalt intézkedését tudatja a zágrábi város és egyházm. klerusával. D. ut supra [D. apud Villamnovam, Avinionensis diocesis, II. Non. Aug., pápaságának 4. évében [1356.]].

Reg.: ASV. Reg. Av. v. 134., f. 77r (Df. 289 533.).

R.: Áldásy 41. (231. szám); Áldásy A., TT. 18 (1895) 83. (231. szám) (Reg. alapján).

\section{7. (1356.) aug. 4. Villanova közelében, avignoni egyházm.}

[VI.] Ince pápa a 431. számú oklevélben foglalt intézkedését tudatja [I.] Lajos királlyal (U). D. ut supra [D. apud Villamnovam, Avinionensis diocesis, II. Non. Aug., pápaságának 4. évében [1356.]].

Megj.: Apparátusa megegyezik a 436. számú oklevélével.

\section{1356. aug. 4 .}

[I] Lajos király (H, Da, C, Ra, Se, G, L, Cu, Bu, princ. Sal., mont. S. Angeli dom.) tekintettel a fiú utód nélkül elhalálozott Fony-i Balázs húségére és érdemeire, amelyeket az a néhai Károly király és a királyság iránt tanúsított, eleget téve Balázs egyetlen leánya, Anych kérésének, különleges királyi kegyból a törvény szerint királyi kezére háramló birtokok - bármelyik m.-ben fekszenek is -, továbbá valamennyi haszonvételük és tartozékuk, valamint a hozzájuk kapcsolódó birtokjogok törvényes örökösévé a fiúsított Annát teszi meg, aki új adomány címén élethossziglan birtokolhatja azokat, majd azután mindazok törvényes örököseire szállhatnak. Mivel nevezett Anna, a király hívének, a Gyosgyeur-i várnagynak, Zudor Péter mr.-nek a jegyese, aki érdemes szolgálatokat tett a királynak, így az adományt Anna kérésére rá is kiterjeszti, olyan feltétellel, hogy a szóban forgó birtokjavak örökös nélküli haláluk esetén teljes joggal Zudar Péter fivéreinek (fr. uterinus) a birtokába és tulajdonába háramoljanak. Ennek bizonyságára a király autentikus, függő, kettős ....... [pecsétjével] megerősített privilégiumot bocsát ki. Kelt Miklós zágrábi püspök, udvari alkancellár keze által, a. d. 1356., pridie Non. Aug., uralkodásának 15. évében. Méltóságnévsor: Miklós lévén az esztergomi érsek, egyben ua. m. örökös. c.-e - a kalocsai szék üresedésben -, Vgulinus a spalatói érsek, Miklós az egri, Demeter a váradi — az erdélyi szék üresedésben —, ....... [K]álmán a győri, János a veszprémi, Tamás a csanádi, Mihály a váci, Péter a boszniai, Tamás testvér a szerémi, István testvér a nyitrai és Balázs testvér a knini (Tininiensi) püspök; Konth Miklós a nádor és a kunok bírája, Cykou a tárnokmr., András az erdélyi vajda és a Zonuk-i c., Miklós c. az országbíró, Miklós a Machou-i bán, Leustacius Somogy, Fejér és Tolna m.-k 
c.-e és az egész Szlavónia bánja, Leukus az asztalnok- és a pohárnok-, Dénes a lovászés Tamás az ajtónálló mr., valamint Simon a pozsonyi c. A.

E.: Dl. 4627. (NRA. 604. 32.) Hártyán, alján megerôsítő záradék 1364. dec. 27-i keltezéssel hátoldalán egykorú és késóbbi kéz írásával tárgymegjelölés, a plicán vörös-zöld sodraton a király erôsen megrongálódott kettôspecsétjének töredéke függ.

K.: AO. VI. 495-497. (311. szám) (kihagyásokkal).

R.: T. 41. (1927) 84 .

439. 1356. aug. 5 .

A zobori monostor konventje jelenti Erzsébet királynénak $(\mathrm{H})$ : a garamszentbenedeki (S. Benedicti de iuxta Gron) monostor konventjének és apátjának érdekében júl. 30-án hozzá intézett, itt átírt parancslevelében (l. 415. szám) foglaltaknak eleget téve tanúul adta Geured-i Móric fia: Miklós királyi ember mellé a konventhez tartozó Arnold pap testvért, akik visszatérve egybehangzó jelentést tettek. Eszerint aug. 3-án (f. IV. prox. p. oct. fe. B. Jacobi ap.) kikérdezvén Apati és Ladamar falvak szomszédait és határbirtokosait, megtudták, hogy András vámszedő (tributarius) és a Ladamar-i királyi jobbágyok a szóban forgó Szt. Benedek-monostor Apati falubeli jobbágyai ellen valóban elkövették az oklevélben foglaltakat, ezenfelül a Sasku-i vár várnagyának helyettese, Péter elfogta a mondott monostor konventjének és apátjának molnárát, megverte, megsebesítette és meg is ölte volna, ha az el nem menekül, a malmot pedig szétdarabolva (dissecando) teljesen tönkretette, ahogyan arról saját maga beszámolt a kiküldötteknek, akik mindezen dúlásokat, mivel saját szemükkel látták, megerősítik. Ezenfelül jelentették, hogy László felesége elé terjesztették az elégtétel dolgát, de ezzel nem értek célt. D.f. VI. prox. p. oct. B. Jacobi ap. supradictas, a. d. prenotato [1356.].

E.: EPL. Esztergomi székesfókápt. mlt. Acta radicalia 7. 5. 4. (Df. 235 955.) Papíron, hátoldalán azonos és újkori kéz írásával tárgymegjelölés, valamint kerek zárópecsét nyoma, szalagja, bevágásai.

K.: Str. IV. 154-155. (124. szám).

\section{1356. aug. 6. Mindszentkálla}

János veszprémi püspök és királynéi kancellár színe e. egyháza Acha-ra való néhai jobbágyainak fiai, így Gogan fia, az ifjú (adolescens) Éliás (Elyas), nemkülönben Benedek fia: András, ránézésre 9 éves gyermek (puer) megjelenvén, kinyilvánítják, hogy ínségük szorításában szülői támasz híján, ill. életkoruk miatt nem lévén képesek jogaik megőrzésére, M.-ként 5 pensa-val számolt 7 dénár ellenében eladják Acha birtokon lévő, örökség jogán őket illetô telküket (sessio vel curia fundi) minden haszonvételével és tartozékával, különösképpen a Fyzegh folyó két partján fekvő szántóföldekkel együtt az ugyancsak jelen lévő Mihály fia: Giuke-nek és örököseinek örök birtoklásra, idegen jog sérelme nélkül, olyan feltétellel és szabadsággal, ahogyan elődeik annak idején az egyház jóvoltából rendelkeztek vele. Giuke és utódai az egyház többi jobbágyához hasonlóan szolgálatok és kötelezettségek (servitia et debita) teljesítésével tartoznak a püspök és egyháza számára, ám ha kötelességeik teljesítését megtagadnák, függésüket figyelmen kívül hagynák v. hútlennek bizonyulnának, akkor a telket tartozékaival együtt 
visszaveszi tôlük a püspök ill. bármely utódja. Minderról a püspök autentikus pecsétjével megerősített oklevelet ad ki. D. in Kaal OO. SS., in fe. Sixti, a. d. 1356. A.

E.: Veszprémi érseki és fókápt. 1t. Acsa 1. (Df. 200 208.) Hártyán, hátoldalán azonos és késóbbi kezek írásával tárgymegjelölés, alján vörös sodraton [Garai] János püspök mandorla alakú töredezett pecsétje függ (, rajta gótikus ívek alkotta hármas fülke, bennük 3 Szt. - Szt. Mihály, Szt. Katalin és egy azonosítatlan Szt. — glóriával övezett fejú, álló alakja, alul a püspök térdel, legfelül Mária trónuson ülő alakja).

K.: -

R.: Veszpr. Reg. 190. (473. szám).

\section{1356. aug. 8. Visegrád}

Zeech-i Miklós c., [I.] Lajos király (H) országbírája és Thuruch m. c.-e a Lelez-i konventnek: korábbi idéző levele és a konvent jelentése értelmében a néhai Belus fia: Miklós fia: István Zabolch-ról Zaboch-ról köteles volt színe e. jan. 13-án (in oct. fe. Epiph. d. prox. nunc preteritis) megjelenni Byri-i Tamás ellenében, hogy perkezdet e. megfizesse a 7 időpontban megítélt bírságokból (de judiciis septem terminorum) az országbírónak járó kétharmad és a másik peres félnek járó egyharmad részt, továbbá hogy végsô választ adjon a Tamás anyjának, Zabolch-i Domokos lányának a leánynegyede, nemkülönben a Tamás nagyanyjának hozománya, valamint jegyajándéka fejében a szóban forgó Domokos birtokaiból és részbirtokaiból Tamást megilletô rész kiadása ügyében, amelyeket István vonakodott utóbbinak kiadni. A kitüzött időpontban egyik részrôl Byri-i Tamás felperes, a másik részról pedig a Miklós fia: István képviseletével a Jazou-i egyház konventjének ügyvédvalló levelében felhatalmazott Sy..... fia: Polyan megjelenvén országbírói ítélőszéke e., elóbbi kérte tôle, hogy szólítsa fel az alperest a bírság megfizetésére és a válaszadásra, azonban mert Polyan ....... a bírságot nem fizette meg, hanem — mindenféle ésszerú ok nélkül — kérte annak késóbbi időpontra halasztását, ezért a bíróság úgy határozott, hogy Miklós fia: István máj. 1-jén (in oct. fe. B. Georgii mart.) .............. köteles megjelenni az országbíró e., megfizetni a rá kirótt bírságot kétharmad részben a bírónak, egyharmad részben pedig a peres félnek, $\mathrm{s}$ akkor az ügyben végleges választ is tartozik adni. A kijelölt időpontban mindkét fél személyesen jelent meg az országbíró e., ám Miklós fia: István nehéz helyzetére való tekintettel (urgentibus ipsum quibusdam ingentibus necessaribus) kérte az országbírót, hogy késóbbi időpontban tehessen eleget a rá kirótt bírságok — összességében $42 \mathrm{M}$. — megfizetésének, minthogy sem a bíró, sem a másik fél számára járó rész megfizetésére nem képes, ugyanakkor amennyiben a jogi eljárásrend úgy kívánja, ô egy számára erre kijelölölendő időpontban kész a $42 \mathrm{M}$. bírság fejében mind a bírót, mind pedig a másik felet megilletố részt saját, a Zaboch $\sim$ Zabolch m.-i Zabolch birtokon lévő részbirtokával megfizetni. Mivel pedig szóban forgó részbirtoka becsújéhez a király és az egri kápt. emberének kiküldésére volt szükség az országbíró levelet (l...szám) intézett az egri kápt.-hoz, kérvén, hogy a kápt. adjon hites tanút Pech-i $\sim$ Pechy-i Gergely v. Nogfalu-i Gábor (Gabriel Gabrianus) v. Zonuk-i Tamás királyi emberek valamelyike mellé, akik júl. 1-jén (in oct. fe. Nat. B. Johannis Bapt.) István Zaboch birtokon elterülő birtokrészére menvén az összehívott szomszédok jelenlétében tartoztak bejárni annak határait, és látva ezen elkülönített földdarab nagyságát, minőségét, termékenységét és értékét, fogott bírák közremúködésével a királyi mértéket alkalmazva méréssel v. ha ez nem lehetséges - szemrevételezéssel kellett a kérdéses rész becsújét az ország szokása szerint elvégezniük. Ezt követően pedig a fogott bírák kötelesek voltak a felbe- 
csült birtoknak $14 \mathrm{M}$. értékú részét — azaz a $42 \mathrm{M}$. bírság peres felet illető harmadát - Byri-i Tamás részére iktatni egészen addig szólóan, amíg István v. övéi közül valaki vissza nem váltja azt tőle. Abban az esetben azonban, ha a megbecsült terület értéke nem ért volna fel a szükséges $14 \mathrm{M}$--val, akkor István köteles lett volna azt kipótolni mellette más birtokrészéból. A birtokrész bejárását, iktatását és becsújét követően az egri kápt. a történtekról számot adó írásos jelentést tartozott küldeni aug. 1-jére (ad oct. fe. B. Jacobi ap.) a királynak. E kitúzött határnapon Byry-i Tamás és Miklós fia: István személyesen járultak az országbíró ítélőszéke elé, ahol elóbbi arról számolt be, hogy az országbíró ítéletlevelében foglaltaknak, ill. bírói meghagyásának megfelelően ez elrendelt időpontban Pechy-i Gergely királyi ember az egri kápt. tanúbizonyságával együtt kimentek Zabolch birtokra, hogy elvégezzék a kérdéses rész becsújét és iktatását $14 \mathrm{M}$. értékben, és jóllehet mindez ellentmondás nélkül megtörtént, mégis, mert Pechy-i Gergely királyi ember nem tért vissza az egri kápt.-hoz jelentéstételre, így a kápt. - Gergely távolmaradása miatt — nem volt jogosult oklevelet kiállítani az iktatásról. Tamás bemutatta viszont a kápt. bizonyságlevelét arról, hogy István a maga részéról engedte és megerôsítette az ő beiktatását a Zabolch birtokon lévő 14 M.-ra becsült részén, egyszersmind kérte az országbírót, hogy hozzon ítéletet egyrészt a kifizetés és a birtokba iktatás dolgában, másrészt azzal kapcsolatban is, hogy Gergely királyi ember nem volt hajlandó visszatérni az iktatás megtörténtét megerősítő jelentéstételre a kápt.-hoz. Az országbíró mindezeket mérlegelve, a nagyobb bizonyosság érdekében másik királyi ember és a Lelez-i konvent tanújának kiküldését határozta el az ügyben. Ezért felszólítja a Lelez-i konventet, hogy Zakul-i László fia: János v. Panyalya-i János v. Zolnuk-i Tamás v. Nogfalu-i Gabrianus v. Rakamaz-i Benedek fia: Pouch királyi emberek valamelyike mellé adjon hites tanút, akik okt. 13-án (in quind. fe. B. Mychaelis arch.) Miklós fia: István Zabolch birtokon lévő részbirtokára menvén, az összehívott szomszédok jelenlétében járják be a szóban forgó birtokrész határait, különítsék el azt más birtokoktól, majd ezt követően látva nagyságát, minőségét, termékenységét és értékét, fogott bírák közremúködésével a királyi mértéket alkalmazva méréssel v. — ha ez nem lehetséges - szemrevételezéssel végezzék el a kérdéses rész becsújét az ország szokása szerint, majd a felbecsült birtoknak $14 \mathrm{M}$. értékú részét — azaz a $42 \mathrm{M}$. bírság peres felet illető harmadát - iktassák Byri-i Tamás részére békés birtoklásra egészen addig, amíg István v. övéi közül valaki azt vissza nem váltja tôle. Ha azonban a megbecsült terület értéke nem ér fel a szükséges 14 M.-val, akkor István köteles azt kipótolni más, mellette fekvő birtokrészéból. Mindezek elvégzése u. a királyi ember a konvent tanújának jelenlétében Pechy-i Gergelyt - mivel az a lebonyolított eljárást követően mint királyi ember kötelességszegő módon elmulasztotta a visszatérést az egri kápt.-hoz, hogy ott jelentést tegyen — nov. 8-ra (ad oct. fe. OO. SS.) idézzék meg Tamás ellenében a királyi jelenlét bírósága elé. Ezek u. pedig a konvent írjon mindenre kiterjedô részletes jelentést a királynak ugyancsak nov. 8-ra (ad oct. fe. OO. SS.). Arra való tekintettel, hogy Miklós fia: István a rá kirótt $42 \mathrm{M}$. bírságnak azt a kétharmadát, amely a bírót illeti, még nem fizette meg, az országbíró elrendeli, hogy István nov. 8-án a bírói kétharmad részt - mégpedig immár annak kétszeresét - fizesse meg. D. in Vissegrad, 8. die termini prenotati, a.d. 1356.

E.: D1. 51 714. (Kállay cs. 1t. 1300. 1103.) Papíron, foltokban szakadozott, hátoldalán azonos és késóbbi kéz írásával tárgymegjelölés, valamint kerek zárópecsét töredéke, bevágásai; a pecséttel lezárt hátoldali részen keresztirányban korabeli jegyzet.

Eml.: Az 550. és az 580. számú oklevélben.

K.: - 
R.: Kállay II. 37. (1190. szám).

\section{1356. aug. 8. Visegrád}

Zeech-i Miklós c., [I.] Lajos király (H) országbírája és Turuch m. c.-e a Huzyubach-i János fiainak: Miklósnak és Jánosnak a Szerém (Sirimiensis) m.-i Bodony-i Simon fia: Jánossal szemben viselt ama perét, amely korábbi oklevele értelmében aug. 1-jén (in oct. fe. B. Jacobi ap.) lett volna esedékes a Stimotha birtokon lévő bizonyos földrész beiktatásakor támadt ellentmondás tárgyában, különleges királynéi parancsból kifolyólag a királyi hadoszlás 15. napjára elhalasztja a fennálló állapot fenntartásával. D. in Wyssegrad, 8. die termini prenotati, a. d. 1356.

E.: SNA. Zay cs. ugróci lt. Krasznecz László elenchusa szerint rendezett iratok B 1. 80. G. (Df. 265 645.) Papíron, kerek zárópecsét nyomával, bevágásaival, szalagjával.

K.: -

\section{1356. aug. 8. Visegrád}

Konth Miklós nádor $(\mathrm{H})$, a kunok bírája a Chyuthnuk-i László fiainak: Miklósnak és Lászlónak Zery-i István fia: Lászlóval, valamint Zalona-i Loránd fiaival: Lászlóval, Bartaval és Istvánnal szemben indított ama perét, amely a nádor korábbi oklevele (l....szám) értelmében aug. 1-jén (in 8. fe. B. Jacobi ap.) lett volna esedékes, s amelyben elóbbiek képviseletében a Jazou-i egyház konventjének ügyvédvalló levelében meghatalmazott Zeck-i Benedek fia: István, utóbbiak helyett pedig az ugyanazon konvent ügyvédvalló levelét felmutató Mihály fia: Péter jelentek meg, a felek képviselőinek kérésére okt. 6-ra (ad oct. fe. B. Michaelis arch.) elhalasztja. D. in Wisegrad, 8. die termini prenotati, a. d. 1356.

Má.: Dl. 25 777. (Ismeretlen provenienciájú iratok) 18. sz.-i egyszerú Má.-ban; 16 old. Nro. 11.

Megj.: A Má. közli a hátoldali tárgymegjelölést is, mely a felek nevén és a halasztás időpontján kívül ezt tartalmazza: Stephanus de comitatu Tornensi non venit, Ladislaus filius pro aliis, Bartholomeus filius Lorandi de Szolna cum Jazou ad Andrea.

\section{1356. aug. 8. Gömör falu}

Gömör m. ispánja, ill. alispánja, valamint [szb.-ái] jelentik [I.] Lajos királynak (H), hogy a Sech-i Miklós c., országbíró hozzájuk intézett jún. 1-jén kiadott oklevelében ( $l$. 309. szám) foglaltak szerint eljárva, a szb.-ák közül Zelen-i Miklós c.-t küldték ki a kért vizsgálat elvégzésére, aki visszatérését követően olyan jelentést tett, miszerint aug. 7-én (die domin. prox. p. fe. vincula S. Petri ap.) kikérdezve Ragal és Kazmerteleke birtokoknak a szomszédságában és közelében lévő falvakban az értesüléssel rendelkezőket, megtudta, hogy az aradi egyház éneklőkanonokjának, Péter mr.-nek az országbíró elé terjesztett panaszában megvádolt Mihály fia: Simon azt a bizonyos Kazmerteleke birtokrészt nem szántatta fel és nem is használta, azonban Antal, egykor az aradi egyház kántorának, Péter mr.-nek a birtokán, Szubug falujában idôzve, használta Kazmerteleke földrészt. Simon tehát vétlen az előterjesztett vádakban. D. in villa Gumur, f. II. prox. an. fe. B. Laurenti mart., a. d. supradict. [1356]. 
E.: Dl. 41 287. (Múz. Ta. 1908. 8.) Papíron, melynek felső széle szakadozott, hátlapján azonos kéz írásával címzés, valamint tárgymegjelölés, továbbá 5 gyưrûs zárópecsét töredéke, szalagjai, bevágásai (az egyik pecséten kivehető egy kerék rajzolata).

Má.: 1. Uo., mint E., azzal megegyező jelzet alatt; 2 példányban, az egyik a 20. sz. elején készült egyszerú Má., a másik szintén egyszerú Má. Zsinka Ferenc aláírással.

K.: -

445. (1356.) aug. 10. Villanova közelében, avignoni egyházm.

[VI.] Ince pápa Gradonicus Jánosnak, a velenceiek dózséjának: ahogyan nemrégiben írt levelében és az apostoli szék követe, Bonjohannes fermói püspök révén tudatta a dózséval, a viszály, amely [I.] Lajos király $(\mathrm{H})$ és a dózse között dúl nyugtalanítja a pápát és különösen ártalmas a Ke-i részek miatt. A pápa királyhoz küldött követei révén a napokban értesült arról, hogy a király kész minden közöttük felmerült kérdést és földjeik feletti vitát a pápa kezébe helyezni, hogy a háborút elkerülhessék. Ezért kéri és felszólítja a dózsét, hogy megfontolva mindezeket a békének és egyetértésnek az útját ne vesse el, hanem fogadja el. Azt kéri, hogy döntsön az ügyben mielóbb, hiszen ilyen dolgokban a halogatás veszedelmes, majd válaszát írja meg és a pápa levelét hozzá vívő követ, Péter patti-i (Pactensis) püspök révén küldje el a pápának. D. apud Villamnovam, Avinionensis diocesis, IIII. Id. Aug., pápasága 4. évében [1356.].

K.: F. IX. 2. 504-505. (244. szám); Theiner II. 23-24. (38. szám); Gasnault-Gotteri (2315. szám) Mindhárom v. 238., f. 153-ra való hivatkozással, s utóbbi ezen felül v. 244 G, f. 60. ep. 546; Ljubić II. 329-330 (494. szám) (Commemorialiam V. 79-re hivatkozással).

446. (1356.) aug. 11. Villanova közelében, avignoni egyházm.

[VI.] Ince pápa [I.] Lajos királynak (H): aggodalmát fejezi ki a király és a velencei dózse között húzódó viszály miatt, s abbéli törekvésében, hogy annak bármi módon véget vessen tárgyalt a király szentszéki követével, István választott zágrábi püspökkel, aki úgy tájékoztatta, hogy a király — a béke barátjaként — kész a dózséval való békétlenség okát a pápa kezeibe helyezni és ezen felül a hadjáratot felfüggeszteni. Mindezekról a pápa a velencei dózsét levélben tájékoztatta. A mindenható Isten segedelmével történő békés megegyezés létrehozatala végett Péter patti-i püspököt küldi, kérvén a királyt, viseltessen teljes bizalommal a püspök által előadottakkal kapcsolatban. D. apud Villamnovam, Avinionensis diocesis, III. Id. Aug., pápasága 4. évében [1356.].

K.: F. IX. 2. 503-504. (243. szám); Theiner II. 25-26. (40. szám); Gasnault-Gotteri (2318. szám) Mindhárom v. 238., f. 152-re való hivatkozással.

447. (1356.) aug. 11. Villanova közelében, avignoni egyházm.

[VI.] Ince pápa [I.] Lajos királynak (H): arra kéri a királyt, akit — Isten katonájaként és az egyház bajnokaként - az eretnekek és Itália földjén az egyház lázadói ellen felruházott általános kapitányi hivatallal (officium generalis capitaneus), hogy az eretnekség vétkébe esett Ordelaffis-i Ferenc, Forlí-i polgárt (cives Forliviensis), valamint Manfredis-i 
Vilmos és János, faenza-i polgárokat (cives Faventini) - az apostoli szék követének, Egyed sabinai (sabinensis) püspöknek a tanácsát követve — támadja meg. D. apud Villamnovam, Avinionensis diocesis, III. Id. Aug., pápasága 4. évében [1356.].

Eml.: A 449. számú oklevélben.

K.: Theiner II. 26. (41. szám); Wenzel, Dipl. Eml. II. 479-480. (383. szám); Gasnault—Gotteri (2317. szám) v. 238., f. 152-re való hivatkozással.

448. (1356.) aug. 11. Villanova közelében, avignoni egyházm.

[VI.] Ince pápa [I.] Lajos királynak (H): dicsérő szavakkal illetve a királyt megemlékezik annak az eretnekek ellen vívott harcairól - a tatárok, litvánok és ruténok legyőzéséról, valamint a szerb szakadárok elleni hadjáratáról, melynek kapcsán követei révén hozzá küldött levelében (l. 315. szám) kérte a pápa támogatását -, valamint az Itáliában fenyegetố veszedelemról ( $l$. 447. szám), melyben számít a király katonai támogatására, s mindezekért megengedi, hogy a király — kit kapitányi címmel ruházott fel az egyház védelmében -, az országában befolyó egyházi tizedet 3 éven keresztül ezen célok elérésének anyagi fedezete gyanánt behajthassa és felhasználhassa. D. apud Villamnovam, Avinionensis diocesis, III. Id. Aug., pápasága 4. évében [1356.].

Reg.: ASV. Reg. Av. v. 133., f. 301r-303r (Df. 289 529.).

K.: Theiner II. 24-25. (39. szám); Gasnault-Gotteri 2316. és 2320. szám); Acta Innocenti VI. 160-163. (86. szám) 164-167. (87. szám) (utóbbi tévesen aug. 13-ra keltezve) v. 238., f. 150r-185r-185v-ra való hivatkozással, valamint Gasnault-Gotteri kiadásában további hivatkozás v. 244 G, f. 91, ep. 624.

R.: Áldásy 42. (234. szám); Áldásy A., TT. 18 (1895) 83. (234. szám).

449. (1356.) aug. 11. Villanova közelében, avignoni egyházm.

[VI.] Ince pápa meghagyja a kalocsai érseknek és suffraganeus-ainak, valamint az esztergomi érseknek és suffraganeus-ainak, hogy a fenti levelében leírtaknak megfelelően járjanak el az egyházi tized dolgában. D. apud Villamnovam, Avinionensis diocesis, III. Id. Aug., pápasága 4. évében [1356.].

Reg.: ASV. Reg. Av. v. 133., f. 302r (Df. 289 529).

K.: Gasnault-Gotteri 2321. szám); Acta Innocenti VI. 167-169. (88. szám) (utóbbi tévesen aug. 13-ra keltezve) v. 239, f. 187v; valamint Gasnault-Gotteri kiadásában további hivatkozás v. 244 G, f. 60, ep. 546; f. 90, ep. 623-ra való hivatkozással.

R.: Áldásy 42. (235. és 236. szám); Áldásy A., TT. 18 (1895) 83. (235. és 236. szám).

450. 1356. aug. 13.

[A turóci konvent] e. .......egyik részről Máté, a másik részrôl $\mathrm{M}[\mathrm{yke}]$....... személyesen, ....... András, ....... fia: Benedek nevében ügyvédvalló levélben meghatalmazva, hasonlóképpen Laczk a maga, valamint fivérei (fr. uterinus), Zelnichefeu-i Márton fiai: Márk és ....... nevében ügyvédvalló levéllel eljárva kinyilvánítják, hogy fogott bírák ítélete alapján a közöttük lévő [földdel kapcsolatos] peres ügyben a vitás határokat 
illetôen olyan egyezségre jutottak, amely szerint a havasok felóli (a parte alpium) [részt] a mondott Miklósnak és Máténak, a Dé-ről lévőt Myke-nek, Andrásnak, Benedeknek, Laczk-nak és fivéreinek engedték át a javaikból örök birtoklásra anélkül, hogy bárki ellentmondott volna. A föld és erdő hj.-a: az első határjel út mentén, Ke-re a Thornoucz-i népek földjénél gyümölcsfa alatt földjel, Ny felé megkerüli az Okolpotok forrását (capud), egyenesen Ny felé tartva leereszkedik egy patak forrásához, ott zilfa fa, át a patakon Malchek rét alsó széléhez (finis), ott földjel, a patakban Dé felé ereszkedik, cserjés, hévíz forrása, másik cserjés, Ny felé egy malom árkához, ezen át eléri a Zelniche folyót, ahol a határ lezárul. A konvent a felek kérésére függőpecsétjével megerősített oklevelet ad ki. D. sabb. prox. p. fe. B. Laurentii mart., a. d. 1356.

E.: $\quad$ Dl. 41 288. (Múz. Ta. Majláth) Hártyán, melynek felső része szakadt, alján a turóci konvent hártyaszalagon függő töredezett szélü pecsétje (a pecsétképen kivehető Szűz Mária trónuson ülő, koronás alakja oldalról, amint a toga-szerû́ ruhát viselő, nagyobbacska gyermek Jézust, magával szembefordítva, kezében tartja; körirata: +S(IGILLVM) CO[(N)VENTVS B(EA)TE M(ARIE) D(E) CAST(RO) T]VRVC).

Má.: ŠA. v Bytči Mattyasovszky cs. 1t. 45287. (Df. 268 763.); 18. sz.-i egyszerú Má.-ban; kizárólag az E. hátoldalán szereplő információkat tartalmazza.

K.: -

Megj.: Má. az E. hátoldalán található, késóbbi kéz írásával készült határjárást tartalmazza, valamint alsó és felső Mattyassocz területének a Má., ill. az E. hátoldali információjának írásakor meglévő határait, korabeli (18. sz.-i) nevekkel. Írásképük és névalakjaik megegyeznek. E. hátoldalán — jobb felől - egy másik kéz írásával ugyancsak olvasható egy töredékes hj.

\section{1356. aug. 13. [Ó-]Fehértó}

Cantor (dict.) Bereck Zabolch-i alispán és a m. szb.-i emlékezetül adják, hogy miután Semien-i Lengel (dict.) János fia: László mr. megfizette azt a nekik járó 4 ft. békebírságot, amely a Kallo-i Iwan fia: Demeter mr.-rel szemben - részint e Demeter mr. serviensének, Andrásnak az elfogása, és Demeter rovására elkövetett más jogtalanságok miatt

— fennforgó ügy kapcsán illette meg őket, felmentik ót minden további követelés alól.

D. in Feyrtho, sabb. prox. an. fe. Ass. virg. glor., a. d. 1356.

E.: Dl. 51 715. (Kállay cs. lt. 1300. 1132.) Papíron, hátoldalán 3 rányomott pecsét töredéke, kivehetô pecsétképpel.

K.: AO. VI. 497. (312. szám).

R.: Kállay II. 37-38. (1191. szám); Piti F., Szabolcs m. 133. (519. szám).

452. 1356. aug. 14 .

A Scepus-i Szt. Márton-egyház kápt.-ja jelenti [I.] Lajos királynak (H): miután megkapták a király itt átírt márc. 24-én kelt oklevelét (l.138. szám), az abban foglaltaknak eleget téve tanúul adták a kért vizsgálat lefolytatásához Lászlót, kanonoktársuknak, Tamás mr.-nek a klerikusát Zedlych-i Vörös (Rufus) László királyi ember mellé, akik visszatérve jelentették, hogy aug. 8-án és 9-én (f. II et III. prox. p. quind. fe. B. Jacobi ap.) nyíltan és titokban kikérdeztek mindenkit az értesüléssel rendelkezók köréból, ti. Jazou, 
Scepsy és Macronch birtok szomszédait, különösképpen pedig Felnemethy-i János fia: Miklóst, Pomaerus [?] (dict.) István fia: Péter mr. Bodolo-i officialis-át. A vizsgálat eredményeként megtudták, hogy a Scepsy-i bíró, az esküdtek és a polgárok v. hospes-ek 3 éve [1354.] jún. 3. [?] (f. III. prox. p. fe. Penth. cuius iam tertia preterisset revolutio annualis) Pált, a Jazou-i konvent erdejének famulus-át és őrét — akire a konvent a mondott egyház, ill. monostor erdejének őrzését és védelmezését bízta - , amiatt hogy Pál a favágóktól (secator, desolator) nem többet, mint mindösze 2 fejszét elvett zálogul (pro vadio) az ország szokása szerint, a monostor Jazou birtokának jogszolgáltatói révén (per justiciarios) elfogatták, és fogságában 15 napon át folyamatosan a nyakához, lábaihoz és kezeihez erôsített vasbéklyóban (ferramentum) tartatták. Ezenfelül pedig azt akarták, hogy [1356.?] jún. 9-én (f. V. prox. an. ipsum fe. Penth iam prox. preteritum) a monostor officialis-át, Jakabot - aki éppen ekkor....... férfiak és asszonyok társaságában, közöttük Miklós testvér Jazou-i prépost leánytestvérének fiával, Col (dict.) Miklóssal, nemkülönben a prépost sógorával (sororius) együtt Jazou-ról Váradra, Szt. László sírjához indult zarándoklatra búnbocsánatért - , a Bo[dolo-i] officialis Felnemethy-i János fia: Miklós Ma[c]ronch falu határában fogja el, mivelhogy Jakab a Jazou-i monostor mondott erdejében az erdőirtásért zálogot vett tôlük (ipsis vadium recepisset). János fia: Miklós visszaidézte, hogy Jakab és társai zarándokok voltak, és ártatlannak találta óket az említett Scepsy-i bíró s az ottani esküdtek és hospesek által ellenük felhozott vádjakban, ezért nem volt hajlandó elfogatni óket. A bíró, az esküdtek és a hospes-ek azonban Jakabot és társait önhatalmúlag mégis elfogták, és Miklós prépost nóvérének fiát, Col Miklóst, továbbá a prépost sógorát, Nicho-t jól helybenhagyták (fortiter percussos), majd megfosztván ôket dolgaiktól, Scepsy királyi birtok határában szabadon engedték mindet; kivéve Jakabot, akit hátrakötött kézzel, a monostor jogsérelmére bevittek Scepsy birtokra, és ha Torna-i János mr. fiai: László és Egyed mr.-ek, valamint Sarno-i Kathay (dict.) Miklós fiai: Deseu és János nem járnak közbe érdekében, továbbá ha Miklós prépost - nem önszántából, hanem féltében a kényszernek engedve — bizonyos kikényszerített megegyezés formájában nem engedi meg a Scepsy-i hospes-eknek az említett erdő használatát, akkor Jakab officialis-t kétségkívül mint valami gonosztevőt kerékbe törik (rotare seu in rotis tormentare tamquam latronem). D. die domin. prox. p. dictas quind. fe. B. Jacobi ap., a. d. prenotato [1356.]

E.: SNA. Jászói prépostság mlt. Oklevelek és iratok 36. (Df. 232 799.) Papíron, hátoldalán azonos kéz írásával címzés és tárgymegjelölés, valamint kerek zárópecsét töredéke, bevágásai.

K.: -

\section{3. (1356.) aug. 18. Villanova közelében, avignoni egyházm.}

[VI.] Ince pápa [I.] Lajos királynak (H): meghallgatva Egyed vincenzai püspök eléje terjesztett panaszát, mely szerint - kevés kivételtól eltekintve - megfosztották ót vincenzai egyházához tartozó javaitól és jogaitól, kéri a királyt, hogy eleget téve a püspök kérésének, nyújtsa neki segítő jobbját és támogassa javai és jogai visszaszerzésében. D. apud Villamnovam, Avinionensis diocesis, XV Kal. Sept., pápasága 4. évében [1356.].

K.: Theiner II. 26. (42. szám); Gasnault-Gotteri 2327. szám v. 238 f., 161-re, s utóbbi ezen felül még v. 244 F, f. 125, ep. 313-ra hivatkozással.

R.: Áldásy 43. (239. szám); Áldásy A., TT. 18 (1895) 84. (239. szám) v. 244 F, f. 125, ep. 313-ra hivatkozással. 


\section{4. (1356.) aug. 18. Villanova közelében, avignoni egyházm.}

[VI.] Ince pápa [I.] Lajos királynak (H): a pápa megemlékezvén arról a levelélról, mely a király azon tervét tartalmazza, miszerint félreesóbb részeken küzd az eretnekek ellen, akiket saját országában figyelmen kívül hagy. Ezért a pápa inti, kéri és arra buzdítja a királyt, hogy Boszniából és országa más részeiből is űzze el az eretnekséget. D. apud Villamnovam Avinionensis diocesis XV Kal. Sept., pápasága 4. évében [1356.].

K.: Theiner II. 27. (43. szám); Acta Innocentii VI. 169-170. (89. szám) (tévesen aug. 16ra keltezve); Gasnault_Gotteri 2328. szám v. 238 f. 161-re, s utóbbi ezen felül még v. 244 G, f. 63, ep. 555-re hivatkozással.

R.: Áldásy 42-43. (237. szám); Áldásy A., TT. 18 (1895) 84. (237. szám) v. 244 G, f. 63, ep. 555-re hivatkozással.

455. (1356.) aug. 18. Villanova közelében, avignoni egyházm.

[VI.] Ince pápa [I.] Lajos királynak (H): a pápa kéri és buzdítja Krisztus valamennyi hívét, hogy imádkozzanak a Szerbia országában élő eretnekek ellen küzdő [I.] Lajos király (H) győzelméért, hosszú életéért és hogy a Mindenható örvendeztesse meg utódokkal, amiért cserébe 40 napi búnbocsánatot ígér (quadraginta dies de injunctis vobis penitentiis). D. apud Villamnovam Avinionensis diocesis XV Kal. Sept., pápasága 4. évében [1356.].

K.: Theiner II. 27. (44. szám); Wenzel, Dipl. Eml. II. 480-481. (384. szám); Gasnault—Gotteri 2329. szám v. 238., f. 162; v. 244. G, f. 64, ep. 557. alapján.

R.: Áldásy 43. (238. szám); Áldásy A., TT. 18 (1895) 84. (238. szám) v. 244. G, f. 64, ep. 557-re hivatkozással.

\section{1356. aug. 18. Visegrád}

[I.] Lajos király $(\mathrm{H})$ tudatván a Lelez-i konventtel a színe e. Tyba-i Lőrinc fiainak: Györgynek és Lászlónak a panaszából szerzett azon értesülését, amely szerint júl. 1-jén (f. VI. prox. p. fe. Nat. B. Johannis Bapt.) Noghmihal-i Jakou fia: János Makzey nevú Jezeneui jobbágyukat Noghmihal faluban saját kezúleg megverte és megsebesítette, jóllehet György és János között per van függóben, utasítja a címzettet, hogy Lőrinc fia: János v. Dezsố v. Lukács ill. Pál — mind Korchwa-iak —, v. pedig Nempti-i Dénes fia: László királyi emberek valamelyikével küldje ki saját emberét hites tanúul az ismertetett panasz kivizsgálására, majd ennek eredményét jelentsék írásban számára. D. in Wyssegrad, 4. die fe. Assump. B. virg., a. d. 1356.
Á.: Az 538. számú oklevélben.
K.: Sztáray I. 255. (148. szám).

\section{1356. aug. 18. Visegrád}

[I.] Lajos király $(\mathrm{H})$ tudatván Vngh m. c.-ével, alispánjával és a m. 4 szb.-ájával a színe e. Tyba-i Lőrinc fiainak: Györgynek és Lászlónak a panaszából szerzett azon értesülését, 
amely szerint júl. 1-jén (f. VI. prox. p. fe. Nat. B. Johannis Bapt.) Nogmihal-i Jakou fia: János Makzey nevú Jezeneu-i jobbágyukat Noghmihal faluban saját kezúleg megverte és megsebesítette, jóllehet György és János között per van függóben, utasítja a címzetteket, hogy küldjenek ki 2 szb.-át a panasz kivizsgálására, majd ennek eredményét jelentsék írásban számára. D. in Wyssegrad, 4. die fe. Assump. B. virg., a. d. 1356.

Á.: A 634. számú oklevélben.

K.: Sztáray I. 256. (149. szám). Jóllehet a kiadó teljesen egyezőnek mondja a királyi parancsot a 255. oldalon, 148. szám alatt közölt, a leleszi konventhez intézett királyi paranccsal, a két átírt oklevél nem teljesen azonos (eltérés a Nogmihal névalak és a vizsgálat elvégzésével megbízottak személye).

458. (1356.) aug. 19. Villanova közelében, avignoni egyházm.

[VI.] Ince pápa Miklós [fia:] Jánosnak, az erdélyi egyházm. klerikusának — a pápához eljutott szavahihető tanúságtételek alapján, melyekben János érdemeirôl számoltak be - különös kegyként a....... [Domokos] erdélyi püspök collatio-jához tartozó egyházi beneficium-ot szándékszik juttatni, s ezért jelen oklevélben a majdani megüresedésig számára rezerválja azt, mely javadalom évenként nem lépheti túl lélekgondozással (cum cura) a 25, anélkül (sine cura) a 18 ezüst M.-át. D. apud Villamnovam, Avinionensis diocesis, XIIII. Kal. Sept., pápasága 4. évében [1356.].

Reg.: ASV. Reg. Av. v. 132., f. 263v (Df. 289 512.).

R.: Áldásy 43. (240. szám); Áldásy A., TT. 18 (1895) 84. (240. szám); Doc. Rom. Hist. C. XI. 33. (35. szám) (románul); Erd. Okm. III. 309. (850. szám) (Reg. alapján).

459. (1356.) aug. 19. Villanova közelében, avignoni egyházm.

[VI.] Ince pápa tájékoztatja az esztergomi egyházm.-i [!] Closmonustra-i monostor apátját, a váradi prápostot és az avignoni Szt. Agricola-egyház dékánját az előző oklevélben (l. 458. szám) foglalt rezervációról és kéri, hogy ha alkalmas javadalom üresedik meg, akkor a megnevezett Jánost vezessék abba be. D. ut supra [D. apud Villamnovam, Avinionensis diocesis, XIIII. Kal. Sept., pápasága 4. évében [1356.]].

Megj.: Apparátusa megegyezik a 458. számú oklevélével.

\section{0. (1356.) aug. 19. Villanova közelében, avignoni egyházm.}

[VI.] Ince pápa Fehérvári (de Albaregali) Jakab [fia:] Istvánnak, a veszprémi egyházm. presbiterének - a pápához eljutott szavahihetô tanúságtételek alapján, melyekben István érdemeiról számoltak be - különös kegyként a....... [székes-]fehérvári prépost collatiojához tartozó egyházi beneficium-ot szándékszik juttatni, s ezért jelen oklevélben a majdani megüresedésig számára rezerválja azt, mely javadalom évenként nem lépheti túl lélekgondozással (cum cura) a 25, anélkül (sine cura) a 18 ezüst M.-át. D. apud Villamnovam, Avinionensis diocesis, XIIII. Kal. Sept., pápasága 4. évében [1356.].

Reg.: ASV. Reg. Av. v. 132., f. 368r-v (Df. 289 513.). 
K.: Vespr. II. 168. (194. szám) (kivonatos) aug. 24-re keltezve a bejegyzést, ennek oka a dátumban szereplő XIIII téves olvasata VIIII.

R.: Áldásy 43. (241. szám); Áldásy A., TT. 18 (1895) 84. (241. szám) (Reg. alapján).

461. (1356.) aug. 19. Villanova közelében, avignoni egyházm.

[VI.] Ince pápa tájékoztatja a veszprémi püspököt, a veszprémi egyházm.-i óbudai prépostot és az avignoni egyház sekrestyéjét az előző oklevélben ( $l$. 460. szám) foglalt rezervációról és kéri, hogy ha alkalmas javadalom üresedik meg, akkor a megnevezett Istvánt vezessék abba be. D. ut supra [D. apud Villamnovam, Avinionensis diocesis, XIIII. Kal. Sept., pápasága 4. évében [1356.]].

Megj.: Apparátusa megegyezik a 460. számú oklevélével.

\section{2. (1356.) aug. 19. Villanova közelében, avignoni egyházm.}

[VI.] Ince pápa Diacus-i Benedek [fia:] Domokosnak, a boszniai egyházm. klerikusának - a pápához eljutott szavahihető tanúságtételek alapján, melyekben Domokos érdemeiról számoltak be - különös kegyként a kalocsai érsek collatio-jához tartozó egyházi beneficium-ot szándékszik juttatni, s ezért jelen oklevélben a majdani megüresedésig számára rezerválja azt, mely javadalom évenként nem lépheti túl lélekgondozással (cum cura) a 25, anélkül (sine cura) a 18 ezüst M.-át. D. apud Villamnovam, Avinionensis diocesis, XIIII. Kal. Sept., pápasága 4. évében [1356.].

Reg.: ASV. Reg. Av. v. 132., f. 371v (Df. 289 514.).

R.: Áldásy 43. (242. szám); Áldásy A., TT. 18 (1895) 85. (242. szám) (Reg. alapján).

463. (1356.) aug. 19. Villanova közelében, avignoni egyházm.

[VI.] Ince pápa tájékoztatja a boszniai és a szerémi püspököket, valamint az avignoni Szt. Agricola-egyház dékánját aelőző oklevélben (l. 462. szám) foglalt rezervációról és kéri, hogy ha alkalmas javadalom üresedik meg, akkor a megnevezett Domokost vezessék abba be. D. ut supra [D. apud Villamnovam, Avinionensis diocesis, XIIII. Kal. Sept., pápasága 4. évében [1356.]].

Megj.: Apparátusa megegyezik a 462. számú oklevélével.

\section{4. (1356.) aug. 19. Villanova közelében, avignoni egyházm.}

[VI.] Ince pápa Radcha-i Kozma [fia:] Mártonnak, a zágrábi egyházm. klerikusának — a pápához eljutott szavahihető tanúságtételek alapján, melyekben Márton érdemeiről számoltak be - különös kegyként a zágrábi püspök collatio-jához tartozó egyházi beneficium-ot szándékszik juttatni, s ezért jelen oklevélben a majdani megüresedésig számára rezerválja azt, mely javadalom évenként nem lépheti túl lélekgondozással (cum cura) a 25, anélkül (sine cura) a 18 ezüst M.-át. D. apud Villamnovam, Avinionensis diocesis, XIIII. Kal. Sept., pápasága 4. évében [1356.].

Reg.: ASV. Reg. Av. v. 133., f. 32r-v (Df. 289 520.). 
R.: Áldásy 43-44. (243. szám); Áldásy A., TT. 18 (1895) 85. (243. szám) (Reg. alapján).

465. (1356.) aug. 19. Villanova közelében, avignoni egyházm.

[VI.] Ince pápa tájékoztatja a zágrábi egyházm.-i zágrábi és csázmai prépostot, és az avignoni Szt. Agricola-egyház dékánját az előző oklevélben (l.464. szám) foglalt rezervációról és kéri, hogy ha alkalmas javadalom üresedik meg, akkor a megnevezett Mártont vezessék abba be. D. ut supra [D. apud Villamnovam, Avinionensis diocesis, XIIII. Kal. Sept., pápasága 4. évében [1356.]].

Reg.: ASV. Reg. Av. v. 133., f. 32v (Df. 289 520.).

R.: Áldásy 43-44. (243. szám); Áldásy A., TT. 18 (1895) 85. (243. szám) (Reg. alapján).

466. (1356.) aug. 19. Villanova közelében, avignoni egyházm.

[VI.] Ince pápa a néhai Miklós fia Jakabtól származó Miklós [fia:] Tamásnak (Thome Nicolai nata quondam Jacobi Nicolai), a pécsi egyházm. klerikusának - a pápához eljutott szavahihető tanúságtételek alapján, melyekben Tamás érdemeiről számoltak be — különös kegyként a....... [Kálmán] győri püspök collatio-jához tartozó egyházi beneficium-ot szándékszik juttatni, s ezért jelen oklevélben a majdani megüresedésig számára rezerválja azt, mely javadalom évenként nem lépheti túl lélekgondozással (cum cura) a 25, anélkül (sine cura) a 18 ezüst M.-át. D. apud Villamnovam, Avinionensis diocesis, XIIII. Kal. Sept., pápasága 4. évében [1356.].

Reg.: ASV. Reg. Av. v. 133., f. 34r-v (Df. 289 521.).

R.: Áldásy 44. (244. szám); Áldásy A., TT. 18 (1895) 85. (232. szám) (Reg. alapján).

467. (1356.) aug. 19. Villanova közelében, avignoni egyházm.

[VI.] Ince pápa tájékoztatja a Keresztelő Szt. János-egyház prépostját, a pécsi főesp.-t és az avignoni Szt. Agricola-egyház dékánját az előző oklevélben (l. 466. szám) foglalt rezervációról és kéri, hogy ha alkalmas javadalom üresedik meg, akkor a megnevezett Tamást vezessék abba be. D. ut supra [D. apud Villamnovam, Avinionensis diocesis, XIIII. Kal. Sept., pápasága 4. évében [1356.]].

Reg.: ASV. Reg. Av. v. 133., f. 34v (Df. 289 521.).

\section{8. (1356.) aug. 19. Villanova közelében, avignoni egyházm.}

[VI.] Ince pápa Ábrahám [fia:] Miklósnak, a zágrábi egyházm. klerikusának — a pápához eljutott szavahihető tanúságtételek alapján, melyekben Miklós érdemeiról számoltak be - különös kegyként a veszprémi egyházm.-i budai egyház prépostjának collatio-jához tartozó egyházi beneficium-ot szándékszik juttatni, s ezért jelen oklevélben a majdani megüresedésig számára rezerválja azt, mely javadalom évenként nem lépheti túl lélekgondozással (cum cura) a 25, anélkül (sine cura) a 18 ezüst M.-át. D. apud Villamnovam, Avinionensis diocesis, XIIII. Kal. Sept., pápasága 4. évében [1356.].

Reg.: ASV. Reg. Av. v. 133., f. 40r-v (Df. 289 523.). 
R.: Áldásy 44. (246. szám); Áldásy A., TT. 18 (1895) 85. (246. szám) (Reg. alapján).

469. (1356.) aug. 19. Villanova közelében, avignoni egyházm.

[VI.] Ince pápa tájékoztatja a zágrábi egyházm.-i zágrábi és csázmai prépostot, és az avignoni Szt. Agricola-egyház dékánját az előző oklevélben (l.468. szám) foglalt rezervációról és kéri, hogy ha alkalmas javadalom üresedik meg, akkor a megnevezett Miklóst vezessék abba be. D. ut supra [D. apud Villamnovam, Avinionensis diocesis, XIIII. Kal. Sept., pápasága 4. évében [1356.]].

Reg.: ASV. Reg. Av. v. 133., f. 40v (Df. 289 523.).

R.: Áldásy 44. (246. szám); Áldásy A., TT. 18 (1895) 85. (246. szám) (Reg. alapján).

\section{0. (1356.) aug. 19. Villanova közelében, avignoni egyházm.}

[VI.] Ince pápa Gergely [fia:] Sándornak, a pécsi egyházm. klerikusának - a pápához eljutott szavahihető tanúságtételek alapján, melyekben Sándor érdemeiről számoltak be - különös kegyként az esztergomi egyházm.-i pozsonyi egyház prépostjának a collatio-jához tartozó egyházi beneficium-ot szándékszik juttatni, s ezért jelen oklevélben a majdani megüresedésig számára rezerválja azt, mely javadalom évenként nem lépheti túl lélekgondozással (cum cura) a 25, anélkül (sine cura) a 18 ezüst M.-át. D. apud Villamnovam, Avinionensis diocesis, XIIII. Kal. Sept., pápasága 4. évében [1356.].

Reg.: ASV. Reg. Av. v. 133., f. 60v (Df. 289 524.).

R.: Áldásy 44. (247. szám); Áldásy A., TT. 18 (1895) 85-86. (247. szám) (Reg. alapján).

471. (1356.) aug. 19. Villanova közelében, avignoni egyházm.

[VI.] Ince pápa tájékoztatja a veszprémi és nyitrai püspököket, valamint az avignoni Szt. Agricola-egyház dékánját az előző oklevélben (l.470. szám) foglalt rezervációról és kéri, hogy ha alkalmas javadalom üresedik meg, akkor a megnevezett Sándort vezessék abba be. D. ut supra [D. apud Villamnovam, Avinionensis diocesis, XIIII. Kal. Sept., pápasága 4. évében [1356.]].

Reg.: ASV. Reg. Av. v. 133., f. 60v-r (Df. 289 524.).

R.: Áldásy 44. (247. szám); Áldásy A., TT. 18 (1895) 85-86. (247. szám) (Reg. alapján).

\section{2. (1356.) aug. 19. Villanova közelében, avignoni egyházm.}

[VI.] Ince pápa Patha-i János [fia:] Miklósnak, a veszprémi egyházm.-i budai egyház kanonokjának - a pápához eljutott szavahihető tanúságtételek alapján, melyekben Miklós életéról és érdemeiról számoltak be - különös kegyként a veszprémi egyházm.-i budai egyházban lévő alszerpapi és papi prebendák közül (prebende subdiaconales et sacerdotales) papi prebendát rezervál számára teljes jogával és minden bevételével. Ezzel kapcsoltban figyelmezteti a veszprémi püspököt, valamint a szóban forgó egyház kápt.ját és prépostját - akikhez a collatio tartozik —, hogy ne cselekedjenek rezerválása ellenében, s a prebenda megüresedésétôl számított 1 hónapon belül vezessék be 
abba Miklóst v. megbízottját (procurator); Miklós pedig, amint részesül a neki juttatott javadalomból, köteles az addig kezén lévő alszerpapi prebendájától megválni. D. apud Villamnovam, Avinionensis diocesis, XIIII. Kal. Sept., pápasága 4. évében [1356.].

Reg.: ASV. Reg. Av. v. 134., f. 322r-v (Df. 289 537.).

K.: Vespr. II. 168-169. (195. szám) (kivonatos) aug. 24-re keltezve a bejegyzést, ennek oka a dátumban szereplő XIIII téves olvasata VIIII.

R.: Áldásy 44. (248. szám); Áldásy A., TT. 18 (1895) 86. (248. szám) (Reg. alapján).

\section{3. (1356.) aug. 19. Villanova közelében, avignoni egyházm.}

[VI.] Ince pápa tájékoztatja az esztergomi érseket, a zágrábi egyházm.-i csanádi prépostot és az avignoni egyház sekrestyéjét az előző oklevélben (l. 472. szám) foglalt rezervációról és kéri, hogy ha alkalmas javadalom üresedik meg, akkor a megnevezett Miklóst vezessék abba be. D. ut supra [D. apud Villamnovam, Avinionensis diocesis, XIIII. Kal. Sept., pápasága 4. évében [1356.]].

Megj:: Apparátusa megegyezik a 472. számú oklevélével.

\section{4. (1356.) aug. 19. Villanova közelében, avignoni egyházm.}

[VI.] Ince pápa Thomenouch-i Dénes [fia:] Jánosnak, a pécsi egyházm.-i Posaga-i Szt. Péter-egyház kanonokjának - a pápához eljutott szavahihető tanúságtételek alapján, melyekben János életérôl és érdemeirôl számoltak be — különös kegyként a pécsi egyházm.i Posaga-i Szt. Péter-egyházban kanonokságot rezervál számára teljes joggal és az abból származó jövedelmet és prebendát. Ezzel kapcsoltban figyelmezteti a szóban forgó egyház illetékeseit, hogy ne cselekedjenek rezerválása ellenében, s a prebenda megüresedésétól számított 1 hónapon belül vezessék be abba Jánost v. megbízottját (procurator); János pedig, amint részesül a neki juttatott javadalomból, köteles az addig kezén lévő javadalmától megválni. D. apud Villamnovam, Avinionensis diocesis, XIIII. Kal. Sept., pápasága 4. évében [1356.].

Reg.: ASV. Reg. Av. v. 134., f. 323r-v (Df. 289 537.).

R.: Áldásy 45. (249. szám); Áldásy A., TT. 18 (1895) 86. (249. szám) (Reg. alapján).

\section{5. (1356.) aug. 19. Villanova közelében, avignoni egyházm.}

[VI.] Ince pápa tájékoztatja a kalocsai érseket, a boszniai püspököt és az avignoni Szt. agricola-egyház dékánját az előző oklevélben (l. 474. szám) foglalt rezervációról és kéri, hogy ha alkalmas javadalom üresedik meg, akkor a Jánost vezessék abba be. D. ut supra [D. apud Villamnovam, Avinionensis diocesis, XIIII. Kal. Sept., pápasága 4. évében [1356.]].

Reg.: ASV. Reg. Av. v. 134., f. 323v -324r (Df. 289 537.).

R.: Áldásy 45. (249. szám); Áldásy A., TT. 18 (1895) 86. (249. szám) (Reg. alapján). 
476. (1356.) aug. 19. Villanova közelében, avignoni egyházm.

[VI.] Ince pápa Dyacus-i Tamás [fia:] Barnabásnak, az esztergomi egyházm.-i szepesi egyház kanonokjának - a pápához eljutott szavahihető tanúságtételek alapján, melyekben Barnabás érdemeiről számoltak be - különös kegyként az esztergomi egyházm.-i szepesi egyházban kanonokságot rezervál számára teljes joggal és az abból származó jövedelmet és prebendát. Ezzel kapcsoltban figyelmezteti az esztergomi érseket, ...... prépostot, a kápt.-t és szóban forgó egyház illetékeseit — akikhez a collatio tartozik —, hogy ne cselekedjenek rezerválása ellenében, s a prebenda megüresedésétől számított 1 hónapon belül vezessék be abba Barnabást v. megbízottját (procurator); Barnabás pedig, amint részesül a neki juttatott javadalomból, köteles az addig kezén lévő javadalmától megválni. D. apud Villamnovam, Avinionensis diocesis, XIIII. Kal. Sept., pápasága 4. évében [1356.].

Reg.: ASV. Reg. Av. v. 134., f. 325r-v (Df. 289 538.).

R.: Áldásy 45. (250. szám); Áldásy A., TT. 18 (1895) 86. (250. szám) (Reg. alapján).

\section{7. (1356.) aug. 19. Villanova közelében, avignoni egyházm.}

[VI.] Ince pápa tájékoztatja a konstantinápolyi pátriárkát, az egri- és a boszniai püspököt az előző oklevélben (l. 476. szám) foglalt rezervációról és kéri, hogy ha alkalmas javadalom üresedik meg, akkor Barnabást vezessék abba be. D. ut supra [D. apud Villamnovam, Avinionensis diocesis, XIIII. Kal. Sept., pápasága 4. évében [1356.]].

Reg.: ASV. Reg. Av. v. 134., f. 325v-326r (Df. 289 538.).

R.: Áldásy 45. (250. szám); Áldásy A., TT. 18 (1895) 86. (250. szám) (Reg. alapján).

478. (1356.) aug. 20. Villanova közelében, avignoni egyházm.

[VI.] Ince pápa Urbán [fia:] Domokosnak, a pécsi egyházm. klerikusának — a pápához eljutott szavahihetô tanúságtételek alapján, melyekben Domokos érdemeiról számoltak be — különös kegyként a pécsi püspöknek a collatio-jához tartozó egyházi beneficiumot szándékszik juttatni, s ezért jelen oklevélben a majdani megüresedésig számára rezerválja azt, mely javadalom évenként nem lépheti túl lélekgondozással (cum cura) a 25, anélkül (sine cura) a 18 ezüst M.-át. D. apud Villamnovam, Avinionensis diocesis, XIII. Kal. Sept., pápasága 4. évében [1356.].

Reg.: ASV. Reg. Av. v. 133., f. 37r-v (Df. 289 522.).

R.: Áldásy 44. (245. szám); Áldásy A., TT. 18 (1895) 85. (245. szám) Reg. alapján; tévesen aug. 19-re datálva.

\section{9. (1356.) aug. 20. Villanova közelében, avignoni egyházm.}

[VI.] Ince pápa tájékoztatja a zágrábi és boszniai püspököket, valamint az avignoni egyház sekrestyéjét az előző oklevélben (l. 478. szám) foglalt rezervációról és kéri, hogy ha alkalmas javadalom üresedik meg, akkor a megnevezett Domokost vezessék abba be. D. ut supra [D. apud Villamnovam, Avinionensis diocesis, XIII. Kal. Sept., pápasága 4. évében [1356.]]. 
Reg.: ASV. Reg. Av. v. 133., f. 37v (Df. 289 522.).

R.: Áldásy 44. (245. szám); Áldásy A., TT. 18 (1895) 85. (245. szám) Reg. alapján; tévesen aug. 19-re datálva.

480. (1356.) aug. 21. Villanova közelében, avignoni egyházm.

[VI.] Ince pápa [I.] Lajos király (H) pártfogásába ajánlja a Szentszék követeit, Péter pattii (Pactensis), és Vilmos sisipolitani (Sisipolitanus) püspököt, akiket bizonyos ügyben a romániai részekre (ad partes Romanie) küldött. D. apud Villamnovam Avinionensis diocesis XII. Kal. Sept., pápasága 4. évében [1356.].

K.: Gasnault-Gotteri 2335. szám Reg. Vat. v. 238., f. 162'; v. 244 F, f. 126, ep. 314.-re hivatkozással.

R.: Áldásy 45. (251. szám); Áldásy A., TT. 18 (1895) 86. (251. szám) v. 244 F, f. 126, ep. 314.-re hivatkozással.

481. (1356.) aug. 21. Villanova közelében, avignoni egyházm.

[VI.] Ince pápa meghallgatva István választott zágrábi püspök kérését, engedélyezi, hogy István zágrábi püspökké való felszentelését - melyről korábbi oklevelében ( $l$. 431. szám) értesítette a címzettet - Húsvét vasárnapra [1357. ápr. 9.] (ad fe. Resurrectionis domin.) elhalasszák. Azonban István ez idő alatt is köteles az egyház irányításáról gondoskodni, hogy az ne szenvedjen sérelmet a késedelem miatt sem lelkiekben, sem anyagiakban. D. apud Villamnovam, Avinionensis diocesis, VIII. Kal. Sept., pápasága 4. évében [1356.].

Reg.: ASV. Reg. Av. v. 133., f. 261v (Df. 289 527.).

R.: Áldásy 45. (252. szám); Áldásy A., TT. 18 (1895) 86. (252. szám) (Reg. alapján).

482. (1356. aug. 22. - okt. 6. között)

Zeech- Miklós országbíró az Erzsébet királyné és Vilmos bíboros között Moniorous és Taath birtok elválasztása során utóbbi fél részérôl támasztott ellentmondás ügyében aug. 22-re elrendelt oklevél-bemutatást okt. 6-ra halasztja.

Eml.: Az 529. számú oklevélben.

K.: -

Megj:: Az oklevél keltezésének fenti idóbeli határok közé tételét az Eml. oklevélben az iratok bemutatására első ízben kijelölt időpont, majd a bemutatás elhalasztására kitúzött határnap adta.

483. 1356. aug. 24. Knin

Balázs testvér, knini püspök e. a néhai Helye fiai: Glauogoztius és Domaldus a maguk és fiaik nevében, s velük együtt unokáik: Horuatinus, valamint Nerad megjelenvén, kinyilvánítják, hogy birtokukban van András királynak $(\mathrm{H})$ Cetina ügyében kiállított 
privilégiuma, egész Cetina, a hozzá kapcsolódó valamennyi jogával, valamint a (vlg.) Polye mezőn Kanyane és Othua falvak királyi bőkezúségból történő adományozásáról. Az oklevelet a püspök megvizsgálta és hitelesnek találta azt. Ezután Helye fiai és unokái nyíltan előadják, hogy azon jótétemények fejében, amelyekben a néhai Nelepcius c. [fia:] János c. részesíti ôket, önszántukból átadják a szóban forgó privilégiumot és az abban foglaltakat valamennyi joggal együtt János c.-nek és örököseinek visszavonhatatlan birtoklásra és hasznainak élvezetére úgy, hogy azokat - mind életében, mint halálában - megtarthassa, eladhassa és elajándékozhassa; azt is akarják, hogy ha valaki más jogellenesen birtokolna valamit a privilégiumba foglaltakból, akkor az ilyeneket János c. bíróság elé idézhesse; hozzáfüzték még, hogy ha valamely más kiváltságlevele(ke)t találnának maguknál v. bárki másnál v. bármi mást, ami érintené az átadott javakat, de nincs belefoglalva a Jánosnak átadott kiváltságlevélbe, azt mind János c. kezére juttatják, ugyanakkor, ha János c. bírói úton szerez birtokokat, helyeket v. földeket a privilégiumban leírtak alapján, akkor azokat köteles fele részben megosztani velük. Minderről a püspök a folyamodók kérésére pecsétje felfüggesztésével megerősített oklevelet ad ki Zeuoyg-i Györgynek, Jarig c.-nek, Budizlaus c. [fiának:] Gergelynek, Vzdolya-i Iwannak és Wlk fia: Gard-nak, valamint más, külön ezért összehívottaknak a jelenlétében. D. Tynnini, in fe. B. Bartholomei ap., a. d. 1356.

E.: Dl. 38 490. (Frangepán cs. 1t. 14.) Hártyán, hátoldalán késóbbi kezek írásával tárgymegjelölés (egyik - talán — cirill betûs írás), alján pecsét felfüggesztésére utaló bevágások.

K.: -

Megj:: II. András király privilégiumát pontosan nem sikerült meghatározni; vö. Reg. Arp. 256. szám.

\section{4. (1356.) aug. 25. Villanova közelében, avignoni egyházm.}

[VI.] Ince pápa tudatja [I.] Lajos királlyal (H), hogy a Római Kúria szokása szerint visszatartja a Kúria lt.-ban (in archivio) azt a levelet, melyet a király procuratora és követe, István zágrábi püspök jutatott el a pápához, s amelyben a király a szerbiai eretnekek és hitetlenek elleni harcban kérte a pápa támogatását. D. apud Villamnovam Avinionensis diocesis VIII. Kal. Sept., pápasága 4. évében [1356.].

K.: Acta Innocentii VI. 176. (93. szám); Gasnault-Gotteri 2338. szám v. 238, f. 165. alapján; s utóbbi ezen felül v. 244 F, f. 126, ep. 316-ra hivatkozással.

R.: Áldásy 45. (253. szám); Áldásy A., TT. 18 (1895) 86. (253. szám) v. 244 F, f. 126, ep. 316-ra hivatkozással.

485. 1356. aug. 27.

Az egri egyház kápt.-ja - miként azt 1356. aug. 27-én (in a. d. 1356. sabb. prox. p. fe. S. Bartholomei ap.) kelt oklevele tanúsítja - átírja a király parancsára sekrestyéjéből előkeresett, 1272-ben (i. a. d. 1272.) kelt privilégiumát, amely többek között magában foglalta, hogy a kápt. e. egyik részról Sarus-i Domokos c., a másikról pedig ennek serviens-e, Mihály [! Э: Máté] c. megjelenvén, elóbbi kijelentette, hogy ő azt a Gömör m.-i Pogon földet, amelyet [V.] István király $(\mathrm{H})$ helytállása jutalmául - mert vele volt Feketuhalm-nál, majd pedig a nevezett királyért vérét ontotta az Irswazug-i csatában — 
neki adományozott, a részére teljesített szolgálatok viszonzásaképpen szavatosság vállalása mellett odaadományozta Máté c.-nek és örököseinek visszavonhatatlanul, teljes jogú békés birtoklásra.

Tá.: 1. Opuliai László nádor 1360. szept. 30. u. > [Lackfi] Imre nádor, 1372. okt. 17. Dl. 71 776. (Csoma cs. ragyolci lt. 4.).

2. Tá. 1. > Garai Miklós nádor, 1384. jún. 19. ŠA. Košice (Kassa). Rozsnyói püspökség lt. Oklevelek 15. (Df. 277 864.).

K.: -

Megj.: V. István említet oklevelének közelebbi azonosítása nem vezetett eredményre.

486. 1356. aug. 28.

Péter prépost és a Lelez-i Szt. Kereszt-egyház konventje e. Felleztemer-i János fiai: Gál és Mihály kinyilvánítják, hogy részint amiatt, mert rokonuk (proximus), István fia: Jakab alkalmas idóben gyakran segítette óket pereikben s más ügyes-bajos dolgaikban, részint pedig mert nemes nagyanyjuk hozományának és jegyajándékának kifizetése is ezt indokolja, testvériesen megosztoznak Jakabbal, valamint fivéreivel (fr.-es uterini), Györggyel és Miklóssal a Felleztemer birtokból óket megillető részen, annak valamennyi tartozékával és haszonvételével együtt olyan módon, hogy az osztásra bocsátott birtokrész egyharmadát ezentúl örökre és visszavonhatatlanul Jakab és fivérei, ill. örököseik, valamint azok utódai birtokolják a jelen oklevél jogérvényénél fogva. A felek kifejezték teljes abbéli egyetértésüket is, hogy ôk, a jelenlévők — v. csak valaki közülük - mielóbb elvigyék az egri egyház kápt.-jához a jelen iratot, s a nagyobb biztonság kedvéért privilégiumot állíttassanak ki róla, e tekintetben pedig egyes érdekeltek távolléte sem képezheti akadályát a dolognak. D. in die domin. prox. an. fe. Decoll. B. Johannis Bapt., a. d. 1356.

Á.: Egri kápt., 1364. aug. 20. D1. 85 356. (Sztáray cs. 1t. 141.).

K.: Sztáray I. 254. (147. szám).

\section{1356. szept. 1. Visegrád}

[I.] Lajos király $(\mathrm{H})$ utasítja a Jazov-i egyház [konventjét], hogy Ranywa-i [?] Kysed fia: István [?] királyi ember mellé küldjön tanút Assuan birtokra, annak a panasznak a kivizsgálására, melyet Zeech-i László fiai: Tamás, Mihály és László emeltek Ezen-i Tamás fia: János ellenében, akinek elzálogosították a szóban forgó birtokukat az előzô év [1355.] nov. 30-tól 1 évre (ab fe. B. Andree ap. nunc preterito usque revolutionem eiusdem fe.). Most viszont úgy látják, hogy István megkárosította ôket és jobbágyaikat 16 ökörrel, továbbá 2 jobbágyházzal, amelyeket jobbágyaival a maga Ezen birtokára vitetett, a földet pedig felszántatta. D. Wyssegrad, in. fe. B. Egidii abb., a. d. 1356.
Á.: Az 522. számú oklevélben.
K.: - 
488. 1356. szept. 3.

A velencei államtanács követeket küld a pápához a I. Lajos királlyal $(\mathrm{H})$ való béketárgyalások ügyében, valamint a zágrábi püspökhöz a fegyverszünet érdekében.

R.: Óváry 48. (66. szám) (Velencei lt.-ra való hivatkozással).

489. 1356. szept. 3.

Lukács (Luchacius) mr., János mr. Vngh m.-i alispánja és a 4 szb. tudatják: színük e. Radich-i Lucha $\sim$ Luca fia Tamás fiai: Lơrinc és János eltiltották ugyanazon Lucha fia Miklós fia: Pétert attól, hogy Radich és Arad birtokok felét elajándékozza, Vaychic fia: Pétert pedig attól, hogy elfogadja v. elfoglalja azokat, mivel a szóban forgó birtokok nővérük, Chala nemesasszony leánynegyedéhez tartoznak, akit pedig attól a telektól (sessio) tiltanak, amelyen jelenleg tartózkodik. D. sabb. an. fe. Nat. virg. glor., a. d. 1356.

E.: D1. 69 681. (Kende cs. 1t. 30.) Vízfoltos papíron, szélei szakadozottak, hátoldalán azonos kéz írásával tárgymegjelölés, valamint zárópecsét rögzítésére utaló bevágások.

K.: -

490. (1356.) szept. 4. Villanova közelében, avignoni egyházm.

[VI.] Ince pápai azzal a kéréssel fordul [I.] Lajos királyhoz (H), hogy támogassa a színe elé járulni szándékozó Egyed vicenzai érseket, aki a király segítsége révén reméli egyháza jogainak visszaállítását. D. apud Villamnovam, Avinionensis diocesis, II. Non. Sept., pápasága 4. évében [1356.].

R.: Gasnault-Gotteri (2352. szám) (v. 238 f. 161 és v. 244 F f. 132, ep. 326. alapján).

491. 1356. szept. 6.

Az egri egyház kápt.-ja jelenti [I.] Lajos királynak (H): megkapták a király júl. 18-án kelt, s itt átírt parancslevelét (l. 402. szám), és az abban foglaltak szerint eljárva tanúul állították az ott leírt ügy kivizsgálására László fia: János királyi ember mellé László karpapot. A kiküldöttek visszatérve jelentették, hogy kikérdezve mindenkit különösen a nevezett birtok határosait és a szomszédokat, olyan értesüléseket szereztek, miszerint Tereztenie-i Baynok (dict.) Miklós fiai: Dénes és János, valamint Matha fia: Miklós famulus, továbbá Domolaz-i Tekus fia: Jánosnak az officialis-a, Zeuld (dict.) Simon jún. 26-án (in die domin. an. ipsum fe. B. Ladislai regis) erőszakkal és fegyveresen rohanták le Lőrinc Capulna birtokát, Miklós Capulna-i falunagy udvarából (curia) pedig miután bezúzták udvara kapuját - elhajtottak 2 marhát, amelyeket Balaht-i András fia: Miklós ragadott el zálog gyanánt urának tiltott erdejében. D. f. III. prox. an. fe. Nat. B. virg., a. supradic. [1356].

E.: ŠA. v Levoci. Andrássy cs. krasznahorkai lt. 72. C. (Df. 265 490.) Papíron, hátoldaláról nem készült Fk.

K.: - 
492. 1356. szept. 9.

A velencei államtanács megbízza a pápai nunciust, hogy tudassa a kalocsai érsekkel, miszerint elfogadják a fegyverszünetet az "uti possidetis" elvének fenntartásával.

R.: Óváry 48-49. (67. szám) (Velencei lt.-ra való hivatkozással).

\section{1356. szept. 12. Visegrád}

[I.] Lajos király $(\mathrm{H})$ tudatja: Pozsony város polgárainak és hospes-einek jóléte és boldogulása érdekében különös királyi kegyet gyakorolván megparancsolja minden érintettnek, hogy ne akadályozzák őket a német só (theutonicalis sal) használatában. D. Wissegrad, f. II. prox. p. fe. Nat. virg. glor., sub a. d. 1356.

Á.: 1. Pozsonyi kápt., 1454. jún. 26. AMB. Pozsony város lt. Középkori oklevelek és levelek. 1671. (Df. 240 300.).

2. Pozsonyi kápt., 1454. júl. 8. Uo., 1677. (Df. 240 306.).

K.: F. IX. 7. 145-146. (91. szám) (Á. 1. alapján).

Megj.: Á. közlése szerint E.-je I. Lajos király titkos pecsétjével megerősített nyílt oklevél volt.

494. (1356. szept. 15.e.)

Zeech-i Miklós országbíró - [1356] szept. 15. e. kelt oklevelében - utasítja a budai egyház kápt.-ját, hogy Vasard-i Jakab v. szentmiklósi (de S. Nicolao) Bakou v. Panka (dict.) Péter királyi emberek valamelyikének társaságában állítson tanút Miklós nádor fia: Domokos mr. és István nyitrai püspök, ill. az ő törvényes képviselőik mellé, akik szept. 15-én (in oct. fe. Nat. virg. glor.) Lakach birtokra menvén a szomszédok és határosok jelenlétében járják be a szóban forgó birtoknak a nevezett püspök és egyházának Paztuh birtokától elválasztó határát. Ha a hj. során adódó vitás területek hovatartozása kapcsán egyességre jutnak, akkor azé legyen a kérdéses terület, akit kijelölnek, a vitás helyre pedig új határjeleket állítsanak; ha valamely résszel kapcsolatban ellentétbe kerülnének, akkor a kérdéses rész becsújét végezzék el lehetőleg a királyi mértéket használva, ám ha mérni nem tudnának, úgy az ország szokása szerint fogott bírák közremúködésével tegyék meg szemre a becsút. A hj.-t követően a történtekről számot adó írásos jelentést kér a király számára okt. 6-ra (ad oct. fe. B. Mychael arch.).

Eml.: Az 534. számú oklevélben.

K.: -

495. (1356. szept. 15.- okt. 6.)

A budai egyház kápt.-ja - eleget téve a Zeech-i Miklós országbíró korábbi parancslevelében foglaltaknak (l. 494. szám) - jelentésében tudatja az országbíróval, hogy Panka (dict.) Péter királyi ember a mellé adott tanúval, János mr.-rel, a Boldogságos Szűzegyházának kanonokjával, a kápt. prebendarius-ával szept. 15-én (in oct. fe. Nat. virg. glor.) Lakach birtokra kimenvén, az összehívott szomszédok és határosok jelenlétében 
nem tudták bejárni a birtok határát, mivel a felek közül csak István nyitrai püspök volt ott, és hiába várták a törvény szerint magszabott 4 napon keresztül a másik felet, Domokos mr.-t, az nem jelent meg, és képviselőjét sem küldte el maga helyett.

Eml.: Az 534. számú oklevélben.

K.: -

Megj.: Az irat kiadásának terminus ante quem-je a jelentés bemutatására az országbíró által megszabott, az érdekelt felek által pedig betartott okt. 6-i határnapból adódik, míg a terminus post quem a megkísérelt hj. szept. 15-i napjából következik. Vö. az 534. számú oklevéllel.

496. (1356. szept. 16.e.)

[I.] Lajos király utasítja a váradi kápt.-t, hogy a megnevezett királyi ember mellé adjon hites tanút egy Bihar m.-ben lefolytatandó vizsgálat elvégzésére.

Eml.: A 497. számú oklevélben.

K.: -

497. 1356. szept. 16.

A váradi kápt. - 1356. szept. 16-án (f. VI. prox. p. fe. Exalt. S. Crucis) kelt oklevelében tudatja [I.] Lajos királlyal, hogy a parancslevelében (l. 496. szám) foglaltaknak megfelelően az ott megnevezett királyi ember társaságában kiküldte hites tanúját Bihar m.-be vizsgálat lefolytatása végett. Ezek ott az értesüléssel rendelkezôk kikérdezése révén kiderítették, hogy Gergely fiainak: István és László mr.-eknek, valamint Paznan fia: Miklósnak Zenthmarthon falubeli és Wylak-i jobbágyai egy árokkal tönkretették Bohth-i Tamásnak és fiának, Jánosnak Bolch birtokán a Berekyo folyón lévő átjárójukat, majd más megengedhetetlen dolgokat is elkövetve tértek vissza Zenthmarthon birtokra.

Tá.: Garai László nádor, 1448. jan. 13. Dl. 37 180. (Kolozsmonostori konv. o. lt. Cista comitatuum. Bihar.) Füzet alakú 15. századi egyszerú Má.-ban; 19-20. old.

K.: -

498. 1356. szept. 17. Buda

[I.] Lajos király $(\mathrm{H})$ a néhai Gara-i András fiainak: Miklósnak és Pálnak királyi szolgálatban szerzett érdemeit megjutalmazván új adomány címén örökre szólóan eladományozza nekik a néhai Chynba (dict.) István fiai: Pethew és István valamennyi, az ország bármely m.-jében fekvő, magtalan haláluk következtében királyi kézre visszaháramlott birtokát és részbirtokát összes haszonvételükkel és tartozékukkal együtt különösen a Walkou m.-i Wylak-ot, továbbá a Posoga m.-ben fekvő Orboa-t a hasonló nevú várral egyetemben, nemkülönben Dobouch birtokot. Jelen oklevél visszahozatala esetére annak autentikus pecsétje alatt történő átírását ígéri. D. Bude, sabb. prox. p. oct. fe. Nat. virg. glor., 1356.

Á.: Mária királynő, 1384. jún. 28. Dl. 33 740. (NRA. 1511 31.). 
Tá.: Szécsi Miklós országbíró, 1382. aug. 23. Dl. 33 726. (NRA. 1511 19.).

K.: Smič. XII. 363-364. (274. szám) (Á.-ról); Smič. XVI. 309. (251. szám) (Tá.-ról).

R.: Wertner M, Sz. 31 (1897) 913-914.

499. (1356. szept. 17. u. - szept. 26. e.)

[I.] Lajos király meghallgatva Gara-i Miklós bánnak és Gara-i Pálnak a Welike-i nemesekkel szemben emelt panaszát, utasítja a pécsi kápt., hogy állítson tanút a nevezettek Orboua birtokba történő iktatása ügyében eljáró királyi ember mellé.

Eml.: Az 504. számú oklevélben.

K.: Smic. XVI. 306. (251. szám).

Megj.: A dátum meghatározásához a szóban forgó birtok adományozását rögzítő királyi oklevél és az iktatás meghiúsulásáról hírt adó kápt.-i jelentés nyújtanak támpontot. Vö. a 498. számú oklevéllel.

500. 1356. szept. 20.

Nagy (Magnus) Pál kőrösi ispán és Kis- (Minori [! abl.] ) Kemluk-i várnagy, valamint Demeter fia: Miklós kőrösi c. terrestris színe e. egyik részrôl Wlkowy fia: Salamon kőrösi nemes várjobbágy Kemnichyche-ről és felesége Berus asszony, a másik részról pedig Ink fia János fia János fia: Dénes mr. megjelenvén, Salamon kinyilvánította, hogy mivel öregségére fiú örökös nélkül maradt, gondoskodni kíván valamennyi birtokáról és részbirtokáról akár Kemnichyche-ben, akár máshol birtokolja azokat Körös m.-ben, nemkülönben felesége, Berus asszony hozományáról és jegyajándékáról is, így ezeket mind odaadja, ill. eladja nevezett Dénes mr.-nek és örököseinek $20 \mathrm{M}$. dénár készpénz ellenében örökre szóló birtoklásra, olyan, Dénes mr. által is elfogadott feltétellel, hogy ố maga - ti. Salamon - és felesége életük végéig megmaradnak a birtokokban és azok igazgatásában, továbbá, hogy az adományozás nem érinti a Katalin és Anthola nevû leányaikat megillető leánynegyedet. Minderról az ispán és a c. terrestris függőpecsétjeikkel megerősített oklevelet adnak ki. D. f. III. prox. p. fe. Exalt. S. Crucis, a. d. 1356.

E.: HDA. Obitelj Draskovic: Archivum maius 22. 11. (Df. 233 160.) Hártyán, alján függőpecsét zsinege, AO. szerint két pecsét nyomával, melyek rózsaszínú selyemzsinóron függnek.

K.: AO. VI. 497-498. (313. szám) (kihagyásokkal).

501. 1356. szept. 23.

Zeech-i Miklós országbíró - 1356. szept. 23-án (f. VI. prox. p. fe. B. Mathei ap. et ev.) kelt nyílt oklevelében - tudatja, hogy Wereb-i János fia: György és ennek fia: Benedek a Nógrád m.-i Harkyan birtokon lévő birtokrészüket valamennyi haszonvételével együtt az oklevél keltétől számított 5 évre 6 ft.-ért elzálogosítják Sándor fia: János mr.-nek az iratban részletezett feltételek mellett.

Tá.: Szécsi Miklós országbíró, 1357. ápr. 27. Dl. 4640. (NRA. 391 25.). 
Má.: Uo., Tá.-val megegyező jelzet alatt, arról készült egyszerú, újkori Má.-ban.

K.: AO. VI. 568-569. (363. szám) (kihagyásokkal).

\section{1356. szept. 26. Visegrád}

Zeech-i Miklós c., [I.] Lajos király $(\mathrm{H})$ országbírája, Turuch m. c.-e tudtul adja: Velyke-i Beke fia: László 1355. nov. 8-ra (ad. oct. fe. B. Martini conf., i. a. d. 1355.) a király, ill. az országbíró elé perbe hívta Dobouch-i Cymba (dict.) István fia: Istvánt, mivel az tiltó ellentmondásával meggátolta, hogy Stychnyk-i Márk királyi ember a Posaga-i kápt.-tól írásos királyi parancsra kiküldött hites ember tanúbizonysága mellett iktassa részére a Posaga m.-i Felső- (Superior) Felsew- és Alsó- (Inferior) Alsow- Olsow-Orbova Orboua birtokokot. A különféle okokra hivatkozó felek akaratából az országbíró a pert azután [1356.] jún. 19-re (ad oct. fe. Penth. prox. tunc venturas) halasztotta azzal, hogy a felek addig v. kiegyeznek egymással, v. végső döntéssel ő zárja le akkor a pert. Ezen időpont eljöttekor egyik részről az ura, Beke fia: László képviseletét a Posaga-i kápt. meghatalmazásával ellátó Péter fia: György, a másik részről pedig az István fia: István nevében - ugyanazon kápt. levelében - megbízott Iwanka fia: Miklós jelentek meg színe e., és bemutatták a Posaga-i kápt. [1356.] jún. 21-én (f. III. prox. p. fe. S. Trinitatis prox. tunc preteritum) kiállított nyílt oklevelét (l. 347. szám). Az abban foglaltak szerint a Posaga-i kápt. e. egyik részról Dobouch-i Cymba (dict.) István fia: István, a másik részról pedig Velyke-i Tamás fia Beke fia: László kinyilvánították, hogy a Posaga m.-i Felsew- és Alsow-Orboua birtokokkal kapcsolatos perben, amelyet István ôsei és atyafiai László és fivére őseivel folytattak, és azóta is zajlik István és László között, fogott bírák közremúködésével egyezségre jutottak egymással. Ennek értelmében István fia: István Felsew- és Alsow-Orboua birtokokat minden haszonvételükkel és tartozékukkal együtt - elismerve, hogy azokat jogellenesen nem bitorolhatja tovább - visszaadja Beke fiainak: Lászlónak, Miklósnak és Tamásnak, valamint ezen Tamás fia Miklós fia: Lászlónak, továbbá Velyke-i Simon fia: Jánosnak örökre és visszavonhatatlanul, továbbá átadja peres ellenfeleinek valamennyi, a birtokokkal v. tartozékaikkal kapcsolatos perben bármilyen hatóság által a per kezdetétôl ez ideig kiállított oklevelét, egyszersmind arra az esetre, ha a késóbbiekben bárki ilyesfélét mégis bemutatna a bíróság e., azt tekintsék hatálytalannak. Ezzel szemben Beke felsorolt fiai, valamint Miklós fia: László és Simon fia: János elismerték, hogy a per tárgyát képező birtokok illetéktelen birtoklásának megszüntével, ill. e javak visszakapásával ók teljes körú elégtételhez jutottak. Az oklevél bemutatása u. a László és fivérei képviseletét ellátó György, kérte megbízóinak királyi ember révén történő birtokba iktatását, mire az országbíró, valamint bárók és nemesek köréból kikerült bírótársai arról rendelkeztek (l. 348. szám), hogy Bagyun-i János fia: Péter v. Deuecher-i Miklós fia: Márton - a király ajtónállói -, v. Abhostyan-i Pál fia: János királyi emberek valamelyike a Posaga-i kápt. tanúbizonysága mellett végezze el Felsew- és Alsow-Orbaua birtokok hj.-t, és azok iktatását Beke fia: László és atyafisága részére, figyelmen kívül hagyva István és mások esetleges ellentmondását. Az országbíró a tanúállítás érdekében a Posaga-i kápt.-hoz fordult, s az eljárásról számot adó kápt.-i jelentés bemutatását Beke fia: László és peres társai részéről [1356.] szept. 15-re (ad oct. fe. Nat. virg. glor.) kérte. Ezen időpont elérkeztekor a László képviseletére a nevezett kápt. levelében meghatalmazott Péter fia: György bemutatta a kért kápt.-i jelentését (l. 409. szám), amelyből kiderült, hogy az elrendelt jogeljárást Bagyun-i János fia: Péter királyi ember a Posaga-i kápt. részérôl kiküldött Luka őrkanonok tanúskodása mellett [1356.] júl. 23-án (sabb., in fe. B. Appolinaris ep. et mart.) az összehívott szomszédok és határtársak jelenlétében ellentmondás nélkül végrehajtotta, s Felsew- 
és Alsow-Orboua birtokokat Beke fiai: László, Miklós és Tamás, valamint Miklós fia: László, nemkülönben Velyke-i Simon fia: János részére iktatta. Mindezek nyomán az országbíró autentikus függő pecsétjével ellátott privilégiumot bocsát ki. D. in Wyssegrad, 12. die oct. fe. Nat. virg. glor. predictarum, a. d. 1356.

Á.: Pozsegai kápt., 1371. máj. 17. Dl. 33 606. (NRA. 1509. 34.).

K.: AO. VI. 499-503. (314. szám) (kihagyásokkal); Smič. XII. 366-370. (276. szám).

\section{1356. szept. 26. Gömör}

Kemen fia: János mr., Konya mr. alispánja és Gumur m. szb.-ái emlékezetül adják: Hethyi Antal jelentette, hogy eleget téve Puthnuk-i Veche (dict.) Miklós fia: László mr. kérésének a m. pecsétjével szept. 24-én (sabb. prox. p. fe. B. Mathey ap.) Puthnuk-i Miklós fia: János mr. Dyenyzfalua falujába ment azzal a céllal, hogy azt a bizonyos pey színú lovat (equum pey coloris), amelyet János mr. jobbágyánál, Veres (dict.) Péternél láttak, Tamás fia: Lukács (Lukachius) nevében eltiltsa attól. D. in villa Gumur, f. II. prox. p. fe. iam dict. B. Matheii ap., a. d. 1356.

E.: Dl. 89 330. (Radvánszky cs. sajókazai lt. 4. 7.) Papíron, hátoldalán azonos kéz írásával tárgymegjelölés, valamint 3 zárópecsét töredéke (egyiken egy galamb alakja látható, a másikon talán egy ágaskodó ló v. ahhoz hasonló állat), szalagjai, bevágásai.

K.: -

504. 1356. szept. 26. körül

A pécsi kápt., miként azt [I.] Lajos királyhoz írott - a királynak a színe e. Gara-i Miklós bán és Gara-i Pál által a Welike-i nemesekkel szemben emelt panasz nyomán küldött parancslevelét ( $l$. 499. szám) megválaszoló - jelentése bizonyítja, tanúskodás végett kiküldte néhai Pál bán fia István fia: Pál mr. királyi ember társaságában, valamint a nevezett Gara-i Miklós bán és Pál kíséretében Márton mr. Baranya-i főesp.-t, akik 1356. szept. 26-án (f. II. prox. an. fe. B. Mychaelis arch., in a. d. 1356.) kimentek a Posoga-i Orboua birtokra, amelyet Gara-i András említett fiai királyi adományba kaptak más birtokok mellett a magtalanul elhalt néhai Cymba (dict.) István egykori birtokainak sorában, s ott az összehívott határosok és szomszédok jelenlétében be akarták iktatni e Miklós bánt és Pált a szóban forgó birtok, valamint az ottani Orboua vár és tartozékaik tulajdonába, Welike-i Beke fia: Tamás, továbbá fivérei, Miklós és László, valamint Simon fia: János, nemkülönben Miklós fia: László Welike-i nemesek ellentmondtak az iktatásnak, amiért is őket a királyi ember okt. 13-ra (ad quind. fe. B. Mychaelis arch.) a királyi jelenlét elé idézte Gara-i András fiai ellenében.

Tá.: Bebek István országbíró, 1360. máj. 1. > Szécsi Miklós országbíró, 1382. aug. 23. Dl. 33 726. (NRA. 1511. 19.).

K.: Smič. XVI. 306-307. (251. szám) (Tá.-alapján). 
Az erdélyi egyház kápt.-ja emlékezetül adja: az ura, Regun-i Dénes fia: Tamás mr. képviseletét ellátó Indal-i Péter fia: Gál tiltakozott színe e. amiatt, hogy Chegh birtokot, amelyet Tamás mr. egykor szolgálatai fejében ajándékozott el famulus-ának, Makra-i (dict.) Pálnak állandó használatra, most Pál fiai megpróbálják elidegeníteni, holott az ország szokásjoga értelmében ezt csak Tamás mr.-nek ajánlhatnák fel kiváltásra. Tiltja emiatt Pál fiait: Pétert, Miklóst és Jánost a birtok mindennemú elidegenítésétől, másokat pedig a szóban forgó birtok bármilyen formában történő megszerzésétól, egyszersmind a kápt.-tól tiltakozó s egyben tiltó oklelevél kiadását kéri ura, Tamás mr. számára. D. in fe. BB. Cosmae et Damiani mart., a. d. 1356.

E.: AL. Cluj. Cluj-Napoca (Kolozsvár). Erdélyi Múzeum Egyesület egykori lt. Bánffy cs. nemzetségi lt. 61. (Df. 260 640.). K. és R. alapján papíron, hátoldalán azonos kéz írásával tárgymegjelölés (eltérő névalak: Macra), zárlatán a kápt. pecsétjének töredéke.

K.: Bánffy I. 210-211. (172. szám).

R.: Erdélyi Okm. III. 309. (851. szám); Doc. Rom. Hist. XI. C. 33-34. (36. szám) (román fordításban is).

\section{1356. szept. 29. Visegrád}

Zeech-i Miklós c., [I.] Lajos király (H) országbírája, Thuruch m. c.-e felszólítja a Scepus-i egyház kápt.-ját, hogy Mochola-i Bálint v. Miklós v. Kellemes-i István v. Kellemes-i Bosou v. Pál fia: András királyi emberek valamelyike mellé állítson hites tanút ahhoz az idézéshez, amelynek nyomán Wytez-i Lőrinc, Peteuch $\sim$ Peteuz $\sim$ Peteucz fia Miklós fiai: Péter és Miklós, valamint Peteuz fiai: György, László, Mihály és Péter, nemkülönben a mondott Peteucz másik fiának, Jánosnak a fia: Jakab alkalmas idóben megjelenni tartoznak a király jelenléte e. Bertold-i Egyed fiai: Demeter és Simon ellenében. Az idézés napjáról és helyéről, valamint a megidézettek nevéról írásos jelentést kér a király számára. D. in Wyssegrad, in fe. B. Michaelis arch. a. d. 1356.

Á.: Az 511. számú oklevélben.

Má.: Uo., Á.-val megegyező jelzet alatt, egyszerű modernkori Má-ban.

K.: F. IX. 2. 542-543. (264. szám) Á.-ról, Jankovics gyưjjteményében őrzött oklevélre való hivatkozással.

507. 1356. szept. 29. $u$.

Kopus-i Vince Vng-i alesp., Mukach-i [!] Miklós, Rakus-i Pál papok jelentik Domokosnak az erdélyi egyház prépostjának, az egri egyház kanonokjának, Miklós egri püspök lelkiekben általános vikáriusának: miután megkapták a címzett mindenre kiterjedô parancslevelét, mely tartalmazta az első és a második kijelölt időpontot, valamint többek között azt, hogy szept. 26-án (f. II. prox. an. fe. B. Michaelis arch.) ismét menjenek ki Brod birtokra, Balázs fia: György felperes, v. képviselője jelenlétében, majd vezessék be a birtok negyedrészébe, és késedelem nélkül az őszi termés betakarítását is tegyék lehetôvé, ha nem történik ellentmondás. Ha pedig az alperesek v. bárki más nyíltan v. titokban bármi módon akadályozná a birtokbavételt v. a haszonélvezetet, azt ennek 
tudomásukra jutásakor azonnal, még a per elindulása e. 10 M.-ra büntessék, melyet a bírói rész kiadása nélkül teljesen Györgynek fizessenek ki. Jelen oklevél kiadói a parancslevél kézhezvételét követően szept. 26-án (f. II. prox. an. fe. B. Michaelis arch.) kimentek a szóban forgó birtokra, ahol a személyesen megjelent peres felek, valamint az összehívott határosok és szomszédok jelenlétében az alperesek teljes egyetértésben kijelentették, hogy a birtok egyik szegletét György és fiai számára a terméssel együtt átengedik márc. 16-án (oct. die Cynerum iam venturas) határidóig. Hj.: A Stara folyó mellett álló, határjelnek használt 3 körtefától indul É felé, kis távolság után egy füzfás patak felé fordul, melyet fyzes Eyr-nek hívnak, ezután Dé felé fordul (ad partem merigionalem) [!] és elér egy körtefát, azután Ny felé haladva elér egy másik patakot, és ennek mentén halad Ke felé a Strara [!] folyóig, ahol véget ér. István fia: Domokos, László és fiai kötelezték magukat, hogy Balázs fia György fia: István és György képviselője kárára a birtokon, annak telkén (sessio et mansio) a határidőig semmilyen változtatást nem tesznek. A kijelölt időpontban a nevezett birtokot annak minden jogával a felperes birtokában találták. D........ p. fe. B. Michaelis arch. a. d. 1356.

E.: D1. 77 169. (Zichy cs. zsélyi lt. 218. B 62.) Papíron, alján szakadás, hátoldalán kisebb ovális pecsét halvány nyoma, bevágásai.

K.: Zichy III 32-34. (19. szám).

R.: Bónis-Balogh 133. (1215. szám); Erdélyi Okm. III. 309. (852. szám).

\section{8. (1356.) szept. 30. Avignon}

[VI.] Ince pápa végrendelkezési joggal ruházza fel János [fia:] Bereck győri prépostot. D. Avinione, II. Kal. Oct., pápasága 4. évében [1356.].

Reg.: ASV. Reg. Av. v. 133., f. 323v (Df. 289 530.).

R.: Áldásy 47. (258. szám); Áldásy A., TT. 18 (1895) 88. (258. szám)(Reg. alapján).

509. 1356. okt. 1.

János c. és Miklós c. farkastelki (de villa Farkasii) bírák, Medyesch földjének provincialis bírái tudomására hozzák valamennyi bírónak v. azok helyetteseinek, akikhez ez a levél eljut: Almáson (in Almasio) az odavaló Hese kegyetlenül meggyilkolta az ugyancsak ott élő Mihályt, a Busd-i Witcha (gen.: Witche) [fia:] Miklósnak, Herbordus [fia:] Péternek és Hennlingus-nak az atyjafiát (fr.), majd az emberölés bưne miatt az Almásra való (de Almasio) Simon c. a gyilkos Hese-t Schars határáig (in territorium Schars) üldözte, végül Medyesch-re vitte törvény elé, ahol elítélték és lefejezték. Az irat kiadói az említett három atyafi és Simon c. kérésére a provincialis bírói pecsétjükkel megerősített jelen oklevéllel igazolják az emberölési ügyben folytatott eljárás és meghozott ítélet jogosságát. D. sabb. p. fe. S. Michaelis arch., a. d. 1356. Kérik egyszersmind: amennyiben úgy adódna, hogy az ügyben panaszt emelnének valamelyikük színe e., fogadják el, hogy a nevezettek maguk gyakoroltak jogszolgáltatást, fordított helyzetben az ehhez hasonló nagyobb búnesetben - ha ez eléjük kerülne - ók is eszerint kezelik majd irányukban a helyzetet.

E.: AL. Cluj. Cluj-Napoca (Kolozsvár). Erdélyi Múzeum Egyesület egykori lt. Kemény József gyújteménye 35. (Df. 253 445.). K. és R. szerint papíron, hátoldalán kerek pecsét nyoma. 
K.: $\quad$ AKÖG. 5 (1850) 376-377. (10. szám); ZW. II. 122. (705. szám).; Doc. Rom. Hist. C. XI. 35-36 (38. szám) (román fordításban is).

R.: Szabó K., Erd. Múz. okl. 24. (100. szám); Szabó K., TT. 12 (1889) 543. (100. szám); Erdélyi Okm. III. 309. (853. szám).

510. 1356. okt. 4. Eger

Domokos, az erdélyi egyház prépostja, az egri egyház kanonokja és Miklós egri püspöknek lelkiekben általános vikáriusa emlékezetül adja: Somus-i György fia János fia: Péter mr. 1356. okt. 4-én (f. III. prox. p. fe. S. Dionisii mart., a. videlicet Nat. d. 1356.) különös jelenléte e. kijelentette, hogy bírói engedéllyel a maga és fivérei (fr. uterini) nevében is egyezséget kötött Jezeney (dict.) Péter mr. deák nemes feleségével és ennek fiával, Miklós mr. deákkal azon kereset dolgában, melyet a szóban forgó asszony támasztott velük szemben hozomány, jegyajándék és leánynegyed ügyében. Az oklevél kibocsátója nyugtatja a feleket egyezségükről, amelynek részleteit egy másik oklevele fogja teljesebben tartalmazni. D. Agrie, die et a. supradictis. [1356].

E.: AM. Košíc Archivum secretum Jeszeney T 22. (Df. 269 788.) Hátoldalán azonos és késóbbi kéz írásával tárgymegjelölés, valamint kerek pecsét töredéke.

K.: -

511. 1356. okt. 4 .

A Scepus-i Szt. Márton egyház kápt.-ja jelenti [I.] Lajos királynak (H), hogy a Zeech-i Miklós c., királyi országbíró, Thuruch m.-i c. itt átírt, szept. 29-én kelt oklevelében (l. 506. szám) foglaltaknak megfelelően Kellemes-i István királyi ember mellé Miklós alszerpapot (subdiaconus) ad ták tanúul, akik Zenthkeresth birtokon okt. 3-án (f. II. prox. predict.) [Bertold-i] Egyed fiaival: Demeterrel és Simonnal szemben a király színe elé idézték Wytez-i Lőrincet, valamint Miklós fiait: Pétert és Miklóst, továbbá Peteuz $\sim$ Peteucz [ Peteuch] fiait: Györgyöt, Lászlót, Mihályt és Pétert, nemkülönben János fia: Jakabot nov. 8-ra (oct. fe. OO. SS. prox. affuturas). D. f. III. prox. p. diem fe. S. Michaelis arch., a. d. prenotato [1356.].

E.: Dl. 41 289. (Múz. Ta. Berthóty 49.) Papíron, hátoldalán - vízszintesen - azonos kéz írásával tárgymegjelölés, valamint kerek zárópecsét töredéke, szalagja, bevágásai; a pecséttel lezárt hátoldali részen keresztirányban korabeli jegyzetek.

Má.: Uo., mint E., azzal megegyező jelzet alatt; jelenkori Má.-ban.

K.: F. IX. 2. 542-543. (264. szám.) (kihagyásokkal). A Jankovics gyưjteményében lévő E.-re hivatkozva.

Megj.: A []-ben közölt névalakok a hátoldalról származnak.

512. (1356. okt. 6. e.)

Domokos, az erdélyi egyház prépostja, az egri egyház kanonokja és Miklós egri püspöknek lelki ügyekben általános vikáriusa perhalasztó levelében kötelezi a felperest, Jezenei (dict.) Péter mr. deák nemes feleségét - aki Komlos Isalch-i Miklós fia Kantor 
(dict.) Andrásnak a leánya -, valamint az alpereseket, Somus-i György fia János fiait: Pétert, Lászlót, Juanka-t, Jánost, Istvánt és Pált, hogy okt. 6-án (in oct. fe. S. Michaëlis arch.) személyesen v. törvényes képviselőik útján oklevél-bemutatás végett jelenjenek meg bírói színe e. a szóban forgó asszony és annak néhai anyja hozományával, jegyajándékával és leánynegyedével kapcsolatos kereset ügyében.

Eml.: Az 524. számú oklevélben.

K.: F. IX. 2. 514-515. (251. szám)(Eml.-ben).

513. (1356. okt. 6. e.)

Zeech-i Miklós országbíró a Kuerd birtok iktatásakor és a határok felállításakor támadt ellentmondás ügyében okt. 6-ra ([ad] oct. fe. B. Michaelis arch.) rendeli bírói színe elé a feleket, Pest város polgárait és hospes-eit, velük szemben pedig a Nyulak szigeti (de Insula Leporum) apácákat.

Eml.: Az 530. számú oklevélben.

K.: AO. VI. 503. (316. szám) (Eml.-ben).

514. (1356. okt. 6. e.)

Zeech- Miklós országbíró okt.6-ra ([ad] oct. fe. B. Mychaelis arch.) rendeli bíró színe elé László fia: Pétert és Rozgun-i János fia: Lászlót Tamás fiai: Miklós és László ellenében.

Eml.: Az 531. számú oklevélben.

K.: -

515. (1356. okt. 6. e.)

Zeech- Miklós országbíró okt.6-ra ([ad] oct. fe. B. Mychaelis arch.) rendeli bíró színe elé Machala-i Marcell fia Péter fiait: Jánost és Henriket Kanthor (dict.) Bereck és Loránd ellenében.

Eml.: Az 532. számú oklevélben.

K.: -

516. (1356. okt. 6. e.)

Zeech- Miklós országbíró okt.6-ra ([ad] oct. fe. B. Mychaelis arch.) rendeli bíró színe elé Trepk fia Miklós fia: Mihály deák Ders fia: Miklós mr. ellenébe.

Eml.: Az 533. számú oklevélben.

K.: - 
A Clusmunustra-i Szt. Szűz-monostor konventje tudatja: a színe e. egyik részrôl megjelenő Gereu fia: János kijelentette, hogy sürgető szükségtől szorongatva a Bihar m.-i Bedech birtokon lévő birtokrészét minden haszonvételével együtt az oklevél keltének napjától a legközelebbi [1357.] márc. 22-ig (usque oct. diei medii Quadr. prox. venturas) - M.-ként 50 garassal számolt - 4 M.-ért elzálogosítja a másik részről megjelent Monustur-i Jakab fia: István mr.-nek; hozzátéve, hogy ha késlekedne a zálog visszaváltásával, akkor a mondott pénz kétszeresét fogja megfizetni. D. in oct. fe. B. Michaelis arch., a. d. 1356.

E.: D1. 28 071. (Kolozsmonostori konvent o. lt.-a, Cista comitatuum, Bihar G 72.) Papíron, hátoldalán késóbbi kéz írásával tárgymegjelölés, valamint kerek pecsét nyoma, bevágásai.

K.: AO. VI. 503. (315. szám) (kihagyásokkal); Doc. Rom. Hist. XI. C. 36. (39. szám) (román fordításban is)

Facs.: Doc. Rom. Hist. C. XI. 650.

R.: Erdélyi Okm. III. 309-310. (854. szám).

518. 1356. okt. 7.

A pécsi egyház kápt.-ja e. 1356. okt. 7-én (a. d. 1356., f. VI. prox. p. oct. fe. B. Michaelis arch.) megjelent a Cornutus Baldo (gen.: Baldonis) testvérnek, a Je-i Szt. János rend keresztesei magyar-szlavón perjelének, továbbá rendjének képviseletét ellátó Benedek pap, a Szt. Kozma és Damján vértanú-egyház rector-a, és ellentmondással élt azzal kapcsolatban, hogy a királyi ember, valamint a kápt. tanúja beiktassák a néhai Gara-i András fiait: Miklóst és Pált a szóban forgó rend Dobsa és Negune birtokának tulajdonába, egyszersmind tiltotta Miklóst és Pált a birtokok elfoglalásától és megszerezésétôl, valamint határjelek állításától. D. die et a. prenotatis.

E.: Dl. 106 130. (Székesfehérvári keresztesek konventje 3. 1. 17.) Papíron, hátoldalán azonos kéz írásával tárgymegjelölés (eltérő névalak: (pro fratre Balduno Cornuto), valamint mandorla alakú zárópecsét töredéke, szalagjai.

K.: F. IX. 2. 520. (253. szám) Hevenesi gyưjtemény, tom. I., p. 267-re utaló hivatkozással.

R.: Wertner M., Száz. 31 (1897) 914.

\section{1356. okt. 8. [Nagy-]Kálló}

Cantor (dict.) Bereck mr. Zabolch-i alispán és a m. szb.-i emlékezetül adják: Semien-i Lengel (dict) János fia: László mr. színük elé járulva tiltakozott az ellen, hogy okt. 1jén (sabb. prox. p. fe. B. Michaelis arch.), amikor ő éppen a m.-i vásáron volt fivéreivel, és házában nem tartózkodott senki, Panala-i Péter fiainak jobbágya, Lazar (dict.) Péter elvitte az ô Zakol-i (dict.) János nevû́ jobbágyának pej színú lovát (peicolor) és jelenleg is magánál tartja illetéktelenül. D. in Kallo, sabb. prox. p. oct. B. Michaelis arch., a. d. 1356.

E.: D1. 51 716. (Kállay cs. lt. 1300. 1122.) Papíron, hátoldalán azonos kéz írásával tárgymegjelölés, valamint 2 kerek zárópecsét töredéke, bevágásaik és az egyik szalagja. 
K.: -

R.: Kállay II. 38. (1192. szám); Piti F., Szabolcs m. 134. (521. szám).

\section{1356. okt. 8. [Nagy-]Kálló}

Cantor (dict.) Bereck Zabolch-i alispán és a m. szb-ái emlékezetül adják: miután Waradai László fia: János törvényesen eléjük idézte Gyre-i Miklós fia: Miklóst, a kijelölt időpontban színük e. az elóbbi János mr. képviseletével ügyvédvalló levélben meghatalmazott famulus-a, Iwahtheluku-i Dénes fia: Miklós, vele szemben pedig a szóban forgó Miklós nevében ügyvédvalló levéllel eljáró famulus-a, Miklós fia: János jelentek meg. Utóbbi bemutatta a király 1354-ben kibocsátott oklevelét, amelynek értelmében Miklós fia: Miklós valamennyi perét a királyi hadoszlás 15. napjára kötelesek elhalasztani, azonban a bemutatás késedelmesnek bizonyult, így a bíróság a m. nemeseivel együtt Gyre-i Miklós fia: Miklóst királyi bírságban marasztalja el Warada-i László fia: János mr. ellenében. D. in Kallo, sab. prox. p. oct. B. Michaelis arch., a. d. 1356.

E.: Dl. 77 170. (Zichy cs. zsélyi lt. 1. B 294.) Papíron, hátoldalán azonos kéz írásával tárgymegjelölés, valamint 3 kerek zárópecsét töredéke, szalagjai, bevágásai.

K.: Z. III. 34-35. (20. szám).

R.: Piti F., Szabolcs m. 134. (522. szám).

\section{1356. okt. 9. Szentimre}

Domokos az erdélyi részek alvajdája tudatja az erdélyi egyház kápt.-jával: Kerulew-i János fiai: Ágoston és György a színe elé idézték Syle-i Miklós fiait: Mihályt és Pétert, valamint Kerulew-i János fiait: Gált és Mihályt annak a Kerulew birtokon lévő részbirtoknak az ügyében, amely az erdélyi kápt. privilégiumában foglaltak szerint Ágostont és Györgyöt nagyanyjuk leánynegyede jogcímén illette meg. Erre hivatkozva kérték a megidézett osztályos atyafiaikat, hogy határjelekkel válasszák el és adják ki részüket. A felsorolt társait törvényesen képviselő Syle-i Miklós fia: István erre hajlandónak mutatkozott, amiért is az alvajda kéri a kápt.-t, küldjön tanút Nagy (Magnus) Ladan v. György alvajdai emberek valamelyike mellé a következő vasárnapon (die domin. prox. venturo) [okt. 16.] a mondott birtokra, hogy ott a szomszédok és határosok, különösen pedig az osztályosok összehívását követően a kápt. privilégiuma alapján válasszák el a kérdéses birtokrészt, és iktassák be abba nevezett Ágostont és Györgyöt. Ha pedig valaki más mégis ellentmondással élne, akkor azt idézzék az alvajda elé alkalmas időre, majd ezt követően az osztály menetéről a határ vonalának futásával együtt, és ha szükséges, az idézettek nevéról, valamint az idézés idejéról nyolcad napra (ad 8. diem) [okt. 23-ra] küldjenek jelentést neki. D. in S. Emerico, 4. die oct. fe. B. Mychaelis arch., a. d. 1356.

E.: AL. Cluj. Cluj-Napoca (Kolozsvár). Erdélyi Múzeum Egyesület egykori lt. Törzsgyưjtemény. Oklevelek és iratok 24. (Df. 253 653.) Papíron, K. és R. alapján hátoldalán címzés, valamint kerek zárópecsét nyoma.

K.: Doc. Rom. Hist. XI. C. 37-38. (40. szám) (román fordításban is).

R.: Szabó K., TT. 1889. 543-544. (101. szám); Szabó K., Erd. Múz. okl. 24-25. (101. szám); Erdélyi Okm. III. 310. (855. szám). 
Miklós prépost és a Jazov-i Keresztelő Szt. János-monostor [konventje] jelenti [I.] Lajos királynak (H): az itt átírt, szept. 1-jén kelt parancslevelében (l. 487. szám) foglaltaknak eleget téve tanúul adták Kysed fia: István [?] királyi ember mellé Frigyes testvért a kért vizsgálat lebonyolítására, akik visszatértük u. jelentették, hogy okt. 6-án és 7-én (V. et VI. f. prox. preteritis) bejárva Beregh, Zabowch, Vngh és Zemlin m.-ket, az értesüléssel rendelkezők körében - kivált is Assuan birtok szomszédai és határosai között - vizsgálatot folytattak. Ennek eredménye szerint Ezen-i Tamás fia: János valóban zálogba vette Zeech-i László fiainak Assuan birtokát, és el akarván azt népteleníteni, elragadta a jobbágyok ökreit, és 2 házat átvitetett a maga Ezen birtokára, továbbá egy földet ....... felszántatott a zálogba adóknak komoly kárt okozva ezzel, azonban az eltulajdonított értékek számáról a kérdezók nem tudtak meg biztosat. D. die domin. prox. p. fe. B. Francisci, a. supradicto [1356].

E.: AL. Cluj. Cluj-Napoca (Kolozsvár). Erdélyi Múzeum Egyesület egykori lt. Vécsey cs. lt. 33. (28.) (Df. 254 251) Papíron, vízfoltos, szakadozott, hátoldalán azonos kéz írásával tárgymegjelölés, valamint kerek zárópecsét töredéke.

K.: -

523. 1356. okt. 10.

A pécsi egyház kápt.-ja tudtul adja: Mykola-i Péter fia: István mr., Wolkow m.-i nemes bemutatta színe e. a kápt. korábbi és régi pecsétjével megerősített és chirographált (alphabeto intercisum) privilégiumát kérvén, hogy a nagyobb biztonság érdekében azt írja át és új pecsétjével - amit most használ - pecsételje meg, amely kérést a kápt. teljesíti. Actum VI. Yd. Oct., a. ab Incarn. d. 1356. Kelt János mr. olvasókanonok keze által, Miklós mr. éneklő-, György őr- és Nyitrai János mr. dékánkanonok (magistro Johanne Nitriensi decano ecclesiae nostrae) jelenlétében.

E.: Dl. 1875. (NRA. 575. 10.) Hátoldalán azonos kéz írásával tárgymegjelölés, az oklevélre piros-zöld sodraton a kápt. mandorla alakú rongált pecsétje (rajta kivehető Szt. Péter trónon ülő alakjának bizonyos részletei, valamint a körirat: +S(IGILLVM) CAPITVLI ECCL(ES)IE QVINQVE ECCL(ES)IEN(SIS)) van felfüggesztve.

Má.: Uo., mint E., azzal megegyező jelzet alatt; egyszerú újkori Má-ban.

K.: Smič. XII. 370. (277. szám) (E.-ról).

Megj:: Az oklevélben átírt 1244 januárjában kelt privilégium kiadása 1. W. XI. 337. (241. szám).

\section{1356. okt. 11. Eger}

Domokos, az erdélyi egyház prépostja, az egri egyház kanonokja és Miklós egri püspöknek lelki ügyekben általános vikáriusa tudatja: korábbi halasztó levelében (l. 512. szám) kötelezte a felperest, Jezenei (dict.) Péter mr. deák nemes feleségét, - aki Komlos Jsalch-i Miklós fia Kantor (dict.) Andrásnak a leánya -, valamint az alpereseket, Somus-i György fia János fiait: Pétert, Lászlót, Juanka-t, Jánost, Istvánt és Pált, hogy okt. 6-án (in oct. fe. S. Michaëlis arch.) személyesen v. törvényes képviselőik útján oklevél-bemutatás 
végett jelenjenek meg bírói színe e. a szóban forgó asszony és annak néhai anyja hozományával, jegyajándékával és leánynegyedével kapcsolatos kereset ügyében. A kitûzött időpontban a felperes oldaláról a Jazo-i Jazow-i prépost és konvent ügyvédvalló levelében anyja képviseletére meghatalmazott Miklós mr., az alperesek részéról pedig a maga valamint - az egri kápt., továbbá a Jazo-i prépost és konvent ügyvédvalló levelei alapján - fivérei nevében is eljáró János fia: Péter mr. jelentek meg a vikárius e. Bemutattak több oklevelet, így a korábbi vikárius, László prépost és kanonok, valamint a jelenlegi vikárius, nemkülönben a néhai János pap, az Wyvar-i egyház egykori rektora és László prépost helyettese (vices gerens) által kiadottakat. Ezekból többek között az derült ki, hogy a felperes ügyvédjének, az anyját képviselő Miklósnak először László prépost e., majd pedig annak bírói döntése értelmében a Jazo-i prépost és konventje e. tanúkat kellet állítania arra vonatkozólag, miszerint a Sarus m.-ben fekvő Margonia birtok, valamint a hozzá tartozó birtokok és földek, amelyeknek a követelt járandóságok egy részét képezik, egykoron a felperes úrasszony apjához, Andráshoz - következésképpen utódlási alapon hozzájuk, azaz leányához és annak képviselőként eljáró fiához, Miklóshoz - tartoztak, így járna belólük az úrasszony követelésének megfelelő rész nekik, András azonban e javakat elidegenítve örökre szóló szerződéssel eladta az említett György fia: Jánosnak és e János testvérének, Péter c.-nek, mindezek igazolására viszont semmikor sehol nem sikerült tanúkat állítania. Ennek elmaradása és még egyéb körülmények közbejötte miatt a perben eleddig meghiúsult a döntéshozatal, $\mathrm{s}$ a bemutatott oklevelekból az is kiderült, hogy az eljárás során a feleket többször marasztalták el különböző bírságokban. Domokos vikárius, valamint bírótársai, továbbá a püspöki törvényszéknél akkor közremúködő fogott bírák a körülmények megismerését követően már-már végső ítéletet kívántak hozni a perben, amikor János fia: Péter mr. és a felperest képviselő Péter fia: Miklós engedélyt kértek a bíróságtól a közöttük fogott bírák közvetítésével létrehozandó megegyezésre. A hozzájárulást megadva a bíróság elbocsátotta a feleket, majd amikor nevezettek visszatértek, egybehangzóan a következő egyezségükról adtak számot: Megállapodásuk értelmében a felperes Miklós viszonozván a másik fél részéról iránta és fivérei iránt minden tekintetben megnyilvánuló segítő szándékot, ugyanakkor a per kimenetelét teljesen kétségesnek ítélve meg, anyja részéról lemond minden eddig támasztott követelésről, s eddigi igényeik teljesítése alól mentesíti Péter mr.-t és annak fivéreit. A bíróság tanúsítja, hogy a felek kölcsönösen lemondtak egymással szembeni bírságaik megfizetésérôl - kivéve azokból a bírót illető részt -, egyszersmind valamennyi, a per során egymás ellenében kiállított oklevelüket hatálytalanoknak nyilvánítják. Minderről Domokos vikárius autentikus függőpecsétjével megerősített oklevelet ad ki, ugyanakkor megígéri, hogy oklevelének az egri egyház kápt.-ja elé történő mielóbbi visszahozatala esetén kieszközli tartalmának megerôsítését a kápt. részérôl kiállítandó oklevél révén. D. Agrie, f. III. prox. p. fe. S. Dyonisii mart., a. d. 1356.

Á.: Az 527. számú oklevélben.

K.: F. IX. 2. 514-518. (251. szám).

R.: Bónis - Balogh 133. (1216. szám); Erdélyi Okm. III. 310. (856. szám).

Megj:: A felek okt. 6-i bírósági megjelenése miatt a dátumban szereplő ünnep az okt. 9-i Dénes naphoz (fe. Dionysii Rustici et Eleutherii et sociorum) kapcsolandó. 
Zeech-i Miklós országbíró felszólítja a Lelez-i konventet, hogy a felsorolt királyi emberek valamelyike mellé adjon tanút, akik okt. 13-án kimenve Zabolch, Balsa, Nyreghaz és Olazy nevú birtokokra, s ott összehívván a határosokat és szomszédokat, járják be a szóban forgó birtokok határait, becsüljék fel azokat, ezt követően pedig a konvent küldjön a történtekrôl írásos jelentést nov. 8-ra (ad oct. fe. OO. SS. prox.) a királynak.

Eml.: Az 551. számú oklevélben.

K.: -

\section{1356. okt. 13. Buda}

[I.] Lajos király - miként 1356. okt. 13-án, Budán kelt ([D.] Bude, in quind. fe. B. Michaelis arch., a. d. 1356.) nyílt oklevele tanúsítja - a színe e. megjelent a Royche-i kerületból való (de districtu de Royche) Mihály fia Jakab fia: Domokos kérésére hú szolgálatai jutalmaként a nevezettnek Konzka birtokával közvetlenül szomszédos Izkyrfelde birtokát, amely királyi várföld (castra terram) volt, és jogosan háramlott Domokosra - miután e föld az említett Royche vár jobbágyságától elvétetett - a kérelmező szabad birtokai közé sorolja, egyszersmind hozzájárul, hogy azt a többi birtokához hasonlóan nemesi szabadsággal birtokolhassa.

Tá.: Cillei Ulrik szlavón bán, 1454. jan. 25. Dl. 34 011. (NRA. 1675. 19.).

K.: Smič. XII. 371. (278. szám).

527. 1356. okt. 13.

Az egri egyház kápt.-ja tudtul adja: Somus-i György fia János fia: Péter mr. saját és fivérei: László, Iwanka, János, István és Pál nevében színe elé járulván bemutatta Domokos erdélyi prépost, egyben [egri] kanonok és Miklós egri püspököt lelki ügyekben helyettesító általános vikárius okt. 11-én kiadott privilégiumát (l. 524. szám), és a nagyobb biztonság érdekében kérte, hogy azt a kápt. írja át, amely kérésnek az eleget is tesz autentikus függőpecsétjével megpecsételt, egyszersmind $\mathrm{Az} \mathrm{ABC}$ betúivel chirographált oklevelének kiadásával. László prépost, Miklós őr-, Imre olvasó-, György éneklókanonok, András Zemlyn-i, Domokos Borsua-i, Sándor Patha-i, Sándor Tarcha-i, Benedek Pankota-i főesp.-ek jelenlétében. D. in quind. dict. fe. S. Michaelis arch., a. supradicto [1356.]. [I.] Lajos lévén a király (H), Miklós az esztergomi-, másik Miklós a kalocsai érsek, Miklós az egri püspök.

E.: Dl. 4628. (NRA. 1538. 25.) Papíron, alul az ABC betúivel chirographálás, aljára vörös-lila sodraton az egri kápt. kerek pecsétje (rajta oldalról, dicsfénnyel övezett fejét háta felé fordító, kiterjesztett szárnyú sas, karmaiban írószalagot szorít, rajta IOANNES felirat; a pecsét körirata: + S(IGILLVM) CAPIT(V)LI AGRIEN(SIS) ECCL(ES)IE POST PLAGAM) van függesztve, hátoldalán késóbbi kéz írásával tárgymegjelölés.

K.: F. IX. 2. 518-519. (252. szám) A bécsi udvari kamaránál őrzött E.-re hivatkozó Széchényigyújt. tom. V. nro. 70. alapján. 
Kálmán, a győri egyház püspöke a Rabakus-i alesp.-eknek (vicearchidiaconi), Tamásnak a Myhaly-i, és a másik Tamásnak a Beledy-i egyházak rektorainak: Adam mr., Fortunadfalua-i nemes jelentéséból megtudta, hogy a Vycha-i $\sim$ Wycha-i $\sim$ Vicha-i egyházközség tagjai, ill. népei (plebezani et populi) elhagyták a temetkezésre kijelölt, szentandársfalvi (de villa S. Andree) anyaegyházukat, és Vycha faluban Szt. Ferenc tiszteletére kápolnát emeltek. Ezért a püspök a szentandrásfalvi egyház jogainak védelmében meghagyja, hogy a címzettek kiközösítő büntetés terhe alatt keressék fel levelének vételét követően Vycha falut, s az ottani hivőknek tiltsák meg, hogy e levél keltétól kezdődően ott temetkezzenek, akik pedig másként tennének, azokat minden egyes vasár- és ünnepnapon a gyertyák kioltása és a harangok megszólaltatása közepette kiközösítettekként hirdessenek ki, ha pedig valakit mégis a szóban forgó kápolnában v. amellett temetnének el, akkor azt kiközösítő büntetés terhe alatt át kell temettetniük a szentandrási anyaegyházba. D. Jaurini, V. f. prox. in quind. B. Michaelis arch. a. d. 1356.

E.: MTA. Kvt. Oklevélgyújtemény 129. (Df. 243 774.).

K.: $\quad$ F. IX. 7. 156-157. (96. szám) (E.-rôl, Czech János közlése alapján).

Megj:: Tekintettel arra, hogy az inscriptio-ban discretis viris et honestis vycearchyd. de Rabakus rövidített alak szerepel, így nehéz eldönteni, hogy a regesztában felsoroltak szerint 3 személyról van szó (ahogyan azt F. alapján értelmeztem) v. valójában a 2 rektor egyben alesp. is.

\section{1356. okt. 13.}

Zeech- Miklós c., [I.] Lajos király (H) országbírája, Turuch m. c.-e tudatja az esztergomi egyház kápt.-jával: ismeretes, hogy Erzsébet királyné $(\mathrm{H})$ a kápt. idézólevelének (l. 291. szám) tanúsága szerint jún. 2-ra (ad vig. fe. Assc. d. prox. preteritam) a királyi jelenlét elé perbe idézte Vilmos (Gillermus) bíborost, titeli prépostot, a [budafel-]hévizi Szt. Háromság-egyház kereszteseinek (cruciferorum S. Trinitatis de Calidis Aquis), továbbá az esztergom-i Szt. István király-egyházának (S. regis Stephani de Stirgonio) mr.-ét a Monyorous Moniorous birtok határainak felállítását akadályozó ellentmondás ügyében. Más peridőpont elsóbbsége miatt (propter prioritatem termini) azonban júl. 1-jére (ad oct. fe. Nat. B. Johannis bapt. tunc prox. venturas) halasztották a pert, amely időpont eljövetelekor Demeter mr., a király gyứrúspecsétjének őre jelent meg a királynét annak ügyvédvalló levele révén képviselve Vilmos bíborossal szemben, s bemutatták a kápt.nak a hj.-ról írott oklevelét. Ebben — megerősítve a királyné előterjesztését — az állt, hogy a parancslevélben foglaltaknak megfelelően Vadach-i Teke fia: Péter királyi ember a tanúbizonyságul küldött Miklós presbiternek, az esztergomi egyház javadalmasának (prebendarius) a társaságában máj. 18-án (f. IV. prox. p. 22. die fe. Passce d. prox. preterita) felkeresték a királyné Moniorous birtokát, s ott elsóként azon a részen, ahol a királyné birtoka a szentkirályi keresztesek Taath birtokával határos, valamennyi határtárs és szomszéd jelenlétében 4 határjelet állítottak fel a régi határjelek mellett. Ekkor azonban a keresztesek mr.-ének officialis-a tiltakozását fejezte ki, amely tiltásnak és ellentmondásnak az okát a királyné Vilmos bíborostól akarta megtudni. Mindezek hallatán a bíboros képviseletével a keresztesek magistarus-ának ügyvédvalló levelében megbízott Bertalan mr., a titeli egyház kanonokja azt felelte, hogy a kiküldöttek a hj. során Taath birtokból egy nagy földdarabot - - amelyról a bíboros okleveles bizonyítékokkal rendelkezik, és azokat kitúzött időpontban be is tudja mutatni - választottak le, és azt 
a királyné Moniorous birtokához akarták csatolni. Az országbíró az ország nemeseivel együtt törvényt ülve elrendelte, hogy a per eldöntése érdekében Vilmos aug. 22-én (in oct. fe. Ass. virg. glor.) mutassa be valamennyi, Taath birtok tulajdonlására vonatkozó oklevelét a királyné ellenében. A kitűzött időpontot az országbíró utóbb oklevelében ( $l$. 482. szám) okt. 6-ra (ad oct. fe. B. Michael arch.) halasztotta, amelynek elérkeztekor színe e. egyik részról a királyné képviseletét annak ügyvédvalló levelével ellátó Demeter mr., a királyi gyưrúspecsét őre, valamint mellette Taar $\sim$ Tar (dict) Mihály mr., a királynéi udvar ifja jelentek meg, és felszólították a Vilmos nevében a keresztesek magistratusának ügyvédvalló levelében meghatalmazott Bertalan mr. titeli kanonokot az oklevelek bemutatására. Bertalan bemutatta IV. Béla király $(\mathrm{H})$ 1259-ben kelt privilégiumát, amely tartalmazta Florentius-nak, az acconi egyház püspökének 1256-ban kelt kiváltságlevelét, amelyben a püspök átírta és megerősítette II. Géza (Geysa) király (H) fiának, III. Béla királynak 1181-ben a Szt. István király-egyház alapításakor és megadományozása, valamint az esztergomi ispotály megalapítása ügyében kiállított privilégiumát. III. Béla oklevele többek között leírta, hogy a szóban forgó egyház és ispotály Taaath [!] falu földjét - melynek egyházát Szt György vértanú emlékezetére alapították a leírt határok mentén adományul kapja. Erre válaszul a királyné képviselői 4 privilégiumot mutattak be: úgymint [IV.] László király (H) 1277-ben kelt privilégiumát; Péter testvérnek, az esztergomi Szt. István király ispotálya mr.-ének s ugyanezen hely konventjének 1282-ben kelt kiváltságlevelét; az esztergomi kápt. 1281-ben kiadott privilégiumát, végezetül ugyanennek a kápt.-nak [1356.] máj. 13-án kelt (VI. f. prox. p. quind. fe. Passce d., a. in presenti [1356.]) kiváltságlevelét (l. 285. szám). A kápt. 1281-ben írott okleveléból kiderül, hogy Moniorous birtokot Mária királyné $(\mathrm{H})$ adományozta Pálnak, a néhai veszprémi püspöknek és fivérének, Benedek c.-nek hú szolgálataik jutalmául, ahogyan azt Mária királyné [1269. évi] privilégiuma is tartalmazza. Az országbíró az ország nemeseinek tanácsával mindezeket látva úgy határoz, hogy a szóban forgó 2 birtok, Moniorous és Taath határait a 2 privilégium alapján válasszák el egymástól, s utasítja a kápt.-t, hogy a királyi ember mellé az ügy nagyobb bizonyossága érdekében több tanút küldjön ki, akik a két fél oldalára a királyi udvarból külön erre a feladatra kiküldött Jakab mr., az országbíró protonotarius-a, továbbá Rohman-i György - Cykou királyi tárnokmr. helyettese (vices gerens) -- társaságában nov. 11-én (in fe. B. Martini conf.) menjenek ki a vita tárgyát képező határjelekhez, s ott az összehívott határosok és szomszédok, valamint a felek képviselőinek jelenlétében 2, a helyszínen is bemutatandó oklevél —- ti. III. Béla királyé, amelyet Vilmos képviselője mutatott be, valamint a királyné oldaláról bemutatott másik [az esztergomi kápt.-tól származó 1281. évi] oklevél - alapján járják meg a határokat. Taath birtok határát a bíboros képviselőjének útmutatását követve Béla király privilégiuma alapján, míg Moniorous birtokét a királyné képviselőjének útmutatása szerint a kápt. privilégiuma alapján jelöljék ki. Ahol ez nem lehetséges, ott a határvonal futását kövessék, ha pedig vita támad a hj. közben, okleveleik alapján jussanak egyezségre, s a régi határjel mellé állítsanak újat. Ha a vitát ekként nem tudják elrendezni, akkor fogott bírák közremúködésével a királyi mértéket alkalmazva méréssel, v. - ha ez nem lenne lehetséges -- szemrevételezéssel végezzék el szükség esetén a vitás földdarab becsújét. A történtekról pedig mindenre kiterjedő jelentést írjanak a királynak nov. 18-ra (ad 8. diem predict. fe. B. Martini conf.). D. in Vissegrad, 8. die termini prenotati, a. d.1356.

E.: Dl 4581. (MKA. Acta eccl. ord. et mon. Vet. Buda 1. 6.) Papíron, hátoldalán azonos kéz írásával tárgymegjelölés, valamint kerek zárópecsét töredéke, bevágásai, írott hártyaszalagja.

Eml.: Az 572. számú oklevélben. 
Megj:: A bemutatott privilégiumok közül: III. Béla 1181. évi oklevelét 1. Reg. Arp. 132. szám; IV. Béla és Florentius püspök privilégiumát uo. 1230. szám; [IV.] László királyét uo. 2833. szám; Mária királyné 1261.évi, az esztergomi kápt. 1281. privilégiumában említett 1269. évi privilégiumát l. Reg. Arp. duc., regin. 77. szám; az utóbbi kápt. említő oklevelét pedig 1. W. IX. 307-309. (220. szám) alatt.

\section{1356. okt. 13. Visegrád}

Zeech-i Miklós c., [I.] Lajos király (H) országbírája, Turuch m. c.-e emlékezetül adja: a korábbi oklevelében (l. 513. szám) foglaltak alapján okt. 6-án (in oct. fe. B. Michaelis arch.) a Kuerd birtok iktatásakor és a határok felállításakor támadt ellentmondás ügyében megjelent színe e. egyik részrôl a Pest város polgárait és hospes-eit képviselő Petermanus fia: Jakab pesti polgár, vele szemben pedig a Nyulak szigeti (de Insula Leporum) apácák képviseletét ügyvédvalló levelükkel ellátó Balázs testvér. Az országbíró a pert a felek képviselőinek akaratából máj. 1-jére (ad oct. fe. B. Georgii mart. nunc venturas) halasztja azzal, hogy addig a felek a királyné által erre kijelölt Cyko királynéi tárnokmr. e. fogott bírák békéltetése révén, valamint a felperes polgárok és hospes-ek oldalán királyi emberként kiküldendő Harkyan-i András v. Bodoch fia: Dénes v. Vecherch-i Bogar (dict.) Jakab v. Bilye-i Kozma fia: Miklós v. Tete-i Beke, míg az alperes apácák részéról eljáró Dex-i [?] János v. Ordas (dict.) János v. Tyba fia: Jakab valamelyikének közremúködésével, ill. a budai kápt. tanújának jelenlétében Kuerd birtokon - okleveles bizonyítást követően - jussanak egyezségre a határok felállítása ügyében, majd a megállapodásról a budai kápt. által kiállított oklevelet vigyék el az országbírónak [1357.] máj. 1-jére (ad oct. fe. B. Georgii mart.). D. in Vissegrad, 8. die termini prenotati, a. d. 1356.

E.: Dl. 4629. (MKA. Acta eccl. ord. et mon. Poson. 55. 8.) Papíron, hátoldalán azonos és késóbbi kéz írásával tárgymegjelölés valamint kerek zárópecsét nyoma, szalagja, bevágásai.

K.: AO. VI. 503-504. (316. szám) (kihagyásokkal).

R.: Bakács, Pest megye 207. (713. szám).

\section{1356. okt. 13. Visegrád}

Zeech- Miklós c., [I.] Lajos király (H) országbírája, Turuch m. c.-e a László fia: Péternek és Rozgun-i János fia: Lászlónak Tamás fiaival: Miklóssal és Lászlóval szemben indított ama perét, amely az országbíró korábbi oklevele ( $l$. 514. szám) értelmében okt. 6-án (in oct. fe. B. Mychaelis arch.) lett volna esedékes, s amelyben elóbbiek képviseletében a Jazou-i konvent ügyvédvalló levelében meghatalmazott Vörös (Rufus) István, Tamás fiai helyett pedig a szepesi kápt. ügyvédvalló levelét felmutató Imre fia: Péter jelentek meg Wzma birtok ügyében, ill. László király privilégiumának Tamás fiai általi újbóli bemutatása végett - amely oklevelet a néhai országbíró, Druget Miklós már látott, és amelynek bemutatása e. Tamás fiai $4 \mathrm{M}$. bírságot kötelesek fizetni Péternek és Lászlónak -, a felek képviselőinek akaratából [1357.] máj. 1-jére (ad. oct. fe. B. Georgii mart.) elhalasztja a fennálló állapot fenntartásával. D. in Vissegrad, 8. die termini prenotati a. d., 1356. 
E.: Dl. 4630. (NRA. 17. 20.) Papíron, hátoldalán azonos kéz írásával tárgymegjelölés, valamint kerek zárópecsét nyoma, bevágásai; szélén a pecsét által lezárt részen keresztben közel korú kézzel más ügyben kelt kancelláriai jegyzet.

K.: -

\section{1356. okt. 13. Visegrád}

Zeech-i Miklós c., [I.] Lajos király (H) országbírája, Turuch m. c.-e azt a pert, amelyben a korábbi oklevele értelmében (l. 515. szám) okt. 6-ra (in. oct. fe. B. Mychaelis arch.) színe elé idézett Machala-i Marcell fia Péter fiai: János és Henrik (Hericus) helyett a Lelez-i konvent ügyvédvalló levelével Vörös (Rufus) Miklós járt el, velük szemben pedig Kanthor (dict.) Bereck és Loránd képviseletében a váradi kápt. ügyvédvalló levelében meghatalmazott Mihály szabó (sartor) jelent meg, nevezett képviselők akaratából a korábbi állapot fenntartása mellett [1357.] jan. 8-ra (ad oct. diei Stennarum nunc venturas) elhalasztja. D. in Vissegrad 8. die term. prenotati, a. d. 1356.

E.: Dl. 51 717. (Kállay cs. lt. 1300. 1116.) Papíron, hátoldalán azonos kéz írásával tárgymegjelölés (eltérő névalakjai: Herricus és Kantor), valamint az országbíró kerek zárópecsétjének töredéke; a pecsét által lezárt részen közel korú kézzel más ügyben írt kancelláriai jegyzet keresztben.

K.: -

R.: Kállay II. 38. (1193. szám).

\section{1356. okt. 13. Visegrád}

Zeech-i Miklós c., [I.] Lajos király (H) országbírája, Turuch m. c.-e emlékezetül adja: korábbi oklevelében (1. 516. szám) foglaltak szerint okt. 6-án (in oct. fe. B. Michaelis arch.) megjelent színe e. Trepk fia Miklós fia: Mihály deák Ders fia: Miklós mr. ellenében azt állítván, hogy Miklós mr. 3 évvel korábban szept. 29-én (in fe. B. Michaelis arch. cuius 3. preterisset revolutio annualis) Chokna-i officialis-át, Demetert és valamennyi jobbágyát ráküldte a panasztevő Mihály - lakóhelyéül is szolgáló - Suernye birtokára, ahonnan ezek ellopták 45 darab nagytermetú marháját, ót magát pedig életveszélyesen megsebesítették. Ezen felül 4 évvel ezelőtt nov. 16-án (f. IV. prox. p. fe. B. Martini conf. cuius 4. preterisset revolutio annualis) a megvádolt Miklós mr. Chokna-i jobbágyai révén felégetett egy bizonyos erdőt, amely Suernye birtokhoz tartozott, s ezzel $100 \mathrm{M}$. kárt okozott a panasztevőnek. Ezt hallva a pécsi kápt. ügyvédvalló levelében meghatalmazott Mihály fia: János ártatlannak mondta urát, Miklós mr.-t az ellene felhozott vétségek elkövetésében. Mivel Mihály vállalta, hogy tanúval igazolja az ökrök eltulajdonításával és a maga sebesülésével kapcsolatos panaszát, ezért a bíróság elrendeli, hogy Mihály deák [1357] ápr. 15-én (sabb. prox. p. fe. Passce d. prox. venturis) a somogyi konvent e. szavahihető tanúkkal igazolja fenti állítását, amelyről máj. 1-jére (ad oct. fe. B. Georgii mart.) kér az országbíró írásos jelentést. Ugyanekkor ítéletet fog hozni az erdő felégetése ügyében, továbbá, mivel az országbíró és a somogyi konvent bemutatott további okleveleiben foglaltak szerint Ders fia: Miklós mr. semmibe vette az ítéletet a közöttük folyó egyik perben, ezért őt $3 \mathrm{M}$. bírságban marasztalják el, amelynek megfizetésére kötelezik ốt a kitúzött időpontban, kétharmad részben a bíró, egyharmad részben pedig peres ellenfele, Mihály részére. D. in Vysegrad, 8 die termini prenotati, a. d. 1356. 
E.: Dl. 69 976. (Sibrik cs. 1t. 22.) Papíron, hátoldalán azonos kéz írásával tárgymegjelölés, valamint 2 pecsét nyomai - az országbíróé (részben olvasható köriratú) és egy másik kerek zárópecsété - töredéke, szalagja, bevágásai.

K.: -

\section{1356. okt. 13. Visegrád}

Zeech-i Miklós c., [I.] Lajos király (H) országbírája, Turuch m. c.-e a budai egyház kápt.jának: korábbi ítéletlevelében (l. 494. szám) kérte a kápt.-t, hogy Vasard-i Jakab v. szentmiklósi (de S. Nicolao) Bakou v. Patyka Panka (dict.) Péter királyi emberek valamelyikével szept. 15-én (in oct. fe. Nat. virg. glor.) küldje ki hites tanúját Miklós nádor fia: Domokos mr. és a nyitrai egyház püspöke, István v. azok törvényes képviselői oldalán Lakach birtokra, ahol az összehívott szomszédok és határosok jelenlétében járják be régi határjelei mentén a szóban forgó birtoknak azt a határszakaszát, amely a nyitrai püspöknek és egyházának Paztuh Pazthuh birtokától választja el azt. Ha a hj. alkalmával a felek egyességre jutnak, akkor ki-ki maradjon a maga birtokának örökkön tartó élvezetében a határjelek megújításával. Ha pedig valamely résszel kapcsolatban ellentétbe kerülnének, akkor fogott bírák közremúködésével a vitás rész minőségét és nagyságát meghatározva v. méréssel a királyi mértéket használva v. - ha ezt nem tudják végrehajtani - szemmel megítélve végezzék el a kérdéses birtokrész becsújét az ország szokása szerint, ezt követően pedig az eljárásról írjanak jelentést a királynak okt. 6-ig (ad oct. fe. B. Mychaelis arch.). A kitüzött időpont elérkeztekor az országbíró ítélőszéke e. egyik részről Domokos mr. képviseletében László fia: László - Miklós nádor ügyvédvalló levelében meghatalmazva -, a másik részről pedig az István püspök nevében a püspök által kiállított meghatalmazó levéllel eljáró Hynd-i Mihály megjelenvén, bemutatták a kápt. jelentését (l. 495. szám). Az számot adva az országbíró ítéletlevelében foglaltak teljesítéséról, tudatja, hogy Payka (dict.) Péter királyi ember társaságában a kápt. javadalmasát (prebendarius), a Boldogságos Szúz egyházának kanonokját, János mr.-t küldte ki tanúságtételre, akik szept. 15-én (in oct. fe. Nat. virg. glor.) a szomszédok és határosok jelenlétében kimentek a mondott birtokra, de a határt nem tudták megjárni, mivel a püspök - a törvény szerint szabott - 4 napon keresztült hiába várt Domokos mr.-re, az nem jelent meg és nem is küldött senkit maga helyett. Az országbíró erre ismételten felszólítja a kápt.-t, hogy [1357.] júl. 8-án ([in] quind. fe. Nat. B. Johannis Bapt.) járjon el újra a fentiekben leírtak szerint, majd a történtekröl jelentsen a királynak [1357.] júl. 15ig (ad 8. diem earumdem quind.); a távolmaradó felperest, Domokos mr.-t pedig 6 M. ugyanezen időpontig megfizetendő - királyi bírságban marasztalja el. D. in Wissegrad, 8. die termini prenotati, a. d. 1356.

E.: 1. ŠA. Nitra (Nyitra). Uzsovics cs. könyöki lt. 36. (Df. 266 385.)

2. Štátny Oblastný Archív v Nitre, Pracovisko Šal a, Botka-Vezekény cs. 1t. 2250. (Df. 290 633.) Mindkét Fk. ugyanarról az oklevélról készült. Papíron, hátoldalán azonos és késóbbi kéz írásával is tárgymegjelölés, valamint kerek zárópecsét nyoma, bevágásai.

K.: -

535. (1356. okt. 13-19. között)

[I.] Lajos király értesítvén a vasvári kápt.-t azon panaszról, melyet Vgh-i Vgh fia: Lőrinc 
terjesztett eléje - miszerint Durugd-i István fia: Pál Vgh birtokon lévő részbirtokának terményeit (fructus) és haszonvételeit immár 6 éve hatalmaskodva bitorolja, s ezzel súlyos károkat okoz nekik, ezenfelül pedig [1356.] okt. 13-án (f. V. prox. an. fe. B. Galli conf. prox. preteritum) a panaszos Lőrincet feleségével együtt jogtalanul ki is zárta a mondott birtokrészrôl —, utasítja a kápt.-t, hogy a kijelölt királyi ember társaságában küldjön ki hites tanút István fia: Pál megidézéséhez a nádor elé a nevezett Lőrinc és felesége ellenében, majd a történtekrôl - az idézés időpontjával együtt - jelentsenek a nádornak.

Eml.: Az 542. és az 584. számú oklevélben.

K.: -

\section{6. (1356.) okt. 14. Avignon}

[VI.] Ince pápa Miklós egykori zágrábi püspöknek, választott kalocsai érseknek: teljesítve kérését, amelyet az új érseknek a bácsi egyházba delegált követe, Miklós fia: János szerémi főesp. terjesztett eléje, nevezett által palliumot, vagyis főpapi hivatali jogkörének teljességét kifejező hatalmi jelvényt (palleum insigne videlicet plenitudinis pontificalis officii) küld neki -, amelynek átadásával a váradi és a szerémi püspököket bízza meg. D. Avinione, II. Id. Oct., pápasága 4. évében [1356.].

Reg.: ASV. Reg. Av. 133., f. 281r-281v (Df. 289 528.).

R.: Áldásy 47. (259. szám); Áldásy A., TT. 18. (1895) 88. (259. szám) (Reg. alapján).

\section{7. (1356.) okt. 14. Avignon}

[VI.] Ince pápa megbízza a váradi és a szerémi püspököket, hogy ruházzák fel Miklós egykori zágrábi püspököt, választott kalocsai érseket azzal a palliummal, amelyet az érsek kérését közvetítő Miklós fia: János szerémi főesp., a nevezett érseknek a bácsi egyházba delegált követe (in ecclesiam Bachien. nuntium) révén küld el hozzájuk. D. Avinione, II. Id. Oct., pápasága 4. évében [1356.].

Reg.: ASV. Reg. Av. 133., f. 281v (Df. 289 528.).

R.: Áldásy 47. (259. szám); Áldásy, TT. 18. (1895) 88. (259. szám) (Reg. alapján).

538. 1356. okt. 16.

Péter prépost és a Lelez-i Szt. Kereszt-egyház konventje jelenti [I.] Lajos királynak (H): eleget téve a király itt átírt aug. 18-án kelt parancslevelében (l. 456. szám) foglaltaknak, Korchwa-i Pál királyi ember mellett András testvért küldték ki tanúul, akik visszatérve jelentették, hogy az értesüléssel rendelkezók körében, kivált a Jezeneu és Nogmihal birtokok környékén élők között vizsgálatot folytattak, s ennek eredményeként Tyba-i Lőrinc fiainak panaszát igaznak találták. D. in fe. B. Galli conf., a. supradicto [1356.].

E.: Dl. 85 315. (Sztáray cs. 1t. 101.) Papíron, hátlapján azonos és késóbbi kéz írásával tárgymegjelölés, valamint a leleszi konvent - részben olvasható köriratú ([+SIGILLVM CONVEN]TVS DE LELES) - kerek zárópecsétjének töredéke, bevágásai.

K.: Sztáray I. 255-256. (148. szám). 
[I.] Lajos király - 1356. okt. 17-én (a. d. 1356., XVI. Kal. Nov.), uralkodásának 15. évében kelt, kettős pecsétjével megerősített, 1364. febr. 25-én (a. d. 1364 V. Kal. Marc.), uralkodásának 23. évében pedig alsó szélén hitelesítő záradékkal és új kettős pecsétjével ellátott oklevelében - egyebek mellett tudatja: Erzsébet királynéval egyetértésben úgy határoztak, hogy Óbuda városát (oppidum) a vámmal és a révvel (tributum fori seu navium) együtt királyi kezükhöz vonják, amely elvett Pesth-i és Kerepes-i rév- és vámjövedelmekért a korábbi tulajdonos óbudai kápt.-t és egyházat a cserében nekik adott Zala és Somogy m.-i Komar, Galambok, Zenthpeter és Korws birtokokkal kárpótolja. Meghagyja továbbá a szóban forgó kápt.-nak, hogy az óbudai apácák jogügyleteiben minden eljárás során, kivált is az oklevélkiadás tekintetben, ugyanúgy járjon el - mellőzve minden akadékoskodást és kelletlenséget -, ahogyan más egyházakkal, ill. a főpapokkal, bárókkal és nemesekkel kapcsolatban viselkedni szokott.

Tá.: 1. Pálóci László országbíró, 1449. ápr. 12. Dl. 14 211. (MKA. Acta eccl. ord. et mon. Vet. Buda 23. 7.).

2. Ország Mihály nádor, 1472. szept. 29. Dl. 16. (MKA. Acta eccl. ord. et mon. Vet. Buda 16. 22.) 16. századi egyszerú Má.-ban.

R.: Bakács, Pest megye 209. (716. szám); Bónis-Balogh 133. (1217. szám).

540. 1356. okt. 18.

A veszprémi egyház kápt.-ja e. Odo testvér zirci apát teljes konventje képviseletében kijelenti, hogy a Torna folyón Berend birtokon lévő bizonyos malomhelyet, amely egykor Laurente $\sim$ Leurente (gen.) mr.-é volt, nem akarván rossz lelkiismerettel, meggyőződésével ellentétesen birtokolni, visszaadja azt Laurente fia: Beke-nek és az ô fiainak: Lőrincnek és Lászlónak valamint ezek örököseinek örök birtoklásra. D. f. III. prox. p. fe. B. Galli conf., a. [d.] 1[3]56.

E.: Dl. 41 290. (Múz. Ta. Véghely) Papíron, hátoldalán közel korú kéz írásával tárgymegjelölés, valamint a veszprémi kápt. kerek rányomott pecsétjének töredéke (rajta kivehető a kiterjesztett szárnyú Mihály arkangyal álló alakja, lábai e. sárkány hever, részben olvasható a körirat: +[S]IGILLVM CAP[I]TVLI VE[S]PRI[MIEN]SIS).

K.: -

541. 1356. okt. 19.

A Clusmu[nu]stra-iBoldogságos Szúz-monostor konventje emlékezetül adja, hogy az ura, Regun-i Dénes fia: Tamás mr. helyetteseként és nevében színük e. megjelenő Vörös (Ruphus) Mihály tiltakozott az ellen, hogy jóllehet a Konth Miklós erdélyi vajda congergatio-ján törvényen kívül helyezett Lamperth-i Ceh (dict.) Tamást, akivel kapcsolatban ugyanott valamennyi nemes és ülnök elrendelte, hogy senki - - ti. az elítélt rokonai - nem tarthatja ôt birtokán, mégis, Macra-i Pál fiai: Miklós és Péter azon a Cheg nevú birtokon [rejtegetik], amelyet a panasztevő Tamás adományozott Pálnak. D. IV. f. prox. p. fe. B. Galli conf., a. d. 1356. 
E.: AL. Cluj. Cluj-Napoca (Kolozsvár). Erdélyi Múzeum Egyesület egykori lt. Bánffy cs. nemzetségi lt. 62. (Df. 260 641.) K és R. szerint eredetije papíron, hátoldalán tárgymegjelölés, valamint kerek zárópecsét töredéke.

K.: Bánffy 211. (173. szám) (tévesen praescriptum-nak és nem proscriptum-nak nevezi Ceh (dict.) Tamást); Doc. Rom. Hist. C. XI. 38-39. (41. szám) (román fordításban is). Mind a két kiadás szerint befejezetlen maradt a szöveg, s ekként egészítették ki: prefatum Thomam dictum Ceh de Lampert tenerent et servarent.

R.: Erdélyi Okm. III. 310-311. (858. szám).

542. (1356. okt. 19.u.)

A kápt. eleget téve [I.] Lajos király parancsának (l. 535. szám), Gyarman fia: Miklós királyi ember társaságában János klérikust küldte tanúul az idézés foganatosításához, akik visszatérve jelentették, hogy [1356.] okt. 19-én (f. IV. prox. p. fe. B Luce ew. prox. preteritum) Durugd-i István fia: Pált Vgh birtokon lévő zálogbirtokán [1356.] nov. 8-ra (ad. oct. fe. OO. SS.) megidézték a nádor elé Lőrinc és felesége ellenében.

Eml.: Az 584. számú oklevélben.

K.: -

543. (1356. okt. 22. e.)

Cantor (dict.) Bereck Zabolch-i alispán és a m. szb.-ái a Ladam-i [!] Fülöp fia: Fülöp mr. és Semien-i László fia: Mihály mr. között zajló pert okt. 22-re (sab. prox. an. fe. Symonis at Jude ap.) elhalasztják.

Eml.: Az 544. számú oklevélben.

K.: -

\section{1356. okt. 22. [Nagy-]Kálló}

Cantor (dict.) Bereck mr., Zabolch-i alispán és a m. szb.-ái korábbi halasztó oklevelükben (l. 543. szám) kötelezték Ladam-i [!] Fülöp fia: Fülöp mr.-t, vele szemben pedig Semien-i László fia: Mihály mr.-t, hogy okt. 22-én (sab. prox. an. fe. Symonis at Jude ap.) jelenjenek meg színük e. Az időpont eljövetelekor Mihály mr. személyesen, Fülöp mr. helyett pedig ügyvédvalló levélben meghatalmazott serviens-e jelent meg, s elóbbi előterjesztette 32ft.-tal [?] kapcsolatos keresetét. A pert végül Fülöp képviselőjének kérésére tizenöt nappal (nov. 5-re; ad quind. datarum prenotatarum) elhalasztják teljes válaszadásra. D. in Kallo, termino ante dicto, a. d. 1356.

E.: Dl. 51 718. (Kállay cs. lt. 1300. 1121.) Papíron, hátoldalán azonos kéz írásával tárgymegjelölés, valamint 2 kerek zárópecsét töredéke, bevágásai, szalagjai.

K.: -

R.: Kállay II. 38 (1194. szám); Piti F., Szabolcs m. 134. (522. szám). 


\section{1356. okt. 23. Visegrád}

[I.] Lajos király (H) utasítja a pécsi egyház kápt.-ját, hogy Mykola-i Phile fia Péter fia: István számára keressék elő és írják azt a Halmas birtokra vonatkozó privilégiumot, amelynek kezén lévő példányát István elveszítette, azonban másik példánya a pécsi egyház sekrestyéjében v. levéltárában (conservatorium) van; inti ôket, nehogy valamilyen hamisság vagy cselvetés jöjjön közbe mindezek teljesítésekor ( ad cautelam caventes tamen, ne fraus et dolus interveniat in hac parte). D. in Vyssegrad, die domin. prox. p. fe. B. Luce ewang., a. d. 1356.

Á.: A 635. számú oklevélben.

K.: -

Megj.: Á. alapján E.-je a király gyưrû́specsétjével ellátott, zárt oklevél volt.

\section{1356. okt. 23. Visegrád}

[I.] Lajos király $(\mathrm{H})$ kéri a Jazou-i konventet, hogy vizsgálja ki Gál fiainak: Fábiánnak, Péternek és Pálnak eléje terjesztett panaszát, amely szerint [Hogun-i.......Domokos.......] Turos (dict.) Jánossal együtt, valamint István fia: János és Péter, Ordov-i hospes-ekkel együtt júl. 14-én (f. V. prox. p. fe. [Margarethe virg.]) ....... hatalmaskodva rárontottak Tereztenye birtokra, ahol Pálnak egy ujját levágta...... A király utasítja a konventet, hogy küldje ki tanúját ....... Lazov-i Lack fia: Miklós királyi ember társaságában a vizsgálat lebonyolítására, majd annak eredményről tegyen írásos jelentést számára. D. in Wyssegrad, 3. die fe. undecim milium virg., a. d. 135[6].
Á.: A 644. számú oklevélben.
K.: -
R.: Piti F., Vay 444. (164. szám).

Megj.: Az oklevélról készült Fk. több helyen olvashatatlan, maga az oklevél helyenként szakadozott, ill. erős vízfoltok takarják írását; a betoldott elemek az átíró oklevélből származnak.

\section{1356. okt. 23. Zágráb}

[I.] Lajos király $(\mathrm{H})$ tudtul adja: Endred-i Moch fia János fia Jakab lányának, egyben Zobonya fia: János mr. feleségének, Chano nemes asszonynak a kérését teljesítvén, tekintettel férje és Zobonya fia: László mr. királyi szolgálatban szerzett érdemeire is, arra az esetre, ha a szóban forgó asszony fivére, János fia Jakab fia: János utód nélkül halna meg, s birtokai a törvény szerint valamennyi tartozékukkal és haszonvételükkel együtt királyi kézre háramlanának, akkor ezen atyai birtokok felében a különleges királyi kegye folytán fiúsított (verum heredum et succesorem sicut filium naturalem instituimus et creamus) Chano asszonyt teszi meg törvényes örökössé, a birtokok másik felét pedig új adomány címén Zobonya fia:László mr.-nek és örököseinek adományozza idegen jog sérelme nélkül. D. Zagrabie, die domin. prox. an. fe. S. Demetrii mart., a. d. 1356.

Á.: I. Lajos király, 1364. dec. 27. > nyitrai kápt., 1382. szept. 29. Dl. 98 281. (Tabula provincialis, Acta post advocatos 19. 32. 8.). Az átíró oklevél szerint E.-je a király nagyobb pecsétjével ellátott nyílt oklevél volt. 
K.: -

548. 1356. okt. 24.

Az egri kápt. e. - miként azt 1356. okt. 24-én (f. II. prox. an. fe. BB. Symonis et Jude ap., a. d. 1356.) kelt oklevele tanúsítja - a László fia: Péter és János fia: László Rozgon-i nemesek képviseletét ellátó famulus-uk, Chura fia: Simon megjelenvén, említett urainak, valamint a mondott Péter fiainak: Miklósnak és Lőrincnek a nevében is tiltakozott az ellen, hogy Nekchee-i (Tá. 2., 3.: Nekche-i) Miklós fia: Denk mr. és elődei jogtalanul elfoglalták urainak a Zemplén m.-i Chychwa (Tá. 2.: Chuchwa) kerületben (districtus) fekvő Chemernye, Chaklyo (Tá. 2.: Chaklo) és Sowkuth (Tá. 2.: Sowkwth, Tá. 3.: Sokuth) birtokait, amelyeket Denk fia: Sándor azóta is elfoglalva tart.

Tá.: 1. Bebek Detre nádor, 1402. ápr. 20. Dl. 2449. (NRA. 569. 34.).

2. Tá. 1. > Szécsényi Frank országbíró, 1402. jún. 17. Dl. 8616. (NRA. 596. 5.) (Vö. ZsO. II. 1587. szám).

3. Tá. 1. > Garai Miklós nádor, 1405. nov. 15. Dl. 3801. (NRA. 602. 47.).

K.: -

549. (1356). okt. 25. Avignon

[VI.] Ince pápa Caucina-i Arnoldnak, a krakkói egyház scolasticus-ának, az apostoli szék követének: a római egyház ügyeinek előmozdítása és intézése érdekében Mo.-ra, Lo.-ra és az ezeknek alávetett területekre érvényes - apostoli levelekben rögzített - felhatalmazását kiterjeszti a boroszlói (Wratislaviensis), Kamień-i (Caminensis) és Lebus-i (Lubucensis) egyházmegyékre és városokra, továbbá a római egyház érdekében eddig ott végzett munkálkodását is jóváhagyja. D. Avinione, VIII. Kal. Nov., pápasága 4. évében [1356.].

Reg.: Gasnault-Gotteri (2456. szám) (feltüntetett hivatkozása: v. 238, f. 226; v. 244 F, f. 155, ep. 380; v. 243, f. 11.).

K.: Theiner, Mon. Pol. 579-580. (773. szám).

R.: Áldásy 47-48. (262. szám); Áldásy, TT. 18 (1895) 88-89. (262. szám) (feltüntetett hivatkozása: R. V. v. 238. f. 226.).

550. 1356. okt. 27.

Péter prépost és a Lelez-i Szt. Kereszt-egyház konventje jelenti [I.] Lajos királynak $(\mathrm{H})$ : a Zeech-i Miklós országbíró levelében (l. 441. szám) foglaltakat teljesítve Zakud-i László fia: János királyi ember mellett kiküld ték János testvért tanúbizonyság végett, akik visszatérve jelentették, hogy okt. 13-án (in quind. fe. B. Mychaelis arch.) Miklós fia: István Zabolch $\sim$ Zobulch birtokon lévő részbirtokára mentek, s ott az utasításnak megfelelően az összehívott határosok és szomszédok jelenlétében be akarták járni a szóban forgó birtokrész határait, hogy azt becsû́ elvégzése u. iktassák Byri-i Tamás részére. Ám azonkívül, hogy a mondott birtokrészen lévő telekbe és a hozzá tartozó szántóföldekbe és haszonvételekbe beiktatták Tamást, az utasítás többi rendelkezésének nem tudtak 
eleget tenni, egyrészt mert az összehívottak közül senki nem jelent meg, márpedig ez elengedhetetlen a fentiek végrehajtásához, másrészt pedig azért, mivel Balázs fia: Pálnak a helyszínre küldött officialis-a, Fynnas (dict.) István ura nevében eltiltotta óket a birtokrész becsújétől és az iktatástól. Ezt követően okt. 16-án (4. die quind. predict.) egy másik - az országbírói oklevelében ugyancsak szereplő — királyi ember, Noghfolu-i Gábor (Gabrianus) a konvent tanúbizonysága mellett nov. 8-ra ([ad] oct. fe. OO. SS.) a királyi jelenlét elé idézte Pech-i Gergely királyi embert Byri-i Tamás ellenében, mivel az — jóllehet korábban iktatás végett a mondott birtokon járt az egri kápt. emberével —nem tért vissza az egri kápt.-hoz jelenteni, ezenfelül Miklós fia: Istvánt figyelmeztették, hogy a rá kirótt $42 \mathrm{M}$. bírságnak a kétharmad részét, valamint azoknak a kétszeresét ne késlekedjen megfizetni az országbírónak ugyanezen időpontban. D. in vig. fe. BB. Symonis et Jude ap., a. d. 1356.

E.: D1. 51 719. (Kállay cs. lt. 1300. 1105.) Papíron, hátoldalán azonos kéz írásával tárgymegjelölés, valamint a leleszi konvent kerek zárópecsétjének töredéke (részben olvasható körirattal: [+ SIGILLVM CONVEN]TVS DE LELES), bevágásai, írott szalagja.

Eml.: Az 580. számú oklevélben.
K.: -
R.: Kállay II. 38-39. (1195. szám).

551. 1356. okt. 27.

Péter prépost és a Lelez-i Szt. Kereszt-egyház konventje jelenti [I.] Lajos királynak (H): a Zeech-i Miklós országbíró levelében (l. 525. szám) foglaltaknak megfelelően Zakuli László fia: János királyi ember mellé tanúul adta János testvért, hogy okt. 13-án (in quind. fe. B. Michaelis arch.) Zabolch, Balsa, Nyreghaz és Olazy birtokokon az összehívott határosok és szomszédok jelenlétében végrehajtsanak minden, az oklevélben előírt eljárást, majd a birtokok becsüjét is elvégezvén nov. 8-ra (ad oct. fe. OO. SS. prox.) a konvent írásos jelentést küldjön a király számára, ő pedig az abban írottak alapján tudja majd kitűzni a Biry-i Tamás javára teljesítendő fizetési kötelezettség határnapját Miklós fia: István számára, amely fizetség mindazon járandóságokat rendezi, amelyek Zabolch-i Domokos részbirtokaiból a Zeech-i Miklós szóban forgó oklevelében név szerint említett úrasszonyokat jog szerint megilletik. A kiküldötteknek a konvent e. tett jelentéséből kiderült, hogy a kijelölt időpontban kimentek Zabolch birtokra, valamint a többi nevezett birtokra és tartozékaikra is, ám amikor Zabolch-i Miklós fia: István jelenlétében elsóként a szóban forgó birtokot, majd sorra a többit is be akarták járni, felmérni és felbecsülni, ebben Balázs fia: Pálnak —- odaküldött officialis-a, Fynnas (dict.) István révén —- bejelentett tiltakozása megakadályozta ôket, amely tiltás, mint István kijelentette, nem a hj. ellen, hanem a felmérés és a becsú meghiúsítására irányult. D. in vig. fe. BB. Symonis et Jude ap., a. d. 1356.

E.: Dl. 51 720. (Kállay cs. 1t. 1300. 1106.) Papíron, hátoldalán azonos és késóbbi kéz kezek írásával tárgymegjelölés, valamint a leleszi konvent kerek zárópecsétjének töredéke (rajta kivehető a kereszt csúcsa és a holdsarló; olvasható körirattal: + S(IGILLVM) CONVENTVS DE LELES), bevágásai, szalagja.

K.: AO. VI. 511-512. (318. szám) (kihagyásokkal).

R.: Kállay II. 39. (1196. szám). 
A budai egyház kápt.-ja e. -- miként azt 1356. okt. 28-án (in a. d. 1356., in fe. SS. Simonis et Jude ap.) kelt privilégiuma tanúsítja - a néhai Simon vajda fiai: Miklós és Gergely megjelenvén, kijelentették, hogy Pest m.-i öröklött birtokaikat, Sambuk-ot és Szenthegyed-et valamennyi haszonvételükkel együtt a szomszédok és határosok tudtával elzálogosítják Káth-i János fia: István mr.-nek 300 —- már teljesen megfizetett jó súlyú arany ft.-ért addig, amíg vissza nem tudják váltani, s megígérték, hogy azokkal szemben, akik háborgatni merészelnék a zálogba vevőt és fiait a birtokokat érintő leánynegyed, hozomány és jegyajándék ügyében, saját fáradtságukon és költségükön védelmezik meg óket.

Tá.: Kont Miklós nádor, 1366. febr. 8. Dl. 63 914. (Beniczky cs. 1t. 23.)18. sz.-i egyszerú Má.-ban.

K.: -

\section{3. (1356.) okt. 31. Avignon}

István pápai kamarás emlékeztetve arra a haladékra, amelyben Tamás csanádi püspök a pénzbeli fizetség dolgában korábban részesült ezen kötelezettségének határidejét [1357.] febr. 2-ig (usque ad. fe. Purif. B. Marie prox. venturis) tovább halasztja. D. Avinione, die ultima mensis Oct., a. indictione XV., [VI. Ince] pápaságának 4. évében [1356.].

Reg.: ASV. Reg. Av. v. 122., f. 460r (Df. 289 436.).

K.: -

554. (1356.) okt. 31. Avignon

István pápai kamarás emlékeztetve arra a haladékra, amelyben Szigfríd pannonhalmi apát a pénzbeli fizetség dolgában korábban részesült, ezen kötelezettségének határidejét [1357.] aug. 15-ig (usque ad. fe. Ass. B. Marie) tovább halasztja. D. Avinione, die ultima mensis Oct., a. indictione XV., [VI. Ince] pápaságának 4. évében [1356.].

Reg.: ASV. Reg. Av. v. 122., f. 460v (Df. 289 436.).

K.: -

Megj.: Vö. az 555. számú oklevéllel.

555. 1356. okt. 31. Avignon

Vilmos (Guillelmus) tusculumi püspök, bíboros, a római egyház bíborosi kollégiumának kamarása (episcopus Tusculanus cardinalis sacri collegii reverendorum patrum dominorum Romanae ecclesie cardinalium camerarius) emlékezetül adja: átgondolván mindazon súlyos terheket, amelyekről a Szigfríd (Sieffredus) testvér, a győri egyházm.ben lévő bencés rendi pannonhalmi Szt. Márton-monostor apátja részéről hozzá eljuttatott s színe e. ismertetett híradásából értesült, ezekre tekintettel haladékot enged [1357.] aug. 15-ig (ad fe. Ass. B. Marie prox. venturum terminum) a pápának és bíborosoknak 
járó servitium-ok megfizetésében, noha azok teljesítését az apát meghatározott büntetések, feltételek és határidók kikötése mellett önként vállalta, azt mégis elmulasztotta. Ha ezen időpontig sem tesz eleget fizetési kötelezettségeinek, úgy a kilátásba helyezett büntetések érvénybe lépnek. D. Avinione, die ultima Oct., a. Nat. d. 1356, indictione XV., VI. Ince pápa pápaságának 4. évében.

E.: BFL. Capsarium 36 Z 436. (442). (Df. 207 232.) Hártyán, hátoldalán késóbbi kézzel tárgymegjelölés, alján befúzött hártyaszalag (ráírva: R), melyre vörös színú, töredezett szélû́ pecsét van erősítve (rajta kivehető Szűz Mária alakja, jobbjában a gyermek Jézus, baljában liliom). A plicaturán kívül Iohannes de Liparra olvasható, K. alapján belül 1 flor. 2 gross.

K.: P. II. 427. (153. szám).

Megj.: Jó minőségű, digitalizált változatát 1.

http://www.mom-ca.uni-koeln.de/mom/HU-PBFL/PannHOSB/1356_X_31/charter\#anchor?q=207232

556. 1356. nov. 1.

Az egri egyház kápt.-ja jelenti [I.] Lajos királynak (H): a király itt átírt, aug. 3-án kelt parancslevelében (l. 423. szám) foglaltaknak eleget téve Kis (Parvus) Jakab királyi ember társaságában tanúul küldte ki az egri egyház Szt. Erzsébet-oltárának mr.-ét, Péter papot, akik visszatérve egybehangzóan jelentették, hogy okt. 27-én (in vig. fe. BB. Symonis et Jude ap.) a Borsod m.-i Olnad birtokra mentek, ahol a törvényesen összehívott határosok és szomszédok — különösen pedig Ábrahám (Abram) fia: János és Miklós fia: János Peturi-i nemesek - jelenlétében bejárták a birtokok határait minden tartozékaikkal és haszonvételeikkel együtt, majd beiktatták azok tulajdonába Zudar (dict.) Péter mr.-t és fivéreit, valamint örököseit örök birtoklásra, mivel senki nem emelt ellentmondást. D. in die fe. OO. SS., a. supradicto [1356.].

Á.: I. Lajos király, 1357. márc. 5. Dl. 4626. (NRA. 1538. 24.).

K.: -

\section{1356. nov. 1 Bobovac vár alatt, [a bosnyák bán] udvarában}

Thuerdco, egész Bosznia, Ozora (Vzure) és Só (Solle) bánja fivérével, valamint anyjával, Ilonával együtt tudatja, hogy meghallgatva a boszniai egyház püspökének, Péternek a bán és valamennyi bárója elé terjesztett panaszát, mely szerint némelyek hatalmaskodása és jogtalan cselekedetei következtében az Vsura-ban lévő Szt. Péter-egyház Dubimcham birtokát, melyet a bán elődje, a néhai Nagy (Magnus) Prezda, a bán nagybátyjának, Nagy Istvánnak a nagyapja (avus) engedett át, és István bán is megerősített - ahogyan azt a bemutatott privilégium is tanúsítja -, egyrészt mert az egyházat a bán gyarapítani akarja, másrészt saját és elődei lelki üdvéért, továbbá [I.] Lajos király (H) kérésére is újra Szt. Péter Vsura-i egyházának adja a szóban forgó birtokot valamennyi földjével, falvaival, hasznával és jövedelmével együtt - - ahogyan azt Prezda említet privilégiuma tartalmazza - és ezek tulajdonában a mondott egyházat örökre megerősíti. Ennek bizonyságára függőpecsétjével ellátott oklevelet bocsát ki. D. in curia nostra, sub castro Boboch, in fe. OO. SS., a. d. 1356.

Á.: XI. Gergely pápa, 1375. okt. 31. ASV. Reg. Av. v. 197., f. 263v (Df. 291 030.). 
K.: Thallóczy 60-61. (6. szám) (Á.-ról).

\section{1356. nov. 4.}

[I.] Lajos király (H, Da, C, Ra, Se, G, L, Cu, Bu, princ. Sal., mont. S. Angeli dom.) Kapruncha város polgárainak és hospes-einek kérésére —- más, alapításától fogva szabadságot élvezô görög városokhoz hasonlóan — szabadságjogokkal ruházza fel ôket, melyeket a következóképpen szabályoz: [1.] minden Újév napján kötelesek követeik révén éves adót fizetni $40 \mathrm{M}$. használatban lévő vert pénzben, M.-ként 5 pensa-val számolva. [2.] Ha egy polgár egy másik polgárral szemben jogsértést követ el, és azt rábizonyítják, a sértettnek 10 pensa-t, a közösséggel szemben pedig 100 dénárt köteles fizetni. [3.] Ha valaki háromszori figyelmeztetés u. sem tér jobb belátásra, minden vagyona a közösségre szálljon, őt magát pedig úzzék ki a városból. [4.] Ha valaki pofon üt valakit, v. rosszindulatúan hajánál fogva rángat, ugyanazt a büntetést szenvedje el; amikor mindezt a bíró ítélő széke e. követi el v. másutt, a bíró szeme láttára, kétszeres büntetést érdemel; akkor, ha a bíró v. valamely ülnök személyével szemben merészeli elkövetni, büntetésként 10 M.-t köteles fizetni, aminek ha nem tud eleget tenni, kezét veszítse el. [5.] Ha valaki késsel, karddal, lándzsával, nyíllal v. hasonló módon megsebez valakit, de a sértett — tagjai fogyatkozása nélkül — meggyógyul, fizesse meg a sértett orvosát, a sértettnek 20 pensa-t, a város javára pedig 5-öt adjon; ha azonban a sértett megnyomorodik, fizesse meg az orvosát, a sértettnek 10 M.-t, a város javára pedig 2 M.-t. [6.] Ha valaki embert öl és elmenekül, vagyonának kétharmada illesse a meggyilkolt szüleit, egyharmada a várost; ha elfogják az elkövetőt, a szokás szerint vétessék rajta bosszú, kivéve, ha valaki játék közben, előre megfontolt szándék nélkül követte azt el; ez esetben fizessen 100 pensa-t a meggyilkolt rokonainak, 20 pensa-t pedig a közösség javára. Ha a gyilkosnak nincs elegendő vagyona ehhez, döntsenek fölötte a polgárok. [7.] Ha valaki kívülról jön a városba, és elkövet valamit a város határain belül - akár az utcán, akár egy házban, akár a piacon -- a város bírája ítélkezzék felette, mintha csak helyi lakos volna. [8.] Ha egy idegen vagyoni természetű ügyben v. valamely sérelem miatt egyezségre akar jutni valakivel a városból, menjen a város bírája elé, és ne lehessen semmilyen ügyet párbajjal eldönteni, csakis tanúk és eskütétel alapján szülessen döntés. A tanúkat és esküdteket a leteendő eskü alkalmával egyenként és külön vegyék figyelembe, az ugyanazon szabadsággal rendelkező és egyforma állapotú tanúk pedig egyformán vétessenek tekintetbe. [9.] Akár idegen a helyi lakosnál, akár helyi lakos az idegennél lovat, ökröt v. más lopott javakat talál, állítson tanúkat. [10.] A város polgára semmilyen más törvényszék, csak a városi törvényszék e. köteles megjelenni; abban az esetben pedig, ha a bíró pártossággal gyanúsítható és a felperes törvényes óvást emel, a város előkelóinek összehívásával, a bíró jelenlétében szülessen ítélet. Amennyiben a döntésében kételkedik a felperes, a királyi jelenlét elé idézheti óket, ám ez esetben egyedül a bíró köteles a királyhoz menni. [11.] Bármely ügyben, ha valaki a város bíráját v. a polgárokat, a király jelenléte elé idézi, csak a város bírájának kell mennie; és ha valaki valamelyik polgárt v. polgárokat - a város bírájának ítélete nélkül — a királyhoz idéz, helyette v. helyettük a bíró köteles menni, akinek a költségeit az idéző tartozik megfizetni. [12.] A polgárok szabadon és évente választhatnak bírót és plébánost is egyházuk élére. [13.] Ha valakit patvarkodás v. hamis tanúskodás miatt elítélnek, az nem lehet se bíró, se ülnök, se tanácstag. [14.] Ha a város lakosa örökös nélkül hal meg, ingó vagyonáról szabadon rendelkezhessen, azonban ingatlanai, házai telke, szőlői, és épületei - polgártársai javaslata alapján - feleségére v. rokonaira maradjanak, úgy, hogy azok ne tudják örökségüket a város joghatóságán kívül helyezni. [15.] Ha valaki 
végrendelet nélkül hal meg, és nincs felesége, gyermekei, sem rokonai, akkor vagyonának kétharmad része - a polgárok tanácsára hites emberek által — a szegényeknek és az egyháznak adassék, egyharmad része pedig a város javára fordíttassék. [16.] Az uralkodó végül keddenként tartandó heti vásárról rendelkezik, ezen kívül pedig napi piacot engedélyez. Mindezekrôl kettős függőpecsétjével megerősített privilégiumot bocsát ki. Kelt Miklós választott kalocsai érsek, udvari kancellár keze által a. d. 1356. pridie Non. Nov., uralkodásának 15. évében. Méltóságnévsor: Miklós lévén az esztergomi érsek, egyben ua. m. örökös c.-e, Vglinus a spalatói érsek, Miklós az egri, Demeter a váradi, Miklós a pécsi, - az erdélyi püspökség üresedésben -, Kálmán a győri, János a veszprémi, István a választott zágrábi, Tamás a csanádi, Mihály a váci, Péter a boszniai, Tamás testvér a szerémi, István testvér a nyitrai, és Balázs testvér a knini püspök. Konth Miklós lévén a nádor és a kunok bírája, Cykou a tárnokmr., András az erdélyi vajda és Zonuk-i c., Miklós c. az országbíró, Miklós a Machow-i bán, Leustachius mr. Somogy, Fejér és Tolna m.-k c.-e és az egész Szlavónia bánja, Leukus az asztalnok- és pohárnokmr., Dénes a lovász- és Tamás az ajtónállómr.-ek, valamint Simon pozsonyi c. A.

E.: HDA. Grad Koprivnica 1. 7. (Df. 267 993.). Smič. szerint E.-je hártyán; Fk. alapján hátoldalán késóbbi kéz írásával tárgymegjelölés, valamint függőpecsét zsinege.

Á.: 1. Zágrábi kápt., 1372. febr. 2. HDA. Grad Koprivnica 1. 8. (Df. 267 994.) (E.-ről).

2. Á. 1. > Zsigmond király, 1394. márc. 5. HDA. Grad Koprivnica 1. 9. (Df. 267 995.).

3. Á. 2. > Zsigmond király, 1411. aug. 29. > Cillei Ulrik zagoriai c., 1442. márc. 18. HDA. Grad Koprivnica 1. 10. (Df. 267 996.).

4. Á. 3. > I. Mátyás király, 1459. szept. 19. HDA. Grad Koprivnica 1. 11. (Df. 267 997.).

5. Á. 1. > zágrábi kápt., 1479. febr. 11. HDA. Grad Koprivnica 1. 12. (Df. 267 998.).

K.: Kercselich, Not. praelim. 242.; Katona, Hist. crit. X. 157-159.; F. IX/2. 493-494. (238. szám); Vjesnik II. 174-176.; Smič. XII. 373-376. (280.szám) (E.-ről).

R.: Doc. Rom. Hist. C. XI. 39-40. (42. szám) (románul).

Megj.: Zsigmond király 1411. évi átíró oklevelét (Á. 3. és Á. 4.) 1. ZsO. III. 870. Á. 2. ZSO. nem tartja számon.

559. 1356. nov. 4 .

A Clusmonostra-i Boldogságos Szűz Mária-monostor konventje pecsétjével megerősített nyílt oklevelet bocsát ki a színe e. egyik részrôl megjelenő Aba nembeli Chente (dict.) János fia: János, valamint Wos (dict.) Miklós mr. ügyében, akik közül elóbbi kinyilvánította, hogy bizonyos belső Zonuk m.-i Borzua hegyet és Huzyumezev birtokot, melyek örökségként képezik tulajdonát, minden haszonvételével és tartozékával együtt [sógorának] Wos (dict.) Miklós mr.-nek és fiainak —- akik e János lánytestvérétôl (soror uterina) születtek - , nevezetesen Lászlónak, Istvánnak, Pálnak és Jánosnak ad örökre és visszavonhatatlanul, mégpedig úgy, hogy a birtokok jövedelméból azok kötelesek ót élete végéig eltartani. D. 4. die fe. OO. SS., a. d. 1356. 
E.: - K. és R. szerint eredetije hártyára íródott, hátlapján pecsét töredékével, egykor a Wass cs. 1t.-ban őrizték (XXXVIII/25. jelzet alatt), mára nyoma veszett.

K.: HOkl. 261-262. (246. szám); Doc. Rom. Hist. C. XI. 40-41 (43. szám) (román fordításban is).

R.: Wass cs., cegei lt. 251. (110. szám); Erdélyi Okm. III. 311. (859. szám).

\section{1356. nov. 4.}

A nyitrai egyház kápt.-ja e. Zamard-i Tot (dict.) Pál mr. fia: Bereck a maga, valamint a kápt. ügyvédvalló levelében meghatalmazva - apja nevében is olyan bevallást tesz, miszerint megengedik Jardan-i Leonardus fiainak: Miklósnak, Istvánnak és Jánosnak, hogy szabadon elzálogosítsák Jardan v. bármely más birtokukat [1356.] nov. 1-jétől (a fe. OO. SS. prox. preterito) [1357.] jan. 6-ig (usque fe. Epiph. d. nunc affuturum). D. f. VI. prox. p. fe. OO. SS., a. d. 1356.

E.: Dl. 4632. (NRA. 1671.77.) Papíron, hátoldalán azonos kéz írásával tárgymegjelölés, valamint a kápt. kerek zárópecsétjének töredéke.

K.: -

561. 1356. nov. 4.

A nyitrai egyház kápt.-ja tudatja: színe e. egyik részről Zamard-i Benedek fia: Tot (dict.) Pál mr. és fia: Bereck a maga, valamint elóbbi a fiai, utóbbi pedig a fivérei, jelesül Simon, János és András nevében is, a másik részről pedig Jardan-i Leonárd fiai: Miklós, István és János megjelenvén, egyetértésben kijelentették, hogy birtokperükben fogott bírák közremúködésével olyan egyezségre jutottak, amely szerint dec. 7-én (in oct. B. Andree ap.) Leonárd fiainak Nyitra m.-ben fekvő Jardan, Zerbeth és Belhozth $\sim$ Belhesth birtokaiból a kápt. tanújának jelenlétében kiadják Pál mr.-nek és feleségének aki Leonárd fiainak nővére (soror uterina) — és az ô utódaiknak az óket megilletố negyedet, mégpedig a következőképpen: Zerbeth-ben kétnegyedet -- egyiket a Jardanban, a másikat a Zerbeth-ben járó negyedrész gyanánt - a harmadik negyedet pedig Belhesth-en. Kikötötték, hogy ha bármelyikük örökös nélkül halna meg, akkor részeik jog szerint maradjanak együtt a túlélő fél kezén lévő fennmaradó részekkel, továbbá, hogy a birtokrészeket sem eladni, sem elzálogosítani, sem más módon elidegeníteni nem szabad egymáson kívül másoknak, kivéve, ha a másik fél azokat megvenni v. zálogba venni nem tudja v. nem akarja. Vállalják továbbá, hogy birtokjogukban egymást közös fáradtsággal és költségen védelmezni fogják. Ezenfelül Pál mr. és felesége fiaikkal együtt kötelesek elköltözni Jardan birtokról saját birtokukra, továbbá a felek valamennyi, a szóban forgó birtokokkal kapcsolatban egymással szemben kiállíttatott oklevelüket hatálytalanoknak nyilvánítják, egyezségüket pedig — annak megsértése esetére - párbajvesztes hatalmaskodók büntetésének terhe alatt szavatolják. D. f. VI. prox. p. fe. OO. SS., a. d. 1356.

Á.: 1. Esztergomi kápt., 1370. júl. 20. Dl. 62 528. (Motesiczky cs. 1t. 60.) Hátoldalán az átíró oklevél 1380-ra vonatkozó évjelölésével.

2. Á. 1. > ua., 1720. jún. 25. Uo., mint Á. 1., azzal megegyező jelzet alatt; 1-4. old.; 18. sz.-i egyszerú Má.-ban. 
Má.: 1. Uo., mint Á. 1., azzal megegyezô jelzet alatt; 18. sz.-i egyszerú Má.-ban, az átíró oklevél 1380. júl. 20-i dátumával.

2. Dl. 14 029. (NRA. 1094. 10.) Á. 1.-rôl készült 18. sz.-i egyszerú Má.-ban.

Eml.: A 629. számú oklevélben.

K.: -

562. 1356. nov. 4.

A zágrábi egyház kápt.-ja tudatja, hogy 1356. nov. 4-én (a. d. 1356., f. VI. prox. p. fe. OO. SS.) színe e. megjelentek a Jaak nemzetségéből való Fiach fia Tamás fiai: Balázs és Imre -- ügyvédvalló levéllel képviselve fivérüket (uterinus fr.), Jánost is -, és kijelentették, hogy a szegénységtől és szükségtől szorongattatván a Welika folyó mellett fekvő, a néhai István fia: Miklós bán Pryncholch és Tyburchouch birtokával határos Welika öröklött birtokukat $40 \mathrm{M}$. jó dénárért eladják Miklós egykori bánnak és fiainak: István, Ferenc, János, Miklós és László mr.-eknek, valamint azok örököseinek, továbbá valamennyi, a birtokhoz kapcsolódó oklevelüket ugyancsak átadják, hogy a késóbbiek során sem ôk, sem utódaik ne követelhessék azt vissza. Az ügylet megerősítésére a kápt. pecsétjével ellátott oklevelet bocsát ki. D. die et a. supradictis.

E.: Dl. 4633. (NRA. 602. 7.) Vonalazott hártyán, hátoldalán azonos és késóbbi kéz írásával tárgymegjelölés, alján vörös sodraton a zágrábi kápt. mandorla alakú pecsétje függ (rajta Szt. István glóriás, koronás, trónuson ülő alakja látható, baljában országalma, jobbjában jogar; körirata: +S(IGILLVM) CAPITVLI SAGRABIENSIS).

Á.: Zágrábi kápt., 1372. nov. 8. Dl. 4634. (NRA. 602. 7.).

K.: AO. VI. 513-514. (320. szám) (kihagyásokkal); Smic. XII. 371-372. (279. szám) Mindkettő E.-ről.

563. (1356. nov. 8. e.)

István erdélyi alvajda perhalasztó oklevele Beld-i László fia: László és András fia: Balázs panaszának az erdélyi rész nemesei és más jogállású emberei részére nov. 8-án (in oct. fe. OO. SS.) Torda-n tartott congregatio generalis alkalmával történő előterjesztésére vonatkozóan.

Eml.: Az 579. számú oklevélben.

K.: $\quad$ Doc. Rom. Hist. C. XI. 48. (48. szám) (Eml-ben).

564. 1356. nov. 8 .

[I.] Lajos király (H, Da, C, Ra, Se, G, L, Co, Bu, princ. Sal., mont. S. Angeli dom.) tudatja: jóllehet Szlavónia hajdani bánjainak adománya, melyet Jakussinch birtokon a Kaproncza-i Koproncha-i Szt. Miklós vértanú-egyház javára tettek, az okleveleikben foglaltak szerint alaptalannak látszik, hiszen ez királyi birtok volt, amely királyi beleegyezés nélkül nem adományozható, mégis a király kegyes előrelátással betartja a mondott egyháznak tett ígéretet, és azt a különleges királyi földet, Jakussinch birtokot (predium), valamennyi haszonvételével és tartozékával együtt királyi adomány címén elő- 
kelői és bárói tanácsára, bizonyos várnagyok és officiális-ok jelenlétében a szóban forgó egyháznak adományozza azon határok mentén, melyek a mondott bánok érvénytelenített privilégiumaiban leírattak. Hj.: a határ Dé-ről indul a Kaznothina folyó mellett, körte- és cseresznyefák között, ahonnan bemegy egy völgybe, melyen keresztül É felé 2 völgy között egy dombra ér, rajta egy berken (nemus) keresztül Izderner szólőhöz jut, majd Ny felé egy úton halad tovább É-ra, majd egy dombon és egy régi úton menve leszáll a völgybe, azon keresztül egy másik völgybe, majd felfelé a völgy bejáratához (ad caput ipsius vallis) tartva elérkezik Jackya szőlőjéhez, innen Ke felé egy völgyön át É-nak fordul Izdenchech föld szomszédságában, és Ribnachk-hoz ér, majd gesztenyefákhoz, aztán pedig Ny felé egy útra jut, amely mellett É felől Mochilla völgybe tart, majd ezen keresztül egy dombhoz, ahol Kozma fiainak a szőlője van, ezt követően Wlkodnigh föld falujával határos úton halad tovább Dé felé, majd Kaznichina patakhoz ér, ahol Dragssin hatósági kerületével (veznicatus) kerül szomszédságba, a patakban feljebb menve egy völgybe jut, majd Dé felé eléri a völgy bejáratát, innen Ny felé egy dombon cseresznyefákhoz, ahonnan leszállva visszaér az elsó határjelhez. Mivel Szt. Imre vértanú kápolnája Kaproncha vára alatt van, és — tudomásuk szerint — mindig Szt. Miklós vértanú-egyházának volt alávetve, ezért ez a kápolna korábbi szokás szerint birtokával és minden más jogával Szt. Miklós-egyházának legyen alárendelve. Mindezekrôl a király autentikus kettős pecsétjével megerôsített privilégiumot ad ki. Kelt Miklós választott kalocsai érsek (archyelecti confirmati ecclesie Colloczensis) s egyben udvari kancellár keze által, a. d. 1356. VI. Id. Nov., uralkodásának 15. évében. Méltóságnévsor: Miklós lévén az esztergomi érsek és a m. örökös c.-e, Bálint [!] a spalatói érsek, Miklós az egri, Demeter a váradi, Miklós a pécsi - az erdélyi szék üresedésben -, Kálmán a győri, János a veszprémi, István a választott zágrábi, Tamás a csanádi, Mihály a váci, Péter a boszniai, Tamás testvér a szerémi, István testvér a nyitrai, Balázs testvér a knini püspök; Konch Miklós a nádor s egyben a kunok bírája, Cykon [!] a tárnokmr., András az erdélyi vajda, s egyben a Zonuk m.-i c., Miklós az országbíró, Miklós a Machou-i bán, Leustachius mr. a Somogy-, Fehér- és Tolna m.-i c., s egyben egész Szlavónia bánja, Lencus [!] az asztalnok- és pohárnokmr., Dénes a lovászmr., Tamás az ajtónállómr., Simon a Pozsony m.-i c.

Á.: Csázmai kápt., 1610. okt. 23. > csázmai kápt., 1628. aug. 8. AH. Akademije Diplomata latina 5. 12. (Df. 230 457.) E.-je hártyára íródott nyílt oklevél volt.

K.: -

\section{1356. nov. 8. Zágráb}

Leustachius, Szlavónia vikáriusa a Gerinus polgár elleni perben, miután tanácskozott a Szt. Mária[-egyház] apátjával, Hanoldus-szal, Miklós kalocsai választott érsekkel (archielectus) és István zágrábi választott (electus) [püspökkel], ítéletet hoz a fürdő ügyében. Zagrabiae, 12. die termini p. fe. SS Simonis et Iudae, a. 1356.

E.: -

R.: Kercselich, Hist. eccl. Zagrab. 132., s ez alapján F. IX. 2. 567. (273. szám).

566. 1356. nov. 9.

[I.] Lajos király (H, Da, C, Ra, Se, G, L, Cu, Bu, Sal., mont. S. Angeli dom.) tudatja: mivel Hleuna-i Gales fia: Gergely nemes ember a királynak adta Byztriche várát Hleuna-ban 
valamennyi falvával és haszonvételével egyetemben, ezért cserében a király a szlavóniai Chaua királyi földet valamennyi falvával, haszonvételével és jövedelmével (fructusficatio) nevezett Gergelynek és örököseinek adományozza örökre és visszavonhatatlanul idegen jog sérelme nélkül, melynek bizonyságára autentikus kettős függőpecsétjével megerősített privilégiumot bocsát ki. Kelt Miklós választott kalocsai érseknek, egyben a királyi udvar kancellárjának a keze által, a. d. 1356, V. Id. Nov., uralkodása 15. évében. Méltóságnévsor: Miklós lévén az esztergomi érsek s egyben a m. örökös c.-e, Vglinus a spalatói érsek, Miklós az egri püspök, Demeter a váradi, Miklós a pécsi - az erdélyi szék üresedésben -, Kálmán a győri, János a veszprémi, István a választott zágrábi, Tamás a csanádi, Mihály a váci, Péter a [boszniai] (Poznensis !), Tamás testvér a szerémi, István testvér a nyitrai, Balázs testvér a knini püspök; Kont Miklós a nádor s egyben a kunok bírája, Cykow a tárnokmr., András az erdélyi vajda s egyben a Zonuk-i c., Miklós az országbíró, Miklós a Machow-i bán, Leustachyus az egész Szlavónia bánja, Somogy, Fejér és Tolna m.-k c.-e, Leukus az asztalnok- és pohárnokmr., Dénes a lovászmr., Tamás az ajtónállómr., Simon a pozsonyi c. A.

Á.: Zágrábi kápt., 1358. márc. 20. Dl. 35 863. (Kukuljevics-gyújtemény).

K.: Smič. XII. 376-377. (281. szám) (Á.-ról).

R.: Doc. Rom. Hist. C. XI. 41. (44. szám) (románul).

567. 1356. nov. 10.

[I.] Lajos király (H, Da, C, Ra, Se, G, L, Co, Bu, princ. Sal., mont. S. Angeli dom.) a színe e. teljes kápt.-ját is képviselő Jakab zágrábi prépost kérésére és oklevél-bemutatása alapján főpapjainak és báróinak a tanácsára átírja s autentikus kettős pecsétjének ráfüggesztésével megerősíti [IV.] Béla király $(\mathrm{H})$ Thoplica földjének és határjelek állításának ügyében 1247. szept. 11-én kiállított privilégiumát. Kelt Miklós választott kalocsai érsek s egyben udvari kancellár keze által, a. d. 1356., IV. Id. mensis Nov., uralkodásának 15. évében. Méltóságnévsor: Miklós lévén az esztergomi érsek s ua. m. örökös c.-e, Vglinus a spalatói érsek, Miklós az egri, Demeter a váradi, Miklós a pécsi, István a választott zágrábi, János a veszprémi, Kálmán a gyơri, Mihály a váci, Péter a boszniai, Tamás testvér a szerémi, István testvér a nyitrai, és Balázs testvér a knini püspök; Konth Miklós lévén a nádor és a kunok bírája, András az erdélyi vajda és Zonuk-i c., Cikou a tárnokmr., Zechi Miklós c. az országbíró s Turich [!]-i c., Miklós a Machow-i bán, Leustachius az egész Szlavónia bánja, Somogy, Fejér és Tolna m.-i c., Dénes a lovász-, Leukus az asztalnok- és a pohárnokmr., Péter fia: Tamás az ajtónálló mr., valamint Móric fia: Simon a pozsonyi c. A.

Á.: Zsigmond király, 1427. nov. 11. HDA. Archivum capituli Zagrabiensis: Acta antiqua 52. 5. E. (Df. 288 958.). Az átíró oklevélben foglaltak szerint az eredeti privilégium I. Lajos király 2 kettőspecsétjével volt megerősítve és az alsó szélén 1364. okt. 25-én kelt megerősítő záradékkal is el volt látva, utóbbit Zsigmond király oklevele ugyancsak átírta.

Má.: HDA. Archivum capituli Zagrabiensis: Acta antiqua S.N. (Df. 257 259.) 18. sz.-i egyszerú Má.-ban Á.-ról.

K.: - 
Megj.: IV. Béla király - saját korábbi, 1225. évi privilégiumát átíró - a zágrábi kápt. részére kiadott adománylevelét 1 . Reg. Arp. I. 861. szám (ebben Á. igen, de Má. nincs említve).

568. 1356. nov. 10.

A vasvári egyház kápt.-ja emlékezetül adja: a Sopron m.-i Viccha-i János fia: Tamás személyesen megjelenvén színe e. kinyilvánította, hogy a Sopron m.-i Lous és a lakatlan Kalach birtokokon lévő valamennyi részbirtokát haszonvételeikkel és tartozékaikkal együtt 10 évre 70 M. - M.-ként 10 pensa-val számolt — széles bécsi dénárért elzálogosítja Balay fia: Gyure mr.-nek olyan módon, hogy a szóban forgó javakat ezen 10 év elteltéig nem válthatja vissza tőle, a 10 év elteltekor (v. utána bármikor) viszont a mondott $70 \mathrm{M}$. — de nem valamiféle javak becsértéke - ellenében lehetôsége lesz a zálog visszaváltására. Tamás köteles a zálogidőn belül szavatolni Gyure mr. háborítatlan birtoklását, ám ha e vállalásának nem akarna v. nem tudna eleget tenni, akkor egy másik birtokán kell egy azonos értékú rész biztosításával Gyure mr.-t kárpótolnia, miként erre nézve Tamás önként kötelezettséget is vállalt. D. f. V. prox. an. fe. B. Martini conf., a. d. 1356. A kápt. az oklevél visszahozatalának esetére privilégium kiállítását ígéri az ügyben.

E.: D1. 90 918. (Khuen-Héderváry cs. lt., Viczay és Khuen-Héderváry cs. 1. NB 12. 1.) Hártyán, a szöveg utolsó harmadánál, a hosszanti hajtásvonal mentén foltos, ezért elmosódott az írás. Hátoldalán késóbbi kezek írásával tárgymegjelölés, valamint kerek rányomott pecsét töredéke, bevágásai.

Tá.: György esztergomi érsek, királyi vikárius és nádori bíró, 1437. márc. 13. Dl. 86347. (Ostffy cs. lt. 145.).

K.: -

\section{1356. nov. 10. Torda}

András erdélyi vajda és Zonuk-i c. emlékezetül adja: Kelnuk-i Salamon fia Miklós fiainak: Istvánnak és Andrásnak Enyed-i Mihály c.-szel szemben fennforgó, Domokos alvajda e. régóta húzódó perét a néhai Peturfolua-i Hennyng fia: Miklós ue. Fehér m.-i Peturfolua-n lévő birtokrésze, valamennyi szőlőjének fele, nemkülönben Sebus városban fekvő telke (unus fundus curiae), továbbá Peturfolua-i 3 malmának harmadrésze tárgyában a nevezett alvajda a per fontosságára és a jelenlévő nemesek alacsony számára tekintettel — oklevelének (l. 418. szám) tanúsága szerint — áttette az ő vajdai jelenléte elé aug. 1-jére (ad oct. fe. B. Jacobi ap.), mindkét felet okleveles bizonyításra szólítván fel. Az időpont elérkeztekor István és András személyesen, Mihály c. helyett pedig famulus-a, Simon jelent meg a vajda e. - annak ügyvédvalló levelében maghatalmazva - és jóllehet mind két fél bemutatta volna okleveleit, a vajda levelében ( $l .419$. szám) az ügy nagyobb bizonyossága érdekében az erdélyi rész nemeseinek congregatiojára halasztotta [nov. 8.] a pert, ahol is István és András nevében Salamon fia Miklós fiai: Salamon, Mihály és Miklós - a nevezettek fivérei (fr. uterinus) — jelentek meg, a másik fél részérôl pedig Enyed-i Mihály járult színe elé, s ott kijelentették, hogy fogott bírák közvetítésével egyezségre jutottak egymással. Ennek értelmében Hennyng fia: Miklós fentebb felsorolt tulajdonait minden haszonvételükkel és tartozékaikkal együtt a néhai István erdélyi vajda -- András vajda fivérének és elődjének — privilégiumában foglal- 
tak szerint átengedik Enyed-i Mihály c.-nek és örököseinek örök birtoklásra, egyszersmind valamennyi vonatkozó peres oklevelüket semmisnek nyilvánítják —- ahogyan azt Mihály c. is megteszi —, egyben kötelezik magukat, hogy Mihályt és örököseit — saját költségükön - megvédik jogos tulajdonukban, és ha ők maguk v. utódaik követelnék vissza a mondottakat, akkor patvarkodás vétségében marasztalják el őket. Mindezek megerősítésére András vajda függőpecséttel ellátott oklevelet ad ki Mihály c. számára. D. Torde, 3. die oct. fe OO. SS., a. d. 1356.

Á.: Erdélyi kápt., 1357. márc. 3. Dl. 77 183. (Zichy cs. zsélyi lt. 218. B 63.).

K.: Zichy III. 48-50. (33. szám); ZW. II. 123-124. (706. szám); Doc. Rom. Hist. C. XI. 41-44. (45. szám) (román fordításban is) Mindhárom Á.-ról.

R.: Erdélyi Okm. III. 311-312. (861. szám).

Megj.: A [ ]-ben közölt információ ZW.-ből származik.

\section{1356. nov. 13. Torda}

András erdélyi vajda és Zonuk-i c. bizonyítja, hogy az erdélyi rész nemeseinek és más jogállású embereinek közössége számára nov. 8-án (in oct. fe. OO. SS.) Tordán (Thorde) általa tartott generalis congregatio alkalmával Bokws-i Derekaas (dict.) János fia: Simon mr. nemes szólásra emelkedve azt kérte tőle, hogy a $7 \mathrm{~m}$. hivatalban lévő szb.-áit, esküdt ülnökeit és más állapotú embereit szólítsa fel tanúságtételre arra nézve, miszerint az egykoron apjának, Jánosnak a tulajdonában volt Belsó-Zonuk (de Zonuk Interiori) m.-i Sumkwth, Koplyan és Kachko birtokokat —- amelyek jelenleg mind királyi kézen vannak — László egykori erdélyi vajda azért foglalta el a nevezett Jánostól, mert az nem akart a Szt. Koronával szemben hútlenné válni, és a vajda többszöri kérésére sem vállalta el, hogy annak famulus-a legyen. A tanúságtevő́k megerősítették Simon állítását. D. in Thorda, 6. die congregationis nostre prenotate, a. d. 1356.

Á.: Az 588. számú oklevélben.

K.: AO. VI. 517-518. (322. szám) (kihagyásokkal); Doc. Rom. Hist. C. XI. 44-45 (46. szám) (román fordításban is) (mindkettő Á.-ról).

R.: Erdélyi Okm. III. 312. (862. szám).

\section{1356. nov. 13. Torda}

András erdélyi vajda és Zonuk-i c. emlékezetül adja: az erdélyi rész nemeseinek és más jogállású embereinek közössége számára nov. 8-án (in oct. fe. OO. SS.) Tordán (Thorde) általa tartott generalis congregatio alkalmával a tömegból bizonyos Kémendi $\sim$ Kimend-i nemesek, név szerint Demeter fiai: István és János, valamint Gyurk fia: Mihály szólásra emelkedve előadták, hogy az egykori erdélyi vajda, Tamás elfoglalta és elidegenítette tőlük a Kimend birtokukkal határos Simaliget birtokrészüket, amely örökségi jogon volt tulajdonukban. A panaszt az ülnökök és a $7 \mathrm{~m}$. szb.-i esküvel erősítették meg. D. Thorde, 6. die congregationis nostre, praedicto a. d. 1356.

Má.: Dl. 37 221. (Erdélyi kincstári lt. Erdélyi fiscalis lt. 18. 2423. Misc.)

K.: -

Megj.: Az Erdélyi Okm. nem tartja nyilván az oklevelet, ahogyan Doc. Rom. Hist. sem. 
Az esztergomi egyház kápt.-ja jelenti [I.] Lajos királynak (H): a Zech-i Miklós országbíró ítéletlevelében (l. 529. szám) foglalt parancs szerint a kápt. nov. 11-én (in fe. B. Martini conf.) Jakab mr.-rel, az országbíró protonotarius-ával és Ruhman-i György királyi emberrel tanúul küldte Mátyás komáromi és Miklós honti főesp.-eket és kanonokokat az Erzsébet királyné $(\mathrm{H})$ és az esztergom-szentkirályi keresztesek (cruciferorum de Sancto Rege de Strigonio) mr.-e között az Esztergom m.-i Monyaros $\sim$ Monyarus és Taat birtokok elhatárolása körül támadt perben. Ezek visszatérve jelentették, hogy nov. 11-én a határjelek ügyében a szomszédok és határosok jelenlétében kimentek a helyszínre. Bertalan mr., az esztergom-szentkirályi és [budafel-]hévízi (de Calidis Aquis) keresztesek mr.-ének, Vilmos (Gwillermus) bíborosnak a törvényes képviselője ott bemutatta [IV.] Béla király $(\mathrm{H})$ privilégiumát, és mivel abban pontosan nem írták le a határjeleket, amelyek Taat birtoktól elválasztják Monyaros-t, hanem általánosságban ôsi határjeleknek nevezték azokat, ezért megkérték Bertalant, hogy mutassa meg a jeleket. Legelóbb Dé felől 2 régi földjelet mutatott, amelyeknek egyike Taat, a másika Epzeu birtokon van; erre válaszul a királyné képviselője az egyik határjelet Monyaros-tól, a másikat Epzeutől való elkülönítő határjelnek mondta, amit oklevéllel is azonnal bizonyítani tudott. Bertalan mr. ezután Ny felé egy dombnak az oldalában mutatott egy nem túl régi földjelet, azt állítván, hogy az ôsi megjelölés, jóllehet rókakotoréknak (fovea vulpina) tûnt; majd ennek a dombnak a lábánál Monyaros felett mutatott egy nem túl régi, inkább új jelet, aminek környékén további régi határjelet - a királyi és kápt.-i emberek kérdésére - nem tudott mutatni; majd ugyancsak Ny felé, telepített szőlők (vineas inibi plantatas) között mutatott egy új határjelet, de régit nem; és mivel Monyaros birtok Taat-tal nem sok helyen határos, sốt távolabb nem is, a királyné képviselője által bemutatott esztergomi kápt.-i privilégium alapján jelölték ki a határt a következőképpen. Hj.: Ke felől nagy út (vlg.) kuvesuth, amelynek közelében új jelet emeltek, Dé-re szántóföldeken keresztül 2 földjel, közülük egyet Bertalan is megmutatott, e mellé egy újat is emeltek, így egyik Epzeu Dé-i részének, a másik Monyaros Ny-i részének elválasztását jelöli. Itt véget is ért a hj., mivel a további határjelek Beren, Peel és Bayoth birtokoktól választják el Monyaros-t, amelyek pontos elhatárolását a királyné képviselóje által bemutatott országbírói oklevél késóbbre halasztotta. A birtokok elválasztása alapján Monyaros birtok a királynét illeti, Taat pedig a keresztesek mr.-ét, következésképpen Szt. István király egyházát, ám mert az utóbbi fél képviselője által hivatkozott privilégium alapján bemutatott határjelölés alkalmatlannak és megbízhatatlannak bizonyult - mintha éppen csak e képviselő alkotta volna legújabban a jeleket -, így a tanúk, a fogott bírák, továbbá a szomszédok és határosok, valamint a felek képviselóinek jelenlétében új határjelek emelésére volt szükség Monyaros valódi határai mentén a kápt. privilégiuma alapján. A keresztesek mr.-ének, Vilmos bíborosnak a képviselője által a korábbi hj. során támasztott ellentmondással összefüggésben a vitás földet 2 ekealjra becsülték, míg a másik darab földet, amelyet a királyné képviselője az előző hj. alkalmával és most is Monyaros-hoz tartozónak mondott, [IV.] Béla király említett privilégiuma alapján Taathoz kapcsolták, nagyságát pedig 1 ekealjban határozták meg. D. in fe. B. Briccii conf., a. d. 1356.

E.: Dl. 4635. (Acta eccl. ord. et mon. Vet. Buda 1. 7.) Papíron, hátoldalán azonos és késóbbi kéz írásával tárgymegjelölés valamint kerek zárópecsét töredéke, szalagja.

Má.: 1. Dl. 68 094. (Ghyczy cs. 1t. 12.) 18. századi egyszerú Má.-ban.

2. EPL. Acta radicalia I 126. (Df. 248 367.) Újkori egyszerú Má.-ban. 
K.: F. IX. 3. 668-672. (6. szám) (E.-ról, esztergomi kápt. lt. Caps. IX. fas. 3. nro 7.); AO. VI. 514-517. (321. szám) (kihagyásokkal; E.-ről); Str. IV. 155-157. (125. szám). Utóbbi hozza az E. és a Má. 2. közötti eltéréseket is, azonban Má. 1. létezését nem említi.

Megj.: IV. Béla király említett privilégiumát 1. Reg. Arp. IV. 1744. szám.

\section{1356. nov. 13. Pozsony}

Lengel (dict.) Péter mr. pozsonyi alispán a pozsonyi egyház kápt.-jának: Jakus pozsonyi bíró elpanaszolta, hogy Pudmer (dict.) István és Screnstul Scemch-i hospesek nov. 10-én (in vig. fe. Martini conf.) az éjszaka csendjében rossz szándéktól vezérelve Thol...folua birtokra mentek, ahol a bírónak a jobbágyát, Andrást minden ok nélkül meggyilkolták. Ezért az alispán kéri a címzettet, hogy az igazság kivizsgálására küldje ki hites emberét tanúskodás végett a $4 \mathrm{szb}$. közül Thukulchen-i Domokos, nemkülönben pedig az alispán embere, Benedek mellé, majd a történtekről neki küldjön írásos jelentést. D. Posoni, 3. die fe. S. Martini conf., a. d. 1356.

E.: SNA. Pozsonyi kápt. hh. 1t. Oklevelek 28. 2. 53. (Df. 227 056.) Sérült, hátoldalán azonos kéz írásával címzés és tárgymegjelölés, valamint zárópecsét töredéke, bevágásai, szalagja.

K.: -

Megj.: Az alispán emberének, Benedeknek a megnevezése u. a sor fölött halvány kiegészítő bejegyzés necnon Johannes filius Jenke.

\section{1356. nov. 14. Torda}

András erdélyi vajda és Zonuk-i c. emlékezetül adja: Péter mr. deák (litteratus), a Clusmunustrai Szt. Szűz-monostor jegyzője, a konvent és annak apátja, László nevében az erdélyi rész nemeseinek összessége számára nov. 8-án (in oct. fe. OO. SS.) Tordán tartott generalis congregatio alkalmával elpanaszolta, hogy a monostorhoz tartozó Clus m.-i Bewna birtokot Kalyan-i János fia: Mannus elfoglalta. Ezt hallván a szintén jelenlévő Mannus azt válaszolta, hogy Bewna az ő öröklött birtoka. Az állítást megcáfolandó, Péter mr. az erdélyi kápt. kiküldötteinek 2 jelentését - közülük az egyik magának András vajdának, a másik István egykori alvajdának szólt - mutatta be, amelyekból kiderült, hogy a vajda és az alvajda emberei a kápt. tanúival vizsgálatot tartottak, s ennek alkalmával bebizonyosodott: Bewna birtok a mondott egyházhoz tartozott és most is oda tartozik. Mivel Péter mr. az apátság birtoklásának jogalapjára vonatkozóan más bizonyító oklevelet nem tudott bemutatni, miután azok a monostor összes javaival együtt elpusztultak, amikor hatalmaskodó és a koronához hútlen emberek elfoglalták azt, ezért a vajda a $7 \mathrm{~m}$. szb.jával, esküdtjeivel és ülnökeivel úgy határozott, hogy Mannus 4 szomszédjával együtt jelenjen meg Szentimrén (in S. Emerico) jan. 13-án (in oct. fe. Epiph. d.), és ott esküvel bizonyítsák, hogy a szóban forgó birtok örökség gyanánt ôt illeti meg. D. in Torda, 7. die congregationis nostre prenotate, a. d. 1356.

E.: Ba. Gyulafehérvári kápt. lt. Kolozsmonostori konvent, Oklevelek 13. v. Com. Kolos. A 77. (Df. 275 174.) Papíron (Beke alapján: „benne harangvirág alaku jegygyel”), hátoldalán azonos és késóbbi kéz írásával tárgymegjelölés, valamint azonos kézzel lapszéli jegyzet, továbbá kerek zárópecsét nyoma, bevágásai. 
Tá.: 1. Macska Domokos alvajda, 1357. jan. 17. Dl. 29 149. (Gyulafehérvári kápt. o. lt. Cista com. Colos 4. 6.).

2. Kolozsmonostori konvent, 1357. febr. 26. > Bertalan erdélyi alvajda, 1393. szept. 26. Dl. 28 735. (Kolozsmonostori konvent o. lt. Metales K 10.).

Má.: Tá. 2.-ról, azzal egyező jelzet alatt; 18. sz.-i egyszerú Má.-ban.

K.: F. IX. 2. 547-549. (267. szám) (Cornides Má.-a alapján); Doc. Rom. Hist. C. XI. 45-48. (47. szám) (román fordításban is).

R.: Beke, Kolozsmonostor 504. (24. szám) nov. 15-ére datálva; Erdélyi Okm. III. 312. (863. szám).

575. (1356. nov. 15.e.)

Konth Miklós nádor utasítja a pécsi kápt.-t, hogy Bodomer-i Besenew (dict.) János nádori ember mellé küldjön tanút tudományvétel céljából Thathfalua birtokra a néhai királyi ajtónállómr., Töttös és fiai által Choth-i Miklós fiai: Bobows (dict.) Lőrinc és Domokos mr.-ekkel szemben elkövetett hatalmaskodás ügyében.

Eml.: Az 583. számú oklevélben.

K.: -

Megj.: Vö. az 586. számú oklevéllel.

576. (1356. nov. 15. e.).

Konth Miklós nádor utasítja a váradi konventet, hogy Sydele-i Tamás fia: Petheu királyi ember mellé küldjön tanút tudományvétel céljából Thoutfalu birtokra a néhai Töttös mr. és fiai által Chaty-i Babous (dict.) Miklós fiai: Domokos, Lőrinc és Miklós mr.-ekkel szemben elkövetett hatalmaskodás ügyében.

Eml.: Az 586. számú oklevélben.

K.: -

Megj.: Vö. az 583. számú oklevéllel.

577. 1356. nov. 15.

Delfino János velencei doge nyílt oklevelében tudatja, hogy megállapodásra jutott a hozzá küldött szentszéki követtel, a Velence és a Magyar Királyság közötti ellentét elsimítása ügyében meghatározva a közöttük kötendő egyezség fóbb pontjait.

R.: Óváry 49. (70. szám) (Velencei lt.-ra való hivatkozással).

578. 1356. nov. 15.

A [székes-]fehérvári Szt. István király-egyház ispotályos háza kereszteseinek konventje jelenti [I.] Lajos királynak (H): a néhai Vgal-i Pál mr. fia: Miklós számára a király által 
1 évre kiállított, nagyobb pecsétjével megpecsételt, általános idéző, tudományvételi és tiltó levelében (l. 163. szám) foglaltak alapján Pezzya-i István királyi ember mellé tanúul adták emberüket, András testvért, akiknek a konventhez való visszatérte u. István királyi ember jelentést tett. Eszerint a konventi kiküldött társaságában és tanúságával nov. 12-én (sabb. prox. p. fe. B. Martini conf.) felkereste a Kapurew birtokkal szomszédos és határos falvakat, ahol nyíltan v. titokban kikérdezte az ügyben értesülésekkel bíró nemeseket, nemteleneket, egyháziakat, laikusokat és más rendú-rangú embereket, és olyasforma bizonyosságra jutott, miszerint Tudbeg fia: Domokos és ennek fia: Lő́rinc, Chyko mr. jegyzője (notarius), továbbá Kapurew Kapureu-i Remete (dict.) Miklós nov. 10-én (f. V. prox. an. fe. B. Martini conf.) Vgal-i Pál fia: Miklós mr. Kapureu-i tavát önhatalmúlag lehalászták, továbbá ugyanezen a napon, Miklós mr. famulus-ára, Gegus-ra, aki megkérdezte, hogy miért halásszák le erőszakosan ura tavát, fegyveresen rátámadtak és őt egészen Miklós mr. vámszedőjének (tributartius) házáig üldözték, ahol azután betörték a ház ajtaját, és 4 életveszélyes sebet ejtettek Gegus fején, majd a szóban forgó házból kivonszolták, és félholtan hagyták ott Remete (dict.) Miklós kapuja e., ill. hagyták, hogy az utcán össze-vissza ráncigálják és tovább ütlegeljék, ahogyan azt szemtanúk igazolták. Domokos, Lőrinc és Remete (dict.) Miklós nov. 6-án (domin. die prox. an. fe. B. Martini conf.) Pál fia: Miklós jobbágyának csónakját (navis) a mondott Kapurew-ről elkötötték, és nem adtak cserébe semmit használatáért, ezenkívül pedig Pál fia: Miklós 2 birtokának, Custari és Kapurew birtokoknak a vetéseit és szénáját is fellegeltették és letarolták, nem kis kárt okozva ezzel Miklós mr.-nek. D. f. III. prox. p. predict. fe. B. Martini conf., a. d. 1356.

E.: Dl. 87 319. (Esterházy cs. hercegi ága, Repositorium 47. U 4.) Papíron, bal alsó sarkában az írás egy foltban elhalványult, hátoldalán azonos és késóbbi kéz írásával tárgymegjelölés, valamint mandorla alakú zárópecsét töredéke, bevágásai.

K.: -

Megj.: I. Lajos király említett éves levelét megemlítik még a 180. számú oklevélben.

\section{1356. nov. 15. Torda}

András erdélyi vajda és Zonuk-i c. tudatja: Beld-i László fia: László és András fia: Balázs az egykori alvajda, István halasztó oklevele (l. 563. szám) alapján az erdélyi rész nemesei és más jogállású emberei részére nov. 8-án (in oct. fe. OO. SS.) Tordán tartott generalis congregatio alkalmával megjelentek és kijelentették, hogy Beld birtok a természet jogán, mint örökség illeti meg őket, azonban nővérüknek Jako-tól született fiai: Jakab és Lukács (Lucasius Lucas) a szóban forgó birtokra mentek, majd annak nagyobb részét elfoglalták, amelynek okát meg akarják tőlük tudni. Ezt hallva Jakab a maga és ügyvédvalló levélben maghatalmazva - fivére, Lukács nevében is azt válaszolta, hogy a szóban forgó részt Beld birtokból jogi úton szerezték meg, amit oklevelekkel tudnak bizonyítani. Jóllehet mindkét fél oklevelek bemutatásával akarta igazolni a birtokrészekhez való jogát, mégis fogott bírák közbenjárásával a vajda e. egyezségre jutottak egymással. Ennek értelmében a vajda kéri az erdélyi egyház kápt.-ját, hogy a néhai vajda, Gyog [?]-i András fia: László v. Tate-i Kemyn fia: Márton v. Adorján fia: Péter vajdai emberek valamelyikével küldje ki a kápt. hites tanúját [1357.] febr. 9-én (in oct. fe. Purif. virg. glor.) Beld birtokra, ahol a határosok, szomszédok, valamint a nevezett felek jelenlétében osszák 3 egyenlő részre a birtokot. Ebből 2 részbe Jakabot és Lukácsot, míg ugyanebból a részból 2 jobbágytelekbe, valamint a 3. részbe a nevezett Lászlót és Balázst iktassák be olyan kikötéssel, hogy ha valamelyik fél a megegyezést nem tartaná 
be, úgy patvarkodás búnében marasztalják el, miként azt a békéltetés részvevői - azaz a felek meghatalmazottjai, ill. a vajda, a $7 \mathrm{~m}$. szb.-ái, és az esküdt ülnökök részéról közremúködők - a létrehozott egyezségben elrendezték. Utasítja továbbá a kápt.-t, hogy az iktatásról márc. 22-ig (ad oct. die medii Quadr.) neki írásban jelentsen. D. in Torda, 8 die congregationis nostre prenotate, a. d. 1356.

E.: Dl. 30 687. (Gyulafehérvári kápt. o. lt. Centuriae R 64.) Papíron, hátoldalán késóbbi kézzel Beld, valamint kerek rányomott pecsét töredéke, bevágásai.

K.: Doc. Rom. Hist. C. XI. 48-50. (48. szám) (román fordításban is).

R.: Erdélyi Okm. III. 313. (864. szám).

\section{1356. nov. 17. Visegrád}

Zeech-i Miklós c., [I.] Lajos király (H) országbírája, Turuch m.-i c. tudatja a váradi egyház kápt.-jával: a korábbi oklevelében foglaltak szerint Byry-i Tamás aug. 1-jén (in oct. fe. B. Jacobi ap.) megjelent színe e. a Zabouch-ba való néhai Belus fia Miklós fia: István ellenében, és kérte, hogy nemes anyjának — az említett Belus fivére, Zabouch-i Domokos leányának — leánynegyedét, amely ôt Zabouch, Balsa, Nyereghaz Nyreghaz, Olazy és más birtokokból megilleti, valamint nagyanyjának - Domokos feleségének hozományát és jegyajándékát kapja vissza nevezett Istvántól. Hozzáfüzte, hogy Domokosnak 2 felesége volt, és az ő anyja az első feleségtól született, de Domokosnak volt egy másik lánya is a második feleségétól. Tamás azonban azt a leánynegyedet kéri, amely ôt anyja révén jog szerint megilleti. István elfogadta Tamás kérését, és hozzájárult a nevezett 4 birtok, valamint a többi részbirtok felméréséhez, továbbá a részek átadásához Tamás számára, de mert a birtokosztályt már István elődei végrehajtották, így szükségessé vált a királyi ember és a Lelez-i konvent emberének kiküldése az ügyben. Ezért az országbíró levelet intézett a Lelez-i konventhez (l.441. szám), hites tanú kiküldését kérve Zakul-i László fia: János v. Panyalia-i János v. Zolnuk-i Tamás v. Nogyfalu-i Gabrianus v. Rakamaz-i Benedek fia: Pouch királyi emberek valamelyike mellé, hogy azok okt. 13-án (in quind. fe. B. Mychaelis arch.) kimenvén a szóban forgó birtokokra és tartozékaikra, a szomszédok és határosok, ill. a felek - v. utóbbiak képviselőinek a - jelenlétében járják be határaikat, és miként azok más birtokoktól elkülönülnek, minőségüket és nagyságukat szemrevételezve v. méréssel a királyi mértéket használva, v. — ha ezt nem tudják végrehajtani -, szemmel megítélve végezzék el a birtokok becsújét az ország szokása szerint, ezt követően pedig az eljárásról írjanak jelentést a királynak nov. 8-ig (ad oct. fe. OO. SS.). A kitűzöttt napon az országbíró e. megjelent egyik részről Byry-i Tamás, a másikról pedig az István képviseletére a Jazou-i egyház konventjének ügyvédvalló levelében meghatalmazott Miklós fia: Beke, és bemutatták a Lelez-i konvent jelentését (l. 550. szám), amelyben többek között leírták, hogy a konvent az országbíró parancsára Zakul-i László fia: János királyi ember társaságában tanúul küldte ki János testvért, akik visszatérve jelentették, hogy okt. 13-án (in quind. fe. B. Mychaelis arch.) kimentek Zabouch és a többi 3 birtokra, nemkülönben azok tartozékaira, majd amikor ott Miklós fia: István jelenlétében be akarták járni és fel akarták mérni, ill. becsülni a szóban forgó javakat, ez utóbbi eljárásoktól Fynnas (dict.) István —- Balázs fia: Pál officialis-a —- eltiltotta óket. Ezért az országbíró utasítja a váradi kápt.-t, hogy küldje ki hites tanúját Patha-i Péter fia: Domokos v. Mátyás v. Panyalia-i Péter fia: János ill. atyafija (fr.), László, v. Dedach-i Anyas fia: János v. Malcha-i István fia: András v. Zakul-i Élias (Elyas) királyi emberek valamelyikének társaságában [1357.] márc. 1-jén (in oct. diei Cynerum) Zabouch, Balsa, Nyreghaz és Olazy birtokokra, valamint azok tartozékaira. Ott a szom- 
szédok és határosok összehívását követően a felek v. képviselőik jelenlétében a Belus fivérét, a szóban forgó Byry-i Tamás anyai nagyapját, Domokost egykor megillető birtokrészeknek a negyedét azok minősége, nagysága, jövedelmezősége, használhatósága és éréke tekintetében megvizsgálva, határaik szerint megjárt és más birtokoktól elkülönített állapotukban, v. a királyi mértéket alkalmazva méréssel, v. - - ha ez nem lenne lehetséges - szemrevételezéssel becsüljék fel és állapítsák meg értéküket, függetlenül a Balázs fia: Pál, ill. bárki más részéról esetleg felmerülő ellentmondástól. A kápt. az eljárás végeztével a történtekrôl [1357.] ápr. 16-ig (ad oct. fe. Passce d.) jelentsen írásban a királynak. D. in Wysegrad, 10 die termini prenotati, a. d. 1356.

E.: Dl. 51 722. (Kállay cs. lt. 1300. 1102.) Papíron, hátoldalán azonos és késóbbi kéz írásával tárgymegjelölés, valamint kerek zárópecsét töredéke, bevágásai, írott hártyaszalagja.

K.: -

R.: Kállay II. 39. (1197. szám).

581. (1356. nov. 18.e.)

Zeech-i Miklós c. országbíró utasítja a Saag-i premontrei konventet, hogy állítson tanúkat egyrészt a felperes, Oztroluca-i Och fia: János oldalán eljáró András fia: Sándor v. Magiarfolua-i Vörös (Rufus) Mihály v. András fia: István v. .......duch-i Tamás fia: Dénes v. ennek fivére, Miklós királyi emberek valamelyike mellé, másrészt pedig a Mykou fia: Miklós és Tamás fia: Péter alperesek oldalán közremúködő Precel fia: Erdeuhath v. ennek fivére Petheu v. Guba (dict.) Pál királyi emberek valamelyike mellé az elrendelt tudományvétel lefolytatásához. A kiküldötteknek a peres felek v. az óket helyettesítő, ügyvédvalló levében meghatalmazott törvényes képviselőik jelenlétében nov. 18-án (in. oct. fe. B. Martini conf.) a határosok és szomszédok összehívását követően kell kimenniük Oztroluca $\sim$ Ostroluca $\sim$ Astroluca birtokra, és ott a felperes panasza ügyében kideríteni az igazságot először a birtok szomszédainak, majd mindenki másnak a kikérdezésével. A panasz szerint Mykou fia: Miklós és Tamás fia: Péter márc. 20-án (in domin. Remin.) fényes nappal Och fia: János Oztroluca birtokon lévő házához mentek, és miután ott szekrényét összetörték, 12 ft.-ját és 4 lovát ellopták, felprédálták Oztroluca birtokát, feleségét kegyetlenül megverték, ôt magát pedig meg akarták ölni. Nemkülönben .......szept. 29. [körül] (........ B. Mychaelis arch.) jobbágyaikat utasították, hogy János termőfáit vágják ki, valamint ........ birtokrészről Kubelkut vizet a saját medréból más mederbe tereljék. Az országbíró a fenti ügyben vizsgálatot rendel el, ugyanakkor kéri, hogy a tudományvétel eredményéról a kihallgatottak nevével együtt [1357.] jan. 13-ig (ad oct. fe. Epiph. d.) a konvent küldjön írásos jelentést a királynak.

Eml.: Az 590. számú oklevélben.

K.: -

582. (1356. nov. 18. e.)

Zeech-i Miklós országbíró utasítja a váradi kápt.-t, hogy Egrus-i János fia: László felperes és Vyhel-i Miklós fia: István alperes között zajló per kapcsán Viuzy-i [?] Imre fia: Domokos királyi emberrel küldjön hites tanút nov. 18-án Egrus birtokra vizsgálat lefolytatása végett, majd a történtekról küldjön jelentést a királynak. 
Eml.: A 601. számú oklevélben.

K.: -

583. 1356. nov. 19.

A pécsi egyház kápt.-ja jelenti Konth Miklós nádornak $(\mathrm{H})$, a kunok bírájának: megkapta a nádor tudományvételt elrendelő levelét (l. 575. szám), és az abban foglaltak szerint eljárva Bodomer-i Besenew (dict.) János nádori emberrel kiküldte közhitelü tanúként Bereck mr. kanonokot a vizsgálat lefolytatásához, akik visszatérve jelentést tettek. Eszerint nov. 15-én (f. III. prox. p. fe. B. Briccii conf.) nemesektól és egyéb állapotú emberektól megtudták, hogy a néhai királyi ajtónállómr., Theuteus $\sim$ Thewtews hatalmaskodva elfoglalt bizonyos telki helyeket (loca sessionalia) Choth-i Miklós fiainak: Bobows (dict.) Lőrinc és Domokos mr.-eknek Thathfalua birtokon lévő részbirtokán, és azokra jobbágyokat telepített; most pedig Thewtews mr. fiai: László és Miklós tartják önhatalmúlag birtokukban az apjuk által korábban elfoglalt telkeket Lớrinc és Miklós kárára. D. in fe. B. Elizabeth, a. d. 1356.

E.: HDA. Obitelj Draskovic: Archivum maius 35. 1. (Df. 233 280.) Papíron, hátoldalán azonos kéz írásával tárgymegjelölés, valamint zárópecsét nyoma, bevágásai.

K.: -

584. 1356. nov. 19.

Konth Miklós nádor $(\mathrm{H})$, a kunok bírája emlékezetül adja: bírói színe e. nov. 8-án (in oct. fe. OO. SS.) megjelent Vgh-i Vgh fia: Lőrinc és nemes felesége Durugd-i Dorugd-i István fia: Pál ellenében, s bemutatták előtte a vasvári kápt.-nak azt a, királyi rendelkezés nyomán foganasított idézés végrehajtásáról számot adó, neki szóló jelentését (l. 542. szám), amely magában foglalta egyrészt az említett királyi parancslevél (l. 535. szám) szövegét, másrészt pedig - elmondásuk szerint - leírta előterjesztett keresetüket is. Ennek megfelelően az iratban szó volt többek között arról, hogy Vgh-i Vgh fia: Lőrinc a király színe elé járulván olyan panaszt tett, miszerint Durugd-i István fia: Pál Vgh birtokon lévő részbirtokának terményeit (fructus) és haszonvételeit immár 6 éve hatalmaskodva bitorolja, s ezzel súlyos károkat okoz nekik, ezenfelül pedig [1356.] okt. 13-án (f. V. prox. an. fe. B. Galli conf. prox. preteritum) a panaszos Lórincet feleségével együtt jogtalanul ki is zárta a mondott birtokrészról. Ezt hallva a király utasította a vasvári kápt.-t, hogy a kijelölt királyi ember társaságában küldjenek ki hites tanút István fia: Pál megidézéséhez a nádor elé a nevezett Lőrinc és felesége ellenében, majd a történtekról - az idézés időpontjával együtt -jelentsenek a nádornak. A kápt. a király parancsának megfelelően eljárva, Gyarman fia: Miklós királyi ember társaságában János klérikust küldte tanúul az idézés foganatosításához, akik visszatérve jelentették, hogy [1356.] okt. 19-én (f. IV. prox. p. fe. B Luce ew. prox. preteritum) Durugd-i István fia: Pált Vgh birtokon lévő zálogbirtokán [1356.] nov. 8-ra (ad. oct. fe. OO. SS.) megidézték a nádor elé Lőrinc és felesége ellenében. Az idézőlevél bemutatását követően Lőrinc és felesége kijelentették, hogy a per tárgyát képező részbirtok a sajátjuk, és nem zálogosították el azt Pálnak, aki hatalmaskodva, a törvényes tiltás ellenére tartja birtokában és használja tulajdonukat. Különböző időpontokban kiállított 4 oklevelet mutattak be, amelyek között a vasvári kápt., Vasvár m. alispánja és szb.-ái által kiadott tudományvételi és eltiltó oklevelek szerepeltek. Sorukban az első a vasvári kápt. vizsgálati levele volt király parancsleve- 
lére írt - [1355.] évi - jelentés formájában, és többek között azt tartalmazta, hogy a kápt. a hozzájuk intézett királyi parancslevél szerint eljárva Magas-i Fábián fia: Dénes királyi ember mellé tanúul állította János klérikust a szükséges vizsgálat lefolytatására, akik visszatérve egybehangzó jelentést tettek. Eszerint [1355.] ápr. 14-én (f. III. prox. p. oct. fe. Passce d.) Vasvár m. valamennyi nemesét és nem nemesét, akiket csak lehetett, nyíltan és titokban kikérdezve arról szereztek tudomást, hogy Durugd-i István fia: Pál Vgh birtokon lévő kérdéses birtokrésznek a terményeit és hasznát Lőrinc engedélye nélkül élvezi, annak sorozatos törvényes tiltásai ellenére. Egy másik tudományvételi levelet a m. 4 szb.-ája adott ki 1354-ben (in a. d. 1354.) nyílt oklevél formájában, melyben azt írták, hogy engedve Lơrinc c. kitartó kérésének, kiküldték maguk közül Jekkul c.-t, hogy folytasson az ügyben vizsgálatot, aki ennek nyomán olyan jelentést tett, miszerint [1354.] aug. 10-én (in fe. B. Laurentii mart.) kikérdezvén a $\mathrm{m}$. (provincia) nemeseit és nem nemeseit megtudta, hogy - miképpen azt Levkus mr. alispánnak a hatalmaskodás ügyében jelentették - aug. 7-én (f. V. prox. an. fe. B. Laurentii mart.) famulus-ok és officialisok, ti. Tevtus-i Márton fia: Pál, Feyes (dict.) Péter és Durugd-i István fiai: Pál és István mr.-ek más társaikkal együtt Feyes (dict.) Petev-től Pethev-től 2 ökröt loptak el szénával megrakott szekérrel együtt annak Kauas nevú kaszálójáról, amelyet előzőleg Lőrinc c. adott el neki. A harmadik irat Elleus fia: Miklós mr. alispán és Vasvár m. 4 szb.-ájának a levele volt, mely nyílt oklevélként az előző évben kelt, s a következóket tartalmazta: amikor az alispán és a szb.-ák Vgh-i Lőrinc sorozatos kérésére ugyancsak Jekkul-t küldték ki a panasz kivizsgálásra, az jelentésében arról számolt be, hogy [1355.] márc. 21-én (in fe. B. Benedicti conf.) nemesek, nem nemesek és mindenféle rendú-rangú ember körében tudakolózva olyan értesülésekhez jutott, miszerint Durugd-i István fia: Pál mr. [1355.] márc. 19-én (f. V. prox. an. fe. B. Benedicti conf.) Lőrinc c. szénáját annak Kauas kaszálóján önhatalmúlag a maga 6 kaszásával lekaszáltatta, s ezzel súlyos kárt okozott Lőrincnek. A negyedik oklevél János fia: Levkus mr., Vasvár m. alispánjának és a m. 4 szb.-jának az eltiltó levele volt, amely 1354-ben (in a. d. 1354.) kelt nyílt oklevél formájában, és arról tudósít, hogy amikor az alispán és a szb.ák Lőrinc kérése nyomán tiltás foganatosítására kiküld ték Jekkul c.-t, az visszatérve jelentést tett előttük. Eszerint [1354.] júl. 11-én (f. VI. prox. an. fe. B. Margarete virg. et mart.) Vgh birtokon Durugd-i István fiait: Pált és Istvánt, valamint a hozzájuk tartozókat törvényesen eltiltotta azon termények elhordásától, amelyeket Lőrinc birtokrészén nem nekik termeltek, továbbá a szóban forgó birtokrésznek az ismételt felszántásától, nemkülönben a kaszálókon, ill. a Kauas réten történő kaszálástól (falcari factione fenilium sive feneti Kauas), különösen pedig Lơrinc c. és Vgh-i Tamás fia: János valamennyi birtokrészének, azok terményeinek és haszonvételeinek az elbirtoklásától és erőszakkal való megszerzésétől. Végezetül Zeech-i Miklós országbíró [1356.] ápr. 6.-án (8. die diei medii Quadr., a. in presenti [1356.]) kiállított oklevele (l. 173. szám) arról tanúskodik, hogy Durugd-i István fia: Pált hatalmaskodás és más jogtalanságok ügyében - ahogyan azt az országbíró levele bővebben kifejti - a királyi jelenlét bírósága elé idézték a szóban forgó Lőrinc nemes felesége ellenében, majd a megjelenés elmulasztása miatt $6 \mathrm{M}$. bírságot róttak ki Pálra. Mindezen oklevelek bemutatását követően Lőrinc és felesége Vgh birtokon lévő - István fia: Pálnak el nem elzálogosított - részbirtokuk panaszolt elbitorlása miatt, ill. uralmuk helyreállítása érdekében igazságtételt kértek a nádortól, nemkülönben szorgalmazták a kirótt királyi bírság óket illető harmadrészének kifizetését. Ezeket hallva Veyteh fia: János - Pálnak az egri kápt. ügyvédvalló levelében meghatalmazott képviselője - ekképpen válaszolt: Durugd-i István fia: Pál az Vgh birtokon lévő, Vgh fia: Lőrinc által birtokolt részt nem használja, továbbá sem Lőrincet, sem pedig feleségét nem úzte el arról, azonban Vgh birtokon van egy olyan részbirtoka, amelyet Lőrinc és Tamás fia: János zálogosítottak el neki, és ezt egy késóbbi időpontban okleveles bizonyítékkal is 
igazolni tudja. A nádor - belátva, hogy a vitás föld ügyében a felek között ítéletet hozni most nem lehet - az igazság helyreállítása nélkül elrendeli, hogy színe e. [1357] jan. 13-án (in oct. fe. Epiph. d.) István fia: Pál mutassa be Vgh-i Lőrinc és felesége ellenében szóban forgó okirati bizonyítékát, ugyanakkor fizesse meg Lőrinc feleségének a kirótt királyi bírság ôt megillető harmadát, azaz 2 M.-át. D. in Vysegrad, 12. die termini prenotati, a. d.1356.

E.: Dl. 91 490. (Festetics cs. Veszprém 5.) Papíron, hátoldalán azonos kéz írásával tárgymegjelölés és kerek zárópecsét töredéke, bevágásai.

K.: -

\section{1356. nov. 19. Torda}

András erdélyi vajda és Zonuk-i c. emlékezetül adja: a Clusmonustra-i Boldogságos Szûz-egyház apátja, László testvér bemutatta [I.] Lajos király $(\mathrm{H})$ nevezett egyház valamennyi jobbágyának v. hospes-ének szabadságáról írt nyílt oklevelét, amely rögzítette, hogy Clusmonustra-i falu régebbi alapítású Cluswar városnál (civitas), és minden, a nevezett egyház határai között felmerülö ügyben az apát officialis-a v. bírája jogosult ítélkezni, a területileg illetékes (provincialis) bírónak nincs ítélkezési joga felettük. Mivel a bemutatott oklevél alapján a nevezett egyház népének mindig is a Cluswar-i hospesekhez hasonló szabadságjoga volt, ezért kéri a vajdát, hogy őrizze meg óket ezen jogban. A vajda a kérésnek eleget téve megparancsolja az erdélyi részek valamennyi hivatalban lévő, ill. majdani ispánjánk, várnagyának, officialis-ának és alvajdájának, nemkülönben pedig a többi nemesnek és a városok rector-ainak, akikhez ez az oklevél eljut, hogy a szóban forgó egyház jobbágyainak ügyében ne ítélkezzenek, hanem küldjék azt az apát bírája elé. D. Torde, in fe. B. Elyzabeth, a. d. 1356.

E.: Ba. Gyulafehérvári kápt. 1t. Kolozsmonostori konvent, Oklevelek 14. Com. Kolos. Neoreg. U 25. (Df. 275 175.) Papíron, hátoldalán késóbbi kéz írásával tárgymegjelölés, valamint kerek pecsét nyoma, bevágásai.

K.: ZW. II. 124-125. (707. szám); Doc. Rom. Hist. C. XI. 50-52. (49. szám) (román fordításban is).

R.: Beke, Kolozsmonostor 504. (25. szám); Erdélyi Okm. III. 313. (865. szám); Jakó Zs. Társadalom, egyház, múvelődés 147.

586. 1356. nov. 20.

A váradi monostor konventje jelenti Konth Miklós nádornak, $(\mathrm{H})$ a kunok bírájának: megkapta a nádor levelét (l. 576. szám), és az abban foglaltak szerint Sydele-i Tamás fia: Petheu királyi ember társaságában közhitelú tanúként kiküldte János papot az elrendelt vizsgálat lefolytatásához, akik visszatérve jelentették, hogy nov. 15-én (f. III. prox. p. fe. B. Briccii conf.) kikérdezvén az értesülésekkel rendelkezóket arról szereztek tudomást, hogy a néhai Tutheus mr. a Chaty-i Babous (dict.) Miklós fiai: Domokos, Lőrinc és Miklós mr.-ek birtokrészeinek határán belül fekvő Thoutfalu birtokon 3 telki helyet (loca sessionalia) hatalmaskodva elfoglalt, majd azokra jobbágyokat telepített, most pedig Tutheus mr. fiai: László és Miklós tartják önhatalmúlag birtokukban az apjuk által korábban elfoglalt telkeket Domokos, Lőrinc és Miklós mr.-ek kárára. D. die domin. prox. p. fe. B. Elizabeth, a. d. 1356. 
E.: HDA. Obitelj Draskovic, Archivum maius 71 2. (Df. 233 520.) Papíron, hátoldalán azonos kéz írásával tárgymegjelölés, valamint kerek zárópecsét töredéke, bevágásai, szalagjai.

K.: -

\section{1356. nov. 22. Eger}

Domokos, az erdélyi egyház prépostja, az egri egyház kanonokja, N. [Miklós] egri püspök lelkiekben általános vikáriusa utasítja Istvánt a Varada-i, Jánost a Souar-i és Fülöpöt az Vyfalu-i egyházak rector-ait, Borsua-i és Sarus-i alesp.-eket, hogy jelen oklevél kézhezvételét követően menjenek Vitez-i [?] László fia: Lőrinchez, valamint Egyed fiaihoz: Demeterhez és Simonhoz, mivel már hétszer v. többször megidézték óket Anarchi István fia: László mr. ellenében, ám azok az egyházi bírsággal mit sem törődve nem jelentek meg, és képviselő küldéséről sem gondoskodtak, s óket ezért többszöri bírságban marasztalták el; így a címzettek most a püspök és a vikárius szavával intsék és ösztönözzék óket, hogy [1357.] jan. 20-án (in quind. fe. Epiph. d.) jelenjenek meg Domokos e., ahol kötelesek László ellenvetéseit megválaszolni, továbbá az említett bírságokat illetően fizetési kötelezettségüket Domokosnak, mint bírónak kétharmad részben, a peres ellenfélnek pedig egyharmad részben teljesíteni. Ha mindezeknek eleget tesznek, rendben van, ha mégsem, akkor óket azon jan. 20. elmúltával el kell tiltaniuk valamennyi szentség kiszolgáltatásától, kivéve a haldoklók bünbocsánatát és a keresztelést, ám ha makacsságukban az egyházi tilalom (interdictum) kimondását követő 15 napban is kitartanának, a makacság erősödése súlyosabb büntetést érdemel, olyasformán nevezetesen, hogy ớket mind a saját egyházukban, mind pedig a címzettek egyházaiban —- elsősorban is Eperyes és Sarus városokban - a gyertyák kioltását és a harangok megszólaltatását követően a lakosok (populi) sokasága e. nyilvánosan kiközösítetté kell nyilvánítaniuk (excommunicatos denunciare debeatis) az egyházi törvények alapján, jobbágyaikat és minden kötelékükbe tartozó személyt pedig egyházi tilalom alá kell vetniük. A történtekról a vikárius [1357.] jan. 20-ra (ad quind. fe. Epiph.d.) mindenre kiterjedő jelentést kér. Az eljárás oda- s visszaútját majd lovon tegyék meg a levél vivőjének költségviselésével. (Ibitis tamen et redibitis in equis et expensis latoris presentium.) D. Agrie, in die. S. Celice [!] virg., a. d. 1356.

E.: - Fk. Dl. 96 354. (Vay cs. berkeszi lt. 347.) Nehezen olvasható, foltokban elmosódott. Erdélyi Okm. szerint E.-je papíron, hátoldalán zárópecsét nyoma.

R.: Bónis - Balogh 133. (1219. szám); Erdélyi Okm. III. 313. (867. szám); Piti F., SzSzBSz 42/1 (2007) 56.; Piti, Vay 444-445. (165. szám).

588. 1356. nov. 22.

Az erdélyi egyház kápt.-ja eleget téve a színe elé járuló Derekws (dict.) János fia: Simon mr. kérésének az által bemutatott, András erdélyi vajda által 1356. nov. 13-án kibocsátott nyílt oklevelet (l. 570. szám) átírja és pecsétjével megerősíti. D. in fe. B. Cecilie virg. et mart., a. d. 1356.

E.: Dl. 30 017. (Gyulafehérvári kápt. o. 1t. Cista comitatuum Szatmár 2. 7.) Hártyán, hátoldalán késóbbi kéz írásával tárgymegjelölés, valamint kerek pecsét nyoma, bevágásai. 
Facs.: Doc. Rom. Hist. XI. 650.

K.: Doc. Rom. Hist. XI. 52. (50. szám) (román fordításban is).

R.: Erdélyi Okm. III. 313. (866. szám).

589. +1356. nov. 23. Buda

[I.] Lajos király $(\mathrm{H})$ - 1356. nov. 23-án Budán (Bude, in fe. B. Clementis pape) kelt oklevelének tanúsága szerint -, miután Konth Miklós nádor protonotarius-ának, Jakab mr.-nek Edusturnia nevú erdőjét, amelyet még [I.] Károly király $(\mathrm{H})$ adományozott oda Jakabnak, ill. őseinek, tőle elvette, és azt használatra a Szepesség földjén élő szászoknak átadta, ezért cserében viszont Jakab mr.-t érdemes szolgálatai jutalmául a Palocsa királyi várának a körzetében 2 tagban fekvő, s 2 falu telepítésére elegendő nagyságú királyi tulajdonú Fekete-erdő (Silva Nigra) örök jogon történő eladományozásával kárpótolta, tanú állítására szólítja fel a szepesi kápt.-t ahhoz az eljáráshoz, amelynek során a királyi megbízással eljáró Benedek szepesi prépostnak, királyi káplánnak tisztáznia szükséges az eladományozott erdőrész minemúségét, nagyságát és értékét, továbbá el kell végeznie Jakab mr. bevezetését a neki adományozott erdő uralmába, ill. iktatnia kell azt a nevezett részére, nemkülönben pedig azt is tekintetbe kell vennie, hogy az eladományozással súlyos veszteség éri-e Palocsa várát, avagy nem, végezetül pedig a kápt. a történtekról számot adó írásos jelentéstétellel tartozik a királynak

Tá.: A 630. számú oklevélben.

K.: -

Megj.: Hamis; Vö. a 630. számú oklevéllel.

590. 1356. nov. 23.

István, a premontrei rendi testvérek Saag-i Boldogságos Szúz Mária-monostorának prépostja s a konvent jelentik [I.] Lajos királynak (H): megkapták Zeech-i Miklós c. országbíró hozzájuk intézett levelét (l.581. szám), amelyben az arra adott utasítást, hogy a konvent állítson tanúkat egyrészt a felperes, Oztroluca-i Och fia: János oldalán eljáró András fia: Sándor v. Magiarfolua-i Vörös (Rufus) Mihály v. András fia: István v. .......duch-i Tamás fia: Dénes v. ennek fivére, Miklós királyi emberek valamelyike mellé, másrészt pedig a Mykou fia: Miklós és Tamás fia: Péter alperesek oldalán közremúködő Precel fia: Erdeuhath v. ennek fivére Petheu v. Guba (dict.) Pál királyi emberek valamelyike mellé az elrendelt tudományvétel lefolytatásához. A kiküldötteknek a peres felek v. az óket helyettesítő, ügyvédvalló levében meghatalmazott törvényes képviselőik jelenlétében nov. 18-án (in. oct. fe. B. Martini conf.) a határosok és a szomszédok összehívását követően kell kimenniük Oztroluca $\sim$ Ostroluca $\sim$ Astroluca birtokra, és ott a felperes panasza ügyében kideríteni az igazságot először a birtok szomszédainak, majd mindenki másnak a kikérdezésével. A panasz szerint Mykou fia: Miklós és Tamás fia: Péter márc. 20-án (in domin. Remin.) fényes nappal Och fia: János Oztroluca birtokon lévő házához mentek, és miután ott szekrényét összetörték, 12 ft.-ját és 4 lovát ellopták, felprédálták Oztroluca birtokát, feleségét kegyetlenül megverték, őt magát pedig meg akarták ölni. Nemkülönben .......szept. 29. [körül] (........ . Mychaelis arch.) jobbágyaikat utasították, hogy János termőfáit vágják ki, valamint ........ birtokrészről Kubelkut vizet a saját medréból más mederbe tereljék. Az országbíró a fenti ügyben [1357.] jan. 13-ra 
(ad oct. fe. Epiph. d.) kérte a tudományvétel eredményéról számost adó, s a kihallgatottak nevét is tartalmazó jelentés megküldését a király számára. A parancslevélben foglaltaknak megfelelően a konvent Och fia: János oldalán Henrik (Herricus) pap testvért küldte tanúul Tamás fia: Miklós királyi ember mellé, míg az alperesek, Mykou fia: Miklós és Tamás fia: Péter oldalán közremúködő Erdeuhath királyi ember mellé Miklós pap testvért állították tanúként. A visszatért kiküldöttek jelentették, hogy nov. 18-án (in oct. fe. B. Martini conf.) Oztroluca birtokra mentek, ahol az összehívott határbirtokosok és szomszédok, ill. a peres felek jelenlétében János népei v. hospes-ei egybehangzóan állították, hogy a megvádolt Miklós és Péter a fentiekben leírtak szerint János házához mentek, ahol 12 ft.-ot és János 4 jó [kancáját] ellopták, feleségét megverték, míg ôt magát meg akarták ölni, de azt, hogy a vizet a saját medréból ki terelte el, és a termőfákat ki vágta ki - lévén ók tájékozatlanok - nem tudták megmondani. [A kikérdezettek:] Soos (dict.) Péter fia: Jakab, Ponik-i Thompos fia: János, az ugyaninnen való Tamás fia: Dénes, a Garam folyó melléki (de iuxta fluvium Gron) Orros [?] fia: István, Leskolc-i István fia: Mykus, a Zarnoch-melléki (de iuxta Zarnouch) Bodor fia: Péter, [az ugyaninnen való] Benedek fia: Mihály, Rekolch-i Ábrahám fia: Pál, Kouachi-i Henrik fia: János, ugyaninnen való Domokos fiai: András és Elyas, Likua-i Péter fia: Tamás, Nudozor-i András fia: István, az ugyaninnen való Miklós fia: Tamás nevezett János oldalán állva azt mondták, hogy mindez igaz. A Miklós és Péter oldalán megnyilatkozó jobbágyaik viszont azt mondták, hogy nevezettek ártatlanok mindabban, amiket felhoztak ellenük, s hasonlóképpen Ivan fia: János, Dávid fia: Péter, ...... fia: Anda [?], Mark fia: Miklós ........acha faluból, Oztroluca-i határbirtokosok és szomszédok, nemkülönben Bach..-i János fia: Pál, valamint a Bresnicha-i falunagy, esküdtek és valamennyi lakója (populi), továbbá Budcha-i Miklós fia: Gergely is azt vallották, hogy nevezett Miklós és Péter ártatlanok mindazokban, amiket János felhozott ellenük, ám a zólyomi ispán bírság gyanánt lovakat és a javakat foglalt le tóle. Onnan a király emberei a régi Zólyomba (ad antiquum Zolium) mentek, ahol Pilgramus zólyomi alispán szintén azt mondta nekik, hogy Miklós és Péter nem követtek el semmit a nevezett János ellenében, de az ispán $3 \mathrm{M}$. bírság értékében 4 lovat vett el Jánostól, amely lovak - állítása szerint - ott vannak ônála. D. IV. f. in fe. B. Clementis pape et mart., a. d. 1356.

E.: 1. Dl. 108 176. (Osztroluczki cs. lt.) Papíron, foltos, hajtásvonalak mentén foltokban szakadozott, hátoldalán azonos kéz írásával tárgymegjelölés, valamint a sági konvent kerek zárópecsétjének töredéke (rajta kivehető egy angyal szárnya és a körirat néhány betúje), bevágásai.

2. Osztroluczky cs. osztrolukai lt. 2. (Df. 254 169.).

K.: -

Megj.: E. 2. nem más, mint E. 1.-rôl készült Fk.

591. (1356.) nov. 24. Villanova közelében, avignoni egyházm.

[VI.] Ince pápa megerősíti a váradi püspököt az egri egyházm.-i borsodi főesp.-ségben, amelynek élére Miklós, az egri egyház püspöke jogtalanul nevezte ki a Páduában tanult Bagatha-i János fia: Lászlót az egykori borsodi főesp., Vicarius János halálát követôen. D. Avinione, VIII. Kal. Dec., pápasága 4. évében [1356.].

Reg.: ASV. Reg. Av. v. 134., f. 149v-150r (Df. 289 535.). 
R.: Áldásy 47. (263. szám); Áldásy, TT. 1895. 89. (263. szám); Doc. Rom. Hist. C. XI. 52-53. (51. szám) (románul) utóbbi románul; mindkettő Reg. alapján.

592. (1356.) nov. 24. Villanova közelében, avignoni egyházm.

[VI.] Ince pápa tájékoztatja az esztergomi egyházm.-i [!] Closmonustra-i monostor apátját, a váradi prápostot és az avignoni Szt. Agricola-egyház dékánját az előző oklevélben (l. 591. szám) foglalt rezervációról és kéri, hogy ha alkalmas javadalom üresedik meg, akkor a megnevezett Jánost vezessék abba be. D. ut supra [D. apud Villamnovam, Avinionensis diocesis, XIIII. Kal. Sept., pápasága 4. évében [1356.]].

Megj.: Apparátusa megegyezik az 591. számú oklevélével.

593. +1356. nov. 24. Abramfalva

Zyrma-i István fia: Miklós ugocsai c. és Nialab-i várnagy, valamint a m. 4 szb.-ja tudatja, hogy visszaadták azt a kancát, amelyet Abramfalua-i Simon mr. jobbágyai, [Thana (dict.)] György és [Nagy] Pál jelenlétükben egy Sáswar-i nemesnél, Pál fia: Tamásnál kerestek. D. in eadem Abramfalua, f. prox. an. fe. S. Catherine virg. et mart., a. d. 1356.

E.: -

K.: Szirmay, Ugocsa 32. (fasc. 87. Nro. 1561.); F. IX. 2. 566-567. (273. szám) Mindkettő E.-re való hivatkozással.

R.: C. Tóth, Ugocsa 30. 1356. nov. 25. e.- re keltezve.

Megj.: Mindkét kiadás hozza a hátoldali tárgymegjelölést Pro Thoma, filio Pauli contra Georgium dictum Thana, et Paulum Magnum, Iobbagyones Magistri Simonis de Abramfalua expeditoriae. A []-ben közölt kiegészítések innen származnak. Az oklevél feltehetóleg hamis 1. Komáromy A., Turul (1893) 20.; Wertner M., TT. 30 (1907) 173.

594. (1356. nov. 25.e.)

Zeech-i Miklós országbíró nyílt ítéletlevelében utasítja a vasvári kápt.-t, hogy a felperes, Korog-i Simon fia: Miklós részéról eljáró Telekus-i Gergely fia: Basov, ill. az alperes Nogmortun-i Lőrinc fia: Nykkul mr. részéról közremúködő Reche-i Leukus királyi emberek mellé küldjön ki hites tanúkat Nogkorogh és Radistinch birtokokra birtokosztály végett.

Eml.: A 606. számú oklevélben.

K.: -

595. 1356. nov. 25. Visegrád

[I.] Lajos király - 1356. nov. 25-én Visegrádon (in Wissegrad, in fe. B. Katherine virg. et mart.) kelt oklevelében - elrendeli, hogy Cymba (dict.) István fiai: a néhai Petheu és István azon birtokai u., amelyeket András fiainak adományozott, a javadalmazot- 
tak mentesüljenek mindenféle bírság kifizetése alól, melyeket István fiai még életükben halmoztak fel.

Tá.: Szécsi Miklós országbíró, 1382. aug. 23., Dl. 33 726. (NRA. 1511. 19.).

K.: Smič. XVI. 309. (251. szám).

596. 1356. nov. 25.

Az erdélyi egyház kápt.-ja e. az egyik részról Selk-i Holmanus fiai: Hennyng Hennyngh $\sim$ Hennynh és Miklós, a másik részről pedig Sarselk-i Alardus fia: Cristianus c. megjelenvén, előbbiek kijelentették, hogy a Zepmezew birtok és a Kukullew között fekvő Egurwarpathaka Egurwarpataka birtokukat - amelyet a néhai [I.] Károly király $(\mathrm{H})$ privilégiális oklevele révén minden tartozékával együtt az említett Holmanus-nak adományozott - szorongató szükségtől kényszerítve szavatosság vállalása mellett $200 \mathrm{M}$. finom ezüstért eladták Cristianus c.-nek és örököseinek, s átadták neki a szóban forgó adománylevelet is, míg a birtokra vonatkozó esetleges további, általuk csalárdul visszatartott okleveleket hatálytalanoknak nyilvánítják. Minderrôl a kápt. autentikus függőpecsétjével megerősített privilégiumot bocsát ki. D. in fe. B. Katerine virg. et mart., a. d. 1356. Domokos lévén a prépost és a választott [püspök], Loránd az ôrkanonok, Mihály az éneklőkanonok, Miklós Clus-i főesp. a dékán.

E.: Dl. 31 099. (Gyulafehérvári kápt. o. 1t. Centuriae XX 25.) Hártyán, hátoldalán késóbbi kéz írása, alján zöld zsinegen mandorla alakú pecsét függ (rajta Szt. Mihály kiterjesztett szárnyú, glóriával övezett alakja látható, kezében lándzsát tart, mellyel épen átdöfi a lába e. heverő sárkány fejét; körirata: +S(IGILLVM) CAPITVLI ECCLESIE TRANSSILVANE).

K.: AO. VI. 518-519. (323. szám) (kihagyásokkal); ZW. II. 125-126. (708. szám); Doc. Rom. Hist. C. XI. 53-54. (52. szám) (román fordításban is).

R.: Erdélyi Okm. III. 313-314. (868. szám).

597. (1356. nov. 26. e.)

Zeech-i Miklós országbíró közhitelú tanú állítására szólítja fel a Lelez-i konventet a kijelölt királyi ember mellé Tamás fia: István mr. jan. 8-ra törénő megidézéséhez a királyi jelenlét bírósága elé Warada-i László fia: János mr. ellenében, egyszersmind írásos jelentést kér a történtekről a király számára.

Eml.: A 616. számú oklevélben.

K.: Z. III. 38. (24. szám).

\section{1356. nov. 27. Visegrád}

[I.] Lajos király $(\mathrm{H})$ tanú kiküldésére szólítja fel a Lelez-i konventet Pylis-i Péter v. Pylis-i Lukács (Lucasius) v. Voya-i János fia: Miklós v. Chazar-i János fia: Domokos királyi emberek valamelyike mellett, hogy az Petry-i Sándort és Lőrinc fia: Tamást alkalmas időre a királyi jelenlételé elé idézze Batur-i Bereck fia: Miklós mr. ellenében, majd küldjön 
számára a történtekről számot adó, az idézés napját és helyét, az idézettek nevét, valamint a kitűzött határnapot is tartalmazó írásos jelentést. D. in Vyssegrad, die domin. prox. p. fe. B. Katherine virg. et mart., a. d. 1356.

E.: Dl. 4636. (NRA. 74. 21.) Papíron, hátoldalán azonos kéz írásával tárgymegjelölés/címzés, valamint zárópecsét nyoma, bevágásai.

K.: AO. VI. 519. (324. szám) (kihagyásokkal).

599. (1356. nov. 29. körül)

[I.] Lajos király felszólítja Miklós egri püspököt, hogy az István fia: Imre és Dedych fia: Dedych által nagyanyjuk hitbére, jegyajándéka és leánynegyede miatt Isep alvárnagy ellen a püspök e. indított pert [1357.] jan. 13-ra (ad oct. fe. Epiph. d.) helyezze át a királyi udvarba a bárók tanácsa elé.

Em1.: A 600. számú oklevélben.

K.: -

\section{1356. nov. 29. Visegrád}

[I.] Lajos király $(\mathrm{H})$ tanú állítására szólítja fel a Jazow-i egyház konventjét Sarwar-i Miklós királyi ember mellé, akinek egy másik, a konvent e. is bemutatandó, Isep alvárnagy érdekében kibocsátott királyi oklevelet (l. 599. szám) kell kézbesítenie Miklós egri püspök részére olyan tartalommal, miszerint azt a pert, amelyet István fia: Imre és Dedych fia: Dedych indítottak Isep ellen a püspök színe e. nagyanyjuk hitbéréért, jegyajándékáért és leánynegyedéért, a püspök helyezze át [1357.] jan. 13-ra (ad oct. fe. Epiph. d.) a királyi udvarba a bárók megfontolása elé, s ő azt majd végül vissza fogja tenni a püspök bírósága elé. A konvent köteles jelentésben megírni az egri püspök kézbesítéskor adott válaszát. D. in Wyssegrad, in vig. fe. B. Andre ap., a. d. 1356.

Á.: Jászói konvent, 1357. jan. 20. Dl. 41 293. (Múz. Ta. 1925. 40.).

Má.: Uo, Á-val egyező jelzet alatt; 1927. márc. 15-én készített egyszerú Má.-ban, Baráth Tibor aláírással.

K.: -

R.: Bónis - Balogh 133. (1220. szám).

601. 1356. nov. 29.

A váradi egyház kápt.-ja jelenti [I.] Lajos királynak (H): megkapta Zeech-i Miklós országbíró és Turuch m.-i c. hozzá címzett levelét (l.582. szám) Egrus-i János fia: László felperes és Vyhel-i [M]iklós fia: István alperes között zajló perrel kapcsolatban —- amelyet pecsétjével megjelölve küld vissza a királynak —, és az abban foglalt kérésnek megfelelően Viuzy-i [?] Imre fia: Domokos királyi ember társaságában nov. 18-án (in oct. fe. B. Ma[rtini conf.]) kiküldte tanúként Egrus birtokra karpapját, Tamást a Boldogságos Szűz Mária-oltár rector-át az elintézendők végrehajtásához. A kiküldöttek visszatérve jelentették, hogy nov. 18-án (in oct. fe. B. Martini conf.) a szomszédok és határosok összehívását követően megjárták Egrus birtok határát, és ahol szükséges volt, ott új határjel 
emelésével elválasztották azt a többi birtoktól. Hj: Ke-ről indul a Ke-ről érkező Verbeuchpataka patak gázlója felett, Ny-ra a Kuuechesrew (dict.) [rév], ahol a patakot közút keresztezi, Dé-ról földjel ahonnan a szóban forgó Egres birtok Ny-ról és É felöl esik, Zeuleus város Ke felól, Miklós fia: István Ordou birtoka pedig Dé-ról; Dé felé Egerpataka patak kettéágazása, új földjel, Dé felé Gyulkuspatak patak, közeli úton Ny felé, új földjel, tovább Ny-nak, Gyulkuspatak patak mellett É-ról esó új földjel, keresztül a patakon Dé felé, szántóföldek között emelt földjel, Ny-nak fordul, nagy utat keresztez tovább Ny felé a Chukzele nevư szántóföldek közepében, út mellett Dé-ről új földjel egy régi mellett, tovább Ny felé, ue. út közelében É-ról új határjel egy régi mellett, majd végig új határjeleket emeltek a régiek mellé Egrus birtok Ny-i és Dé-i oldalán, mely utóbbinál Ordou birtok határolja. A hj.-t követően János fia: Lászlót beiktatták a birtokba nem lévén ellentmondás. Amikor azután János fia: László kalauzolása mellett tovább mentek Ny felé, kis távolság u. Ny-ról Dé-nek fordultak, s Hydeguiz patakhoz érkeztek, László a patak mellett mutatott egy az övéihez hasonló határjelet, azt állítva, hogy Egrus birtokának határai Feketepotak birtok határáig terjednek, ezért ama földrészt határjelek állításával kapcsolják Egrus-hoz, s iktassák azt is a részére. Chepanus fia: Zouard jobbágya, László kovács (faber) azonban Leukus fia: Bertalan nevében és helyett eltiltotta óket ettól, így Bertalant a helyszínen megidézték a királyi jelenlét elé László ellenében [1357.] febr. 9-re (oct. fe. Purif. virg. glor.), hogy megindokolja tiltakozását. A vitás földdarab becsújét elvégezve — a mérés kivihetetlensége miatt azt pusztán szemmel megítélve —- 150 ekealjra becsülték fogott bírák és nemesek közremúködésével. D. in vig. fe. B. Andree ap., a. d. 1356.

E.: SNA. Leleszi konvent hh. lt. Metales Ugocsa 10. (Df. 209 668.) Papíron, foltokban sérült, hátoldalán azonos kéz írásával tárgymegjelölés, valamint azonos és késóbbi kézzel jegyzetek, továbbá mandorla alakú zárópecsét töredéke, bevágásai, szalagja.

Má.: Uo., mint E., azzal egyező jelzet alatt;1811. aug. 28-án készített hiteles Má.-ban, Tusnádi Pálffy Salamon jegyző aláírásával.

K.: -

602. 1356. nov. 30 .

A vasvári kápt. e. László fiai: István, Miklós és Pál Zecheud-ről - ahol Mindenszentek tiszteletére emelt egyház áll - egy akarattal kinyilvánítják, hogy Egyhazaszecheud birtokon ingó és ingatlan javaikon egymás között örök időkre szóló osztályt tesznek, először azokat a telkeket (sessiones) választván el, ahol személyes lakóhelyük található. Az első rész Miklósé, ennek határa Ny-on egy régi árok szélén lévő tölgyfánál kezdődik, innen átmegy Zecheud falu Ke-i utcájához (platea); ezen felül ôt illeti még egy telek Dé-ről. A másik telek középen Istváné, amely Miklós része mellett, attól É-ra fekszik, és amelynek határa egy nagy árok pereméig fut, innen pedig egyenesen Dé felé fordul ue. Zecheud birtok utcájáig (platea). A harmadik telek e mellett v. ezzel szemközt terül el Ke felől, és ez képezi Pál birtokát. Megerősítették továbbá, hogy az ingó és ingatlan dolgokat ugyancsak 3 egyenlő részre osztják, amiból mindegyiküket $1-1$ rész illeti, ám mert István kertje (ortus sessionis) nagyobb, ezért 1 ekealja földet Ny-ra - Simon földjének szomszédságában - fivéreinek ad. A mondott egyház kegyurasága, Zecheud falu utcái, valamint szántóföldjei, mezői és valamennyi más haszonvételei és tartozékai közös birtoklásukban maradnak. A kápt. az oklevél visszahozatalának esetére privilégium kibocsátását ígéri. D. in fe. B. Andree ap., a. d. 1356. 
E.: Dl. 41 291. (Múz. Ta. Jankovich) Hártyán, hátoldalán későbbi kéz írásával tárgymegjelölés, valamint kerek pecsét nyoma, bevágásai.

Má.: Uo., mint E., azzal egyező jelzet alatt; modern kori egyszerú Má.-ban, Kardoss Izabella aláírással.

K.: F. IX. 7. 150-151. (94. szám) (kihagyásokkal)Jankovich Miklós gyújteményében őrzött E.-rre való hivatkozással.

R.: C. Harrach E., Vasi Szle 26/1 (1972) 96-104.

603. 1356. nov. 30.

A vasvári egyház kápt.-ja tudatja: színe e. egyik részrôl a Zala m.-i Haholth-i Herbordus fia: Lőrinc és ennek fia: Jakab, a másik részrôl a Zala m.-i Haholth-i Herbordus fia Miklós fia: Miklós mr. megjelenvén kinyilvánították, hogy birtokaikon megosztoztak egymással. Eszerint először Haholth birtokon 2 telek Ny-ról a Boldogságos Szúz Mária-monostor felől Lőrincé és fiáé, Jakabé lesz; szemközt pedig a szóban forgó monostor felól a Ke-i utcasorban 2 jobbágytelek Miklós mr.-nek jut; az utca közepénél Ke-re eső 2 telek Lőrinc mr.-hez és Jakabhoz kerül, míg ezekkel szemközt, a másik, Ny felóli utcarendben középen 2 telket Miklós mr. kap meg, továbbá ugyanezen utcában Ke felől, a Lőrinc mr. és Jakab telkei mellett lévő 2 telek ugyancsak Miklós mr.-hez kerül, míg a másik utcasorban Ny felól a Miklós mr. telkei mellett fekvő 2 telek Lórincet és Jakabot illeti. A birtok egyéb haszonvételeit és a mondott egyház kegyuraságát (patronatus) közösen birtokolják fele-fele arányban. Folkusy birtok kettéosztása: a határ Ke felől a Peleskeryte réten lévő határjelnél kezdődik, Ny felé cseresznyefa Haholth falu konyhakertje mögött (retro ortum), innen átmegy a falu utcájára, É-nak fordulva a falu közepéig halad, onnan Ny felé Szt. Mihály vértanú egyháza dombon át tovább Ny-ra útkereszteződésig (viam crucis), nagy úton Ny felé Palhege dombhoz, majd Ny-i irányban eléri Sehtur birtok határát, az ottani szőlőhegy határjeleitôl É-nak tart hosszan egy kereszttel jelölt nagy tölgyfáig, lefelé Rauazaswelg völgybe, azon át Ke-re Kysteluk földhöz, bozótos, Ke felé tovább, nagy út, onnan tovább a Dé felől eső Huzeufeuld részbirtok széléig, lefelé Ke-nek a Bornuk-ból jövő nagy út menti bozótoshoz, az úton elóbb É-nak, majd letér arról Ke felé, Keukuth nevú vizenyős hely, ill. forrás, Ke felé Peleske vízhez ér. A nevezett Folkusy birtoknak ez az É-ról eső, a fenti határral elválasztott fele a szólóhegyek kivételével Miklós mr. kezére kerül, míg a másik fele, - ti. a leírt határjelek által, Ke-ről a fent nevezett réttől Ny-i irányban a hegyen lévő keresztútig tartóan elválasztott Dé-i rész, amely félbirtoknak a határa egy nagy útnál álló (vlg.) iegenyefa közelében kezdődik, és egészen Haholth birtok határáig, s attól a Peleske vízig terül el — Lőrinc mr.-t és fiát illeti, együtt mindazon haszonvételekkel, amelyek a már mondott határjeleken belül, a Sehtur és Bornuk birtokok határától É-ra fekvő területhez tartoznak. A Folkusy birtokon lévő szigeten levő telek, amelyen egykor Herbordus építtetett magának lakóhelyet - azzal a darab szántófölddel együtt, amely a telekhez közel, attól É-ra található - Miklós mr. tulajdonába került. Felseu Sehtur birtokot ugyancsak 2 részre osztották a falu középvonala mentén Ke-ről Ny-ra, Szt. Adorján vértanú — ott felépített - egyházának irányában haladva. Közülük a Lőrinc és fia tulajdonát képezô fél az említett egyháznál kezdődik, és Dé felé Egurkuth forrásig, Ke felé Rayk birtok határáig, Ny felé pedig Varuchkawyze folyóig terül el. A másik fele, amely Miklóst illeti, É felól elhelyezkedve a szóban forgó Szt. Adorján vértanú egyházánál kezdődik, s É-i irányban Simon fia: György birtokának határáig húzódik, Ke-felé pedig Bornuk és Rayk birtokok határáig terjed ki. Olsosehtur birtok kettéosztása: a határ Ke felól Ne- 
muthfalw falu határában, Sehtur birtok határjelein beül, domboldalban indul, lefelé É-nak, erdős hely, gyümölcsfánál a falu konyhakertjénél elfordul Ny-felé, Sehtur birtok utcája, azon É-nak fordul, Chobudkuta forrástól Ny-nak tart, középütt átszeli a Kendereszygeth szigetet, majd azon túl elér egy útkereszteződést, ahol É felé indul, kereszttel jelölt tölgyfa, Ny-i irányban Varuchka vízfolyáson lévő Dankamolna malom alatt halad át. Olso Sehtur birtoknak a leírt határoktól kezdődő, É-ra kiterjedő fele — ti. Remete falu, ahol Boldogságos Szúz Mária tiszteletére emelt egyház áll, és Sehtur birtok határai között helyezkedik el, Sehtur falu Ke-i utcájával együtt, amely Ke-i irányból a birtok közepén É felé egészen Egurkuth forrásig terjed ki, Ke-i irányban pedig Rayk és Haholth birtokok határáig húzódik — Miklós mr. birtokába került. A másik félbirtok (bele nem értve az Olso Sehtur birtokon lévő kaszálót v. rétet) a mondott határjelektôl kezdődik — nevezetesen idetartozik a Nemuthfalu nevü falu Sehtur birtok Ny-ról eső utcájával együtt - és Dé felé egészen Zenthlazlow, Edelych és Turul birtokok határáig húzódik, Lőrinc mr.-t és fiát, Jakabot illeti meg. Hasonlóképpen teljes egészében a Sehtur birtok területére eső Kendereszygethzenaya kaszáló, nemkülönben pedig a Hothuanusystapaszygethzenaya kaszáló v. rét fele része - amely utóbbi a felek által határjelzés gyanánt meghúzott szántásnyomtól, (vlg.) barazda - kezdődik, és onnan É-ra terül el - Miklós mr. tulajdonába kerül. A másik fele eme kaszálónak, nevezetesen a Dé felé elhelyezkedő része, Lőrinc mr. és fia birtoka lesz. A különféle nevú és elhelyezkedésú hegyek pedig, ill. a rajtuk lévő szőlőknek a hegy- avagy szôlővámja (tributa montium seu vinearum), valamint Ozzenbyk, Zagacya és Chakan erdők a mondott szólők v. szólóhegyek között lévő szántóföldekkel együtt a két fél közös tulajdonában maradnak. Hasonlóképpen közös tulajdont képeznek a Folkusy birtokhoz tartozó osztatlan szántók, amelyek a már említett iegenyefa alatt elhaladó úttól, ill. egy másik dombon lévő útkereszteződéstól kiindulva Ny-i irányban egészen Sehtur birtok határáig terülnek el, s ugyanígy az a sziget és a raja lévő szántók is, ahol Miklós mr. telekkel (curia) és közelében tôle É-ra elhelyezkedő földdarabbal rendelkezik, amely tulajdonrészei kívül esnek a közös birtokláson. Bochfeulde birtokot úgy osztották meg, hogy a határ a maguk telkeinek (curia) kapujai között (inter portas) álló gyümölcsfánál kezdődik, és a 2 telek között É-i irányban haladva egy körtefáig megy. A falu É-ról eső fele ettől a határvonaltól Ke-i irányban egészen egy nagy útig kiterjeszkedve - benne a saját telkével - Miklós mr.-t illeti, míg a másik fele, a leírt határvonaltól Ny-i és Dé-i irányban kiterjedve, benne tulajdon telkükkel, Lőrinc mr. és fia tulajdonába került. Egyéb haszonvételeiket — kivéve az osztozkodás során a feleknek jutott telki helyeket és a telkekhez tartozó kertjeiket (ortus) — közös birtoklásban hagyják meg. Somogy m.-i birtokaik megosztása: Varad birtok Miklós mr.-é, Saarmellek Lőrinc mr.-é és Jakabé; Zygeth és Felseupachuth a Nyarvyze $\sim$ Nyarwyze folyó mellett Miklós mr.é, ezzel szemben Olsopachuch és Lazlowzege birtokok a Renyewyze folyó mellett Lórinc mr.-t és Jakabot illetik meg örökre szóló birtoklásra. Ezenfelül Karazdy [?] birtokuk a Renyewyze folyó mellett, valamint Bork és Nemtyzeg birtokaik Ke felől a Nyarwyze folyó mellett közösek maradnak, míg idegen kézre jutott birtokaikkal kapcsolatban azt vállalták, hogy azokat közös fáradtsággal és költségen szerzik majd vissza, és egymás között azokat is ketté fogják osztani. Szavatolásképpen vállalták, hogy ha valamelyik fél ezen birtokosztály rendelkezéseit megsértené, az 100 M.-t tartozzék a másik félnek ...... [fizetni] a bíró része nélkül. Minderról a kápt. ...... [privilegiális oklevelet] ad ki. D in fe. B. Andree ap., a. d. 1356. A préposti tisztség üresedésben lévén, ill. Herman mr. lévén az őrkanonok és ........-nek a vikáriusa, Domokos mr. az éneklókanonok, Mihály mr. a dékán. A.

E.: D1. 68 228. (Kisfaludy cs. idősebb ága 41.) Hártyán, felül chirographálás (ABC), díszített iniciáléval ellátott, hátoldalán azonos kézzel divisionalis et metalis, alja középen a függőpecséttel együtt kiszakadt. 
K.: Zala I. 565-570. (362. szám).

R.: Somogy m. lt. Évk. 7. (1976) 10, 32.

\section{1356. nov. 30. Visegrád}

Cykou, [I.] Lajos király $(\mathrm{H})$ tárnokmr.-e és borsodi c. tanú kiküldését kéri a pozsonyi egyház kápt.-jától Gutur-i György v. Wayka-i Beke királyi ember valamelyike mellett ahhoz az idézéshez amelynek során a kiküldötteknek a nagyszombati (de Tyrnauia) bírót és a város 12 esküdtjét (jurati cives) alkalmas időre a királyi jelenlét elé kell idézniük Jakus pozsonyi bíró, valamint az ottani esküdtek ellenében. A kápt. az idézés napját és helyét, az idézettek nevét, valamint a kitúzött határnapot is tartalmazó írásos jelentéssel tartozik a király számára D. in Wyssegrad, in fe. B. Andree ap., a. d. 1356.

E.: SNA. Pozsonyi kápt. hh. 1t. 28. 1. 30. (Df. 226 968.) Hátoldalán azonos kéz írásával tárgymegjelölés/címzés, valamint kerek zárópecsét töredéke.

K.: -

605. 1356. dec. 2.

A velencei államtanács Contareno Endrét, Faletro Mihályt és Benintendit küldi követekként Mo.-ra, utasításokkal látja el és teljhatalommal ruházza fel őket az I. Lajos királlyal megkötendő béke, s annak tárgyalása ügyében.

R.: Óváry 49. (71. szám) (Velencei lt.-ra való hivatkozással).

606. 1356. dec. 2.

A vasvári egyház kápt.-ja emlékezetül adja: a Zeech-i Miklós c., [I.] Lajos király (H) országbírája nyílt ítéletlevelében (l. 594. szám) foglaltak értelmében tanúul küldték a királyi emberként Korog-i Simon fia: Miklós oldalán eljáró Telekus-i Gergely fia: Basov, ill. az alperes, Nogmortun-i Lő́rinc fia: Nykkul Nykklinus Nykclinus mr. részéról közremúködő Reche-i Leukus mellett kanonoktársukat, Bertalan mr.-t, valamint Mihály karbeli klerikust, akik visszatérve egybehangzóan jelentették, hogy nov. 25-én (in quind. fe. B. Martini conf.) Nogkorogh és Radistinch birtokokra kimenvén az összehívott szomszédok és határosok, nemkülönben Simon fia: Miklós, ill. a Nykkul mr. képviseletével a királyi kápolnaispán ügyvédvalló levelében meghatalmazott Kerechen-i Bekeu jelenlétében megosztották nevezett birtokokat. A 2 egyenlő részre osztott Nogkorogh birtok É-i fele - Miklós saját telkét (curia) is beleértve - 10 telket foglal magában: Miklós említett telkét, 2 jobbágytelket É felól, továbbá ugyanazon utcában É felől még 2 telket, amelyek a Zombathel-ről jövő nagy út mellett Ke-re esnek, nemkülönben 4 telket a falu közepén az utca Ke-i oldalán, valamint még 1-et Dé-ről a falu határában, amely birtokfél Miklósé lesz kiegészítve azzal az István fia: Farkas (Farkasius) részbirtokából kiszakított 3 telekkel, amelyek Miklós telkével szemközt helyezkednek el, továbbá az ugyanitt lévő Orbochanrevy nevezetú révnek (portus), valamint a molnároknak és a zselléreknek (molendinatores et inquilinus) a felével együtt, azaz ide tartozik még 8 telek a szóban forgó rév környékén a Mura folyó felól. A fennmaradó rész Nykklynus mr.-t illeti, így az említett 3 telek kivételével Farkas (Farkasius) része, azaz 8 telek, amelyekből 4 Nogkorogh falu közepén a Ny-i utcában van, 4 pedig az É-i részen az utca 
végén Ny felól esik. Ideszámít továbbá a szóban forgó révnek ill. vámnak a fele része (cum medietate predicti portus seu tributi), miként a molnárok és a zsellérek fele is 4 telekkel az említett révtől Ke-re. Radistinch birtokot hasonlóképpen 2 részre osztották; az É-i felében az utca Ke-i oldalán 2 telek, valamint ezekkel szemben az utca Ny-i oldalán még 1 telek Simon fia: Miklósnak jut, míg a fennmaradó rész, azaz a Dé-i birtokfélen 3 telek a Mura folyó felól, továbbá az É-i részben az utca Ny-i oldalán még 1 telek Nykclinus mr.-nek a tulajdonába kerül örökre szóló birtoklásra. A felosztás nem sért idegen jogot. A szóban forgó birtokok szántóföldjeit a csapadékos időjárás (propter aquositatem temporis) és a Mura vizének áradása miatt nem tudták megosztani, ezért a felek azokat attól függően, hogy melyik telekhez tartoznak - egyenlően elosztották egymás között, más haszonvételeiket pedig - úgymint legelóket, vizeket, erdőket, ligeteket, réteket, kaszálókat és másokat közös használatára hagyták meg azzal, hogy a haszonvételeket ők ill. jobbágyaik fele-fele részben vehetik igénybe. D. 8 die quind. fe. B. Martini conf. prescriptarum, a. d. 1356.

E.: Dl. 98 399. (Sigray cs. lt. 42. 13.) Papíron, hátoldalán azonos és késóbbi kéz írásával tárgymegjelölés, valamint kerek zárópecsét nyoma, bevágásai.

Má.: Uo., mint E., azzal megegyező jelzet alatt; 18. sz.-i egyszerú Má.-ban.

K.: -

\section{1356. dec. 2. Visegrád}

Zeech-i Miklós c., [I.] Lajos király (H) országbírája, Thuruch m. c.-e tudatván Bereg m. ispánjával v. alispánjával és szb.-áival a színe e. Warada-i László fia: János mr. részéról emelt panaszból szerzett azon értesülést, amely szerint miután Papy-i Gábor fia: Sebestyén aug. 21-én (in domin. die prox. p. fe. B. regis Stephani) saját Syran birtokán, Bartha nevú jobbágyának házában találta a panasztevő János mr. Mark faluból való papját (parochialis sacerdos), Pétert, nyíllal és kardcsapásokkal megsebesítette ôt, majd félholtan hátrahagyta; ezenfelül pedig a pap lovát zablával és nyereggel együtt elkötötte, s bár végül visszaadta azokat, mégis jelentős kárt okozott mindezekkel, minekutána utasítja a címzetteket, hogy 1 v. 2 kiküldöttjük vizsgálja ki a panaszt, majd ennek eredményét jelentsék írásban a királynak. D. in Wissegrad, f. VI. prox. p. fe. B. Andree ap., a. d. 1356.

E.: Dl. 77 172. (Zichy cs. zsélyi 1t. 1. B 283.) Papíron, hátoldalán azonos kéz írásával címzés és tárgymegjelölés, valamint Szécsi Miklós országbíró kör alakú zárópecsétjének töredéke (rajta háromszögú pajzson kétfejú, kiterjesztett szárnyú ragadozómadár), szalagjai, bevágásai.

K.: Z. III. 37. (23. szám).

\section{1356. dec. 2. Visegrád}

Zeech-i Miklós c., [I.] Lajos király (H) országbírája, Thuruch m. c.-e tudatván Bereg m. ispánjával v. alispánjával és szb.-áival a színe e. Warada-i László fia: János mr. részéról emelt panaszból szerzett azon értesülést, amely szerint Keter-i Thatar (dict.) István fiai: Miklós, Simon és Jakab Keter falubeli jobbágyaik révén birtokba vétették és birtokolják a panaszos János mr. Pethe birtokának jövedelmeit, szántóföldjeit más haszonvételeit, amivel kapcsolatban utasítja a címzetteket, hogy 1 v. 2 kiküldöttjük vizsgálja ki a pa- 
naszt, majd ennek eredményét jelentsék írásban a királynak. D. in Wissegrad,f. VI. prox. p. fe. B. Andree ap., a. d. 1356.

E.: D1. 77 173. (Zichy cs. zsélyi lt. 1 B 295.) Papíron, hátoldalán azonos kéz írásával címzés és tárgymegjelölés, valamint Szécsi Miklós országbíró kör alakú zárópecsétjének töredéke (rajta háromszögú pajzson kétfejú, kiterjesztett szárnyú ragadozómadár), szalagjai, bevágásai.

Megj.: Vö. a 633. és a 612. számú oklevéllel.

K.: Z. III. 38-39. (25. szám); Doc. Rom. Hist. C. XI. 54-55. (53. szám) (román fordításban is).

\section{1356. dec. 2. Visegrád}

Zeech-i Miklós c., [I.] Lajos király (H) országbírája, Thuruch m. c.-e a Lelez-i egyház konventjének: a színe elé járult Warada-i László fia: János mr. panasza szerint szentmártoni (de S. Martino) Tamás fia: István mr. nov. 17-én (f. V. prox. an. fe. B. Elizabeth) ráküldte a maga famulus-ait János mr. Tuser birtokára, ahol azok János mr. ott időző Warada-i és Liske-i [!] jobbágyait minden ruhájuktól megfosztották, kettejüket, jelesül Liske-i Ágostont és Kozmát (Cosma) meg is verték, továbbá egy tönkön le akarták vágni a jobbágyok kezét. Az országbíró a történtek kivizsgálásával megbízott királyi emberek — Tereche-i Peteny fia: Mikós v. Gyulahaz-i Lukács fia: László v. Berench-i Domokos fia: János v. Petri-i István —- valamelyikének társaságában küldendő tanú állítására szólítja fel a konventet, egyben a vizsgálat eredményéról számot adó írásos jelentést kér a király számára. D. in Wyssegrad, f. VI. prox. p. fe. B. Andree ap., a. d. 1356.

Á.: A 632. számú oklevélben.

K.: Z. III. 40-41. (27. szám).

\section{1356. dec. 2. Visegrád}

Zeech-i Miklós c., [I.] Lajos király (H) országbírája, Thuruch m. c.-e a Lelez-i egyház konventjének: Warada-i László fia: János mr. panasza szerint Kether-i $\sim$ Keter-i Thatar (dict.) István fia: Miklós Keter falubeli jobbágyaival használtatja és birtokoltatja az ô Pethe birtokának jövedelmét, szántóföldjeit és más haszonvételeit, noha ehhez ô hozzájárulást nem adott, s nyilvánvaló károkat szenved el emiatt. Az országbíró az ügyben meghagyja a konventnek, hogy állítson tanút a történtek kivizsgálásával megbízott királyi emberek - Terece-i Pethenye fia: Miklós v. Gyulahaza-i Lukács (Lukasius) fia: László v. Berench-i Domokos fia: János - valamelyike mellé, majd a vizsgálat eredményéról küldjön írásos jelentést a királynak. D. in Wyssegrad, f. VI. prox. p. fe. B. Andree ap., a. d. 1356.
Á.: A 633. számú oklevélben.
K.: Z. III. 42. (28. szám). 


\section{1356. dec. 2. Visegrád}

Zech-i Miklós c., [I.] Lajos király (H) országbírája, Thuruch m. c.-e tudatván Zabolch m. ispánjával v. alispánjával, és szb.-áival a színe e. Warada-i László fia: János mr. részérôl emelt panaszból szerzett azon értesülését, miszerint szentmártoni (de S. Martino) Tamás fia: István mr. nov. 17-én (f. V. prox. an. fe. B. Elizabeth) ráküldte famulus-ait a panaszos János mr. Tuser birtokára, ahol János mr. ott időző Warada-i és Litke-i jobbágyait minden ruhájuktól megfosztották, kettejüket — a Litke-i Ágostont és Kozmát (Cosmas) — megverték, némelyeknek a kezét pedig egy tönkön levágták, minekutána utasítja a címzetteket, hogy a panaszt 1 v. 2 kiküldött révén vizsgáltassa ki, majd ennek eredményét jelentsék írásban a királynak. D. in Vyssegrad, f. VI. prox. p. fe. B. Andree ap., a. d. 1356.
Á.: A 649. számú oklevélben.
K.: Z. III. 43-44. (29. szám).
R.: Piti F., Szabolcs m. 134. (523. szám).

\section{1356. dec. 2. Visegrád}

Zeech-i Miklós c., [I.] Lajos király (H) országbírája, Thuruch m. c.-e az egri egyház kápt.jának: Warada-i László fia: János mr. panasza szerint Keter-i Thatar (dict.) István fia: Miklós a maga Keter faluba való jobbágyaival birtokba vétette és elbitorolta a panaszos János mr. Pethe birtokának hozadékait, szántóföldjeit, és más haszonvételeit, amihez ő beleegyezését nem adta, s aminek súlyos kárát szenvedi. Az országbíró az ügyben tanú állítására szólítja fel a kápt-t a történtek kivizsgálására kiküldött királyi emberek —- Thereche-i Pethenye fia: Miklós v. Gyulahaza-i Lukács (Luchasius) fia: László v. Berench-i Domokos fia: János v. Duge-i Domokos fia: Miklós v. Zugh-i András fia: Pál — valamelyike mellé, egyszersmind a vizsgálat eredményéról számot adó írásos jelentést kér a király számára. D. in Wissegrad, f. VI. prox. p. fe. B. Andree ap., a. d. 1356.

Á.: $\quad$ Egri kápt., 1357. jan. 20. Dl. 77 181. (Zichy cs. zsélyi lt. 1. B 299.).

K.: Z. III. 45-46. (31. szám).

\section{1356. dec. 2. Déda}

Marochuch mr. Bereg-i c. és a m. 4 szb.-ja emlékezetül adják: nov. 30-án (in fe. B. Andree ap.) [I.] Lajos király nevében a m. nemeseinek és nemteleneinek egésze (universitas) számára tartott generalis congregatio-n István fia: István mr. Bodolo-i nemes azt állította, hogy Imre Vary-i bíró, Orros (dict.) Jakab, nemkülönben Vary-i hospes-ek, továbbá Imre fiai, különösen Jakab a folyó év egyik napján (anno isto una die) hatalmaskodva a panaszos Bodolo birtokára jöttek, sertéseit megkaparintották, majd közülük kettôt levágtak, s ezzel 6 ft. kárt okoztak neki. A m. 12 ülnöke a feszületre tett esküvel bizonyították a hatalmaskodás megtörténtét. D. in villa Deda, VI. f. prox. videlicet 3. die congregacionis antedicte, a. d. 1356.

E.: Dl. 51 723. (Kállay cs. lt. 1300. 1100.) Papíron, hátoldalán késóbbi kéz írásával tárgymegjelölés, valamint 5 pecsét töredéke, bevágásai, szalagjai. 
K.: -

R.: Kállay II. 40. (1200. szám); Neumann T., Bereg m. 44. (55. szám).

\section{1356. dec. 2. Déda}

Marochuch mr. Bereg-i c. és a m. 4 szb.-ja emlékezetül adják: nov. 30-án (in fe. B. Andree ap.) [I.] Lajos király nevében a m. nemeseinek és nemteleneinek egésze (universitas) számára tartott generalis congregatio-n Bodolo-i István fia: István mr. elmondta, hogy bizonyos Borsua-i Bosua-i [!] nemesek zálogba adták neki Hegh-en és Helmech-en fekvố részbirtokaikat, ô pedig szemtől-szembe ezen részek zálogból való kiváltásáról kérdezte Simon fia: Tamást, Deseu fia: Beke-t és más Borsua-i nemeseket, akiket ezek a birtokrészek inkább megillettek, de ők István mr.-nek hagyták azokat. D. in villa Deda, VI. f. prox. videlicet 3. die congregacionis, a. d. 1356.

E.: Dl. 51 724. (Kállay cs. 1t. 1300. 1120.) Papíron, hátoldalán 3 pecsét töredéke és 2 pecsét nyoma, bevágásai, szalagjai.

K.: AO. VI. 519-520. (325. szám) (kihagyásokkal).

R.: Kállay II. 40. 1199. szám; Neumann T., Bereg m. 44. (56. szám).

\section{1356. dec. 2. Déda}

Morochuck királynéi lovászmr. és Bereg-i c., valamint a m. 4 szb.-ja emlékezetül adják: [I.] Lajos király rendelete értelmében Deda faluban nov. 30-án (in fe. B. Andree ap.) a m. nemeseinek és nemteleneinek egésze (universitas) számára tartott generalis congregatio alkalmával Warada-i László fia: János mr. elpanaszolta, hogy bizonyos Syd nevú földdarabját Deseu fiai: János és Domokos mr.-ek Gelienes falubeli jobbágyaik révén hatalmukba kerítették, megmúveltetik és haszonvételeit birtokolják, amely kijelentést 12 ülnök, valamint nemesek és nemtelenek a feszületre tett esküvel igazolták. D. in villa antedicta [Deda], VI.-a f. prox., videlicet 3. die congregationis supradict., a. d. 1356.

E.: Dl. 77 171. (Zichy cs. zsélyi lt. 1. B 281.) Papíron, hátoldalán 5 pecsét töredéke, bevágásai, szalagjai.

K.: Z. III. 36. (22. szám).; Neumann T., Bereg m. 44. (57. szám).

616. 1356. dec. 3.

Péter prépost és a Lelez-i Szt. Kereszt-egyház konventje jelentik [I.] Lajos királynak (H): Zeech-i Miklós országbíró idéző levelének (l. 597. szám) értelmében Jeyke-i Miklós fia: Jakab királyi ember mellé tanúul adták a konvent emberét, András testvért idézés végett, akik visszatérve jelentették, hogy nov. 26-án (sabb. prox. an. fe. B. Andree ap.) Tamás fia: István mr.-t Bezded birtokán a királyi jelenlét bírósága elé idézték Warada-i László fia: János mr. ellenében jan. 8-ra (oct. dieii Strennarum prox.). D. sabb. prox. p. fe. B. Andree prenotatum, a. d. 1356.

E.: Dl. 77 174. (Zichy cs. zsélyi lt. 1. B 282.) Papíron, hátoldalán azonos kéz írásával címzés és tárgymegjelölés, valamint a leleszi konvent kerek zárópecsétje (körirata 
részben kivehető: [+S(IGILLVM)] CONVENTVS DE LELEZ), bevágásai, szalagja; a pecséttel lezárt hátoldali részen keresztirányban korabeli jegyzet.

K.: Z. III. 38. (24. szám).

R.: Jékey, M. Családtört. Szle 5-6 (1937) 113.

\section{1356. dec. 3. Visegrád}

Zeech-i Miklós c., [I.] Lajos király (H) országbírája, Turuch m. c.-e emlékezetül adja: a színe e. megjelenvén egyik részről Bery-i Tamás, a másik részről pedig Swebel visegrádi polgár özvegye előadták, hogy Tamás azt a 11 M.-t, amit egy korábbi királyi oklevélben foglaltak szerint Swebel-tól vett kölcsön, késedelmesen fizette vissza az özvegynek, amiért is bírságként az összeg kétszeresét köteles kifizetni. Egyezségre jutottak az országbíró e., melynek értelmében az özvegy megerősíti, hogy Tamás megfizette neki 11 M. tartozását, továbbá az esedékes bírság harmadrészét. A hiányzó 7,5 M.-át 2 részletben fogja Tamás törleszteni, 4 M.-t [1357.] ápr. 16-án (in oct. fe. Passce d.), a további 3,5 M.-t pedig [1357.] szept. 15-én (in oct. fe. Nat. virg. glor.). Ha nem tenne mindezeknek eleget, párbajvesztesként ítéljék meg; ezenfelül az özvegy hozzáfúzte, hogy Tamás 24 oklevelét, amelyeket eddig zálogként magánál tartott, az országbíró e. visszaadja neki. D. in Vissegrad, sabb. prox. p. fe. B. Andree ap., a. d. 1356.

E.: Dl. 51 725. (Kállay cs. lt. 1300. 1101.) Papíron, hátoldalán kerek pecsét nyoma, bevágásai.

Má.: Uo., mint E., azzal megegyező jelzet alatt; 1785. máj. 8-án készült hiteles Má.-ban.

K.: -

R.: Kállay II. 40. (1201. szám).

618. (1356. dec. 7.e.)

Domokos prépost, Miklós esztergomi érsek vikáriusa e. létrejött egyezség értelmében Nachpal-i Machunka fiai: Imre és János 2 részletben - először dec. 7-én - köteles 44 ft.-ot fizetni Nogpha-i Pál fia: Jánosnak nagyanyja hozománya, jegyajándéka és anyja leánynegyede fejében.

Eml.: A 623. számú oklevélben.

K.: AO. VI. 521. (Eml.-ben).

R.: Justh 19 (26. szám) (Eml.-ben).

619. (1356. dec. 7. e.)

Konth Miklós nádor dec. 7-re rendeli törvényszéke elé Chyuthnuk-i László fiait: Miklóst és Lászlót, velük szemben pedig Zalona-i Loránd fiait: Lászlót, Barta-t és Istvánt a közöttük lévő perben.

Eml.: A 628. számú oklevélben.

K.: - 
Megj.: Vö. a 443. számú oklevéllel.

620. 1356. dec. 7.e.

Konth Miklós nádor $(\mathrm{H})$ és a kunok bírája utasítja az egri kápt.-t, hogy küldje ki hites tanúit Warada-i László fia: János v. Beely-i László fia: Péter v. Tarkan-i Donch fia: László v. Palagh-i Miklós v. Ewr-i Anthaleus fia: Tamás v. Bothfolua-i Both fia: László v. Welkyi Péter nádori emberek valamelyike mellé Bathwa-i Miklós fia: László mr. - - a felperes — oldalán, hasonlóképpen László fia: Tamás v. Zeech-i Detricus fia: István v. Kaponia-i Márton fia: Miklós v. Zeech-i Miklós fia: György v. Ruzka-i Dobow fia: Jakab v. Radich-i Kis (Parvus) László nádori emberek valamelyikének társaságában pedig Job fia: Miklós, és ugyanezen Job fia Domonkos fiainak: János és István Sysloch-i nemeseknek mint alpereseknek - az oldalán dec. 7-én (in oct. fe. S. Andree ap.) a felek v. törvényes képviselőik jelenlétében, miután törvényesen összehívták a szomszédokat és határosokat menjenek egy bizonyos Noska Er-hez, ahol ez az ér kifolyik az Wngh folyóból és vizsgálják meg, hogy vajon a mondott kifolyás fölött valamilyen áttörés (perfossio) az elmúlt 10 évben volt-e (a decem annis hucusque existerit vel existat), majd a szomszédoktól, határosoktól és m. beli nemesektől, nemkülönben másoktól — Istent és hitüket szem e. tartva - azoknak Istenbe vetett hitére, a király és a Szt. Korona iránti húségükre valljanak arról, vajon van-e tudomásuk arról v. hallottak-e róla, hogy a szóban forgó Sysloch-i nemesek a Nosk Er kifolyásának a helyén valamilyen rombolást múveltek. Tudják meg és vizsgálják ki az igazságot, majd a történtekrôl számot adó jelentést küldjenek a nádornak [1357.] jan. 13-ra (ad. oct. fe. Epiph. d.).

Tá.: Egri kápt., 1357. jan. 11. Dl. 31 283. (Csicsery cs. 1t. 72.).

K.: AO. VI. 525-526. (331. szám).

R.: Kárffy Ö., TT. 23 (1900) 407. (csak évre datálva).

\section{1356. dec. 11. Szentimre}

Domokos erdélyi alvajda a Clusmunustra-i Boldogságos Szűz-egyházának konventjéhez: Syberd fia: Péter mr. deák (literatus), a konvent jegyzője a maga és rokonai, Isaach Isaac fia: Mátyás, valamint Benedek fia: Gál nevében András erdélyi vajda és Zonuk-i c. halasztó oklevelében foglaltak szerint dec. 7-én (in oct. fe. B. Andree ap.) megjelent az alvajda e. és bemutatta a konvent 1351-ben Tamás akkori erdélyi vajda számára kiállított jelentését a Lekunche $\sim$ Lekenche folyó közelében, attól Ke-re fekvő Doboka m.-i Lekunche vásárolt birtok visszaszerzése ügyében. Ez többek között tartalmazta, hogy Lekunche birtokot a vajda embere, Fatha-i Mihály fia: Miklós jelenlétében a konvent emberének, János testvérnek a tanúságával visszaszerezték, majd a törvényesen összehívott határosok és szomszédok jelenlétében be akarták abba iktatni Péter mr.-t, Mátyást és Gált, azonban ebben megakadályozta óket Miklós fia: Jakabnak, továbbá a maga és fivére, Miklós, nemkülönben István fiai: István, Balázs és László nevében fellépő Lőrinc fia: Jánosnak az ellentmondása. Óket valamennyi, a birtokkal kapcsolatos oklevelükkel együtt megidézték Péter mr., Mátyás és Gál ellenében Tamás vajda elé [1351.] márc. 30-ra (ad oct. diei medii Quadr.). Bemutatta továbbá Egyed, akkori alvajda halasztó levelének két példányát (duo paria), amelyekben [1351.] jún. 12-re (ad oct. fe. Penth.), majd [1351.] aug. 1-jére (ad oct. fe. B. Jacobi ap.) halasztották az ügyet. Ezenkívül Péter mr. bemutatta Egyed alvajda egy másik halasztólevelét, melyben István fiainak: István- 
nak, Balázsnak és Lászlónak ifjú korára való tekintettel a pert 6 évvel [1356. aug. 1-jére] elhalasztották. Ezen 6 év elteltével Péter mr. maga és nevezett rokonai nevében bemutatta András vajdának az alvajda [1356-ban] kiállított halasztó levelét, melyben Isaach fia: Mátyás, Syberd fia: Péter és Benedek fia: Gál felperesek, valamint Miklós fia: Jakab, Lơrinc fia: Miklós, továbbá Lekunche-i István fiai: István, Balázs és László alperesek Egyed alvajda halasztó oklevele értelmében ez év aug. 4-én (4. die oct. fe. B. Jacobi ap.) kötelesek voltak megjelenni az alvajda színe e. Ezen időpont elérkeztekor egyik részról Syberd fia: Péter mr. a maga, valamint —- megfelelő ügyvédvalló levéllel — rokonai nevében, a másik részról pedig Miklós fia: Jakab, Lőrinc fia: János, István fiai: István, Balázs és László jelentek meg az alvajda e., Lőrinc fia: Miklós azonban sem meg nem jelent, se nem küldött senkit. Péter mr. Lekunche birtokkal kapcsolatban bemutatta az erdélyi egyház kápt.-jának 2 privilégiumát. Közülük az egyikben Zegeu fia: Miklós a maga és fivére, János nevében a Lekunche víz folyása mellett, attól Ke-re fekvő Lekunche örökletes birtokot, atyafia (cognatus) és határosa, Miklós fia: Domokos akaratából eladta az itteni ispotály procurator-ának, Herman besztercei (Bistrisiensis) polgárnak örök jogon 16 helyi M. ezüstért, aki ki is fizette a vételárat. A másik privilégiumban az állt, hogy a mondott kápt. e. Herman 30 M.-ért adta el Lekunche nevú, Zegeu fia: Miklóstól vásárolt földjét - amely a Lekunche folyó folyásától Ke-re fekszik - valamennyi haszonvételével és tartozékával együtt Omodeus fia: Mátyásnak és fivéreinek, Benedeknek, Ábrahámnak és Issach-nak, valamint örököseiknek. Amikor az alvajda és a felperes kérte az alperest nevezett birtok tulajdonlása kapcsán az okleveles bizonyítékok felmutatására, azok nem tudtak ilyet felmutatni, hanem halasztást kértek, melyet $3 \mathrm{M}$. bírság per előtti megfizetése ellenében meg is kaptak; a vajda a következő generalis congregatio-jára halasztotta az oklevél-bemutatást. Péter mr. ugyancsak bemutatta a vajda Tordán tartott újabb generalis congregatio-ja alkalmával kiállított halasztó oklevelét, melyben az állt, hogy jóllehet a felek - nevezett Miklós kivételével, aki ezúttal sem jelent meg és nem is küldött senkit - megjelentek a vajda előtt a generalis congregatio alkalmával, azonban Jakab, János, István, Balázs és László újfent nem tudták bemutatni okleveleiket, hanem kérték, hogy késóbb mutathassák be azokat, mely kérésnek a vajda eleget is tett, dec. 7re (ad oct. fe. B. Andree ap.) Szentimrébe (ad S. Emericum) halasztva a pert, az alperesre ugyanakkor $6 \mathrm{M}$. bírságot rótt ki. Elérkezvén az időpont, jóllehet Syberd fia: Péter, Isaach fia: Mátyás és Benedek fia: Gál megjelent az alvajda e., Miklós fia: Jakab, Lőrinc fia: János és fivére Miklós, valamint István fiai: István, Balázs és László nem jelentek meg, és nem is küldtek senkit. Ezért az alvajda az ország nemeseivel együtt ülve törvényt, miután látta a Lekunche folyó mellett fekvő Lekunche birtokkal kapcsolatos okleveleket, valamennyi haszonvételével és tartozékával Péter mr.-nek, Mátyásnak és Gálnak ítéli a mondott birtokot örök és visszavonhatatlan birtoklásra. Miklós fia: Jakabnak, Lőrinc fiainak: Jánosnak és Miklósnak, valamint István fiainak: Istvánnak, Balázsnak és Lászlónak az ügyben örök hallgatást rendel, eddig be nem mutatott —- az ügyre vonatkozó - okleveleiket pedig semmisnek nyilvánítja. Utasítja továbbá a kápt.-t, hogy szentgyörgyi (de S. Georgio) Herman fia: Miklós v. Galaz-i Demeter fia: János v. Welken fia: János v. Ws-i Iwanka fia: János alvajdai ember valamelyikével küldje ki hites tanúját a Lekunche folyótól Ke-re lévő Lekunche birtokra, ahol a törvényesen összehívott szomszédok és határosok jelenlétében járják be annak határait, ahol pedig szükséges, a régi határjelek mellé állítsanak újakat, különítsék el földjét más birtokoktól, és mivel nevezett Jakab, János, Miklós, István, Balázs és László nem mondhatnak ellent, iktassák be abba Péter mr.-t, Mátyást és Gált, mivel az jog szerint óket illeti. Ha pedig valaki mégis ellentmondana, úgy őt idézzék meg a nevezettek ellenében az alvajda elé alkalmas időre, majd mindezekról — a hj. és iktatás menetéról, az esetleges ellentmondók nevéről, az idézés helyéről és idejéről — jelentsen az alvajdának. D. in S. Emerico, 5. 
die oct. fe. B. Andree ap., a. d. 1356.

E.: Dl. 36 408. (Gyulafehérvári kápt. o. 1t. Cista com. Doboka S 114.) Papíron, hátoldalán az oklevél szövegének utolsó sorai, valamint azonos kéz írásával címzés, későbbi kéz írásával tárgymegjelölés, továbbá kerek zárópecsét nyoma, bevágásai.

Á.: Kolozsmonostori konvent, 1357. jan. 13. > Domokos erdélyi alvajda, 1358. márc. 23. > erdélyi kápt., 1358. márc. 24. Arhivele Statului Cluj. Beszterce város 1t. 4. (Df. 247 225.).

K.: ZW. II. 126-130. (709. szám); Doc. Rom. Hist. C. XI. 55-62. (54. szám) (román fordításban is) mindkettő Á.-ról.

R.: Zimmermann, AZ 18 (1887) 75-107; Berger I. 13. (31. szám) (német nyelvû); továbbá Á.-ról készült regeszta uo. 12. (30. szám); Erd. Okm. III. 314. (869. szám).

Megj.: Az átíró okleveleket 1. Erdélyi Okm. III. 352. (998. és 999. szám).

622. 1356. dec. 11.

A váradi egyház kápt.-ja e. Benedek [fia:] János — az egri egyházmegyéból való nemes asszonyokat, ti. Fany Balázs özvegyét, Lucát és lányukat, Annát, valamint Synka [fia:] Péter nemest és hitvesét, Ilonát képviselve - tiltakozott amiatt, hogy megbízóinak tudomása szerint miközben Peren-i Miklós [fia]: Miklós mr. igyekszik visszaszerezni mindama költségeket és kiadásokat, amelyek a Peren-i Pál nemes, ill. a szóban forgó Anna és említett pertársai között régóta fennforgó házassági perben Pál részéról felmerültek, akkor, amikor Demeter váradi püspök -- a szóban forgó házassági ügyben a Szentszék meghatalmazásával eljáró bíró — valamennyi megidézett érdekelt számára dec. 7-ét (in oct. f. B. Andree ap.) tûzte ki végérvényes határnapul, az Apostoli Szék levelében foglaltakkal szembeszegülve senki nem jelent meg törvényszéke e., még ha a jelzett határnapon a nevezett Miklós mr. Váradon is tartózkodott. Arra az esetre, ha valaki az ellentmondás szándékával lépne fel, ő képviseltjei érdekében ügyvédként kénytelen amiatt óvást emelni, hogy a szóban forgó asszonyokat és Synka [fia:] Pétert illetéktelenül vonták Dyrslaus krakkói kanonok —- a bíróként meghatalmazott (delegatus) krakkói püspök által kirendelt almegbízott (subdelegatus) bíró - e. perbe, és sújtották végül ténylegesen kiközösítő ítélettel, valamint más elmarasztaló büntetésekkel. Az ügyvéd tiltakozása szerint, ha ezek u. az előzőekkel kapcsolatban bárki perli is képviseltjeit, fenti óvási kifogásait, ill. minden egyéb, a jogi kívánalmaknak eleget tevó lépésük megbízóinak védelmére szolgál az ügyben. D. 5. die oct. fe. B. Andree ap. predict., a. d. 1356.

E.: Dl. 4637. (NRA. 1538. 28.) Hártyán, hátoldalán késóbbi kéz írásával tárgymegjelölés, valamint mandorla alakú pecsét nyoma, bevágásai.

K.: AO. VI. 520-521. (326. szám) (kihagyásokkal).

R.: Doc. Rom. Hist. C. XI. 62-63. (55. szám) (románul); Bónis-Balogh 133. (1221. szám).

\section{1356. dec. 12. Esztergom}

Domokos az esztergom-előhegyi Szt. Tamás vértanú-egyház prépostja, Miklós esztergomi érseknek és örökös ispánnak lelki ügyekben vikáriusa függőpecsétjével megerősített privilégiumot bocsát ki, melyben tudtul adja, hogy a korábbi egyezséglevelében 
foglaltak (l. 618. szám) szerint Nachpal-i Machunka fiai: Imre és János nemesek Nogphai Pál fia: Jánosnak nagyanyja hozománya, jegyajándéka és anyja leánynegyede fejében 2 részletben köteleztettek $44 \mathrm{ft}$. megfizetésére, mely kötelezettségüknek az első határnapon, dec. 7-én (oct. fe. B. Andree ap.) eleget tettek, készpénzben megfizetve a teljes összeget. D. Strigonii, 6. die oct. fe. B. Andree ap., a. d. 1356.

E.: Dl. 63 070. (Justh cs. lt. 14.) Hártyán, hátoldalán késóbbi kezek írásaival tárgymegjelölések, alján zöld selyemzsinóron Domokos esztergomi vikárius kerek pecsétje függ, széle töredezett (A MOL leírása alapján „Természetes okker színú viasz, kb $45 \mathrm{~mm}$, függőpecsét. Ábra: gótikus háttérben bibliai jelenet, lenn térdelő férfialak. Felirat: S DOMINI STRIGON.")

K.: AO. VI. 521-522. (327. szám) (kihagyásokkal).

R.: Justh 19. (26. szám).

624. 1356. dec. 13.

Az erdélyi egyház kápt.-ja tudtul adja: András erdélyi vajda és Zolnuk-i c. nov. 8-án (in oct. fe. OO. SS.) Tordán az erdélyi részek nemessége részvételével tartott generalis congregatio-járól visszatérő Loránd őrkanonok, Miklós Clus-i és Miklós Zolnuk-i főesp., György Kraco-i plébános, valamint László Hunyad-i főesp. jelentették, hogy színük e. az egyik részről megjelenő szentkirályi (de S. Rege) Sándor fia: János nemesember szükségtól szoríttatva eladta 20 M. ezüstért a másik részról megjelenő Mihály fia: Bolgar (dict.) Lászlónak és örököseinek a lakatlan Bonchahaza birtokot minden haszonvételével, úgymint szántóföldekkel, kaszálóval, réttel, vizekkel, erdókkel és mindenféle tartozékaival együtt, továbbá Hoczo faluban egy telket (sessio v. curia), halászó- és szőlőhelyet, Vendighordoy és Nogherdo erdőket és a Maros folyón lévő malomhelyet, amelyek egyedül ôt illették. D. III. f. prox. p. oct. fe. B. Andree ap., a. d. 1356.

Á.: Erdélyi kápt., 1393. jan. 13. Dl. 73 801. (Teleki cs. marosvásárhelyi lt. 283.).

K.: Teleki I. 100-101. (63. szám); Doc. Rom. Hist. C. XI. 63-64. (56. szám) (román fordításban is).

R.: Erdélyi Okm. III. 315. (870. szám).

625. (1356. dec. 14. e.)

Zeech-i Miklós országbíró utasítja a Lelez-i konventet, hogy a királyi emberrel kiküldött tanúja révén jan. 8-ra idéztesse a királyi jelenlét bírósága elé Warada-i János mr. ellenébe T[atar] (dict.) István fiait: Miklóst, Simont és Jakabot valamint Marhardus fia: Lászlót, majd az idézésról jelentsen a királynak.

Eml.: A 640. számú oklevélben.

K.: Z. III. 35. (21. szám).

\section{1356. dec. 14. [Gyula-]Fehérvár}

Salamon mr. Torda-i főesp., az erdélyi egyház kápt.-ja által a [püspöki] szék üresedés miatt kirendelt vikáriusa tudatja: kiküldött emberei Fahyd-i László és Tövisfalvi (de 
villa Spinarum) Péter, az egyház rektorai e. Borw (dict.) Miklós mr., továbbá a néhai alvajda, András fiai: László és István, nemkülönben nevezett András fiainak, Andrásnak és Lukácsnak a fiai - - fogott bírák közremúködésével - egyezségre jutván Miklós fia: Miklós és Jakab fia: Péter Gerend-i nemesekkel azok nagyapja, a néhai Miklós c. anyja, Erzsébet leánynegyede kapcsán, amely Salamon fia István fia: néhai László valamennyi birtokából és birtokrészéból a természet jogán óket megillette, megállapodtak. Az egyezség szerint nevezett Gyog-i nemesek a szóban forgó Gerend-i nemeseknek 2 részletben -- úgymint [1357.] márc. 1-jén (in oct. diei Cinerum) és [1357.] jún. 4-én (in oct. fe. Penthecostes) - M.-ként 10 pensa-val számolt 70 M.-t fizetnek részben dénárban, részben egyéb javak becsértékben, nem számítva bele az átadandó posztót (exceptis pannis dare). Kikötötték továbbá, hogy ha az első alkalommal nem fizetnek, bírságolják meg, ha második alkalommal nem fizetnek, akkor az összeg kétszeresét fizessék büntetés gyanánt. Megállapodtak továbbá, hogy ha a késóbbiekben bárki pert indítana v. követeléssel állna elő a kérdéses leánynegyed ügyében, akkor az említett Gerend-i nemesek saját költségükön kötelesek megfelelni azoknak. D. Albe, IV. f. prox. p. oct. fe. B. Andree ap., a. d. 1356.

E.: Dl. 28 910. (Kolozsmonostori konvent o. lt. Neoregestrata N 45.) Papíron, hátoldalán késóbbi kéz írásával tárgymegjelölés, valamint mandorla alakú pecsét töredéke.

Á.: Erdélyi kápt., 1357. ápr. 17. Dl. 30 387. (Gyulafehérvári kápt. o. 1t. Miscellanea 3. 5. 1.).

K.: AO. VI. 522-523. (328. szám) (kihagyásokkal); ZW. II. 130-131. (710. szám.); Doc. Rom. Hist. C. XI 64-66. (57. szám) (román fordításban is) Mindhárom E.-ről.

R.: Erdélyi Okm. III. 315. (871. szám.).

Megj.: Az oklevélben Fahyd-i László neve először Igun-i László formában volt leírva, s a helynév fölé az oklevél leírója írta utóbb a Fahyd alakot.

627. 1356. dec. 14.

Péter prépost és a Lelez-i Szt. Kereszt-egyház konventje eleget téve Warda-i László fia: János mr. kérésének privilégiális formában átírják a konvent által jún. 23-án kiadott nyílt oklevelet (l. 351. szám). D. 2. die fe. B. Lucie virg., a. prenotato [1356.].

E.: Dl. 77 175. (Zichy cs. zsélyi lt. 1. B 297.) Hártyán, az írás elhalványult, foltokban olvashatatlan, az aljáról a függőpecsét —- és vele együtt az oklevél néhány szava - leszakadt.

K.: Z. III. 39-40. (26. szám).

628. 1356. dec. 14.

Konth Miklós nádor $(\mathrm{H})$, a kunok bírája a Chyuthnuk-i László fiainak: Miklósnak és Lászlónak Zalona-i Lóránd fiaival: Lászlóval, Barta-val és Istvánnal szemben indított ama perét, amely a nádor korábbi oklevele (l. 619. szám) értelmében dec. 7-én (in oct. fe. B. Andree ap.) lett volna esedékes, s amelyben László fiainak képviseletében a Jazoui konvent ügyvédvalló levelében meghatalmazott Zeek-i Benedek fia: István, Loránd 
fiai helyett pedig famulus-uk, az ugyancsak a Jazou-i konvent ügyvédvalló levelét felmutató Márton fia: Pethev jelent meg a kitúzött időpontban színe e., a felek kérésére a fennálló állapot fenntartásával [1357.] jan. 13-ra (ad oct. fe. Epiph. d.) elhalasztja. D. in Vysegrad, 8. die termini prenotati, a. d. 1356.

E.: Dl. 4638. (NRA. 1538. 27.) Papíron, hátoldalán azonos kéz írásával tárgymegjelölés, valamint a nádor kerek zárópecsétjének töredéke (melyen 3 egymásra dólő pajzs látható, körirata [+ S(IGILLUM) NICOLAI] KVNT REGNI HVNGARIE PALATINI ET IVDICI(S) COMANOR(UM) részben olvasható), bevágásai.

K.: -

Megj.: Vö. a 443. számú oklevéllel.

629. 1356. dec. 16.

A nyitrai egyház kápt.-ja tudatja, hogy Leonárd fiainak: Miklósnak, Istvánnak és Jánosnak, valamint Zamard-i Tot (dict.) Pál mr.-nek és Klára nevú nemes feleségének, továbbá fiaiknak: Simonnak, Berecknek, Jánosnak és Andrásnak a kérésére a Nyitra m.-i Zerbech $\sim$ Scerbech és [Belhosth] birtokokon lévő lánynegyedbe való beiktatásra - a kápt. korábbi pátensébe (l. 561. szám) foglaltak szerint - dec. 7-én (in oct. fe. B. Andree ap.) kiküldte tanúit, egyik részrôl Bálint succentor-t Pál, felesége és fiai részére, a másik fél részére pedig Tamást, az egyház familiaris-át, akik visszatérve a felek jelenlétében jelentést tettek. Eszerint Leonárd fiai az egyezségüket tartalmazó kápt.-i oklevelében foglaltak alapján a leánynegyedet a következőképpen adják ki: Zerbech birtokon két negyedet, egyet Jardan-ból, egy másikat ugyancsak Zerbech-en, a harmadik negyedet pedig Belhosth-on. Dec. 7-én Zerbech és Belhosth birtokokra menve a szomszédok és határosok, valamint fogott bírák jelenlétében felmérték Zerbech birtok —- Syes (Má. 3.: Dioss) birtok felé eső — felét és haszonvételeit, és ahogyan kellett, Pál mr.-nek, feleségének és fiaiknak adták. A birtokrészt Leonárd fiainak birtokától elválasztó határ a következő: először is 2 földjelet állítottak Sook birtok határjelei mellett Ke-rôl, innen fut Zerbech falu határában lévő 2 földjelhez, majd a falun keresztül, a falu határának közelében emelt 2 földjelhez, tovább a Zerbech faluból Dreno dombhoz vezetô út melletti 2 földjelhez, tovább az úton, melynek mindkét oldalán határjel áll, innen jobbra fordul Ch[.......]vlgye (Má. 3.: Cheslase-vülgye) völgybe, ezen keresztül (vlg.) berch dombocskához, majd egy völgyön keresztül Jelsw nevú úthoz, Zerbech birtok régi határához, ahol 2 új jelet emeltek. D. f. VI. prox. an. fe. B. Thome ap., a. d. 1356.

Á.: Esztergomi kápt., 1380. júl. 20. Dl. 62 528. (Motesiczky cs. 1t. 60.).

Má.: 1. Á.-ról, azzal egyező jelzet alatt; 1720. jún. 25-én kiállított egyszerú Má.-ban.

2. Á.-ról, azzal egyező jelzet alatt (tévesen 1380-as dátummal).

3. D1. 14 029. (NRA. 1094. 10.) Á.-ról készült egyszerú Má.-ban.

K.: -

Megj.: Á. szerint E.-je hártyára íródott. 
Benedek prépost és a Scepus-i Szt. Márton-egyház kápt.-ja tudatják: [I.] Lajos király $(\mathrm{H})$ 1356. nov. 23-án Budán (Bude, fe. B. Clementis pape, a. presenti) kelt, tartalmilag átírt parancsára (1. 589. szám) Benedek szepesi préposttal, a király emberével tanúul küldték Pál éneklókanonokot. Visszatérve jelentették, hogy dec. 10-én (sab. prox. preteritis) Palocsa vár soltészai (schultetis), hospes-ei és polgárai jelenlétében a 2 darabban fekvő, 2 falu telepítésére elegendő fekete erdő birtokába bevezették Jakab mr.-t. Az egyik rész Mussina birtoktól Ke-re, Rilgov et András (Andreas) Vagascha birtoktól Dé-re, Sztara birtoktól Ny-ra, a Poprad folyótól É-ra fekszik. A másik része az erdőnek: egymást követő 3 dombocska szomszédságában É és Ke között, Bajorvagas Ke felől, Dé-ról Dimuich domb, (vlg.) Semene, Ny felól Jakabfalva birtok, É felől új Plavnicz. Ezek tulajdonába beiktatták Jakabot miután kivizsgálták, hogy Palocsa városnak nincs-e ellenvetése az adománnyal szemben. Az egyik erdőrész hj.-a: a határ Ke-en a Poprad folyó partján kezdődik, Ny-i irányba, ahol ezzel szemben folyik a Poprad folyóba a Reutez patak Lo. felól, itt emeltek 2 földjelet, innen Dé felé, a régi Ahoru hegyhez, más néven Javor hegy, Pfafenschit forrás eredetéhez, ahol 2 földjelet állítottak, a hegy gerincén 2 határjelhez, innen ÉNy felé a folyó felé emelkedő Volch halomhoz, aminek a tetején 2 földjel van, innen É felé, a Poprad folyó régi medrében ugyanezen folyóhoz, mellette 2 földjel, a Poprad folyó medrében visszatér az első határjelhez. A másik erdőrész határa: a Plaw-

nicz folyótól É-ra kezdődik egy helyen, a Deorusky nevú patak betorkolásánál, mellette 2 földjelet állítottak, innen Ke felé felmegy az említett dombra, É-ról, a csúcson van 2 földjel, Ke felé másik 2 magaslat tetejére, ahol van 2 földjel, Ke felé Bajorvagasa birtok határához, 2 földjelhez, innen Dé felé Mel Potok patakhoz, ami mellett van 2 földjel, Dé felé Semen hegy gerincére, 2 földjelhez, innen leereszkedik Ny felé Jakab Vagasa határához, 2 földjelhez a hegy tetjén, É felé 2 földjelhez, innen vissza az első határjelhez. Jakab mr. kérésére az ügy megerősítése végett a kápt. függőpecsétjével ellátott és az ABC betúivel chirographált privlégiumot bocsát ki. D. f. VI. prox. an. fe. B. Thome ap., a. d. 1356. Jelen lévén István olvasó-, Pál éneklő-, János őrkanonok, Lambert [fia:] Lambert, Gwamnich Tamás, Liptovia-i Miklós kanonokok. [I.] Lajos lévén a király (H), Gergely [fia:] Miklós a kalocsai érsek.

Má.: Dl. 68 907. (Berzeviczy cs. berzevicei lt. 161.) 18. sz.-i egyszerú, hibás Má.-ban.

K.: -

Megj.: Az irat a szepesi kápt. privilégiumaitól meróben eltérő formula használat alapján hamisnak tekintendő; ezt támasztja alá az oklevél végén olvasható hivatali és méltóságsor, melynek szerepeltetése nem fordul elő a kápt. okleveleiben, valamint a szöveg zavarossága.

631. 1356. dec. 17.

Az egri kápt. e. - miként azt 1356. dec. 17-én (a. d. 1356. sabb. prox. p. fe. S. Lucie virg.) kelt nyílt oklevele tanúsítja —- megjelent egyik részról Bator-i Leustachius fia Miklós fia: János, a másikról pedig Falch-i Jakab fia: Márton és elóbbi kijelentette, hogy mivel nôvére fiát, Mártont — a természet jogán és az ország szokása szerint — megilleti a leánynegyed, így azt Eghazasbator birtokon kiadja neki örök birtoklásra az egyház és mások jogának sérelme nélkül. 
Tá.: 1. Budai kápt., 1372. máj. 10. > Szécsi Miklós országbíró, 1372. jún. 7. HML. 248. 1. Egri székeskápt. mlt. 7. 4. 1. 1. 1. (Df. 210 156.).

2. Budai kápt., 1372. máj. 10. > Szécsi Miklós országbíró, 1372. jún. 7. HML. 248. 2. Egri székeskápt. mlt. 7. 4. 1. 1. 2. (Df. 210 157.).

Má.: Tá. 2-vel egyező jelzet alatt, 1376. jún. 23-i keltezéssel; 18. sz.-i egyszerű Má.-ban.

K.: -

632. 1356. dec. 17.

Péter prépost és a Lelez-i Szt. Kereszt-egyház konventje jelenti [I.] Lajos királynak (H): eleget téve a Zeech-i Miklós országbíró itt átírt dec. 2-án kelt oklevelében (l. 609. szám) foglaltaknak, Lukács (Lukachius) fia: László királyi emberrel Lőrinc testvért küldték tanúul, akik visszatérve jelentették, hogy az értesüléssel rendelkezók körében, kivált a szomszédok között vizsgálatot folytattak. Ennek eredménye szerint szentmárton-i (de S. Martino) István mr. nov. 17-én (f. V. prox. an. fe. B. Elizabeth) famulus-ai révén arra kényszerítette Warada-i János mr. Tuser birtokon időző jobbágyait, hogy vegyék le az összes ruhájukat, majd pedig közülük kettőt - Ágostont és Kozmát (Cosmas) Lytke faluból - ugyanott megveretett és egy tönkön le akarta vágatni a jobbágyok kezét. D. sabb. prox. p. fe. B. Lucie virg., a. supradicto [1356.].

E.: Dl. 77 176. (Zichy cs. zsélyi lt. 1. B 284.) Papíron, hátoldalán azonos kéz írásával címzés és tárgymegjelölés.

K.: Z. III. 40-41. (27. szám).

Megj.: Vö. a 649. számú oklevéllel.

633. 1356. dec. 17.

Péter prépost és a Lelez-i Szt. Kereszt-egyház konventje jelenti [I.] Lajos királynak (H): eleget téve a Zeech-i Miklós országbíró itt átírt dec. 2-án kelt oklevelében (l. 610. szám) foglaltaknak, Lukács (Lukasius) fia: László királyi emberrel Lőrinc testvért küldték tanúul, akik visszatérve jelentették, hogy az értesüléssel rendelkezók körében, kivált a szomszédok között vizsgálatot folytattak. Ennek eredménye szerint Tatar (dict.) István fia: Miklós Keter falubeli jobbágyai révén Warada-i János mr. Pethe birtokának javait, szántóföldjeit és egyéb haszonvételeit megkaparintotta és múvelteti a tulajdonos akarata ellenére. D. sabb. prox. an. fe. B. Thome ap., a. supradicto [1356.].

E.: Dl. 77 177. (Zichy cs. zsélyi lt. 1. B 285.) Papíron, hátoldalán címzés és tárgymegjelölés, valamint a leleszi konvent kerek zárópecsétjének töredéke (körirata részben olvasható [+ S(IGILLVUM)] CONV[(ENTV)S] DE LELE(S)).

K.: Z. III. 41-42. (28. szám); Doc. Rom. Hist. C. XI. 66-67. (58. szám) (román fordításban is).

634. 1356. dec. 17. Kapos

Lukács mr., János mr. alispánja és Vngh m. 4 szb.-ja jelenti [I.] Lajos királynak (H): eleget téve a király itt átírt, aug. 18-án kelt parancslevelében (l. 457. szám) foglaltaknak 2 
kiküldöttjük révén teljesítették a kért vizsgálatot. A kiköldöttek visszatérve jelentették, hogy miután a nemesek és nem nemesek, különösen pedig a Jezeneu és Nogmihal birtok környékén élők körében a vizsgálatot lefolytatták, igaznak találták Tyba-i Lőrinc fiainak panaszát. D. in Kapus, sabb. prox. p. fe. B. Lucie virg., a. prenotato [1356.].

E.: D1. 85 316. (Sztáray cs. 1t. 102.) Papíron, hátoldalán azonos kéz írásával tárgymegjelölés, valamint 4 kisebb és 1 nagyobb zárópecsét töredéke, bevágásai. Sztáray alapján elóbbiek közül kettőn $N$ és $P$ betú vehető ki, ezek a szb.-ák gyưrücspecsétjei, utóbbi az alispán gyưrûspecsétje, melyen egy kiterjesztett szárnyú sas látható, körirata: SIG[IL]V[M COMIT]IS LVCE.

K.: Sztáray I. 256-257. (149. szám).

635. 1356. dec. 18.

A pécsi egyház kápt.-ja tudatja: az urát, a Wlko m.-i Mykola-i Phile fia Péter fia: István mr.-t képviselő Gyulkini-i Gál bemutatta [I.] Lajos király $(\mathrm{H})$ okt. 23-án kelt és itt átírt (l. 545. szám), gyứrúspecsétjével megjelölt zárt oklevelét, melyben foglaltaknak megfelelően az egyház sekrestyéjéból v. conservatorium-ából előkeresték a mondott privilégium másik példányát, majd megvizsgálták, de sem kaparást, sem javítást nem találtak a kápt. korábbi pecsétjével ellátott oklevelén, ezért a kápt. eleget téve a király parancsának szóról szóra átírta - 1251. májusában kelt - privilégiumát és új, nagyobb pecsétjével erôsítette meg azt, majd odaadta István mr.-nek. Actum 15. Kal. Jan., ab Incarn. d. 1356. Kelt János mr. olvasókanonok keze által, Péter székesegyházi főesp., György őrkanonok, János mr. nyitrai dékán jelenlétében.

E.: D1. 37 563. (Hunyadi cs. 1t. 5.) Hártyán, hátoldalán közel korú kéz írásával tárgymegjelölés, alján zöld sodraton a kápt. mandorla alakú pecsétje függ. Pecsétképe: oszlopok tartotta, háromkarályos ívvel záródó baldachin alatt gyöngysorból álló glóriával övezett trónoló Szt. Péter. Az apostolfejedelem állatfejekkel díszített faldistoriumon ül, behajlított jobbkezében hatalmas kulcsot tart, baljában pedig könyvet. A patrónus alakja mellett jobbról és balról monogramja, a S[anctus] P[etrus] látható. A baldachin homlokzatás, Pécs középkori latin nevére - Quinqueesslesiae (Öttemplom) - utalva, öt árkádos épület díszíti, az épületeken fiatornyok figyelhetők meg. Ezzel akarták megelőzni, hogy leszakadjon a korábbinál nehezebb pecsét, amelynek súlyát egyébként növelte, hogy következetesen pólyaszerúen kialakított pecsétágyba nyomták be. Körirata: S(IGILLUM) CAPITVLI ECCL(ES)IE QVINQVE ECCL(ES)IEN(SIS); Koszta L., LK. 67 (1996) 54.

K.: -

Megj:: Farkas pécsi prépost átírt oklevele Holmos birtok adás-vétele kapcsán kelt, 1. F. IV. 2. 121-122.

\section{1356. dec. 19. Visegrád}

Konth Miklós nádor $(\mathrm{H})$, a kunok bírája tudatja a szepesi egyház kápt.-jával: Rycolphus fia László mr. fia: Péter apja nevében színe elé járulván panaszt tett, mivel a néhai bán, Mykch fia: Loránd mr. nem tett eleget az előző nádor és kunbíró, Miklós privilégiumában foglalt egyezségnek, mely szerint Loránd mr. bizonyos Adrianuagasa nevú Sarus m.-i birtokát, 80 telekre kiterjedôt (ad 80 laneos), 1355. máj. 1-én (in. oct. fe. B. Geor- 
gii mart. [sub a. d. 1355.]), ellentmondó nem lévén, valós határai mentén átadja az apját képviselő Péternek, és beiktatja abba. Ezért a nádor kéri a kápt.-t, küldje ki tanúját Olchouicha-i Mihály fia: János v. Segre-i Péter fia: László v. Janusfalua-i Arnold királyi emberrel Loránd mr.-hez, és hívják ki a szóban forgó birtokra ót iktatás végett, ahogyan az egyezséglevél megköveteli. Ha ezt visszautasítja, akkor idézzék a nádor elé László mr.-rel szemben alkalmas időre. A nádor utasítja továbbá a kápt.-t, hogy az iktatásról és a hj.-ról, ill. annak sikertelensége esetén az idézésről - helyéről, az idézettek nevéről és idejéről - jelentést írjon. D. in Wyssegrad, f. II. prox. an. fe. B. Thome ap., a. d. 1356.

Á.: Szepesi kápt., 1357. márc. 12. Dl. 68 910. (Berzeviczy cs. berzevicei lt. 163.).

Tá.: Konth Miklós nádor, 1357. ápr. 19. Dl. 68 911. (Berzeviczy cs. berzevicei lt. 164.).

K.: - -

Megj.: A []-be foglalt információ a Tá.-ból származik.

\section{1356. dec. 19. Trencsén}

Pál mr. trencséni alispán és várnagy, valamint a m. szb.-i emlékezetül adják: korábbi idéző és halasztó okleveleikben foglaltak szerint Neporaz-i Bodmer fia András fia: Miklós mr. felperes perbe fogta a másik Neporaz-ra való Lukács (Lucachius) fia: Tamást egy mindkét Neporaz birtokon keresztül folyó víz (aqua) ügyében. Többszöri elnapolást követôen a pert legvégül dec. 19-re (f. II. prox. p. fe. B. Lucie virg.) halasztották, amikor is színük e. Lukács fia: Tamás m.-beli nemesekkel és másokkal együtt - az ország ôsi szokása szerint - esküt tett András fia: Miklós ellenében arról, hogy az a víz saját, atyafiai (fr.) és rokonai (generationes) birtokán keresztülfolyik. Az eskütétel napján egyik részrôl András fia: Miklós mr. fivérével (fr. uterinus), Mártonnal, a másik részről Lukács fia: Tamás apjával, Kozma (Cozmas) fia: Lukáccsal és atyafiával (fr.), Bosan-i Iwan fia: András törvényes képviselővel eléjük járultak, és jóllehet Tamás - az ítéletnek megfelelően - tanúkkal igazolta saját igazát Miklós mr. ellenében, mégis a jövôbeni békesség kedvéért elrendelték, hogy fogott bírák - úgymint Streche-i Mihály fia: András c., Turchan-i Chuka (dict.) Miklós, Leuna-i Móric fia: Tamás és Dormanus c., valamint mások - közvetítésével egyezzenek ki. A létrejött megegyezés értelmében, mivel mindkét Neporaz nevú birtokuk, amelyiknek egyike Miklós mr.-nek és atyafiainak (fr.) a birtokában van, a másikat pedig Tamás apjával és egyéb atyafiaival (fr.) egyenlően felosztva használta, a szóban forgó részek v. azok tartozékainak elfoglalása miatt közöttük számos viszálynak és pernek volt az okozója, ezért elválasztják a birtokokat. Tehát [1357.] márc. 22-én (in oct. medi Quadr. prox. nunc venturis) nevezett felek v. törvényes képviselőik a m.-i kiküldöttekkel együtt menjenek ki mindkét Neporaz birtokra, és ott a fogott bírák jelenlétében járják be a birtokokat régi határaik mentén, és ha szemmel nem tudják megmérni, de szükségesnek tartják, ott mérjék meg a szántóföldeket, a megmúvelt és múvelés alatt nem álló szántókat, erdóket, legelóket, valamint azok valamennyi haszonvételét, majd osszák 2 egyenlő részre. Ezeknek egyik fele Miklós mr. és atyafiai (fr.) Neporaz birtokához legyen kapcsolva, a másik fele pedig Tamás és atyafiai (fr.) Neporaz birtokához tartozzék ezentúl, úgy, hogy azt a patakot (fluvius) v. vizet, ami Lukács fia: Tamás és atyafiai Neporaz faluján folyik keresztül Miklós mr., atyafiai, továbbá valamennyi jobbágyuk és minden hozzátartozójuk közösen használhassa mostantól, majdan pedig utódaik is így tehessenek békességben, mindenféle ellentmondás nélkül. Kivételt képez, hogy Tamás v. atyafiai közül bárki elrendelhet halászatot a mondott patakon, azonban Miklós mr. v. atyafiai v. utódaik v. más hozzátartozóik elóbbiek 
engedélye nélkül abban a tóban (piscina) nem halásztathatnak, és malmot sem építhetnek a patak azon szakaszán, amely elóbbieknek a birtokán van. Nem mellőzhető, hogy a birtokosztály alól kivételt képez egy bizonyos Kelechen földdarab, amelyet - a felek elbeszélése alapján - még Tamás őse (avus) adott viszonzásul Miklós mr. és atyafiai ősének saját részéből kivéve, ezért az érintetlenül és szabadon Miklós mr.-é és atyafiaié marad. Miklós mr. és fivére, Márton vállalták, hogy ha nem tartanák be az egyezségben foglaltakat, akkor bírságban marasztaltassanak el. Ha pedig Tamás v. bárki a rokonságából megszegné az egyezséget, akkor annak valamennyi terhét legyenek kötelesek viselni, ahogyan arra Tamás, apja Lukács és atyafia Bosan-i Iwan fia: András kötelezettséget vállaltak. A feleknek azt is kötelezettségül szabták, hogy a birtokosztályt követő 15. napon az osztályeredményét írásban bemutatva számot adjanak a történtekrốl. D. Trenchiny, II. f. supradicta [p. fe. B. Lucie virg.], a. d. 1356.

E.: D1. 49 028. (Bossányi cs. 1t. A 74.) Hártyán, hátoldalán közel korú és késóbbi kéz írásával tárgymegjelölés, továbbá egy nagyobb kerek, valamint két kisebb pecsét nyoma, szalagjai, bevágásai.

Má.: Uo., mint E., azzal megegyező jelzet alatt; modern kori egyszerú Má.-ban, Csernák Margit aláírással.

K.: -

\section{1356. dec. 20. Visegrád}

[I.] Lajos király $(\mathrm{H})$ tudatja, hogy eleget tett a veszprémi kolostor apácáinak apátnője, Erzsébet és Jugith [!] nővér (soror) saját és rendjük teljes konventjének nevében előadott kérésének, hogy nyílt oklevél formájában írja át Kálmán király $(\mathrm{H})$ bemutatott privilégiumát, amely tartalmazta Szt. Istvánnak, Mo. első királyának a veszprémi monostor számára tett birtokadományait. Kérésüket azzal indokolták, hogy békétlenség (temporis impacatitatem) és az utak veszélyessége miatt, jogi ügyeik intézésekor nem merik azt magukkal vinni. D. in Vissegrad, in vig. fe. B. Thome ap., a. d. 1356.

E.: Dl. 4580. (MKA. Acta Jes. Jaurin. 2. 8.) Hártyán, első sora vonalazott, hátoldalán késóbbi kéz írásával tárgymegjelölés, valamint kerek pecsét lenyomata, bevágásai.

Má.: Dl. 444. (MKA. Acta Jes. Jaurin. 31. 2. 53.) Egyszerú újkori Má.; 53-54. old.

K.: DHA. I. 369-370. (136/II. szám) H. (rövid kivonatban).

Megj.: Kálmán király 1109-ben kelt interpolált privilégiumát 1 . Reg. Arp. 42. szám, valamint DHA. I. 368-380. (136/II. szám).

639. 1356. dec. 20.

Az egri kápt. e. —- miként azt 1356. dec. 20-án (in vig. fe. B. Thome ap., a. d. 1356.) kelt (átadásra, kézbesítésre vonatkozó) oklevele tanúsítja — Péter fia: Mihály a közelebbi szomszédság okán formálván igényt birtoklásra, eltiltotta Tamás fia András fia: Gergelyt és Lelez-i Zok fia Simon fia: Lászlót egy Nadasd birtokon lévő birtokrész elzálogosításától és eladásától, Péter mr. fôesp.-t és Varyu (dict) Miklós mr.-t annak megvásárlásától v. zálogba vételétól.

Tá.: 1. Bebek István országbíró, 1361. szept. 26. D1. 90 823. (Csoma cs. devecseri lt. 58.) 
2. uo.; Tá. 1-rôl készült 19. sz.-i egyszerú Má.-ban.

K.: -

640. 1356. dec. 20.

Péter prépost és a Lelez-i Szt. Kereszt-egyház konventje jelentik [I.] Lajos királynak $(\mathrm{H})$ : eleget téve a Zeech-i Miklós országbíró idéző levelében (l. 625. szám) foglaltaknak Dugei Domokos fia: Miklós királyi ember a kiküldött Lőrinc testvérrel dec. 14-én (2. die fe. B. Lucie virg.) a királyi jelenlét bírósága elé idézte Warada-i János mr.-rel szemben T[atar] (dict.) István fiait: Miklóst, Simont és Jakabot Kuther birtokon, valamint Marhardus fia: Lászlót Olchwa birtokon [1357.] jan. 8-ra (oct. diei Strennarum prox.). D. in vig. fe. B. Thome ap., a. d. 1356.

E.: Dl. 77 178. (Zichy cs. zsélyi lt. 1. B 298.) Papíron, hátoldalán azonos kéz írásával tárgymegjelölés, valamint 2 késóbbi jegyzet, továbbá a leleszi konvent kerek zárópecsétjének bevágásai és töredéke, helyenként olvasható körirattal ([+S(IGILLVM) CONVENTVS] DE LEL[ES]).

K.: Z. III. 35-36. (21. szám).

641. 1356. dec. 20.

A pozsonyi egyház kápt.-ja tudatja: Klára nemes asszony, Petus Verkyne-i nemes özvegye, Vata-i János fia: László felesége, férjének és előző férjétől született lányának, Erzsébetnek a nevében is kijelentette, hogy Verkyne birtok u. járó hozományát, jegyajándékát és leánynegyedét szavatosság vállalása mellett eladta az ugyancsak megjelent Jakus c., pozsonyi bírónak örök birtoklásra $60 \mathrm{M}$. —- M.-ként 10 pensa-val számolt — széles királyi dénárért, lemondva minden ezekkel kapcsolatos jogaikról. Ennek bizonyságára a kápt. az ABC betúivel chirographált és autentikus pecsétjével megpecsételt privilégiumot ad ki Jakus c. bíró részére. D. in vig. [B.] Thome [ap.], a. d. 1356.

E.: AM. Bratislavy. Pozsony város tanácsa 131. (Df. 238 756.) Hártyán, alul az ABC betûivel chirographálás, továbbá függőpecsét zsinege látható.

K.: -

R.: Ortvay, Pozsony III. 319; AMB. Inventár 27. (137. szám (cseh nyelven).

642. 1356. dec. 20.

A váci kápt. e — miként azt 1356. dec. 20-án (in oct. fe. B. Lucie virg. et mart., a. d. 1356) kelt oklevele tanúsítja - megjelent egyik részről Balogh (dict.) Miklós fia: János, s a másikról Wereb-i János fia: György, és elóbbi kijelentette, hogy Györgynek a Nógrád m.-i Harkyan birtokon lévő részbirtokát, amit 4 évre tőle zálogba vett $5 \mathrm{M}$.-ért, a 4 éve leteltével, miután visszakapta az 5 M.-át, visszaadta Györgynek.

Tá.: 1. Bebek Detre nádor, 1398. nov. 4. D1. 4582. (NRA. 392. 7.).

2. Bebek Detre nádor, 1398. jún. 9. Dl. 8386. (NRA. 1776. 1.) Foltokban kiszakadt, a kérdéses oklevél csak részben olvasható, a keltezés hiányzik. 


\section{1356. dec. 21. Visegrád}

Konth Miklós nádor $(\mathrm{H})$, a kunok bírája tudatja: amikor dec. 7-én (in oct.fe. B. Andree ap.) Tamás testvér szerémi, István testvér nyitrai, Tamás testvér csanádi, Péter testvér boszniai püspökökkel, valamint Cyko királyi tárnokmr.-rel, Levstachius, egész Szlavónia bánjával, Gyletus fia: János mr. Baymoch-i várnaggyal és a királyság több más előkelőjével és nemesével együtt ítélkeztek peres ügyekben, színük e. Olivér mr., a királynéi udvar bírája s egyben szatmári c. kijelentette, hogy Zygethfew birtokot a Duna folyón lévő révvel és révpénzzel (portu et naulo), valamint egyéb tartozékaival és haszonvételeivel együtt, — a Szt. Istvánnak, Mo. első királyának adományát régisége okán megújító — Kálmán király (H) 1109-es privilégiuma alapján visszaadja az azokat megillető veszprémi Dicsőséges Szúz-egyháznak és apácáinak örök birtoklásra, saját örököseinek semmiféle jogot nem tartva fenn. Ezen ügy bizonyosságára nevezettek nyílt oklevelet állítanak ki a szóban forgó egyháznak és apácáinak. D. in Vysegrad, in fe. B. Thome ap., a. d. 1356.

E.: Dl. 4639. (MKA. Acta Jes. Jaurin. 10. 4.) Hártyán, hátoldalán azonos és késóbbi kéz írásával tárgymegjelölés, valamint kerek pecsét töredéke, szalagja.

K.: AO. VI. 523-524. (329. szám) (kihagyásokkal); DHA I. 374. (136/II. szám) (kihagyásokkal).

R.: Doc. Rom. Hist. C. XI. 67. (59. szám) (románul).

Megj.: Kálmán király 1109-ben kelt interpolált privilégiumát 1 . Reg. Arp. I./3. 15-16. (42. szám), valamint DHA. I. 368-380. (136/II. szám).

644. 1356. dec. 22.

A Jazou-i konvent jelenti [I.] L[ajos] királynak (H): megkapták a király itt átírt okt. 23án kelt parancslevelét (l. 546. szám) és az abban foglaltaknak eleget téve Lazov-i Lachk fia: Miklós királyi emberrel Domokos testvért küldték ki hites tanúul, akik visszatérve jelentették, hogy Tereztenye birtokon minden értesüléssel rendelkezót —- különösen a szomszédokat - kikérdeztek és a vizsgálat eredményeként megtudták, hogy Honguni ........[Lampert fia?] Domokos, Ordov-i officialis Turos (dict.) Jánossal, valamint István fiai: János és Péter Ordov-i hospes-ekkel júl. [14-én] ([f. V. prox. p. fe.] Margarethe virg.) Gál fiai: Fábián, Pál és Péter Tereztenye birtokon levő házához ment, ott levágta Pál egyik ujját, Pétert pedig életveszélyesen megsebesítette a fején. D. 2. die fe. B. Thome ap., a. supradicto [1356.].

E.: D1. 96 355. (Vay cs. berkeszi lt. 346.) Rossz minőségú fényképfelvétel, foltokban olvashatatlan. Papíron, R. szerint hátoldalán kerek zárópecsét lenyomata látható.

K.: -

R.: Piti F., Vay 445. (166. szám).

Megj.: A [] között adott betoldások az átírt oklevélből származnak. 
[VI.] Ince pápa Arnoldus de la Caucina krakkói kanonoknak, a Szentszék követének és Raymundus de Sancro-Michaele fegyvernöknek: meghatalmazza őket és segédeiket v. utódaikat, hogy beszedjék a Szentszéket illető adókat Mo.-on, Lo.-ban és Cseho.-ban és utasítja őket az összegyúlt adó átadására Planis-i Rafael, Damián és Albert kereskedőknek valamint desmalalosilis társaságuk v. ezek Brieg [-i?] intézői tagjainak (socios societatis desmalalosilis seu eorum factorum Brieg). D. Avinione, 6. Kal. Jan., pápasága 5. évében [1356.].

Reg.: Áldásy A., TT. 1895. 89. (266. szám); Áldásy 48. (266. szám) (Reg. Vat. v. 243., f. 84r alapján).

\section{1356. dec. 28. Visegrád}

[I.] Lajos király $(\mathrm{H})$ tudósítván Leustachius-t, Szlavónia (regnum Sclavonie) általános vikáriusát, Somogy, Fejér és Tolna m.-k c.-ét a Keer-i Gergely fia György nemes özvegyének és gyermekkorú fiának, Sebestyénnek, nemkülönben atyafiainak (fr. patrueles), a nevezett Gergely másik fiának, Miklósnak, továbá János fia: Péternek a keserves panaszából szerzett azon értesülésről, miszerint Pascha Paska fiai: Jakab mr. és László önhatalmúlag, királyi ember és más kápt.-i v. konventi tanú közremúködése nélkül kivetették és kizárták őket Achad, Keer és Echyr Echyn nevű Somogy m.-i birtokaikból, jóllehet azokat bemutatott hatályos okiratok bizonysága szerint peres úton szerezték vissza Pascha fiaitól, majd a hatalmaskodók jobbágyaik révén kezükre vonták a szóban forgó birtokok minden haszonvételét, és azokat azóta is folyamatosan birtokolják, miközben pedig maguk a panaszosok idegen házakban kényszerülnek rejtőzködésre, utasítja a címzettet, hogy amennyiben megbizonyosodik a panasz helytállóságáról, járjon el a somogyi konvent kiküldendő tanúbizonysága mellett —- ahová a közremúködés érdekében továbbítani kell e levelet — a panaszosok bevezetésében felsorolt birtokaikba, az őket illetố jogon történő beiktatásukban örökre szóló birtoklásukhoz, valamint jogaik megvédelmezésében valamennyi illetéktelen zaklatóval szemben. D. in Vyssegrad, in fe. S. Innocentium, a. d. 1356.

Á.: Somogyi konvent, 1357. febr. 5. Dl. 41 295. (Múz. Ta. Zobothin).

Má.: Uo., mint Á., azzal megegyező jelzet alatt; modernkori egyszerú Má.-ban.

K.: Zichy VI. 5-6. (5. szám).

R.: Somogy m. 1t. Évk. 29 (1998) 251. szám.

647. 1356. dec. 29.

A nyitrai egyház kápt.-ja e. Rakoch-i István fia: András és Miklós fia: Ewzun a maga, valamint Rakoch-i Ábrahám fia: Pál nevében tiltakozólag kifogásolták, hogy János, Demeter, és Jakab mr. - a kápt. kanonokjai -, nemkülönben az ugyancsak Rakoch-ról való Pál fia: István és Miklós fia: Pál É felól a Machalapataka vízfolyás mellett az ô Rakoch birtokuk határát meg akarják járni, ott új határjeleket akarnak kitűzni, és a birtokot eszerint akarják a maguk részére iktatni, amiért is nem a hj.-tól, hanem a határkitúzéstôl és az iktatástól tiltják Pál és Miklós említett fiait. D. in fe. B. Thome mart., a. d. 1356. 
E.: Dl. 73 041. (Rakovszky cs. 1t. 4.) Papíron, hátoldalán azonos valamint 2 késóbbi kéz írásával tárgymegjelölés, továbbá kerek zárópecsét töredéke, bevágásai.

K.: -

648. 1356. dec. 29.

A Scepus-i Szt. Márton-egyház kápt.-ja e. Valter fia Miklós özvegye, Gerardus leánya, a Torkeu vár alatti faluból való Erzsébet úrasszony kinyilvánítja, hogy azt a faluban található egész telkét (curia), valamint a falu határában lévő, a falu megszokott mértékének megfelelő kültelki földjét (et unum laneum terre in metis ville eiusdem, secundum consuetam mensuram ipsius ville), amelyet Rykolphus fia: Rykolphus mr. egykor jószántából a kápt. privilégiumában adományozott el örökre szólóan Valternek, ill. Miklósnak, most haszonvételei, jogai és tartozékai teljességével együtt eladta eme Rykolphus mr.nek örök birtoklásra a tőle megkapott $40 \mathrm{M}$. finom ezüst ellenében. D. f. V. p.fe. Nat. Christi a. eiusdem 1356.

E.: Dl. 105 333. (Berzeviczy cs. berzevicei lt.) Hártyán, hátoldalán késóbbi kéz írásával tárgymegjelölés, valamint kerek pecsét töredéke, bevágásai.

K.: -

649. 1356. dec. 31. [Ó-]Fehértó

Cantor (dict.) Bereck Zabolch-i alispán és m. szb.-ái jelentik [I.] Lajos királynak (H): megkapták Zech-i Miklós országbíró itt átírt dec. 2-án kelt oklevelét (l. 611. szám) és az abban foglaltaknak eleget téve kiküldtek 2 szb.-t, Guth-i Salamon fia: János mr.-t, valamint Bogdan-i Oliver fia: Demeter mr.-t az ügy kivizsgálására, akik visszatérve egybehangzó jelentést tettek. Eszerint titokban és nyíltan kikérdeztek mindenkit, akit lehetett, különös tekintettel a birtok határosaira és szomszédaira, és megtudták, hogy szentmártoni (de S. Martino) István mr. nov. 17-én (V.f. superius expressa) János mr.-nek Waradai és Lytke-i jobbágyait ennek Tuser nevû birtokán minden ruhájuktól megfosztatta, továbbá közülük kettőt —- Ágostont és Kozmát (Cosmas) Lytke faluból — ugyanott megverni parancsolta és egy tönkön le akarta vágatni a jobbágyok kezét famulusa-ival. D. in Feyrtho, sabb. prox. an. diei Strennarum, a. supradicto [1356.].

E.: Dl. 77 179. (Zichy cs. zsélyi lt. 1. B 296.) Papíron, hátoldalán azonos kéz írásával tárgymegjelölés valamint címzés, továbbá 3 zárópecsét töredéke és további 2 lenyomata.

K.: Z. III. 43-44. (29. szám).

R.: Piti F., Szabolcs m. 134-135. (524. szám)

Megj.: Vö. a 632. számú oklevéllel.

650. 1356.

[I.] Lajos király —- miként azt 1356-ban (in a. d. 1356.) kelt privilégiuma tanúsítja átírja és megerősíti 1355. évi nyílt oklevelét, amelyben mérlegelve Cesanis-i Jakab mr., 
Jadra-i [miles] húségét és érdemeit, új adomány címén örökre szólóan neki adományozza a Szlavóniában, Wrana közelében lévő, fél német mérföld kiterjedésû (in circuitu in metis per medium milliare theothonicum) Sowynath dombot, valamint az elmondások szerint királyi adományozás hatálya alá eső Banyawaz és Cassith falvakat valamennyi haszonvételükkel és tartozékaikkal együtt régi határaik között, idegen jog sérelme nélkül.

Tá.: Szécsi Miklós dalmát és szlavón bán, 1361. nov. 15. > I. Lajos király, 1367. jún. 2. Dl. 87 423. (Esterházy cs. hercegi ága, Repositorium 43. A 8.).

K.: Alsószlavónia 70-71. (48. szám), s ennek nyomán Smič. XIII. 186-187. (127. szám).

Megj.: A [ ] között adott kiegészítés a tartalmi átarást adó oklevél más, ezen iraton kívül eső szakaszából származik.

651. 1356.

[I.] Lajos király —- miként azt 1356-ban (a. d. 1356.) kelt oklevele tanúsítja —átírja 1352. évi kiváltságlevelét, amelynek értelmében Maroucha-i és Glaunycha-i várjobbágyait, nevezetesen Mihály fia: Miklóst, János fia: Pétert, Miklós fia: Antalt, Marcho (gen.: Marchonis) fia: Márkot, András fiait: Wank-ot és Jánost, Jaconus (gen.: Jaconi) fia: Homodeust, Vencel (Wenzlaus) fia: Miklós-t, Péter fia: Iwan-t, Pál fia: Jánost, Simon fia: Istvánt, valamint Mártont és Heruk-ot az oklevélben részletezett érdemeik alapján kiveszi jobbágyi állapotukból és a nevezett vár joghatóságából (a jobagionatu seu qualicunque juridictione castri memorati), egyszersmind őket összes szerzett és ezután megszerzendő földjeikkel együtt a királyi serviens-ek sorába emeli édesanyjának, Erzsébet királynénak és fivérének, István hercegnek az egyetértésével.

Tá.: Marcali Dénes szlavón bán, 1419. ápr. 9. Dl. 100 415. ( Batthyány cs. lt. Acta antiqua. Hrassina 4. 4. 26.).

K.: -

Megj.: Marcali Dénes bán tartalmi átírást adó oklevelét 1. ZsO. VII. 290. szám alatt.

652. 1356.

[I.] Lajos [király] levele Wyssegrad-i Istvánnak Kwkerth birtokról.

Reg.: AM. Košíc. Kassa város titkos lt. Scheutzlichov inventár. Elenchus iurium et privilegiorum Cassoviensis. 63 A AAA 20. (Df. 287 451.); 19. old. Csak éves dátummal.

K.: -

653. 1356.

[I.] Lajos király több oklevelet erősít meg átírván azokat Pál fia: Miklós számára.

Reg.: Dunántúli Református Egyházkerület Könyvtára Kézirattár: Oklevelek 26. (Df. 292 657.).

K.: Köblös, DREL. (9. szám). 


\section{1356. Zágráb}

Margit, egész Szlavónia, Ho. és Da hercegnéje a zágráb-előhegyi Boldogságos Szűzegyház színe elé járult remete testvéreinek kérésére és oklevél-bemutatása alapján autentikus függőpecsétje alatt átírva privilegiálisan megerősíti a zágrábi kápt. hozzá intézett, Priztawchyna Pryztawschyna birtok iktatása ügyében jan. 15-i keletû zárt oklevelét (l. 29. szám). D. Zagrabie, Péter vasvári prépost és a hercegnéi udvar kancellárjának keze által., a. eiusdem 1356. predicto.

E.: - Tkalčić és Smič. szerint az irat Zágrábban, „in archivo regni C[roatie] S[clavonie] D[almatie]", Act. Convent. Remet. fasc. I. nr. 10. jelzet alatt található. Tkalčić közlése szerint kopott hártyára írt privilégium függőpecséttel, mely sárga sodraton függ. A MOL nem tartja nyilván az iratot.

Tá.: 1. Alsólendvai Bánfi István és János szlavón bán, 1382. jan. 5. > Zsigmond király, 1405. aug. 26. Dl. 34 350. (AP. Remete 2. 1.).

2. Csázmai kápt., 1425. ápr. 18. > Pálóci Máté országbíró, 1425. jún. 19. Dl. 34963. (AP. Remete 2. 12.).

Eml.: Inventarium 12-13.

K.: Arkiv III. 86-87. (9. szám) (E.-ról); Tkalčić, Mon. civ. Zagr. I. 210-211. (235. szám) (E.-rôl); Smič. XII. 383-384. (286. szám) (E.-ról v. Tkalčić nyomán); Doc. Art. Paulin. III. 321. (Eml.-ról).

R.: Mályusz, E. LK. 5 (1927) 136-137. (4. szám); Halász, É. Fons 2007/1. 118 (12. szám); Halász É., Szlavón 240. (468. szám).

Megj.: A regeszta az eredetit használó Tkalčić kiadása alapján készült. A kiadásokban eltérố névalakok szerepelnek, így az Arkiv-ban: Prysztawchyna, Prystawschyna. Minthogy mindkét Tá. többlet információt tartalmaz, nevezetesen megadják, hogy Pristauchyna (Tá. 1.) Pryscanchyna (Tá. 2.) birtok Grachan $\sim$ Grachyan mellett fekszik, továbbá azt az utasítást, mely szerint az oklevélben megnevezett hercegnéi és a kápt.-i ember iktassa be a birtok tulajdonába a testvéreket, így a Tá.-t adó irat összefoglaló információi közé a jan. 14-i hercegnéi parancslevélből vett adatok is belekerültek, ill. azok kiegészültek, további, más —- bizonytalanul meghatározható - forrásból szerzett értesülésekkel. Vö. a 26. számú oklevéllel.

655. 1356.

Az egri kápt. e. György és Lajos c.-ek adásvételi ügyben kinyilvánítják beleegyezésüket Lampert egri püspök érdekében. A kápt. kiküldött tagjai és a föld határosai a következőképpen állapították meg a határt: az első határjel körtefa alatt a Zekzo folyó közelében, amely Ny felól elválasztja Nagyberukzeg-et az egri kápt. földjétól, ugyanitt másik földjeltől Ke felé nagy réten át Zylfabercy-hez, Nemuthazow völgy, benne földjel és körtefa (vlg.) ketheuskurtwelfa jelöli a határt, innen rowazlyk nevú bercz-en keresztül Ke felé, Kuzepheg domb, azon Ny felól földjel, a domb alatt Dé-ről kis Lakus, innen Surkozow völgy felé tovább, ott kút (puteus) a Zaznahegye domb alatt, közelében kőjel, amelyet nevezett c.-ek a egri püspök határjelének mondtak, és amely elválasztja Kuth földet az egritól, ahogyan a püspök registrumában is áll, aztán berch-hez ér, amelyet Magosheghbertzy-nek neveznek, ott 2 földjel, közülük az egyik Benedeké és Lodoméré a másik Teek-é, innen régi úthoz, ahol 2 határjel áll, tovább egy síkságon keresztül 
2 határjelhez Barlobas özvegyének legelőjéig, azon át Thurmastheluk-ig, ott 2 határjel, Zykzo folyónál újabb 2 határjel, át a folyón, és visszatérve az első határjelhez véget is ér a határ.

Má.: HML. 462. Egri székesfőkápt. mlt. 12. 3. 1. 3. (Df. 210 378.); 4-5. old. Protocollum jellegú, kivonatos - elsősorban határleírásokat tartalmazó - 16. sz.-i kéztôl származó feljegyzés.

K.: -

656. 1356.

Az egri kápt. e. - miként azt 1356-ban (in a. d. 1356.) kelt privilégiuma tanúsítja Berechk-i János fia Miklós fia: János a maga, valamint kisfia (parvulus), János nevében is kijelentette, hogy súlyos ínségtől szorongatva a Zemplén m.-i Berechk nevú birtokából leválasztott mezőt, amely a Karacha faluból Patak városba vezető út alsó szakaszától Dé-re fekszik, valamint egy bizonyos földdarabot, amely a Sebeser vízfolyástól kezdődően Woyuda birtok határáig, majd innen lefelé egészen Luka birtok határáig terjed, s amelyen a (vlg.) Lygeth nevezetú halmok és egy elhagyatott rét terül el, valamennyi haszonvételével és tartozékával együtt eladja a Cazmer-i Mykocha fia: Pál c. által képviselt Luka-i János fia: Pál mr.-nek 11 M. kassai garasért.

Tá.: Szécsi Miklós országbíró, 1358. máj. 8. Dl. 4720. (MKA. NRA. 258. 19.).

K.: AO. VII. 184-185. (97. szám).

657. 1356.

A Saagh-i konvent - miként azt 1356-ban (a. d. 1356.) kiállított kiváltságlevele tanúsítja - átírja 1341-ben kiállított nyílt oklevelét [egy Palasth birtokon fekvő földrész $3 \mathrm{M}$. értékben lebonyolított adásvétele tárgyában] (l. Anjou-oklt. XXV. 744. szám).

Tá.: Szécsi Miklós országbíró, 1358. nov. 7. KML. 3031. (1. 1. 29.) Palásthy cs. 1t. 1. 1. 29. (Df. 281 821.).

K.: Palásthy I. 108. (85. szám); Kub. 212. (130. szám) Mindkettő Tá.-ban.

Megj.: Mivel az átírt oklevél bemutatására Szécsi Miklós országbíró e. 1356. máj. 1-jén került sor, ezen időpont az átírás keltének terminus ante quem-jének meghatározásához szolgál támpontul. Szécsi Miklós országbíró tartalmi átírást adó 1358. évi oklevelének magyar nyelvű kivonatát 1. még Tóth K., Palásthy 95-96. (80. szám).

658. 1356.

[A vasvári egyház kápt.-ja ?] e. Mihály fia: Miklós tiltakozott amiatt, hogy Mihály c. 3 évvel korábban [1353. ?] febr. 25-én [v. : (1354.) márc. 17-én] (in f. II. prox. p. domin. Oculi,cuius nunc 3. preterisset revolutio annualis) hatalmaskodva rátört Kuchk birtokon az ottani Szt. György vértanú-egyház temetőjére, amely bírói ítélet, ill. egyezség révén került Miklóshoz, s ott Miklós atyjának, Mihálynak a sírját kiásatta, majd abba egyik jobbágyának a holttestét temettette el, és mindezt tovább tetézte azzal, hogy még ugyanabban az évben, aratás idején Kuchk birtokon az ugyancsak bírói 
döntés, ill. egyezség értelmében Miklóshoz került földdarabról 100 holdnyi vetés után a kepéket elhordatta magának. Mindezek igazolása érdekében Miklósnak tanúkat kellett állítania az oklevelet kiadó hiteleshely elé, aki a kitűzött időpontban meg is jelent a tanúkkal. A 3 elsőrendủ tanú (principales testes) közül legelóbb Kuchk-i Imre fia: Lőrinc járult eléjük és tanúskodva azt vallotta, hogy ő 3 évvel korábban a fentebb megadott vasárnapot követő hétfő́n (f. II. prox. p. domin. Oculi, cuius nunc 3. preterisset revolutio annualis) a maga Kuchk-i birtokrészéről a Kuchk birtokon lévő Szt. György vértanúegyházához ment, hogy meghallgassa az istentiszteletet ahová Mihály c. ugyanazon a napon hatalmaskodva odajővén, az egyháznak a temetőjében - mely bírói úton, ill. egyezség révén jutott Mihály fia: Miklós kezére - kiásatta Miklós atyjának, Mihálynak a sírját, és abba beleltemettette egyik jobbágyának a holttestét, ám azután nem is elégedett meg ennyivel, hanem még ugyanabban az évben, aratás idején Kuchk birtokon, az ugyancsak bírói döntés, ill. egyezség értelmében Miklóshoz került földdarabról 100 holdnyi vetés után elrabolta a kepéket. Ugyanezt vallotta a második tanú, Symon-i István fia: Miklós is, aki a fent leírt eset megtörténtét akkor látta, amikor ő maga a fentebb jelzett, 3 évvel korábbi idóben éppen S[e]htur-ból akart hazatérni Symon-i birtokára, útközben pedig a mondott Kuchk birtokon lévő Szt. György vértanú-egyházához érve szemtanúja lett Mihály c. hatalmaskodásának; a kepék elviteléról is ugyanazt vallotta. Hasonlóképpen tanúskodott a 3. tanú, Koch-i Dama fia: Pál, aki azt vallotta, hogy a mondott napon Kald-ról éppen haza akart menni a Koch birtokán lévő házába, amikor is a Kuchk birtokon lévő Szt. György vértanú-egyházához érkezve látta, miként tört Mihály c. hatalmaskodva a szóban forgó - Kuchk birtokon lévő - egyház temetőjére, mely bírói ítélet, ill. egyezség révén került Mihály fia: Miklós birtokába, s ott Miklós apjának a sírját kiásatta, majd abba egyik jobbágyának holttestét temettette el; továbbá ő is megemlékezett az ugyanabban az évben elkövetett rablásról. Több más tanú is ugyanezeket vallotta, nevezetesen: Koch-i Pál fia: Miklós, Koch-i Domokos fia: János, Kubulkuth-i Och fia: János, Lanch-i Isaak fia: Lanch, ugyaninnen ennek a Lanch-nak a fivére, János, Kuchk-i Pál fia: Illés (Elias), ugyaninnen Imre fia: Mihály, Peder-i Nykkul fia: Endurl, valamint ennek fivére, Jakab, Kuchk-i Péter fia: János, Lanch-i Bereck fia: István, Lanchi Tyba fia: Mihály - több nemessel és nem nemessel együtt - mind megerősítették a

3 tanú vallomását, állítva, hogy a történteket ismerik és látták. D. 3. die productionis testimonii prenotati, a. d. 1356.

E.: Dl. 37 168. (Ismeretlen provenienciájú iratok) Papíron, hátoldalán azonos és késóbbi kéz írásával tárgymegjelölés (utóbbi magyarul), valamint kerek zárópecsét töredéke, szalagja, bevágásai. A töredéken kivehető pár betú, ami alapján - figyelembe véve az oklevélben szereplő birtokok elhelyezkedését - feltételezhető, hogy a vasvári kápt. az oklevél kiadója. A pecsét körirata: [S(IGILLVM) CAPITVLI ECCLESIE CA]STRIF[ERREI].

K.: -

659. 1356.

Zeech-i Miklós országbíró e. - miként azt 1356-ban (in a. d. 1356.) kelt nyílt oklevele tanúsítja - [Taskan-i Péter fia:] Jakab nemesnek az özvegye előterjesztette panaszát, amelyre [Pechul-i deák] Péter mr.[, a néhai Vilmos nádor prothonotarius-a] válaszolt (s mindezeket az oklevél részletesen tartalmazta), ezenfelül pedig szóban előadták mindazokat, amelyek Pál c. [egykori királyi országbíró 1339. évi] privilégiumában (l. Anjouoklt. XXIII. 765. szám) foglaltattak. Az előadottakat látva és megértve az országbíró az 
ország nemeseivel és előkelőivel együtt úgy határoztak, hogy meghagyván a feleket eddigi tulajdonukban, Pechul birtokon lévő részbirtokaikat minden haszonvételükkel együtt úgy birtokolják ezentúl is, ahogyan azt Pál c. [országbíró] kiváltságlevele tartalmazza. Eszerint Péter mr. azokból a madarakból (aves), amelyek a malom fölött elterülő nádasban élnek, és amelyeket a malom gátjának környékén, ill. a gáton sikerül megfogni, mivel a malom negyedrésze a szóban forgó özvegyet illeti, köteles a madarak negyedét is átadni neki, viszont ha a madarak a nádasból Péter földje (ad portionem seu terram) felé szállnak, és ott leereszkedve ejtik el őket, azokból semmi sem jár az özvegynek. Ellenben, ha a madarak a nádasból átrepülnek az özvegy területére, és ott kerítik kézre ôket, akkor a zsákmányból semmi nem jár Péter mr.-nek.

Tá.: Ugrin fia Miklós országbíró, 1359 . júl. 29. Dl. 37 249. (Hajas Ede gyújteménye).

K.: -

R.: Bakács, Pest m. 209. (717. szám).

Megj.: A [ ] közötti kiegészítések a tartalmi átírást adó oklevél más, ezen irat ismertetésén kívül eső szakaszaiból származnak.

660. 1356. (?) Visegrád

[Dénes] királyi [lovászmr.] Egeerzeeg-i officialis-ainak megparancsolja hogy királyi [emberrel] és a csanádi egyház kápt.-jának [tanújával] a királyi oklevélben foglaltak szerint [eljárva] .........menjenek ki Heem fia (dict.) Pál: fia: Benedek mr. (magister Benedictus filii Pauli dicti filii Heem) ....... nevú birtokára [és a] törvényesen [összehívott szomszédok és határosok jelenlétében] járják be annak határait Benedek mr.-nek, a kiküldött királyi és [kápt.-i] emberek által ....... [ahol szükséges határjeleket] állíttassanak. D. in Vyssegrad, f. II. p. ......., a. d. 135[6.?].

E.: Dl. 103 291. (Batthyány cs. lt. jelzet nélküli oklevelek) Papíron, bal fele hiányzik, hátoldalán Dénes királyi lovászmr. kerek pecsétjének töredéke (rajta kiterjesztett szárnyú, álló sárkány alakja látható szembő́l, fejét oldalra fordítja; körirata: + S(IGILLVM) DIONISV M(AGISTRI) AGASONV(M) D(OMI)NI REGIS COM(ITIS)S D(E) CRAS(S)O ET D(E) KEVE.)

K.: -

661. 1356. (?)

György egri főesp. és vikárius oklevelében beiktatja a pálosokat két malomhely birtokába.

Eml.: Inventarium 49.

K.: Doc. Art. Paulin. III. 212. (Eml.-ről).

Megj.: A keltezés bizonytalansága abból ered, hogy a szöveget fenntartó közlés határozottan nem nevezi meg az adomány idejét, hanem csak a malomhelyek eladományozása kapcsán támadt perről szólva utal az 1356. évre. 
662. 1356. (?)

Aba nb. Imre fia: János ítéletlevele, amelyben a jobbágyai és a barátok között 2 malomhely körül forgó perben a szerzeteseknek ad igazat.

Megj.: Apparátusa megegyezik a 661. számú oklevélével.

663. 1356. (?)

Az egri kápt. átírja Aba nb. Imre fia: János ítéletlevelét.

Megj.: Apparátusa megegyezik a 661. számú oklevélével.

664. 1356.

A Baxa család megalapítja Szt. Pál remetéinek Essen-i kolostorát. A. d. 1356.

K.: F. IX. 7. 164. (100. szám) A pálosok lt.-ra való hivatkozással.

\section{1356. Fülek}

A Fylek városbeli falunagy, esküdtek, polgárok (cives et concives) és hospes-ek tudatják urukkal, Simon fia: Imre mr.-rel, hogy a bírói színe e. 2 Kallow-i hospes, Miklós szabó és Pál mészáros ellenében a maga és valamennyiük javaival kapcsolatos tiltás miatt (ratione prohibitionis omnium [?] et suarum rerum) perben álló György fia: Péter ártatlansága és vétlensége mellett ók becsületszavukra egyöntetúen kiállnak a nevezett peres ellenfelekkel szemben, minthogy az ügyben kezességvállalásra Péter nem számíthat, az a személy pedig - név szerint Chako -, akit esküt tevô tanú gyanánt bírói széke elé állíthatott volna, időközben elhalálozott, amit mind igaz szavukra istenfélelemmel tanúsítanak D. in loco antedict., f. II. prox. preterito, a. d. 1356.

E.: Dl. 51 726. (Kállay cs. lt. 1300. 118.) Papíron, hátoldalán azonos kéz írásával címzés és tárgymegjelölés (eltérô névalak: Filekk), valamint kerek zárópecsét töredéke, bevágásai.

Má.: Uo., mint E., azzal megegyező jelzet alatt, modern kori egyszerú Má.-ban; Fetter Klára aláírással (és sok hibával).

R.: Kállay II. 41. (1202. szám).

K.: -

666. 1356.

tudatják, hogy amikor és fiának panaszát a királyné elé terjesztette, mivel ............. az oklevél kiadó bírói széke elé vitték a pert .... ...... [ahol bemutatták] az ügyben eddig kelt okleveleket és halasztó leveleket előadták Nemeth (dict.) János mr. és fivére Gergely ellenében a Zala m.-i nemteleneknek [1356.] máj. 2. [?] (f. II. prox. p. oct. fe. Passce d. tunc prox.........) Gergely fia: ezeknek Sebehodnogfeuld birtokáról a mondott várbirtoknak István mr.-nek és 
a szb.-áknak előadta az igazat ezért valamennyi nemest akaratából, visszatérve egybehangzóan jelentették, hogy Sebehodnog $\sim$ Sebehognog.............. Sebehodnogfeuld birtokot a mondott Sebehodnog embernek [örökös] nélkül ugyanott bemutatta a királynak ez ügyben kelt nyílt oklevelét az igazságot a nemesek egybehangzó jelentése alapján .............. ahol a közös vizsgálat alapján a parancs szerint Dagad-ban a kápt.-tól ............... nemkülönben Fynire-i [?] Péter fia: Mihály v. Jakab fia: Pál királyi emberek valamelyikével szept. 15-én (in oct. fe. Nat. virg. glor.) .............. és ha alkalmasnak látszik, ugyancsak egyszer és az ítélkezésben előrehaladva arról maga Sebehodnog tartozik v. maga Sebehodnog várnépbeli ember (homo castrensis) volt és örökös nélkül halt meg, ezért .............. mindenféleképpen derítsék ki az igazságot, majd ezt követően a vizsgálat lefolytatásáról ............ okt. 6 [-ra?] (........ oct. fe. B. Mychaelis arch.) mivel királyi rendeletre nyolcadnapra (oct. diei.......) .............. a fehérvári kápt. fenti ügyben kiadott ....... [oklevele] .............. a felperes Kun (dict.) István oldalán akik visszatérve egybehangzóan jelentették, hogy kimenve a mondott birtokra először Bezdred-i László [fia?] Lőrinc fia István fia: valamint ugyanezen Lőrinc fia: Dénesnek, hasonlóképpen fiának 200

híján hozzákapcsolt és felállított, valamint 50 nemtelen v. és Sebehodnog a zalai vár nemes jobbágya volt Nemeth János mr. és fivére, Gergely által a szóban forgó birtokra Zethgerolth-i, Sytke-i István, Zanthou-i László fia: Bothka, valamint m.-beliek (conprovincionales) számára ..................... zalai földet, de várnépbeli ember (homo castrensis) és örökös nélkül haláloznának el, és mivel ....... fia: István ................... Sebedehudnegfeuld birtok a mondott felek között per tárgyát képezố még nem .............. kérik, hogy küldje ki tanúját ................... hasonlóképpen László fia : Bothka v. Weruh-i András v. Hegen fia: Kaloz ...................... ott törvényesen összehívottak és a feleknek v. képviselóiknek a jelenlétében kimenve ..................... és királyi mértékkel megmérve vagy ha megmérni [ nem lehet, akkor megbecsülve] terménye és haszna alapján és a birtok felmérését követően a történtekról mindenre [kiterjedổ jelentést küldjön] [a.] d. 1356.

E.: SNA. Esterházy cs. cseszneki ágának lt. Oklevelek és iratok Muraközy József elenchusa szerint 386. (Df. 259 204.) Papíron, csonka.

K.: -

Megj.: Jó minőségú digitalizált változatát 1 .

http://www.mom-ca.uni-koeln.de/mom/SK-SNA/4173-RodEsterhazi-CesneckaLinia/386/charter. Vö. a Rumy cs. Sebehadnagyföldével kapcsolatos okleveleivel Dl. 49 631; 49 632; 49633; 49634; 49 638; 49 639; 49 640; 49 641; 49 643; 49 644; 49 645; 49646.

667. 1356 .

Herroy fia: Miklós kérésére Kukmér birtokát és földjét elválasztják Terestyén fia: András Szaldy [?] birtokától, benne Zik folyó, Kukmer-i és Prástyen-i erdó, 3 tilos erdó Kukmer határain belül, Prástya határjelölő helynevek.

Tá.: Dl. 103 292. (Batthyány cs. lt. Senioratus, Németújvár 4. 2.) Elnagyolt írású és megszövegezésú egyszerú 17. sz.-i kivonat.

K.: - 